ANDRÉ NEGRÃO DE MOURA

REMEDIAÇÃO DE ÁREAS CONTAMINADAS COM METAIS PESADOS UTILIZANDO ACIDITHIOBACILLUS $s p$ 
ANDRÉ NEGRÃO DE MOURA

REMEDIAÇÃO DE ÁREAS CONTAMINADAS COM METAIS PESADOS UTILIZANDO ACIDITHIOBACILLUS $s p$

Tese apresentada à Escola Politécnica da Universidade de São Paulo para a obtenção do título de Doutor em Engenharia.

São Paulo 
ANDRÉ NEGRÃO DE MOURA

\section{REMEDIAÇÃO DE ÁREAS CONTAMINADAS COM METAIS PESADOS UTILIZANDO ACIDITHIOBACILLUS $s p$}

Tese apresentada à Escola Politécnica da Universidade de São Paulo para a obtenção do título de Doutor em Engenharia.

Área de Concentração: Engenharia Hidráulica e Sanitária.

Orientadora: Profa $\mathrm{Dr}^{\mathrm{a}}$ Dione Mari Morita

São Paulo 
Este exemplar foi revisado e alterado em relação à versão original, sob responsabilidade única do autor com a anuência de sua orientadora.

São Paulo, 13 de Dezembro de 2006.

Assinatura do autor:

Assinatura da orientadora:

FICHA CATALOGRÁFICA

Moura, André Negrão de

Remediação de áreas contaminadas com metais pesados utilizando Acidithiobacillus sp I A.N. de Moura. -- São Paulo, 2006.

251 p.

Tese (Doutorado) - Escola Politécnica da Universidade de São Paulo. Departamento de Engenharia Hidráulica e Sanitária.

1.Contaminação 2.Solo tropical 3.Lixiviação 4. Chumbo 5.Zinco I.Universidade de São Paulo. Escola Politécnica. Departamento de Engenharia Hidráulica e Sanitária Il.t. 


\section{DEDICATÓRIA}

Aos meus queridos e amados pais João e Maria por me trazerem a este mundo e nele me ensinar a lutar.

À minha querida e amada esposa Adriana pelo incentivo, ajuda, apoio e paciência, que foram de fundamental importância na execução deste trabalho.

Aos meus queridos e amados filhos Henry, Erik e Kenzo que, mais do que ninguém, sofreram com minha ausência durante a execução deste trabalho: saibam que tudo que faço é pensando em vocês e este trabalho não foi exceção. 


\section{AGRADECIMENTOS}

Por certo a execução deste trabalho contou com a colaboração de muitas pessoas que, por vezes, deixaram de lado seus afazeres para auxiliar seu desenvolvimento e, as quais sou grato. No entanto, não seria justo nem possível citar nominalmente todas elas sob pena de, traído pela memória, me esquecer de alguém.

Portanto, o autor limita-se a expressar seu agradecimento à pessoa e às instituições que viabilizaram e contribuíram do início ao fim para o desenvolvimento desta pesquisa:

Prof $^{\mathrm{a}} \mathrm{Dr}^{\mathrm{a}}$ Dione Mari Morita; mestra de profundos e inquestionáveis conhecimentos da ciência; pela paciência e habilidade nata em ensinar, pela perseverança em buscar a perfeição em tudo que faz e, por trazer luz para iluminar o intelecto de todos aqueles que tem a honra de poder compartilhar sua experiência e sabedoria. Meus mais sinceros agradecimentos àquela que perde um aluno mas ganha um amigo.

Fundo Setorial de Recursos Hídricos (CT-Hidro), pela concessão da bolsa de doutorado, processo no 140915/2002-8, que permitiu ao autor dedicar-se em tempo integral para o desenvolvimento desta pesquisa.

Fundação de Amparo à Pesquisa do Estado de São Paulo (FAPESP), pela concessão do auxílio pesquisa, processo n 04/08039-4, que permitiu a execução deste pesquisa. 
A curiosidade é a força motriz do conhecimento, pois lança-nos em direção ao desconhecido, onde a ausência de certezas e a busca por respostas inquietam o espírito humano. Nosso conhecimento contemporâneo é fruto de inquietações ancestrais e será ampliado até o fim de nossa raça, pois o Homem é curioso por natureza e sua sede por respostas insaciável.

André Negrão de Moura 


\section{RESUMO}

A "Região dos Lagos" de Santa Gertrudes é um exemplo das muitas áreas contaminadas com metais pesados existentes no Estado de São Paulo e no Brasil. O pólo de Revestimentos Cerâmicos de Santa Gertrudes dispôs inadequadamente seus resíduos sólidos e águas residuárias diretamente no solo por mais de três décadas, contaminando uma área de $1,5 \mathrm{~km}^{2}$. A despeito das incertezas que cercam e que prejudicam a plena compreensão de um processo de bioremediação de um solo contaminado, esta pesquisa avalia a influência do pH inicial e da adição de inoculo e nutrientes sobre a eficiência de remoção de chumbo $(\mathrm{Pb})$ e zinco $(\mathrm{Zn})$ de um latossolo vermelho, submetido à biolixiviação com Acidithiobacillus ferrooxidans e Acidithiobacillus thiooxidans. Este solo apresenta elevados teores de óxidos de ferro $(8,3 \%)$ e alumínio (16,8 \%), argila (57\%), chumbo (717 mg/kg) e zinco (181 $\mathrm{mg} / \mathrm{kg}$ ). Os experimentos foram conduzidos em reatores em batelada, monitorados durante 30 dias e resultaram na solubilização de até 3,6 mgPb/L e 50,0 mgZn/L. Constatou-se que para este solo e sob as condições experimentais utilizadas, não foi necessária a redução inicial do pH; a solubilização do chumbo foi inexpressiva, provavelmente, devido à sua precipitação na forma de $\mathrm{PbSO}_{4}$; a do zinco decorreu, principalmente, da liberação de íons $\mathrm{H}^{+}$, produzidos durante a dissociação dos nutrientes, em particular o $\mathrm{FeSO}_{4}$, que promoveram a acidificação do meio. Embora a lixiviação química tenha sido o principal mecanismo de solubilização do zinco, a biolixiviação devido a Acidithiobacillus ferrooxidans indígenas foi registrada e incrementou em até $17 \%$ a lixiviação deste elemento, a partir do décimo dia de experimentação.

Palavaras-chave: Contaminação. Solo tropical. Biolixiviação. Chumbo. Zinco. 


\begin{abstract}
The "Lake Region" of Santa Gertrudes is one of several contaminated sites with heavy metals in São Paulo State, Brazil. As in other regions of this country, in the 1970's the ceramic industries of Santa Gertrudes disposed their solid wastes and wastewaters directly in soil and contaminated an area of $1.5 \mathrm{~km}^{2}$. Biological solubilization of lead $(\mathrm{Pb})$ and zinc $(\mathrm{Zn})$ from soil of the Lake Region was tested in batch reactors. The biological process used the leaching capacity of Acidithiobacillus ferroxidans and Acidithiobacillus thiooxidans. Tests were performed to determine the influence of initial $\mathrm{pH}$, the percentage of inoculum and the addition of nutrients on the efficiency of removal of these metals. The soil contained high concentration of iron oxides (8.3 \%) and aluminum (16.8\%), clay (57\%), lead (717 mg/kg) and zinc (181 $\mathrm{mg} / \mathrm{kg}$ ). It was not necessary to reduce the initial $\mathrm{pH}$ of soil. Solubilization of lead (up to $3.6 \mathrm{mg} / \mathrm{L}$ ) and zinc (up to $50 \mathrm{mg} / \mathrm{L}$ ) was obtained, but the solubilization of $\mathrm{Pb}$ was low, probably because the element was precipitated as $\mathrm{PbSO}_{4}$. The solubilization of zinc was strongly correlated with the release of $\mathrm{H}^{+}$ions produced from nutrient dissociation, particularly $\mathrm{FeSO}_{4}$, which promoted the acidification of solution. Although chemical solubilization was the main mechanism of $\mathrm{Zn}$ removal, biological solubilization by indigenous Acidithiobacillus ferroxidans was detected, reaching up to $17 \%$ of the total element leached after 10 days of testing.
\end{abstract}

Keywords: Contamination. Tropical soil. Bioleaching. Lead. Zinc. 


\section{SUMÁRIO}

página

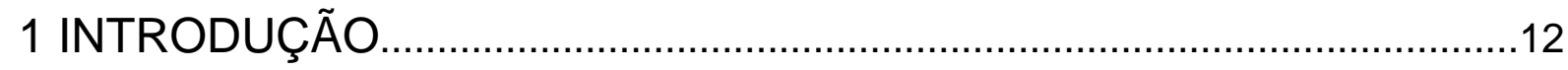

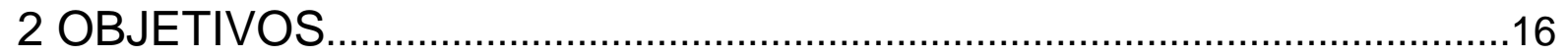

3 REVISÃO DA LITERATURA

3.1 Conceituação de termos e expressões..........................................................17

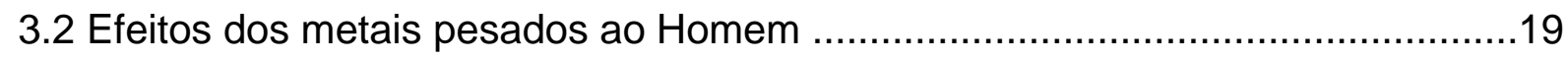

3.3 Dinâmica e comportamento dos metais pesados no solo...................................23

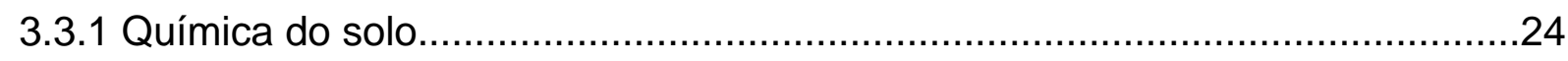

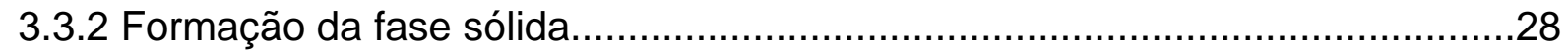

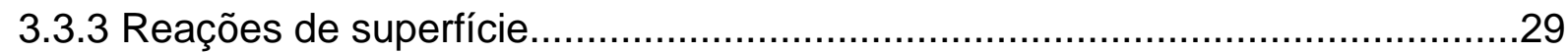

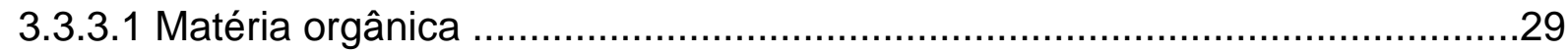

3.3.3.2 Argilominerais, óxidos, hidróxidos e carbonatos.........................................32

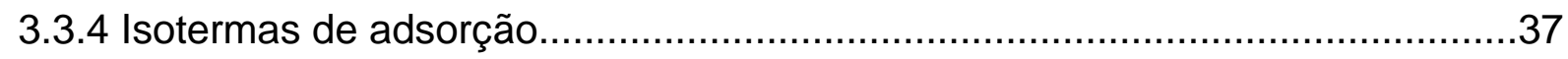

3.4 Tecnologias de remediação de áreas contaminadas com metais pesados..........38

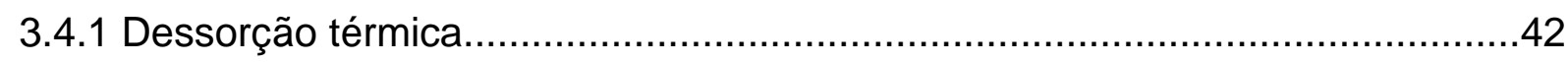

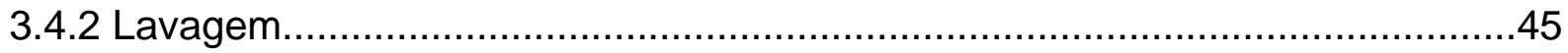

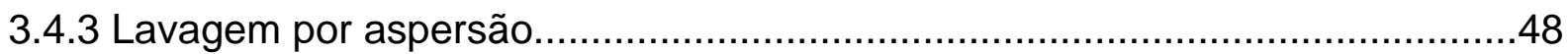

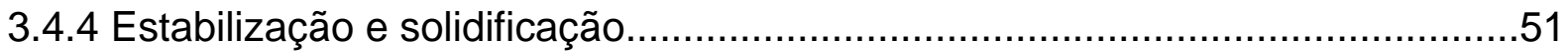

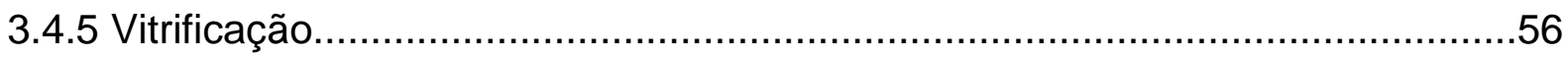

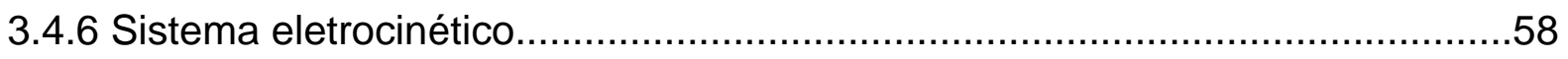

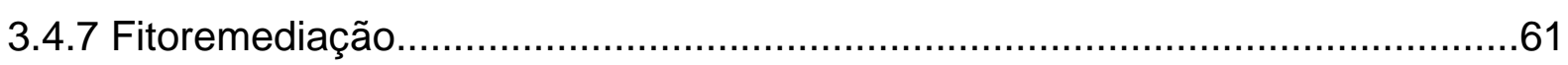

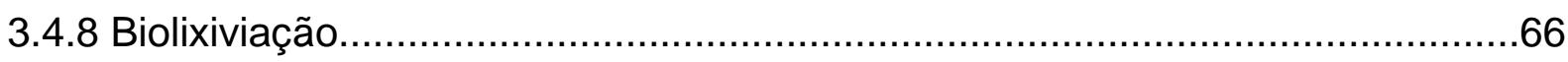

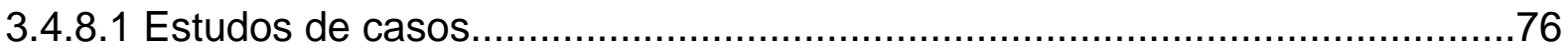

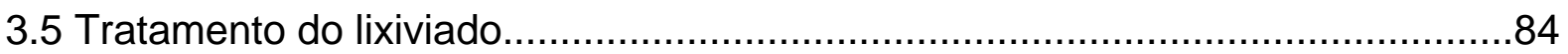

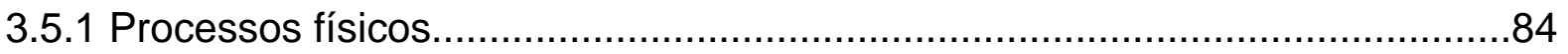

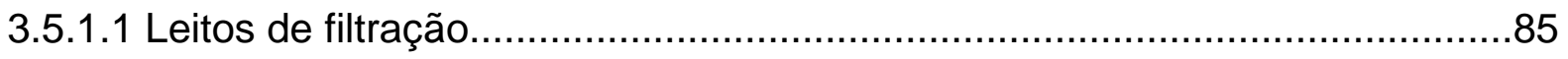

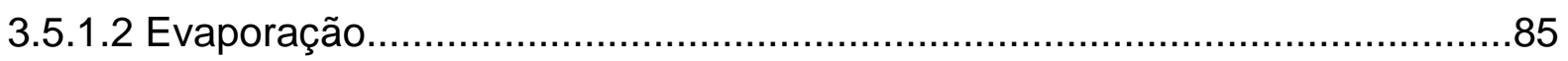

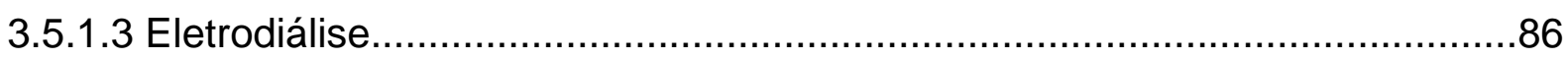

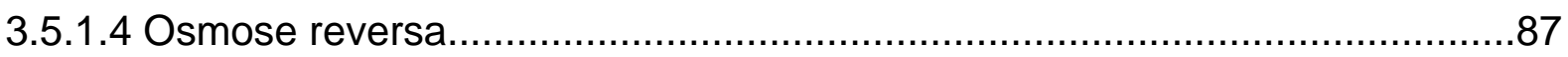


3.5.2 Processos químicos .88

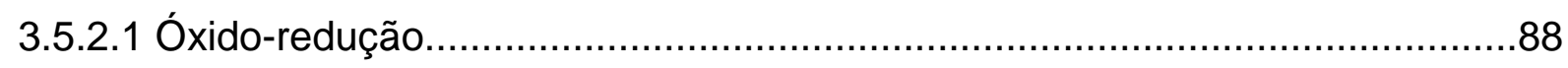

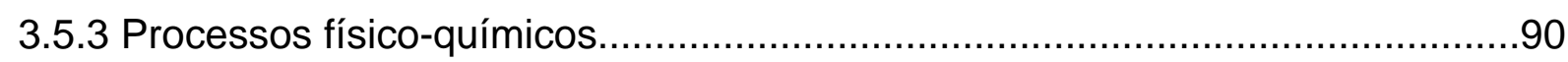

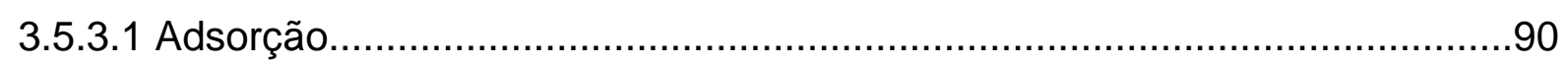

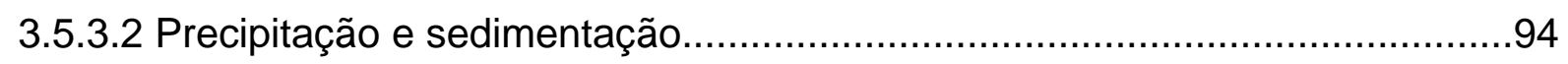

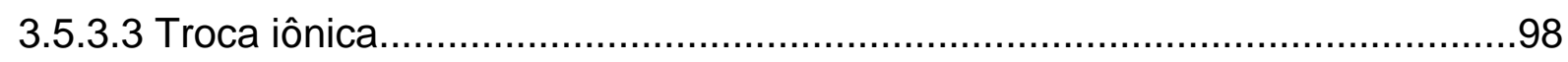

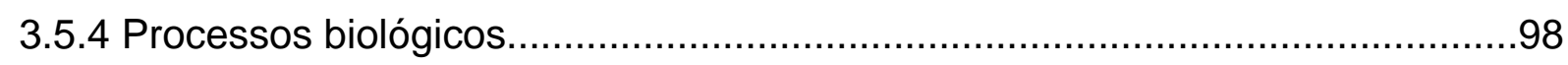

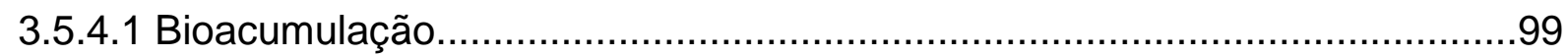

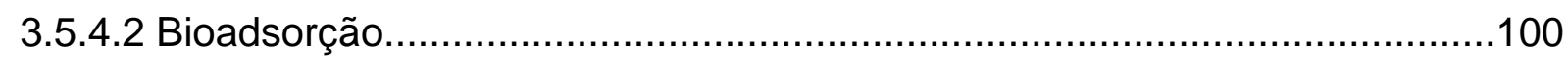

\section{MATERIAL E MÉTODOS}

4.1 Descrição do local objeto do estudo: Região dos Lagos de Santa

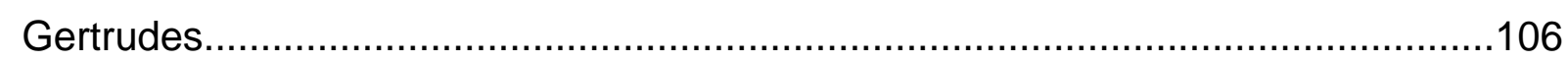

4.2 Resíduos gerados pela indústria de revestimento cerâmico.............................110

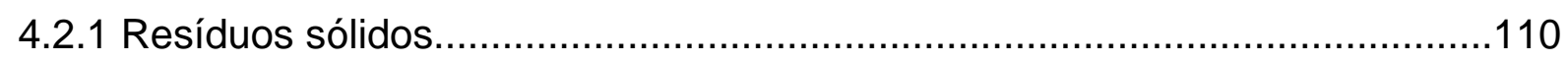

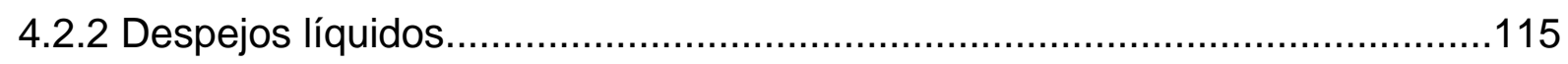

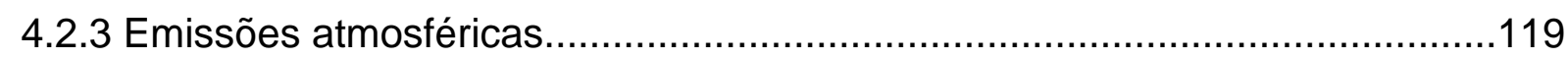

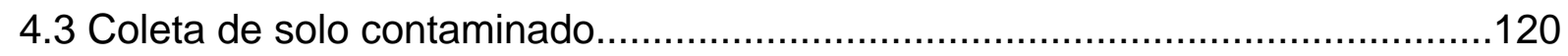

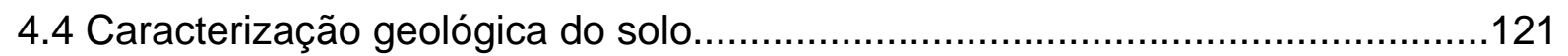

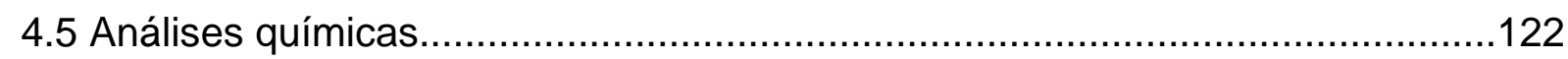

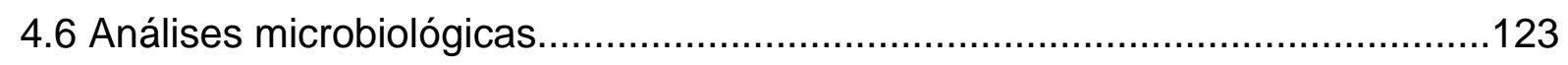

4.7 Produção das suspensões bacterianas......................................................125

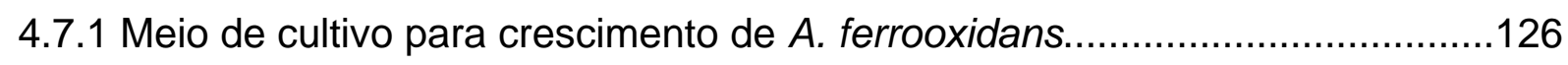

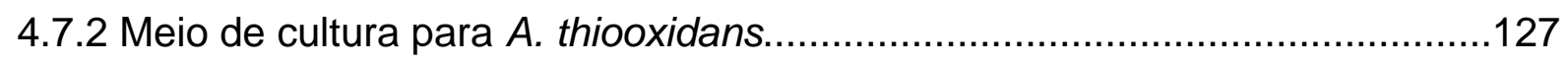

4.7.3 Purificação e concentração de células.......................................................128

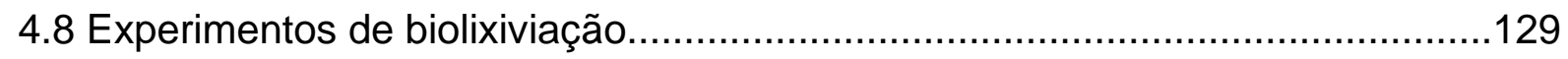

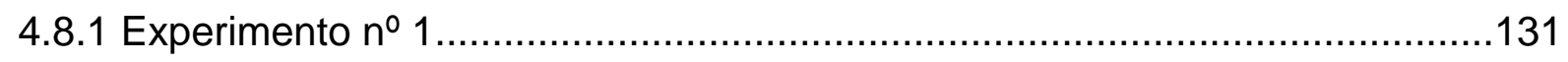

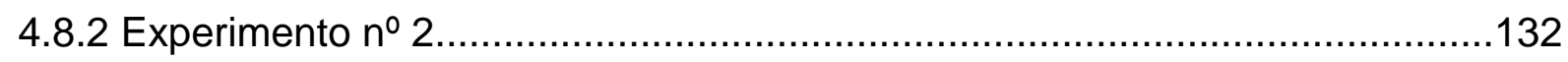

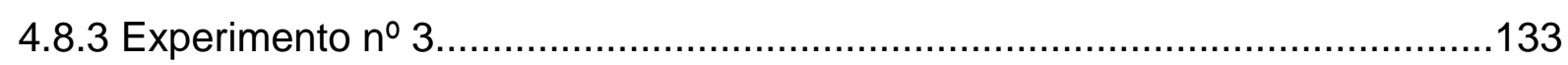

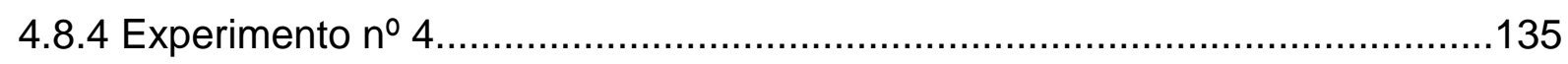

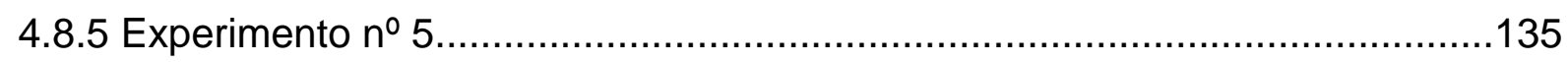

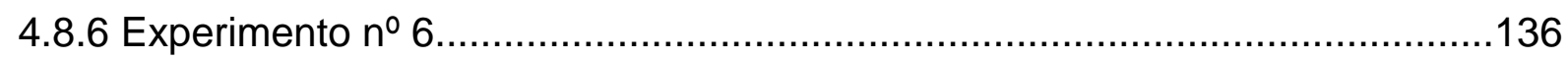

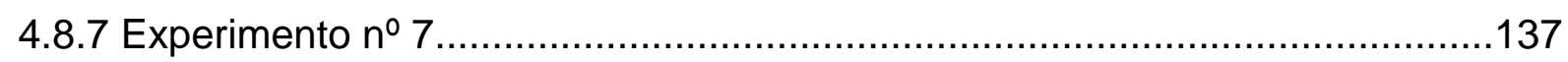

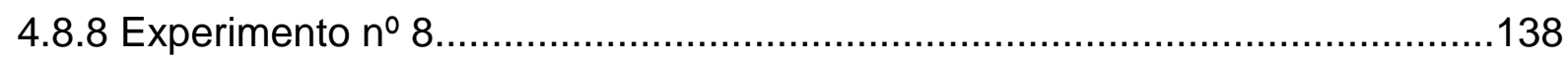




\section{RESULTADOS}

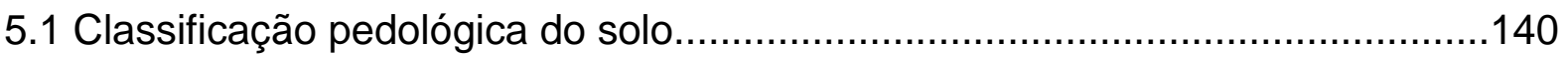

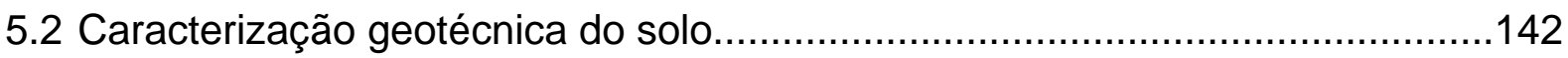

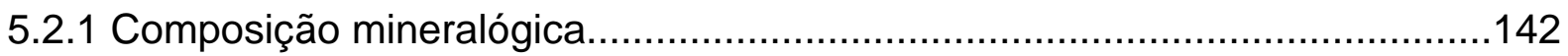

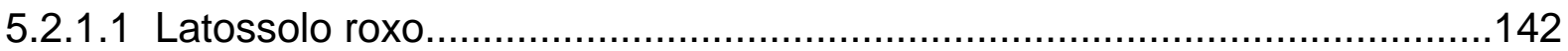

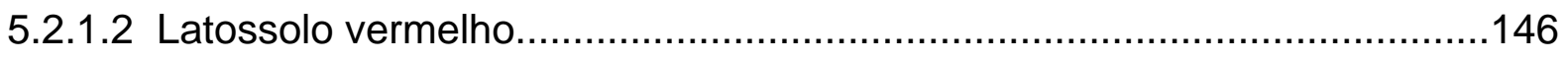

5.2.2 Massa específica dos grãos e curvas granulométricas...................................149

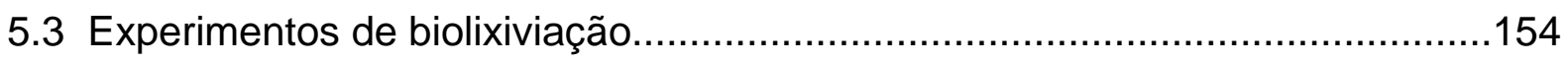

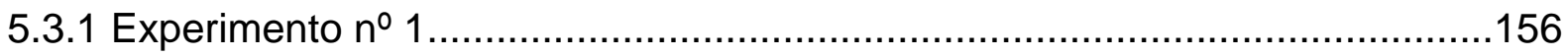

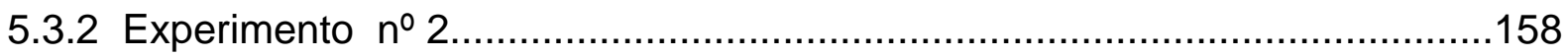

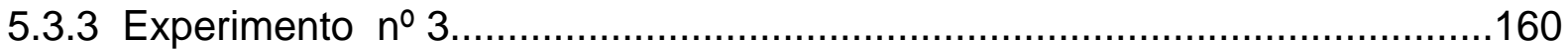

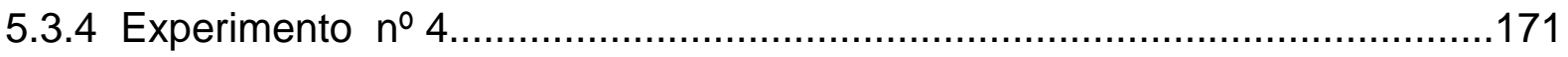

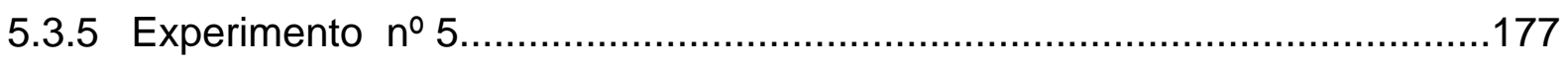

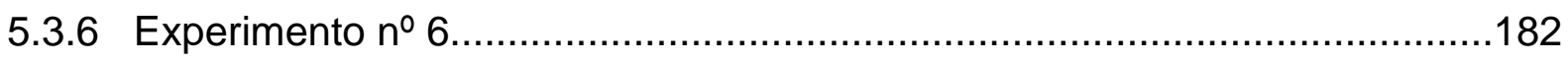

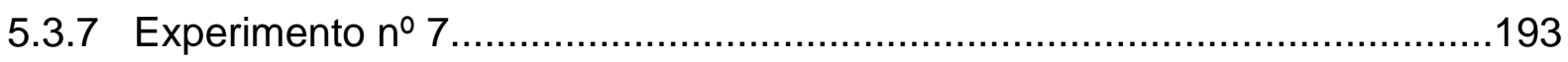

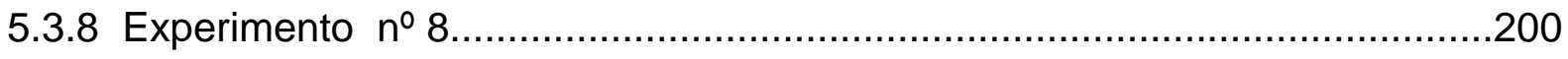

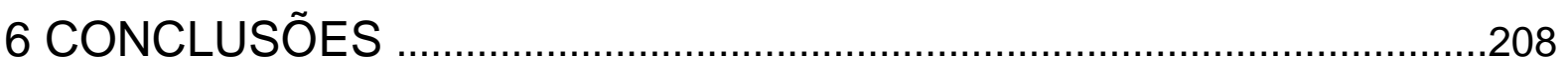

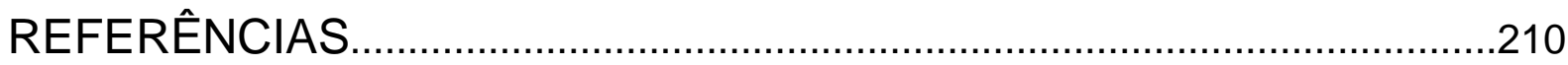

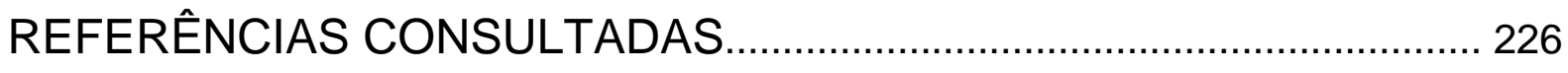

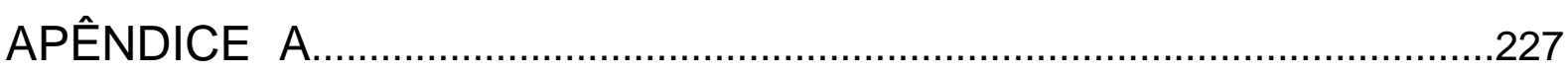




\section{INTRODUÇÃO}

A contaminação do solo com os mais diferentes resíduos acompanha a história da civilização humana desde seu imemorável início. Todavia, ao longo do tempo, o Homem foi descobrindo novos materiais e, conseqüentemente, gerando novos tipos de resíduos.

Os processos de industrialização, que transformaram o mundo desde meados do século XVIII, e a exploração não sustentável dos recursos naturais deles decorrentes legaram à humanidade um conjunto de "passivos ambientais", pelos quais ela sofre as conseqüências hoje e, se nada for feito, também sofrerão as gerações futuras.

A geração de resíduos é inerente a qualquer processo produtivo, todavia, estes foram inadequadamente dispostos por décadas e, no Estado de São Paulo, somente a partir de 1975, surgiram as primeiras leis ambientais, que regulamentaram o uso do solo para proteção de mananciais, caracterizaram poluição, contaminação, bem como impuseram padrões para emissão de efluentes, critérios para acondicionamento e disposição de resíduos sólidos.

Até então, os resíduos gerados pelas indústrias brasileiras tinham um destino certo: se líquidos, eram lançados in natura no corpo d'água mais próximo ou se sólidos, simplesmente eram enterrados no solo. Esta "modalidade" de disposição de resíduos industriais foi sendo gradativamente banida e atualmente, permite-se somente aquela que atenda as exigências legais quanto à segurança do meio ambiente.

Como conseqüência direta do aprimoramento da legislação ambiental brasileira, a qual atualmente é restritiva para a disposição de resíduos sólidos no solo - principalmente os perigosos - as indústrias que os geram são obrigadas a estocá-los ou promover seu tratamento e posterior destinação final. A estocagem de resíduos perigosos é uma solução temporária para o problema de sua destinação, todavia, caminha para tornar-se um novo problema, pois onde estocar tanto resíduo? Segundo MORITA (2001), foram gerados no Estado de São Paulo, somente em 2000, 342.455 toneladas de resíduo Classe I (perigoso). 
Assimilada a necessidade de proteção dos recursos hídricos e da atmosfera, pois estes dois compartimentos ambientais possuem a água e o oxigênio, que são imprescindíveis à manutenção da vida na Terra, na década de 1990, a preocupação passou a ser o solo.

O compartimento solo tem sido explorado impiedosamente há séculos e ao contrário dos rios, onde se pode enxergar os peixes mortos em suas águas imundas e sentir o fedor dos gases que delas emanam, e do ar, onde se pode sentir, fisiologicamente, os efeitos provocados pela poluição atmosférica, não é possível, na maioria dos casos, observar e inferir que o mesmo esteja contaminado e que possa causar qualquer dano à biota e ao Homem.

Devido às características peculiares do compartimento solo de não "transparecer" a contaminação nele disposta, ele funciona há séculos como um verdadeiro sumidouro, pois tem sido utilizado como destino final para todo tipo de resíduos sólidos e líquidos. A condição de sumidouro do solo só recentemente passou a ser questionada e tem razões óbvias: o subsolo armazena mais água doce do que os mananciais superficiais e, tais reservas estão sendo contaminadas e a produção de alimentos, afetada pela contaminação dos solos agricultáveis.

A legislação ambiental brasileira, a despeito de suas imperfeições, assegura níveis mínimos de proteção ao meio ambiente contra futuras agressões que possa vir a sofrer, entretanto, sobre os atos insanos cometidos no passado, somente é aplicável nos casos onde se conhecem os responsáveis pela degradação, que então, são responsabilizados pelo passivo ambiental gerado. Entretanto, não se conhecem os responsáveis pela contaminação de muitas áreas, logo, não existem culpados e, muito menos os responsáveis para promover sua remediação, ou seja, estas áreas, com seus solos, águas e sedimentos contaminados, constituem-se, certamente, no maior passivo ambiental contemporâneo.

Nos doze países da União Européia, até 2000, tinham sido identificadas cerca de 300 mil áreas contaminadas e estimadas 1.500 .000 potencialmente contaminadas, ou seja, áreas onde estão sendo ou foram desenvolvidas atividades potencialmente poluidoras. Na Alemanha, uma estimativa de 1993 apontou que a remediação de 23.600 sítios contaminados poderia ter um custo de $€ \$ 92$ bilhões a $€ \$ 462$ bilhões, dependendo da tecnologia a ser empregada (EEA, 2000). Na Holanda, existem cerca de 100 mil locais contaminados, com custo previsto para remediação de US\$ 50 bilhões (EEA, 2000). 
Segundo o OTA (1983) apud PAGE (1997), os Estados Unidos da América (EUA) tinham aproximadamente 600.000 áreas contaminadas com substâncias tóxicas até 1983, embora muitas não representassem riscos à saúde humana. Até 1993, as áreas contaminadas com metais pesados, associados ou não com compostos orgânicos, representavam 22 \% do total (USGAA, 1993 apud PAGE, 1997). Especialistas previram que os EUA deveriam investir de US\$ 400 bilhões a US\$ 1,7 trilhões nas próximas três décadas para promover a remediação destas áreas (RUSSEL et alii, 1991 apud PAGE, 1997). O passivo ambiental norte americano é incalculável, pois não se conhece, nacionalmente, o número total de áreas contaminadas, embora os principais programas governamentais já tenham realizado a remediação, completa ou parcial, em 2.255 das 4.500 consideradas prioritárias (USEPA, 2003a).

Um diagnóstico preliminar do Ministério da Saúde, realizado entre 2001 e 2003, indicou a existência de 15.237 áreas potencialmente contaminadas no país, entretanto, um diagnóstico confirmatório identificou a existência de 689 áreas potenciais e efetivas com populações expostas ou sob risco de exposição a solos contaminados. Atualmente, este número é de 703 áreas (BRASIL, 2006).

Regionalmente, um panorama da situação foi apresentado em maio de 2002, quando a CETESB tornou pública a primeira relação de áreas contaminadas do Estado de São Paulo, na qual figuravam 255 sítios contaminados. A última atualização desta relação, divulgada em novembro de 2005, apontou a existência de 1.596 áreas, das quais 564 tinham algum processo de remediação em andamento, 144 possuíam proposta e apenas 29 já haviam concluído a descontaminação (CETESB, 2005b). Dentre as diversas espécies e substâncias químicas encontradas nestas áreas, os metais pesados eram os responsáveis, isolados ou não, pela contaminação de aproximadamente 217 sítios. Todavia, a necessidade de estudos mais detalhados sobre 859 das 1.596 áreas contaminadas, que ainda não possuem proposta de remediação, poderá apontar a presença de metais em outros sítios.

Dentre as 564 áreas contaminadas paulistas que realizavam alguma atividade de remediação até novembro de 2005 e dentre as 217 contaminadas com metais pesados, inclui-se o pólo cerâmico de Santa Gertrudes, que constitui um exemplo típico das equivocadas práticas de tratamento e destinação final de resíduos industriais utilizadas até um passado recente. 
A região tem suportado, há mais de três décadas, a extração de argila por parte das indústrias de revestimento cerâmico, o que provocou a formação de cavas, originando o que se convencionou chamar de região dos lagos, que, por sua vez, vieram a ser contaminados pelo lançamento de resíduos da linha de esmaltação das cerâmicas, contendo boro e metais pesados, entre eles, cádmio, chumbo, níquel e zinco.

A região dos lagos de Santa Gertrudes está inserida na microbacia do Córrego da Fazenda Itaqui, um afluente do Ribeirão Claro, que por sua vez, é afluente do Rio Corumbataí, o qual abastece sete municípios do interior paulista e beneficia aproximadamente 650 mil habitantes. A área contaminada está situada na porção mais à montante da bacia hidrográfica e possui aproximadamente 1,5km².

A experimentação e a utilização de microrganismos capazes de promover a biolixiviação de metais pesados, aqui considerados como sendo todos os metais reconhecidamente ou potencialmente capazes de provocar efeitos deletérios à saúde humana e à biota, é uma linha de pesquisa recente, pois a existência de microrganismos com tais habilidades foi pouco pesquisada no passado; admitia-se que a recuperação de áreas contaminadas por estes metais somente fosse possível através de métodos físicos e/ou químicos.

A descoberta de microrganismos, notadamente fungos e bactérias, capazes de biolixiviar metais pesados, a partir da degradação de compostos associados a estes, tem possibilitado o uso destes agentes biológicos como ferramenta de remoção ou biolixiviação de espécies metálicas contidas em matrizes sólidas ou semi-sólidas. O conhecimento do tema, até aqui restrito às atividades de mineração, deve ser repassado e ampliado pelas diversas áreas envolvidas com meio ambiente e, em particular, aplicado na remediação de áreas contaminadas com metais pesados.

Os reconhecidos efeitos e potenciais riscos representados pelos metais pesados à saúde humana e à biota, aliados à necessidade de buscar novas alternativas tecnológicas para a remediação de solos contaminados com tais elementos químicos, motivou o desenvolvimento desta pesquisa, para investigar a aplicação da bioremediação utilizando bactérias do gênero Acidithiobacillus sp. A extensão da contaminação por metais pesados na Região dos Lagos de Santa Gertrudes culminou com a escolha da mesma para a realização de um estudo de caso. 


\section{OBJETIVOS}

Esta pesquisa teve como objetivos principais, a experimentação e a avaliação do desempenho das espécies de Acidithiobacillus ferrooxidans e Acidithiobacillus thiooxidans utilizados como agentes biológicos, para a biolixiviação de chumbo $(\mathrm{Pb})$ e zinco $(\mathrm{Zn})$ presentes no solo de uma área contaminada.

Os objetivos específicos para o processo de biolixiviação foram:

$\checkmark$ Determinar as máximas solubilizações dos elementos $\mathrm{Zn}$ e Pb;

$\checkmark$ Verificar os mecanismos de remoção destes metais;

$\checkmark$ Verificar a influência de: pH, substrato, teor de solo, adição de inóculo e duração do experimento;

$\checkmark$ Verificar o pH como indicador;

$\checkmark$ Avaliar o impacto da biolixiviação sobre a microbiota natural do solo. 


\section{REVISÃO DA LITERATURA}

Após a introdução do leitor ao contexto ambiental em que se insere esta pesquisa, pretende-se neste capítulo, discorrer sobre o tema objeto do trabalho. Para tanto, a revisão bibliográfica foi separada em três assuntos interrelacionados: os efeitos deletérios que os metais pesados causam ou podem causar ao Homem, a dinâmica e o comportamento destes elementos no solo e, finalmente, as tecnologias em uso ou em desenvolvimento destinadas à remediação de solos contaminados com estes poluentes.

O capítulo intitulado "Técnicas de remediação de solos contaminados com metais pesados" não se limitou a discutir a biolixiviação bacteriana, que é o foco central da pesquisa, pois a carência de bibliografia nacional sobre este tema motivou a inclusão de todos os métodos e técnicas aplicáveis à remediação de solos contaminados por tais elementos.

\subsection{Conceituação de termos e expressões}

Antes de prosseguir, é de fundamental importância a compreensão dos principais conceitos que serão discutidos a seguir. O manual de áreas contaminadas elaborado pela Companhia de Tecnologia de Saneamento Ambiental - CETESB - em colaboração com o Deutsche Gesellschaft für Technische Zusammenarbeit -GTZ (CETESB; GTZ, 2001), apresenta as seguintes definições para os termos de interesse nesta pesquisa:

Área contaminada: Área onde há comprovadamente poluição causada por quaisquer substâncias ou resíduos que nela tenham sido depositados, acumulados, armazenados, enterrados ou infiltrados, e que determina impactos negativos sobre os bens a proteger;

> Área potencialmente contaminada: Área onde estão sendo desenvolvidas ou onde foram desenvolvidas atividades potencialmente contaminadoras; 
> Área suspeita de contaminação: Área na qual, após a realização de uma avaliação preliminar, foram observadas indicações que induzem a suspeitar da presença de contaminação;

> Atividade potencialmente contaminadora: É aquela em que ocorre o manejo de substâncias cujas características físico-químicas, biológicas e toxicológicas podem acarretar danos aos bens a proteger, caso entrem em contato com os mesmos;

$>$ Bens a proteger: São considerados como bens a proteger:

$\checkmark$ saúde e bem-estar da população;

$\checkmark$ fauna e flora;

$\checkmark$ qualidade do solo, das águas e do ar;

$\checkmark$ interesses de proteção à natureza/paisagem;

$\checkmark$ ordenação territorial e planejamento regional e urbano;

$\checkmark$ segurança e ordem pública.

$>$ Valores de intervenção: São valores-limite usados para induzir medidas de remediação imediata;

> Valores de investigação: São valores-limite para uma investigação simplificada que poderá indicar a necessidade de uma investigação mais detalhada na área avaliada;

> Valores - limite: Teor máximo de determinado elemento ou substância no meio avaliado, que ao ser ultrapassado implica a adoção de ações específicas;

> Valores naturais: São as concentrações observadas naturalmente no solo, água subterrânea e outros meios.

A remediação, que pode ser definida como o conjunto de técnicas utilizadas para reduzir ou eliminar a contaminação do solo, da água superficial ou subterrânea de áreas contaminadas, é uma atividade recente que vem sendo realizada em muitos países ao redor do mundo (PAGE, 1997; GROUDEV et alii, 2001; MULLIGAN; YONG; GIBBS, 2001; GENÇ et alii, 2002; RIVETT et alii, 2002). Sua complexidade e elevado custo tem motivado a busca por tecnologias mais simples e de menor custo, que assegurem resultados similares ou melhores às tecnologias já disponíveis.

Diante das diferentes definições sobre o termo metal pesado, faz-se necessário esclarecer que para efeito deste trabalho, tal termo empregar-se-á tão 
somente aos elementos químicos, reconhecidamente ou potencialmente, capazes de provocar efeitos deletérios à saúde humana e aos ecossistemas.

\subsection{Efeitos dos metais pesados ao Homem}

O breve resumo, apresentado a seguir, sobre os metais pesados $\mathrm{Cd}, \mathrm{Pb}, \mathrm{Ni}$ e Zn, que são as espécies químicas presentes em teores considerados nocivos no solo da área contaminada em estudo, tem por objetivo ilustrar as graves implicações de saúde pública que representam estes elementos, presentes em grande número de áreas contaminadas, haja vista a vasta gama de aplicação destes metais nas mais diferentes atividades industriais desenvolvidas no Brasil e em outros tantos países.

A citação dos danos à saúde humana e aos animais tem caráter puramente informativo, pois os efeitos da exposição a qualquer substância perigosa dependem da dose, duração, forma de exposição, hábitos e peculiaridades das pessoas, animais e ambientes e da presença de outros elementos químicos. Informações detalhadas sobre os efeitos de metais sobre os genes podem ser obtidas em BEYERSMANN (2002).

Investigações toxicológicas e biológicas indicam que metais pesados, como o cádmio ( $\mathrm{Cd}$ ) e o chumbo $(\mathrm{Pb})$, não são essenciais ou benéficos aos organismos vivos, nem mesmo em dosagens consideradas extremamente baixas. Outros metais como níquel (Ni) e zinco ( $\mathrm{Zn}$ ), embora não tipicamente tóxicos, podem assim tornarse, quando em concentrações elevadas. Outro agravante está no fato de estas espécies químicas poderem ser cumulativas em organismos vivos.

O Homem pode ser exposto aos metais pesados através da respiração, ingestão de água e alimentos, contato com mucosas, etc. Estudos recentes relatam a exposição de humanos através da ingestão de frutas e vegetais, produzidos em solos contaminados com metais pesados e sugerem sua associação com 0 crescimento endêmico de casos de câncer gastrintestinal (TÜRKDOGAN et alii, 2002). Mesmo os recém-nascidos já sofrem os efeitos nocivos da contaminação com metais pesados, pois desde sua gestação, estão expostos através da dieta alimentar 
da mãe e, após o nascimento, a todas as fontes ambientais existentes (PATRIARCA et alii, 2000).

O cádmio $(\mathrm{Cd})$ é um elemento químico altamente tóxico ao ser humano, já sendo reconhecido como um elemento carcinógeno pela International Agency for Research on Cancer (BEYERSMANN, 2002; WAISBERG et alii , 2003). Estudos já concluídos (IPCS, 1992; ATSDR, 1999a) apresentaram os seguintes resultados sobre a exposição ao cádmio:

$>$ Para cobaias (ratos e coelhos):

$\checkmark$ Exposição através da inalação de 5 a $20 \mathrm{mg} / \mathrm{m}^{3}$ por 50 a $120 \mathrm{~min}$ : edema pulmonar letal, fibroses e aparecimento de eczemas;

$\checkmark$ Doses a partir de $200 \mathrm{mg} / \mathrm{L}$ em água, administradas por via oral, por um período de onze meses: danos à mucosa gástrica intestinal, elevação da pressão arterial, anemia, doenças do fígado, dano no sistema nervoso;

$\checkmark$ Injeções de 2 a $4 \mathrm{mg} / \mathrm{kg}$ de massa corpórea: necrose nos testículos, ovários, fígado e pequenos danos arteriais.

Para o Homem:

$\checkmark$ Exposição prolongada através da inalação (a partir de $5 \mathrm{mg} / \mathrm{m}^{3}$ por um período de oito horas): pneumonites aguda com edema pulmonar, que pode ser letal;

$\checkmark$ Ingestão de 16 mg de cádmio por litro de água: severa irritação estomacal, indução ao vômito e diarréia;

$\checkmark$ Exposição prolongada através da ingestão de sais solúveis de cádmio (a partir de 2,0 $\mu \mathrm{g} / \mathrm{kg} / \mathrm{dia}$ durante 70 anos): gastroenterite grave; acúmulo de cádmio nos rins, acarretando doenças renais, danos nos pulmões e fragilização dos ossos;

$\checkmark$ Exposição ocupacional prolongada através da inalação (3 a $15 \mathrm{mg} / \mathrm{m}^{3}$ durante 20 anos): severos efeitos crônicos, predominantemente nos pulmões e rins;

$\checkmark$ Efeitos renais crônicos também foram observados entre a população comum.

Segundo WAISBERG et alii (2003), o Cd é um potente carcinógeno e tem sido associado com câncer de pulmão, próstata, pâncreas e rim. Dos efeitos da exposição ao $\mathrm{Cd}$, os problemas renais são os mais comuns na população não ocupacionalmente exposta (BEYERSMANN, 2002). Uma análise profunda sobre os mecanismos celular e molecular da carcinogenicidade do $\mathrm{Cd}$ pode ser encontrada em WAISBERG et alii (2003). 
O chumbo (Pb) apresenta-se, na natureza, na forma de compostos inorgânicos, tais como sulfetos e óxidos; forma sais com ácidos orgânicos (e. g. láctico e acético) e também compostos orgânicos estáveis (e. g. chumbo tetrametila e chumbo tetraetila). A Agency For Toxic Substances and Disease Registry (ATSDR, 1999b) e a United States Environmental Protection Agency (USEPA, 2003b) apresentaram informações sobre os efeitos do chumbo sobre a saúde humana, tomando como base a concentração do metal no sangue. Dentre os principais efeitos incluem-se:

> Decréscimo de quociente de inteligência (QI) a partir de 0,02 mg/dL;

> Efeitos sobre o sistema nervoso, com déficit nas funções cognitivas, a partir de $0,03 \mathrm{mg} / \mathrm{dL}$;

$>$ Diminuição das funções sensoriais motoras, nervosas involuntárias e renais a partir de 0,03 mg/dL;

> Retardamento do crescimento e problemas na audição em crianças a partir de $0,02 \mathrm{mg} / \mathrm{dL}$;

$>$ Possibilidade de partos prematuros e de nascimento de bebês com baixo peso a partir de 0,01 mg/dL;

$>$ Inibição da formação de hemoglobina, provocando um bloqueio metabólico e aumentando as concentrações de PbS no sangue;

$>$ Ataxia, convulsões e até coma.

ORLOV et alii (1991) realizaram um estudo de saúde ocupacional em uma fábrica de PVC (policloreto de vinila), cujos trabalhadores tinham sido expostos a aerossóis e poeira contaminada com $\mathrm{Pb}$, em concentrações de $12,8 \mathrm{mg} \mathrm{Pb} / \mathrm{m}^{3}$ de ar a $1,0 \mathrm{mg} \mathrm{Pb} / \mathrm{m}^{3}$ de ar (valor médio de $0,86 \mathrm{mg} \mathrm{Pb} / \mathrm{m}^{3}$ de ar). Estes autores constataram elevado teor de $\mathrm{Pb}$ nos dentes (166 mg Pb/kg a 57,7 mg Pb/kg) da população de estudo em relação à de controle $(6,2 \mathrm{mg} \mathrm{Pb/kg})$. Foi observada significativa redução das funções motora e sensorial dos trabalhadores sujeitos à contaminação de $12,8 \mathrm{mg} \mathrm{Pb} / \mathrm{m}^{3}$, cuja concentração de $\mathrm{Pb}$ no sangue alcançava 1,8 $\mu \mathrm{molPb} / \mathrm{L}$ (valor médio de 0,59 $\mu \mathrm{mol} \mathrm{Pb} / \mathrm{L}$ ).

Estudos efetuados em seres humanos não comprovaram a carcinogenicidade do $\mathrm{Pb}$, entretanto, roedores expostos a altas doses do metal desenvolveram tumores. Existe a suspeita do acetato e do fosfato de chumbo serem carcinógenos (ATSDR, 1999b; USEPA, 2003b). 
O níquel (Ni) apresenta-se, naturalmente, na forma de óxidos e sulfetos e é amplamente utilizado na produção de ligas metálicas, as quais são empregadas na fabricação de moedas, jóias e peças metálicas em geral. Embora o Ni seja considerado um micronutriente, estudos da ATSDR (1997) apresentaram os seguintes resultados sobre a exposição ao níquel:

$>$ Em cobaias (doses a partir de 0,02 $\mathrm{mg} / \mathrm{kg} . \mathrm{d}$ ):

$\checkmark$ Danos nas mucosas;

$\checkmark$ Reação inflamatória no trato respiratório;

$\checkmark$ Hiperplasia epitelial;

$\checkmark$ Pneumoconiose;

$\checkmark$ Inibição na síntese do DNA;

$\checkmark$ Mutação cromossômica;

$\checkmark$ Danos aos rins e fígado;

$\checkmark$ Fibrose pulmonar, etc.

$>$ Em seres humanos:

$\checkmark$ Sintomas da intoxicação ao carbonil níquel: cefaléia frontal, vertigem, náusea, vômito, insônia, irritabilidade, seguidos por sintomas similares a da pneumonia (doses a partir de $0,02 \mathrm{mg} / \mathrm{kg}$ );

$\checkmark$ A maioria dos efeitos adversos de saúde provocados pelo níquel no Homem é de origem alérgica;

$\checkmark$ As pessoas sensíveis ao níquel podem apresentar erupções na pele e ataques de asma após o contato com o metal $\left(2,0 \mu \mathrm{g} / \mathrm{m}^{3}\right)$;

$\checkmark$ Efeitos crônicos: rinite, sinusite, perfuração do septo nasal, asma, fibrose pulmonar, etc (doses e tempo de exposição variáveis, tipicamente 0,020 $\mathrm{mg} / \mathrm{kg}$.dia).

As principais fontes de contaminação da população não ocupacionalmente exposta ao $\mathrm{Ni}$ são a ingestão de alimentos e água, além do uso de tabaco contaminado com o metal. O Ni foi considerado carcinógeno pela Organização Mundial da Saúde em 1998.

O zinco ( $\mathrm{Zn})$ é elemento essencial para seres humanos, animais e vegetais superiores, sendo também considerado micronutriente das plantas. Não há comprovação científica da carcinogenicidade do Zn para animais ou seres humanos, embora tenha sido demonstrado que ele inibe a ação mutagênica de alguns carcinógenos genotóxicos, por outro lado, há evidências que apontam que ele 
também pode ser um co-carcinógeno (USEPA, 1992; WHO, 2001). Estudos da WHO (2001) apresentaram os seguintes resultados sobre a exposição ao Zn:

$>$ Em cobaias (exposição prolongada):

$\checkmark$ Via oral: efeitos no sistema hematopoético, rins e pâncreas, efeitos sobre a reprodução (doses a partir de $150 \mathrm{mg} / \mathrm{kg} / \mathrm{dia}$ nos alimentos administradas durante cinco meses). No geral, o aumento da ingestão de zinco provocou danos à reprodução.

$>$ Em seres humanos:

$\checkmark$ Intoxicação (exposição única e breve ao zinco presente na água ou em bebidas em concentrações de 1000 a 2500 mg/L): mal estar gastrintestinal, náuseas e diarréia;

$\checkmark$ Ingestão desproporcional de zinco em relação ao cobre induz deficiência deste último (doses a partir de 0,3 mg/kg.dia);

$\checkmark$ Ingestão de fármacos contendo zinco tem sido associada a efeitos que vão desde leucopenia e/ou anemia microcítica hipocrômica até a diminuição de concentração de proteínas. Todavia, este quadro foi revertido ao interromperse a terapia com zinco e administrar suplemento de cobre.

\subsection{Dinâmica e comportamento dos metais pesados no solo}

Segundo MCLEAN; BLEDSOE (1992), a mobilidade do metal no solo é determinada pelo tipo e pela quantidade de solo superficial presente, pelo teor do metal de interesse, pelo teor e tipo de íons competitivos e de agentes ligantes (orgânicos e inorgânicos), pelo pH e pelo potencial redox do solo.

Estes autores ressaltaram que a generalização pode servir apenas como um guia grosseiro do comportamento dos metais no solo e que o uso de dados de literatura ou de laboratório, que não retratem adequadamente as características do solo e dos contaminantes da área de interesse, não é adequado para a descrição ou a previsão do comportamento esperado para um dado metal.

Outros fatores que precisam ser considerados sobre a mobilidade de metais no solo são os efeitos de longa duração, que incluem a degradação de compostos orgânicos e a mudança, através de alterações naturais ou decorrentes da atividade 
antrópica, do $\mathrm{pH}$ ou do potencial redox do solo (MCLEAN; BLEDSOE, 1992; STUMM, 1992; LAL; STEWART, 1994; EVANGELOU, 1998). O transporte de material particulado coloidal e o carbono orgânico dissolvido também afetam a mobilidade dos metais no solo.

Importante salientar que a simples presença de metais no solo não é indicativa de contaminação, pois pode ser devido à sua formação geológica, ou seja, é originária da matriz pedológica parental (BOHN; MCNEAL; O'CONNOR, 1985; LAL; STEWART, 1994; EVANGELOU, 1998).

\subsubsection{Química do solo}

Segundo CAMARGO; ALLEONI; CASAGRANDE (2001), a aplicação do conhecimento dos princípios químicos gerais, que podem afetar as reações dos metais no solo, é um caminho eficaz para o entendimento dos processos envolvidos em sua mobilidade e comportamento.

Seguindo esta abordagem, é importante notar que no solo, os cálculos de equilíbrio de reações químicas são normalmente executados na solução do solo, o qual pode apresentar considerável salinidade ou mesmo tão baixa concentração iônica quanto à da água destilada. Logo, faz-se necessário calcular o equilíbrio em ampla faixa de concentração do íon de interesse.

As forças interiônicas de atração entre partículas de cargas elétricas opostas prejudicam significativamente sua mobilidade na solução, além de alterar sua capacidade de manifestar plenamente sua concentração (Teoria de Debye-Hückel) (STUMM, 1992, EVANGELOU, 1998). A intensidade do comportamento de uma espécie iônica em meio aquoso é resultado de todas estas influências, logo, a concentração efetiva deve ser distinta da concentração verdadeira.

Quando uma solução iônica está muito diluída, a concentração efetiva se aproxima da verdadeira e, teoricamente, quando a diluição for infinita (caso em que os íons estariam tão distantes entre si que não exerceriam influência elétrica uns sobre os outros), os valores numéricos de ambas as concentrações seriam iguais (BOHN; MCNEAL; O'CONNOR, 1985; EVANGELOU, 1998; CAMARGO; ALLEONI; CASAGRANDE, 2001). Os autores alertam que embora o procedimento de utilizar a 
concentração verdadeira (e. g. mol/L) seja mais freqüente, há situações em que tal procedimento introduz erros grosseiros, que resultam em sérios desvios das manifestações químicas (atividades) daquelas mostradas pelos valores das concentrações.

Portanto, cabe ressaltar que, terminologicamente, a concentração termodinâmica ou atividade deve ser diferenciada da concentração química (ou apenas concentração). A Equação 1 mostra a relação existente entre a atividade do íon (concentração efetiva) e sua concentração verdadeira:

$\gamma_{i}=a_{i} / c_{i}$

Onde:

$a_{i}=$ atividade do íon (concentração efetiva)

$\mathrm{C}_{\mathrm{i}}=$ concentração verdadeira (e. g. mol/L)

$\gamma_{i}=$ coeficiente de atividade (representa o fator de correção da condição ideal para a real)

Importante notar que soluções iônicas com baixa concentração, onde os íons podem manifestar sua atividade sem interferências, $a_{i}=c_{i}$ e $\gamma_{i}=1$. Já para soluções com alta concentração iônica, $a_{i}<c_{i}$ e $\gamma_{i}<1$.

Durante o processo de distribuição de cádmio $(\mathrm{Cd})$, cromo $(\mathrm{Cr})$, cobre $(\mathrm{Cu})$, mercúrio $(\mathrm{Hg})$, chumbo $(\mathrm{Pb})$ e zinco $(\mathrm{Zn})$ nas camadas do solo, os raios iônicos exercem um importante papel nesta separação.

Há correlação positiva entre a quantidade de metal extraída e o teor de argila das amostras em função da diminuição dos raios iônicos dos elementos, sendo esta relação linear para elementos com número de coordenação seis $(\mathrm{Cu}, \mathrm{Cr}$ e Zn). Uma explicação para tal comportamento é que, durante os processos de intemperismo e de formação do solo, estes elementos são aprisionados em posições octaedrais nos minerais secundários e são mais fortemente retidos quanto menores forem seus tamanhos (CAMARGO, ALLEONI, CASAGRANDE, 2001).

Os elementos $\mathrm{Cd}$ e $\mathrm{Pb}$, cujos números de coordenação são maiores que seis, são muito grandes para ocupar as posições octaedrais e são mais bem correlacionados com a quantidade de matéria orgânica, o que evidencia sua ligação com o material húmico (STUMM, 1992; EVANGELOU, 1998; CAMARGO, ALLEONI, CASAGRANDE, 2001). 
Enfim, diversas são as variáveis que afetam a mobilidade de metais no solo e para o entendimento destes fenômenos, é fundamental o conhecimento e a compreensão da química da solução do solo, a qual será abordada, sucintamente, nos próximos parágrafos.

Os metais podem existir sob várias formas químicas na solução do solo, tanto como íons livres (e.g. $\mathrm{Cd}^{2+}, \mathrm{Zn}^{2+}, \mathrm{Pb}^{2+}$ ), complexos orgânicos e inorgânicos solúveis (e. g. $\mathrm{ZnCl}^{+}, \mathrm{CdCl}_{3}^{-}$), associados à matéria orgânica coloidal e compostos inorgânicos móveis (MCLEAN; BLEDSOE, 1992; LAL; STEWART, 1994; EVANGELOU, 1998).

A Figura 1 mostra os processos que controlam a concentração dos metais na solução do solo.

Um complexo é definido como uma unidade na qual o íon metálico central é ligado por um número de átomos ou moléculas associadas de forma definida (e.g. $\mathrm{ZnSO}_{4}, \mathrm{CdHCO}_{3}{ }^{+}, \mathrm{Cr}(\mathrm{OH})_{4}{ }^{-}$). Já o átomo ou molécula associado(a) é denominado(a) ligante. A concentração total de metal no solo é a soma das concentrações do íon livre, dos complexos orgânicos ou inorgânicos solúveis e do metal associado com a matéria orgânica coloidal ou com compostos inorgânicos (BOHN; MCNEAL; O'CONNOR, 1985; EVANGELOU, 1998).

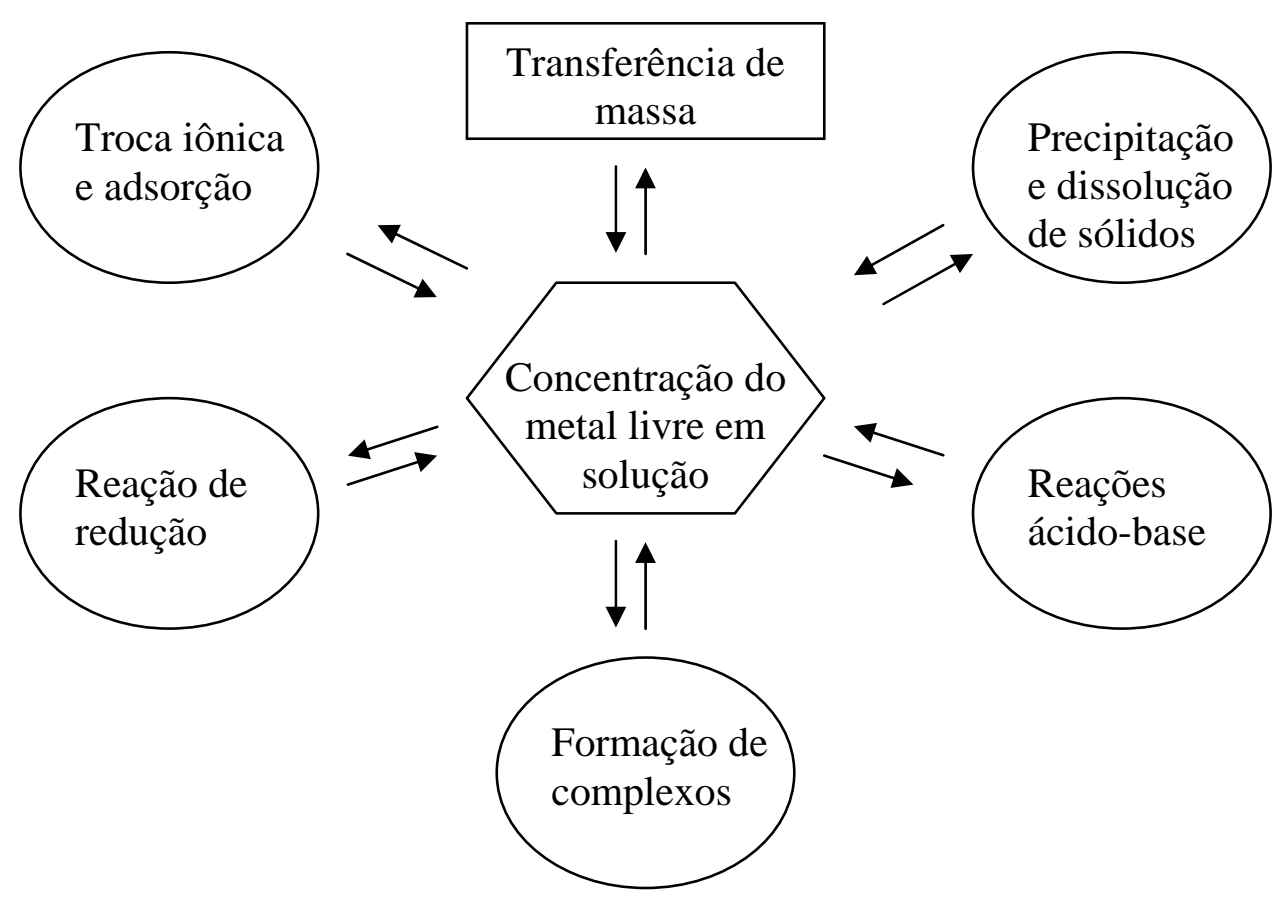

Figura 1 - Principais reações de metais na solução do solo.

Fonte: MATTIGOD et alii (1981) apud MCLEAN; BLEDSOE (1992). 
Os metais formam complexos solúveis tanto com ligantes orgânicos quanto com inorgânicos. Dentre estes, incluem-se $\mathrm{SO}_{4}{ }^{2-}, \mathrm{Cl}^{-}, \mathrm{OH}^{-}, \mathrm{PO}_{4}{ }^{3-}, \mathrm{NO}_{3}{ }^{-}$e $\mathrm{CO}_{3}{ }^{2-}$ (BOHN; MCNEAL; O'CONNOR, 1985; EVANGELOU, 1998). Os compostos alifáticos de baixo peso molecular, os aromáticos, aminoácidos e constituintes solúveis de ácidos fúlvicos estão entre os ligantes orgânicos (BOHN; MCNEAL; O'CONNOR, 1985; LAL; STEWART, 1994; EVANGELOU, 1998).

A complexação orgânica de metais não é tão bem definida quanto a inorgânica, fato que decorre da dificuldade de identificar o elevado número de ligantes orgânicos que podem estar presentes no solo (LAL; STEWART, 1994; MCLEAN; BLEDSOE, 1992).

A presença de espécies complexas na solução do solo pode afetar significativamente o transporte de metais através do mesmo, em relação ao íon metálico. Com a complexação, a espécie metálica resultante pode adquirir uma carga elétrica positiva, negativa ou neutra $-\mathrm{CdCl}_{3}{ }^{-}, \mathrm{CdCl}^{+}, \mathrm{CdCl}_{2}(\mathrm{BOHN} ; \mathrm{MCNEAL}$; O'CONNOR, 1985; STUMM, 1992; EVANGELOU, 1998). O complexo metálico pode ser mais fracamente ou mais fortemente adsorvido na superfície dos constituintes minerais do solo em relação ao íon metálico livre.

A especiação do metal não afeta apenas sua mobilidade no solo como também sua biodisponibilidade e toxicidade. O íon metálico livre é, em geral, a forma mais biodisponível e tóxica (MCLEAN; BLEDSOE, 1992; EVANGELOU, 1998).

Segundo MCLEAN; BLEDSOE (1992), os métodos de previsão baseados na química da solução e da fase sólida não simulam adequadamente o transporte de metais sob condições de campo, pois a química do solo descreve a interação entre as espécies dissolvidas, termo definido como as substâncias que passam por um filtro com diâmetro de poro de 0,45 $\mu \mathrm{m}$.

Entretanto, os metais podem estar associados com partículas coloidais móveis, que incluem óxidos de ferro e manganês, argilominerais e matéria orgânica, cujas superfícies têm elevada capacidade para sorver metais (BOHN; MCNEAL; O'CONNOR, 1985; LAL; STEWART, 1994). Este acréscimo do transporte de contaminantes associado com material coloidal tem sido denominado de transporte facilitado. 


\subsubsection{Formação da fase sólida}

Dentre as reações e processos químicos que os metais estão sujeitos na solução do solo incluem-se a formação da fase sólida (BOHN; MCNEAL; O'CONNOR, 1985; MCLEAN; BLEDSOE, 1992; EVANGELOU, 1998).

De modo geral, os metais podem precipitar e formar uma fase sólida tridimensional, cujo precipitado pode ser um sólido puro (e. g. $\mathrm{CdCO}_{3}, \mathrm{~Pb}(\mathrm{OH})_{2}$, $\mathrm{ZnS}_{2}$ ) ou misto (e. g. $\mathrm{Fe}_{\mathrm{x}} \mathrm{Cr}_{1-\mathrm{x}}(\mathrm{OH})_{3}, \mathrm{Ba}\left(\mathrm{CrO}_{4}, \mathrm{SO}_{4}\right)$ ). Estes últimos são formados quando os diferentes elementos presentes no sistema co-precipitam.

Íons como fosfato, sulfato, sulfeto e carbonato podem interferir nas relações de solubilidade dos elementos metálicos e formar precipitados pouco solúveis. A maior parte dos metais divalentes forma fosfato com fórmula geral $\mathrm{M}_{3}\left(\mathrm{PO}_{4}\right)_{2} \mathrm{nH}_{2} \mathrm{O}$, onde $\mathrm{M}$ é o metal e $\mathrm{n}$ o número de moléculas de água (BOHN; MCNEAL; O'CONNOR, 1985; CAMARGO; ALLEONI; CASAGRANDE, 2001).

$\mathrm{O}$ íon fosfato é o único estado oxidado estável. Os íons $\mathrm{H}_{2} \mathrm{PO}_{4}{ }^{-}$e $\mathrm{HPO}_{4}{ }^{2-}$ são, respectivamente, predominantes em soluções ácidas e básicas. Em solos ácidos, o fosfato está associado com o cálcio. O fosfato, quando adicionado ao solo, é primeiro adsorvido rapidamente e depois é fixado, provavelmente, por precipitação, em formas menos solúveis. Sua fixação é apreciável em todos os tipos de solo, mas principalmente elevada naqueles ricos em hidróxidos de ferro e alumínio amorfos (BOHN; MCNEAL; O'CONNOR, 1985).

Há diversos tipos de co-precipitação: inclusão, adsorção e formação da fase sólida, as quais são distinguidas pelo tipo de associação entre o elemento traço e o mineral hospedeiro. A formação da fase sólida ocorre quando o elemento traço é compatível com o do mineral hospedeiro, que então pode substituí-lo uniformemente.

Os mecanismos de retenção: adsorção superficial, precipitação superficial, co-precipitação e formação da fase sólida pura são difíceis de distinguir experimentalmente. Portanto, o termo sorção é utilizado quando não se sabe qual é o mecanismo responsável pela remoção do metal da solução do solo (LAL; STEWART, 1994).

O comportamento esperado para espécies catiônicas é a redução de sua solubilidade com o aumento do pH (BOHN; MCNEAL; O'CONNOR, 1985; STUMM, 
1992; EVANGELOU, 1998). A atividade da solução de Cd é consideravelmente maior do que a do $\mathrm{Pb}$, comportamento que indica que o primeiro pode ser mais móvel no ambiente.

A formação da fase sólida pode não ser um importante mecanismo comparado com a adsorção em solos naturais, devido às baixas concentrações de elementos-traço nestes sistemas. Todavia, reações de precipitação podem ter importância significativa em sistemas onde as concentrações de metais são elevadas, caso de áreas contaminadas.

$\mathrm{Na}$ fase sólida, pode ocorrer o acúmulo de elementos químicos mediante diferentes vias, com diversos níveis energéticos, que estabelecem a maior ou menor reversibilidade de suas reações de precipitação, dissolução, adsorção e de óxidoredução. Tais reações é que determinam a quantidade do elemento que estará disponível na solução do solo (BOHN; MCNEAL; O'CONNOR, 1985; CAMARGO; ALLEONI; CASAGRANDE, 2001).

\subsubsection{Reações de superfície}

A adsorção difere da precipitação, pois o metal não forma uma nova fase sólida tridimensional; ao invés disso, associa-se à superfície das partículas de solo (BOHN; MCNEAL; O'CONNOR, 1985; STUMM, 1992; EVANGELOU, 1998). A matriz do solo inclui matéria orgânica; argilominerais; óxidos de ferro, alumínio e manganês; hidróxidos; carbonatos e aluminossilicatos amorfos.

\subsubsection{Matéria orgânica}

A fração orgânica do solo é composta de organismos vivos, plantas mortas e resíduos de animais. Em massa, a fração orgânica é a porção mais quimicamente ativa do solo; funciona como um reservatório de vários elementos essenciais; confere uma boa estrutura ao solo; é uma fonte de capacidade de troca catiônica e 
de tamponamento de $\mathrm{pH}$; promove boa relação ar-água; é a maior fonte geoquímica de carbono no solo (BOHN; MCNEAL; O'CONNOR, 1985).

Sob a ótica estritamente química, a matéria orgânica do solo é formada basicamente por dois grupos de compostos principais, os compostos não nitrogenados; formados principalmente por carbohidratos; e os compostos nitrogenados; derivados principalmente de proteínas (BOHN; MCNEAL; O'CONNOR, 1985; EVANGELOU, 1998). Outra subdivisão grosseira da matéria orgânica é entre fração húmica e não húmica (VERNET, 1991).

Dentre os compostos que integram a matéria orgânica do solo inclui-se: sacarídeos, aminoácidos, aminoácidos, aminoácidos heterocíclicos, amidos. Tais compostos surgem da decomposição da matéria orgânica vegetal, promovida por microrganismos e que tem como produto final, o humus. A matéria orgânica encontrada nos solos é composta, principalmente, por substâncias húmicas e pode atingir expressiva participação na composição do solo, mas raramente atinge até 75 \% em massa (BOHN; MCNEAL; O'CONNOR, 1985; VERNET, 1991; EVANGELOU, 1998).

Substâncias húmicas são definidas como polímeros condensados de compostos aromáticos e alifáticos, produzidos pela decomposição de resíduos de plantas e animais, mediada pela síntese microbiológica. São substâncias amorfas, de cor escura, hidrofílicas, têm ampla variação de peso molecular e com base em seu comportamento de solubilidade, são divididas em três principais grupos: a) ácidos húmicos, solúveis em álcali diluído, mas precipitados em solução ácida; b) ácidos fúlvicos, solúveis em solução alcalina e ácida; c) humina, insolúvel em solução alcalina e ácida (BOHN; MCNEAL; O'CONNOR, 1985; VERNET, 1991; EVANGELOU, 1998).

As substâncias húmicas exibem: polifuncionalidade devido a ampla faixa de reatividade do grupo funcional; carga molecular negativa, devido à dissociação de prótons dos vários grupos funcionais; hidrofilia, devido à formação de fortes ligações de hidrogênio com a água das moléculas; confiabilidade estrutural, devido à associação intramolecular e mudanças da conformação molecular em resposta às alterações de $\mathrm{pH}$, potencial redox, concentração de eletrólito e ligação com grupos funcionais (BOHN; MCNEAL; O'CONNOR, 1985; VERNET, 1991; EVANGELOU, 1998). 
Em pH baixo, as moléculas de ácido húmico são agregadas sob a forma de partículas coloidais de baixa ou nenhuma carga, que precipitam. Nesta condição, os ácidos húmicos e fúlvicos podem ser separados (VERNET, 1991).

Ligações de metais com matéria orgânica envolvem um contínuo de sítios reativos, variando de forças fracas de atração até fortes ligações químicas. As substâncias bioquímicas e húmicas fornecem sítios - grupos funcionais ácidos, tais como o carboxílico, o fenólico, o alcoólico e o amino - para adsorção do metal. Nos solos não contaminados, as substâncias húmicas são de origem natural, mas em solos contaminados, os polímeros podem ter como origem o descarte de resíduos ou águas residuárias no solo (BOHN; MCNEAL; O'CONNOR, 1985; VERNET, 1991; MCLEAN; BLEDSOE, 1992; STUMM, 1992).

Segundo CAMARGO; ALLEONI; CASAGRANDE (2001), embora a ligação entre metal e matéria orgânica possa ser vista como do tipo troca iônica entre o íon $\mathrm{H}^{+}$dos grupos funcionais e os íons metálicos, o alto grau de seletividade exibido pelas substâncias húmicas por certos metais sugere que eles coordenem diretamente com aqueles grupos, formando complexos de esfera interna.

As reações químicas de superfície produzem cargas elétricas que dependem do grau de ionização e do pH da solução e estão associadas com as bordas dos argilominerais, com as superfícies de óxidos, hidróxidos e carbonatos e com a matéria orgânica (grupos funcionais ácidos). As cargas surgem da associação e dissociação de prótons da superfície de grupos funcionais. O desenvolvimento de cargas na matéria orgânica é inteiramente dependente do pH e está principalmente associada com a dissociação do $\mathrm{H}^{+}$dos grupos carboxílico e fenólico (BOHN; MCNEAL; O'CONNOR, 1985).

Segundo SPOSITO (1989), quando as moléculas de solvatação de um cátion na solução do solo se orientam e estabelecem interações de ordem eletrostática com os grupos funcionais da matéria orgânica, é formado um complexo de esfera externa. Quando as moléculas de água que solvatam um cátion são trocadas pelos grupamentos funcionais e o cátion passa a se coordenar diretamente aos mesmos por meio de ligações covalentes, é formado um complexo chamado de esfera interna. A Figura 2 mostra, de forma esquemática, os complexos de esfera interna e externa. 


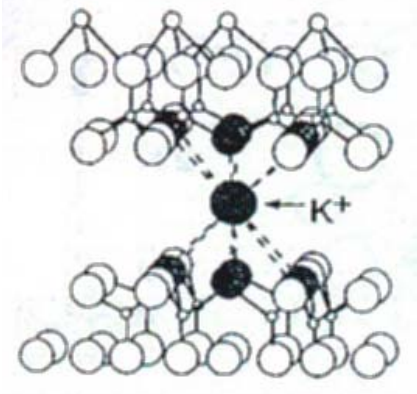

Complexo superficial de esfera interna: $\mathrm{K}^{+}$em vermiculita

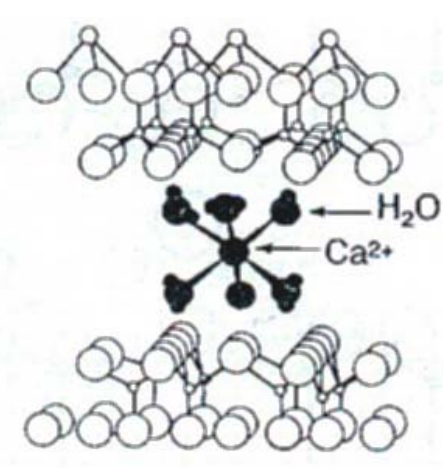

Complexo superficial de esfera externa:

$\mathrm{Ca}\left(\mathrm{H}_{2} \mathrm{O}_{6}\right)^{2+}$ em montmorilonita

Figura 2 - Representação esquemática entre complexos de esferas interna e externa com cátions metálicos e cavidades ditrigonais siloxane 2:1 de argilominerais.

Fonte: SPOSITO (1984) apud EVANGELOU (1998).

\subsubsection{Argilominerais, óxidos, hidróxidos e carbonatos}

As partículas inorgânicas coloidais do solo são compostas, basicamente, por argilominerais e óxidos e hidróxidos de ferro, de alumínio e de manganês. O grupo dos argilominerais inclui a caulinita, a haloisita, a montmorilonita, a ilita, a clorita e a vermiculita com hidróxido de alumínio entre camadas. Estes argilominerais sofrem modificações estruturais durante o processo de intemperismo, que provocam o aparecimento de cargas negativas em suas superfícies (BOHN; MCNEAL; O'CONNOR, 1985; CAMARGO; ALLEONI; CASAGRANDE, 2001).

Segundo STUMM (1992), as superfícies das partículas sólidas podem desenvolver cargas elétricas através de três vias principais: a) reações químicas de superfície; b) imperfeições na superfície sólida causada por substituições isomórficas internas; c) adsorção de espécies hidrofóbicas ou surfactantes.

De maneira geral os óxidos de Fe e Mn são os principais componentes do solo, que controlam a mobilidade dos metais. Em solos áridos, carbonatos minerais podem imobilizar metais, provendo uma superfície de adsorção e nucleação (MCLEAN; BLEDSOE, 1992).

Os óxidos metálicos e outros não silicatos ou silicatos minerais exibem cargas, devido à protonação e à desprotonação do oxigênio coordenado ao metal $\left(\mathrm{Fe}^{3+}, \mathrm{Mn}^{3+}, \mathrm{Mn}^{4+}, \mathrm{Al}^{3+}\right.$ e $\left.\mathrm{Si}^{4+}\right)$ e de grupos funcionais de superfície. Tais cargas, 
positivas ou negativas, são dependentes do $\mathrm{pH}$ e podem variar de $1 \mathrm{mmol} / 100 \mathrm{~g}$ de solo a $30 \mathrm{meq} / 100 \mathrm{~g}$ de solo (EVANGELOU, 1998).

Tanto as cargas negativas ou positivas geradas nestas condições são chamadas de dependentes, pois são modificadas pelo $\mathrm{pH}$, pela força iônica da solução e pela valência do íon predominante. Sob condições mais ácidas, a maioria das superfícies estará carregada positivamente e sob condições mais alcalinas, negativamente (STUMM, 1992, CAMARGO; ALLEONI; CASAGRANDE, 2001).

Os óxidos minerais de ferro, alumínio, titânio, manganês e magnésio não possuem carga permanente, conseqüentemente, sua capacidade de troca catiônica ou aniônica depende do pH do sistema. Soluções de solo que contenham grande quantidade de óxidos de ferro e alumínio têm cargas com forte dependência do $\mathrm{pH}$ e valores muito variáveis de capacidade de troca catiônica (BOHN; MCNEAL; O'CONNOR, 1985).

As imperfeições na superfície sólida, causadas por substituições isomórficas internas, produzem cargas elétricas superficiais permanentes nas partículas, ou seja, tais cargas não dependem do pH ou da concentração iônica da solução que as rodeia. As cargas negativas permanentes nas superfícies resultam da substituição isomórfica (ou iônica) do $\mathrm{Si}^{4+}$ pelo $\mathrm{Al}^{3+}$ em camadas tetraédricas e/ou na substituição do $\mathrm{Al}^{3+}$ pelo $\mathrm{Mg}^{2+}, \mathrm{Fe}^{2+}$ e outros cátions divalentes nas camadas octaédricas de argilas de aluminosilicatos (BOHN; MCNEAL; O'CONNOR, 1985; STUMM, 1992; MCLEAN; BLEDSOE, 1992; CAMARGO; ALLEONI; CASAGRANDE, 2001).

A adsorção de uma espécie hidrofóbica ou um surfactante pode estabelecer uma carga elétrica superficial em uma partícula, pois a adsorção preferencial de uma superfície iônica ativa pode surgir de uma ligação hidrofóbica, de uma ligação do tipo ponte de hidrogênio ou de forças de London-van der Waals. Espécies iônicas, carregando um radical hidrofóbico, podem ligar-se intra ou extra esfericamente na superfície hidratada de uma partícula (STUMM, 1992; EVANGELOU, 1998).

Como descrito anteriormente, diferentes tipos de cargas de superfície contribuem para a carga total das partículas, logo, o estado elétrico da superfície depende da distribuição das cargas livres - eletrônica ou iônica - em sua vizinhança. Tal distribuição é normalmente idealizada como uma dupla camada elétrica; uma camada é imaginada como uma carga fixa ou uma carga superficial anexa à superfície da partícula sólida, enquanto a outra é distribuída mais ou menos 
difusamente no líquido em contato. A Figura 3 mostra uma representação esquemática da dupla camada.

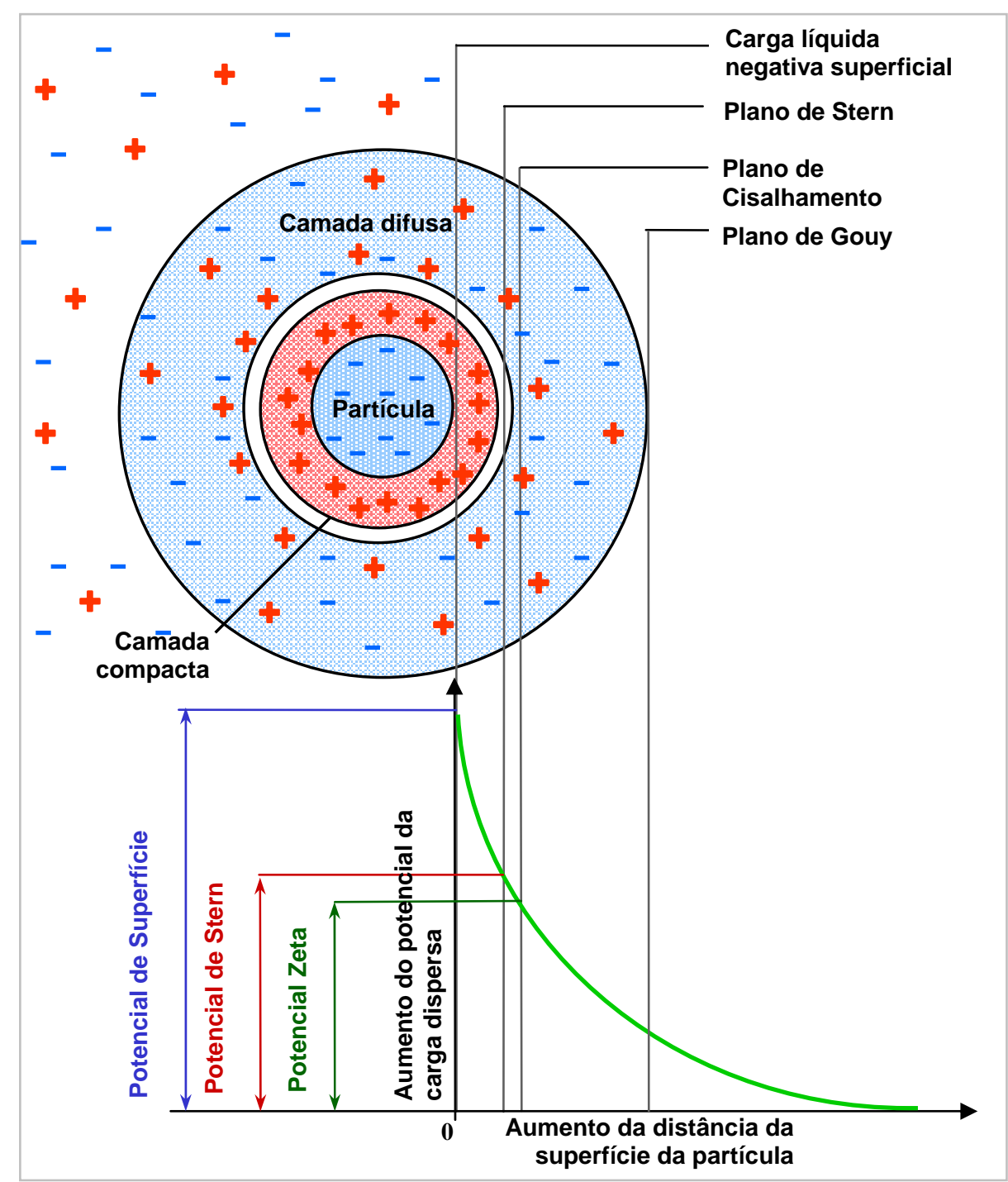

Figura 3 - Representação esquemática da dupla camada.

Fonte : QMCWEB (2006).

Tal modelo é conhecido como de Gouy-Chapman (BOHN; MCNEAL; O'CONNOR, 1985; STUMM, 1992). Para contornar as dificuldades deste modelo, devido às pequenas distâncias e elevado potencial de superfície, condição que resulta em concentração muito elevada de íons próximos à superfície, Stern sugeriu que esta fosse dividida em duas partes: a primeira, constituída de uma camada compacta de íons adsorvidos na superfície e, a segunda, de uma camada difusa. No tratamento de Stern, $\mathrm{o} \mathrm{H}^{+}$e $\mathrm{OH}^{-}$são incorporados no sólido e os íons adsorvidos especificamente são alocados em um plano separado do sólido por uma curta distância. No modelo de formação de complexos superficiais, tanto os íons 
adsorvidos quanto $\mathrm{O} \mathrm{H}^{+}$e $\mathrm{OH}^{-}$pertencem à fase sólida (BOHN; MCNEAL; O'CONNOR, 1985; STUMM, 1992).

A capacidade de troca catiônica é uma medida da capacidade de adsorção de cátions pelos sítios de carga negativa do solo. Este fenômeno possui as seguintes características: é reversível; é controlado pela difusão iônica; é estequiométrico; na maioria dos casos, há seletividade ou preferência de um íon por outro, que está relacionada com o raio iônico hidratado e com a energia de hidratação dos cátions de mesma valência. Um íon de raio iônico hidratado grande é retido com menor intensidade, enquanto que um íon de raio menor chega mais perto da superfície (BOHN; MCNEAL; O'CONNOR, 1985; CAMARGO; ALLEONI; CASAGRANDE 2001).

Diversos tipos de complexos podem ser formados entre o metal e os grupos funcionais da superfície do solo. Metais em associação com um íon difuso ou em um complexo externo estão rodeados por água de hidratação e não estão diretamente ligados à superfície do solo. Estes íons acumulam-se na interface das superfícies carregadas em resposta às forças eletrostáticas. Estas reações são rápidas e reversíveis, com uma fraca dependência da configuração eletrônica da superfície do grupo e do íon adsorvido.

Estas duas interações metal-superfície também têm sido denominadas de reações de troca, devido à introdução de outros cátions no sistema. Em concentrações suficientes, estes causam a substituição ou troca do cátion original. Metais associados com sítios de troca podem, dependendo do ambiente, ser relativamente móveis.

$\mathrm{Na}$ complexação de esfera interna, o metal está ligado diretamente à superfície do solo e não há água de hidratação, o que é distinguido do estado trocável, pela ligação ter um caráter iônico e/ou covalente entre o metal e a superfície. Uma energia de ligação muito maior está envolvida do que em reações de troca e esta depende da configuração eletrônica do metal e da superfície do solo. Este mecanismo de adsorção é chamado de específica.

O termo "específica" implica que existem diferenças na energia de adsorção entre cátions, tais que outros íons, incluindo o $\mathrm{Na}^{+}, \mathrm{Ca}^{2+}, \mathrm{Mg}^{2+}$, não competem efetivamente pelos sítios ativos. Cátions metálicos especificamente adsorvidos são relativamente imóveis e não são afetados por altas concentrações dos principais 
cátions, em virtude de grande diferença de suas energias de adsorção (MCLEAN; BLEDSOE, 1992).

A afinidade relativa da superfície do solo por um cátion metálico cresce com a tendência deste em formar ligações fortes, isto é, complexos internos nas esferas com as superfícies. A ordem geral de preferência por cátions monovalentes pela montmorilonita é $\mathrm{Cs}>\mathrm{Rb}>\mathrm{K}=\mathrm{NH}_{4}>\mathrm{Na}>\mathrm{Li}$ (BOHN; MCNEAL; O'CONNOR, 1985; MCLEAN; BLEDSOE, 1992; STUMM, 1992; EVANGELOU, 1998). Para os metais alcalinos terrosos, a ordem é: $\mathrm{Ba}>\mathrm{Sr}>\mathrm{Ca}>\mathrm{Mg}$. A série de preferência indica uma maior atração do cátion menos hidratado pela superfície.

Para metais de transição, o tamanho do cátion hidratado não pode ser usado como único modo de prever a tendência à adsorção, pois a configuração eletrônica do metal desempenha um papel importante neste fenômeno. A Tabela 1 mostra a afinidade relativa da sorção de alguns metais para alguns tipos de solos e minerais. Embora exista uma elevada afinidade destas superfícies por $\mathrm{Pb}$ e $\mathrm{Cu}$, comparado com Zn e Cd, a ordem específica da afinidade de sorção depende das propriedades dos metais, tipo de superfície e condições experimentais.

Tabela 1 - Afinidade relativa de sorção de metais em alguns tipos de solo e minerais.

\begin{tabular}{ll}
\hline Solo ou constituinte do solo & Ordem relativa de sorção \\
\hline Goethita & $\mathrm{Cu}>\mathrm{Pb}>\mathrm{Zn}>\mathrm{Co}>\mathrm{Cd}$ \\
Óxido de ferro & $\mathrm{Pb}>\mathrm{Cu}>\mathrm{Zn}>\mathrm{Cd}$ \\
Montmorilonita & $\mathrm{Cd}=\mathrm{Zn}>\mathrm{Ni}$ \\
Caulinita & $\mathrm{Cd}>\mathrm{Zn}>\mathrm{Ni}$ \\
Solos & $\mathrm{Pb}>\mathrm{Cu}>\mathrm{Zn}>\mathrm{Cd}>\mathrm{Ni}$ \\
Solos & $\mathrm{Zn}>\mathrm{Ni}>\mathrm{Cd}$ \\
Solos minerais & $\mathrm{Pb}>\mathrm{Cu}>>\mathrm{Zn}>\mathrm{Cd}$ \\
Solos orgânicos & $\mathrm{Pb}>\mathrm{Cu}>>\mathrm{Cd}>\mathrm{Zn}$ \\
Solo & $\mathrm{Pb}>\mathrm{Cu}>>\mathrm{Zn}>\mathrm{Ni}$ \\
\hline
\end{tabular}

Fonte: MCLEAN; BLEDSOE (1992). 


\subsubsection{Isotermas de adsorção}

A capacidade de adsorção do solo é determinada pelo número e pelo tipo de sítios disponíveis. A adsorção do cátion metálico tem sido correlacionada com propriedades do solo como $\mathrm{pH}$, potencial de óxido-redução, conteúdo de argila, matéria orgânica, óxidos de Fe e $\mathrm{Mn}$ e carbonato de cálcio. Os processos de adsorção são afetados por diversos destes fatores, além da forma do metal adicionado ao solo e do solvente introduzido junto com o metal. Os resultados destas interações podem aumentar ou diminuir o movimento dos metais na água do solo (EVANGELOU, 1998).

Estudos de sorção são normalmente conduzidos para avaliar a extensão da retenção de um metal por um solo ou um de seus constituintes. Podem, ainda, ser utilizados como uma tentativa de gerar o coeficiente de distribuição no equilíbrio e também para a comparação da retenção relativa de diversos metais por um solo ou pela retenção relativa de um metal por diversos tipos de solo. Tais estudos também são usados para avaliar o efeito causado por mudanças em parâmetros da solução do solo (e. g. pH, força iônica, adição de cátions competitivos, adição de ligantes orgânicos ou inorgânicos) sobre a retenção do metal (STUMM, 1992; EVANGELOU, 1998).

As equações mais freqüentemente usadas, por sua relativa simplicidade, para descrever o comportamento da sorção de metais em solo são as de Langmuir e de Freundlich (STUMM, 1992; EVANGELOU, 1998).

A equação de Langmuir foi desenvolvida para modelar a adsorção de um gás sobre superfícies sólidas. A derivação desta equação foi baseada na suposição que a adsorção é independente da cobertura da superfície, que não existe interação entre íons adsorvidos e que, somente uma monocamada de adsorção é formada. Estas condições não são tipicamente encontradas na sorção de metais no solo. A equação de Freundlich é uma equação derivada empiricamente para descrever a redução logarítmica na energia de adsorção com relação ao aumento da superfície coberta (STUMM, 1992; EVANGELOU, 1998).

As expressões das isotermas de Langmuir e de Freundlich têm provado serem valiosas na interpretação do comportamento de metais em solos. As equações das isotermas de adsorção foram, entretanto, desenvolvidas para modelar 
a adsorção de gás em sólidos. Entretanto, a sorção de metais por sólidos viola muitas das suposições associadas com tais equações. Também, o mecanismo descrito por estas equações é adsorção, mas é impossível distinguir entre reações de adsorção e de precipitação no solo (MCLEAN; BLEDSOE, 1992; STUMM, 1992; EVANGELOU, 1998).

Equações de isotermas de adsorção não deveriam ser utilizadas para indicar mecanismos sem evidências adicionais, mas elas podem ser usadas para a descrição empírica de dados. Portanto, a aplicabilidade de equações de isotermas de adsorção para a interpretação do fenômeno químico do solo é um assunto controverso.

\subsection{Tecnologias de remediação de áreas contaminadas com metais pesados}

A seleção da(s) técnica(s) a ser(em) utilizada(s) em um projeto de remediação de solo contaminado apresenta como fatores comuns à maioria das referências bibliográficas consultadas: características do sítio, teores e tipos de poluentes, uso futuro da área, efetividade na redução do risco oferecido pelo contaminante, aplicabilidade ao tipo de contaminante; disponibilidade e custo (MULLIGAN; YONG; GIBBS, 2001; RIVETT et alii, 2002).

A revisão da literatura consultada permitiu concluir que diversos países têm investido no aprimoramento das tecnologias já dominadas e no desenvolvimento de novas alternativas, que possibilitem a efetiva remediação de áreas contaminadas com metais pesados. A distinta abordagem dada à questão da contaminação de solos em cada país decorre das diferentes interpretações quanto à importância do problema - o que pode ser "associado" à presença ou ausência de eventos envolvendo a contaminação e morte de seres humanos - que se refletem na legislação local e nas ações dos órgãos executores e fiscalizadores incumbidos de sua aplicação.

As diferentes posturas, quanto à questão da importância e da necessidade de remediação de áreas contaminadas, podem ser ilustradas através de casos de contaminação como os de Minamata - Japão, 1959 (TED, 1996; ALLCHIN, 2006; BOYES; ELLIOTT, 2006); Love Canal - EUA, 1978 (PAGE, 1997; STOSS; FABIAN, 
2000; TSFAA, 2001); Lekkerkerk, Holanda, 1980 (PAGE, 1997); Santo Amaro da Purificação - Brasil, 1975 (CARAVALHO et alii, 1987; CARAVALHO et alii, 2003; MAZONI; CUIUMJIAN, 2002).

A contaminação da baía de Minamata foi provocada pela Corporação Chisso, que descartou, a partir de 1932, resíduo com mercúrio. Este foi incorporado na cadeia alimentar, sob a forma de cloreto de metil-mercúrio e contaminou peixes e ostras, que foram consumidos pela população local. Apesar da epidemia ter se iniciado em 1953, somente em 1959, ela foi associada à contaminação com o mercúrio. Até março de 2000, a "doença de Minamata" tinha oficialmente afetado 2.264 pessoas, que se considerados os casos não oficiais, pode ter atingido 10.000 indivíduos. Oficialmente, durante a epidemia, morreram 43 pessoas e aproximadamente 700 sobreviventes ainda carregam severas seqüelas permanentes (TED, 1996; ALLCHIN, 2006; BOYES; ELLIOTT, 2006).

No caso do Love Canal, a empresa Hooker Chemical armazenou em sua área, no período de 1942 a 1953, aproximadamente 21.000 toneladas de resíduos acondicionados em tambores ou mesmo em forma líquida, que incluíam os compostos: lindano, diversos solventes clorados, benzeno, tolueno, pesticidas e dioxinas. Após fortes chuvas e nevascas nos anos de 1975 e 1976, partes do antigo aterro da Hooker se romperam e a contaminação atingiu a população do Love Canal. Embora os primeiros efeitos sobre a população local tenham sido a redução de peso e sérios defeitos congênitos dos recém nascidos, somente em abril de 1978, quando a contaminação já tinha afetado até as estruturas das casas, 237 famílias foram removidas do site e mais de 100 foram retiradas em 1979 (STOSS; FABIAN, 2000; TSFAA, 2001).

O episódio de contaminação de Lekkerkerk originou-se na década de 1970, quando resíduos industriais contaminados foram utilizados como material de aterro para a construção de 268 casas, em uma área de 8,9 hectares. Metais pesados e compostos orgânicos, particularmente hidrocarbonetos aromáticos, álcoois, acetonas e ésteres, foram encontrados no solo e nas águas superficial e subterrânea da vizinhança. Foram identificados os compostos xileno e tolueno, em concentrações de até 1000 ppm, na atmosfera do interior das residências (PAGE, 1997).

Em 1980, as autoridades evacuaram a área e iniciaram sua remediação. solo contaminado, aproximadamente 153.000 toneladas, foi escavado, removido e tratado em incinerador. A água superficial foi captada e tratada antes de ser 
devolvida ao Rio Lek. A remediação deste sítio teve custo de US\$ 65 milhões (PAGE, 1997).

Os eventos que envolvem a contaminação de Santo Amaro da Purificação tem origem em 1960; quando entrou em operação neste município baiano uma fundição primária de chumbo; e extendem-se até os dias atuais, embora o processamento de minério tenha sido interrompido em 1993. O minério de $\mathrm{Pb}$ utilizado na fundição tinha como principal contaminante o cádmio.

Até 1980 estima-se que tenha sido descartado no ambiente 400 toneladas de $\mathrm{Cd}$ que em conjunto com resíduos de $\mathrm{Pb}$; foram utilizados até para pavimentar vias públicas e quintais de casas; expuseram o meio ambiente e a população aos seus efeitos nocivos. A poluição foi intensa na bacia do Rio Subaé, que atravessa o terreno da empresa, e o passivo ambiental inclui 500.000 toneladas de escória espalhadas pela área da empresa e pela cidade (MAZONI; CUIUMJIAN, 2002; CARVALHO et alii, 2003)

Estudo realizado com 555 crianças de um a nove anos de idade, que residiam num raio de até 900 metros da chaminé da fundição, mostraram que $16 \%$ delas apresentavam PbS no sangue superior a 3,36 $\mu \mathrm{mol} / \mathrm{L}$ (ou $70 \mu \mathrm{g} / 100 \mathrm{~mL}$ ) concentração esta que denotava risco eminente à saúde, podendo demandar tratamento quelante imediato. Quanto ao CdS no sangue, das 396 crianças avaliadas, $96 \%$ apresentaram CdS igual ou superior a 0,0089 $\mu \mathrm{mol} / \mathrm{L}$ (ou 1,0 $\mu \mathrm{g} / \mathrm{L}$ ), que é tomado comumente como valor de referência (CARVALHO et alii, 1987).

Em 1998, novo estudo com 47 crianças de 1 a 4 anos mostrou que $88 \%$ delas apresentavam concentração de $\mathrm{Pb}$ no sangue maior do que $10 \mathrm{mg} / \mathrm{dL}$, e que em 32 \% excediam 20 mg/dL (CARVALHO et alii, 2003).

Outros estudos evidenciaram elevadas concentrações de $\mathrm{Pb}$ e $\mathrm{Cd}$ em sedimentos e moluscos de todo o ecossistema ao norte da Baia de Todos os Santos, local onde desagua o Rio Subaé (CARVALHO et alii, 2003).

Estes eventos trágicos forçaram a mudança da legislação e da postura destes e de outros países frente à questão da contaminação do solo e da água subterrânea, que passaram então, a desempenhar um papel mais pró-ativo em relação às ações de identificação e remediação de áreas contaminadas.

A ausência de casos graves de contaminação em seres humanos, o reconhecimento da gravidade da questão, aliados às particularidades culturais e 
políticas de uso do solo, surgem como fatores possíveis para explicar a abordagem dada à questão do gerenciamento de áreas contaminadas em alguns países.

O Brasil segue atualmente um caminho já trilhado pela Grã-Bretanha, que abordou a questão reativamente, isto é, a área contaminada somente era descoberta e remediada quando fosse destinada a projetos de desenvolvimento do local ou fosse alvo de reclamações por parte da sociedade. A Inglaterra deu início às mudanças da abordagem desta questão com a implantação do primeiro conjunto de regulamentos do Environmental Act de 1995, por meio do "The Contaminated Land (England) Regulations" de 2000 (RIVETT et alii, 2002).

No outro extremo, estão os países que simplesmente não consideram prioritário o problema do manejo e do gerenciamento de áreas contaminadas, seja pela "inexistência" das mesmas ou pela irrelevância conferida à questão.

O Brasil não pode e nem deve passar décadas simplesmente discutindo e desenvolvendo modelos de gestão de áreas contaminadas; há certamente necessidade destas discussões, todavia, não é nada proveitoso e nem produtivo a reinvenção de modelos de gerenciamento, que já demonstraram sua efetividade e eficácia em outros países, embora seja necessária a adequação daqueles às necessidades e peculiaridades brasileiras.

Esforços devem ser concentrados na identificação e no desenvolvimento de técnicas e de processos de remediação de áreas contaminadas (incluindo solo, sedimentos e água subterrânea), que possibilitem a destruição dos contaminantes alvos, embora seja uma realidade latente que métodos de transferência ainda continuarão em uso por longo espaço de tempo.

As técnicas e processos de transferência de contaminantes são uma abordagem simplista para solução do problema, pois se constituem em uma solução temporária e de curto prazo. Em particular, no caso dos metais pesados, visto que não há como destruí-los, apenas modificar seu estado de oxidação e/ou transferi-los, há necessidade do desenvolvimento de tecnologias mais eficientes e eficazes que garantam seu aproveitamento em produtos ou aprisionamento em matrizes de elevada vida útil.

As técnicas tradicionais de remediação de solos contaminados com metais pesados são baseadas em processos físicos, químicos, térmicos ou uma combinação entre eles e, pela utilização de plantas (fitoremediação). 
O uso de microrganismos para o tratamento de solos e resíduos contaminados com metais pesados é uma alternativa tecnológica que tem sido estudada e avaliada somente nas duas últimas décadas e os resultados obtidos em experimentos em escala laboratorial e piloto permitem concluir que tal abordagem é possível e viável (KREBS et alii, 1997; BROMBACHER; BACHOFEN; BRANDL, 1998; STEED et alii, 2000; BRANDL, 2001; BRANDL; BOSSHARD; WEGMANN, 2001; LLOYD, 2002).

Segundo a USEPA (1997c), as tecnologias úteis e eficazes para a remediação de solos contaminados com os metais pesados podem ser divididas em três grupos:

> Contenção: encapsulamento e barreiras (vertical e horizontal);

> Estabilização/solidificação: encapsulamento com resina ou cimento e vitrificação;

> Separação/concentração: lavagem, aspersão, dessorção térmica e eletrocinética.

Em face de carência de bibliografia nacional sobre as tecnologias disponíveis para a remediação de solo contaminado com metais pesados, optou-se por apresentar uma descrição geral dos principais métodos e técnicas empregadas para solos, assim como para o lixiviado produzido. Além da descrição das diferentes técnicas disponíveis, serão fornecidos exemplos de aplicações reportadas na literatura consultada.

\subsubsection{Dessorção térmica}

A dessorção térmica é uma técnica ex situ, que utiliza energia calorífica para aquecer solo e/ou resíduo contaminado até obter a volatilização dos compostos orgânicos, água e metais de baixo ponto de sublimação. Um sistema de arraste com gás ou vácuo transporta o material volatilizado para um sistema de tratamento de gases, que remove os contaminantes através de processos físicos e/ou químicos. Baseado na temperatura do forno, os processos de dessorção podem ser agrupados em dois grupos: de alta temperatura, $320^{\circ} \mathrm{C}$ a $560{ }^{\circ} \mathrm{C}$, e baixa temperatura, $90{ }^{\circ} \mathrm{C}$ a $320{ }^{\circ} \mathrm{C}$ (FREEMAN; HARRIS, 1995; PAGE, 1997; WATTS, 1997; MULLIGAN; YONG; GIBBS, 2001). 
Embora a dessorção térmica seja uma técnica eficiente para a remoção de compostos orgânicos, sua eficiência para a remoção de metais é limitada, exceto para o $\mathrm{Hg}$ e o $\mathrm{Pb}$. A temperatura utilizada no processo geralmente não oxida os metais presentes no meio contaminado; outra fonte de interferência é a presença de compostos clorados, que podem afetar a volatilização de alguns metais (e.g. chumbo). Portanto, não é uma alternativa para a remediação de áreas contaminadas exclusivamente por metais, todavia, pode ser aplicada em áreas contaminadas com compostos orgânicos e metais e, neste caso, poderá ocorrer a remoção parcial de espécies metálicas com baixo ponto de sublimação. As emissões geradas durante o processo de remediação devem ser tratadas, sendo a adsorção em carvão ativado, uma das alternativas empregadas (WATTS, 1997).

A Figura 4 mostra as principais unidades e processos envolvidos em um projeto de remediação de solo utilizando dessorção térmica.

A Federal Remediation Technologies Roundtable - FRTR (2000) e a USEPA (2003c) relataram a utilização da dessorção térmica para a remediação de solo contaminado por compostos orgânicos e metais em dois sítios. O primeiro caso, 0 Letterkenny Army Depot. Superfund Site teve seu solo remediado entre setembro/1993 a outubro/1994. Os principais contaminantes da área eram o tricloroetileno (TCE) e o chumbo, cujos teores máximos no solo eram de $30 \mathrm{~g} / \mathrm{kg}$ e $10 \mathrm{~g} / \mathrm{kg}$, respectivamente. Os objetivos do projeto eram reduzir os teores de TCE para $0,05 \mathrm{mg} / \mathrm{kg}$ e o de $\mathrm{Pb}$ (não foi especificada a meta para este elemento no artigo).

Neste projeto de remediação, foram tratados $13.106 \mathrm{~m}^{3}$ de solo contaminado, com umidade de $15 \%$ a $25 \%$, a temperaturas de até $232{ }^{\circ} \mathrm{C}$. Embora $3.500 \mathrm{~m}^{3}$ de solo não tenham atendido a redução desejada para o $\mathrm{Pb}$ (na referência, não foi citada a meta) e tenha sido necessária sua estabilização para disposição em aterro externo, foi atingida a meta para a redução do TCE. O custo desta aplicação,

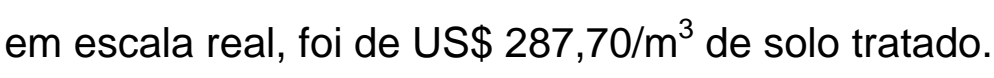

A USEPA (1997d) relatou a utilização da dessorção térmica no Arlington Blending and Packaging Superfund Site, onde os trabalhos de remediação foram executados entre janeiro a julho de 1996, em uma área de 0,93 ha, cujo solo estava contaminado com até $390 \mathrm{mg}$ clordano/kg, até $70 \mathrm{mg}$ endrin/kg, até $130 \mathrm{mg}$ pentaclorofenol/kg e até $370 \mathrm{mg} \mathrm{As} / \mathrm{kg}$. Os objetivos deste projeto, fixados pelo Comprehensive Environmental Response, Compensation, and Liability Act 
(CERCLA), eram reduzir os teores dos contaminantes no solo para os seguintes valores: 3,3 mg clordano/ kg; 0,608 mg endrin/kg; 0,3 mg heptacloro/kg; 0,635 mg pentaclorofenol/kg; 0,2 mg epóxido de heptacloro/kg e 25 mg a 100 mg As/kg.

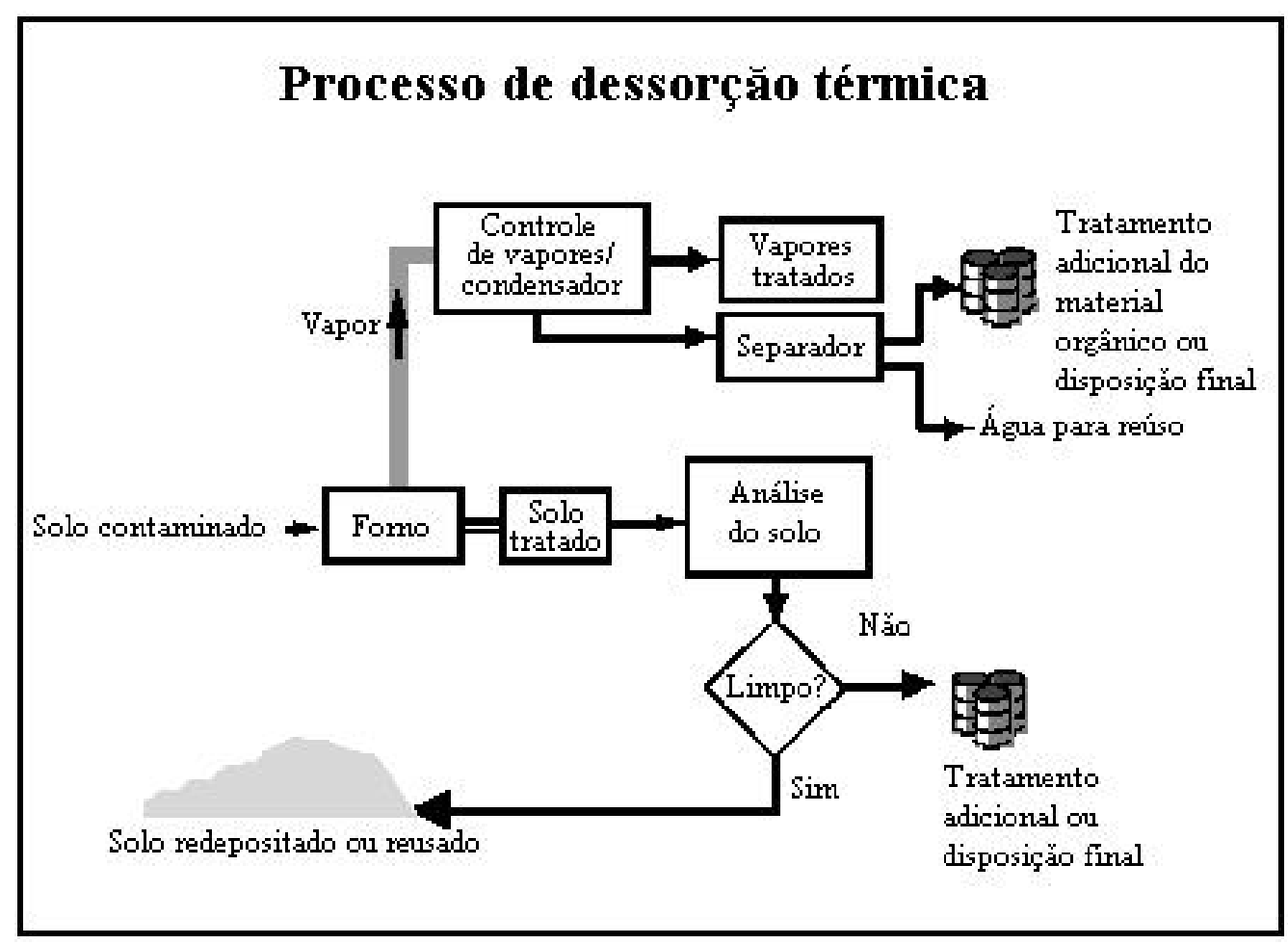

Figura 4 - Esquema genérico de um processo de dessorção térmica aplicada à remediação de solo contaminado.

Fonte: USEPA (1997a).

Nesta aplicação em escala real, foram escavados até uma profundidade média de 2,10 $\mathrm{m}$ e processados em temperaturas de $304^{\circ} \mathrm{C}$ a $399^{\circ} \mathrm{C}, 42.095 \mathrm{t}$ $\left(11.470 \mathrm{~m}^{3}\right.$ ) de solo contaminado (areno siltoso, $17 \%$ de umidade e pH =6,8) e, deste total, apenas $500 \mathrm{t}$ não atenderam o limite máximo imposto para o As e tiveram de ser dispostas em aterro externo ao sítio. Os gases da queima foram submetidos a tratamento (sistema composto por ciclones e colunas de carvão ativado) para remoção do As volatilizado. O monitoramento dos gases revelou que a eficiência de remoção de As foi superior a 99,99 \%. Os objetivos de redução dos compostos orgânicos foram atingidos, embora tenha havido a necessidade de realizar o reprocessamento de uma parcela da massa total de solo. O custo desta aplicação foi de cerca de US\$105/t de solo tratado.

A USEPA (2002a) e a FRTR (2002) relataram a aplicação da dessorção térmica no aterro sanitário Lipari, durante o período de setembro/1994 a setembro/1999, onde $72.576 \mathrm{t}$ de solo foram remediados a temperaturas de $390{ }^{\circ} \mathrm{C} \mathrm{a}$ $454{ }^{\circ} \mathrm{C}$. Este continha os seguintes teores de poluentes (USEPA, 1988): $11 \mathrm{mg}$ 
$\mathrm{Sb} / \mathrm{kg}, 30 \mathrm{mg} \mathrm{As} / \mathrm{kg}, 35 \mathrm{mg} \mathrm{Ba} / \mathrm{kg}, 1,6 \mathrm{mg} \mathrm{Be} / \mathrm{kg}, 50 \mathrm{mg} \mathrm{Cd} / \mathrm{kg}, 251 \mathrm{mg} \mathrm{Cr} / \mathrm{kg}, 13 \mathrm{mg}$ Co/kg, 763 mg Cu/kg, 56 mg Pb/kg, 1,4 mg Hg/kg, 19 mg Ni/kg, 1 mg Ag/kg, 94 mg V/kg e $278 \mathrm{mg} Z \mathrm{n} / \mathrm{kg}$. Neste projeto, 95 \% da massa de solo atingiu os objetivos de remoção desejados (10 mg Sb/kg, 20 mg As/kg, 400 mg Ba/kg, 1 mg Be/kg, 3 mg $\mathrm{Cd} / \mathrm{kg}, 100 \mathrm{mg} \mathrm{Cr} / \mathrm{kg}, 170 \mathrm{mg} \mathrm{Cu} / \mathrm{kg}, 500 \mathrm{mg} \mathrm{Pb} / \mathrm{kg}, 4$ mg Se/kg, 1 mg Mb/kg, $1 \mathrm{mg}$ $\mathrm{Hg} / \mathrm{kg}, 100 \mathrm{mg} \mathrm{Ni} / \mathrm{kg}, 5 \mathrm{mg} \mathrm{Ag/kg,} 5 \mathrm{mg} \mathrm{Tl} / \mathrm{kg}, 100 \mathrm{mg} \mathrm{V} / \mathrm{kg}, 35 \mathrm{mg}$ Zn/kg), sendo que o custo da aplicação foi de US\$ 75,00/t de solo tratado.

Outro caso de aplicação da tecnologia, reportado por FRTR (2002) e USEPA (2003d), foi o de Cape Fear Wood Preserving, cujo solo tinha sido contaminado com hidrocarbonetos aromáticos polinucleares, benzeno e metais ( $\mathrm{As}, \mathrm{Cr}$ e $\mathrm{Cu}$ ). O solo da área foi contaminado, durante décadas, por descargas provenientes da preservação de madeira.

A despeito da referência bibliográfica não citar os teores iniciais dos poluentes, a tecnologia foi aplicada de julho/1998 a abril/1999, em temperatura de $455^{\circ} \mathrm{C}$, para o tratamento de $154.496 \mathrm{t}\left(86.400 \mathrm{~m}^{3}\right)$ de solo contaminado e mostrouse eficiente na remoção dos contaminantes presentes, tendo reduzido o teor de metais a $94 \mathrm{mg} \mathrm{As/Kg}$ e $88 \mathrm{mg} \mathrm{Cr} / \mathrm{kg}$. O custo desta aplicação foi de US\$ 64,00/t de solo tratado.

\subsubsection{Lavagem}

A lavagem é uma técnica de tratamento que pode ser desenvolvida in situ ou ex situ. A alternativa ex situ envolve a remoção do solo ou do sedimento contaminado e o seu processamento em uma unidade de tratamento. Este processo pode incluir a separação e lavagem somente da fração de finos (argila e silte) ou de todo o material contaminado. A tendência de concentração dos metais pesados, assim como de outros contaminantes, nas menores partículas de solo justifica sua segregação e possibilita que um menor volume de material seja submetido ao tratamento e, por conseqüência, o processo tenha menor custo final (USEPA, 1991; WATTS, 1997).

O agente químico utilizado neste tipo de lavagem deve possuir a capacidade de dessorver e mobilizar as espécies metálicas adsorvidas nas partículas de solo e, 
dentre as substâncias que possuem tais características, incluem-se ácidos, quelantes e surfactantes. A escolha do agente a ser empregado depende tanto de sua disponibilidade e custo, quanto das características físico-químicas do solo e da presença de espécies ou substâncias químicas com as quais ele possa reagir e formar subprodutos indesejados.

O uso de ácido durante a etapa de lavagem deve-se à sua capacidade de reduzir $\mathrm{o} \mathrm{pH}$ até valores que permitam a solubilização das diferentes espécies metálicas presentes no meio, entretanto, seu uso acarreta alterações químicas e físicas no solo, devido à dissolução dos minerais presentes, o que acaba por reduzir a sua fertilidade. Solos com pH acima de 7,0 podem demandar considerável quantidade de ácidos e, neste caso, torna-se mais viável o uso de um quelante. A utilização de EDTA, o agente quelante mais comum, deve ser cuidadosamente analisado face às suas implicações de saúde e segurança, pois é um composto de baixa e lenta degradação, além de ser difícil a separação do metal pesado contido no complexo organometálico formado (HONG; TOKUNAGA; TAJIUCHI, 2002).

HONG; TOKUNAGA; TAJIUCHI (2002) investigaram o uso da saponina, um biosurfactante extraído de vegetais, para a remediação de três diferentes tipos de solos contaminados com metais pesados (solo A: $1484 \mathrm{mg} \mathrm{Cd} / \mathrm{kg}, 2155 \mathrm{mg} \mathrm{Cu} / \mathrm{kg}$, $7288 \mathrm{mg} \mathrm{Pb} / \mathrm{kg}, 692 \mathrm{mg} \mathrm{Zn/kg;} \mathrm{solo} \mathrm{B:} 1026 \mathrm{mg} \mathrm{Cd} / \mathrm{kg}, 2181 \mathrm{mg} \mathrm{Cu} / \mathrm{kg}, 7161 \mathrm{mg}$ Pb/kg, $551 \mathrm{mg} \mathrm{Zn/kg} \mathrm{e} \mathrm{solo} \mathrm{C:} 701 \mathrm{mg} \mathrm{Cd} / \mathrm{kg}, 1521 \mathrm{mg} \mathrm{Cu} / \mathrm{kg}, 5253 \mathrm{mg} \mathrm{Pb/kg,} 472$ mg Zn/kg) e concluíram que a remoção dos metais variava em função da concentração de saponina e do pH do meio. Neste estudo, obteram-se remoções acima de 99,99\% de $\mathrm{Cd}(\mathrm{pH} \sim 3,0$, solos $\mathrm{B}$ e C), $60 \%$ de $\mathrm{Cu}$ ( $\mathrm{pH}=4,0$, solo $\mathrm{C}$ ), 50 $\% \mathrm{~Pb}(\mathrm{pH}=3,5$, solo $\mathrm{C})$ e $50 \%$ de $\mathrm{Zn}(\mathrm{pH} \sim 4,0$, solos A, B e C).

Após a lavagem, o solo pode retornar à área sob intervenção ou receber outra destinação. A água de lavagem, que contém os íons metálicos, pode ser tratada através de processos físico-químicos tradicionais (precipitação, oxidação) ou de processos mais avançados (e.g. membranas), decisão que depende da viabilidade ou não da recuperação dos metais presentes.

Dentre os fatores que afetam negativamente $o$ desempenho e a aplicabilidade desta técnica incluem-se:

> Fração de finos: quanto maior sua quantidade, menor será a eficiência do processo, pois os contaminantes tendem a ficar fortemente adsorvidos e são difíceis de remover; 
> Presença de outros contaminantes: a presença de contaminantes orgânicos ou inorgânicos com propriedades distintas dos metais pesados requer uma abordagem diferente do problema, pois pode haver a necessidade da utilização de surfactante ou de solventes orgânicos para sua remoção prévia, antes da lavagem ácida do material e, ainda, requerer etapas adicionais no tratamento da água de lavagem e das emissões gasosas eventualmente produzidas.

A USEPA (1995a) reportou a aplicação da lavagem ex situ na área do King of Prussia Technical Corporation Superfund Site, executada durante o período de junho/1993 a outubro/1994. A contaminação era exclusivamente devida aos metais prata $(\mathrm{Ag}), \mathrm{As}$, berílio $(\mathrm{Be}), \mathrm{Cd}, \mathrm{Cr}, \mathrm{Cu}, \mathrm{Hg}, \mathrm{Ni}, \mathrm{Pb}$, selênio $(\mathrm{Se}), \mathrm{Zn}$, que se concentravam no sedimento - 8,01 g Cr/kg, 9,07 g Cu/kg, 0,10 g Hg/kg - e no lodo $11,30 \mathrm{~g} \mathrm{Cr} / \mathrm{kg}, 16,30 \mathrm{~g} \mathrm{Cu} / \mathrm{kg}, 11,10 \mathrm{~g} \mathrm{Ni} / \mathrm{kg}, 0,39 \mathrm{~g} \mathrm{Hg} / \mathrm{kg}$ - de antigas lagoas de tratamento existentes no local.

A Figura 5 mostra os principais processos envolvidos na aplicação da técnica de lavagem ex situ.

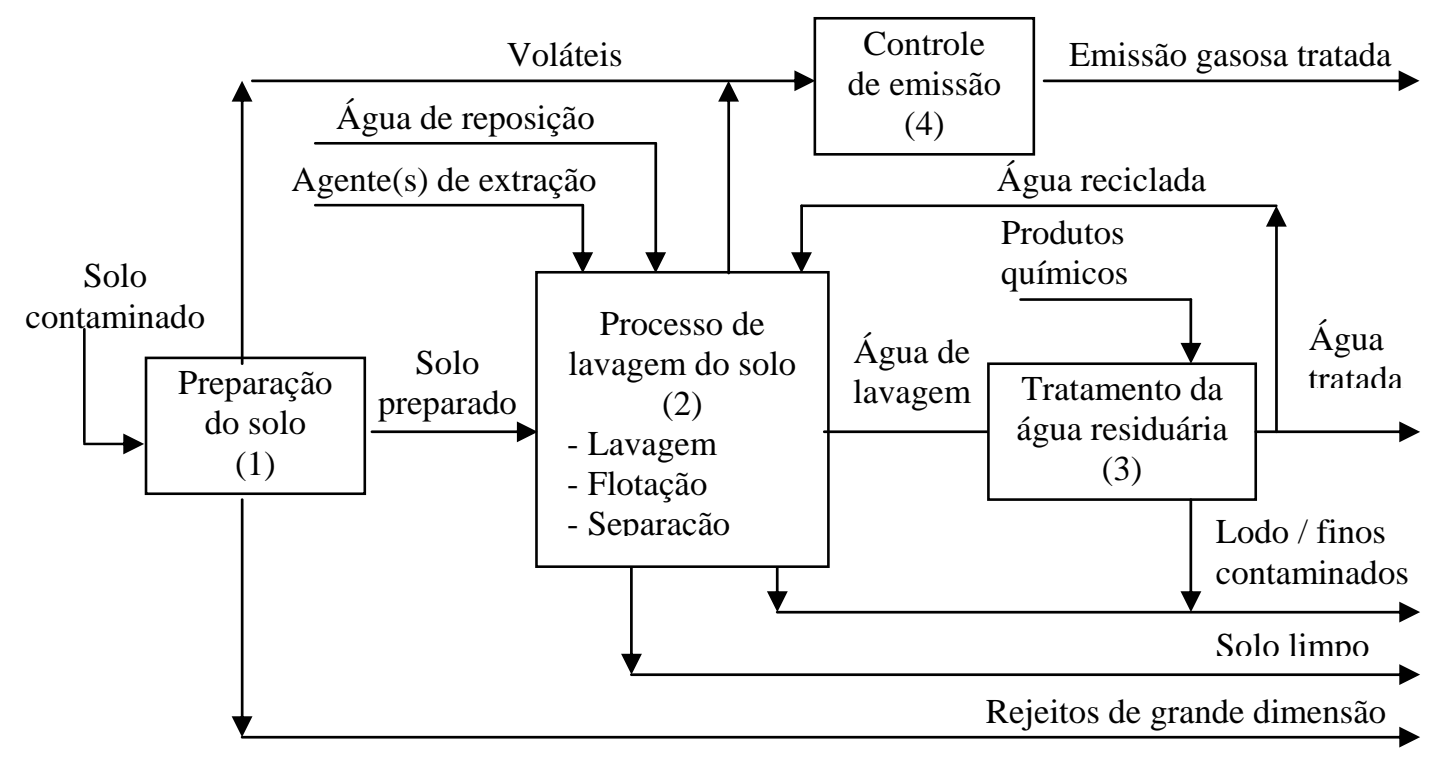

Figura 5 - Lavagem de solo aplicável de acordo com a faixa de tamanho de partícula.

Fonte: USEPA (1991).

O sistema de tratamento era composto por peneiras, tanques de flotação e tratamento de lodo, conforme mostra a Figura 6, e tinha por objetivo reduzir os teores dos metais no solo para os seguintes valores: $5 \mathrm{mg} \mathrm{Ag} / \mathrm{kg}, 190 \mathrm{mg} \mathrm{As} / \mathrm{kg}, 485$ $\mathrm{mg} \mathrm{Be} / \mathrm{kg}, 107 \mathrm{mg} \mathrm{Cd} / \mathrm{kg}, 483 \mathrm{mg} \mathrm{Cr} / \mathrm{kg}, 3.571 \mathrm{mg} \mathrm{Cu} / \mathrm{kg}, 1,0 \mathrm{mg} \mathrm{Hg} / \mathrm{kg}, 1.935 \mathrm{mg}$ $\mathrm{Ni} / \mathrm{kg}, 500 \mathrm{mg} \mathrm{Pb} / \mathrm{kg}, 4 \mathrm{mg} \mathrm{Se} / \mathrm{kg}, 3.800 \mathrm{mg} \mathrm{Zn/kg}$. Foram tratadas $17.418 \mathrm{t}$ de solo e 
sedimento e, ao final do processo, todos os objetivos foram atingidos. O custo final desta aplicação, em escala real, foi de US\$ 442,10/t, valor que incluiu a disposição externa em aterro de resíduos.

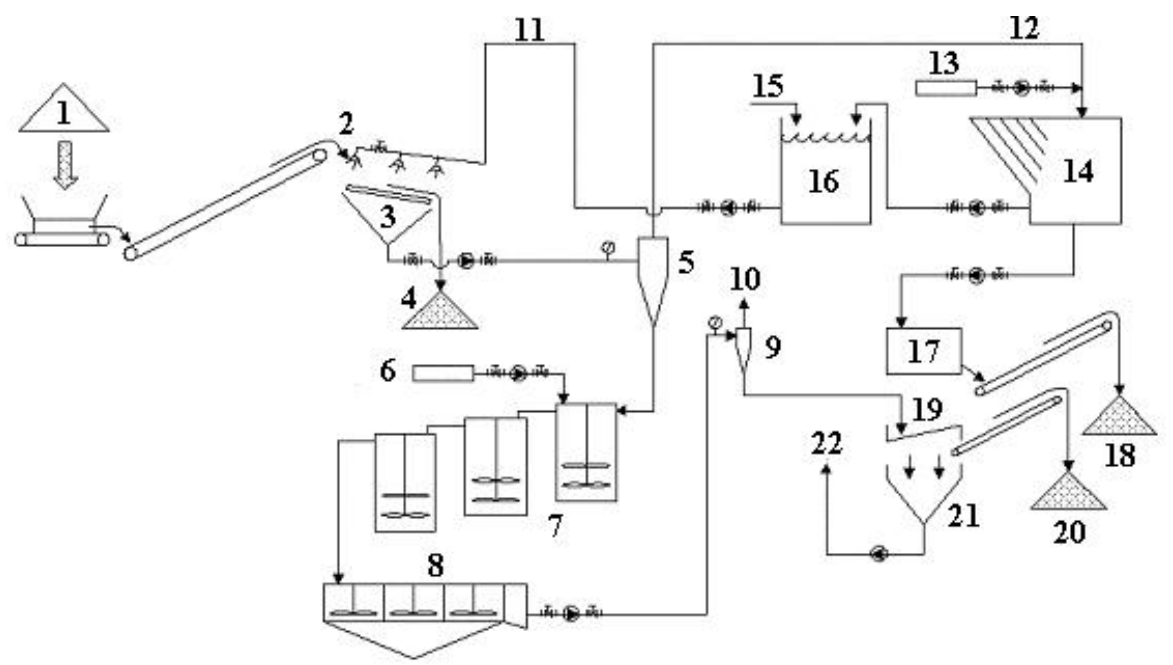

Nota: alimentação de solo (1), peneira (2), reservatório da suspensão de água de lavagem + sólidos (3), material limpo retido na peneira (4), hidrociclone multi-estágio (5), surfactante (6), lavagem de material sólido (7), tanques de flotação (8), sólidos desaguados (9), água (vai para 16) (10), água reciclada (11), água contendo finos em suspensão (12) polímeros (13), decantador lamelar (14), reposição de água (15), reservatório de água (16), filtro prensa (17), lodo desaguado (18), peneira fina para areia (19), areia limpa (20), reservatório da suspensão da água de lavagem + sólidos finos (21), água (vai para 16) (22).

Figura 6 - Esquema geral da unidade de tratamento empregada na lavagem de solo do sítio King of Prússia Technical Corporation Superfund.

Fonte: USEPA (1995a).

\subsubsection{Lavagem por aspersão}

A lavagem por aspersão ou flushing é uma técnica in situ de remediação de solo, na qual um agente de lavagem é aspergido sobre a superfície da área contaminada, de modo a carrear os contaminantes presentes para a água subterrânea, a qual é coletada por um sistema de drenagem e recalcada para a superfície, onde é tratada e reciclada no processo (FREEMAN; HARRIS, 1995; ROOTE, 1997).

A lavagem por aspersão emprega ácidos, biosurfactantes, agentes quelantes ou redutores para a remoção de metais pesados e está sujeita a 
interferência de outros contaminantes presentes no meio, especialmente de substâncias orgânicas. Segundo MULLIGAN; YONG; GIBBS (2001), uma melhoria necessária para esta tecnologia é o desenvolvimento de aditivos não tóxicos, para minimizar os riscos de contaminação do aqüífero subterrâneo.

Embora esta técnica possa ser utilizada para a remoção de diversos contaminantes, a viabilidade de sua aplicação está intimamente vinculada à permeabilidade do solo, logo, solos com coeficiente de condutividade hidráulica (K) baixos ( $\left.K<1,0 \cdot 10^{-5} \mathrm{~cm} / \mathrm{s}\right)$ podem exigir muito tempo para a infiltração da solução de lavagem, o que pode inviabilizar o uso da técnica. Solos com $\mathrm{K}>1,0.10^{-3} \mathrm{~cm} / \mathrm{s}$ são considerados ideais para o emprego desta técnica, embora solos de menor condutividade hidráulica também possam ser remediados, isto é, aqueles com valores de $\mathrm{K}$ maiores do que $1,0 \cdot 10^{-5} \mathrm{~cm} / \mathrm{s}$ e menores do que $1,0 \cdot 10^{-3} \mathrm{~cm} / \mathrm{s}$ (FREEMAN; HARRIS, 1995; ROOTE, 1997).

A lavagem por aspersão, ao contrário da ex situ, demanda longos períodos de tempo para a descontaminação de uma área qualquer, pois é um processo que reduz gradativamente o teor do poluente no solo. Um desafio desta técnica é impedir que os contaminantes carreados para a água subterrânea não contaminem o aqüífero. Desta forma, é fundamental o conhecimento da hidrologia da área, assim como garantir que o sistema de drenagem colete e recalque toda a água contaminada.

O tratamento da água subterrânea é, normalmente, realizado através de processo físico-químico e a água tratada é utilizada novamente na lavagem do solo. A Figura 7 mostra, esquematicamente, um sistema de lavagem por aspersão.

Segundo ROOTE (1997), a solução de lavagem remove os contaminantes através das seguintes vias:

$>$ Solubilização;

$>$ Formação de emulsão e

$>$ Reações químicas. 
1

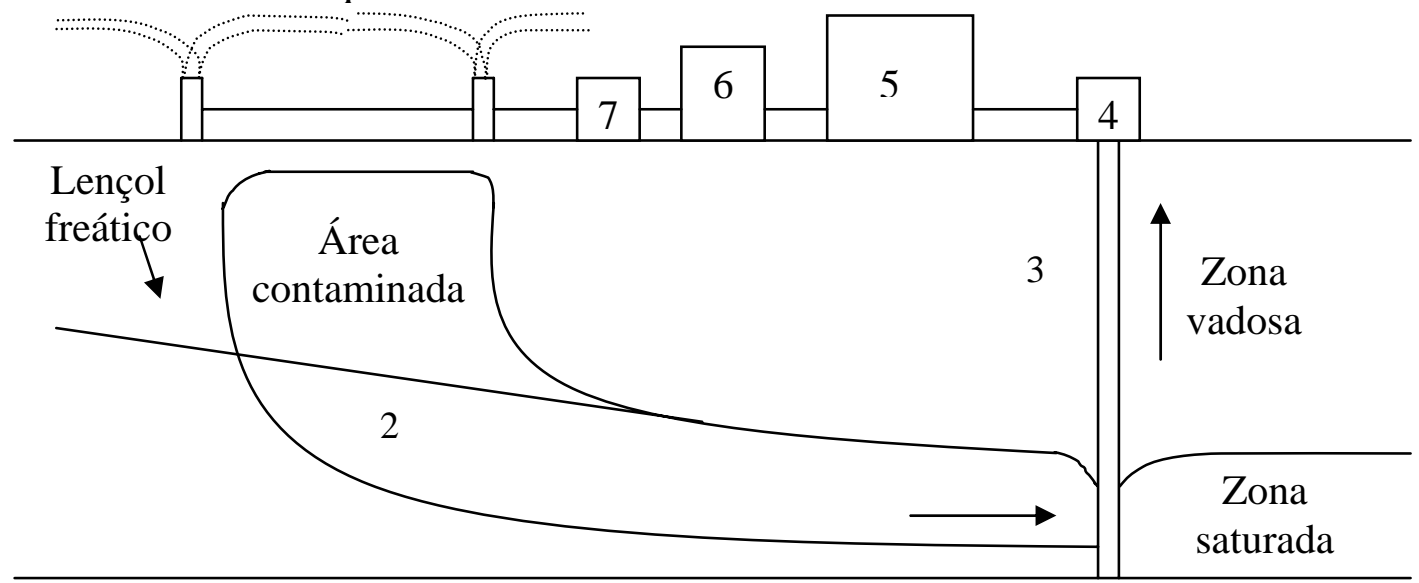

Zona de baixa permeabilidade

Nota: 1 - aplicação da água de lavagem por aspersão, 2 - coleta do lixiviado, 3 - poço de extração da água subterrânea, 4 e 7 - sistemas de recalque, 5 - tratamento da água subterrânea, 6 - adição dos produtos químicos de lavagem.

Figura 7 - Esquema básico de um sistema de lavagem por aspersão para remediação de solo contaminado.

Fonte: Adaptado de FREEMAN; HARRIS (1995).

A lavagem por aspersão apresenta as seguintes vantagens e limitações (ROOTE, 1997):

Vantagens:

$\checkmark$ Elimina a necessidade de escavação, carregamento e transporte do material contaminado;

$\checkmark$ Se comparada apenas à percolação de água através do solo, este sistema apresenta uma maior velocidade do processo de remediação e abrevia seu término;

$\checkmark$ Pode ser utilizado em conjunto com outras tecnologias ou em estágios, para casos complexos.

Limitações:

$\checkmark$ Potencial de espalhar o contaminante ao redor da área de captura, lateralmente e/ou verticalmente, se o sistema de extração não for adequadamente projetado ou construído ou se o controle hidráulico não for mantido ou se houver vazamento de água contaminada da zona de tratamento para a de descarga;

$\checkmark$ Incertezas envolvidas na previsão do desempenho e no tempo necessário para a lavagem atingir os objetivos do projeto; 
$\checkmark$ Condições geológicas do sítio (e.g. baixa permeabilidade do solo, altos teores de argila ou matéria orgânica, elevado grau de heterogeneidade ou permeabilidade secundária, proximidade de área de recarga de aqǘfero);

$\checkmark$ A solução de lavagem pode ficar aderida ao solo, acelerar o crescimento de microrganismos, causar precipitação ou outras reações com o solo ou a água subterrânea, resultando na redução de sua porosidade;

$\checkmark$ A incapacidade de separar o aditivo de lavagem do concentrado pode resultar em alto consumo de produtos químicos e elevar o custo final do processo.

STURGES JR; MCBETH JR; PRATT (1991) relataram a utilização da lavagem por aspersão para a remoção de $\mathrm{Cr}$ total no United Chrome Products Superfund Site, onde a contaminação no solo atingia até $60 \mathrm{~g} / \mathrm{kg}$ e na água subterrânea até $19 \mathrm{~g} / \mathrm{L}$, sendo $5 \mathrm{~g} / \mathrm{L}$ de $\mathrm{Cr}^{6+}$. A remediação do solo contaminado teve início em 1988 e somente nos primeiros 2,5 anos de tratamento, a concentração de $\mathrm{Cr}^{6+}$ na água subterrânea foi reduzida de $5 \mathrm{~g} / \mathrm{L}$ para $50 \mathrm{mg} / \mathrm{L}$, sendo que a média da pluma de contaminação baixou de 1,9 g/L para $207 \mathrm{mg} / \mathrm{L}$ após o tratamento dos primeiros $15.000 \mathrm{~m}^{3}$.

\subsubsection{Estabilização e solidificação}

Segundo a USEPA (2000), estabilização é a técnica que reduz quimicamente o potencial de periculosidade do resíduo através da conversão do contaminante para uma forma menos solúvel ou tóxica, sem necessariamente modificar as características físicas do material contaminado. Já, a solidificação é definida como a técnica que encapsula os resíduos, formando um material sólido e não necessariamente envolve uma interação química entre o contaminante e o agente solidificante. A solidificação pode ser complementada por processos mecânicos ou reações químicas entre o agente solidificante e o resíduo. O produto da solidificação pode tomar a forma de um bloco ou um material granular (LaGREGA; BUCKINGHAM; EVANS, 1994; FREEMAN; HARRIS, 1995; WATTS, 1997; USEPA, 2000; MULLIGAN; YONG; GIBBS, 2001).

Ambos os processos, estabilização e solidificação, podem ser aplicados in situ ou ex situ e tem por objetivos a redução da toxicidade, da solubilidade e da 
mobilidade dos contaminantes no solo, além de melhorar as propriedades do material estabilizado (LaGREGA; BUCKINGHAM; EVANS, 1994).

A despeito de serem técnicas distintas, a solidificação e a estabilização são empregadas freqüentemente em conjunto, pois combinam resíduo e/ou solo e/ou lodo com agentes de tratamento para imobilizar física e quimicamente os contaminantes perigosos contidos em tais materiais (USEPA, 2000). LaGREGA; BUCKINGHAM; EVANS (1994) consideraram a estabilização/solidificação como uma solução de remediação mais permanente do que outras alternativas. Segundo MULLIGAN; YONG; GIBBS (2001), os métodos de descontaminação de metais têm se concentrado em processos na fase sólida, tal como a estabilização/solidificação, devido à baixa mobilidade dos poluentes.

Segundo a USEPA (2000), a estabilização/solidificação foi utilizada na remediação de 167 sítios nos EUA entre 1982 a 1998 e deste total, 56 \% estavam contaminados exclusivamente com metais pesados. Se considerada a contaminação com metais associados a compostos orgânicos e/ou radionuclídeos, o percentual dos sítios contaminados com metais alcançava $90 \%$ das áreas remediadas. Esta tecnologia já foi o segundo tipo de tratamento mais empregado pelo Superfund, mas tem sido substituída por técnicas alternativas desde 1998. As razões apontadas para a substituição da aplicação da estabilização/solidificação incluem:

> A diminuição do volume de material contaminado está inviabilizando a aplicação da tecnologia;

> Possibilidade de não atingir os padrões legais requeridos para os contaminantes do sítio;

$>$ Elevado custo;

> A tecnologia havia sido originalmente selecionada para o tratamento de resíduos já submetidos a outros processos de tratamento, logo, quando pouco ou nenhum resíduo é gerado, a estabilização/solidificação deixa de ser necessária;

$>$ Preocupação da comunidade;

$>$ Problemas de implantação e

> Possibilidade de não reduzir significativamente a mobilidade de resíduos específicos.

Os processos de estabilização/solidificação utilizam os seguintes mecanismos, para atingir seus objetivos (LaGREGA; BUCKINGHAM; EVANS, 1994): Absorção; 
> Adsorção;

> Desintoxicação, conseqüência das reações químicas e físico-químicas que reduzem a toxicidade do metal, tais como reações de redução ou oxidação, formação de compostos inorgânicos ou complexação com substâncias orgânicas;

> Macroencapsulamento;

$>$ Microemcapsulamento e

$>$ Precipitação.

Diversos tipos de agentes ligantes podem ser utilizados nos processos de estabilização/solidificação, entretanto, as características dos contaminantes presentes no solo, sejam orgânicos e/ou inorgânicos, determinarão a escolha do(s) ligante(s) a ser(em) utilizado(s). Dentre os agentes que já comprovaram sua efetividade para a estabilização/solidificação de material (solo e lodo) contaminado com metais pesados, incluem-se (LaGREGA; BUCKINGHAM; EVANS, 1994; USEPA, 2000; MULLIGAN; YONG; GIBBS, 2001):

> Cimento: efetivo, sob determinadas condições, para todos os metais pesados, mas a presença de compostos orgânicos pode interferir no processo de hidratação do cimento, o que refletirá na resistência mecânica do material solidificado;

> Pozolana: efetividade demonstrada para $\mathrm{Cd}, \mathrm{Cr}$ e $\mathrm{Pb}$;

> Material termoplástico (asfalto, betume, polietileno, polipropileno, etc): efetividade demonstrada para $\mathrm{As}, \mathrm{Cr}$ e $\mathrm{Cu}$. A presença de compostos orgânicos no solo contaminado demanda a coleta e o tratamento dos vapores produzidos durante 0 processo e

> Polímeros orgânicos: efetividade demonstrada para As.

Outros materiais que já demonstraram potencial em experimentos de bancada e/ou projetos de demonstração de campo, de serem utilizados para estabilização/solidificação de solos contaminados com metais pesados, incluem fosfatos, cinza resultante da queima de carvão mineral, cal virgem, enxofre, zeólita (sintetizada a partir de cinza de carvão), lama vermelha do processamento de bauxita, etc. (CICCU et alii, 2003; DERMATAS; MENG, 2003; LIN et alii, 1998; WANG et alii, 2001). Um dos problemas relatados durante o uso de cinza de carvão associada com cal virgem foi a formação excessiva de etringita na presença de sulfato, material expansivo que causa dilatação da matriz sólida, deteriorando-a. 
Entretanto, este problema pode ser evitado mediante a adição de hidróxido de bário (DERMATAS; MENG, 2003).

A aplicabilidade da estabilização/solidificação é baseada na capacidade do ligante de imobilizar o metal. A cinética de equilíbrio solo-contaminante-ligante é complicada, já que muitos são os fatores que influenciam a mobilidade do metal. Logo, não é possível generalizar a aplicação de um dado ligante ou dos resultados que podem ser produzidos para diferentes metais (USEPA, 1997c).

A despeito da inexistência de dados sobre 0 desempenho da estabilização/solidificação em longo prazo, as condições ambientais as quais o material tratado está exposto podem afetar sua estabilidade e, segundo KLICH et alii (1999), os resíduos estabilizados com cimento são vulneráveis aos mesmos processos químicos e físicos de degradação do concreto e de outros materiais de cimento, logo, tem o potencial de se desintegrarem após um período de 50 a 100 anos.

Cabe ressaltar que os experimentos de laboratório e/ou testes de lixiviação que utilizam soluções ácidas (a partir de ácidos fracos, como o ácido acético) para avaliar a mobilidade de contaminantes aprisionados na matriz sólida, produzida pelo processo de tratamento de estabilização/solidificação, não representam adequadamente os efeitos dos agentes ambientais (sol, chuva, poluição, etc) sobre a matriz sólida, assim, os "ótimos" resultados reportados sobre a redução da lixiviação de metais pesados e de outros contaminantes, deve ser objeto de criteriosa avaliação.

HIRATA (1997) realizou ensaios de lixiviação utilizando corpos de prova moldados com sedimento contaminado com metais pesados $\mathrm{e}$ estabilizados/solidificados com cimento Portland. Os resultados obtidos demonstraram as deficiências e a falta de representatividade do método de lixiviação utilizado para avaliação do desprendimento de contaminantes, sob a ação dos agentes ambientais, confinados na matriz de cimento.

Os ensaios de lixiviação conduzidos por HIRATA (1997) foram realizados conforme a norma brasileira NBR 10005/87 e, visto que esta norma não define a dimensão mínima das partículas do sólido a ser lixiviado, esta autora triturou os corpos de prova até a obtenção de partículas com dimensão $\leq 9,5 \mathrm{~mm}$. As principais características dos ensaios foram: elevado consumo de ácido acético 0,5 M (até $1 \mathrm{~L}$ ), necessário para ajustar o pH durante os ensaios; a estabilização do pH abaixo de 
9,0, após a adição de $223 \mathrm{~mL}$ de ácido durante as 2 primeiras horas; e valores iniciais e finais do $\mathrm{pH}$, respectivamente, de 10,8 e de 6,2, não atingindo o valor de $5,0 \pm 0,2$, estabelecido pela norma.

Segundo esta autora, os altos valores de $\mathrm{pH}$ e repetidos ajustes em curtos intervalos de tempo durante todo o ensaio, sugeriram a inadequabilidade do ensaio de lixiviação para resíduos estabilizados/solidificados com cimento Portland e, que uma melhor reprodução das condições ambientais que atuam sobre materiais estabilizados/solidificados com cimento Portland, poderia ser obtida com o uso dos ácidos nítrico ou sulfúrico nos ensaios de lixiviação.

Outra constatação importante de HIRATA (1997), a partir de ensaios de lixiviação realizados somente com cimento Portland, foi de que este continha teores de $\mathrm{Cd}$, Cr, Ni e Zn superiores àqueles presentes no sedimento contaminado e de $\mathrm{Hg}$, $\mathrm{Cu}$ e $\mathrm{Pb}$, da mesma ordem de magnitude desta matriz.

A partir dos resultados obtidos por esta autora, é razoável considerar que o ácido acético não é suficientemente forte para atacar a matriz sólida e apenas lixivia sua alcalinidade e, portanto, apenas uma pequena parcela dos metais é lixiviada. Os elevados teores de metais presentes na própria constituição do cimento Portland permitiram supor que grande parte dos metais lixiviados (se não todos) provinha do próprio cimento e não do material contaminado estabilizado/solidificado com o mesmo.

As Figuras 8 e 9 mostram, respectivamente, os processos básicos envolvidos em aplicações in e ex situ das técnicas de estabilização e solidificação.

A FRTR (2001) relatou a realização de projetos de demonstração entre fevereiro a junho de 1998, utilizando tecnologia de estabilização/solidificação para a remediação de solo contaminado com $\mathrm{Pb}$, na Massachusetts Military Reservation, Training Range and Impact Area. O uso da área como campo de tiro entre 1935 a 1940 causou a contaminação do solo com teores de até $12.200 \mathrm{mg} \mathrm{Pb/kg}$. Visando reduzir ao máximo a contaminação e a recuperação de $\mathrm{Pb}$, as atividades de descontaminação foram realizadas tanto in situ quanto ex situ.

O agente de estabilização utilizado para imobilizar o $\mathrm{Pb}$ foi o MAECTITE ${ }^{\circledR}$, que é um líquido que reage com o elemento e produz um cristal mineral sintético geoquimicamente estável, cujo princípio ativo não foi informado na referência. Foram processados $17.713 \mathrm{~m}^{3}$ de solo (13.600 $\mathrm{m}^{3}$ ex situ e $4.113 \mathrm{~m}^{3}$ in situ), que 
possibilitaram reduzir a concentração de $\mathrm{Pb}$ no lixiviado para menos do que 0,5 $\mathrm{mg}$ $\mathrm{Pb} / \mathrm{L}$, ou seja, o resultado obtido foi muito superior à meta (<5,0 mg Pb/L). O custo do tratamento foi de US\$197,50/m³ de solo tratado.

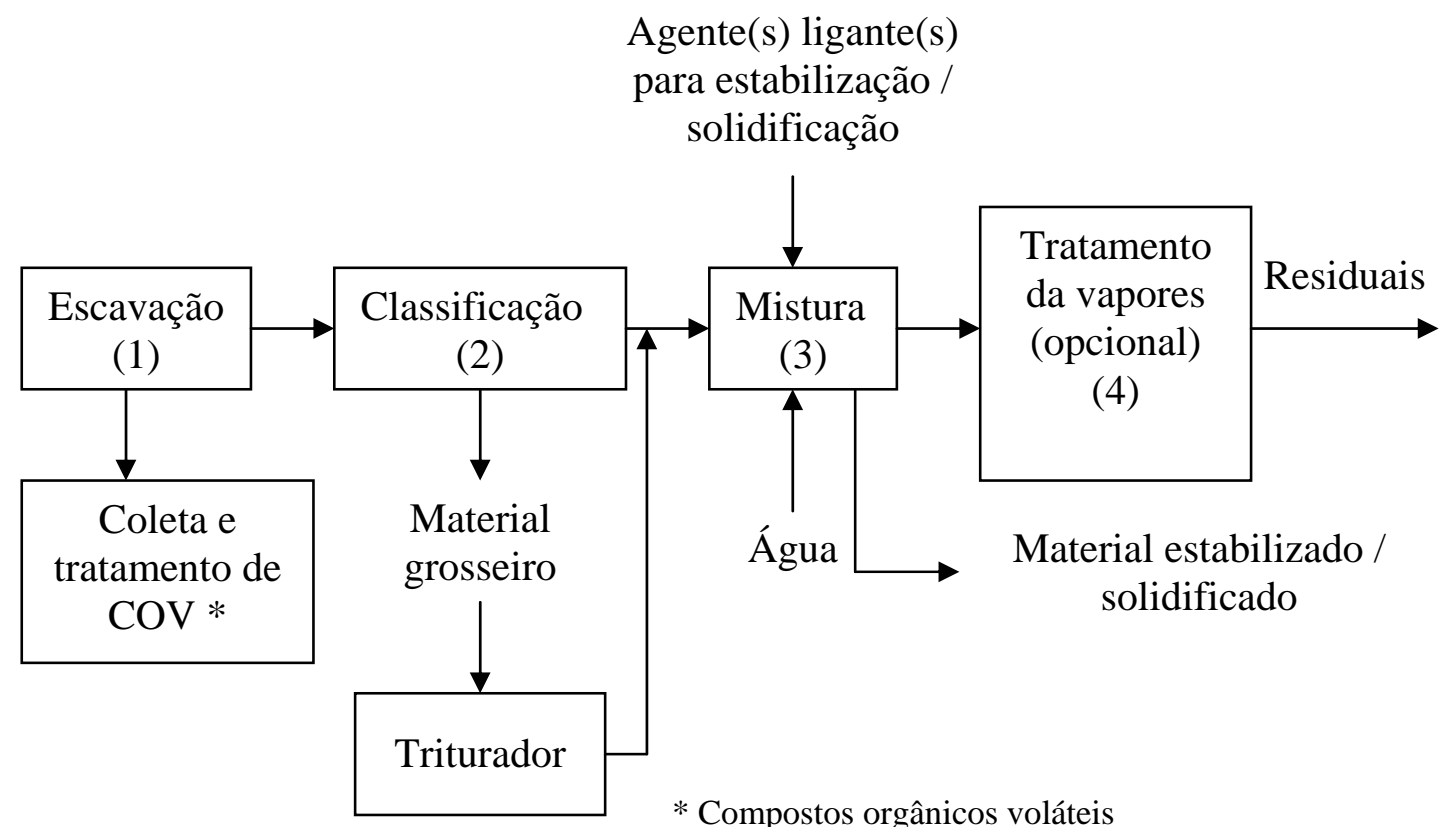

Figura 8 - Elementos genéricos de um processo típico de estabilização/solidificação ex situ de solos contaminados.

Fonte: FREEMAN; HARRIS (1995).

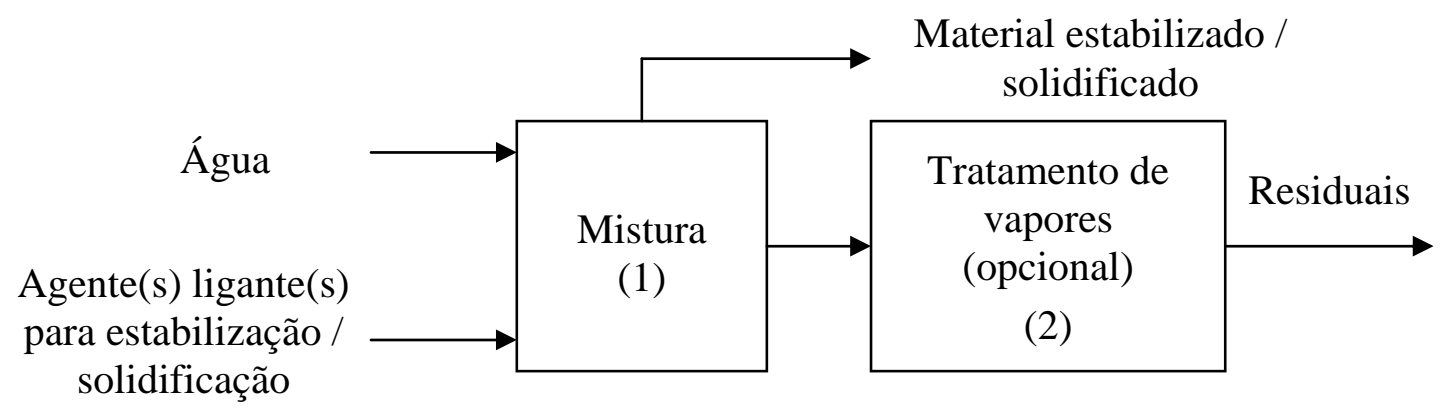

Figura 9 - Elementos genéricos de um processo típico de estabilização/solidificação in situ de solos contaminados.

Fonte: FREEMAN; HARRIS (1995).

\subsubsection{Vitrificação}

A vitrificação é uma técnica de tratamento baseada no uso de energia calorífica, obtida através da energia elétrica, para promover a fusão do material 
sólido contaminado, seja solo, sedimento ou resíduo industrial. Sua aplicação na remediação de áreas contaminadas é usualmente in situ, apesar de poder ser aplicado ex situ. A vitrificação é um método de remediação de alto custo, mas é uma alternativa aplicável ao tratamento de solos contaminados por múltiplos poluentes, tendo sido utilizada em casos onde há poucas alternativas de tratamento disponíveis (LaGREGA; BUCKINGHAM; EVANS, 1994; FREEMAN; HARRIS, 1995; MULLIGAN; YONG; GIBBS, 2001).

A vitrificação do solo é obtida mediante a passagem de uma corrente elétrica, através de uma malha de eletrodos instalados em determinada profundidade e arranjo, no solo contaminado. A corrente elétrica aplicada aquece o solo a temperaturas de $1600{ }^{\circ} \mathrm{C}$ a $2000{ }^{\circ} \mathrm{C}$, o que é suficiente para fundir a grande maioria dos minerais presentes, e obtém-se como produto final um bloco sólido quimicamente inerte (FREEMAN; HARRIS, 1995; MULLIGAN; YONG; GIBBS, 2001).

A presença de compostos orgânicos, notadamente os inflamáveis e explosivos, é uma limitação para a aplicação desta técnica; por outro lado, outros compostos orgânicos podem ser volatilizados durante o processo, o que demanda tratamento dos gases emitidos.

A vitrificação não é conveniente para solos saturados, pois demanda o rebaixamento do lençol freático ou uma maior necessidade de energia para promover a fusão do material. A profundidade da contaminação no solo é outro fator limitante, pois a técnica tem mostrado resultados até a profundidade de 5,8 $\mathrm{m}$ (LaGREGA; BUCKINGHAM; EVANS, 1994; FREEMAN; HARRIS, 1995).

A USEPA (1995b) relatou a aplicação da vitrificação in situ no Parsons Chemical/ETM Enterprises Superfund Site, executada entre maio/1993 a maio/1994. Os contaminantes presentes neste sítio incluíam pesticidas, ftalatos, hidrocarbonetos

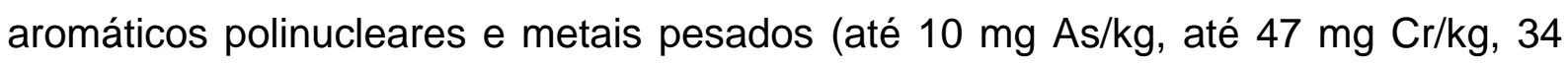

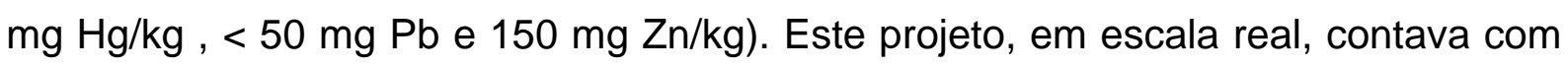
um sistema composto por 9 células de fundição de 7,9 m x 7,9 m x 4,9 m (comprimento $x$ largura $\times$ profundidade) e tratou um volume de $2.294 \mathrm{~m}^{3}$ de solo silto argiloso. O objetivo deste projeto era reduzir o teor de $\mathrm{Hg}$ no solo para $12 \mathrm{mg} / \mathrm{kg}$.

A Figura 10 mostra as três etapas básicas do processo de vitrificação in situ, que tem início com a introdução dos eletrodos de grafite e fritas de vidro no solo (A); a seguir, este sofre subsidência, formando um monólito (B) e é concluído com o recobrimento deste e a recomposição da superfície da área (C). 
Os resultados deste projeto indicaram que seu objetivo foi alcançado e que as concentrações de todos os metais nos testes de lixiviação ficaram abaixo de 5 mg/L. O tempo requerido para a fundição variou de 10 a 19,5 dias, consumiu de 559

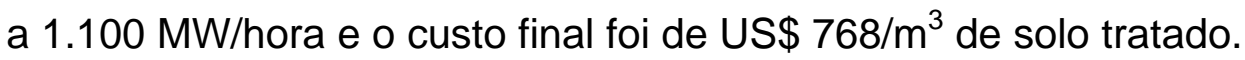

\section{A \\ B \\ C}

Grafite e fritas de vidro para

iniciar o processo

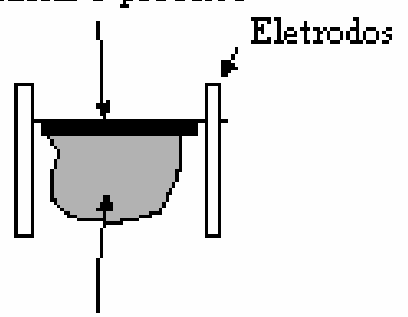

Solo da área

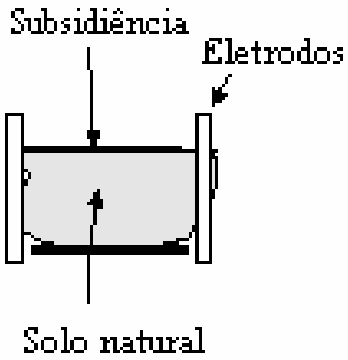

Aterro sobre o monolito

contaminada

Figura 10: Diagrama básico de um processo de vitrificação in situ para remediação de solos contaminados.

Fonte: MULLIGAN; YONG; GIBBS (2001).

\subsubsection{Sistema eletrocinético}

A eletrocinética baseia-se na passagem de uma corrente elétrica de baixa intensidade entre um cátodo e um ânodo introduzidos no solo contaminado. Íons metálicos e pequenas partículas carregadas eletricamente são atraídos pelos eletrodos: cátions para o ânodo e ânions para o cátodo. Para que o transporte ocorra, é fundamental que os íons estejam em solução aquosa. São utilizadas soluções para manter o pH no poço onde estão localizados os eletrodos e, assim, evita-se a precipitação e prejuízos à operação do sistema.

Tais soluções são continuamente recicladas para a remoção dos contaminantes. Um gradiente hidráulico inicia o movimento por eletromigração (elementos químicos com carga elétrica), passa pela eletrosmose (movimento do fluido), pela eletroforese (movimento de partículas carregadas) e termina com a eletrólise - reações químicas devido ao campo magnético formado (MULLIGAN; YONG; GIBBS, 2001). 
Teoricamente, metais, sob a forma de íons solúveis e ligados ao solo como óxidos, hidróxidos e carbonatos, são passíveis de serem removidos por essa técnica, mesmo em solos argilosos e, tem se mostrado mais eficiente para solos saturados. A eletrocinética tem sido pouco utilizada nos EUA, embora já seja empregada em escala real na Europa. É uma alternativa promissora para a remediação de solo argiloso e profundidade moderada de contaminação, todavia, há a necessidade de melhorar os fluidos de extração e a configuração dos eletrodos (MULLIGAN; YONG; GIBBS, 2001).

Segundo a USEPA (2002b), os principais fatores que afetam o desempenho do sistema eletrocinético são:

> Propriedade do contaminante: a aplicabilidade da técnica depende da solubilidade das espécies químicas. Pode ser utilizada para compostos polares solúveis em ácido, mas não é aplicável a metais insolúveis neste solvente;

> Salinidade e capacidade de troca de cátions: a técnica é mais eficiente quando estes parâmetros são baixos, a redução do íon cloreto pelo processo também pode resultar na produção de gás cloro;

> Mistura do solo (água intersticial): requer uma umidade do solo adequada, entretanto, a adição de algum fluido para o preenchimento dos poros pode ser necessária para solos que não atendam às condições operacionais indicadas pelo fabricante do equipamento. É mais indicado para solos saturados;

$>$ Polaridade e magnitude da carga iônica: afetam a direção e o sentido do movimento do contaminante e

$>\mathrm{pH}$ : afeta o processo e causa a precipitação do contaminante e de outras espécies presentes no solo, reduzindo sua permeabilidade e inibindo a recuperação do contaminante alvo. A deposição da precipitação de sólidos pode ser prevenida mediante a lavagem do cátodo com água ou ácido.

A Figura 11 mostra, esquematicamente, os mecanismos e unidades existentes em um sistema eletrocinético.

A FRTR (2001) relatou a realização de um projeto de demonstração, utilizando esta tecnologia entre dezembro/1997 a junho/1998, em Alameda Naval Air Station Point, uma área contaminada com teores de até 2,06 g Cr/kg de solo, devido à disposição de despejos de galvanoplastia.

Foi utilizado um volume de $38,4 \mathrm{~m}^{3}$ de solo alcalino contaminado e, o objetivo do projeto de demonstração era reduzir o teor de $\mathrm{Cr}$ para $30 \mathrm{mg} / \mathrm{kg}$. O 
sistema atingiu o objetivo na maioria das camadas de solo, entretanto, na interface solo/cimento do piso, que era a mais contaminada, a meta não foi atingida.

Durante o experimento, o nível do lençol freático abaixou além do limite estabelecido e houve a necessidade de usar bentonita para manter o nível da solução de extração no poço onde estavam localizados os eletrodos; estimou-se que tal modificação reduziu em 50 \% a eficiência do sistema. Ao final do projeto de demonstração e com base nos dados coletados antes e após o tratamento, concluiuse que $12 \%$ do $\mathrm{Cr}$ total foi removido. O custo foi de $\mathrm{US} \$ 118,00 / \mathrm{m}^{3}$ de solo tratado.

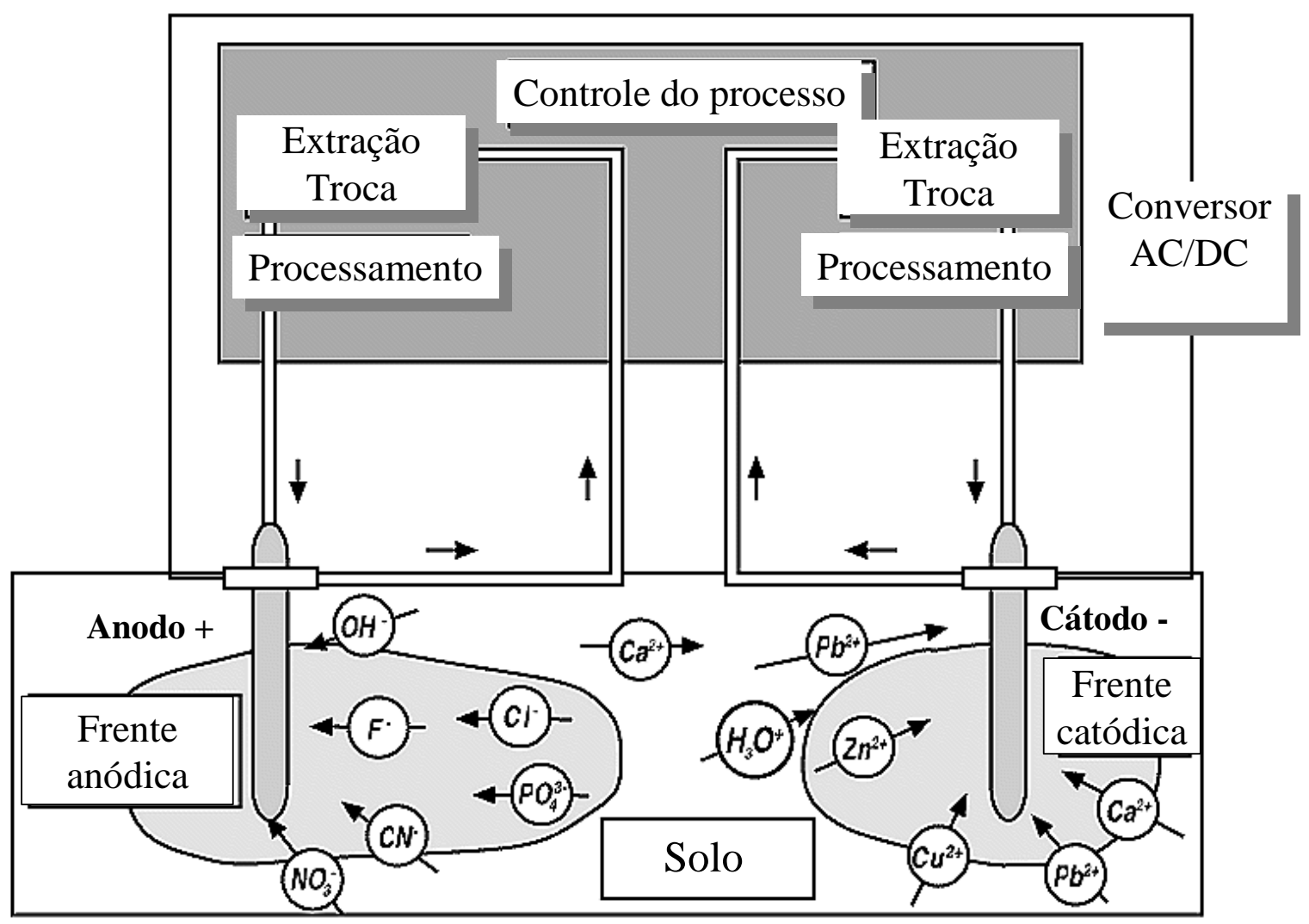

Figura 11 - Esquema básico de um sistema eletrocinético para remoção de compostos inorgânicos de solos contaminados.

Fonte: USEPA (1997c).

A USAEC (2003a) e a FRTR (2002) reportaram um caso de aplicação desta tecnologia, em um experimento demonstrativo em uma área de $2.023 \mathrm{~m}^{2}$, para a remediação de solo arenoso contaminado com metais - até $25.100 \mathrm{mg} \mathrm{Cr} / \mathrm{kg}$ e até $1.810 \mathrm{mg} \mathrm{Cd} / \mathrm{kg}$ - no sítio da Naval Air Weapons Station Point Mugu. A contaminação do solo tinha como origem o lançamento de resíduos da unidade de galvanoplastia e tratamento de superfícies metálicas.

O objetivo do projeto de demonstração era reduzir a contaminação do solo a $2.500 \mathrm{mg} \mathrm{Cr} / \mathrm{kg}$ e $100 \mathrm{mg} \mathrm{Cd} / \mathrm{kg}$. Testes de laboratório, realizados previamente ao 
projeto de demonstração, indicaram que a tecnologia poderia ser utilizada com sucesso, entretanto, após 22 semanas, o projeto foi suspenso, pois os objetivos não haviam sido atingidos em campo.

O baixo desempenho da tecnologia não permitiu sequer quantificar os contaminantes eletrocineticamente mobilizados. Relatou-se ainda, que houve aumento do teor de compostos orgânicos voláteis no solo, primeiramente devido à formação de trihalometanos resultante da geração de $\mathrm{Cl}_{2}$ no ânodo, pela presença de cloretos na água subterrânea, associada ao prolongamento do tempo requerido para a extração dos contaminantes do solo.

Os resultados fornecidos pelos testes de laboratório não refletiram adequadamente os efeitos das condições do sítio, o que ditou o fracasso deste projeto de demonstração. O custo do tratamento para um projeto em escala real, extrapolado a partir dos resultados obtidos em campo, seria de US $\$ 1560,00 / \mathrm{m}^{3}$ de solo tratado.

Outros projetos de demonstração, utilizando o sistema eletrocinético, incluem os realizados nos sítios da Active Power Substation (verão/1998) e da Sandia National Laboratories (maio-novembro/1996) (FRTR, 2000).

Os resultados adversos obtidos nestes projetos permitiram concluir que a eletrocinética precisa ser aprimorada antes de sua aplicação em escala real e, como ressalta o USAEC (2003), problemas como a geração de trihalometanos, os efeitos sobre íons de ocorrência natural, a metodologia de previsão de desempenho da tecnologia, o projeto do eletrodo e seu efeito sobre a forma e a intensidade do campo magnético e a metodologia para determinar a configuração dos eletrodos sob condições de campo precisam ser resolvidos antes de a tecnologia tornar-se viável.

\subsubsection{Fitoremediação}

A fitoremediação é a tecnologia baseada no emprego de espécies vegetais capazes de capturar, transportar, armazenar e imobilizar elementos químicos durante seu ciclo de vida. Os elementos capturados pelas plantas restringem-se à sua fração biodisponível, que é passível de ser transportada através das raízes das plantas durante os processos de nutrição destas. O armazenamento dos elementos 
químicos dá-se nas fibras vegetais, podendo-se concentrar mais em determinadas partes da planta (e.g. raiz, caule, folha), o que depende das características do composto químico e da espécie vegetal utilizada no processo de tratamento (MULLIGAN; YONG; GIBBS, 2001).

A resistência para sobreviver em solos contaminados com altos teores de metais e a habilidade de removê-los desta matriz são características naturais ou geneticamente modificadas que certas espécies vegetais exibem e são a essência da fitoremediação, que, em última análise, é apenas mais uma alternativa para transferência e concentração de metais e não uma solução definitiva para o problema.

A USEPA (1997b) define a fitoremediação como o uso de plantas para remoção, contenção ou transformação, para formas inofensivas, de contaminantes ambientais. Esta definição aplica-se a todos os processos biológicos, físicos e químicos, que são influenciados por plantas e que contribuem para a remoção de contaminantes presentes no solo.

São características gerais da fitoremediação (USEPA, 1997b; USEPA, 2001):

> Indicada para sítios com baixa a moderada dispersão de metais e com solo capaz de suportar o crescimento de plantas;

> A aplicação é limitada à profundidade da zona de raiz da planta e

> Requer muito tempo - geralmente anos - quando comparada com outras tecnologias.

A aplicação da fitoremediação depende do tipo e biodisponibilidade do contaminante alvo, do clima da região e das características hidrogeoquímicas e agronômicas do solo do sítio, pois tais fatores determinam a escolha da(s) espécie(s) vegetal(is) - que possui(em) mecanismo(s) específico(s) de ação capaz(es) de promover(em) a remediação desejada. Os principais mecanismos de ação utilizados pelas plantas, sobre os quais se apóiam a fitoremediação de solos contaminados com metais, incluem (USEPA, 1997b; USEPA, 2001; MULLIGAN; YONG; GIBBS, 2001):

> Fitoextração: emprega plantas hiperacumuladoras - que contenham em seu tecido mais de $0,1 \%$ (em massa seca) de $\mathrm{Ni}, \mathrm{Co}, \mathrm{Cu}, \mathrm{Cr}$ ou qualquer percentual de Zn e Mn - para absorver espécies metálicas do solo e concentrá-las nas 
raízes, caule/ramos e folhas e que são parcial ou totalmente removidas do solo após terem atingido a capacidade máxima de acumulação;

> Fitoestabilização: emprega plantas capazes de tolerar elevados teores de metais no solo e que são capazes de imobilizá-los por sorção, precipitação, complexação ou redução do seu estado de oxidação. Tais plantas limitam a mobilidade e a biodisponibilidade dos metais no solo, mas devem exibir baixos níveis de acumulação nas raízes, para eliminar a possibilidade da massa vegetal vir a tornar-se resíduo perigoso. Esta abordagem da fitoremediação utiliza espécies de plantas arbóreas de ciclo longo ao invés de culturas de ciclo curto;

> Rizofiltração: emprega plantas, cujas raízes sejam capazes de concentrar e precipitar os metais sob formas menos tóxicas. Esta variação da fitoremediação usa plantas para remover metais por sorção e não envolve processos biológicos. Todavia, a bioremediação pode ser associada com plantas para otimizar a degradação microbiológica na rizosfera e

> Fitovolatilização: emprega plantas capazes de remover metais do solo, como Se, Hg, compostos orgânicos voláteis e eliminá-los de seus tecidos durante a evapotranspiração.

Segundo MULLIGAN; YONG; GIBBS (2001), a fitoremediação é uma tecnologia em desenvolvimento, mas pode ser útil para a remediação de solos contaminados com baixos teores de metais, que possam ser tratados em longo prazo. Para estes autores, dentre os problemas que ainda precisam ser resolvidos desta tecnologia incluem-se: melhorar o acúmulo de metais nas plantas e o desenvolvimento de técnicas de extração para determinação de metais na massa vegetal.

A Tabela 2 apresenta um resumo dos mecanismos de ação que as plantas utilizam para sobreviver em um solo contaminado, bem como os poluentes passíveis de serem removidos através de cada um deles.

A FRTR (2000) relatou a aplicação de fitoremediação para a remoção de metais de solos contaminados. O primeiro caso citado foi o de um teste de bancada, realizado na Argonne National Laboratory West, entre maio a outubro de 1998. Foram utilizadas espécies de canola, kochia e salgueiro híbrido (Prairie cascade) para o tratamento de solo contaminado com 44,85 mg Cr/kg, < 1,5 mg Hg/kg e 56,32 
mg Zn/kg. Foram empregados EDTA e ácido cítrico para melhorar a eficiência da técnica.

Este estudo apontou o salgueiro como sendo a mais eficiente na captura de metais entre as três plantas avaliadas, pois fora capaz de remover do solo 4 \% a 5 \% de Zn e 2 \% de Cr e, portanto, poderia ser utilizado em campo para a remoção destes metais, podendo alcançar, anualmente, reduções de até $14 \%$ de Zn e $3 \%$ a 4 \% de Cr, em períodos de 6 a 7 anos para a remoção do Zn e de 9 anos para a do Cr.

A USACE (2003b) relatou os resultados obtidos com 0 uso da fitoremediação em um projeto de demonstração, realizado na Twin Cities Army Ammunition Plant, de 1998 a 1999. Este teste utilizou plantas de milho (cultivo 1) e de mostarda branca (cultivo 2) para remoção de metais em duas áreas de $809 \mathrm{~m}^{2}$, contaminadas com $\mathrm{Sn}, \mathrm{As}, \mathrm{Be}, \mathrm{Ba}, \mathrm{Cr}$ e $\mathrm{Pb}$, embora o principal contaminante fosse o $\mathrm{Pb}$, com valores médios, na camada de 0,00 m a 0,15 m, de 358 ppm e 2.610 ppm, respectivamente. Foram utilizados EDTA e ácido acético para aumentar a solubilidade dos metais e otimizar sua captura pelas plantas.

Tabela 2 - Aplicações da fitoremediação em solos contaminados.

\begin{tabular}{|c|c|c|c|}
\hline Aplicação & Descrição & Poluentes & Tipos de plantas \\
\hline Fitotransformação & $\begin{array}{l}\text { Sorção, absorção e } \\
\text { transporte de poluentes }\end{array}$ & $\begin{array}{l}\text { Compostos } \\
\text { orgânicos, incluindo } \\
\text { nitroaromáticos e } \\
\text { alifáticos clorados } \\
\text { Comnostos }\end{array}$ & Árvores e gramas \\
\hline $\begin{array}{l}\text { Biodegradação } \\
\text { na rizosfera }\end{array}$ & $\begin{array}{l}\text { Biodegradação na } \\
\text { rizosfera estimulada por } \\
\text { plantas }\end{array}$ & $\begin{array}{l}\text { compostos } \\
\text { orgânicos (e.g. } \\
\text { PAHs, } \\
\text { hidrocarbonetos do } \\
\text { petróleo, TNT, } \\
\text { pesticidas) }\end{array}$ & $\begin{array}{l}\text { Gramas, alfafa, } \\
\text { muitas outras } \\
\text { espécies } \\
\text { incluindo plantas) }\end{array}$ \\
\hline Fitoestabilização & $\begin{array}{l}\text { Estabilização de } \\
\text { poluentes por ligação } \\
\text { e/ou redução da } \\
\text { lixiviação }\end{array}$ & $\begin{array}{l}\text { Metais e compostos } \\
\text { orgânicos }\end{array}$ & $\begin{array}{l}\text { Várias plantas } \\
\text { com sistema } \\
\text { radicular profundo } \\
\text { ou fibroso }\end{array}$ \\
\hline Fitoextração & $\begin{array}{l}\text { Absorção de poluentes } \\
\text { do solo para as raízes ou } \\
\text { para os galhos e ramos } \\
\text { que podem ser ceifados }\end{array}$ & $\begin{array}{l}\text { Metais, compostos } \\
\text { orgânicos e } \\
\text { radionuclídeos }\end{array}$ & $\begin{array}{l}\text { Variedades } \\
\text { naturais } \\
\text { selecionadas de } \\
\text { plantas } \\
\text { hiperacumuladora } \\
\text { s (e.g. Thalaspi } \\
\text { sp, Alyssum sp , } \\
\text { Brassica sp) }\end{array}$ \\
\hline
\end{tabular}

Fonte: Adaptado de SCHNOOR (2002). 
Este projeto de demonstração não atingiu os resultados esperados, pois experimentos em estufa indicaram que a cultura de milho (em massa seca) poderia concentrar 0,85\% de $\mathrm{Pb}$, mas no campo obteve-se apenas 0,65 \% de $\mathrm{Pb}$ para um sítio e 0,13 \% para outro, enquanto que a cultura de mostarda branca (em massa seca) poderia concentrar $1,5 \%$ de $\mathrm{Pb}$, mas o projeto de demonstração resultou em apenas $0,083 \%$ de $\mathrm{Pb}$ para um sítio e 0,034 \% de $\mathrm{Pb}$ para outro. O custo estimado para a implantação em escala real desta tecnologia, admitindo duas culturas por ano (um cultivo de milho e outra de mostarda branca), condições sub-ótimas de crescimento das plantas, teor médio de 2.500 ppm de $\mathrm{Pb}$ e duração de cinco anos, é de US $\$ 9,70 / \mathrm{m}^{3}$ de solo tratado/ano.

Um outro caso citado por FRTR (2000) é a aplicação em escala real da fitoremediação na Ensign-Bickford Company, realizada entre abril e outubro de 1998. Este projeto utilizou três cultivos de mostarda indiana e de girassol para a redução da contaminação de $\mathrm{Pb}$ (média de $635 \mathrm{mg} \mathrm{Pb} / \mathrm{kg}$ e valor máximo de $4.000 \mathrm{mg} \mathrm{Pb} / \mathrm{kg}$ ) em uma área contaminada de 0,95 ha.

Este projeto apresentou bons resultados e possibilitou a redução do teor médio de chumbo para $478 \mathrm{mg} / \mathrm{kg}$. A remoção de $\mathrm{Pb}$ pela mostarda indiana (em massa seca) variou de $342 \mathrm{mg} \mathrm{Pb/kg} \mathrm{(cultivo} \mathrm{1)} \mathrm{até} 3.252 \mathrm{mg} \mathrm{Pb/kg} \mathrm{(cultivo} \mathrm{3),}$ enquanto que a remoção de Pb pelo girassol manteve-se em média em 1.000 mg $\mathrm{Pb} / \mathrm{kg}$ (cultivo 1 a 3 ).

A FRTR (2002) relatou a aplicação da fitoremediação em dois projetos demonstrativos para a remoção de metais pesados do solo. No primeiro caso, o solo da área do Magic Marker estava contaminado com teores de até 57,11 g Pb/kg, decorrente da produção de baterias e para remover o metal da camada superficial do solo foram realizados três cultivos, de maio/1997 a novembro/1998, utilizando espécies de mostarda indiana (Brassica juncea, dois cultivos) e girassol (Helianthus annus, um cultivo).

O experimento foi realizado em uma área de 23,5 $\mathrm{m} \times 15,20 \mathrm{~m} \times 0,15 \mathrm{~m}$ (comprimento $x$ largura $x$ profundidade). Ao final do ciclo de vida, as plantas exibiram os seguintes teores (em base seca) de Pb: cultivo 1 (B. juncea) $=830 \mathrm{mg} \mathrm{Pb/kg}$, cultivo $2(B$. juncea) $=2.300 \mathrm{mg} \mathrm{Pb} / \mathrm{kg}$ e cultivo 3 (H. annus $)=400 \mathrm{mg} \mathrm{Pb/kg}$. O tratamento possibilitou a redução de $17 \%$ do teor de $\mathrm{Pb}$ em massa seca de solo, onde este excedia $400 \mathrm{mg} \mathrm{Pb/kg}$. 
O segundo caso, relatado pelo FRTR (2002), diz respeito à demonstração da tecnologia realizada em Fort Dix, cuja área foi contaminada com Pb em decorrência da produção de armas. A fitoremediação foi utilizada, neste caso, como um tratamento complementar à lavagem do solo e tinha por objetivo reduzir o teor de contaminação de $516 \mathrm{mg} \mathrm{Pb/kg} \mathrm{para} 400 \mathrm{mg} \mathrm{Pb/kg}$. O experimento ex situ foi realizado em uma célula de 1 ha, onde foram feitos três cultivos, entre abril a outubro de 2000, utilizando espécies de mostarda indiana (B. juncea, cultivo 1$)$, girassol ( $H$. annus, cultivo 2) e uma mistura de centeio e cevada (Secale cereale e Hordeum vulgare, cultivo 3). O teor de $\mathrm{Pb}$ no tecido das plantas - em base seca - atingiu 437 mg Pb/kg (cultura 1), $1.675 \mathrm{mg} \mathrm{Pb/kg} \mathrm{(cultivo} \mathrm{2)} \mathrm{e} 4.395 \mathrm{mg} \mathrm{Pb/kg} \mathrm{(cultivo} \mathrm{3).} \mathrm{O} \mathrm{teor}$ médio de $\mathrm{Pb}$ no solo foi reduzido para $182 \mathrm{mg} \mathrm{Pb/kg}$ de 0,00 m a 0,15 $\mathrm{m}$ e para 398 $\mathrm{mg} \mathrm{Pb/kg}$ de solo, de 0,15 $\mathrm{m}$ a 0,30 $\mathrm{m}$ de profundidade. Cabe ressaltar que ambos os casos reportados por FRTR (2002) superaram as expectativas iniciais dos envolvidos com o projeto.

\subsubsection{Biolixiviação}

A seguir, é apresentada a discussão teórica e o estado da arte sobre biolixiviação, sobre a qual se assenta a investigação científica proposta neste trabalho.

Devido à recente reclassificação de algumas espécies do gênero Thiobacillus sp para um novo gênero denominado Acidithiobacillus sp, proposta por KELLY e WOOD (KELLY; WOOD, 2000), T. ferrooxidans, T. thiooxidans, T. albertensis e T. caldus foram apresentadas como as quatro espécies com descrição válida para o Acidithiobacillus sp. Portanto, no presente trabalho, as espécies supracitadas são apresentadas como membros do Acidithiobacillus sp, mesmo onde as referências bibliográficas consultadas as identificavam como sendo do gênero Thiobacillus sp.

Muitos centros de pesquisa internacionais e alguns nacionais têm voltado seus esforços para o estudo e o desenvolvimento de processos biológicos de remediação de solos e sedimentos contaminados com metais pesados, que até a década de 1990, eram considerados como impraticáveis (FREEMAN; HARRIS, 
1995; ROULIER et alii,1989). Contrariando os preconceitos até então vigentes, KUYUCAK et alii (1991) e DVORAK et alii (1992) identificaram as bactérias sulfato redutoras como um meio economicamente viável para remover metais pesados das águas de drenagem de minas ácidas.

Os estudos e pesquisas sobre o tema já possibilitaram o desenvolvimento de diversas tecnologias para remoção de contaminantes do solo, particularmente de compostos orgânicos, e.g. hidrocarbonetos (FREEMAN; HARRIS, 1995; PAGE, 1997). Entretanto, apesar do conhecimento acumulado no último século, quando se identificaram as primeiras espécies de Acidithiobacillus sp, foi limitado o avanço obtido sobre o conhecimento da habilidade de determinadas espécies de fungos e bactérias de promoverem a mobilização, mediante a biolixiviação de metais presentes em materiais sólidos.

Atualmente, ainda são poucas as técnicas disponíveis para a extração microbiológica de metais, estando limitadas a processos baseados na biolixiviação e na bio-oxidação (MULLIGAN; YONG; GIBBS, 2001).

A biolixiviação pode ser definida como a dissolução de metais de sua fonte mineral por certos organismos de ocorrência natural ou como o uso de microrganismos para modificar o estado de oxidação química destes elementos, de modo que estes possam ser extraídos de um material, quando a água é filtrada através dele (ATLAS; BARTHA, 1997 e PARKER, 1992 apud BRANDL 2001).

Embora a biolixiviação seja confundida com a bio-oxidação, há de se deixar claro que são processos distintos, pois a primeira refere-se à conversão de um metal em sua forma cristalina para a sua forma solúvel, mediante a ação de um microrganismo, enquanto que a segunda, a oxidação microbiológica do mineral hospedeiro, que contém os metais de interesse e que resulta na concentração destes metais no resíduo sólido remanescente. Termos como biomineração, bioextração e biorecuperação também são aplicados para descrever a mobilização de metais de materiais sólidos através de bactérias e fungos (BRANDL, 2001).

O primeiro setor a se beneficiar do conhecimento sobre a biolixiviação foi a mineração, pois permitiu-lhe ampliar a extração de metais nobres, embora ela tenha sido praticada inconscientemente na Europa desde o Império Romano (BRANDL, 2001). Apesar de a biolixiviação poder ser aplicada para a extração de muitos metais, dentre os quais: cádmio $(\mathrm{Cd})$, chumbo $(\mathrm{Pb})$, cobalto $(\mathrm{Co})$, cobre $(\mathrm{Cu})$, estanho $(\mathrm{Sn})$ magnésio $(\mathrm{Mg})$, níquel $(\mathrm{Ni})$, prata $(\mathrm{Ag})$, ouro $(\mathrm{Au})$ e urânio $(\mathrm{U})$, apenas 
$\mathrm{Au}, \mathrm{Cu}, \mathrm{Ni}$ e $\mathrm{U}$ são industrialmente recuperados de rejeitos ou de minério bruto. Outra aplicação industrial da biolixiviação é a remoção de sulfeto de ferro do carvão mineral (KREBS et alii, 1997).

O processo de biolixiviação ou biomineração, quando aplicado em larga escala para a recuperação de metais de minérios ou de outras fontes, é coberta pela área de biohidrometalurgia, um campo interdisciplinar que engloba e combina a microbiologia, a geoquímica, a biotecnologia, a hidrometalurgia, a mineralogia, a geologia, a engenharia química e a engenharia de minas (BRANDL, 2001).

Uma grande variedade de microrganismos é conhecida por realizar a biolixiviação de metais, principalmente em depósitos de minérios e em paredes e tetos de minas. A mobilização de metais em minas constitui-se em um grande problema ambiental em qualquer parte do mundo (HERBERT JR, 1999; EEA, 2000; ESPOSITO et alii, 2001; GROUDEV et alii, 2001; CICCU et alii, 2003, etc), pois a atividade biológica, aeróbia ou anaeróbia, provoca a acidificação e a conseqüente contaminação com metais pesados das águas superficiais e subterrâneas adjacentes.

Portanto, o grave impacto ambiental provocado pela acidificação das águas presentes nas minas ensejou o aprofundamento do estudo sobre as causas de sua ocorrência e possíveis meios de controle. O conhecimento acumulado sobre o tema tem sido gradativamente incorporado e aplicado para a remediação de áreas contaminadas com metais pesados (HERBERT JR, 1999; BRANDL, 2001; MULLIGAN; YONG; GIBBS, 2001).

Embora os microrganismos não possam destruir os metais, eles são capazes de alterar suas propriedades químicas através de vários mecanismos, alguns dos quais podem ser usados para a remediação de áreas contaminadas. Em alguns casos, estes mecanismos envolvem vias bioquímicas altamente específicas para proteger a célula da toxicidade dos metais pesados (LLOYD, 2002).

A extração do metal retido no solo somente é possível em baixos valores de pH (MULLIGAN; YONG; GIBBS, 2001). A biolixiviação de metais ocorre através de processos biológicos de dissolução oxidativa de sulfetos metálicos e de íons ferrosos e pode ser realizada através da via aeróbia, onde o oxigênio é o aceptor de elétrons; ou anaeróbia, onde o aceptor de elétrons pode ser o íon $\mathrm{Fe}^{3+}$ ou $\mathrm{NO}_{3}{ }^{-}(\mathrm{HERBERT}$ JR, 1999; BRANDL, 2001). 
$\mathrm{Na}$ oxidação de misturas complexas de sulfetos, as interações galvânicas têm efeitos significativos na biolixiviação por $A$. ferrooxidans. Presume-se que tais bactérias sustentem estas interações não somente pela oxidação do íon ferroso para íon férrico, mas também, pela oxidação do enxofre elementar para ácido sulfúrico, mantendo a superfície do material exposta (LIZAMA; SUZUKI, 1991).

A mobilização de um metal pesado presente no solo decorre da sua solubilização por um ácido, tal como $\mathrm{O} \mathrm{H}_{2} \mathrm{SO}_{4}$, produzido durante processos de oxidação (atmosférica e biológica) de sulfeto mineral ou pela redução biológica do enxofre. Logo, a mobilização de metais pesados somente é possível de ser obtida por microrganismos que produzam ácidos e/ou metabólitos capazes de promover sua lixiviação de materiais sólidos que os contenham.

Dentre todos os microrganismos capazes de biolixiviar metais, espécies de bactérias e fungos são descritas na literatura (HERBERT JR, 1999; BRANDL, 2001), todavia, espécies de leveduras, flagelados, amebas e protozoários também já foram encontradas em água ácida de minas de cobre (BRANDL, 2001), constatação que reforça a tese de que a biolixiviação de metais não se deve exclusivamente a uma única espécie, mas a um consórcio microbiano formado por diversas espécies de microrganismos.

Uma mostra da grande diversidade de espécies de microrganismos presentes em um processo de biolixiviação de solo contaminado com metais pesados e radionuclídeos foi relatada por GROUDEV et alii (2001), a qual é apresentada na Tabela 3.

As espécies de Acidithiobacillus estão entre os microrganismos mais estudados, pois são capazes de suportar condições ambientais extremamente agressivas (e.g. $\mathrm{pH}=1$ ); produzem uma solução muito ácida, que é capaz de dissolver a maioria dos metais; são tolerantes a elevadas concentrações de metais pesados; utilizam uma fonte de energia de baixo custo, se comparado com outros microrganismos quimiorganotróficos e mantém sua atividade biológica, mesmo em condições anaeróbias (HERBERT JR, 1999; KREBS; BACHOFEN; BRANDL, 2001).

A bactéria $A$. ferrooxidans pertence ao grupo dos organismos quimiotróficos, tem a forma de bastonete, mede entre 0,5 - 1,0 $\mu \mathrm{m}$, não produz esporos, é gramnegativa, é flagelada e tem mobilidade, é acidófila, sua fisiologia é baseada na fixação do $\mathrm{CO}_{2}$, de onde retira o carbono para a síntese de novo material celular, obtém energia a partir da oxidação do $\mathrm{Fe}^{2+}$ ou de compostos reduzidos ou 
parcialmente reduzidos de enxofre (incluindo sulfeto, enxofre elementar e tiossulfato) presentes no meio; o sulfato é o produto final da oxidação dos compostos de enxofre. Embora tenha sido caracterizada originalmente como uma espécie estritamente aeróbia, constatou-se, posteriormente, que também pode se desenvolver em ambiente anóxico (BOSECKER, 1997; HERBERT JR, 1999; BRANDL, 2001). A Figura 12 mostra uma microfotografia do A. ferrooxidans.

Tabela 3 - Densidade de vários grupos fisiológicos de microrganismos presentes em um solo durante a bioremediação de uma área contaminada, sob condições de campo.

\begin{tabular}{|c|c|c|}
\hline Microrganismo & $\begin{array}{c}\text { Horizonte A do solo (0- } \\
25 \mathrm{~cm}), n^{\circ} \text { células } / \mathrm{g} \text { de } \\
\text { solo seco }\end{array}$ & $\begin{array}{l}\text { Horizonte B do solo } \\
(26-80 \mathrm{~cm}), \mathrm{n}^{\circ} \\
\text { células } / \mathrm{g} \text { de solo seco }\end{array}$ \\
\hline Bactéria heterotrófica aeróbia & $10^{6}-10^{8}$ & $10^{4}-10^{6}$ \\
\hline Oligocarbófilas & $10^{3}-10^{7}$ & $102-10^{5}$ \\
\hline $\begin{array}{l}\text { Microrganismos degradadores } \\
\text { de celulose }\end{array}$ & $10^{6}-10^{6}$ & $10^{2}-10^{4}$ \\
\hline $\begin{array}{l}\text { Bactérias fixadoras de } \\
\text { nitrogênio }\end{array}$ & $10^{3}-10^{5}$ & $10^{2}-10^{4}$ \\
\hline Bactéria nitrificante & $10^{2}-10^{5}$ & $10^{1}-10^{3}$ \\
\hline $\begin{array}{l}\text { Bactéria quimiolitotrófica } \\
\text { oxidante de enxofre }\end{array}$ & $10^{3}-10^{7}$ & $10^{2}-10^{5}$ \\
\hline $\begin{array}{l}\text { Bactéria quimiolitotrófica } \\
\text { oxidante de ferro }\end{array}$ & $1-10^{1}$ & $0-10^{1}$ \\
\hline $\begin{array}{l}\text { Bactéria heterotrófica } \\
\text { anaeróbia }\end{array}$ & $10^{3}-10^{6}$ & $10^{3}-10^{7}$ \\
\hline Bactéria desnitrificante & $10^{3}-10^{5}$ & $10^{3}-10^{5}$ \\
\hline $\begin{array}{l}\text { Bactéria anaeróbia } \\
\text { fermentadora de carboidratos } \\
\text { com produção de gás }\end{array}$ & $10^{3}-10^{5}$ & $10^{3}-10^{6}$ \\
\hline Bactéria redutora de sulfato & $10^{3}-10^{5}$ & $10^{4}-10^{7}$ \\
\hline Bactéria redutora de $\mathrm{Fe}^{3+}$ & $10^{2}-10^{4}$ & $10^{2}-10^{5}$ \\
\hline Bactéria redutora de $\mathrm{Mn}^{4+}$ & $10^{1}-10^{3}$ & $10^{2}-10^{4}$ \\
\hline Bactéria metanogênica & $0-10^{2}$ & $1-10^{5}$ \\
\hline Estreptomicetos & $10^{3}-10^{6}$ & $10^{2}-10^{4}$ \\
\hline Fungos & $10^{3}-10^{6}$ & $10^{2}-10^{4}$ \\
\hline Número total de células & $1.10^{8}-6.10^{8}$ & $1.10^{6}-5.10^{7}$ \\
\hline
\end{tabular}

Fonte: GROUDEV et alii (2001).

O crescimento de $A$. thiooxidans em partículas de enxofre é suportado pela excreção de metabólitos que atuam como biosurfactantes, os quais facilitam a oxidação do enxofre elementar. Na presença de biosurfactantes, que modificam a tensão superficial do mineral, a dessorção do metal da superfície sólida pode ser 
melhorada e resulta no aumento de mobilidade em meio poroso (BRANDL, 2001). A Figura 13 mostra uma microfotografia do $A$. thiooxidans.

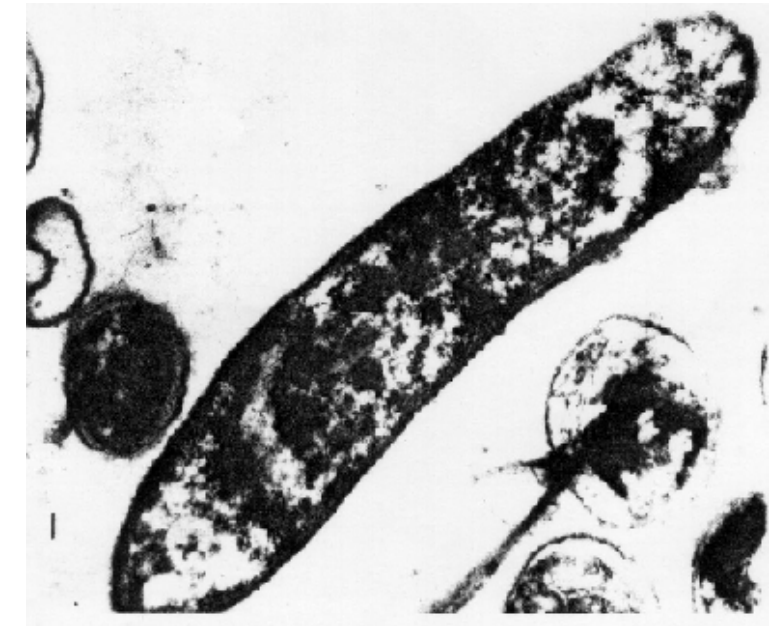

Figura 12 - Microfotografia de $A$. ferrooxidans em suspensão (ampliação de 30.000 vezes).

Fonte: COLORADO SCHOOL OF MINES (2003).

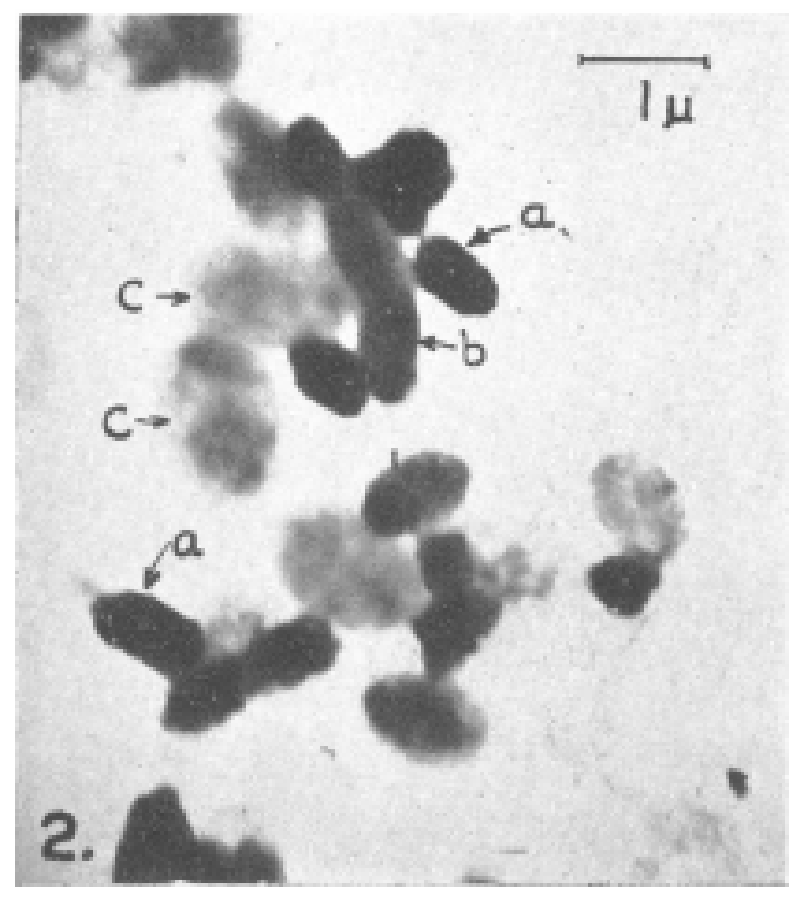

Figura 13 - Microfotografia de $A$. thiooxidans em suspensão (ampliação de 12.000 vezes).

Fonte: UMBREIT; ANDERSON (1941).

A despeito das muitas vantagens exibidas pelos Acidithiobacillus sp, seu crescimento é lento, se comparado com bactérias quimiorganotróficas, o que se deve à sua menor produção de energia em relação ao consumo de substrato. Devese considerar ainda que condições de cultivo sub-ótimas podem reduzir ainda mais 
as taxas de crescimento e, por conseguinte, prolongar a duração do processo de biolixiviação (KREBS; BACHOFEN; BRANDL, 2001).

A lixiviação e mobilização dos metais presentes em materiais sólidos pelos microrganismos compreendem três princípios: reações de oxidação, formação de ácidos orgânicos ou inorgânicos e excreção de agentes complexantes.

A mediação pelas reações de redução é baseada na transferência de elétrons dos minerais para os microrganismos; em caso de contato físico entre os sólidos e os microrganismos; ou pela oxidação do $\mathrm{Fe}^{2+}$ para $\mathrm{Fe}^{3+}$, onde o íon férrico catalisa a solubilização do metal (KREBS et alii, 1997; BRANDL, 2001). BOON; RAS; HEIJNEN (1999) e BOON et alii (1999) estudaram profundamente a cinética da oxidação do $\mathrm{Fe}^{2+}$ pelo $A$. ferrooxidans, o que torna esta literatura uma referência para aqueles que desejem aprofundar os conhecimentos sobre o tema.

Inicialmente, foi proposto um modelo de dois mecanismos envolvidos na mobilização de metais. Segundo este modelo, pelo mecanismo direto, os microrganismos poderiam oxidar um sulfeto metálico, obtendo elétrons diretamente do mineral reduzido e para tanto, haveria a necessidade das células estabelecerem um contato físico com a superfície do mineral. Pelo mecanismo indireto, a oxidação do metal reduzido seria mediada pelo $\mathrm{Fe}^{3+}$, originado da oxidação do $\mathrm{Fe}^{2+}$ presente no mineral, que sendo um agente oxidante, promoveria a oxidação química do sulfeto metálico. $\mathrm{O} \mathrm{Fe}^{3+}$ seria reduzido para $\mathrm{Fe}^{2+}$, que por sua vez, seria biologicamente oxidado para $\mathrm{Fe}^{3+}$. Este mecanismo supostamente não exigiria um contato físico entre a célula e a superfície do metal (BRANDL, 2001).

A reação de oxidação de um sulfeto metálico genérico através o mecanismo direto poderia ser representada pela Reação (1) e através do mecanismo indireto, pelas Reações (2), (3) e (4) (BOSECKER, 1997):

$$
\begin{aligned}
& \mathrm{MeS}+2 \mathrm{O}_{2}+\text { bactérias } \rightarrow \mathrm{MeSO}_{4} \\
& \mathrm{MeS}+\mathrm{Fe}_{2}\left(\mathrm{SO}_{4}\right)_{3} \rightarrow \mathrm{MeSO}_{4}+2 \mathrm{FeSO}_{4}+\mathrm{S}^{0} \\
& 2 \mathrm{FeSO}_{4}+\mathrm{H}_{2} \mathrm{SO}_{4}+\mathrm{O}_{2}+\text { bactéria. } \rightarrow \mathrm{Fe}_{2}\left(\mathrm{SO}_{4}\right)_{3}+\mathrm{H}_{2} \mathrm{O} \\
& 2 \mathrm{~S}^{0}+3 \mathrm{O}_{2}+2 \mathrm{H}_{2} \mathrm{O}+\text { bactéria } \rightarrow 2 \mathrm{H}_{2} \mathrm{SO}_{4}
\end{aligned}
$$

A Figura 14 mostra, esquematicamente, a ação dos mecanismos direto e indireto envolvidos na oxidação de sulfetos metálicos. 


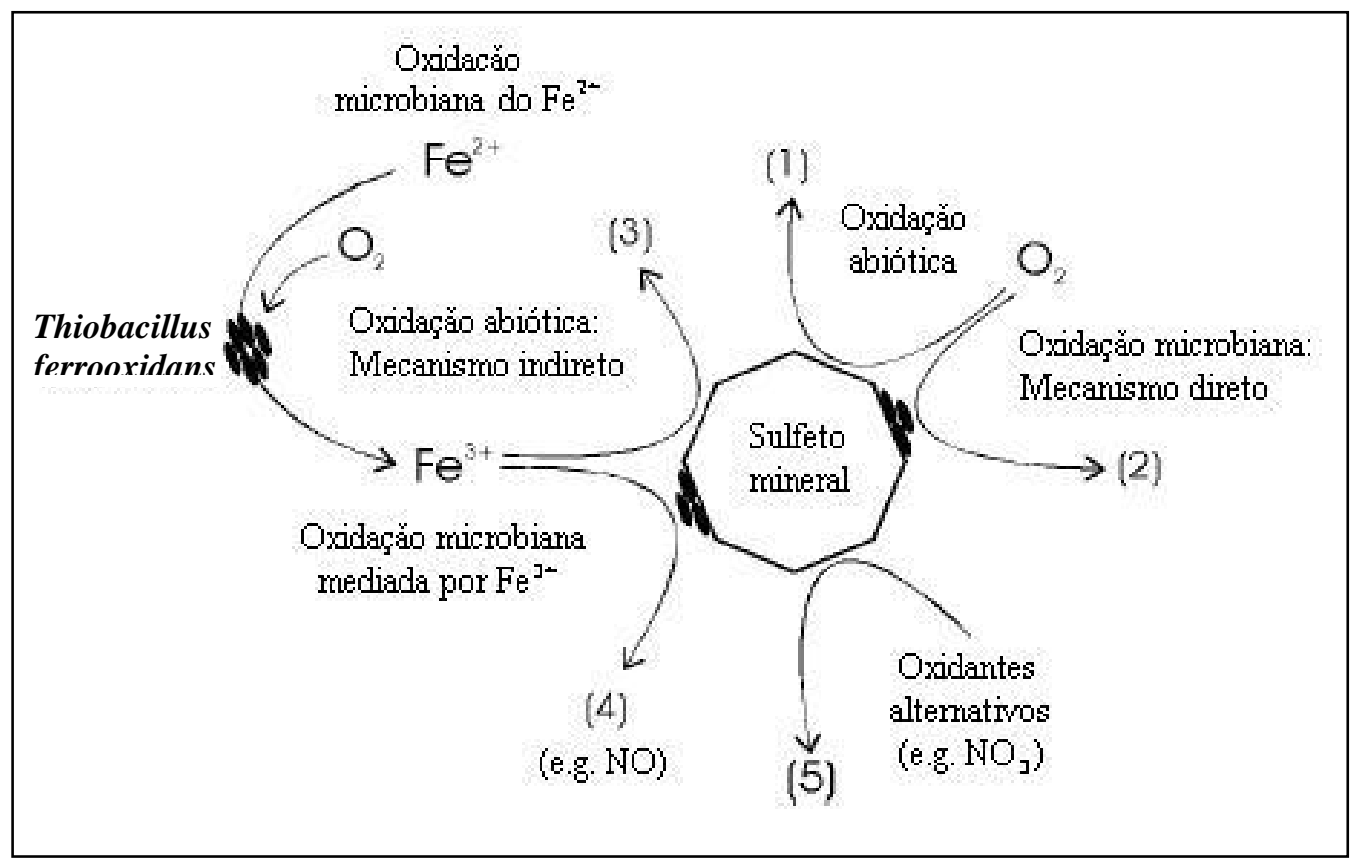

Figura 14 - Rotas alternativas na oxidação de sulfetos minerais sujeitas às condições ambientais.

Fonte: HERBERT JR. (1999).

Portanto, a ação bacteriana sobre sulfetos metálicos resulta na formação dos sulfatos metálicos correspondentes, já a ação sobre o enxofre elementar resulta em ácido sulfúrico e sobre o íon ferroso, em íon férrico. A ação bacteriana catalisa em até $10^{6}$ vezes a reação de oxidação química em meio ácido. Para que a oxidação bacteriana do enxofre e do ferro ocorra no ambiente, as reações precisam ser termodinamicamente possíveis e, embora os microrganismos não possam mudar as relações termodinâmicas, eles atuam como aceleradores das taxas de catálise das reações químicas (HERBERT JR, 1999).

Segundo BRANDL (2001), os conceitos dos mecanismos direto e indireto estão sendo revistos e substituídos por outros que não dependem desta definição "restrita". Os novos mecanismos são os seguintes:

A célula tem que estar ligada ao mineral e em contato físico com a superfície deste;

> A célula produz e excreta polímeros, este exopolímero contém $\mathrm{Fe}^{3+}$, que é complexado com ácido glicônico, o exopolímero faz parte do primeiro mecanismo de fixação;

> Formação de tiossulfato como intermediário durante a oxidação dos compostos de enxofre e 
> Formação de enxofre ou grânulos de politionato no espaço periplasmático ou na membrana celular.

Visto que não se encontraram evidências para um processo mediado enzimaticamente, foram propostos dois novos mecanismos de biolixiviação dos sulfetos minerais: tiossulfato e polissulfeto; todavia, é a estrutura do mineral quem dita qual será o mecanismo de lixiviação que prevalecerá.

No mecanismo tiossulfato, este composto é o principal produto intermediário da oxidação (e. g. oxidação da pirita molibdenita). No mecanismo polissulfeto, este e o enxofre elementar são os principais produtos da oxidação (e. g. oxidação da galena, esfarelita). A presença de $\mathrm{Fe}^{3+}$ no início da degradação mineral é um requisito importante. As Reações (5) e (6) representam o mecanismo tiossulfato, válido para $\mathrm{FeS}_{2}, \mathrm{MoS}_{2}$ e $\mathrm{WS}_{2}$, as Reações (7), (8) e (9) representam o mecanismo polissulfeto, válidas para $\mathrm{PbS}, \mathrm{CuFeS}, \mathrm{ZnS}, \mathrm{MnS}, \mathrm{As}_{2} \mathrm{~S}_{3}$ e $\mathrm{As}_{3} \mathrm{~S}_{4}$ :

$$
\begin{aligned}
& \mathrm{FeS}_{2}+6 \mathrm{Fe}^{3+}+3 \mathrm{H}_{2} \mathrm{O} \rightarrow \mathrm{S}_{2} \mathrm{O}_{3}{ }^{2-}+7 \mathrm{Fe}^{2+}+6 \mathrm{H}^{+} \\
& \mathrm{S}_{2} \mathrm{O}_{3}{ }^{2-}+8 \mathrm{Fe}^{3+}+5 \mathrm{H}_{2} \mathrm{O} \rightarrow 2 \mathrm{SO}_{4}{ }^{2-}+8 \mathrm{Fe}^{2+}+10 \mathrm{H}^{+} \\
& 2 \mathrm{MeS}+2 \mathrm{Fe}^{3+}+2 \mathrm{H}^{+} \rightarrow 2 \mathrm{Me}^{2+}+\mathrm{H}_{2} \mathrm{~S}_{\mathrm{n}}+2 \mathrm{Fe}^{2+} \\
& \mathrm{H}_{2} \mathrm{~S}_{\mathrm{n}}+2 \mathrm{Fe}^{3+} \rightarrow 0,25 \mathrm{~S}_{8}+2 \mathrm{Fe}^{2+}+2 \mathrm{H}^{+} \\
& 0,25 \mathrm{~S}_{8}+3 \mathrm{O}_{2}+2 \mathrm{H}_{2} \mathrm{O} \rightarrow 2 \mathrm{SO}_{4}{ }^{2-}+4 \mathrm{H}^{+}
\end{aligned}
$$

Uma discussão profunda sobre o tema foi realizada recentemente por SAND et alii (2001) e TRIBUTSCH (2001) e mostrou que a controvérsia sobre os mecanismos envolvidos na biolixiviação de metais ainda persiste.

As transformações enzimáticas catalisadas pelos microrganismos envolvem artifícios bioquímicos destinados a proteger suas próprias células da toxicidade dos metais pesados que, em última instância, podem ser úteis para aplicações de bioremediação. Muitos processos de desintoxicação microbiana envolvem o lançamento ou excreção dos íons metálicos de suas células, que em muitos casos, resulta em elevadas concentrações locais de metal na superfície da célula, onde eles podem reagir com ligantes biogênicos e precipitar (LLOYD, 2002).

BROMBACHER; BACHOFEN; BRANDL (1998) utilizaram a solução ácida resultante do crescimento bacteriano, mas isento de células, para a condução dos ensaios de lixiviação, os quais apresentaram melhores resultados do que a solução contendo células, mas que foi submetida à autoclave. Estes resultados indicaram que compostos envolvidos no transporte de elétrons, como rusticianina (proteína 
contendo cobre), citocromos e proteínas ferro-enxofre, presentes no espaço periplasmático das células, são excretados por elas e catalisam a oxidação de compostos metálicos reduzidos e que tais enzimas foram inativadas no meio autoclavado.

Segundo BRANDL (2001), em muitos ambientes de lixiviação, as condições, especialmente as concentrações de $\mathrm{Fe}^{2+}$ e $\mathrm{Fe}^{3+}$, variam com a duração do processo de lixiviação, o que torna difícil avaliar a importância e o efeito da presença de um dado microrganismo.

Tanto fatores físico-químicos quanto microbiológicos do ambiente de lixiviação afetam a taxa e a eficiência do processo. As propriedades do sólido a ser lixiviado também são de importância capital. A atividade do próprio microrganismo, a fonte de energia, a composição mineralógica do material a ser lixiviado, a densidade de polpa, a temperatura e o tamanho da partícula, são fatores que afetam adversamente a lixiviação (BRANDL, 2001). A Tabela 4 apresenta os principais fatores que influenciam a oxidação biológica de minerais e a mobilização de seus metais.

Segundo BRANDL (2001), a oxidação microbiológica pode ser inibida por diversos fatores, e. g. compostos orgânicos, agentes com superfície ativa, solventes, metais específicos e agentes de extração ou flotação. Biocidas podem ser utilizados como inibidores seletivos para impedir o crescimento de microrganismos indesejáveis e, deste modo, reduzir a competição das espécies de microrganismos e melhorar a eficiência da biolixiviação. Compostos gasosos também podem exibir efeitos inibitórios, e. g. $\mathrm{CO}_{2}$ na fase aquosa em concentração superior a $10 \mathrm{mg} / \mathrm{L}$ inibe o crescimento de $A$. ferrooxidans em minério de pirita-arsenopirita-pirrotita; a concentração ótima de $\mathrm{CO}_{2}$ está na faixa de $3 \mathrm{mg} / \mathrm{L}$ a $7 \mathrm{mg} / \mathrm{L}$.

A co-precipitação de metais durante o processo de biolixiviação pode reduzir a eficiência do processo, pois a precipitação dos presentes no lixiviado sobre a superfície do mineral pode torná-lo inacessível à lixiviação bacteriana.

A solubilização do metal pode ser facilitada por metabólitos biológicos excretados por outros microrganismos além do Acidithiobacillus $s p$, que fazem parte do consórcio microbiano encontrado nas operações de lixiviação. Dentre as substâncias que podem melhorar o processo incluem-se aminoácidos (cistina), fosforo-lipídeos e lipídeos neutros. 
Tabela 4 - Fatores e parâmetros que influenciam a oxidação biológica de minerais e a mobilização de seus metais.

\begin{tabular}{|c|c|}
\hline Fator & Parâmetro \\
\hline $\begin{array}{l}\text { Parâmetros físico-químicos de um } \\
\text { ambiente de biolixiviação }\end{array}$ & $\begin{array}{l}\text { Temperatura, pH, potencial redox, } \\
\text { conteúdo e disponibilidade de água, } \\
\text { conteúdo de } \mathrm{CO}_{2} \text {, transferência de } \\
\text { massa, disponibilidade de nutrientes, } \\
\text { concentração de } \mathrm{Fe}^{3+} \text {, luz, pressão, } \\
\text { tensão superficial e presença de } \\
\text { inibidores. }\end{array}$ \\
\hline $\begin{array}{l}\text { Parâmetros microbiológicos de um } \\
\text { ambiente de biolixiviação }\end{array}$ & $\begin{array}{l}\text { Diversidade microbiológica, } \\
\text { densidade populacional, atividade } \\
\text { microbiana, distribuição espacial dos } \\
\text { microrganismos, tolerância ao metal } \\
\text { e capacidade de adaptação. }\end{array}$ \\
\hline $\begin{array}{l}\text { Propriedades do mineral a ser } \\
\text { biolixiviado }\end{array}$ & $\begin{array}{l}\text { Tipo de mineral, composição } \\
\text { mineralógica, disseminação do } \\
\text { mineral, tamanho dos grãos, área } \\
\text { superficial, hidrofobicidade, } \\
\text { interações galvânicas e formação de } \\
\text { minerais secundários. }\end{array}$ \\
\hline Processo de biolixiviação & $\begin{array}{l}\text { Modo de lixiviação (in situ, em pilha, } \\
\text { aterro ou reator), densidade de polpa, } \\
\text { taxa de agitação (caso seja em } \\
\text { reator) e geometria (caso seja em } \\
\text { pilha). }\end{array}$ \\
\hline
\end{tabular}

Fonte: BRANDL (2001).

\subsubsection{Estudos de casos}

Os estudos de caso serão apresentados em ordem cronológica, pois visam expressar o rumo tomado nas pesquisas sobre biolixiviação.

CHARTIER; COUILLARD (1997) relataram a execução de experimentos de biolixiviação, utilizando sedimentos contaminados com metais e $A$. ferrooxidans e Thiobacilli sp como agentes biológicos. Tais experimentos foram executados em reatores de $500 \mathrm{~mL}$, em bateladas, que tiveram duração máxima de 96 hs. Este estudo teve por objetivo averiguar se o processo por eles desenvolvido para lodos de esgoto poderia ser aplicado para sedimentos. Os experimentos avaliaram a 
influência do pH inicial, da quantidade de inóculo introduzido e da adição de nitrogênio e fosfato sobre a eficiência do processo de biolixiviação.

O sedimento utilizado nos experimentos apresentava a seguinte composição: $3 \%$ areia; $57 \%$ de silte; 40 \% de argila; 10,2 \% de matéria orgânica; $7,7 \%$ de carbono total; 0,67 \% de Nitrogênio Total Kjeldahl; 0,48 \% de enxofre total e os seguintes teores de metais: $367 \mathrm{mg} / \mathrm{kg} \mathrm{Pb;} 2.667 \mathrm{mg} / \mathrm{kg} \mathrm{Zn;} 97 \mathrm{mg} / \mathrm{kg} \mathrm{Cu} ; 863$ mg/kg Mn; 79 mg/kg Ni; 173 mg/kg Cr e 4 mg/kg Cd.

Foi utilizada uma linhagem pura de $A$. ferrooxidans, mas os autores consideraram provável o desenvolvimento de uma cultura mista durante os experimentos, pois essa foi adaptada gradativamente ao sedimento contaminado durante um mês. Para favorecer o crescimento desta bactéria, foi adicionado como substrato $20 \mathrm{~g} \mathrm{FeSO}_{4} .7 \mathrm{H}_{2} \mathrm{O} / 100 \mathrm{~g}$ de sedimento seco e para reduzir o custo deste substrato, ele foi obtido de um resíduo industrial contaminado com: 20,3 mg/kg Pb; 620 mg/kg Zn; 2,5 mg/kg Cu; 350 mg/kg Mn; 50 mg/kg Ni; 7,5 mg/kg Cr.

Todos os experimentos foram executados em duplicata e com suspensão a 3 \%. Para diluição do sedimento, utilizou-se água destilada e $0 \mathrm{H}_{2} \mathrm{SO}_{4}$ para correção do $\mathrm{pH}$. Os frascos foram mantidos a $20^{\circ} \mathrm{C}$, em $100 \mathrm{rpm}$, por um período de quatro dias.

Nos quatro experimentos executados para avaliar o efeito inicial do $\mathrm{pH}$, adicionou-se variada quantidade de inóculo (volume/volume): 0 \%, 10 \%, $20 \%$ e 30 $\%$, além de $\left(\mathrm{NH}_{4}\right)_{2} \mathrm{SO}_{4}$ e fosfato. O substrato foi utilizado sempre na razão de $20 \%$ sobre a massa seca de sedimento no reator.

Nos cinco experimentos executados para averiguar a presença de linhagens indígenas no sedimento, utilizou-se:

a) sedimento acidificado $(\mathrm{pH}=4,0)+20 \%$ em massa de substrato;

b) 02 reatores com sedimento sem acidificar $(\mathrm{pH}=7,0)$ : 01 reator com $20 \% \mathrm{em}$ massa de substrato e 01 reator sem substrato;

c) 01 reator com sedimento esterilizado em autoclave acidificado $(\mathrm{pH}=4,0)+20$ $\%$ em massa de substrato;

d) 01 reator acidificado $(\mathrm{pH}=4,0)+20 \%$ em massa de substrato $+20 \%$ volume/volume de inóculo.

O arranjo experimental resultou na solubilização de 80 \% a 90 \% para o Zn, de $60 \%$ a $80 \%$ para o Cu e não atingiu $30 \%$ para o $\mathrm{Pb}$. Segundo estes autores, a solubilização do $\mathrm{Zn}$ foi estritamente dependente do $\mathrm{pH}$; para o $\mathrm{Cu}$, ela foi função do 
pH e do potencial de óxido redução; para o $\mathrm{Pb}, \mathrm{o}$ pH afetou sua solubilidade e, nos ensaios que utilizaram elevado percentual de inóculo, o Pb precipitou. Dentre outros fatores, os autores sugeriram que a presença de sulfato interferiu/controlou a solubilidade do Pb (CHARTIER; COUILLARD, 1997).

GROUDEV; SPASOVA; GEORGIEV (2001) reportaram a realização de experimentos de bioremediação in situ de solos agrícolas contaminados, em decorrência de atividades de mineração, com radionuclídeos ( $U$ e $R a$ ) e metais pesados ( $\mathrm{Cd}, \mathrm{Cu}$ e $\mathrm{Zn})$, os quais se concentravam principalmente na camada superior do solo $(0 \mathrm{~cm}$ a $30 \mathrm{~cm})$.

Os experimentos foram conduzidos em duas áreas de $20 \mathrm{~m} \times 10 \mathrm{~m}$, sendo cada uma submetida a um método diferente de tratamento, embora tivessem em comum a solubilização inicial dos contaminantes, proporcionada através de solução de água acidificada até $\mathrm{pH}=3,5$ a 4,5 com $\mathrm{H}_{2} \mathrm{SO}_{4}$.

O primeiro método de tratamento baseava-se na lavagem ácida por aspersão e a remoção dos contaminantes dissolvidos no lixiviado. O segundo era baseado na estimulação da atividade de bactérias sulfato redutoras, que deveriam promover a transferência dos contaminantes dissolvidos para a camada subsuperficial $(31 \mathrm{~cm}-80 \mathrm{~cm}$ ) do solo e, a sua desintoxicação e imobilização na base desta camada. A atividade das bactérias sulfato redutoras foi estimulada mediante a injeção de água e compostos orgânicos. Ambos os lixiviados foram submetidos ao tratamento em wetlands e o efluente do tratamento foi reutilizado no tratamento do solo.

A análise da microfauna do solo contaminado revelou uma rica variedade de microrganismos. As bactérias acidófilas mesofílicas $A$. ferrooxidans, $A$. thiooxidans e Leptsporidium ferrooxidans foram os microrganismos mais prevalecentes na camada superior do solo $(0 \mathrm{~cm}$ a $30 \mathrm{~cm})$, mas algumas espécies basofílicas quimiolitotróficas (principalmente $T$. thioparus e $T$. denitrificans) e algumas espécies heterotróficas também estavam presentes em elevado número.

Os experimentos evidenciaram que, em condições naturais, a oxidação bacteriana dos sulfetos minerais no solo era contínua, mas lenta. O número e a atividade dos microrganismos quimiolitotróficos acidófilos no solo foram limitados por alguns fatores ambientais essenciais, tais como o elevado valor de pH $(4,4$ a 4,6), o déficit de oxigênio no solo, a insuficiência de umidade durante longos períodos de tempo e a ausência de nutrientes importantes, tais como nitrogênio e fósforo. A 
deficiência de nutrientes foi solucionada mediante a adição de zeólita saturada com fosfato de amônio, que forneceu íons fosfato e amônio para a comunidade microbiológica e melhorou as propriedades físicas e mecânicas do solo.

Segundo os autores, a solubilização dos contaminantes na área submetida ao tratamento com aspersão foi resultado, principalmente, da atividade da microfauna indígena do solo. Todavia, a acidificação do meio resultou no aumento do número de bactérias quimiolitotróficas e uma pequena redução do número de espécies heterotróficas. Os resultados obtidos por este método, para o tratamento da camada superficial $(0 \mathrm{~cm}$ a $30 \mathrm{~cm}$ ) são apresentados na Tabela 5 . Na área submetida ao tratamento, apenas uma pequena fração dos contaminantes foi lixiviada, sendo que a maioria foi convertida para a forma de sulfetos insolúveis e o urânio, $\quad \mathrm{UO}_{2}$, que se concentraram na base da camada subsuperficial $(31 \mathrm{~cm}$ a 80 $\mathrm{cm})$.

Tabela 5 - Elementos tóxicos no horizonte $A(0 \mathrm{~cm}$ a $30 \mathrm{~cm})$ do solo, antes a após a bioremediação.

\begin{tabular}{|c|c|c|c|c|c|}
\hline Parâmetros & $\mathbf{U}$ & $\mathbf{R a}$ & $\mathrm{Cu}$ & Zn & Cd \\
\hline \multicolumn{6}{|l|}{ Teor do elemento tóxico (ppm) } \\
\hline Antes do tratamento & 82 & 640 & 230 & 170 & 3,5 \\
\hline Após o tratamento & 23 & 23 & 68 & 51 & 1,2 \\
\hline \multicolumn{6}{|l|}{ Fração biolixiviada (ppm) } \\
\hline \multicolumn{6}{|l|}{ a) Pela lixiviação com DTPA } \\
\hline Antes do tratamento & 12 & 120 & 41 & 35 & 0,7 \\
\hline Após o tratamento & 3,2 & 25 & 2,8 & 2,4 & 0,02 \\
\hline b) Pela lixiviação com EDTA & 28 & 45 & 17 & 14 & 03 \\
\hline Antes do tratamento & $\begin{array}{l}2,0 \\
0,5\end{array}$ & 10 & 12 & 12 & 0,3 \\
\hline Após o tratamento & & 10 & 1,2 & 1,2 & 0,01 \\
\hline \multicolumn{6}{|l|}{$\begin{array}{l}\text { Fração trocável }+ \text { carbonato facilmente } \\
\text { lixiviados }(\mathrm{ppm})\end{array}$} \\
\hline Antes do tratamento & 14 & 140 & 59 & 48 & 1,0 \\
\hline Após o tratamento & 3,0 & 25 & 3,7 & 5,0 & 0,03 \\
\hline \multicolumn{6}{|l|}{ Fração inerte (ppm) } \\
\hline Antes do tratamento & 24 & 260 & 91 & 82 & 1,9 \\
\hline Após o tratamento & 16 & 170 & 59 & 41 & 0,9 \\
\hline \multicolumn{6}{|l|}{$\begin{array}{l}\text { Elementos solubilizados durante o teste de } \\
\text { toxicidade (ppm) }\end{array}$} \\
\hline Antes do tratamento & 1,45 & 0,35 & 6,40 & 7,10 & 0,12 \\
\hline Após o tratamento & 0,28 & 0,10 & 0,32 & 0,28 & 0,01 \\
\hline
\end{tabular}

Nota: O conteúdo de Ra é apresentado em $\mathrm{Bq} / \mathrm{kg}$ de solo seco ou Bq/L.

Fonte: GROUDEV; SPASOVA; GEORGIEV (2001).

BRANDL; BOSSHARD; WEGMANN (2001) conduziram experimentos para avaliar a capacidade de bactérias ( $A$. ferrooxidans e $A$. thiooxidans) e fungos (Aspergillus niger e Penicillum simplicissimum) em biolixiviar metais pesados 
contidos em sucatas de equipamentos elétricos e eletrônicos, cujos teores de metais no material fino (sucata triturada) utilizado nos experimentos eram de $237 \mathrm{mg} \mathrm{Al} / \mathrm{kg}$, $80 \mathrm{mg} \mathrm{Cu} / \mathrm{kg}, 20$ mg Pb /kg, 15 mg Ni/kg, 23 mg Sn /kg e 26 mg Zn/kg.

Os experimentos utilizando culturas mistas de $A$. ferrooxidans e $A$. thiooxidans, conduzidos a temperatura de $30{ }^{\circ} \mathrm{C}$, resultaram na mobilização de mais de 90 \% de Al, Cu, Ni e Zn para concentração de 5 g sucata/L e 10 g/L e 22 \% Cu, 60 \% Ni e 95 \% Zn para concentração de $100 \mathrm{~g}$ sucata/L. A. niger foi capaz de mobilizar 90 \% de Al, $40 \%$ de $\mathrm{Cu}, 80 \%$ de Ni, $45 \%$ de Pb, $40 \%$ de Sn e $65 \%$ de Zn para concentração de $1 \mathrm{~g}$ sucata/L. e $P$. simplicissimum, 60 \% de Al, $10 \%$ de Cu, $>99 \%$ de $\mathrm{Ni},>98 \%$ de $\mathrm{Pb}, 60 \%$ de $\mathrm{Sn}$ e > $99 \%$ de Zn em concentração de $1 \mathrm{~g}$ sucata/L. O Pb precipitou sob a forma $\mathrm{PbSO}_{4}$ e $\mathrm{Sn}$ sob a forma de $\mathrm{SnO}$ em todos os experimentos realizados.

A sucata mostrou-se tóxica às culturas expostas a partir de $100 \mathrm{~g} / \mathrm{L} \mathrm{e}$, embora não tenha sido determinada a causa ou os mecanismos de toxicidade envolvidos, os autores especularam que ela poderia ser decorrente do elevado teor de Al no resíduo. Entretanto, após um período de adaptação (sete dias para as bactérias e de pelo menos seis semanas para os fungos), o crescimento microbiano pôde ser conduzido sem inibição até $100 \mathrm{~g}$ sucata/L.

BOSSHARD; BACHOFEN; BRANDL (1996) e BROMBACHER; BACHOFEN; BRANDL (1998) sugeriram a divisão do processo de biolixiviação em duas etapas: crescimento bacteriano (na ausência do substrato contaminado) e biolixiviação; como forma de melhorar o rendimento do processo, além de proporcionar as seguintes vantagens:

A biomassa não entra em contato direto com o material contaminado com o metal, permitindo sua reciclagem;

$>$ O resíduo do processo não é contaminado pela biomassa e

> Podem ser aplicadas altas concentrações do material contaminado em relação ao processo em uma só etapa, o que resulta no aumento da recuperação do metal.

KREBS; BACHOFEN; BRANDL (2001) avaliaram a estimulação do crescimento de bactérias oxidantes de enxofre, para a otimização da eficiência de lixiviação de metais contidos em material particulado, resultante da incineração de resíduo sólido urbano, que apresentava os seguintes teores de metais: 70,00 $\mathrm{g}$ $\mathrm{Al} / \mathrm{kg} ; 0,49 \mathrm{~g} \mathrm{Cd} / \mathrm{kg} ; 0,70 \mathrm{~g} \mathrm{Cr} / \mathrm{kg} ; 1,10 \mathrm{~g} \mathrm{Cu} / \mathrm{kg} ; 0,14 \mathrm{~g} \mathrm{Ni} / \mathrm{kg} ; 8,90 \mathrm{~g} \mathrm{~Pb} / \mathrm{kg} ; 9,30 \mathrm{~g}$ 
$\mathrm{Sn} / \mathrm{kg} ; 12,00 \mathrm{~g} \mathrm{Ti} / \mathrm{kg} ; 31,00 \mathrm{~g} \mathrm{Zn} / \mathrm{kg}$. Este estudo avaliou o uso A. thiooxidans em associação com lodo de esgoto (anóxico) e concluiu que a adição do lodo aumentava a acidificação da suspensão e, como conseqüência, reduzia o tempo de processamento em $50 \%$.

Segundo estes autores, o uso do lodo de esgoto apresenta as vantagens de conter muitos nutrientes (e.g. elementos traço e amônio); ser disponível em grande quantidade a baixo custo; conter compostos adicionais de enxofre reduzido, que podem ser utilizados como fontes de energia pelos Acidithiobacillus sp e de possuir diversas espécies indígenas deste gênero de bactérias, que também eram capazes de biolixiviar metais pesados e assim contribuir para acentuar a acidificação da solução de biolixiviação. O uso do lodo nos experimentos permitiu a redução de 50 \% no tempo de duração do processo de biolixiviação, entretanto, não resultou em aumento da eficiência do processo, se comparado ao resultado final obtido pelos experimentos que não o utilizaram.

Estes autores reportaram ter alcançado eficiências de remoção de 60 \% de Al; mais de $80 \%$ de Cd, Cu e Zn; $10 \%$ de Cr; $30 \%$ de Ni e menos de $5 \%$ de Pb, para as condições do experimento (concentração de cinza de 0,5 \% a 4,0 \% peso/volume, $\mathrm{pH}=1,0$ a 1,5 e duração do experimento = 22 semanas).

Muitos dos ensaios e experimentos reportados pela literatura (HERBERT JR, 1999, BROMBACHER; BACHOFEN; BRANDL, 1998; KREBS; BACHOFEN; BRANDL, 2001; KREBS et alii, 2001; FRANÇA, 2003) concluíram que o uso de suspensões mistas de $A$. ferrooxidans e $A$. thiooxidans resultaram em maior eficiência na remoção de metais, quando comparada à obtida por tais espécies isoladamente.

Embora usualmente não seja(m) determinada(s) a(s) causa(s) ou o(s) mecanismo(s) da toxicidade exercida pelos diversos resíduos ou solos contaminados com metais pesados sobre os microrganismos utilizados nos processos de biolixiviação reportados na literatura, há consenso que os principais parâmetros que governam a biolixiviação são o pH, a temperatura, a afinidade da espécie de Acidithiobacillus sp ao(s) metal(is) alvo(s), a capacidade de tamponamento do material contaminado, a presença de espécies indígenas de Acidithiobacillus sp no meio, a disponibilidade de compostos reduzidos de enxofre e de alguma fonte de carbono no meio (KREBS et alii, 1997; KREBS; BACHOFEN; BRANDL, 2001; BRANDL; BOSSHARD; WEGMANN, 2001; DOBLER et alii, 2001). 
O efeito tampão, exercido pelo material contaminado com metal sobre a solução submetida à biolixiviação, requer que uma quantidade adicional de ácido seja produzida para neutralizá-lo, o que resulta em maior quantidade de substrato e em maior duração do processo. Por conseguinte, o pH é um dos parâmetros chave na biolixiviação, estando sua cinética estreitamente relacionada às reações de óxido-redução do enxofre e seus compostos presentes no meio e, também afeta a duração do processo (KREBS; BACHOFEN; BRANDL, 2001).

Embora a duração de um processo de biolixiviação possa ser reduzida mediante o uso de uma fonte adicional de energia e de espécies indígenas de Acidithiobacillus sp (e.g. adição de lodo de esgoto), há um limite máximo para a eficiência do processo, não sendo este citado na referência (KREBS; BACHOFEN; BRANDL, 2001).

ZAGURY et alii (2001) relataram o uso de reatores semi-contínuos para a biolixiviação de solos contaminados com $\mathrm{Cu}, \mathrm{Mn}$ e $\mathrm{Zn}$. Estes pesquisadores utilizaram como inóculo, microrganismos indígenas do solo, previamente adaptados e adição dos substratos $\mathrm{FeSO}_{4} .7 \mathrm{H}_{2} \mathrm{O}(5 \mathrm{~g} / \mathrm{L})$ e $\left(\mathrm{NH}_{4}\right)_{2} \mathrm{SO}_{4}(3 \mathrm{~g} / \mathrm{L})$. Obtiveram a solubilização (após 2 dias) de até $47 \%$ de Cu, $34 \%$ de Mn e $40 \%$ de Zn, numa suspensão de solo de $100 \mathrm{~g} / \mathrm{L}$. O solo utilizado neste experimento apresentava os seguintes teores de metais: $39 \pm 1 \mathrm{mg} / \mathrm{kg} \mathrm{Cu}, 840 \pm 47 \mathrm{mg} / \mathrm{kg} \mathrm{Mn}$ e $163 \pm 3 \mathrm{mg} / \mathrm{kg}$ $\mathrm{Zn}$.

ZAGURY et alii (2001) conseguiram reduzir a duração do processo de biolixiviação de 10 dias (reatores em batelada) para 2 dias e ainda aumentar a eficiência da solubilização dos elementos de interesse. Eles citaram, ainda, os resultados de outra pesquisa em que utilizaram reatores em batelada com concentração de solo de $15 \mathrm{~g} / \mathrm{L}$ e concluíram que o aumento desta de $15 \mathrm{~g} / \mathrm{L}$ para $100 \mathrm{~g} / \mathrm{L}$ teve pouco efeito sobre a solubilização do metal. Nos experimentos executados em batelada, o pH inicial era de 4,02 e o final, 2,34. Nos reatores semicontínuos, estes valores foram de 2,81 e 2,45, respectivamente.

ZAGURY et alii (2001) observaram oxidação do $\mathrm{Fe}^{2+}$ para $\mathrm{Fe}^{3+}$, o que resultou no aumento do potencial de óxido-redução (POR). A oxidação foi associada com o aumento do POR e com a acidificação da suspensão. Quanto ao pH, os autores consideraram que a faixa de $\mathrm{pH}=2$ era uma condição favorável para a solubilização de metais em solos, entretanto, além do pH e do POR da suspensão, o particionamento do metal no solo poderia explicar as baixas eficiências obtidas para 
cada um dos elementos. Ressalta-se ainda, que tais pesquisadores reconheceram a forte influência das condições iniciais, principalmente $0 \mathrm{pH}$, na solubilização dos metais, pois registraram solubilização de $24 \%$ de Cu, $11 \%$ de $\mathrm{Mn}$ e $15 \%$ de Zn, no início do experimento, usando reatores semi-contínuos.

LORS; TIFFREAU; LABOUDIGUE (2004) avaliaram a influência da atividade bacteriana na solubilização de metais pesados presentes em sedimentos contaminados. Também investigaram a ocorrência de bactérias indígenas oxidantes de sulfato e seu potencial de lixiviar metais tóxicos de materiais dragados e, o impacto na acidificação do meio na solubilização do metal.

O sedimento utilizado nos experimentos apresentava os seguintes teores dos elementos de interesse: $50.000 \pm 4.000 \mathrm{mg} \mathrm{Ca} / \mathrm{kg}, 6.600 \pm 300 \mathrm{mg} \mathrm{Zn/kg,} 770 \pm$ $15 \mathrm{mg} \mathrm{Pb} / \mathrm{kg}, 190 \pm 10 \mathrm{mg} \mathrm{Cd} / \mathrm{kg}, 150 \pm 10 \mathrm{mg} \mathrm{Cu} / \mathrm{kg}, 273 \pm 5 \mathrm{mg} \mathrm{Mn} / \mathrm{kg}, 3.600 \pm$ $200 \mathrm{mg} \mathrm{P} / \mathrm{kg}, \quad 18.000 \pm 1.000 \mathrm{mg} \mathrm{Fe} / \mathrm{kg}, 6,5 \pm 0,5 \mathrm{mg}$ carbono orgânico total $/ \mathrm{kg}$. O sedimento natural apresentava $\mathrm{pH}=7,2 \pm 0,1$ e umidade de $53 \pm 6$. \%.

Estes experimentos foram conduzidos com sedimentos anóxicos frescos e esterilizados por radiação gama. Os ensaios foram executados em batelada, em frascos de $250 \mathrm{~mL}$, que foram mantidos em temperatura de $20^{\circ} \mathrm{C}$ e em agitação constante num agitador horizontal, por período de até 98 dias. Foram utilizadas 72 amostras divididas nas quatro condições de estudo: esterilizada, não esterilizada, solução neutra e solução ácida.

Este trabalho evidenciou que o principal papel no processo de mobilização de metais coube aos microrganismos indígenas do sedimento dragado. Para os ensaios em meio neutro, a solubilização de Zn e Cd decorreu principalmente da ativação bacteriana das fases sulfídricas. A participação de bactérias oxidantes de sulfato, como o $A$. thiooxidans, no processo foi claramente evidenciada, sendo que outras espécies, como o $T$. thioparus, também podem ter desempenhado alguma função, ainda que nos primeiros estágios da oxidação.

A acidificação para $\mathrm{pH}=4$ nos experimentos com sedimento esterilizado não apresentou influência sobre a liberação de $\mathrm{Zn}$ ou $\mathrm{Cd}$, devido ao efeito de tamponamento promovido pela calcita presente no sedimento. Para as amostras com sedimento não estéril, a acidificação resultou em uma redução no pH da solução, mas que também foi rapidamente ajustada pela presença da calcita no sedimento. Esta acidificação inicial foi suficiente para aumentar em 10 vezes a 
cinética de liberação do $\mathrm{Cd}$ e do Zn. Com base neste comportamento, os autores sugeriram atenção para as condições usadas nos experimentos de resuspensão e seu uso em avaliação de risco, caso o sedimento estudado exiba uma elevada capacidade de tamponamento.

Outro fato relevante deste estudo é o efeito da esterilização sobre a cinética de liberação do $\mathrm{Cu}$, pois a esta resultou na liberação de grande quantidade de carbono orgânico dissolvido e $\mathrm{Cu}$, cujas concentrações apresentaram correlação linear. Esta constatação evidenciou a forte associação entre o $\mathrm{Cu}$ e a matéria orgânica presente no sedimento.

\subsection{Tratamento do lixiviado}

O tratamento do lixiviado, contendo os íons metálicos, removidos do material contaminado submetido à descontaminação/tratamento, pode visar dois objetivos distintos: o tratamento da água residuária para o atendimento da legislação aplicável, ou o tratamento da água residuária associada com a recuperação dos metais em solução.

A recuperação de metais depende de seu valor comercial e da viabilização técnica e econômica do processo de recuperação. Embora seja tecnicamente possível, a recuperação da grande maioria dos íons metálicos, normalmente, não é o objetivo principal do tratamento do lixiviado produzido em um processo de remediação de solo.

A remoção de íons metálicos do lixiviado pode ser realizada através de processos físicos, químicos, físico-químicos e biológicos e, uma revisão da literatura deste assunto é apresentada a seguir.

\subsubsection{Processos físicos}

Os processos físicos capazes de remover íons metálicos da água podem ser agrupados em três categorias: a) leitos de filtração, b) evaporação e c) membranas. 


\subsubsection{Leitos de filtração}

Os leitos de filtração, a exemplo dos filtros lentos para tratamento de água, tem seu funcionamento baseado em mecanismos de transporte e aderência, ou seja:

$>$ Transporte:

$\checkmark$ Ação de coar;

$\checkmark$ Difusão Browniana;

$\checkmark$ Sedimentação;

$\checkmark$ Interceptação;

$\checkmark$ Ação hidrodinâmica; e

$\checkmark$ Impacto inercial.

Aderência:

$\checkmark$ Forças eletrostáticas;

$\checkmark$ Forças de Van der Vaals;

$\checkmark$ Adsorção mútua; e

$\checkmark$ Reações de hidratação.

Todavia, dado que os metais estão em solução no lixiviado, somente os mecanismos de aderência serão atuantes no leito filtrante, assim, a capacidade de troca do meio filtrante e sua afinidade com os íons metálicos presentes no lixiviado são fundamentais para o adequado funcionamento do sistema.

MARQUEZ et alii (2003) reportaram o uso da filtração em leito de argila (esmectita/caulinita) como sendo uma alternativa tão ou mais eficiente que a adsorção em carvão ativado, para a remoção de $\mathrm{Ni}$ em solução sintética. A alternativa indicada para o destino final da argila contaminada foi a fabricação de telhas.

\subsubsection{Evaporação}

A grande diferença entre as pressões de vapor da água e dos íons metálicos permite que estes sejam segregados da solução através da evaporação da água. Os 
dois principais métodos empregados são lagoas de evaporação e evaporadores mecânicos (WEF, 1994).

Lagoas de evaporação dependem somente de condições climáticas (taxa de evaporação, precipitação e temperatura). O uso de lagoas de evaporação é viável somente em regiões onde a taxa de evaporação supera a de precipitação, haja disponibilidade de área e represente uma alternativa técnica e econômica competitiva com outras alternativas técnicas de remoção dos metais.

Evaporadores mecânicos são equipamentos muito eficientes para a concentração e remoção de íons metálicos e são de uso corrente em muitos processos industriais. Apesar de constituir-se em uma alternativa técnica, a literatura consultada não apresentou nenhum exemplo da aplicação que utilizasse tal tecnologia.

\subsubsection{Eletrodiálise}

A eletrodiálise é um processo eletroquímico contínuo de separação que emprega membranas, carregadas eletricamente, e uma diferença de potencial para separar espécies iônicas e outros componentes não carregados presentes em uma solução aquosa.

$\mathrm{Na}$ eletrodiálise, os eletrólitos são transferidos de uma solução menos concentrada para outra mais concentrada com a ajuda da energia elétrica. A purificação do solvente é obtida através da passagem pela membrana.

A direção e a velocidade do fluxo iônico depende da corrente e da densidade de potência assim como das características da solução das câmaras do ânodo e do cátodo. A taxa de transporte do soluto do liquido adjacente para a membrana pode ser controlada pela difusão através da membrana (USEPA, 1994).

A membrana utilizada possui a habilidade de permitir a passagem de determinados íons e de impedir outras espécies. São capazes, ainda, de distinguir tanto as espécies de carga positiva das de carga negativa quanto os íons de mesma carga. Determinadas membranas tem a habilidade de transportar preferencialmente íons monovalentes ao invés de íons divalentes (AWWARF; LE; WRCSA, 1996). 
Apesar desta tecnologia não ser explicitamente citada, para o tratamento do lixiviado produzido em nenhum dos estudos de caso contidos na bibliografia consultada, ela é apresentada como uma alternativa quando se pretende recuperar os metais em solução.

\subsubsection{Osmose reversa}

Osmose reversa explora uma propriedade termodinâmica de cada solução: a pressão osmótica, que é a exata pressão que precisa ser aplicada sobre o lado da solução, contida em um compartimento divido por uma membrana semipermeável, para interromper o fluxo do solvente para o compartimento de solvente puro. A osmose reversa nada mais é que a aplicação de uma força maior que a osmótica sobre a solução, de forma a inverter o fluxo e direcionar o solvente do lado da solução para o lado do solvente puro (PAREKH, 1988). Ou seja, é um processo no qual a transferência de massa de íons através das membranas é controlada pela difusão (AWWARF; LE; WRCSA, 1996).

Diversas forças de condução são possíveis em transporte por membrana, os principais são: pressão, concentração, potencial elétrico e temperatura (PAREKH, 1988). Os arranjos típicos de instalações de osmose reversa empregam grande quantidade de módulos de filtração, os quais são agregados em conjuntos de menor número de módulos (AWWARF; LE; WRCSA, 1996).

Embora a aplicação de sistemas de membranas estejam em expansão e seja uma alternativa técnica para o tratamento do lixiviado produzido no processo de remediação de solo contaminado com metais e outros compostos orgânicos e inorgânicos, seu uso ainda é restrito a aplicações específicas na indústria e na potabilização de água para abastecimento público.

Um aspecto crítico dos processos que utilizam membranas é a escolha destes elementos, pois fatores como durabilidade, resistência às condições do tratamento físico-químico, estabilidade em altas temperaturas e baixa resistência elétrica, são fundamentais para o sucesso na remoção dos cátions e ânions de interesse. Fatores operacionais também afetam o desempenho de um sistema de 
membranas e são tão importantes quanto a escolha das membranas, entre tais fatores incluem-se pH e a turbulência do fluxo (USEPA, 1994).

\subsubsection{Processos químicos}

\subsubsection{1 Óxido-redução}

Reações de óxido-redução implicam na transferência de elétrons entre as diferentes espécies, substâncias e compostos químicos envolvidos em uma reação química, que por sua vez, resultam na mudança do estado de oxidação dos participantes da reação. Tanto a oxidação quanto a redução ocorrem em toda e qualquer reação química onde haja a troca de elétrons, pois se uma substância é oxidada, a outra obrigatoriamente é reduzida (FREEMAN; HARRIS, 1995).

O tratamento do lixiviado através de processos de óxido-redução tem por objetivo reduzir ou eliminar a toxicidade exibida pelos íons metálicos presentes, a qual está diretamente relacionada aos seus estados de oxidação e, é definido em função das peculiaridades de cada íon, visto que tanto cátions quanto ânions podem ser oxidados ou reduzidos, o que depende unicamente do estado de oxidação de cada espécie química.

No processo de oxidação química, o estado de oxidação do íon metálico é aumentado enquanto o do agente oxidante é diminuído. O produto deste processo é o óxido do metal presente, o qual precipita facilmente da solução. Dentre os principais agentes oxidantes incluem-se: ozônio, peróxido de hidrogênio, cloro e dióxido de cloro. Apesar do processo de oxidação não ser seletivo, o agente oxidante é, portanto, os ânions presentes no lixiviado determinarão a escolha do agente oxidante passível de oxidá-los.

Ao contrário do processo de oxidação, no processo de redução, o estado de oxidação do contaminante é reduzido enquanto o do reagente é aumentado, ou seja, os íons metálicos são convertidos, mediante o uso de um agente redutor, para as formas elementares de seus metais, permitindo sua reciclagem. (FORD, 1992, HAAS; VAMOS, 1995). 
Embora os processos de óxido-redução sejam passíveis de serem aplicados a todos os compostos metálicos possíveis de serem oxidados ou reduzidos quimicamente, tais processos são aplicados apenas em situações em que se deseje reduzir a toxicidade e/ou a mobilidade do composto metálico original, afim de evitar a propagação do contaminante, a contaminação de subprodutos do processo de tratamento ou mesmo facilitar sua remoção do lixiviado.

Um exemplo desta situação é o caso da redução do $\mathrm{Cr}^{6+}$, que é mais tóxico e móvel do que o $\mathrm{Cr}^{3+}$, logo, é desejável, primeiro reduzir o $\mathrm{Cr}^{6+}$ antes de proceder sua remoção do lixiviado, por exemplo, através da precipitação química (USEPA, 1997c, USEPA, 1999). Outro exemplo desta situação é a oxidação do $\mathrm{As}^{3+}$ para $\mathrm{As}^{5+}$, que é menos solúvel que $\mathrm{As}^{3+} \mathrm{e}$, portanto, proporciona melhores resultados quando se utiliza processos de precipitação química para a remoção de As do lixiviado (USEPA, 2002b).

São características comuns aos processos de óxido-redução (FREMAN; HARRIS, 1995):

Não seletividade: todo material passível de ser oxidado ou reduzido reagirá com o agente oxidante/redutor;

> Mistura: o agente oxidante/redutor precisa ser adequadamente misturado ao lixiviado para garantir que as reações sejam homogêneas em toda a massa líquida;

$>\mathrm{pH}$ : precisa ser controlado e mantido na faixa de valores ideal para a reação do agente oxidante/redutor e o contaminante alvo;

> Escolha do agente oxidante/redutor: depende das características e propriedades químicas do agente e do contaminante presentes no lixiviado;

$>$ Limitações:

$\checkmark$ Caso as reações não sejam completadas: permanência de residual do contaminante no lixiviado tratado e/ou a formação de compostos intermediários que podem ser mais tóxicos que o contaminante original; e

$\checkmark$ Causas das reações incompletas: a adição de quantidade insuficiente do agente oxidante/redutor, a inibição das reações de oxidação/redução devido ao valor do $\mathrm{pH}$ (abaixo ou acima dos valores ótimos para a reação), a força do agente oxidante/redutor, a presença de compostos interferentes que consomem o agente oxidante/redutor ou, ainda, mistura ou tempo de contato inadequados entre o agente oxidante/redutor e o contaminante. 
O monitoramento das concentrações do residual do agente oxidante/redutor, do contaminante e dos produtos gerados é fundamental para garantir que as reações de oxidação/redução sejam completas.

Os processos de óxido-redução, apesar de serem métodos de destruição de contaminantes, não são viáveis para o tratamento de lixiviado contendo elevada concentração de íons metálicos (ou contaminantes orgânicos), visto que demanda grande quantidade de agente oxidante/redutor, logo, é uma alternativa de elevado custo operacional.

\subsubsection{Processos físico-químicos}

\subsubsection{Adsorção}

A adsorção envolve a separação de compostos em solução e sua deposição sobre a superfície de um material adsorvente. É uma técnica originalmente utilizada para a remoção de compostos orgânicos, embora haja relatos na literatura sobre sua utilização na remoção de metais pesados, particularmente de mercúrio orgânico e inorgânico (FAUST; ALY, 1999) .

A sorção é um fenômeno de equilíbrio em que atuam três mecanismos: eletrostático, físico e químico. O mecanismo eletrostático ocorre como o resultado de forças atrativas associadas entre o adsorvato e o adsorvente e é o principal mecanismo na adsorção de metais. O mecanismo de atração física é atribuído a processos de ligações fracas causadas por forças de atração intermoleculares, tais como as pontes de hidrogênio e forças de Van der Waals. O mecanismo químico é caracterizado por uma ligação forte e mais permanente que o mecanismo físico e tem todas as características de uma verdadeira ligação química (WATTS, 1997).

Dentre os diversos tipos de adsorventes conhecidos, o carvão ativado em pó (sob a forma L-carbono) e a alumina são os materiais com maior capacidade de adsorver íons metálicos (BAE et alii, 2000).

WASAY, BARRINGTON; TOKUNAGA (1999) avaliaram a eficiência de carvão ativado granular (CAG), de alumina ativada granular (AAG), de solução de 
cloreto férrico (SCF) (a $5 \%$ ) e de hidróxido de sódio, para o tratamento de lixiviado contaminado com os metais $\mathrm{Cd}, \mathrm{Cr}, \mathrm{Cu}, \mathrm{Hg}, \mathrm{Mn}, \mathrm{Pb}$ e $\mathrm{Zn}$. O solo utilizado nos experimentos estava contaminado com teores de metais que variavam de $840 \mathrm{mg} / \mathrm{kg}$ a 2,8 $\mathrm{g} / \mathrm{kg}$ e, o lixiviado resultante da lavagem, utilizando soluções de EDTA e DTPA, possuía as seguintes características: $36,4 \mathrm{mg} \mathrm{Cd} / \mathrm{L}, 15,0 \mathrm{mg} \mathrm{Cr} / \mathrm{L}, 7,4 \mathrm{mg}$ $\mathrm{Cu} / \mathrm{L}, 2,5 \mathrm{mg} \mathrm{Hg} / \mathrm{L}, 32,5 \mathrm{mg} \mathrm{Mn} / \mathrm{L}, 76,3 \mathrm{mg} \mathrm{Pb} / \mathrm{L}$ e 13,8 mg Zn/L, totalizando $184 \mathrm{mg}$ metais/L; pH da solução = 4,4.

A Tabela 6 apresenta os parâmetros ótimos para a remoção de quelatos metálicos, bem como, os resultados obtidos com a sua utilização. Os resultados evidenciaram o melhor desempenho do CAG na remoção dos quelatos metálicos. Para os autores, os resultados obtidos sugeriram que a adsorção de metais pesados à superfície do CAG podia ser governada pela presença de complexos metálicos ao invés de íons metálicos livres.

Tabela 6 - Condições para a máxima remoção de quelato metálico usando diferentes adsorventes/precipitantes.

\begin{tabular}{|c|c|c|c|c|c|c|c|c|}
\hline $\begin{array}{l}\text { Adsorventel } \\
\text { precipitante }\end{array}$ & $\begin{array}{l}\text { Parâmetro de } \\
\text { tratabilidade }\end{array}$ & Cd & $\mathrm{Cr}$ & $\mathrm{Cu}$ & $\mathrm{Hg}$ & Mn & $\mathrm{Pb}$ & $\mathrm{Zn}$ \\
\hline CAG & $\begin{array}{c}\mathrm{pH} \\
\text { Tempo (h) } \\
\% \text { de remoção }\end{array}$ & $\begin{array}{c}>7,7 \\
7 \\
89\end{array}$ & $\begin{array}{c}5,4-6,2 \\
6 \\
75-77\end{array}$ & $\begin{array}{c}>7,7 \\
6 \\
87\end{array}$ & $\begin{array}{c}5,4-6,9 \\
5 \\
96-97\end{array}$ & $\begin{array}{c}>7,7 \\
6 \\
78\end{array}$ & $\begin{array}{c}6,9-7,7 \\
6 \\
92-95\end{array}$ & $\begin{array}{c}>7,7 \\
7 \\
84\end{array}$ \\
\hline AGA & $\begin{array}{c}\mathrm{pH} \\
\text { Tempo (h) } \\
\text { \% de remoção }\end{array}$ & $\begin{array}{c}8,1- \\
8,9 \\
12 \\
23-34\end{array}$ & $\begin{array}{c}8,1-8,9 \\
12 \\
25-33\end{array}$ & $\begin{array}{c}8,1- \\
8,9 \\
12 \\
9-17\end{array}$ & $\begin{array}{c}8,1-8,9 \\
12 \\
58-64\end{array}$ & $\begin{array}{c}8,1-8,9 \\
12 \\
22-24\end{array}$ & $\begin{array}{c}8,1-8,9 \\
12 \\
27-41\end{array}$ & $\begin{array}{c}8,1-8,9 \\
12 \\
27-34\end{array}$ \\
\hline SCF & $\begin{array}{c}\mathrm{pH} \\
\text { Tempo (h) } \\
\text { \% de remoção }\end{array}$ & $\begin{array}{c}3,3- \\
6,8 \\
12 \\
7-11\end{array}$ & $\begin{array}{c}3,3-6,8 \\
12 \\
11-15\end{array}$ & $\begin{array}{c}3,3- \\
6,8 \\
12 \\
23-40\end{array}$ & $\begin{array}{c}3,3-6,8 \\
12 \\
82-92\end{array}$ & $\begin{array}{c}3,3-6,8 \\
12 \\
13-16\end{array}$ & $\begin{array}{c}3,3-6,8 \\
12 \\
16-18\end{array}$ & $\begin{array}{c}3,3-6,8 \\
12 \\
10-14\end{array}$ \\
\hline $\mathrm{NaOH}$ & $\begin{array}{c}\mathrm{pH} \\
\text { Tempo (h) } \\
\% \text { de remoção }\end{array}$ & $\begin{array}{l}9,5 \\
12 \\
16\end{array}$ & $\begin{array}{l}9,5 \\
12 \\
10\end{array}$ & $\begin{array}{c}9,5 \\
12 \\
9\end{array}$ & $\begin{array}{l}9,5 \\
12 \\
52\end{array}$ & $\begin{array}{l}9,5 \\
12 \\
15\end{array}$ & $\begin{array}{l}9,5 \\
12 \\
15\end{array}$ & $\begin{array}{l}9,5 \\
12 \\
12\end{array}$ \\
\hline
\end{tabular}

Nota: CAG = carvão ativado granular; AAG = alumina ativada granular; SCF = solução de cloreto férrico.

Fonte: WASAY; BARRINGTON; TOKUNAGA (1999).

Estes autores concluíram que o CAG poderia ser utilizado para adsorver quelatos metálicos dissolvidos em lixiviado gerado durante o processo de lavagem de solo com ácidos orgânicos fracos e/ou seus sais, EDTA e DTPA. Sugeriram, ainda, que o CAG fosse utilizado em um sistema de três tanques em série, onde o conteúdo do primeiro deveria ser mantido em $\mathrm{pH}=6,9$ para a remoção do Hg; o do segundo em $\mathrm{pH}=7,7$ para a remoção de $\mathrm{Cd}, \mathrm{Cu}, \mathrm{Mn}, \mathrm{Pb}$ e $\mathrm{Zn}$ e do terceiro em $\mathrm{pH}=$ 5,4 para a remoção de $\mathrm{Cr}$. O CAG poderia ser regenerado com solução de $\mathrm{HCl}$ e os 
metais recuperados poderiam ser utilizados pela indústria para a fabricação de ligas metálicas.

A Figura 15 mostra um esquema geral de um sistema em série de colunas de carvão ativado granular, utilizado para a remoção de contaminantes contidos no lixiviado. A configuração de unidades em série do sistema tem por objetivo maximizar a remoção dos contaminantes alvo, especialmente quando há competitividade entre os contaminantes pelos sítios ativos do material adsorvente (neste caso o carvão ativado), logo, as diferentes unidades (colunas de carvão ativado) do sistema podem remover seletivamente os contaminantes alvo do lixiviado.

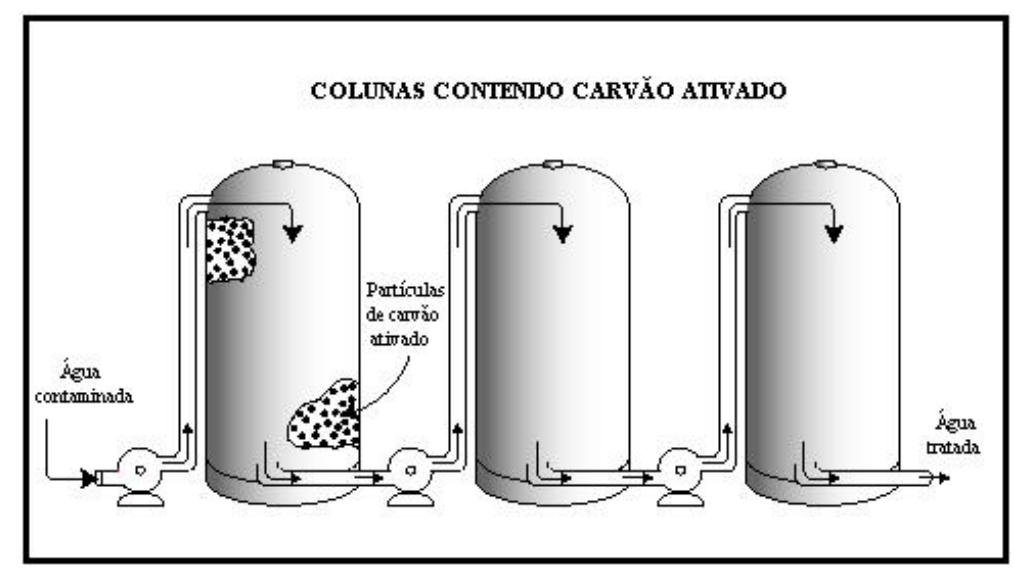

Figura 15 - Colunas de carvão ativado.

Fonte: USEPA (2001).

A identificação de materiais naturais, de baixo custo, de fácil disponibilidade e de aceitável capacidade de adsorção é um desafio que fomenta a experimentação dos mais diversos materiais disponíveis na natureza ou provenientes de diferentes processos industriais.

MEUNIER; BLAIS; TYAGI (2002) realizaram um estudo para selecionar um material natural capaz de adsorver íons de metais pesados do lixiviado produzido durante a remediação de solo e avaliar o efeito da composição do metal e do tamanho da partícula sobre a capacidade de remoção.

O solo utilizado nos experimentos estava contaminado com diversos metais (1,9 mg Cd/kg, $120 \mathrm{mg} \mathrm{Cr/kg,} 175$ mg Cu/kg, 457 mg Mn/kg, 80 mg Ni/kg, 817 mg $\mathrm{Pb} / \mathrm{kg}$ e $565 \mathrm{mg} \mathrm{Zn} / \mathrm{kg}$ ), os quais foram transferidos para o lixiviado ( $\mathrm{pH}=1,97 ; 0,061$ mg Cd/L; 3,910 mg Cu/L; 0,237 mg Ni/L; 28,400 mg Pb/L e 10,040 mg Zn/L) após lavagem com $\mathrm{HCl}$. Cascas de árvores (pinho, cedro e abeto) e de fruto (cacau) e 
minerais (rocha vulcânica e vermiculita) foram utilizados como adsorventes. A Tabela 7 mostra a capacidade de adsorção exibida por cada um destes materiais.

Este trabalho concluiu que o melhor adsorvente para a remoção de $\mathrm{Pb}$ foi a casca de cacau, que apresentou uma capacidade máxima de fixação de 2,60 mg $\mathrm{Pb} / \mathrm{g}$ ( $\mathrm{pH}$ inicial = 1,59; 45,4 mg Pb/L) para o lixiviado. Foi reportado, ainda, que a presença de vários metais e cátions no lixiviado resultou na redução da capacidade de remoção do $\mathrm{Pb}$, o que pode ser explicado pela competição entre os diferentes íons pelos sítios disponíveis na superfície do adsorvente que, é um fenômeno reportado por outros autores citados ao longo do presente texto.

A busca por novos materiais, para a produção de membranas, intensificouse na última década e, desde então, foram produzidas e avaliadas diversas membranas de materiais orgânicos (GENÇ et alii, 2002). Estes pesquisadores avaliaram a eficiência da membrana quelante composta de polihidroximetacrilatoquitosan MX 5 BR, também conhecida como membrana de rede interpenetrante, produzida pela empresa norte-americana Procion Brown, para a remoção de íons de $\mathrm{Cd}^{2+}, \mathrm{Pb}^{2+}, \mathrm{Hg}^{2+}$; em diversas concentrações (30 a $400 \mathrm{mg} / \mathrm{L}$ ), valores de $\mathrm{pH}$ de 2 a 6 , temperatura controlada em $20^{\circ} \mathrm{C}$, velocidade de agitação de $600 \mathrm{~min}^{-1}$ e tempo de adsorção de 1 hora; e concluíram, que sob as condições de ensaio, a máxima capacidade de adsorção da membrana foi de $18,5 \mathrm{mg} \mathrm{Cd}^{2+} / \mathrm{g}, 22,7 \mathrm{mg} \mathrm{Pb}^{2+} / \mathrm{g}$ e 68,8 $\mathrm{mg} \mathrm{Hg}^{2+} / \mathrm{g}$.

Tabela 7 - Concentração de metais solúveis no lixiviado do solo após 24 h de adsorção usando $20 \mathrm{~g} / \mathrm{L}$ de cada material adsorvente.

\begin{tabular}{lccccccc}
\hline \multicolumn{1}{c}{ Adsorvente } & pH & POR (mV) & Concentração de metais solúveis \\
& & & Cd & Cu & Ni & Pb & Zn \\
\hline Controle & 1,97 & 525 & 0,061 & 3,91 & 0,237 & 28,4 & 10,04 \\
Casca de cacau & 3,00 & 307 & 0,059 & 1,31 & 0,232 & 2,7 & 8,69 \\
Vermiculita & 2,05 & 428 & 0,060 & 3,69 & 0,228 & 25,9 & 9,47 \\
Rocha vulcânica & 1,95 & 517 & 0,058 & 3,84 & 0,236 & 27,5 & 9,85 \\
Casca de pinho & 2,08 & 409 & 0,057 & 3,26 & 0,217 & 20,0 & 9,73 \\
Casca de cedro & 2,12 & 390 & 0,058 & 2,22 & 0,227 & 12,5 & 9,48 \\
Casca de abeto & 2,34 & 390 & 0,060 & 2,92 & 0,219 & 16,8 & 9,74 \\
\hline
\end{tabular}

Nota: $\mathrm{POR}=$ potencial de óxido-redução.

Fonte: Adaptado de MEUNIER; BLAIS; TYAGI (2002).

Este estudo também avaliou a capacidade de adsorção da membrana sob condição de competição (adsorção de suas soluções ternárias), neste caso, os 
experimentos utilizaram soluções de 196,70 $\mathrm{mg} \mathrm{Cd}^{2+} / \mathrm{L}, 362,25 \mathrm{mg} \mathrm{Pb}^{2+} / \mathrm{L}$ e 351,05 $\mathrm{mg} \mathrm{Hg}^{2+} / \mathrm{L}$ e culminaram nos seguintes resultados, para $\mathrm{pH}=5,0$ e temperatura de $20{ }^{\circ} \mathrm{C}$ constantes: $1,8 \mathrm{mg} \mathrm{Cd}^{2+} / \mathrm{g}, 2,2 \mathrm{mg}, \mathrm{Pb}^{2+} / \mathrm{g}$ e $52,6 \mathrm{mg} \mathrm{Hg}^{2+} / \mathrm{g}$. A lavagem da membrana com $\mathrm{HNO}_{3}(0,01 \mathrm{M})$ resultou em dessorção superior à $95 \%$ de todas os íons, após cinco ciclos de lavagens.

A membrana, como adsorvente ideal, deve possuir estruturas de micro ou macroporos, disponibilidade de grupos reativos para ligação com os íons metálicos e estabilidade física e química, sob condições extremas (GENÇ et alii, 2002).

Segundo HUANG; HUANG; MOREHART (1991), íons de $\mathrm{H}^{+}, \mathrm{Na}^{+}, \mathrm{Ca}^{2+} \mathrm{e}$ $\mathrm{Mg}^{2+}$ competem com os íons metálicos pelos sítios ativos do adsorvente, entretanto, $\mathrm{H}^{+}$e $\mathrm{Na}^{+}$mantém uma ligação mais fraca com o sítio ativo do que o metal e o $\mathrm{Na}^{+}$, em condição de competição com o íons metálicos, pode não afetar significativamente a adsorção destes, conclusão esta, obtida a partir de resultados de experimentos onde a concentração de $\mathrm{Na}^{+}$era 1000 maior do que a de $\mathrm{Cu}^{2+}$. Já

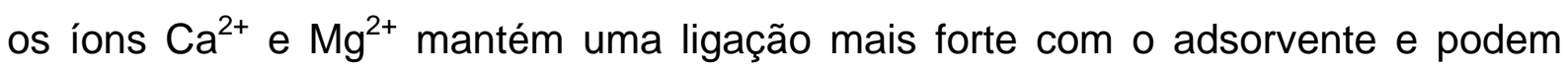
afetar significativamente a adsorção de íons metálicos quando em condição de competição.

\subsubsection{Precipitação e sedimentação}

A precipitação de espécies metálicas em solução no lixiviado baseia-se na redução da solubilidade dos metais presentes na solução ou na formação de seus compostos insolúveis sob determinadas condições do meio. A redução de solubilidade de íons metálicos é obtida mediante a variação do valor do $\mathrm{pH}$, que é conduzida através da adição de um agente acidificante e/ou alcalinizante, o qual é definido em função dos íons presentes. A formação de compostos metálicos insolúveis envolve a adição de coagulantes na solução, que também é definido em função dos íons presentes na solução.

O precipitado formado, seja a própria espécie metálica ou o composto metálico, pode então ser separado da água através de um processo físico, como filtração ou sedimentação. A adição de agentes coagulantes ou floculantes tem o 
objetivo de agregar os cristais formados e de melhorar sua separação da fase líquida (HAAS; VAMOS, 1995).

Íons metálicos presentes no lixiviado sob a forma de complexos organometálicos, tais como os formados durante a lavagem do solo com EDTA e NTA, podem ser removidos da solução mediante a acidificação do meio (exceto o $\mathrm{Hg}$ ) ou sua precipitação sob a forma de hidróxido, sulfeto ou oxalato. Ácidos minerais podem causar a dissociação do complexo metal-EDTA, mas a precipitação do EDTA somente poderá ocorrer se a concentração da espécie de EDTA protonada for superior à sua solubilidade. Em meio alcalino $(\mathrm{pH}>9,0) 0$ complexo poderá ser dissociado pela precipitação do metal sob a forma de seu hidróxido (USEPA, 1994).

Os íons metálicos são precipitados sob a forma de hidróxidos ou sulfetos dos metais correspondentes, que então concentram-se no lodo gerado. A precipitação não é um processo destrutivo, mas sim uma técnica de transferência dos íons metálicos e de outros contaminantes de um meio líquido para um sólido, portanto, não constitui uma solução definitiva para o problema.

Os metais $\mathrm{Cd}, \mathrm{Pb}, \mathrm{Ni}$ e $\mathrm{Zn}$ podem ser precipitados tanto sob a forma de hidróxido quanto de sulfeto; $\mathrm{Cd}, \mathrm{Pb}$ e Ni também podem ser precipitados sob a forma de carbonato (FORD, 1992; HAAS; VAMOS, 1995).

O Cd precipita melhor sob a forma de hidróxido e sulfeto e pode ser coprecipitado usando sais de Al. O Pb não precipita eficientemente sob as formas de hidróxido e de sulfeto, sendo mais eficiente sob a forma de carbonato. O Ni precipitase eficientemente sob a forma de hidróxido mas, em águas fortemente complexadas, a precipitação sob a forma de sulfeto oferece melhor resultado. O Zn é precipitado eficientemente sob a forma de hidróxido e oferece limitada eficiência sob a forma de sulfeto (FORD, 1992).

A precipitação sob a forma de hidróxido é obtida mediante a adição de um reagente alcalino (e.g. cal hidratada), que eleva o $\mathrm{pH}$ da solução até que o limite de solubilidade do metal seja excedido, quando então, o mesmo precipita.

A precipitação sob a forma de sulfeto envolve a reação do metal dissolvido com o íon sulfeto $\left(\mathrm{S}^{2-}\right)$, para formar um sulfeto metálico relativamente insolúvel, que então precipita. O uso de sulfeto para a precipitação de metais deve ser considerado com cuidado, pois pode haver produção de gás sulfídrico, principalmente em meio básico, que é letal em baixas concentrações em ambientes fechados. Outras 
características do uso do sulfeto incluem o maior custo do processo em relação à precipitação via hidróxido, a necessidade de controle contínuo do processo e a elevada produção de lodo (WEF, 1994).

A precipitação sob a forma de carbonato metálico demanda a adição de uma base para elevar o pH da solução e, caso não haja carbonato livre, de um carbonato inorgânico (e.g. $\mathrm{Na}_{2} \mathrm{CO}_{3}$ ). Embora o processo requeira um meio alcalino sua eficiência é reduzida em $\mathrm{pH}$ acima de 10, devido a formação de complexos de hidróxidos metálicos (HAAS; VAMOS, 1995).

A precipitação é influenciada por diversos fatores, que incluem (FORD, 1992):

$>$ pH da solução;

$>$ Sal formado;

> Cinética de formação;

> Agentes complexantes;

> Formação de co-precipitantes; e

Eficiência de remoção de sólidos em suspensão.

A precipitação química em meio alcalino apresenta como principais desvantagens: a elevada demanda de álcali para elevar o $\mathrm{pH}$ até atingir a faixa de valor ótimo para a precipitação dos hidróxidos metálicos e a elevada produção de lodo. Em meio ácido, os metais podem ser arrastados e precipitados através dos ânions sulfeto $\left(\mathrm{S}^{2-}\right)$ e oxalato $\left(\mathrm{C}_{2} \mathrm{H}_{2} \mathrm{O}^{2-}\right)$, sendo que o sulfeto apresenta a desvantagem de ser incapaz de precipitar alguns metais em $\mathrm{pH}$ baixo (para $\mathrm{pH} \leq 5$ somente se formam e precipitam os sulfetos de $\mathrm{Ag}, \mathrm{Cd}, \mathrm{Pb}$ e $\mathrm{Zn}$, cuja solublidade (mg/L) em pH $=5$ é, respecitvamente, $10^{-8}, 10^{-3}, 10^{-3}$ e $10^{-2}$ ), o que não ocorre com o oxalato, logo, o oxalato é mais adequado para tal aplicação (ZIELINSKI; BUCA; FAMULSKI, 1998 e HAAS; VAMOS, 1995).

ZIELINSKI; BUCA; FAMULSKI (1998) avaliaram o uso do D2EPA (ácido di(2-etilexil) fosfórico) diluído em querosene como agente de extração de metais $\left(\mathrm{Ni}^{2+}, \mathrm{Cd}^{2+}, \mathrm{Cu}^{2+}, \mathrm{Zn}^{2+} \mathrm{e} \mathrm{Pb}^{2+}\right)$, contidos em uma solução ácida. Apesar da elevada eficiência obtida no arraste e precipitação dos metais das soluções sintéticas contendo apenas um metal, utilizando solução de D2EPA a 30\% em querosene, 30 $\mathrm{g} \mathrm{H}_{2} \mathrm{C}_{2} \mathrm{O}_{4}$ ( $97 \%$ para $\mathrm{Cu}^{2+}$ e $\mathrm{Zn}^{2+}$ e $87 \%$ para o $\mathrm{Pb}^{2+}$ ), não se obteve o mesmo resultado tanto para os sistemas contendo dois e três metais quanto para a água residuária industrial contendo metais (69,50 g Cu/L; $230 \mathrm{~g} \mathrm{Cr}(\mathrm{II}$ e VI)/L; 0,02 g Fe/L; 
42,5 g Ni/L e $162 \mathrm{~g} \mathrm{Zn/L).} \mathrm{Neste} \mathrm{caso,} \mathrm{utilizando} \mathrm{solução} \mathrm{de} \mathrm{D2EPA} \mathrm{a} 10 \%$ em querosene e $\mathrm{pH}=3,2$, os autores relataram ter obtido eficiência de arraste de $92 \%$ para $\mathrm{Cu}^{2+}$ e maior que $77 \%$ para $\mathrm{Zn}^{2+}$ e $\mathrm{Ni}^{2+}$ e $30 \%$ para o $\mathrm{Cr}$; a eficiência da precipitação foi de $68 \%$ para $\mathrm{Zn}^{2+}$ e inferior a $20 \%$ para $\mathrm{Ni}^{2+}, \mathrm{Cu}^{2+}$ e $\mathrm{Cr}$.

As conclusões principais deste trabalho foram de que o D2EPA é um composto eficiente para a extração de íons metálicos contidos em solução ácida e, que ajuste do $\mathrm{pH}$, através da adição de oxalato, permite a separação parcial e a efetiva recuperação do metal. Os autores também concluíram os resultados obtidos para o sistema monometal não podem ser extrapolados para o tratamento do lixiviado produzido durante a remediação de solos contaminados com metais, que, tipicamente, possui mais de uma espécie metálica. Entretanto, o uso do D2EPA pode ser uma alternativa interessante para a extração de metais em solução no lixiviado oriundo de solos contaminados.

A Figura 15 mostra a variação da eficiência da extração de metais pela solução D2EPA a $30 \%$ em querosene em função do pH. O comportamento homogêneo dos metais permite que sejam seletivamente extraídos da solução.

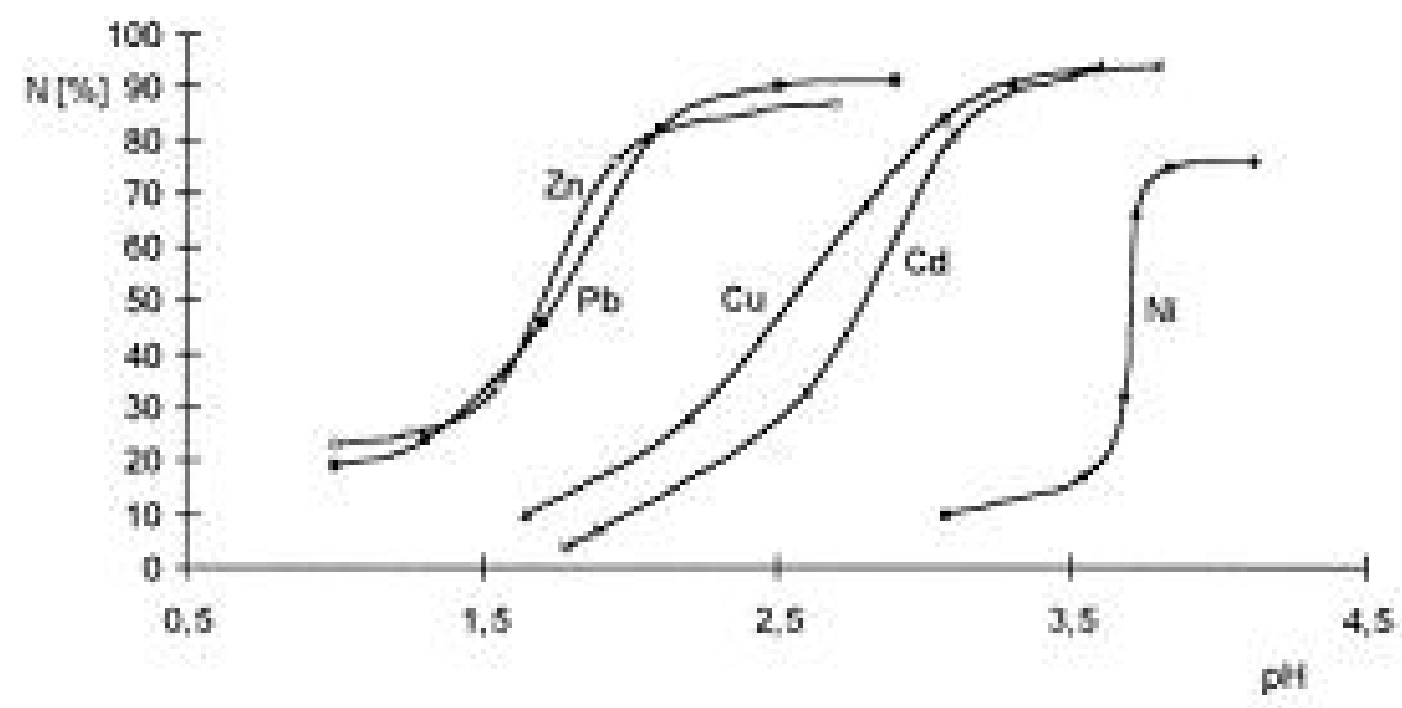

Figura 16 - Eficiência de extração $(\mathrm{N})$ versus pH da solução de extração: solução $30 \%$ de D2EHPA em querosene.

Fonte: ZIELINSKI; BUCA; FAMULSKI (1998). 


\subsubsection{Troca iônica}

Os processos de troca iônica baseiam-se na utilização de resinas, orgânicas ou inorgânicas, trocadoras de íons. A troca de íons ocorre entre a fase sólida do trocador de íons e o lixiviado submetido ao dispositivo de tratamento, que pode ser uma coluna ou um reator recheado com resina (FORD, 1992, HAAS; VAMOS, 1995, AWWA; ASCE, 1998).

As resinas são sólidos homogêneos e a troca de íons da fase líquida para a sólida ocorre na sua superfície. Os íons, então, espalham-se através do polímero solvatado, de um sítio de troca de íon para outro em direção ao centro da resina(AWWA; ASCE, 1998).

O conhecimento dos íons presentes no lixiviado é fundamental para a escolha da resina adequada, pois estas são seletivas a determinado íon, ou conjunto de íons. Após o uso, a resina pode ser regenerada, todavia, sua vida útil é finita e decresce ao longo do tempo, logo, é um processo indicado para o tratamento de lixiviado contendo baixa concentração de íons, o que permite um maior tempo de operação do sistema e uma menor freqüência de regeneração da resina, que por sua vez, reflete no aumento da vida útil da unidade.

\subsubsection{Processos biológicos}

Os processos biológicos de tratamento de metais pesados utilizam os diferentes mecanismos de desintoxicação que certas espécies de microrganismos utilizam quando seu hábitat é contaminado por eles. A impossibilidade de biodegradação dos metais força os microrganismos a recorrer à outros meios de promover a sua imobilização, solubilização ou inertização e, dentre os mecanismos empregados neste intento, incluem-se (KING; LONG; SHELDON, 1998):

$>$ Adsorção ;

> Troca iônica;

> Precipitação extracelular; 
> Formação de complexos organometálicos.

A toxicidade que um metal exibe para o organismo exposto não limita-se somente ao seu estado de oxidação, mas também o pH do meio, todavia, a redução ou a oxidação das espécies metálicas elimina ou reduz a toxicidade dos metais. A redução das espécies metálicas permite que as mesmas sejam convertidas para formas metálicas estáveis e insolúveis $(\mathrm{Hg}$ e Se podem ser reduzidos para sua forma metálica; $\mathrm{Pb}$ e $\mathrm{Zn}$ para a forma de seus sulfetos) ou permaneçam como íons menos tóxicos (redução de $\mathrm{Cr}^{6+}$ para $\mathrm{Cr}^{3+}$ ) (KING; LONG; SHELDON, 1998).

Os quatro mecanismos supracitados podem ser agrupados em dois processos biológicos básicos: bioacumulação e biotransformação.

\subsubsection{Bioacumulação}

A bioacumulação é a capacidade, natural ou conferida intencionalmente, dos organismos vivos de acumularem substâncias específicas no interior ou na superfície de suas células. Pesquisas utilizando engenharia genética já demonstraram, em escala de laboratório, que bactérias geneticamente modificadas ampliaram sua capacidade de bioacumular íons metálicos (BAE et alii, 2000).

Os organismos superiores respondem à presença de metais pesados com a produção de peptídios ricos em cisteína, tal como glutationa, fitoquelatinas e metalotioneínas, que se ligam a íons metálicos e os transformam em formas biologicamente inativas. A possibilidade de modificar geneticamente organismos que abrigam genes sintéticos, que codificam proteínas análogas a fitoquelatinas, com comprimento de cadeia precisamente definida, permitiram a BAE et alii (2000) demonstrarem, pela primeira vez, a capacidade de ligação a metais de qualquer fitoquelatina ou organismo modificado contendo até 20 cisteínas.

No estudo realizado por BAE et alii (2000) foram introduzidas alterações genéticas em culturas de $E$. coli - modificadas através da técnica de transferência de fragmentos de DNA chamada plasmídeos, que também é citada por KING; LONG; SHELDON (1998) para a remoção de compostos orgânicos clorados - que resultaram na ampliação da capacidade de remoção de $\mathrm{Cd}^{2+}$ de aproximadamente 4

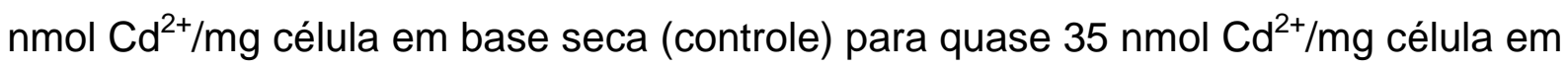


base seca no perioplasma e aproximadamente $55 \mathrm{nmol} \mathrm{Cd}^{2+} / \mathrm{mg}$ célula em base seca na superfície da célula. Segundo estes autores, a acumulação de metal é fortemente dependente da afinidade de ligação da superfície exposta do peptídeo e a quantidade deste na superfície da célula.

KING; LONG; SHELDON (1998) reportaram, ainda, a possibilidade da remoção e recuperação de $\mathrm{Cd}$ e $\mathrm{Cu}$ através de sua concentração em biopolímeros produzidos por microrganismos.

A aplicação da engenharia genética na melhoria de microrganismos naturalmente capazes de adsorver íons metálicos, tem o potencial de desenvolver espécies que exibam elevada afinidade de ligação à determinado elemento ou grupo de elementos metálicos, o que pode torná-la uma alternativa economicamente viável para a recuperação e reutilização de metais.

\subsubsection{Bioadsorção}

A capacidade de sorção não é exclusividade de elementos abióticos, pois também é exibida por diversas espécies de microrganismos, que possuem ainda, a vantagem de serem seletivos a determinados íons de metais pesados, mesmo que em soluções com elevada concentração de íons de metais alcalinos e alcalinos terrosos (ESPOSITO et alii, 2001). A bioadsorção pode ser definida como um metabolismo independente da sorção (ou seja seus mecanismos de ação não dependem dos mecanismos eletrostático, físico e químico que governam a sorção) de metais pesados à biomassa. A superfície da célula possui cargas negativas em $\mathrm{pH}=7,0$, devido à presença de grupos carboxila, amino, hidroxila, fosfatos e sulfidril e pode adsorver cátions metálicos (LLOYD, 2002).

Certos microrganismos, quando em presença de metais tóxicos, são capazes de secretar proteína, lipoproteína ou polissacarídeo, sob a forma de uma camada que recobre a célula e que é uma ligação para a superfície externa de sua membrana celular e tem por objetivo atrair e capturar os íons metálicos (KING; LONG; SHELDON, 1998). Segundo estes autores, esta ação defensiva da célula serve, aparentemente, para:

> Fornecer um sítio de ligação que retira o íon metálico da solução; 
> Isolar o íon metálico, impedindo-o de atravessar a membrana celular; e

- Trazer o íon metálico para junto da célula para combiná-lo com outros ligantes orgânicos para a formação de complexos organometálicos, que podem reduzir a toxicidade do metal ou fornecer um mecanismo para mobilizá-lo para longe do organismo.

A bioadsorção de metais pesados é afetada por diversos fatores que incluem o pH, a força iônica, a concentração de biomassa, a temperatura e a presença de diferentes íons metálicos na solução, que competem pelos sítios ativos existentes na superfície do adsorvente (ESPOSITO et alii., 2001).

A Figura 17 mostra um esquema que sintetiza os vários meios pelos quais a bactéria reage com a presença de metais $\left(\mathrm{Me}^{2+}\right)$ no meio, com relação ao compartimento celular que abriga a resposta celular. Estes mecanismos incluem as ligações intra e extracelulares (e assim a imobilização) do metal com a proteína cognata (freqüentemente uma metalotioneína) ou um ânion compatível, a biotransformação de um íon tóxico para uma forma menos tóxica ou mais volátil e a conseqüente redução do metal (VALLS; LORENZO, 2002).

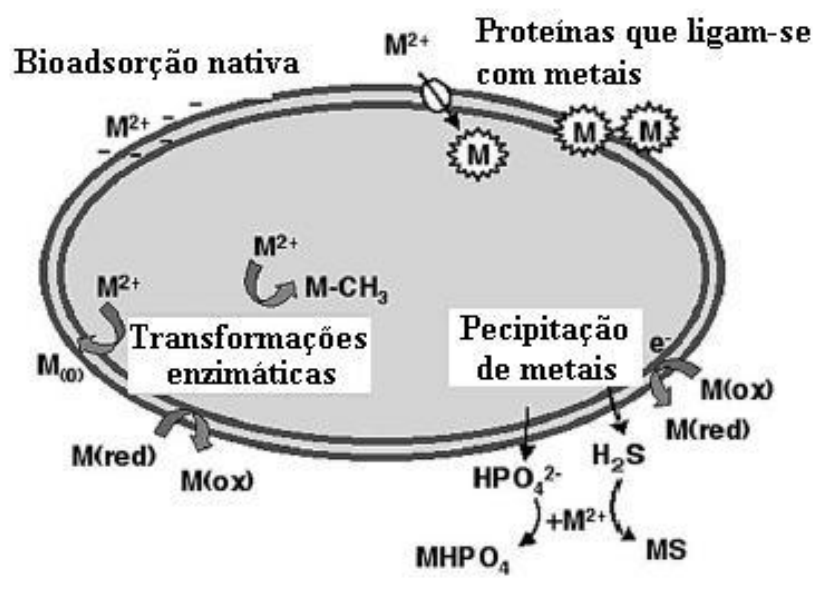

Figura 17 - Resposta bacteriana à concentração tóxica de íons metálicos.

Fonte: VALLS; LORENZO (2002).

HUANG; HUANG; MOREHART (1991) estudaram a remoção de $\mathrm{Cd}^{2+}, \mathrm{Cu}^{2+}$, $\mathrm{Ni}^{2+}, \mathrm{Pb}^{2+}$ e $\mathrm{Zn}^{2+}$ utilizando Aspergillus oryzae (células vivas, regeneradas e mortas), em escala de laboratório, sob as seguintes condições:

$>$ Reatores em batelada;

> Água residuária artificial;

$>$ Concentração de metais: $2.10^{-6} \mathrm{M}$ a $1.10^{-4} \mathrm{M}$ (para valores constantes de $\mathrm{pH}$ ); e 
$>\mathrm{pH}$ : 2 a 9 (experimentos com concentração constante de metais $=5 \cdot 10^{-5} \mathrm{M}, \mathrm{a}$ força iônica foi de $5.10^{-2} \mathrm{M}$ adicionado como $\mathrm{NaClO}_{4}$.

Estes pesquisadores relataram ter obtido remoções de $90 \%$ de $\mathrm{Cd}^{2+}(\mathrm{pH}=$ 9,0 e biomassa reutilizada após lavagem ácida); > $95 \%$ de $\mathrm{Cu}^{2+}(\mathrm{pH}=6,5$, biomassa

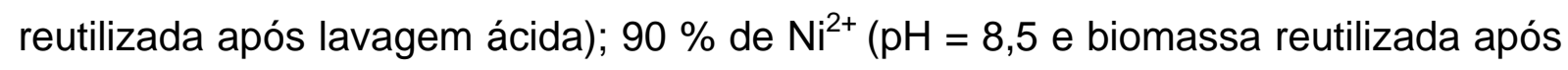
lavagem ácida); $>95 \%$ de $\mathrm{Pb}^{2+}(\mathrm{pH}=7,0$ e biomassa morta $)$ e $>90 \%$ de $\mathrm{Zn}^{2+}(\mathrm{pH}=$ 8,0 e biomassa reutilizada após lavagem ácida); em experimentos conduzidos com concentração fixa de metais $\left(5 \cdot 10^{-2} \mathrm{M}\right)$ e $\mathrm{pH}$ variável. Em termos relativos, as capacidades máximas de adsorção de $A$. oryzae obtidas, para as condições do experimento $\left(\mathrm{pH}=5,0 \pm 0,02\right.$; concentração de metais $=5 \cdot 10^{-5} \mathrm{M}$ e $A$. oryzae $=5$ g/L), foram de:

> $514 \pm 7 \mu$ mole $\mathrm{Cd}^{2+} / \mathrm{g}$ base seca (C/N 10, biomassa tratada com lavagem ácida);

$>536 \pm 15 \mu$ mole $\mathrm{Cu}^{2+} / \mathrm{g}$ base seca ( $/ \mathrm{N} \mathrm{10}$, biomassa tratada com lavagem ácida);

$>382 \pm 9 \mu$ mole $\mathrm{Ni}^{2+} / \mathrm{g}$ base seca (C/N 10, biomassa tratada com lavagem ácida);

$>560 \mu$ mole $\mathrm{Pb}^{2+} / \mathrm{g}$ base seca (C/N 3, biomassa tratada com lavagem ácida); e

$>420 \pm 9 \mu$ mole $\mathrm{Zn}^{2+} / \mathrm{g}$ base seca (C/N 3, biomassa tratada com lavagem ácida).

Este estudo concluiu que a remoção de íons metálicos era determinada por diversos fatores, mas que o mais importante era o $\mathrm{pH}$. Os experimentos demonstraram, ainda, que a relação $\mathrm{C} / \mathrm{N}$ afetava a adsorção dos íons e que a abundância de $\mathrm{N}$ no meio de cultivo resultava no crescimento de micelas com maior quantidade deste elemento na superfície da célula e por conseguinte, no aumento de sítios de ligação para os íons metálicos.

O uso de biomassa confinada em reatores, mediante o uso de membranas de micro e/ou ultrafiltração, é outra alternativa para a remoção de íons metálicos (BARBA; BEOLCHINI; VEGLIÒ, 2001, VEGLIÒ et alii, 2002). BARBA; BEOLCHINI; VEGLIÒ (2001) desenvolveram um modelo, cujo objetivo foi simular o efeito das principais condições operacionais no processo; perfil dos metais no fluxo de saída e remoção cumulativa dos íons; de modo a predizer com 95 \% de confiabilidade os resultados experimentais. A calibração do modelo foi realizada através de experimentos utilizando Arthrobacter sp., para a remoção de $\mathrm{Cu}^{2+}$ (concentração no afluente $=10 \mathrm{mg} \mathrm{Cu}^{2+} / \mathrm{L}$, vazão $=3,5 \mathrm{~mL} / \mathrm{min}$, concentração de biomassa $=1 \mathrm{~g} / \mathrm{L}$, volume de reação $=500 \mathrm{~mL}$ ). 
Estes autores relataram que as simulações, fornecidas pelo modelo calibrado com os dados experimentais, possibilitaram alcançar os objetivos pretendidos, entretanto, os resultados deveriam ser verificados por outros estudos.

VEGLIÒ et alii (2002), utilizaram Sphaerotilus natans, também confinadas em reatores isolados por membranas de ultra e microfiltração, para a remoção de $\mathrm{Cu}^{2+}$ e $\mathrm{Pb}^{2+}$ em um sistema binário, cujo objetivo final era avaliar o comportamento destes metais que apresentavam diferentes afinidades em relação ao bioadsorvente utilizado.

O comportamento dos metais foi avaliado em condições de competitividade, simulado com base nos parâmetros de equilíbrio da isoterma de Langmuir (determinados em testes do tipo batelada), de modo que, segundo os autores, foi possível reproduzir qualitativamente o comportamento experimental da bioadsorção multimetal em reatores em série. Os resultados produzidos por este estudo indicaram que em condições de competitividade, o metal de menor afinidade ao adsorvente dessorve deste para a liberação do sítio ativo para o metal de maior afinidade, o que resulta em maior eficiência de remoção deste em relação àquele.

A alternativa proposta pelos autores para a melhora do desempenho do sistema estudado foi a utilização de estágios adicionais, o que poderia melhorar a eficiência de remoção, principalmente, dos metais de baixa afinidade ao adsorvente.

ESPOSITO et alii (2001) também estudaram S. natans e investigaram o efeito do $\mathrm{pH}$ e da concentração da biomassa sobre a bioadsorção de $\mathrm{Cu}^{2+}$ e $\mathrm{Cd}^{2+}$ em solução. Os resultados experimentais evidenciaram que a parede celular da espécie em estudo continha dois principais grupos ácidos, que por hipótese e com base em dados bibliográficos, foram admitidos serem constituídos pelos grupos carboxílico e fosfato, com um total de $5 \mathrm{meq} / \mathrm{g}$.

Os experimentos conduzidos por estes autores avaliaram o efeito do $\mathrm{pH}$ entre os valores de 3 a 6 e da concentração da biomassa (liofilizada) entre 0,5 g/L a $2,0 \mathrm{~g} / \mathrm{L}$. Os valores máximos de adsorção obtidos, expressos como o número de miliequivalentes de $\mathrm{OH}$, foram de $1,81 \mathrm{meq} \mathrm{Cu}^{2+} / \mathrm{g}$ e de $0,78 \mathrm{meq} \mathrm{Cd}^{2+} / \mathrm{g}$ para a seguinte condição operacional: $\mathrm{pH}=6 ; 25^{\circ} \mathrm{C}$; concentração afluente $=0,5 \mathrm{~g} \mathrm{Cu}^{2+} / \mathrm{L}$ a 1,0 g/L; concentração de biomassa $=0,0 \mathrm{~g} / \mathrm{L}$ a $1,0 \mathrm{~g} / \mathrm{L}$.

As Tabelas 8 e 9 mostram outros bioadsorventes, com suas respectivas capacidades de adsorção, para remoção de $\mathrm{Cu}^{2+} \mathrm{e} \mathrm{Cd}^{2+}$ citados na literatura. 
Tabela 8 - Bioadsorventes para remoção de cobre.

\begin{tabular}{|c|c|c|c|c|c|}
\hline \multirow[b]{2}{*}{ Bioadsorvente } & \multirow{2}{*}{$\begin{array}{c}Q_{\max } \\
(\mathrm{meq} / \mathrm{g})\end{array}$} & \multicolumn{4}{|c|}{ Condições operacionais } \\
\hline & & pH & $\mathrm{T}\left({ }^{\circ} \mathrm{C}\right)$ & $\underset{(m g / L)}{C}$ & $X(g / L)$ \\
\hline Arthrobacter $s p$. & 1,42 & 6 & 25 & $0-100$ & 2 \\
\hline Casca de pinheiro & 1,00 & ND & 25 & $0-400$ & ND \\
\hline Chlorella vulgaris & 1,15 & 4 & 25 & $0-250$ & 2 \\
\hline Rhizopus arrhizus & 1,11 & 4 & 25 & $0-200$ & 1 \\
\hline Pseudomonas aeruginosa & 0,72 & 5 & 25 & $0-250$ & $1-2$ \\
\hline Zoogloea ramigera & 1,13 & 4 & 25 & $0-200$ & 1 \\
\hline Ascophyllum nodosum & 1,95 & 4,5 & 25 & $0-350$ & ND \\
\hline Streptoyces noursei & 0,36 & 5,5 & 30 & 180 & 0,4 \\
\hline Pseudonomas syringae & 0,85 & ND & 22 & $0,6-65$ & 3,5 \\
\hline Saccharomyces cerevisiae & 0,01 & 4 & 25 & 3,2 & 2 \\
\hline Galoderna lucidum & 0,84 & 5 & ND & $5-50$ & ND \\
\hline Aureobasidium pullulans & 0,24 & 5,5 & 25 & $1-320$ & 1 \\
\hline Aureobasidium pullulans & 0,24 & 5,5 & 25 & $1-320$ & 1 \\
\hline Cladosporium resinae & 0,54 & 5,5 & 25 & $1-320$ & 1 \\
\hline Rhizopus arrhizus & 0,35 & 5,5 & 25 & $0,6-25$ & ND \\
\hline Zoogloea ramigera & 8,51 & 5,5 & ND & $25-125$ & ND \\
\hline
\end{tabular}

Nota: $q_{\max }=$ capacidade máxima de adsorção do íon metálico; $C=$ concentração do metal na solução de alimentação; $X$ = concentração de biomassa; $N D=$ não disponível.

Fonte: Adaptado de ESPOSITO et alii (2001).

Tabela 9 - Bioadsorventes para remoção de cádmio.

\begin{tabular}{lccccc}
\hline \multicolumn{1}{c}{ Bioadsorvente } & $\begin{array}{c}\mathbf{Q}_{\text {max }} \\
\text { (meq/g) }\end{array}$ & $\mathbf{p H}$ & $\mathbf{T}\left({ }^{\circ} \mathbf{C}\right)$ & $\begin{array}{c}\text { Condições operacionais } \\
(\mathbf{m g} / \mathbf{L})\end{array}$ & X (g/L) \\
\hline Arthrobacter sp. & 0,001 & 6 & 25 & $0-100$ & 2 \\
Casca de pinheiro & 0,30 & $\mathrm{ND}$ & 25 & $0-400$ & $\mathrm{ND}$ \\
Pseudomonas aeruginosa & 0,76 & 6 & 25 & $0-250$ & $1-2$ \\
Sargassum fluitans & 1,81 & 4,5 & 25 & $\mathrm{ND}$ & $\mathrm{ND}$ \\
Ascophyllum nodosum & 1,49 & 4,5 & 25 & $0-350$ & $\mathrm{ND}$ \\
Streptoyces noursei & 0,06 & 6 & 30 & $1-110$ & 3,5 \\
Rhizopus arrhizus & 0,44 & 3,5 & 26 & $10-400$ & $\mathrm{ND}$ \\
Rhizopus arrhizus & 0,48 & $6-7$ & $\mathrm{ND}$ & $10-600$ & 3 \\
Saccharomyces cerevisiae & 0,01 & 5 & 25 & 5,6 & 2 \\
Sargassum natans & 2,04 & 3,5 & 26 & $10-400$ & $\mathrm{ND}$ \\
Bactéria gram-positiva & 0,33 & 6,6 & 30 & 10 & 0,2 \\
Bactéria gram-negativa & 0,24 & 6,6 & 30 & 10 & 0,2 \\
Ascophylum nodosum & 3,47 & 4,9 & 26 & $10-600$ & $2-5$ \\
& & & & & continua...
\end{tabular}


conclusão.

\begin{tabular}{lccccc}
\hline \multicolumn{1}{c}{ Bioadsorvente } & $\begin{array}{c}\mathbf{Q}_{\text {max }} \\
\text { (meq/g) }\end{array}$ & $\mathbf{p H}$ & $\mathbf{T}\left({ }^{\circ} \mathbf{C}\right)$ & $\begin{array}{c}\text { C } \\
(\mathbf{m g} / \mathbf{L})\end{array}$ & $\mathbf{X}(\mathbf{g} / \mathbf{L})$ \\
\hline Arthrobacter globiformis & 0,003 & 7 & 20 & 1 & 0,6 \\
Arthrobacter viscosus & 0,01 & 7 & 20 & 1 & 0,6 \\
$\begin{array}{l}\text { Exopolisacarídeos } \\
\text { Arthrobacter viscosus }\end{array}$ & 0,06 & 7 & 20 & 1 & 0,6 \\
Alcaligenes sp. & 0,18 & $4-8$ & 25 & 10 & 0,38 \\
\hline
\end{tabular}

Nota: $\mathrm{q}_{\max }=$ capacidade máxima de adsorção do íon metálico; $\mathrm{C}=$ concentração do metal na solução de alimentação; $X=$ concentração de biomassa; ND = não disponível.

Fonte: Adaptado de ESPOSITO et alii (2001). 


\section{MATERIAL E MÉTODOS}

\subsection{Descrição do local objeto do estudo: Região dos Lagos de Santa Gertrudes}

O afloramento da Formação Corumbataí propiciou a instalação de muitas indústrias cerâmicas na região que abrange os municípios de Araras, Cordeirópolis, Ipeúna, Iracemápolis, Limeira, Piracicaba, Rio Claro e Santa Gertrudes e que forma o maior pólo cerâmico do país, responsável por 50 \% da produção nacional de revestimentos (CETESB, 2001b, BNDES, 2001).

As indústrias deste pólo utilizam tecnologia de produção denominada "via seca". Com 39 empresas, sua produção em 2004 foi de aproximadamente 250 milhões de metros quadrados de revestimentos, mantendo mais de 5.000 empregos diretos. Este pólo respondeu por $22 \%$ do volume de exportação nacional de revestimentos cerâmicos em 2003, sendo os países americanos (do Norte e Latina) e africanos, os principais mercados consumidores (CARIDADE; TORKOMIAN, 2001; BNDES, 2001; ASPACER, 2005).

A abundância de argila, matéria-prima básica da indústria cerâmica, no município de Santa Gertrudes, viabilizou a instalação da maior parte das indústrias do pólo nesta cidade: vinte e duas (CETESB, 2002b). Particularmente, a região dos lagos foi utilizada para a extração de argila e quando esta se exauria, a lavra era suspensa e as cavas abandonadas, passando-se a exploração para áreas no entorno (CETESB, 2001b).

As cavas abandonadas foram, com o passar do tempo, sendo preenchidas pela água do aqüífero freático e pelos resíduos líquidos e sólidos gerados pelas indústrias cerâmicas, formando assim, os lagos atualmente existentes nesta região.

As Figuras 19 e 20 mostram, respectivamente, a localização geográfica do pólo cerâmico de Santa Gertrudes no Estado de São Paulo e uma vista aérea da "Região dos Lagos". 


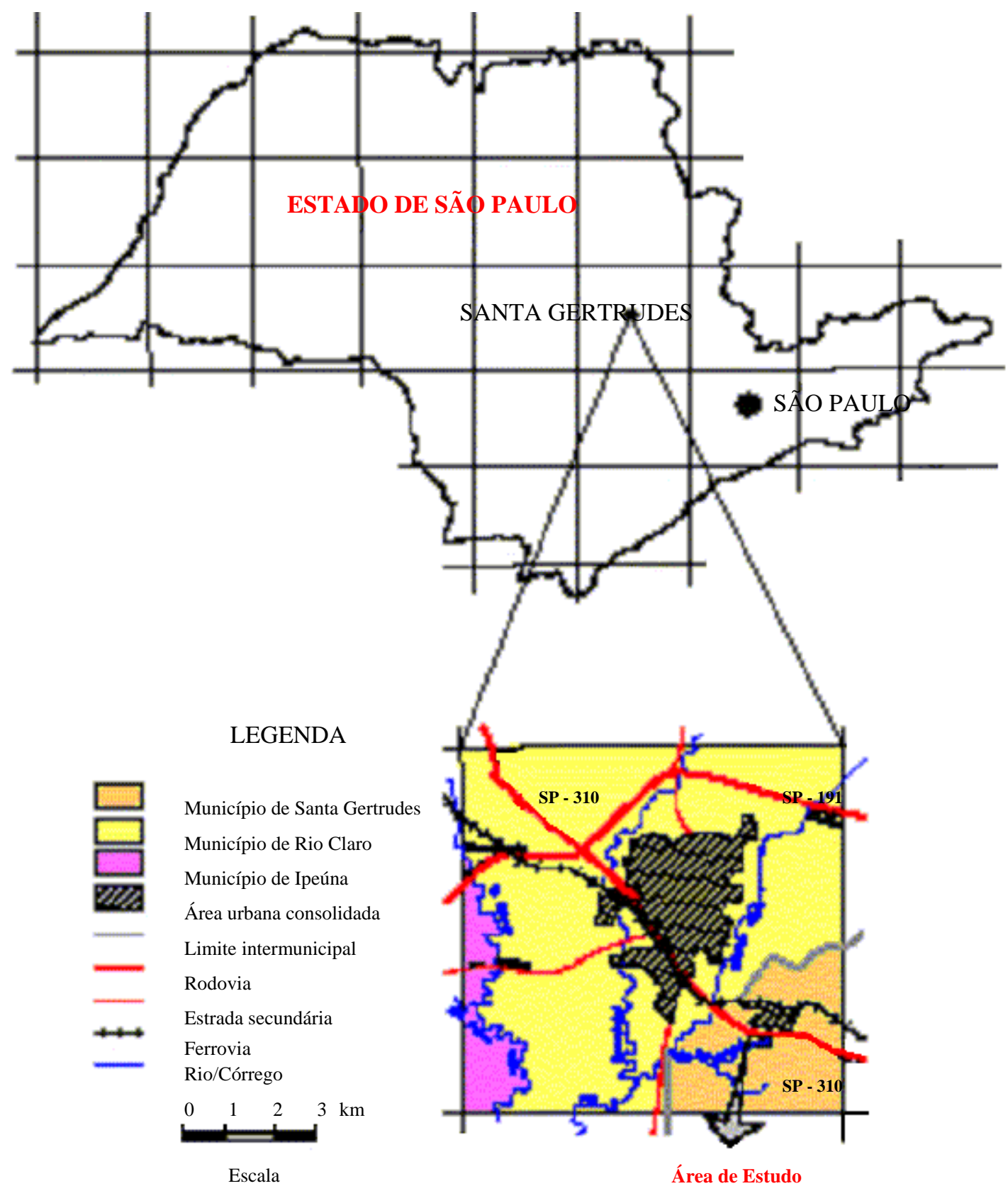

Figura 19 - Localização geográfica do pólo cerâmico de Santa Gertrudes no Estado de São Paulo.

Fonte: Adaptado de SILVA (2001).

Os primeiros indícios de contaminação do solo da região resultaram de análises de amostras de solo realizadas pela CETESB em 1997, as quais apresentavam teores de até $2,24 \mathrm{~g} \mathrm{~Pb} / \mathrm{kg}$, até $4 \mathrm{mg} \mathrm{Cd} / \mathrm{Kg}$ e até $820 \mathrm{mg} \mathrm{Zn/kg}$. A confirmação da contaminação da área (uma vez que as investigações foram realizadas também nas águas subterrâneas e nos sedimentos) decorreu, em parte, da pesquisa realizada por SILVA (2001) e de novas análises de solo feitas pela CETESB e pela empresa GEO-INF. Estas apresentaram resultados indicando a 
existência de "focos" de contaminação na área dos lagos (CETESB, 2001a; GEOINF, 2002).

O processo de avaliação da contaminação na área dos lagos passou por todas as fases previstas pelo manual de gerenciamento de áreas contaminadas da CETESB (CETESB; GTZ, 2001): avaliação preliminar, investigação confirmatória, investigação detalhada, avaliação de risco, investigação para remediação, projeto de remediação e remediação (CETESB, 2001a; CETESB, 2001b). Entretanto, o projeto de remediação e a remediação não foram executados para todos os focos de contaminação da área.

A magnitude da contaminação do solo da região pode ser avaliada mediante simples comparação dos resultados das análises já realizadas e os valores orientadores de contaminantes para o solo atualmente utilizado pela CETESB (Tabela 10).

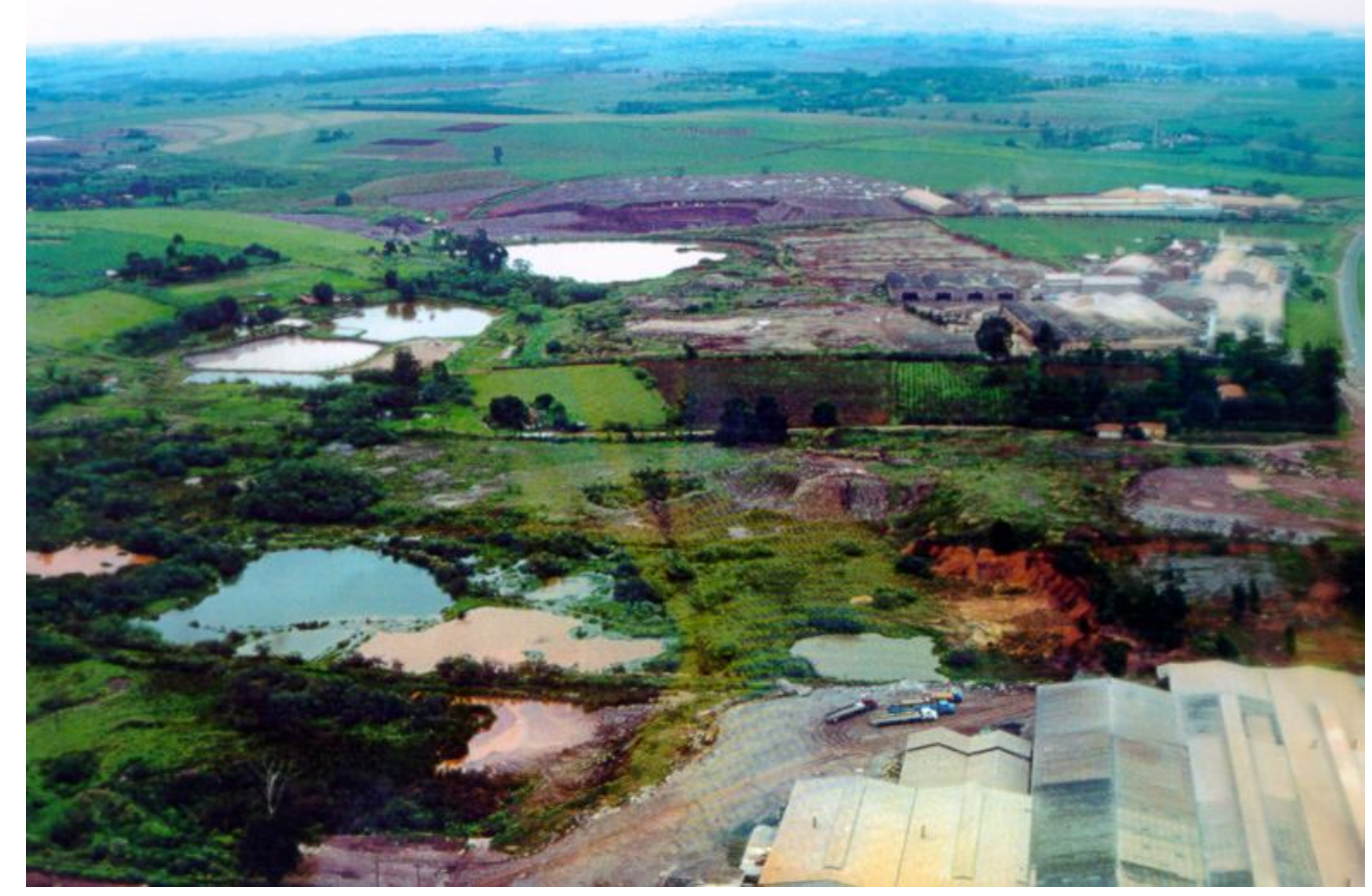

Figura 20 - Vista área da Região dos Lagos de Santa Gertrudes. Fonte: SÃO PAULO (2003).

Além das análises de solo, a CETESB realizou, em 2001, análises de amostras de sedimentos dos lagos, que também apontaram contaminação, e da água do aqüífero subterrâneo, onde foi detectada a presença de diversos contaminantes, sendo Cd e B os principais elementos que se apresentavam em concentrações muito acima dos padrões de potabilidade nacionais e internacionais $(0,005 \mathrm{mg} \mathrm{Cd} / \mathrm{L}$ e $5,0 \mathrm{mg} \mathrm{B} / \mathrm{L})$. Este estudo constatou que o aqüífero artesiano 
(amostra coletada em poço de $280 \mathrm{~m}$ de profundidade) já apresentava contaminação por B (CETESB, 2001a).

Diante da gravidade da contaminação nesta área, a CETESB desaconselhou o uso do solo para atividades agro-pastoris, bem como o da água do aqüífero freático e artesiano para consumo humano, dessedentação de animais e irrigação (CETESB, 2001a). A contaminação do aqüífero subterrâneo (freático e profundo) levou, em junho de 2002, a Secretaria de Saúde do Estado de São Paulo, através da DIR XV de Piracicaba, a interditar os poços da região dos lagos, a fim de impedir o uso da água subterrânea para o consumo humano (SÃO PAULO, 2003).

Tabela 10 - Análises de amostras de solo da região dos lagos e comparação dos teores de contaminantes com os valores orientadores para solos no Estado de São

Paulo.

\begin{tabular}{|c|c|c|c|c|c|c|c|}
\hline \multirow[t]{2}{*}{ Elemento } & \multicolumn{3}{|c|}{$\begin{array}{l}\text { Contaminação do solo - } \\
\text { teores máximos } \\
\text { determinados para as } \\
\text { amostras (mg/kg) } \\
\text { Profundidade de } \\
\text { amostragem }\end{array}$} & \multicolumn{4}{|c|}{$\begin{array}{l}\text { Valores orientadores para solos (mg/kg) } \\
\text { Referência Intervenção }\end{array}$} \\
\hline & $\begin{array}{c}0,0 \mathrm{~m} \\
\mathrm{a} \\
0,2 \mathrm{~m}\end{array}$ & $\begin{array}{c}0,5 \mathrm{~m} \\
\mathrm{a} \\
0,6 \mathrm{~m}\end{array}$ & $\begin{array}{c}0,0 \mathrm{~m} \\
\mathrm{a} \\
3,6 \mathrm{~m} * *\end{array}$ & $\begin{array}{c}\text { de } \\
\text { qualidade }\end{array}$ & Prevenção & $\underset{* \star * \star}{\text { Agrícola }}$ & Industrial \\
\hline $\mathrm{Pb}$ & 529 & 2.890 & 27.129 & 17 & 72 & 180 & 900 \\
\hline $\mathrm{Cd}$ & - & - & 3,22 & $<0,5$ & 1,3 & 3 & 20 \\
\hline Co & 30,7 & 28,4 & - & 13 & 25 & 35 & 90 \\
\hline $\mathrm{Cu}$ & 91,6 & 127 & - & 35 & 60 & 200 & 600 \\
\hline $\mathrm{Na}$ & 3150 & 1060 & - & - & - & - & - \\
\hline $\mathrm{Zn}$ & 77,2 & 453 & 2627 & 60 & 300 & 450 & 2000 \\
\hline B & $8,8^{* * *}$ & $3,5^{\star \star \star}$ & 2345 & - & - & - & - \\
\hline
\end{tabular}

Nota: * análises executadas por CETESB, ** análises realizadas por GEO-INF, *** resultado referente ao boro solúvel expressa como $\mathrm{mg} / \mathrm{L}$, ${ }^{* \star \star *}$ área de proteção máxima.

Fonte: Adaptado de CETESB (2001a), CETESB (2005a) e GEO-INF (2002).

Apesar da CETESB proibir desde 1995 o descarte de resíduos nos lagos e ter obrigado as cerâmicas do município de Santa Gertrudes a armazenarem e destinarem adequadamente os mesmos, o quadro de degradação ambiental instalado na região ainda hoje permanece sem uma solução final (CETESB, 2002a). Embora já tenham sido iniciadas ações para remoção do solo contaminado visando a remediação do local, este sítio ainda integra, sob a classificação de área em 
processo de remediação, a lista de áreas contaminadas, publicada pela CETESB em Novembro de 2005 (CETESB, 2005b).

\subsection{Resíduos gerados pela indústria de revestimento cerâmico}

A produção de revestimentos cerâmicos utiliza em seu processo produtivo elementos potencialmente tóxicos como $\mathrm{Ba}, \mathrm{Cd}, \mathrm{Cr}, \mathrm{Ni}, \mathrm{Pb}$ e $\mathrm{Zn}$, que são empregados na elaboração de fritas, esmaltes, corantes, pigmentos e fundentes.

A seguir é apresentado um resumo dos três fluxos de subprodutos originários da produção de revestimento cerâmico.

\subsubsection{Resíduos sólidos}

Os resíduos sólidos gerados pela indústria de revestimentos cerâmicos podem ser divididos em duas categorias: perdas do processo e subprodutos dos sistemas de tratamento e, segundo MONFORT et alii (1994), apud MORAIS; SICHIERI; PAWLICKA (2001), os principais resíduos gerados por esta indústria compreendem:

$>$ Lodo (raspa): resultante do tratamento das águas de barbotina, operações de limpeza e preparo de esmaltes;

$>$ Produtos acabados: peças queimadas fora de especificação, defeituosas ou quebradas;

$>$ Resíduos de depuração de gases; e

> Restos de matérias-primas, aditivos e peças cruas.

A Tabela 11 mostra os principais resíduos sólidos gerados pela indústria de revestimentos cerâmicos agrupados de acordo com as etapas de produção. 
Tabela 11 - Identificação e classificação dos resíduos gerados pela indústria de revestimentos cerâmicos, segundo sua origem e etapa produtiva.

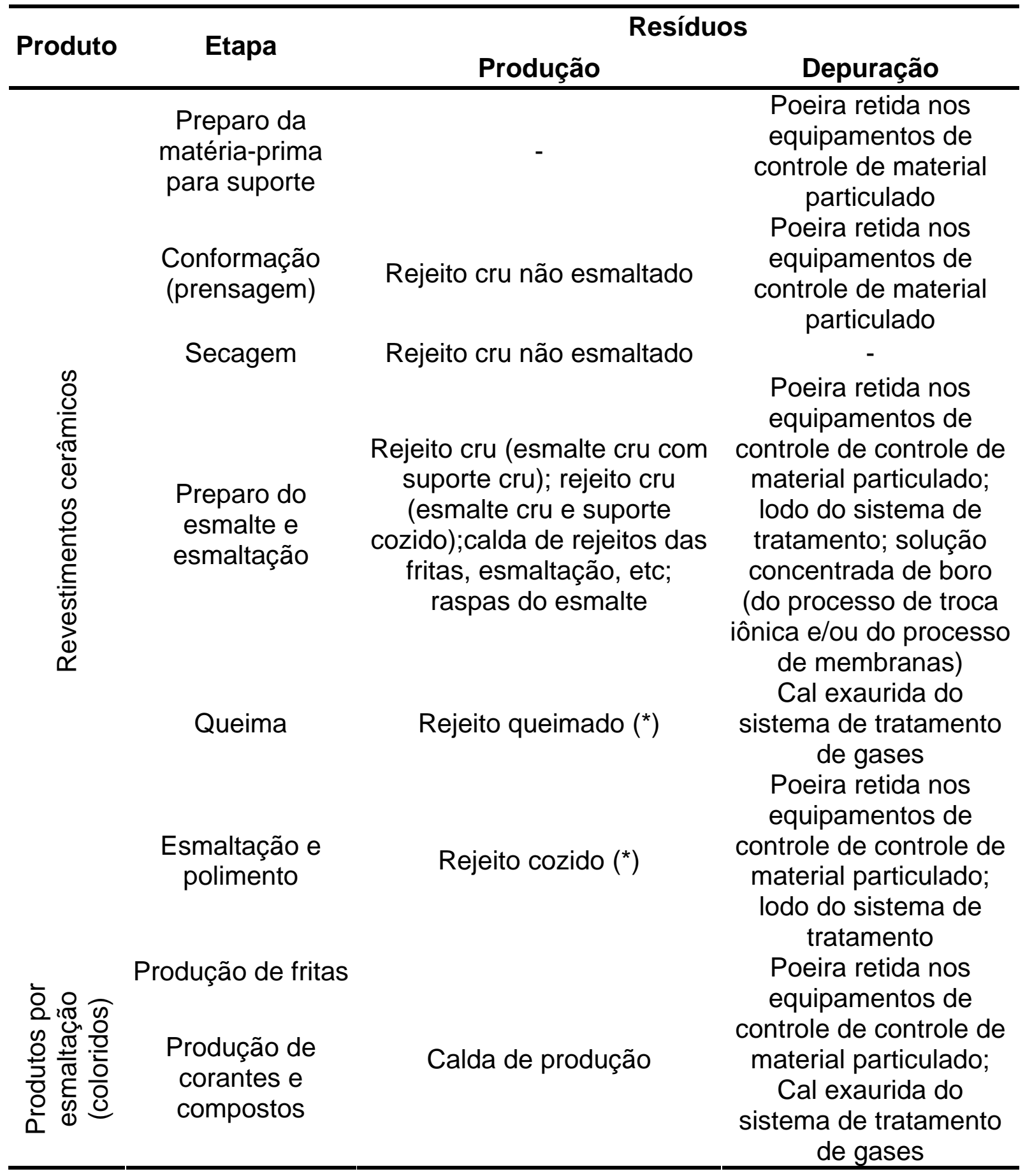

Nota: $\left(^{*}\right)$ = incluí as peças defeituosas descartadas na etapa de produção.

Fonte: Adaptado de BUSANI et alii (1995), apud SOARES et alii (2002).

Perdas de produtos químicos e o material estéril proveniente da jazida também convertem-se em resíduos da indústria, embora este último não ofereça risco ambiental visto que não ingressa no processamento, logo, não é contaminado, exceto se for acondicionado em conjunto com material contaminado. As peças 
danificadas, que já receberam o acabamento superficial mas não foram submetidas à queima e as perdas de produtos químicos, compõem a parcela desta categoria que apresenta o maior potencial de contaminação, pois os metais pesados nestes materiais não estão inertes.

A quantidade de resíduos gerados pela indústria é variável, pois depende do controle de processamento, da qualidade das matérias-primas, do nível e controle de qualidade dos produtos, podendo ser estimada entre $1 \%$ a $20 \%$ da produção nas indústrias brasileiras (MORAIS; SICHIERI; PAWLICKA, 2001; MORAIS; SICHIERI, 2002). Segundo CETESB (2002a), a produção de resíduos é de aproximadamente 6 $\%$, em massa, das matérias-primas utilizadas no processo.

No pólo de Santa Gertrudes a geração de lodo é estimada em $40 \mathrm{~g} / \mathrm{m}^{2}$ de piso produzido e, considerando a produção registrada em dezembro de 2001 (18 x $10^{6} \mathrm{~m}^{2}$ ), foram gerados 720 t deste resíduo naquele mês (CETESB, 2001c).

Segundo MONFORT et alii (1994), apud MORAIS; SICHIERI (2002), a composição dos resíduos sólidos é avaliada como sendo correspondente, em massa, à: 10 \% em lodo, da estação de tratamento de água residuária industrial ETARI; 11,6 \% em partículas de purificação do ar; 49 \% em resíduos crus e 29,4 \% em resíduos queimados (cacos e peças fora de especificação ou defeituosas).

Segundo reportado por MORAIS; SICHIERI; PAWLICKA (2001) e CETESB (2001b), algumas indústrias de revestimentos cerâmicos do pólo de Santa Gertrudes, por utilizarem o processo via seca, já incorporam em seus processos produtivos todos os resíduos gerados em suas ETARI, procedimento este, que é padrão nas indústrias cerâmicas européias (SOARES et alii, 2002). Os resíduos queimados são utilizados como material de revestimento de estradas de terra, como substituto da brita na pavimentação de vias ou são vendidos a preços baixos e/ou doados para serem utilizados como ladrilho.

Segundo levantamento realizado em 2001 pela CETESB (CETESB, 2001b), as indústrias do pólo de Santa Gertrudes utilizam-se das seguintes alternativas para o gerenciamento do lodo:

> $42 \%$ a incorporam à massa crua;

$>22 \%$ a incorporam ao material de cobertura (esmalte/engobe);

$>16 \%$ armazenam;

$>6$ enviam para serem processadas por terceiros;

$>6$ \%ão geram raspas; 
$>8 \%$ não informaram suas políticas sobre a questão.

MORAIS; SICHIERI; PAWLICKA (2001) realizaram a caracterização química e térmica e, determinaram a composição mineralógica e a distribuição granulométrica da massa crua, dos resíduos queimados e do lodo de ETARI, produzidos pelas indústrias de revestimentos cerâmicos do pólo de Santa Gertrudes.

O estudo revelou a seguinte caracterização mineralógica, realizada através de difração de raios-x:

> Massa crua: quartzo, ilita, caulinita e albita;

> Resíduo queimado: complexo vítreo (característica de argilas queimadas), fases cristalinas quartzo e mulita;

$>$ Lodo: quartzo, ilita, caulinita, anatase, calcita e material amorfo (componente dos insumos vidrados).

Dentre os resíduos gerados, o lodo, por resultar, basicamente, do preparo do esmalte, foi classificado como um material tóxico a partir dos ensaios de lixiviação (realizados de acordo com a NBR 10004 - resíduos sólidos e NBR 1005 - lixiviação de resíduos), pois as concentrações de $\mathrm{Pb}$ inorgânico e $\mathrm{Cr}$ total nos lixiviados excederam os valores máximos permitidos pela legislação brasileira ( $5 \mathrm{mg} \mathrm{Pb} / \mathrm{L}$ e 5 mg Cr/L). Os demais resíduos são, normalmente, considerados inertes; apesar dos ensaios de lixiviação realizados terem classificado o resíduo queimado como sendo tóxico, pois este também excedeu a concentração de Cr total no lixiviado; e podem ser utilizados como chamote, atuando no controle dimensional das peças (MORAIS; SICHIERI, 2002).

Segundo a CETESB (CETESB 2001c; CETESB 2002a) o lodo de ETARI foi classificado como resíduo Classe I na década de 1980, mas devido a atuação da companhia, houve substituição de matérias-primas e, já na década de 1990, o lodo passou a ser enquadrado na Classe II. A divergência entre a classificação obtida por MORAIS; SICHIERI (2002) e as realizadas pela CETESB podem indicar, admitindo a equivalência da metodologia dos ensaios e ausência de erros experimentais, que indústrias da região talvez não tenham eliminado completamente o uso de metais pesados de seus processos produtivos.

A Tabela 12 mostra o resultado de ensaios de lixiviação, utilizando amostras coletadas em todas as indústrias do pólo de Santa Gertrudes, realizados por MORAIS; SICHIERI (2002). 
Tabela 12 - Análise de lixiviação de resíduos.

\begin{tabular}{ccccc}
\hline & \multicolumn{2}{c}{$\begin{array}{c}\text { Resíduo da ETARI } \\
\text { Extrato (mg/L) }\end{array}$} & \multicolumn{2}{c}{$\begin{array}{c}\text { Resíduo queimado } \\
\text { Extrato (mg/L) }\end{array}$} \\
Elemento & $\begin{array}{c}\text { Determinação } \\
\text { experimental }\end{array}$ & $\begin{array}{c}\text { Limite } \\
\text { máximo }\end{array}$ & $\begin{array}{c}\text { Determinação } \\
\text { experimental }\end{array}$ & $\begin{array}{c}\text { Limite } \\
\text { máximo }\end{array}$ \\
\hline $\mathrm{Ca}$ & 5.677 & $\mathrm{Ni}$ & 5.493 & $\mathrm{Ni}$ \\
$\mathrm{Mg}$ & 16,97 & $\mathrm{Ni}$ & 1.800 & $\mathrm{Ni}$ \\
$\mathrm{Fe}$ & 30,9 & $\mathrm{Ni}$ & $\mathrm{Ab}$ & $\mathrm{Ni}$ \\
$\mathrm{Zn}$ & 44,7 & $\mathrm{Ni}$ & 102,6 & $\mathrm{Ni}$ \\
$\mathrm{Pb}$ inorg. & 38,6 & 5,0 & $\mathrm{Ab}$ & 5,0 \\
$\mathrm{Cd}$ & $\mathrm{ab}$ & 0,5 & $\mathrm{Ab}$ & 0,5 \\
$\mathrm{Mn}$ & 209,8 & $\mathrm{Ni}$ & $\mathrm{Ab}$ & $\mathrm{Ni}$ \\
$\mathrm{Cu}$ & 4,63 & $\mathrm{Ni}$ & 37,8 & $\mathrm{Ni}$ \\
$\mathrm{Ni}$ & 20,1 & $\mathrm{Ni}$ & 16,2 & $\mathrm{Ni}$ \\
$\mathrm{Al}$ & $\mathrm{ab}$ & $\mathrm{Ni}$ & 1.755 & $\mathrm{Ni}$ \\
$\mathrm{Cr}$ total & 4,63 & 5,0 & 5,2 & 5,0 \\
\hline
\end{tabular}

Nota: $a b$ = abaixo do limite de detecção do equipamento e ni = não informado pela norma. Fonte: MORAIS; SICHIERI (2002).

A Tabela 13 mostra a variação de teores, dos diversos elementos químicos presentes no lodo de ETARI, observada nas análises químicas realizadas por SILVA (2001) com amostras de lodo provenientes de três indústrias de revestimento cerâmico do pólo de Santa Gertrudes.

Tabela 13 - Características químicas do lodo de ETARI.

\begin{tabular}{cccc}
\hline Elemento & Variação do Teor (g/kg) & Elemento & Variação do Teor $\mathbf{( g / k g )}$ \\
\hline $\mathrm{Pb}$ & $0,67-6,34$ & $\mathrm{Ba}$ & $0,25-14,49$ \\
$\mathrm{Zn}$ & $0,35-12,59$ & $\mathrm{Ag}$ & $\mathrm{ab}-1,3$ \\
$\mathrm{Ni}$ & $0,02-0,47$ & $\mathrm{Cd}$ & $\mathrm{ab}-0,76$ \\
$\mathrm{Cu}$ & $0,015-0,064$ & $\mathrm{Mo}$ & $\mathrm{ab}-0,01$ \\
$\mathrm{Co}$ & $0,001-0,070$ & $\mathrm{Zr}$ & $8,57-38,09$ \\
$\mathrm{Cr}$ & $0,002-2,12$ & $\mathrm{~B}$ & $8,36-29,70$ \\
$\mathrm{Se}$ & $\mathrm{ab}-0,007$ & $\mathrm{As}$ & $0,007-0,042$ \\
\hline
\end{tabular}

Nota: $a b$ = abaixo do limite de detecção do equipamento.

Fonte: Adaptado de SILVA (2001).

A apresentação da caracterização química dos resíduos sólidos supracitados tem por finalidade apenas ilustrar o assunto, pois tais características variam de acordo com o tipo de peça produzida, das matérias-primas utilizadas e das características e condições operacionais dos processos envolvidos, portanto, 
tais informações não podem e nem devem ser generalizadas para caracterização de tais resíduos.

\subsubsection{Despejos líquidos}

A produção de revestimento cerâmico produz pequena quantidade de água residuária, visto que a demanda de água no processo produtivo é relativamente pequena. $\mathrm{O}$ consumo de água, para o processo via seca, pode assumir valores de 2,10 L/m ${ }^{2}$ a $7,32 \mathrm{~L} / \mathrm{m}^{2}$ de piso produzido (CETESB, 2002a). Segundo BUSANI et alii (1995) apud SOARES et alii (2002), a demanda água para o processo de moagem a úmido pode variar de $7 \mathrm{~L} / \mathrm{m}^{2}$ a $15 \mathrm{~L} / \mathrm{m}^{2}$ de piso produzido e, a demanda para o preparo de esmaltes e esmaltação pode variar de $7 \mathrm{~L} / \mathrm{m}^{2}$ a $15 \mathrm{~L} / \mathrm{m}^{2}$ de piso produzido, sendo o limite inferior um valor mais realístico para as indústrias modernas. O consumo de água está intimamente relacionado com as características do processo produtivo.

A geração de água residuária decorre de perdas no processo, notadamente durante a produção de esmaltes, esmaltação, polimento e coloração, produção de fritas, corantes e compostos (SOARES et alii, 2002). A Tabela 14 mostra os principais pontos de geração de efluentes no processo industrial da produção de revestimentos cerâmicos.

Considerando que o principal insumo do processo é a argila, é natural que esteja presente em grande quantidade no efluente, entretanto, diversos outros minerais utilizados no processo; tais como sílica, caulim e feldspato; também podem estar presentes. Os diversos óxidos utilizados como pigmentos e fundentes também estão presentes na água residuária.

A água de lavagem dos equipamentos, particularmente os da linha de esmaltação, é a principal fonte de água residuária da indústria cerâmica e, a despeito de seu volume reduzido, carreia a maior parcela dos insumos, a base de metais pesados, perdidos durante o processo. 
Tabela 14 - Uso de água e geração de efluentes na indústria de revestimentos cerâmicos.

\begin{tabular}{|c|c|c|c|c|c|c|}
\hline \multirow{2}{*}{ Produto } & \multirow{2}{*}{ Etapa } & \multirow{2}{*}{$\begin{array}{l}\text { Principais } \\
\text { operações }\end{array}$} & \multirow{2}{*}{$\begin{array}{c}\text { Função } \\
\text { da água } \\
\text { Matéria- } \\
\text { prima }\end{array}$} & \multicolumn{3}{|c|}{ Forma de emissão da água } \\
\hline & & & & $\begin{array}{l}\text { Fluido de } \\
\text { processo }\end{array}$ & Vapor & Efluente \\
\hline \multirow{12}{*}{ 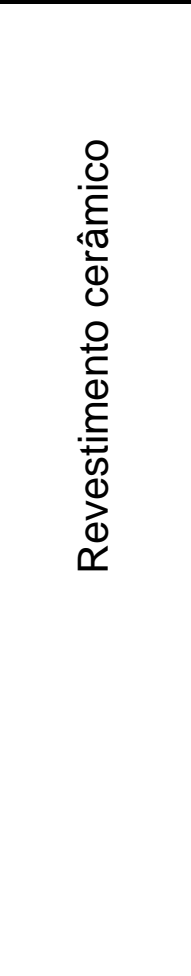 } & Preparo da & $\begin{array}{c}\text { Moagem à } \\
\text { seco - } \\
\text { umidificação }\end{array}$ & $X$ & - & - & - \\
\hline & $\begin{array}{l}\text { materıa-prıma } \\
\text { para suporte }\end{array}$ & $\begin{array}{l}\text { Moagem à } \\
\text { úmido }\end{array}$ & $X$ & L & - & - \\
\hline & & Atomização & - & L & $X$ & - \\
\hline & $\begin{array}{l}\text { Conformação } \\
\text { (prensagem) }\end{array}$ & 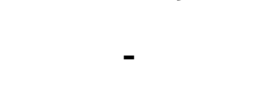 & - & $\mathrm{R}$ & - & - \\
\hline & Secagem & - & - & - & $X$ & - \\
\hline & Preparo de & $\begin{array}{l}\text { Moagem do } \\
\text { esmalte }\end{array}$ & $X$ & $\mathrm{~L}$ & - & $x$ \\
\hline & esmaltes e & Esmaltação & - & L & - & $X$ \\
\hline & esmaltação & $\begin{array}{l}\text { Secagem do } \\
\text { revestimento }\end{array}$ & - & - & $X$ & - \\
\hline & & $\begin{array}{c}\text { Grés } \\
\text { porcelanato }\end{array}$ & & & $X$ & - \\
\hline & Queima & Biscoito & - & - & & \\
\hline & & Vidrado & & & & \\
\hline & & Monoqueima & & & & \\
\hline \multirow{4}{*}{ 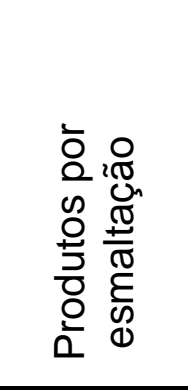 } & $\begin{array}{c}\text { Corte e } \\
\text { polimento }\end{array}$ & - & - & R L & - & $X$ \\
\hline & $\begin{array}{l}\text { Produção de } \\
\text { fritas }\end{array}$ & - & - & $\mathrm{R}$ & $X$ & $X$ \\
\hline & $\begin{array}{c}\text { Produção de } \\
\text { corantes e }\end{array}$ & $\begin{array}{l}\text { Moagem de } \\
\text { óxidos }\end{array}$ & $X$ & $L$ & - & $X$ \\
\hline & compostos & $\begin{array}{l}\text { Secagem e } \\
\text { atomização }\end{array}$ & - & L & $X$ & $X$ \\
\hline
\end{tabular}

Nota: $R=$ resfriamento e $L=$ lavagem.

Fonte: Adaptado de BUSANI et alii (1995), apud SOARES et alii (2002).

FERRARI (2000), caracterizou a água residuária gerada em diversas partes do processo produtivo da indústria cerâmica. A Figura 21 mostra o processo produtivo avaliado e apresenta os pontos de amostragem. A Tabela 15 mostra as características químicas dos efluentes gerados nas diferentes etapas do processo. 


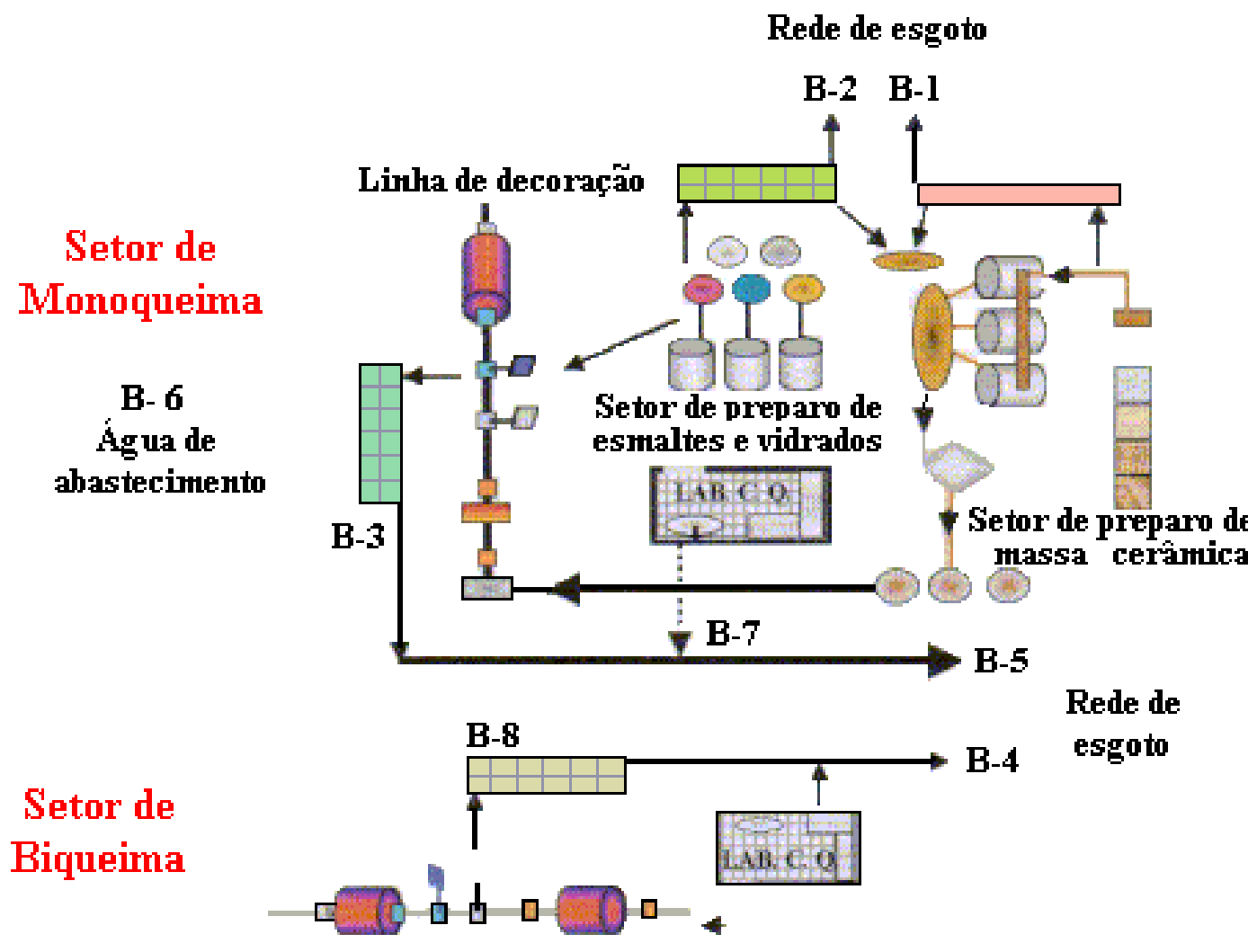

Nota : B-1 = efluente do setor de moagem de matéria-prima natural; B-2 = efluente do setor de preparo de esmaltes e vidrado (PTV); B-3 = efluente da linha de decoração da monoqueima; B-4 = efluente final do setor de biqueima; B-5 = efluente da linha de decoração da monoqueima e do laboratório de controle de qualidade; B-6 = água de abastecimento; B-7 = efluente do laboratório de controle de qualidade; B-8 = efluente da linha de decoração do setor de biqueima.

Figura 21 - Localização e identificação dos pontos de amostragem de água residuária.

Fonte: Adaptado de FERRARI (2000).

Tabela 15 - Caracterização química da água residuária em cada etapa do processo produtivo via úmida.

\begin{tabular}{|c|c|c|c|c|c|c|c|c|}
\hline \multirow{3}{*}{ Elemento } & \multicolumn{8}{|c|}{ Concentração (mg/L) } \\
\hline & \multicolumn{8}{|c|}{ Pontos } \\
\hline & B-1 & B-2 & B-3 & B-4 & B-5 & B-6 & B-7 & B-8 \\
\hline $\mathrm{Cd}$ & $\begin{array}{l}0,01- \\
0,02\end{array}$ & $\begin{array}{l}0,01- \\
0,02\end{array}$ & $\begin{array}{l}0,01- \\
0,03\end{array}$ & $\begin{array}{l}0,02- \\
1,50\end{array}$ & $\begin{array}{l}<0,01- \\
0,02\end{array}$ & $\begin{array}{l}<0,01- \\
0,01\end{array}$ & $\begin{array}{l}0,02- \\
0,09\end{array}$ & $\begin{array}{l}<0,01- \\
0,10\end{array}$ \\
\hline $\mathrm{Pb}$ & $a b-0,40$ & $\begin{array}{l}2,00- \\
41,0\end{array}$ & $\begin{array}{l}1,30- \\
6,70\end{array}$ & $\begin{array}{l}0,90- \\
45,60\end{array}$ & $\begin{array}{l}0,60- \\
4,00\end{array}$ & $\begin{array}{l}a b- \\
0,15\end{array}$ & $\begin{array}{l}6,00- \\
60,0\end{array}$ & $\begin{array}{l}0,07- \\
0,50\end{array}$ \\
\hline $\mathrm{Zn}$ & $\begin{array}{l}0,40- \\
0,59\end{array}$ & $\begin{array}{l}6,00- \\
33,80\end{array}$ & $\begin{array}{l}8,00- \\
12,10\end{array}$ & $\begin{array}{l}1,00- \\
7,00\end{array}$ & $\begin{array}{l}3,00- \\
11,80\end{array}$ & $\begin{array}{l}0,40- \\
2,10\end{array}$ & $\begin{array}{l}26,0- \\
107,6\end{array}$ & $\begin{array}{l}1,40- \\
34,0\end{array}$ \\
\hline $\mathrm{Ni}$ & $\begin{array}{l}0,02- \\
0,20\end{array}$ & $\begin{array}{l}0,10- \\
0,29\end{array}$ & $\begin{array}{l}0,20- \\
0,30\end{array}$ & $\begin{array}{l}a b- \\
0,20\end{array}$ & $\begin{array}{l}a b- \\
0,20\end{array}$ & $\begin{array}{l}a b- \\
0,20\end{array}$ & $\begin{array}{l}0,05- \\
0,13\end{array}$ & $\begin{array}{l}\text { Ab- } \\
0,20\end{array}$ \\
\hline $\mathrm{Ba}$ & $\begin{array}{l}0,24- \\
1,80\end{array}$ & $\begin{array}{l}1,16- \\
10,6\end{array}$ & $\begin{array}{l}0,80- \\
2,90\end{array}$ & $\begin{array}{l}0,21- \\
2,50\end{array}$ & $\begin{array}{l}0,60- \\
3,20\end{array}$ & $\begin{array}{l}a b- \\
0,05\end{array}$ & $\begin{array}{l}1,30- \\
29,0\end{array}$ & $\begin{array}{c}0,40- \\
13,0 \\
\text { continua }\end{array}$ \\
\hline
\end{tabular}


conclusão.

\section{Concentração (mg/L)}

Elemento

Pontos

\begin{tabular}{|c|c|c|c|c|c|c|c|c|}
\hline & B-1 & B-2 & B-3 & B-4 & B-5 & B-6 & B-7 & B-8 \\
\hline \multirow{2}{*}{$\mathrm{Ca}$} & $14,9-$ & $33,0-$ & $23,0-$ & $18,4-$ & $12,6-$ & $1,40-$ & $72,9-$ & $5,90-$ \\
\hline & 74,6 & 52,9 & 65,5 & 22,0 & 39,0 & 4,10 & 343 & 17,0 \\
\hline \multirow{2}{*}{$\mathrm{Cr}$} & $0,01-$ & 11 & $a b-$ & 0,01- & $0,01-$ & $a b-$ & $0,06-$ & $A b-$ \\
\hline & 0,13 & dav-0,14 & 0,12 & 0,11 & 0,04 & 0,03 & 0,19 & 0,03 \\
\hline \multirow{2}{*}{$\mathrm{Cu}$} & $0,05-$ & 3005 & ab- & $0,61-$ & ab- & ab- & $0,04-$ & $A b-$ \\
\hline & 0,11 & an-u,us & 0,16 & 1,90 & 0,02 & 0,01 & 0,43 & 0,20 \\
\hline \multirow{2}{*}{ V } & & ab_0 70 & ab- & ab- & $0,13-$ & 0,06- & ab- & $0,10-$ \\
\hline & & & 0,90 & 1,10 & 1,10 & 0,28 & 0,35 & 0,20 \\
\hline \multirow{2}{*}{ Co } & ah-0 10 & ab-0 10 & ab- & ab- & ab- & ab- & ab- & $A b-$ \\
\hline & & & 0,21 & 0,40 & 0,15 & 0,02 & 0,22 & 0,30 \\
\hline
\end{tabular}

Nota: a faixa de valores do $\mathrm{pH}$ das amostras analisadas variou de 7,0 a 9,7 e a temperatura variou de $12{ }^{\circ} \mathrm{C}$ a $25^{\circ} \mathrm{C} ; a b=$ abaixo do limite de deteç̧ão do equipamento.

Fonte: Adaptado de FERRARI (2000).

SILVA (2001) reportou a caraterização química da água residuária somente no final do processo produtivo e, tais dados são apresentados na Tabela 16.

Tabela 16 - Caracterização química da água residuária coletada no tanque de decantação da ETARI.

\begin{tabular}{cc}
\hline Elemento & $\begin{array}{c}\text { Concentração } \\
\text { (mg/L) }\end{array}$ \\
\hline $\mathrm{B}$ & $43,5-55,0$ \\
$\mathrm{Ba}$ & $<0,1$ \\
$\mathrm{Cd}$ & $<0,01$ \\
$\mathrm{Cr}$ & $<0,01$ \\
$\mathrm{~Pb}$ & $0,4-9,3$ \\
$\mathrm{Zn}$ & $0,11-0,23$ \\
\hline
\end{tabular}

Nota: o valor do $\mathrm{pH}$ das amostras analisadas variou de 9,3 a 11,5.

Fonte: Adaptado de SILVA (2001).

Testes de toxicidade aguda, utilizando Daphnia similis, para identificar a concentração de efluente que causa a imobilidade de $50 \%$ dos organismos (concentração efetiva - $\mathrm{CE}_{50 \%}$ ), realizados por FERRARI (2000), apontaram toxicidade positiva para o efluente do setor de biqueima (B-4). 


\subsubsection{Emissões atmosféricas}

A matriz energética utilizada pela indústria cerâmica depende de seu custo, disponibilidade e eficiência. A lenha foi utilizada como fonte de energia nas indústrias de revestimento cerâmico até a segunda metade do século $X X$ e, no Brasil, apenas após a década de 1970 passou a ser substituída por óleo combustível (SOARES et alii, 2002). O óleo combustível também foi gradativamente substituído por gás liquefeito de petróleo - GLP e, mais recentemente, por gás natural.

A queima de combustível fóssil, assim como a queima das peças cerâmicas, acarreta a emissão de diversos gases ( $\mathrm{CO}, \mathrm{SO}_{\mathrm{x}}, \mathrm{NO}_{\mathrm{x}}$ ), todavia, os compostos de maior preocupação ambiental são justamente determinadas espécies químicas presentes nas peças cerâmicas, pois a elevada temperatura de queima provoca a volatilização, mesmo que parcial, de metais como $\mathrm{Pb}, \mathrm{Zn}, \mathrm{Zr}$, Cd e Ni, utilizados no processo e a formação de fluoretos a partir de compostos de flúor (F) naturalmente presentes na argila (CETESB, 2002a).

O processo de queima de peças cerâmicas resulta na produção e emissão de gases, pois muitas das espécies químicas utilizadas no processo industrial ou que ocorrem naturalmente na argila possuem ponto de sublimação inferior à temperatura de queima utilizada no processo industrial, que pode superar $1100{ }^{\circ} \mathrm{C}$ (MORAIS; SICHIERI, 2002). Os elementos volatilizados de maior preocupação são o $\mathrm{Pb}$ e o F.

A maioria das argilas possui compostos $\mathrm{F}$ em teores que variam de 0,03 \% a $0,06 \%$, que a partir de $600{ }^{\circ} \mathrm{C}$ são liberados para a atmosfera sob a forma de fluoretos, principalmente sob a forma de fluoreto de hidrogênio (HF), mas que também podem ser lançados sob a forma de ácido fluossilícico ou tetrafluoreto de silício, em sua forma gasosa e, como fluoreto de cálcio $\left(\mathrm{CaF}_{2}\right)$ sob a forma particulada. O teor de $F$ nos minerais oscilam de $200 \mathrm{mg} / \mathrm{kg}$ a $1,6 \mathrm{~g} / \mathrm{kg}$, existindo minerais como flogopita e tremolita que apresentam, respectivamente, teores de 2,8 $\mathrm{mg} / \mathrm{kg}$ e 2,4 g/kg (CETESB, 2002a; SOARES et alii, 2002). Avaliações realizadas pela CETESB em 15 indústrias de revestimento cerâmico indicaram que a concentração média de fluoretos nos gases de chaminé era de $60 \mathrm{mg} / \mathrm{Nm}^{3}$, o que representava uma taxa de emissão de $2 \mathrm{~kg} \mathrm{~F} / 1000 \mathrm{~m}^{2}$ de piso produzido (CETESB, 2001c). 
A quantidade de $\mathrm{F}^{-}$lançado na atmosfera não depende exclusivamente da quantidade de $\mathrm{F}$ nas matérias-primas, pois a temperatura de queima e o teor de carbonatos alcalinos terrosos são parâmetros que afetam dramaticamente a formação de $\mathrm{F}^{-}$. Quanto maior for a temperatura de queima e menor a duração do processo, maior será a produção de $\mathrm{F}^{-}$, a queima rápida em temperatura menor tende a reduzir sua geração. Quanto maior o teor de carbonato alcalino terroso,

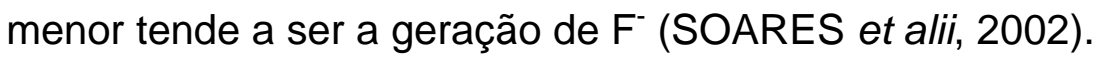

Tal qual os gases emitidos durante o processo de queima, a emissão de material particulado é uma importante fonte de poluição, pois juntas formam as fontes básicas de emissões atmosféricas da indústria de revestimentos cerâmicos. $O$ material particulado é gerado nos setores de preparo da massa (moagem, classificação granulométrica, dosagem e homogeneização) e conformação (CETESB, 2002b).

A emissão de material particulado é da ordem de $38 \mathrm{~kg} / \mathrm{t}$ de argila processada e, somente para o setor de preparo da massa/conformação (prensas) a emissão é da ordem de $17 \mathrm{~kg} / \mathrm{t}$ de argila processada, mas o uso de sistemas de filtros possibilita recuperar acima de $90 \%$ do material em suspensão, o qual pode ser reintroduzido no processo produtivo (CETESB, 2002b).

\subsection{Coleta de solo contaminado}

Foram executadas duas coletas de solo, conforme os seguintes procedimentos:

\section{a) Coleta 1}

Utilizou-se trado manual, de 0,15 m de diâmetro, e procedeu-se a extração de amostras em um perfil de solo de um metro e meio de profundidade. Tendo em vista que o objetivo da avaliação preliminar foi utilizar o solo de um local que apresentasse a maior contaminação pelos metais de interesse, foram selecionados aleatoriamente três pontos na área de estudo (antiga empresa Polyglass), para a realização da coleta. As amostras foram acondicionadas em sacos plásticos e neles mantidas até a realização dos experimentos.

b) Coleta 2 
Face aos baixos teores dos elementos alvo da pesquisa presentes no solo proveniente da coleta 1, optou-se por executar uma nova coleta de material em outro ponto da área contaminada. O item 5.3 apresenta os resultados das análises que ampararam a decisão de efetuar uma nova coleta de solo.

Utilizou-se pá e procedeu-se a coleta de solo proveniente da escavação e limpeza das nascentes existentes na área de estudo. Optou-se por utilizar este material, visto que as nascentes em questão estão situadas na base do talude da área de estudo e como ocorreu o transporte dos contaminantes alvo pelo escoamento superficial, haveria um maior teor destes na parte baixa do terreno em relação às cotas mais elevadas. Para garantir um suprimento de solo ao longo de toda a pesquisa, foi coletado aproximadamente 1 t de material, que foi transportado e acondicionado em reservatório de polietileno até sua utilização.

\subsection{Caracterização geológica do solo}

A caracterização geológica do solo da área em estudo foi executada através dos seguintes ensaios:

> Composição mineralógica, executada através de análises semi-quantitativas por difração e fluorescência de raios-x.;

> Massa específica dos grãos, executada de acordo com a NBR 6508 (ABNT, 1984a);

> Análise granulométrica, executada de acordo com a NBR 7181 (ABNT, 1984b) e

$>$ Densidade aparente, umidade residual e capacidade de campo, executadas de acordo com a Norma CETESB L6.350 (CETESB, 1990).

A preparação das amostras de solo para os ensaios de compactação e de caracterização foi realizada de acordo com a NBR 6457 (ABNT, 1986). 


\subsection{Análises químicas}

As amostras de solo bruto, de solo tratado e de lixiviado utilizadas/geradas durante os experimentos de lixiviação seguiram a seguinte sistemática, quanto à sua coleta e preparo, antes de serem encaminhadas para análise:

- Solo bruto: toda amostra de solo bruto utilizado nos experimentos foi destorroada e peneirada em peneira com malha de $2 \mathrm{~mm}$ para a remoção de material grosseiro. O material resultante foi homogeneizado e procedeu-se a coleta de amostras após seu quarteamento. Das amostras coletadas, determinou-se a umidade, a fim de permitir a expressão dos resultados das análises químicas em relação à massa de solo seco a $103^{\circ} \mathrm{C} \pm 2{ }^{\circ} \mathrm{C}$;

- Solo tratado: o solo tratado (sob a forma de lama) foi coletado em diversas profundidades dos reatores, neste procedimento utilizou-se pipeta de vidro com a ponta quebrada e aspiração por pipetador automático. Em todas as coletas foi controlado o volume e a massa da amostra de lama, a qual recebeu o seguinte tratamento:

a) Centrifugação por 15 min, a 4000 rpm, em temperatura ambiente: o objetivo da centrifugação foi o de promover a separação das fases sólida e líquida da amostra.

b) Fração líquida: após a centrifugação, procedeu-se a coleta do sobrenadante dos tubos de centrífuga e determinou-se seu volume e massa. A amostra líquida foi filtrada em membrana de 0,45 $\mu \mathrm{m}$ de porosidade, recebeu $2 \% \mathrm{v} / \mathrm{v}$ de $\mathrm{HNO}_{3}$ concentrado para sua preservação e foi mantida sob refrigeração a $4{ }^{\circ} \mathrm{C}$ até ser analisada;

c) Fração sólida: após a remoção do sobrenadante, a fração sólida foi removida dos tubos de centrífuga com espátula metálica e procedeu-se a determinação de sua massa úmida e seca. Na determinação da massa, utilizou-se cápsula de porcelana, que foi seca em estufa a $60^{\circ} \mathrm{C}$ por 24 horas. Após a determinação da massa seca, a amostra foi triturada em almofariz e acondicionada em saco plástico, tipo zip lock, até o momento da análise.

A Espectrometria de Emissão Atômica em Plasma de Argônio Acoplado Indutivamente (ICP-AES) foi utilizada para determinar os teores/concentrações dos 
elementos boro $(\mathrm{B})$, cádmio $(\mathrm{Cd})$, chumbo $(\mathrm{Pb})$, fósforo $(\mathrm{P})$, enxofre $(\mathrm{S})$ e zinco $(\mathrm{Zn})$ no solo bruto, no solo tratado e no lixiviado produzido. Os métodos 3050B e 6010B, propostos pelo órgão ambiental norte americano; Environmental Protection Agency EPA; (USEPA, 1996a; USEPA, 1996b), foram empregados nas amostras de solo para a determinação de metais.

A Análise Elementar foi empregada para determinar os teores de carbono (C), hidrogênio $(H)$ e nitrogênio $(N)$ no solo bruto e tratado (tempos inicial e final do processo de biolixiviação).

$\mathrm{O}$ pH foi determinado com potenciômetro Mettler Toledo SevenEasy equipado com eletrodo combinado Mettler Toledo Inlab 420. Todas as medições foram executadas simultaneamente com a homogeneização da suspensão de solo.

\subsection{Análises microbiológicas}

A fim de avaliar o comportamento da microbiota e a evolução da população de $A$. ferrooxidans e $A$. thiooxidans durante os experimentos de biolixiviação, foram executadas três determinações microbiológicas:

$>$ Contagem do número mais provável (NMP) de A. ferrooxidans e A. thiooxidans (CETESB, 1991);

$>$ Contagem de unidades formadoras de colônias (UFC) de bactérias heterotróficas (CETESB, 1996);

> Contagem de bactérias através de microscopia:

$\checkmark$ Contagem utilizando hemocitômetro de Neubauer: procedimento utilizado para contagem de células $A$. ferrooxidans e $A$. thiooxidans em suspensões bacterianas, para determinar as curvas de crescimento de cada uma destas espécies e o número de células utilizadas como inóculo nos experimentos. Este procedimento seguiu o seguinte protocolo:

- Homogeneização da amostra: a amostra foi homogeneizada por 10 min em agitador de tubos tipo vortex e mantida em repouso (para sedimentação de sólidos) por $10 \mathrm{~min}$;

- Coleta da amostra: utilizou-se pipeta com ponteira descartável para coleta do sobrenadante e sua alocação sobre o hemocitômetro de Neubauer; 
- Contagem no microscópio: utilizou-se o contraste de fases (fase 3), filtro de luz amarelo e aumento de 1000 vezes durante o processo de contagem, o qual foi executado em duplicata para cada amostra, pois o hemocitômetro de Neubauer possui duas câmaras para contagem. O hemocitômetro de Neubauer possui um volume definido de $0,1 \mu \mathrm{L}$, para a área restrita da câmara, que foi utilizada para a contagem das células. A densidade de células foi determinada pelas seguintes expressões:

Fator final $=$ fator de diluição $\times 10$

área contada em $\mathrm{mm}^{2}$

Células $/ \mathrm{mL}=$ fator final $\mathrm{x}$ células contadas $\times 1000$

$\checkmark$ Contagem utilizando marcador de DNA: procedimento utilizado para contagem do número total de células bacterianas durante o processo de biolixiviação, onde se utilizou o marcador de DNA 4-6 diamidino-2-phenylindole - DAPI (PORTER; FEIG, 1980; ALEF; NANNIPIERI, 1995) para a marcação das células. Este procedimento seguiu o seguinte protocolo:

- Homogeneização da amostra: mesmo processo descrito para a contagem no hemocitômetro de Neubauer;

- Preparo da lâmina: a lâmina foi previamente limpa e revestida por uma fina película de gelatina, cuja função é auxiliar a fixação da amostra. Tomou-se uma alíquota da amostra ( $2 \mu \mathrm{L}$ ou $10 \mu \mathrm{L}$, que dependeu do tamanho da câmara da lâmina utilizada no procedimento) e com o auxílio da ponteira da pipeta, procedeu-se ao seu espalhamento sobre a superfície da câmara;

- Secagem da amostra: após a deposição e o espalhamento da amostra sobre a câmara da placa, a mesma foi mantida em estufa, a $37^{\circ} \mathrm{C}$, por 45 min, para a secagem e fixação;

- Marcação com o DAPI: após a secagem, cada câmara da placa recebeu uma alíquota de $9 \mu \mathrm{L}$ de água destilada e $1 \mu \mathrm{L}$ de solução de DAPI $(1 \mathrm{mg} / \mathrm{mL})$, que foram homogeneizadas com o auxílio da ponteira da pipeta;

- Incubação: após a aplicação do marcador de DNA, a lâmina foi mantida em temperatura ambiente, em local escuro por 10 min. Este intervalo de tempo é necessário para que ocorram as reações químicas/bioquímicas entre o marcador e o material celular; 
- Finalização do preparo da lâmina: após o período de incubação, a lâmina foi lavada com água destilada e mantida em temperatura ambiente até sua completa secagem. Depois de seca, cada câmara recebeu $3 \mu \mathrm{L}$ de glicerol e PBS (fosfato salino tamponado) para a fixação da lamínula sobre a lâmina;

$\checkmark$ Contagem no microscópio: empregou-se o microscópio Axiovert S100, da marca Zeiss, no modo epifluorescência, com conjunto de filtro no 451366 e aumento de 1000 vezes. Como a contagem de células foi executada através de uma série de imagens capturadas por uma câmera acoplada ao microscópio, cuja área fotografada é 4 vezes inferior à visualizada pela ocular do microscópio, fez-se necessário utilizar a seguinte relação para determinar o número de células na amostra:

$\mathrm{N}^{\circ}$ de células na amostra $=($ média de células por imagem $\times 4)$ xárea da câmara $\left(\mathrm{mm}^{2}\right)$ $0,0283 \mathrm{~mm}^{2}$ (área visualizada pela ocular)

\subsection{Produção das suspensões bacterianas}

O material biológico utilizado constituiu-se de culturas de $A$. ferrooxidans (linhagem LR) e $A$. thiooxidans (linhagem FG01) (GARCIA JR, 1991). As cepas isoladas destas bactérias foram gentilmente fornecidas pelo Prof. Dr. Oswaldo Garcia Júnior, do Laboratório de Biohidrometalurgia do Instituto de Química da UNESP de Araraquara.

A suspensão bacteriana foi produzida de acordo com os seguintes procedimentos:

$>$ Pré-fermentação - nesta etapa, adicionou-se em um frasco Erlenmeyer de 250 $\mathrm{mL}, 10 \mathrm{~mL}$ de inóculo e $100 \mathrm{~mL}$ de meio de cultura e manteve-se o frasco incubado a $30{ }^{\circ} \mathrm{C}$, sob agitação de $200 \mathrm{rpm}$, até que fosse observado o crescimento da cultura (período de cinco a sete dias), o que pôde ser constatado pela mudança da cor do meio (a suspensão de $A$. ferrooxidans passa de incolor para laranja avermelhado e a de $A$. thiooxidans, de incolor e límpido para turvo e levemente amarelado);

> Crescimento - Tendo em vista que foram executados diversos experimentos, que utilizaram diferentes volumes de suspensão bacteriana, segue a descrição do 
procedimento genérico utilizado. Em um recipiente de vidro, adicionou-se o meio de cultivo e $10 \%(\mathrm{v} / \mathrm{v})$ de suspensão pré-fermentada como inóculo, que foi incubado entre $25^{\circ} \mathrm{C}$ a $30^{\circ} \mathrm{C}$, sob aeração fornecida por bomba de aquário, por período de tempo de 3 a 5 dias.

Estes procedimentos foram aplicados para ambas as espécies de Acidithiobacillus $s p$ utilizadas no estudo.

\subsubsection{Meio de cultivo para crescimento de $A$. ferrooxidans}

O meio de cultivo utilizado foi o "9K" proposto por SILVERMAN; LUNDGREN (1959), preparado de acordo com o seguinte procedimento:

$>$ Solução A - dissolveu-se $3,00 \mathrm{~g}$ de $\left(\mathrm{NH}_{4}\right)_{2} \mathrm{SO}_{4}, 0,50 \mathrm{~g}$ de $\mathrm{KH}_{2} \mathrm{PO}_{4}, 0,50 \mathrm{~g}$ de $\mathrm{MgSO}_{4} .7 \mathrm{H}_{2} \mathrm{O}, 0,01 \mathrm{~g}$ de $\mathrm{Ca}\left(\mathrm{NO}_{3}\right)_{2}$ e $0,10 \mathrm{~g}$ de $\mathrm{KCl}$ em $700 \mathrm{~mL}$ de água destilada, com pH previamente ajustado em 2,8, mediante adição de solução de $\mathrm{H}_{2} \mathrm{SO}_{4}$ $0,5 \mathrm{M}$. A solução foi esterilizada em autoclave em temperatura de $120^{\circ} \mathrm{C}$ por 20 $\min$;

> Solução $\mathrm{B}-44,22 \mathrm{~g}$ de $\mathrm{FeSO}_{4} .7 \mathrm{H}_{2} \mathrm{O}$ foi dissolvido em $300 \mathrm{~mL}$ de água destilada e a solução foi posteriormente filtrada em membrana com diâmetro de poro de $0,45 \mu \mathrm{m}$.

As soluções A e B, quando não foram utilizadas imediatamente após seu preparo, foram armazenadas por um período máximo de 15 dias sob refrigeração (4 $\left.{ }^{\circ} \mathrm{C}\right)$. A Figura 22 mostra uma cultura de $A$. ferrooxidans após a oxidação do íon $\mathrm{Fe}^{2+}$. 


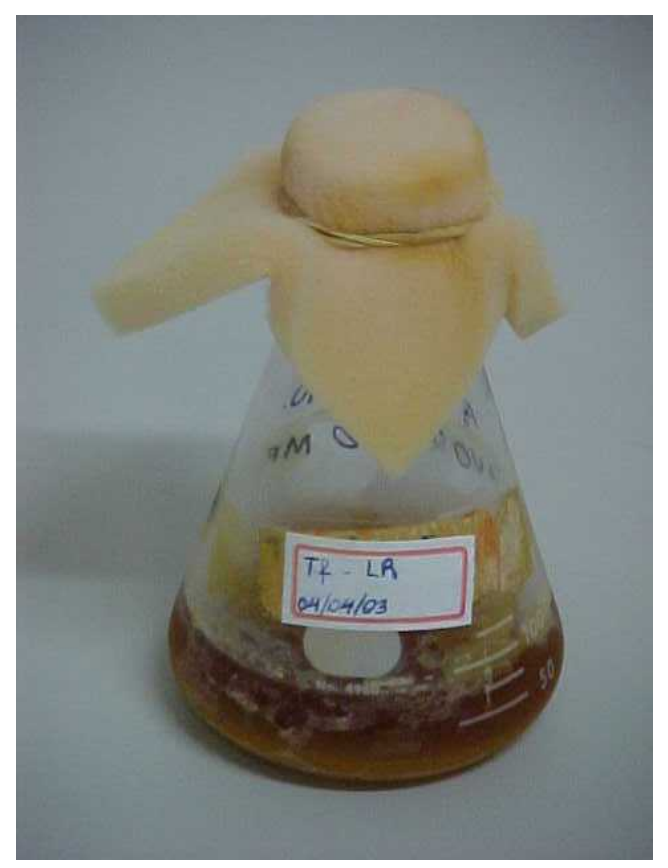

Figura 22 - Cultura de A. ferrooxidans (linhagem LR).

\subsubsection{Meio de cultura para $A$. thiooxidans}

O meio de cultivo utilizado foi o "TK" (TUOVINEN; KELLY, 1973), o qual é composto pela solução $A$ e pelo enxofre, preparado de acordo com o seguinte procedimento:

$\checkmark$ Solução $\mathrm{A}$ - dissolveu-se $0,4 \mathrm{~g}$ de $\left(\mathrm{NH}_{4}\right)_{2} \mathrm{SO}_{4}, 0,40 \mathrm{~g}$ de $\mathrm{KH}_{2} \mathrm{PO}_{4}, 0,40 \mathrm{~g}$ de $\mathrm{MgSO}_{4} .7 \mathrm{H}_{2} \mathrm{O}$ em $1 \mathrm{~L}$ de água destilada, com pH previamente ajustado em 1,8, mediante adição de $\mathrm{H}_{2} \mathrm{SO}_{4}$. A solução foi esterilizada em autoclave em temperatura de $120^{\circ} \mathrm{C}$ por $20 \mathrm{~min}$;

$\checkmark$ Enxofre elementar - $10 \mathrm{~g}$ de enxofre $\left(\mathrm{S}^{0}\right)$ foi embrulhado em papel alumínio e esterilizado em autoclave, em temperatura de $110^{\circ} \mathrm{C}$ por 1 hora. O enxofre foi adicionado à solução $A$, na proporção de $1 \mathrm{~g} / 100 \mathrm{~mL}$, somente no momento do uso do meio de cultura.

A solução $A$, quando não foi utilizada imediatamente após seu preparo, foi armazenada por um período máximo de 15 dias sob refrigeração $\left(4^{\circ} \mathrm{C}\right)$. A Figura 23 mostra uma cultura de $A$. thiooxidans em estágio final de crescimento. 


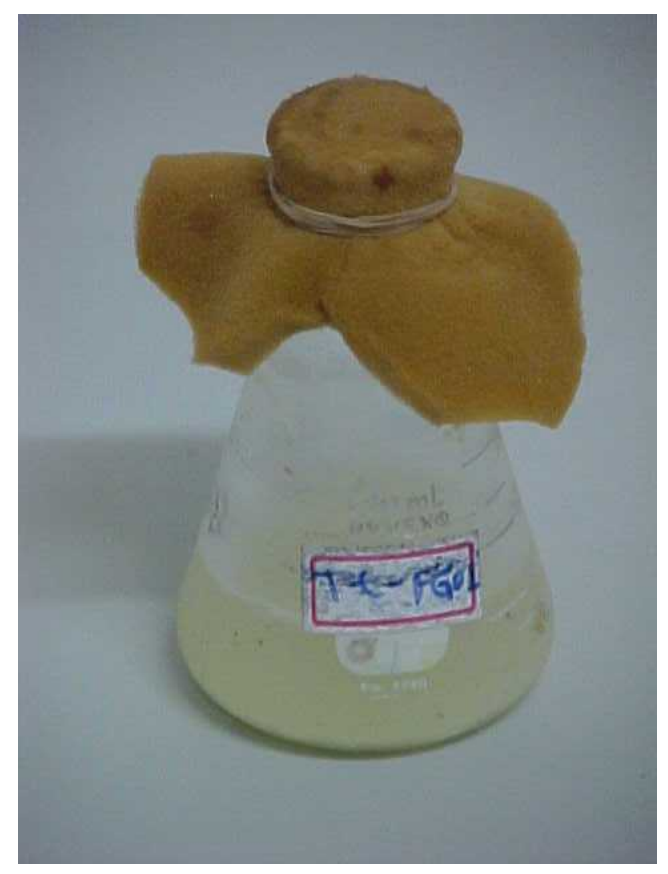

Figura 23 - Cultura de A. thiooxidans (linhagem FG01).

\subsubsection{Purificação e concentração de células}

Devido à elevada acidez das suspensões bacterianas de A. ferrooxidans e de $A$. thiooxidans, ao final dos respectivos períodos de crescimento, optou-se por utilizar um procedimento para minimizar o efeito desta acidez sobre os experimentos e, deste modo, permitir uma avaliação mais precisa da influência destas bactérias sobre o processo de biolixiviação.

O protocolo utilizado baseou-se na metodologia adotada por SILVERMAN; LUNDGREN (1959):

$\checkmark$ Concentração 1: acondicionamento do volume desejado de suspensão bacteriana no tubo de centrífuga, seguido por centrifugação por 30 min (4000 rpm e temperatura ambiente);

$\checkmark$ Lavagem 1: o sobrenadante do tubo foi cuidadosamente removido com o auxílio de uma pipeta e descartado; o centrifugado foi transferido para um frasco tipo FALCON de $50 \mathrm{~mL}$, o qual recebeu água destilada fria. O volume adicionado de água destilada variou de acordo com o volume de suspensão bacteriana centrifugada; todavia, não excedeu $40 \mathrm{~mL}$ para cada frasco FALCON. Após 
adição da água destilada, o frasco foi agitado vigorosamente por pelo menos 2 min e mantido em repouso na câmara fria $\left(4^{\circ} \mathrm{C}\right)$ por pelo menos 6 horas;

$\checkmark$ Lavagem 2: transcorrido o período de repouso, coletou-se cuidadosamente 0 sobrenadante do frasco com o auxílio de uma pipeta e transferiu-se o material para o tubo da centrífuga, que foi centrifugado por $30 \mathrm{~min}$ (4000 rpm e temperatura ambiente). Sempre que necessário, foi utilizada água destilada fria $\left(\mathrm{pH}=2,6 ; 4^{\circ} \mathrm{C}\right)$ para homogeneizar os volumes de todos os tubos submetidos à centrifugação. A seguir, repetiram-se todos os passos da Lavagem 1;

$\checkmark$ Concentração 2: após o período de repouso, coletou-se cuidadosamente o sobrenadante do frasco com o auxílio de uma pipeta e, transferiu-se o material para o tubo da centrífuga, que foi centrifugado por $30 \mathrm{~min}$ (4000 rpm e temperatura ambiente). Sempre que necessário, foi utilizada água destilada fria $\left(\mathrm{pH}=2,6 ; 4^{\circ} \mathrm{C}\right)$ para homogeneizar os volumes de todos os tubos submetidos à centrifugação. Finda esta etapa, o sobrenadante foi cuidadosamente removido e descartado, de modo a restar no tubo somente o centrifugado e o volume de líquido desejado para a concentração das células.

Toda suspensão bacteriana submetida ao processo de concentração e de purificação foi utilizada imediatamente após o procedimento ser finalizado.

\subsection{Experimentos de biolixiviação}

Embora a metodologia utilizada não tenha sido idêntica para todos os experimentos, buscou-se resguardar os objetivos desta pesquisa e obter o maior número de respostas para as questões que, gradativamente, surgiram durante o desenvolvimento deste trabalho. Portanto, a abordagem metodológica adotada visou explorar de diversas maneiras o processo de biolixiviação aplicada a solos, de modo a obter o máximo de informações sobre este processo ao final da pesquisa. A Figura 24 mostra um fluxograma dos experimentos de biolixiviação executados e, de maneira resumida, os objetivos de cada um deles. 


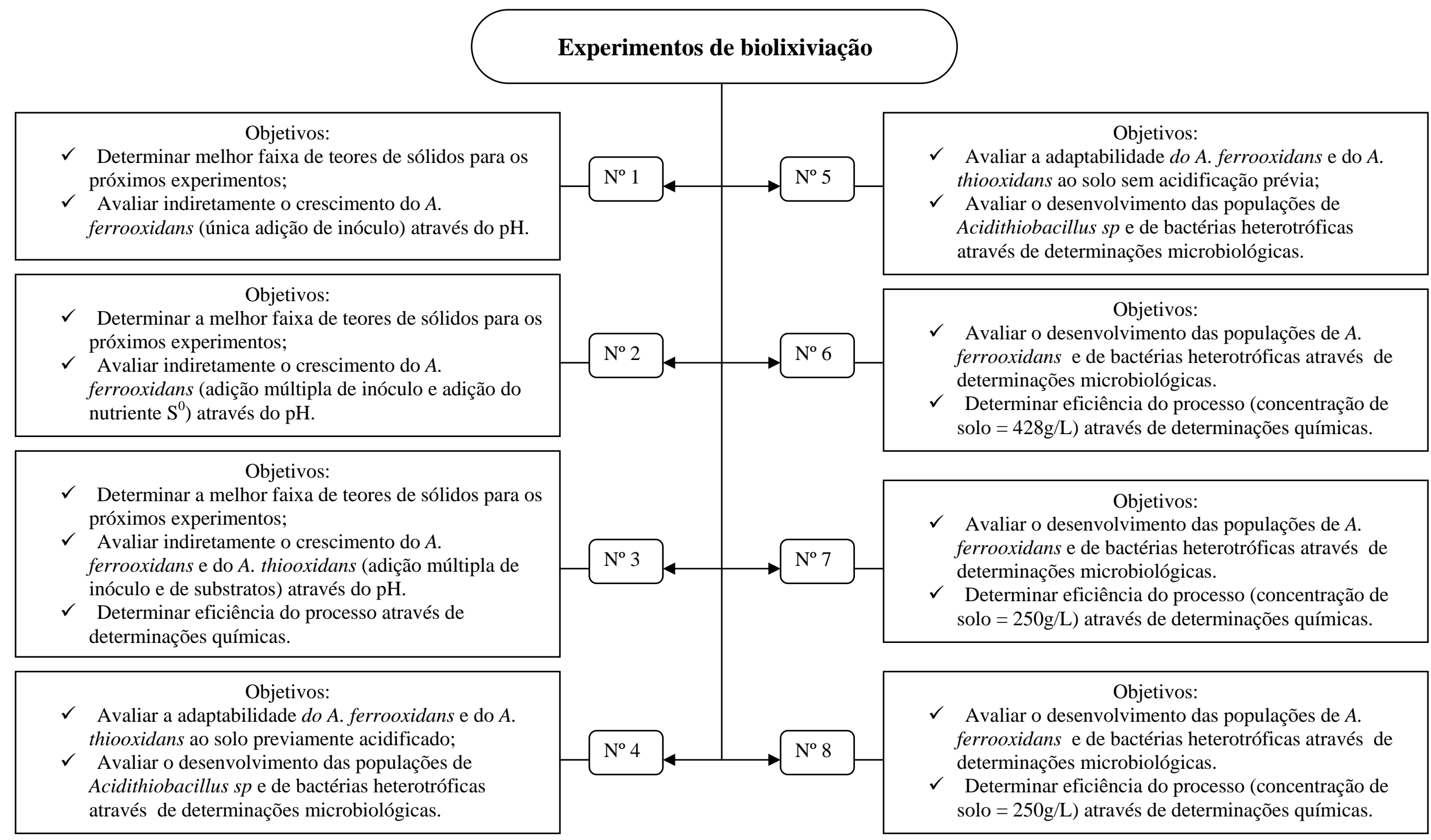

Figura 24 - Fluxograma dos experimentos de biolixiviação. 


\subsubsection{Experimento $n^{\circ} 1$}

Este experimento foi executado em equipamento de banho termostatizado, a $26,4^{\circ} \mathrm{C} \pm 0,6^{\circ} \mathrm{C}$, em reatores de vidro de $5 \mathrm{~L}$ contendo $500 \mathrm{~mL}$ de água destilada e quantidades variadas de latossolo roxo (seco ao ar), de tal forma a obter concentrações de $50 \mathrm{~g} / \mathrm{L}, 100 \mathrm{~g} / \mathrm{L}$ e $200 \mathrm{~g} / \mathrm{L}$. A umidade do solo utilizado foi determinada em 10,6 \% (material seco a $103^{\circ} \mathrm{C} \pm 2{ }^{\circ} \mathrm{C}$ até peso constante).

A suspensão bacteriana de $A$. ferrooxidans, utilizada como inóculo, não recebeu qualquer tratamento para a concentração e purificação de células. Todos os reatores inoculados receberam 5,9 × 109 $\pm 1 \times 10^{9}$ células.

A Figura 25 mostra as partes constituintes do equipamento de banho termostatizado utilizado nos experimentos de biolixiviação $n^{\circ} 1, n^{\circ} 6, n^{\circ} 7$ e $n^{\circ} 8$.

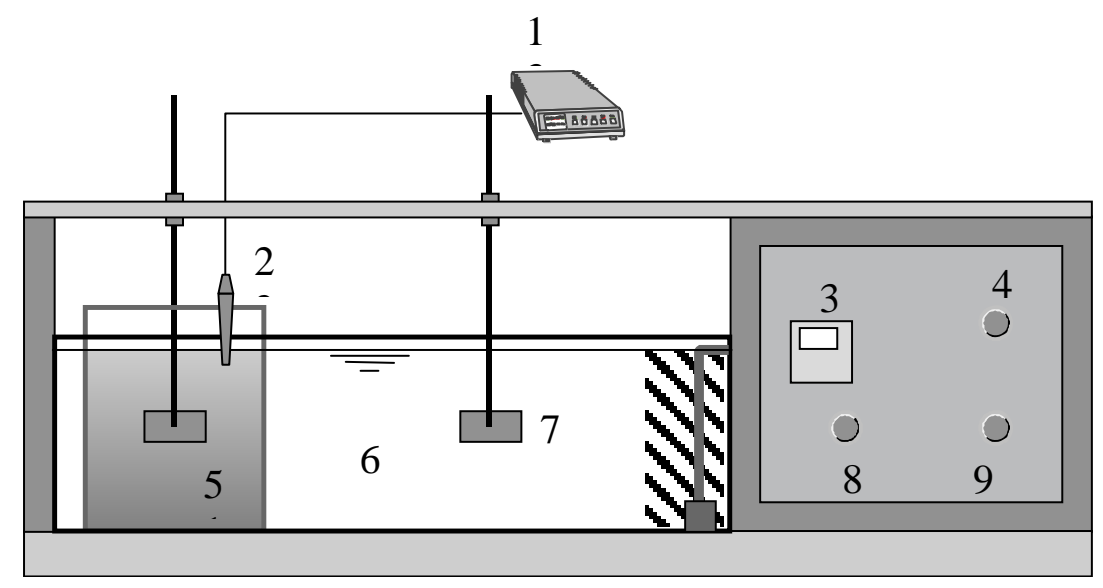

Legenda:

1 - potenciômetro

2 - eletrodo para suspensões

3 - controle de temperatura

4 - controle da rotação

5 - reator de $5 \mathrm{~L}$ (capacidade para 4 unidades)

6 - banho termostático

7 - paleta para mistura

8 - controle do sistema de aquecimento

9 - controle do sistema de resfriamento

Figura 25 - Equipamento de banho termostatizado utilizado na investigação experimental. 


\subsubsection{Experimento $n^{\circ} 2$}

Este experimento foi executado em equipamento de "jar test", em temperatura ambiente $\left(20^{\circ} \mathrm{C}\right.$ ), em reatores de $1 \mathrm{~L}$ (copos Griffin de vidro) contendo $500 \mathrm{~mL}$ de água destilada e quantidades de latossolo roxo variadas, de tal forma a obter concentrações de $100 \mathrm{~g} / \mathrm{L}, 200 \mathrm{~g} / \mathrm{L}, 300 \mathrm{~g} / \mathrm{L}, 400 \mathrm{~g} / \mathrm{L}, 500 \mathrm{~g} / \mathrm{L}$ e $600 \mathrm{~g} / \mathrm{L}$. A umidade do solo utilizado foi determinada em 10,6\% (material seco a $103^{\circ} \mathrm{C} \pm 2{ }^{\circ} \mathrm{C}$ até peso constante).

Neste experimento, foram realizadas três adições de suspensão de $A$. ferrooxidans:

Reator 1 (100 g solo/L): três adições de células (tempo inicial, 2 dias e 14 dias), totalizando $9,24 \times 10^{10} \pm 1,6 \times 10^{10}$ células.

$\checkmark$ Reator 2 (200 g solo/L): três adições de células (tempo inicial, 2 dias e 14 dias), totalizando $9,54 \times 10^{10} \pm 1,65 \times 10^{10}$ células;

$\checkmark$ Reator 3 (300 g solo/L): três adições de células (tempo inicial, 2 dias e 14 dias), totalizando $9,85 \times 10^{10} \pm 1,71 \times 10^{10}$ células;

$\checkmark$ Reator 4 (400 g solo/L): três adições de células (tempo inicial, 2 dias e 14 dias), totalizando $1,02 \times 10^{11} \pm 1,76 \times 10^{10}$ células;

$\checkmark$ Reator 5 (500 g solo/L): três adições de células (tempo inicial, 2 dias e 14 dias), totalizando $1,05 \times 10^{11} \pm 1,81 \times 10^{10}$ células;

$\checkmark$ Reator 6 (600 g solo/L): três adições de células (tempo inicial, 2 dias e 14 dias), totalizando $1,08 \times 10^{11} \pm 1,87 \times 10^{10}$ células.

A Figura 26 mostra o equipamento de jar test em operação.

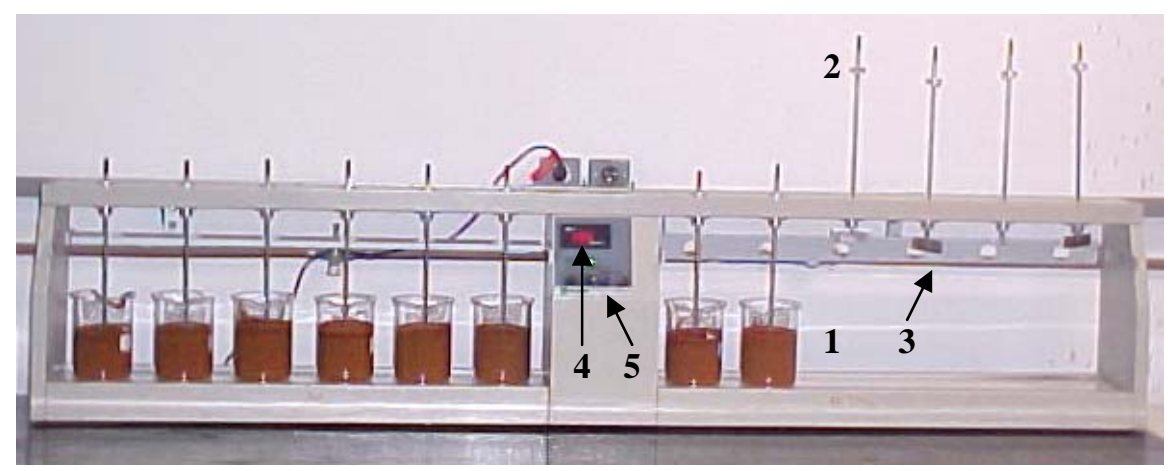

Nota: 1 - Reator (copo Griffin de 1 L ); 2 - Agitador; 3 - Paleta do misturador; 4 Mostrador de rotação; 5 - Controle de rotação.

Figura 26 - Reatores contendo diferentes concentrações de solo. 


\subsubsection{Experimento $n^{\circ} 3$}

O experimento $\mathrm{n}^{\circ} 3$ foi executado em frascos Erlenmeyer de $250 \mathrm{~mL}$, que foram mantidos sob agitação (180 rpm) em equipamento de agitação mecânica, sob temperatura ambiente $\left(27^{\circ} \mathrm{C}\right)$. Neste experimento, avaliou-se a eficiência da biolixiviação na remoção dos elementos $\mathrm{B}, \mathrm{Cd}, \mathrm{Pb}$ e $\mathrm{Zn}$, para as concentrações de latossolo roxo (seco ao ar) de 50 g/L, 100 g/L, 200 g/L, 300 g/L, 400 g/L e 500 g/L, utilizando, isoladamente, as bactérias $A$. ferrooxidans e $A$. thiooxidans. A umidade do solo utilizado foi determinada em 10,6\% (material seco a $103{ }^{\circ} \mathrm{C} \pm 2{ }^{\circ} \mathrm{C}$ até temperatura constante).

Os reatores utilizados no ensaio com o $A$. ferrooxidans receberam um volume de $200 \mathrm{~mL}$ de água destilada e os empregados no ensaio do A. thiooxidans, $150 \mathrm{~mL}$. Além da suspensão bacteriana, os reatores receberam substratos aos 45 dias (ensaio com A. ferrooxidans) e 34 dias (ensaio com A. thiooxidans).

Neste experimento, foram realizadas três adições de suspensão de $A$. ferrooxidans:

$\checkmark$ Reator 1 (50 g solo/L): três adições de células (tempo inicial, 23 dias e 45 dias), totalizando $8,09 \times 10^{9} \pm 1,4 \times 10^{9}$ células.

$\checkmark$ Reator 2 (100 g solo/L): três adições de células (tempo inicial, 23 dias e 45 dias), totalizando $8,66 \times 10^{9} \pm 1,5 \times 10^{9}$ células;

$\checkmark$ Reator 3 (200 g solo/L): três adições de células (tempo inicial, 23 dias e 45 dias), totalizando $9,43 \times 10^{9} \pm 1,63 \times 10^{9}$ células;

$\checkmark$ Reator 4 (300 g solo/L): três adições de células (tempo inicial, 23 dias e 45 dias), totalizando $1,02 \times 10^{10} \pm 1,77 \times 10^{9}$ células;

$\checkmark$ Reator 5 (400 g solo/L): três adições de células (tempo inicial, 23 dias e 45 dias), totalizando $1,1 \times 10^{10} \pm 1,91 \times 10^{9}$ células; e

$\checkmark$ Reator 6 (500 g solo/L): três adições de células (tempo inicial, 23 dias e 45 dias), totalizando $1,18 \times 10^{10} \pm 2,04 \times 10^{9}$ células;

Assim como nos experimentos com A. ferrooxidans, nos com A. thiooxidans, foram realizadas três adições de suspensão bacteriana:

$\checkmark$ Reator 1 (50 g solo/L): três adições de células (tempo inicial, 23 dias e 34 dias), totalizando $1,72 \times 10^{9} \pm 3,25 \times 10^{8}$ células. 
$\checkmark$ Reator 2 (100 g solo/L): três adições de células (tempo inicial, 23 dias e 34 dias), totalizando $1,8 \times 10^{9} \pm 3,41 \times 10^{8}$ células;

$\checkmark$ Reator 3 (200 g solo/L): três adições de células (tempo inicial, 23 dias e 34 dias), totalizando $1,97 \times 10^{9} \pm 3,72 \times 10^{8}$ células;

$\checkmark$ Reator 4 (300 g solo/L): três adições de células (tempo inicial, 23 dias e 34 dias), totalizando $2,13 \times 10^{9} \pm 4,03 \times 10^{8}$ células;

$\checkmark$ Reator 5 (400 g solo/L): três adições de células (tempo inicial, 23 dias e 34 dias), totalizando $2,29 \times 10^{9} \pm 4,34 \times 10^{8}$ células; e

$\checkmark$ Reator 6 (500 g solo/L): três adições de células (tempo inicial, 23 dias e 34 dias), totalizando $2,46 \times 10^{9} \pm 4,65 \times 10^{8}$ células;

Cabe ressaltar que as suspensões bacterianas utilizadas como inóculo nestes ensaios não receberam nenhum tratamento, visando sua concentração ou purificação. As Tabelas 17 e 18 mostram, respectivamente, as massas de substratos utilizadas nos experimentos com $A$. ferrooxidans e $A$. thiooxidans.

Tabela 17 - Substratos utilizados nos reatores do experimento $\mathrm{n}^{\circ} 3$ utilizando $A$. ferrooxidans.

\begin{tabular}{ccccccc}
\hline & \multicolumn{6}{c}{ Massa utilizada (mg) } \\
Substrato & \multicolumn{6}{c}{ Concentração de solo (g/L) } \\
& 50 & 100 & 200 & 300 & $\mathbf{4 0 0}$ & 500 \\
\hline $\mathrm{MgSO}_{4} \cdot 7 \mathrm{H}_{2} \mathrm{O}$ & 16,8 & 17,6 & 19,2 & 20,8 & 24 & 22,4 \\
$\mathrm{~K}_{2} \mathrm{HPO}_{4}$ & 16,8 & 17,6 & 19,2 & 20,8 & 24 & 22,4 \\
$\left(\mathrm{NH}_{4}\right)_{2} \mathrm{SO}_{4}$ & 16,8 & 17,6 & 19,2 & 20,8 & 24 & 22,4 \\
$\mathrm{FeSO}_{4} \cdot 7 \mathrm{H}_{2} \mathrm{O}$ & 1398,6 & 1465,2 & 1598,4 & 1731,6 & 1998 & 1864,8 \\
\hline
\end{tabular}

Tabela 18 - Substratos utilizados nos reatores do experimento $\mathrm{n}^{\circ} 3$ utilizando $A$. thiooxidans.

\begin{tabular}{cccccccc}
\hline & \multicolumn{6}{c}{ Massa utilizada (mg) } \\
Substrato & \multicolumn{6}{c}{ Concentração de solo (g/L) } \\
& $\mathbf{5 0}$ & $\mathbf{1 0 0}$ & $\mathbf{2 0 0}$ & $\mathbf{3 0 0}$ & $\mathbf{4 0 0}$ & $\mathbf{5 0 0}$ \\
\hline $\mathrm{MgSO}_{4} \cdot 7 \mathrm{H}_{2} \mathrm{O}$ & 12,56 & 13,2 & 14,4 & 15,6 & 16,8 & 18 \\
$\mathrm{~K}_{2} \mathrm{HPO}_{4}$ & 12,56 & 13,2 & 14,4 & 15,6 & 16,8 & 18 \\
$\left(\mathrm{NH}_{4}\right)_{2} \mathrm{SO}_{4}$ & 12,56 & 13,2 & 14,4 & 15,6 & 16,8 & 18 \\
$\mathrm{~S}^{0}$ & 314 & 330 & 360 & 390 & 420 & 450 \\
\hline
\end{tabular}




\subsubsection{Experimento $n^{\circ} 4$}

O experimento $\mathrm{n}^{\circ} 4$ foi executado em frascos Erlenmeyer de $250 \mathrm{~mL}$, sem agitação e com temperatura ambiente $\left(23,0{ }^{\circ} \mathrm{C}\right)$. Neste experimento, avaliou-se a adaptação do $A$. ferrooxidans e $A$. thiooxidans ao solo natural (com acidificação prévia) esterilizado.

No processo de esterilização, utilizou-se solo peneirado em malha de 2 $\mathrm{mm}$, que foi acondicionado em um frasco Becker, vedado com papel alumínio, e autoclavado a $120^{\circ} \mathrm{C}$ por 1 hora.

Neste experimento, utilizou-se a concentração de solo de $300 \mathrm{~g} / \mathrm{L}(60 \mathrm{~g}$ latossolo vermelho com umidade de $8,4 \%+200 \mathrm{~mL}$ de água de torneira ), adição de substratos e de suspensão bacteriana concentrada para cada um dos reatores (adição total: $1,43 \times 10^{8} \pm 1,65 \times 10^{7}$ células de $A$. ferrooxidans/reator inoculado e $2,17 \times 10^{8} \pm 6,4 \times 10^{7}$ células de $A$. thiooxidans/reator inoculado).

Os reatores receberam os seguintes substratos:

a) Reator com A. ferrooxidans: 0,6 $\mathrm{g}\left(\mathrm{NH}_{4}\right)_{2} \mathrm{SO}_{4}, 0,1 \mathrm{~g} \mathrm{~K} \mathrm{HPO}_{4}, 0,1$ g $\mathrm{MgSO}_{4} .7 \mathrm{H}_{2} \mathrm{O}, 8,84 \mathrm{~g} \mathrm{FeSO}_{4} .7 \mathrm{H}_{2} \mathrm{O}$;

b) Reator com $A$. thiooxidans: 0,08 $\mathrm{g}\left(\mathrm{NH}_{4}\right)_{2} \mathrm{SO}_{4}, 0,08 \mathrm{~g} \mathrm{~K}_{2} \mathrm{HPO}_{4}$, $0,08 \mathrm{~g} \mathrm{MgSO}_{4} .7 \mathrm{H}_{2} \mathrm{O}, 2 \mathrm{~g} \mathrm{~S}^{0}$.

O experimento foi executado em triplicata e contou com três reatores de controle: branco (água + solo); controle para o A. ferrooxidans (água + solo + substratos utilizados no crescimento do $A$. ferrooxidans) e controle para o $A$. thiooxidans (água + solo + substratos utilizados no crescimento do $A$. thiooxidans).

\subsubsection{Experimento $n^{\circ} 5$}

O experimento $n^{\circ} 5$, a exemplo do $n^{\circ} 4$, foi executado em frascos Erlenmeyer de $250 \mathrm{~mL}$, sem agitação e em temperatura ambiente $\left(23,0{ }^{\circ} \mathrm{C}\right)$. Neste experimento, avaliou-se a adaptação do $A$. ferrooxidans e $A$. thiooxidans ao solo natural (sem acidificação prévia) esterilizado. 
No processo de esterilização, utilizou-se solo peneirado em malha de 2 $\mathrm{mm}$, que foi acondicionado em um frasco Becker, vedado com papel alumínio e autoclavado a $120^{\circ} \mathrm{C}$ por 1 hora.

Neste experimento, utilizou-se a concentração de solo de $300 \mathrm{~g} / \mathrm{L}$ (60 g latossolo vermelho com umidade de $8,4 \%+200 \mathrm{~mL}$ de água de torneira ), adição de substratos e de suspensão bacteriana concentrada para cada um dos reatores (adição total: $1,43 \times 10^{8} \pm 1,65 \times 10^{7}$ células de $A$. ferrooxidans/reator inoculado e $2,17 \times 10^{8} \pm 6,4 \times 10^{7}$ células de $A$. thiooxidans/reator inoculado).

Os reatores receberam os seguintes substratos:

c) Reator com A. ferrooxidans: 0,6 $\mathrm{g}\left(\mathrm{NH}_{4}\right)_{2} \mathrm{SO}_{4}, 0,1 \mathrm{~g} \mathrm{~K}_{2} \mathrm{HPO}_{4}, 0,1$ $\mathrm{g} \mathrm{MgSO}_{4} .7 \mathrm{H}_{2} \mathrm{O}, 8,84 \mathrm{~g} \mathrm{FeSO}_{4} .7 \mathrm{H}_{2} \mathrm{O}$;

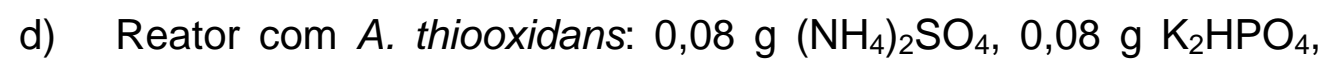
$0,08 \mathrm{~g} \mathrm{MgSO}_{4} .7 \mathrm{H}_{2} \mathrm{O}, 2 \mathrm{~g} \mathrm{~S}^{0}$.

$\mathrm{O}$ experimento foi executado em triplicata e contou com três reatores de controle: branco (água + solo); controle para o A. ferrooxidans (água + solo + substratos utilizados no crescimento do $A$. ferrooxidans) e controle para o $A$. thiooxidans (água + solo + substratos utilizados no crescimento do $A$. thiooxidans). As Figuras 24 e 25 mostram, respectivamente, os reatores utilizados nos experimentos com A. ferrooxidans e A. thiooxidans.

\subsubsection{Experimento $n^{\circ} 6$}

A partir deste experimento, todos os ensaios de biolixiviação foram executados no equipamento de banho termostatizado. Este experimento, assim como os próximos, foi executado simultaneamente em quatro reatores que obedeceram a seguinte configuração:

> Reator 1 (R1): água de torneira desclorada + solo + substratos;

$>$ Reator 2 (R2): água de torneira desclorada + solo + substratos $+\mathrm{H}_{2} \mathrm{SO}_{4}$ (utilizado para acidificar a polpa);

$>$ Reator 3 (R3): água de torneira desclorada + solo + substratos $+\mathrm{H}_{2} \mathrm{SO}_{4}+$ suspensão bacteriana; 
$>$ Reator 4 (R4): água de torneira desclorada + solo + substratos $+\mathrm{H}_{2} \mathrm{SO}_{4}+$ suspensão bacteriana (duplicata).

O experimento de $n^{\circ} 6$ possuiu as seguintes características:

> Reator: frasco retangular em polipropileno com capacidade para 4,5 L;

$>$ Massa de água: 2,8 kg;

$>$ Massa de solo contaminado: $1,2 \mathrm{~kg}$ (428 g solo seco/L de água);

> Umidade do solo: 4,08\%

> Volume de inóculo de A. ferrooxidans: $800 \mathrm{~mL}$, (a suspensão bacteriana purificada e concentrada em $10 \mathrm{~mL}$ );

$>$ Densidade de células no inóculo concentrado $(10 \mathrm{~mL}): 7,96 \times 10^{8} \pm 2,24 \times 10^{8}$ células/mL;

> Densidade de células nos reatores R3 e R4 no tempo 0: 6,91 x 10 $\pm 1,95 \times 10^{6}$ células/g solo seco (admitindo a massa de solo de 1,151 kg, já considerada a umidade de 4,08\%);

> Massas de substratos: 8,4 $\mathrm{g}\left(\mathrm{NH}_{4}\right)_{2} \mathrm{SO}_{4}, 0,28 \mathrm{~g} \mathrm{KCl}, 1,4 \mathrm{~g} \mathrm{~K} \mathrm{HPO}_{4}, 1,4 \mathrm{~g}$ $\mathrm{MgSO}_{4} \cdot 7 \mathrm{H}_{2} \mathrm{O}, 0,028 \mathrm{~g} \mathrm{Ca}\left(\mathrm{NO}_{3}\right)_{2}, 123,8 \mathrm{~g} \mathrm{FeSO}_{4} .7 \mathrm{H}_{2} \mathrm{O}$;

$>$ Rotação: 174 rpm \pm 9 rpm;

$>$ Temperatura: $30^{\circ} \mathrm{C} \pm 1,6^{\circ} \mathrm{C}$;

D Duração do experimento: 30 dias.

\subsubsection{Experimento $n^{\circ} 7$}

O experimento $n^{0} 7$ possuiu as seguintes características:

$>$ Reator: frasco retangular em polipropileno com capacidade para 4,5 L;

> Massa de água: 3,2 kg;

> Massa de solo contaminado: 0,8 kg (250 g solo seco/L de água);

$>$ Umidade do solo: $3,36 \%$

$>$ Volume de inóculo de A. ferrooxidans: $800 \mathrm{~mL}$, (a suspensão bacteriana foi lavada três vezes e concentrada em $10 \mathrm{~mL}$ );

$>$ Densidade de células na inóculo concentrado (10 mL): 1,31 x 10 $10 \pm 8,16 \times$ $10^{8}$ células $/ \mathrm{mL}$ 
$>$ Densidade de células nos reatores R3 e R4 no tempo 0: 1,7 x 10 ${ }^{8} \pm 1,06 \times 10^{7}$ células/g solo seco (admitindo a massa de solo de $0,77 \mathrm{~kg}$, já considerado a umidade de 3,36\%);

$>$ Massas de substratos: 8,4 $\mathrm{g}\left(\mathrm{NH}_{4}\right)_{2} \mathrm{SO}_{4}, 0,28 \mathrm{~g} \mathrm{KCl}, 1,4 \mathrm{~g} \mathrm{~K}_{2} \mathrm{HPO}_{4}, 1,4 \mathrm{~g}$ $\mathrm{MgSO}_{4} .7 \mathrm{H}_{2} \mathrm{O}, 0,028 \mathrm{~g} \mathrm{Ca}\left(\mathrm{NO}_{3}\right)_{2}, 123,8 \mathrm{~g} \mathrm{FeSO}_{4} .7 \mathrm{H}_{2} \mathrm{O}$;

> Rotação: 205 rpm \pm 4 rpm;

$>$ Temperatura: $30,2^{\circ} \mathrm{C} \pm 1,3^{\circ} \mathrm{C}$;

Duração do experimento: 30 dias.

\subsubsection{Experimento $n^{\circ} 8$}

O experimento $\mathrm{n}^{\circ} 8$ possuiu as seguintes características:

> Reator: frasco retangular em polipropileno com capacidade para 4,5 L;

> Massa de água: 3,2 kg;

> Massa de solo contaminado: 0,8 kg (250 g solo seco/L água);

$>$ Umidade do solo: $3,18 \%$

> Volume de inóculo de A. ferrooxidans: $800 \mathrm{~mL}$, (a suspensão bacteriana foi lavada três vezes e concentrada em $40 \mathrm{~mL}$ );

Densidade de células no inóculo concentrado (40 mL): 3,03 x 10 $\pm 4,75$ x $10^{6}$ células $/ \mathrm{mL}$;

$>$ Densidade de células nos reatores R3 e R4 no tempo 0: 3,12 x 10 \pm 4,91 x $10^{6}$ células/ g solo seco (admitindo a massa de solo de 0,77 kg, já considerada a umidade de 3,18\%);

> Massas de substratos: 9,6 g $\left(\mathrm{NH}_{4}\right)_{2} \mathrm{SO}_{4}, 16 \mathrm{~g} \mathrm{FeSO} 4.7 \mathrm{H}_{2} \mathrm{O}$;

> Rotação: 200 rpm \pm 3 rpm;

$>$ Temperatura: $30,4^{\circ} \mathrm{C} \pm 0,5^{\circ} \mathrm{C}$;

> Duração do experimento: 30 dias.

O experimento $n^{\circ} 8$ foi realizado com a mesma concentração de solo utilizada no experimento $\mathrm{n}^{0} 7$, mas apresentou duas diferenças: o inóculo foi concentrado em $40 \mathrm{~mL}$ (ao invés de $10 \mathrm{~mL}$ como nos experimentos $\mathrm{n}^{\circ} 6$ e $\mathrm{n}^{\circ} 7$ ), a composição dos substratos foi modificada (não foram adicionados: $\mathrm{KCl} ; \mathrm{K}_{2} \mathrm{HPO}_{4}$; 
$\mathrm{MgSO}_{4}$ e $\mathrm{Ca}_{2}\left(\mathrm{NO}_{3}\right)$ e a massa de $\left(\mathrm{NH}_{4}\right)_{2} \mathrm{SO}_{4}$ foi aumentada de $8,4 \mathrm{~g}$ para 9,6 $\mathrm{g} \mathrm{e}$ reduzida a de $\mathrm{FeSO}_{4} .7 \mathrm{H}_{2} \mathrm{O}$ de $123,8 \mathrm{~g}$ para $16 \mathrm{~g}$ ).

O objetivo do aumento do volume do inóculo foi o de permitir um melhor contato entre as bactérias e o solo nos reatores e o da modificação nos substratos, reduzir o impacto que eles exercem sobre o pH (particularmente o $\mathrm{FeSO}_{4} .7 \mathrm{H}_{2} \mathrm{O}$ ) e, desta maneira, possibilitar uma avaliação mais precisa e acurada do processo de biolixiviação. 


\section{RESULTADOS}

\subsection{Classificação pedológica do solo}

Segundo o Atlas Ambiental da Bacia do Rio Corumbataí, elaborado pelo CENTRO DE ANÁLISE E PLANEJAMENTO AMBIENTAL (CEAPLA, 2005), o solo da região de estudo esta em área de influência de latossolo roxo. A Figura 27 mostra a ocorrência e a distribuição dos diferentes tipos de solo da bacia do Rio Corumbataí.

Entretanto, ressalta-se que a atividade antropogênica na Região dos Lagos de Santa Gertrudes não mais permite, a rigor, enquadrar pedologicamente o material geológico utilizado nos experimentos aqui reportados como sendo solo, uma vez que ocorreu a mistura de resíduos sólidos com o mesmo. Todavia, para efeito exclusivo de identificação dos dois materiais geológicos utilizados nos experimentos, a classificação pedológica original foi mantida neste trabalho. 


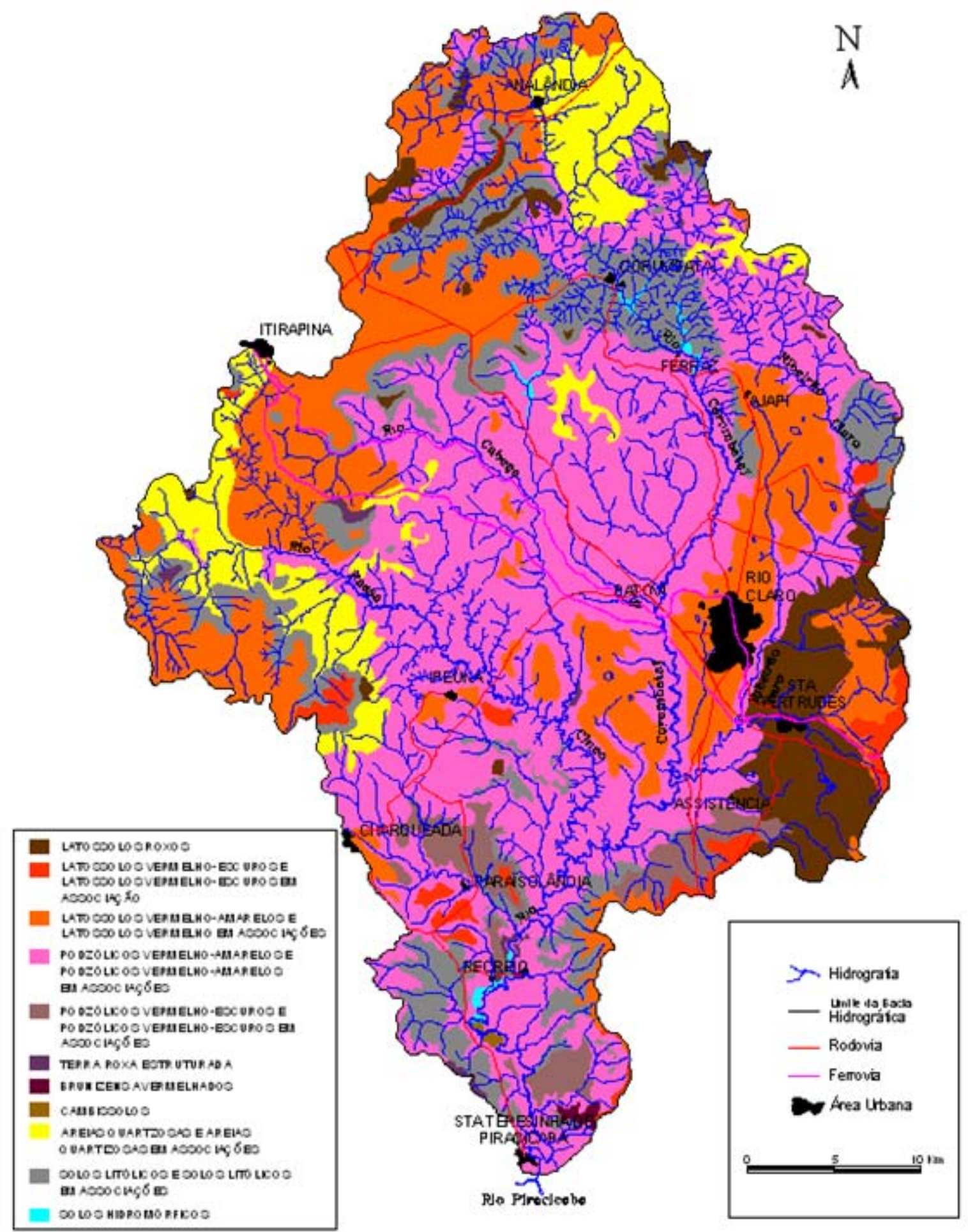

Figura 27- Mapa de solos da bacia hidrogáfica do Rio Corumbataí. Fonte: CEAPLA (2005). 


\subsection{Caracterização geotécnica do solo}

Tendo em vista que foram utilizados dois tipos diferentes de solo para a execução dos experimentos de biolixiviação, eles foram caracterizados separadamente.

\subsubsection{Composição mineralógica}

\subsubsection{Latossolo roxo}

A Tabela 19 permite visualizar os resultados da análise de fluorescência de raios-X. As Figuras 28 e 29 mostram, respectivamente, o difratograma de uma amostra composta do solo coletado em três diferentes pontos da área de estudo e as fases nele identificadas. A Tabela 20 indica os minerais correspondentes a cada uma das fases identificadas na Figura 29.

Tabela 19 - Resultados em \% de óxidos, normalizados a $100 \%$, de amostras de latossolo roxo.

\begin{tabular}{ccccc}
\hline Óxidos & Ponto 1 & Ponto 2 & Ponto 3 & $\begin{array}{c}\text { Amostras } \\
\text { Amostra } \\
\text { composta (P1+ } \\
\text { P2 + P3) }\end{array}$ \\
\hline $\mathrm{MgO}$ & 0,61 & 0,45 & 0,47 & 0,45 \\
$\mathrm{Al}_{2} \mathrm{O}_{3}$ & 22,6 & 24,3 & 23,4 & 22,8 \\
$\mathrm{SiO}_{2}$ & 36,5 & 38,6 & 42,2 & 40,2 \\
$\mathrm{P}_{2} \mathrm{O}_{5}$ & 0,16 & 0,13 & 0,11 & 0,13 \\
$\mathrm{SO}_{3}$ & 0,04 & 0,05 & 0,05 & 0,05 \\
$\mathrm{~K}_{2} \mathrm{O}$ & 0,38 & 0,12 & 0,10 & 0,18 \\
$\mathrm{CaO}$ & 0,18 & 0,17 & 0,22 & 0,18 \\
$\mathrm{TiO}_{2}$ & 5,69 & 6,99 & 9,11 & 7,5 \\
$\mathrm{~V}_{2} \mathrm{O}_{5}$ & 0,09 & 0,11 & 0,09 & 0,08 \\
$\mathrm{Cr}_{2} \mathrm{O}_{3}$ & $<<$ & $<<$ & $<<$ & $<<$ \\
$\mathrm{MnO}$ & 0,12 & 0,11 & 0,12 & 0,11
\end{tabular}

Continua... 
Conclusão.

\begin{tabular}{|c|c|c|c|c|}
\hline \multirow[b]{2}{*}{ Óxidos } & \multicolumn{4}{|c|}{ Amostras } \\
\hline & Ponto 1 & Ponto 2 & Ponto 3 & $\begin{array}{c}\text { Amostra } \\
\text { composta (P1+ } \\
\text { P2 + P3) }\end{array}$ \\
\hline $\mathrm{Fe}_{2} \mathrm{O}_{3}$ & 23,0 & 17,6 & 14,7 & 18,2 \\
\hline $\mathrm{NiO}$ & nd & $<<$ & nd & $\mathrm{Nd}$ \\
\hline $\mathrm{CuO}$ & 0,02 & 0,02 & 0,02 & 0,03 \\
\hline $\mathrm{ZnO}$ & 0,03 & 0,01 & 0,01 & 0,02 \\
\hline $\mathrm{Ga}_{2} \mathrm{O}_{3}$ & nd & $\ll$ & nd & $\ll$ \\
\hline $\mathrm{SrO}$ & $<<$ & $<<$ & $<<$ & $<<$ \\
\hline $\mathrm{Y}_{2} \mathrm{O}_{3}$ & $<<$ & 0,01 & $<<$ & $<<$ \\
\hline $\mathrm{ZrO}_{2}$ & 0,09 & 0,09 & 0,12 & 0,10 \\
\hline $\mathrm{Nb}_{2} \mathrm{O}_{5}$ & $<<$ & 0,01 & 0,01 & 0,02 \\
\hline $\mathrm{PbO}$ & nd & nd & nd & $<<$ \\
\hline $\mathrm{PF}$ & 10,6 & 11,2 & 9,28 & 10,1 \\
\hline
\end{tabular}

Nota:

$<<=$ Traços (menor que 0,01\%)

nd $=$ Elemento não detectado

$\mathrm{PF}=$ Perda ao fogo

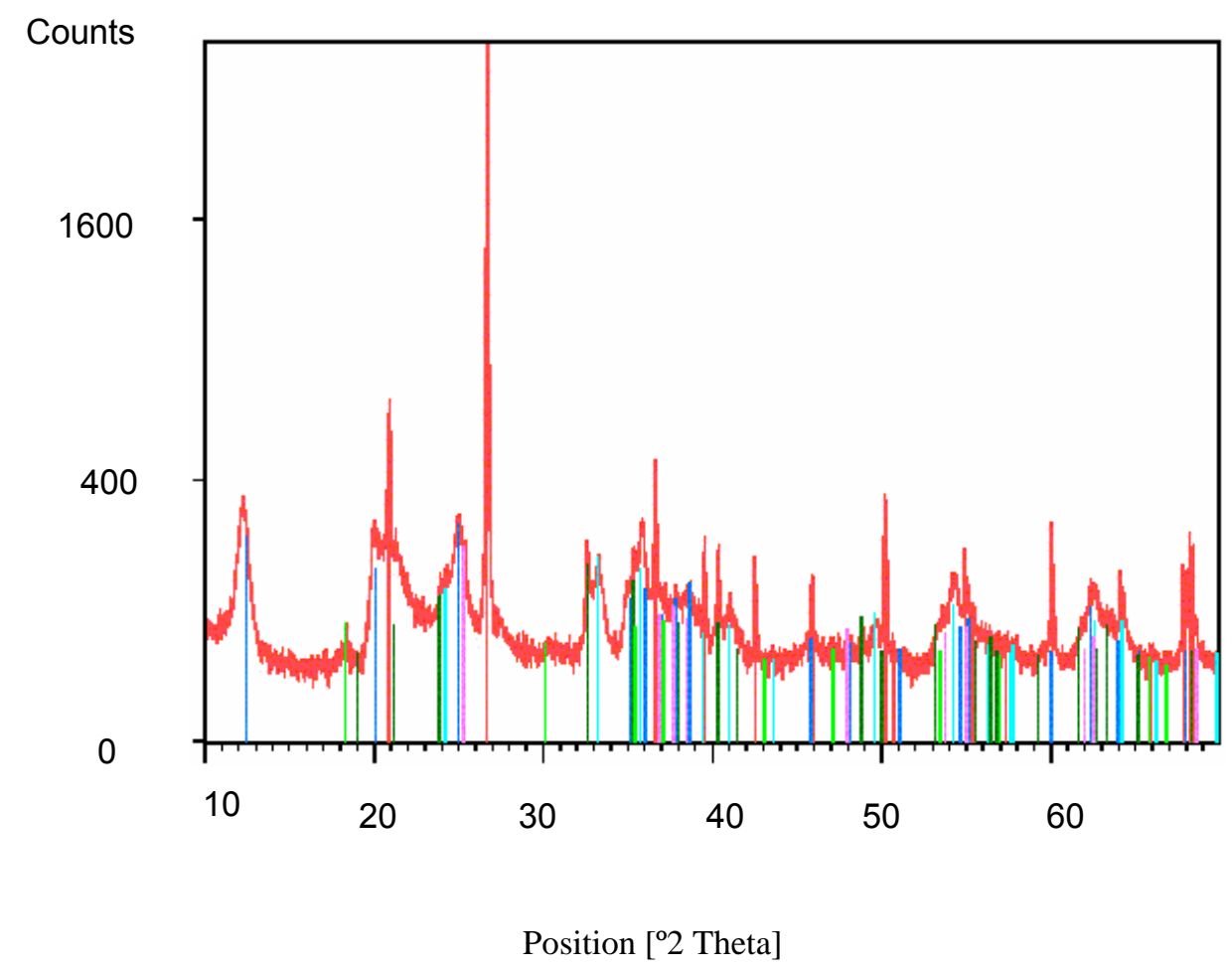

Figura 28 - Difratograma da amostra composta de latossolo roxo da área de estudo. 


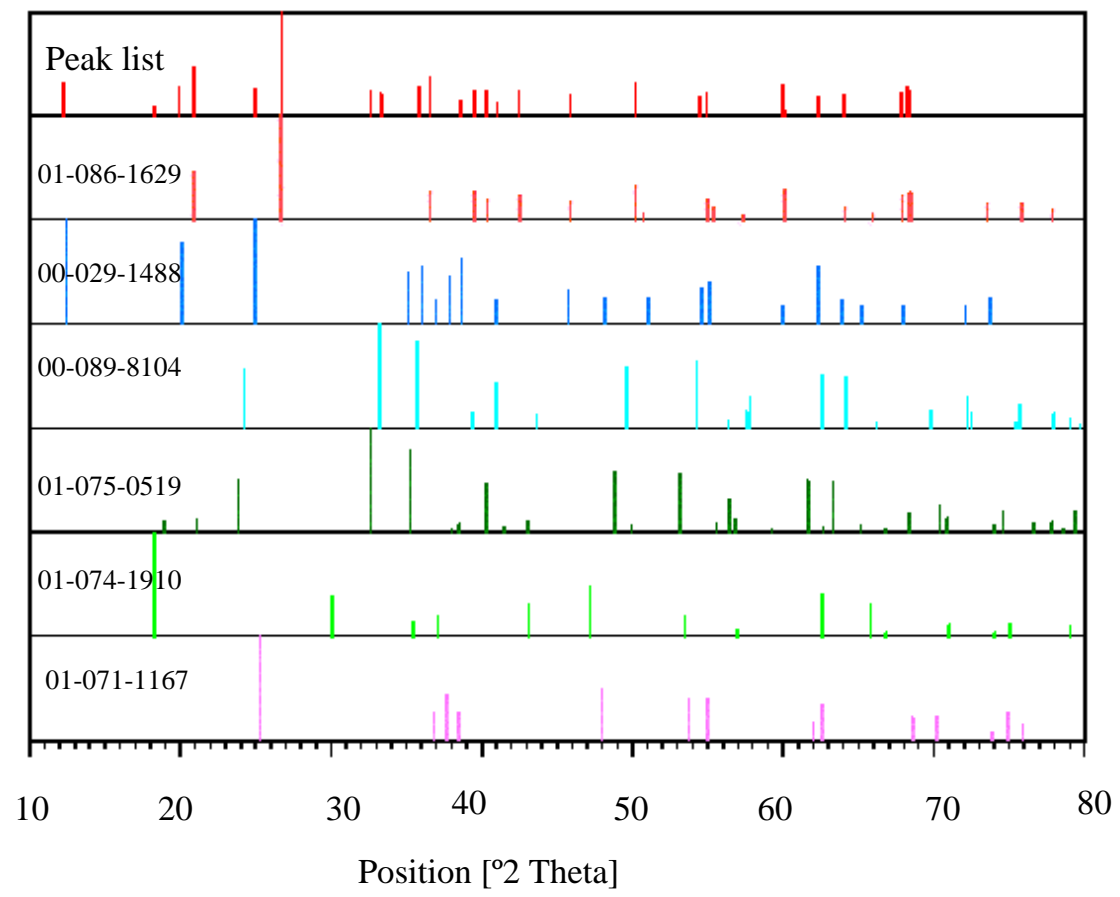

Figura 29 - Fases identificadas no difratograma da Figura 28.

Tabela 20 - Minerais identificados através das fases mostradas na Figura 29.

\begin{tabular}{cccc}
\hline ICDD & $\begin{array}{c}\text { Nome do } \\
\text { composto }\end{array}$ & $\begin{array}{c}\text { Fórmula } \\
\text { química }\end{array}$ & Mineral \\
\hline $01-086-1629$ & Quartzo & $\mathrm{SiO}_{2}$ & Quartzo \\
$00-029-1488$ & Caulinita & $\mathrm{Al}_{2} \mathrm{Si}_{2} \mathrm{O}_{5}(\mathrm{OH})_{4}$ & Caulinita \\
$01-089-8104$ & Hematita & $\mathrm{Fe}_{2} \mathrm{O}_{3}$ & Hematita \\
$01-075-0519$ & Ilmenita & $\mathrm{FeTiO}_{3}$ & Ilmenita \\
$01-074-1910$ & Magnetita & $\mathrm{Fe}_{3} \mathrm{O}_{4}$ & Magnetita \\
$01-071-1167$ & Anatásio & $\mathrm{TiO}_{2}$ & Anatásio \\
\hline
\end{tabular}

Os minerais listados na Tabela 20 permitem associar a amostra do solo à uma área de influência de latossolo roxo.

Embora haja aproximadamente 2000 espécies minerais conhecidas, apenas algumas ocorrem com elevada freqüência. Os seis minerais primários predominantes na crosta terrestre são: feldspatos, quartzo, piroxênio, anfibólios, micas e olivina. Estes integram o grupo dos silicatos que ocupa aproximadamente 93 $\%$ do volume da litosfera, logo, é de longe o mais importante (DANA, 1969; GANDOLFI; BJONBERG; PARAGUASSU, 1999).

O quartzo é um importante mineral constituinte das rochas ígneas que possuem excesso de sílica, tais como o granito, o riólito e o pegmatito. É um mineral extremamente resistente, tanto ao ataque químico quanto ao físico, e assim, a desintegração das rochas ígneas que o contém produz grãos de quartzo, que podem 
se acumular e formar a rocha sedimentar granito. Tal mineral também ocorre em rochas metamórficas, como os gnaisses e os xistos, formando praticamente o único mineral dos quartzitos. Nas rochas, está associado principalmente com o feldspato e a muscovita. Ocorre, ainda, em grande quantidade como areia nos leitos dos rios e praias e como constituinte dos solos (DANA, 1969).

A caulinita é um mineral de ocorrência ampla e o principal constituinte do caulim e das argilas. Sempre um mineral de origem supérgena, sendo derivado, por alteração, dos silicatos de alumínio, particularmente o feldspato. Como um dos produtos de alteração comum da decomposição das rochas, encontra-se nos solos e, sendo transportado pela água, deposita-se sob a forma de camadas de argila, misturada com quartzo e outros materiais, nos sedimentos aquáticos (DANA, 1969).

A caulinita possui estrutura atômica, formada por uma repetição sucessiva de pacotes constituídos de uma camada de tetraedros de sílica e de uma camada de octaedros de alumina, sendo que estes pacotes estão ligados por força atômica do tipo hidrogênio.

A hematita é um mineral amplamente distribuído em rochas de todas as idades e forma o minério de ferro mais abundante e importante. Pode ter como origem, a sublimação das atividades vulcânicas. Ocorre em depósitos metamórficos de contato e como mineral acessório nas rochas ígneas feldspáticas, como o granito (DANA, 1969).

A hematita pode ser encontrada desde a forma de escamas microscópicas até de massas muito grandes, em comparação com as rochas metamórficas regionais, onde pode ter se originado pela alteração da limonita, siderita e magnetita. Tal como a limonita, pode ser formada em massas ou camadas irregulares como resultado da ação do intemperismo. Seu uso principal é como minério de ferro, mas também é empregado como fonte dos pigmentos ocre e vermelho (DANA, 1969).

A ilmenita ocorre em camadas e em massas lenticulares encaixadas no gnaisse e em outras rochas metamórficas cristalinas. É encontrada, freqüentemente, em filões ou massas, como um produto de segregação magmática associada com magnetita. Ocorre também como mineral acessório nas rochas ígneas e é um dos constituintes das areias pretas, associado com a magnetita, o rutículo, o zircão e a monazita. É empregado como fonte de titânio e o dióxido de titânio extraído é utilizado como pigmento em substituição aos compostos de chumbo (DANA, 1969). 
Considerando as informações do parágrafo anterior e o fato de que a área de estudo foi utilizada como local de descarte de resíduos sólidos e despejos líquidos das indústrias cerâmicas da região e, comparando o teor médio de 1,89 \pm 0,78 $\mathrm{mg} \mathrm{TiO}_{2} / \mathrm{kg}$, determinado pelo CEAPLA para os solos da Bacia do Rio Corumbataí (CEAPLA, 2005), com os dados das Tabelas 19 e 21, é lícito afirmar que a presença de ilmenita e anatásio, observada nas amostras de latossolo roxo, pode ter origem antrópica, embora SILVA (2001) tenha analisado o latossolo não contaminado da região e determinado um teor médio de $6,12 \%$ de $\mathrm{TiO}_{2}$.

A magnetita é um minério de ferro comum e encontra-se distribuída, sob a forma de um mineral acessório, em muitas rochas magmáticas. Está associada, mais comumente, com rochas metamórficas cristalinas, embora ocorra também, freqüentemente, em rochas ricas em minerais ferromagnesianos - dioritos, gabros, peridotitos (DANA, 1969).

A ilmenita, a magnetita e a hematita integram o grupo dos minerais denominados secundários, pois são resistentes à ação das intempéries. $O$ anatásio, geralmente, encontra-se associado ao rutilo e à hematita.

\subsubsection{Latossolo vermelho}

Apesar dos diagnósticos preliminar e confirmatório da área indicarem a contaminação por $\mathrm{Pb}, \mathrm{Zn}, \mathrm{Cd}$, Ni e B, estes elementos foram encontrados em baixos teores nas amostras do latossolo roxo. Portanto, optou-se por nova coleta, em local onde haviam sido dispostos sedimentos contaminados oriundos dos lagos da região. Portanto, não é possível comparar a composição mineralógica dos dois latossolos utilizados nesta pesquisa.

A Tabela 21 mostra o resultado fornecido pela análise de fluorescência de raios-X. As Figuras 30 e 31 permitem a visualização, respectivamente, do difratograma de uma amostra composta do solo coletado na área de estudo e das fases cristalinas nele identificadas. A Tabela 22 indica os minerais correspondentes a cada uma das fases identificadas na Figura 31. 
Tabela 21 - Resultados em \% de óxidos, normalizados a $100 \%$, de amostra de latossolo vermelho.

\begin{tabular}{cccc}
\hline Óxidos & $\%$ & Óxidos & $\%$ \\
\hline $\mathrm{Na}_{2} \mathrm{O}$ & 0,32 & $\mathrm{Fe}_{2} \mathrm{O}_{3}$ & 8,31 \\
$\mathrm{MgO}$ & 1,30 & $\mathrm{CO}_{3} \mathrm{O}_{4}$ & 0,02 \\
$\mathrm{Al}_{2} \mathrm{O}_{3}$ & 16,8 & $\mathrm{CuO}$ & 0,03 \\
$\mathrm{SiO}_{2}$ & 61,7 & $\mathrm{ZnO}$ & 0,06 \\
$\mathrm{P}_{2} \mathrm{O}_{5}$ & 0,12 & $\mathrm{Rb}_{2} \mathrm{O}$ & 0,03 \\
$\mathrm{SO}_{3}$ & 0,04 & $\mathrm{SrO}$ & 0,01 \\
$\mathrm{~K}_{2} \mathrm{O}$ & 2,58 & $\mathrm{Y}_{2} \mathrm{O}_{3}$ & 0,01 \\
$\mathrm{CaO} \mathrm{O}$ & 0,42 & $\mathrm{ZrO}_{2}$ & 0,07 \\
$\mathrm{TiO}_{2}$ & 1,00 & $\mathrm{Nb}_{2} \mathrm{O}_{5}$ & 0,00 \\
$\mathrm{~V}_{2} \mathrm{O}_{5}$ & 0,01 & $\mathrm{BaO}$ & 0,08 \\
$\mathrm{Cr}_{2} \mathrm{O}_{3}$ & 0,02 & $\mathrm{PbO}$ & 0,16 \\
$\mathrm{MnO}$ & 0,07 & $\mathrm{PF}$ & 6,90 \\
\hline
\end{tabular}

Nota:

PF: Perda ao fogo.

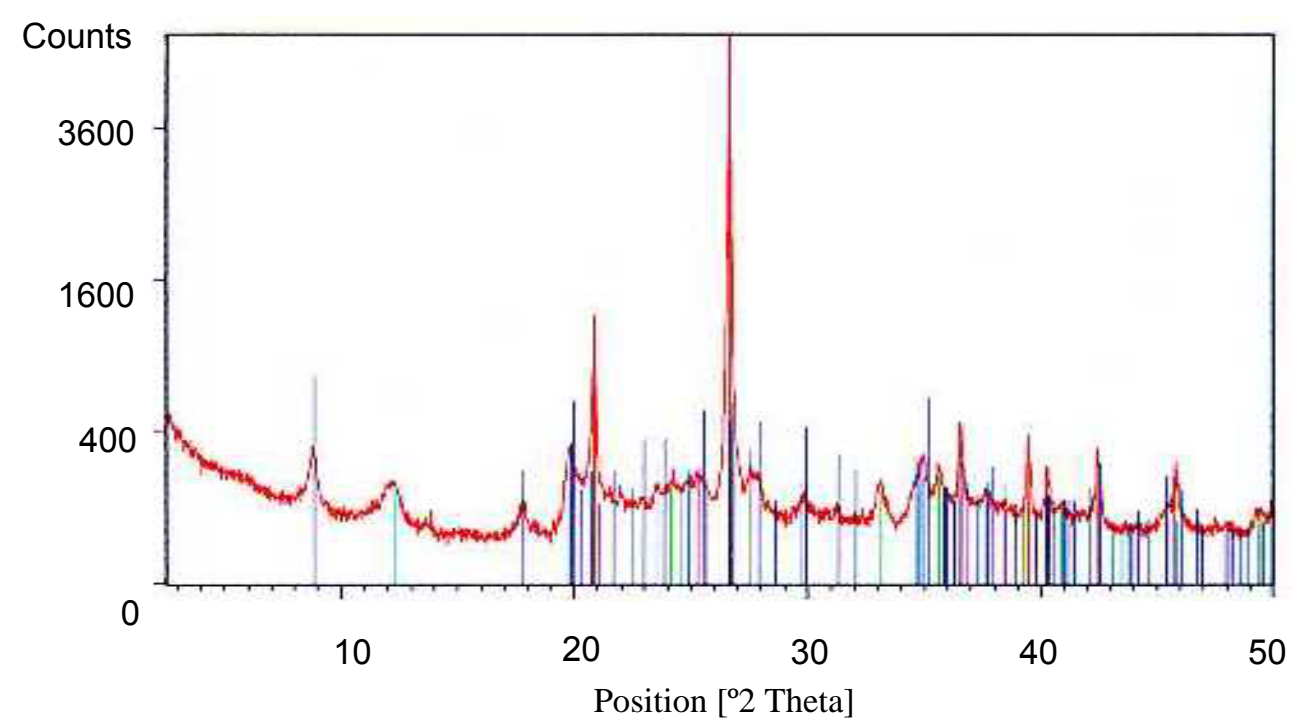

Figura 30 - Difratograma de amostra de rosa da área de estudo. 


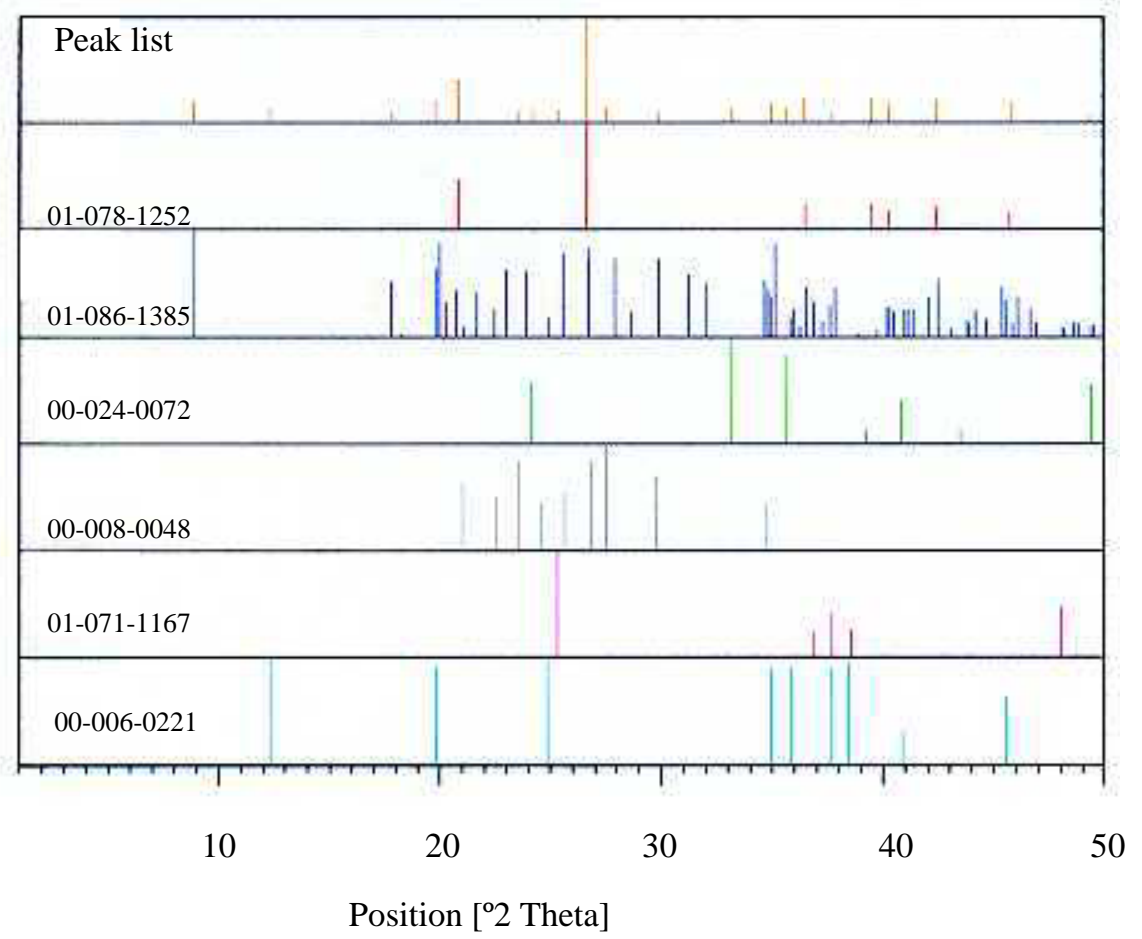

Figura 31 - Fases identificadas no difratograma da Figura 30.

A muscovita é um mineral formador de rocha muito comum. É característico de rochas ígneas silicosas, situadas profundamente, como o granito e o sienito. Muito comum também nas rochas metamórficas, como o gnaisse e o xisto, formando o constituinte principal de certos mica-xistos. A muscovita origina-se também como produto de alteração de diversos outros minerais: topázio, cianita, espodumênio, andaluzita e escapolita. Nos pegmatitos graníticos, ela ocorre associado com o quartzo e o feldspato, com a turmalina, o berilo, a granada, a apatita e a fluorita (DANA, 1969).

Tabela 22 - Minerais identificados através das fases da Figura 31.

\begin{tabular}{cccc}
\hline ICDD & $\begin{array}{c}\text { Nome do } \\
\text { composto }\end{array}$ & Fórmula química & Mineral \\
\hline $01-086-1629$ & Quartzo & $\mathrm{SiO}_{2}$ & Quartzo \\
$01-086-1385$ & Muscovita & $\begin{array}{c}\mathrm{K}_{0,86} \mathrm{Al}_{1,94}\left(\mathrm{Al}_{0,965} \mathrm{Si}_{2,895} \mathrm{O}_{10}\right. \\
\left((\mathrm{OH})_{1,744} \mathrm{~F}_{0,256}\right)\end{array}$ & Muscovita \\
$01-089-8104$ & Hematita & $\mathrm{Fe}_{2} \mathrm{O}_{3}$ & Hematita \\
$00-008-0048$ & Ortoclásio & $\mathrm{K}(\mathrm{Al}, \mathrm{Fe}) \mathrm{Si}_{2} \mathrm{O}_{8}$ & Ortoclásio \\
$01-071-1167$ & Anatásio & $\mathrm{TiO}_{2}$ & Anatásio \\
$00-029-1488$ & Caulinita & $\mathrm{Al}_{2} \mathrm{Si}_{2} \mathrm{O}_{5}(\mathrm{OH})_{4}$ & Caulinita \\
\hline 0 ortoclásio é um dos minerais mais comuns, forma-se durante a & mais cos
\end{tabular}
cristalização das rochas ígneas e pelas atividades hidrotermais nos diques 
pegmatíticos e nas drusas das rochas. Mais raramente, origina-se da cristalização a partir de soluções aquosas, em baixa temperatura, nos filões. De distribuição ampla, ocorre em muitos tipos de rochas ígneas, especialmente granitos, sienitos e nefelina sienitos; nas rochas sedimentares, está presente no arcózio e em certos arenitos e conglomerados; nas rochas metamórficas, nos gnaisses (DANA, 1969).

A muscovita (mica), o ortoclásio (feldspato), o quartzo e as zeólitas são denominados de minerais primários. Estes são os últimos a serem formados no processo de cristalização magmática, ou seja, no processo de resfriamento do magma, e dão origem aos minerais hidrotermais (GANDOLFI; BJONBERG; PARAGUASSU, 1999).

Outro mineral, a rigor, uma associação de minerais, que freqüentemente ocorre nos latossolos, sobretudo na fração pedregulho, é a laterita ou concreção laterítica, constituída essencialmente de óxidos hidratados de ferro e alumínio. A essa substância, se associam, freqüentemente, a magnetita, a ilmenita, a hematita e, sobretudo, o quartzo.

SILVA (2001) concluiu que nesta área ocorre a gênese de solos lateríticos típicos, com remoção de $\mathrm{Na}, \mathrm{K}, \mathrm{Si}, \mathrm{Mg}$, Ca e concentração de Fe, Al, Mn e Ti.

\subsubsection{Massa específica dos grãos e curvas granulométricas}

Os ensaios para determinação da massa específica dos grãos e da curva granulométrica foram executados de acordo com a NBR 7181 (ABNT, 1984a). Os resultados dos ensaios para os latossolo roxo e vermelho são apresentados, na íntegra, no Apêndice $A$.

A massa específica para o latossolo roxo é de $2,92 \mathrm{~g} / \mathrm{cm}^{3}$ e de $2,57 \mathrm{~g} / \mathrm{cm}^{3}$, para o vermelho. As Figuras 32 e 33 mostram, respectivamente, as distribuições granulométricas das duas amostras de solo. 


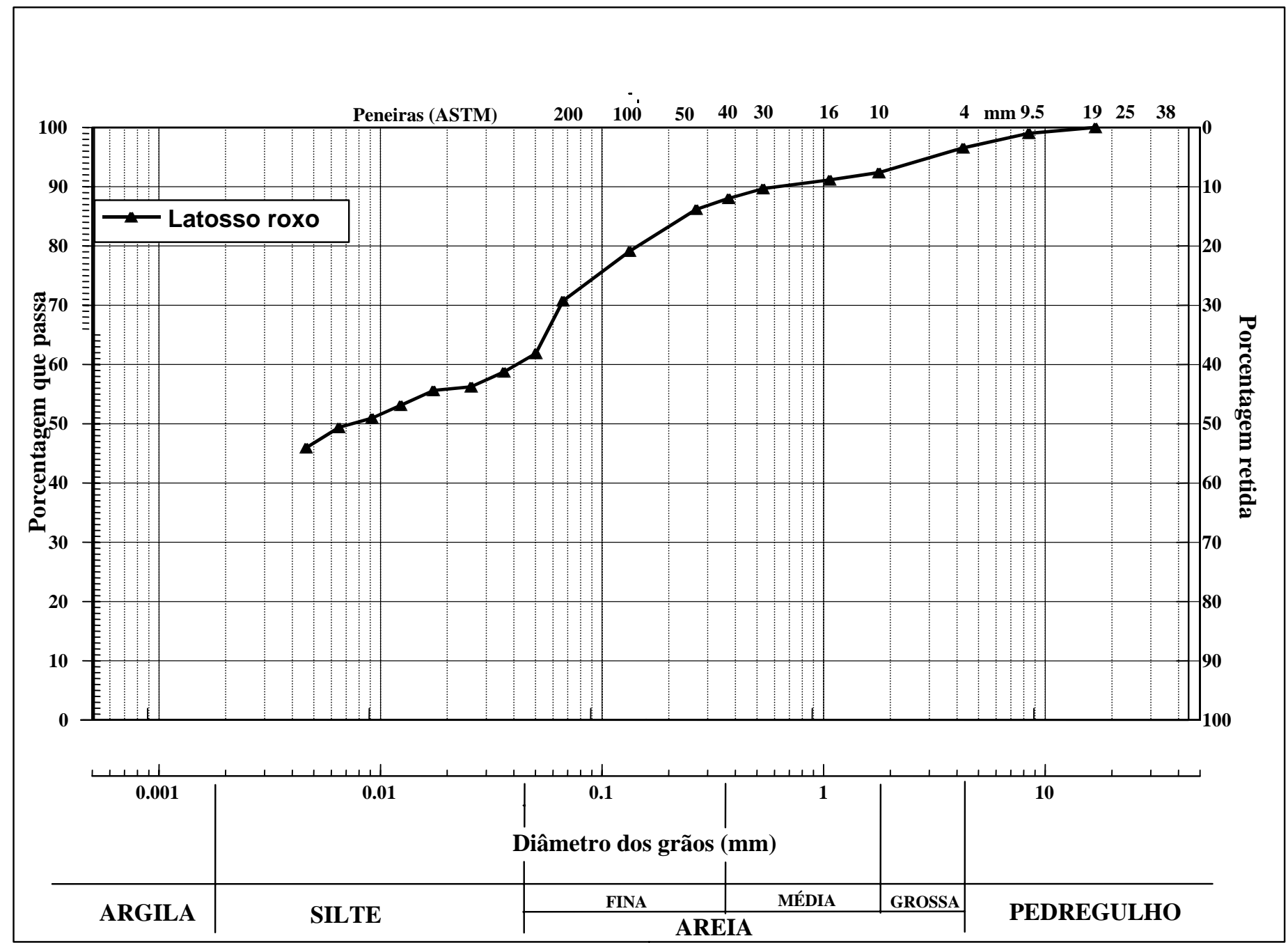

Figura 32 - Distribuição granulométrica do latossolo roxo coletado na área de estudo. 


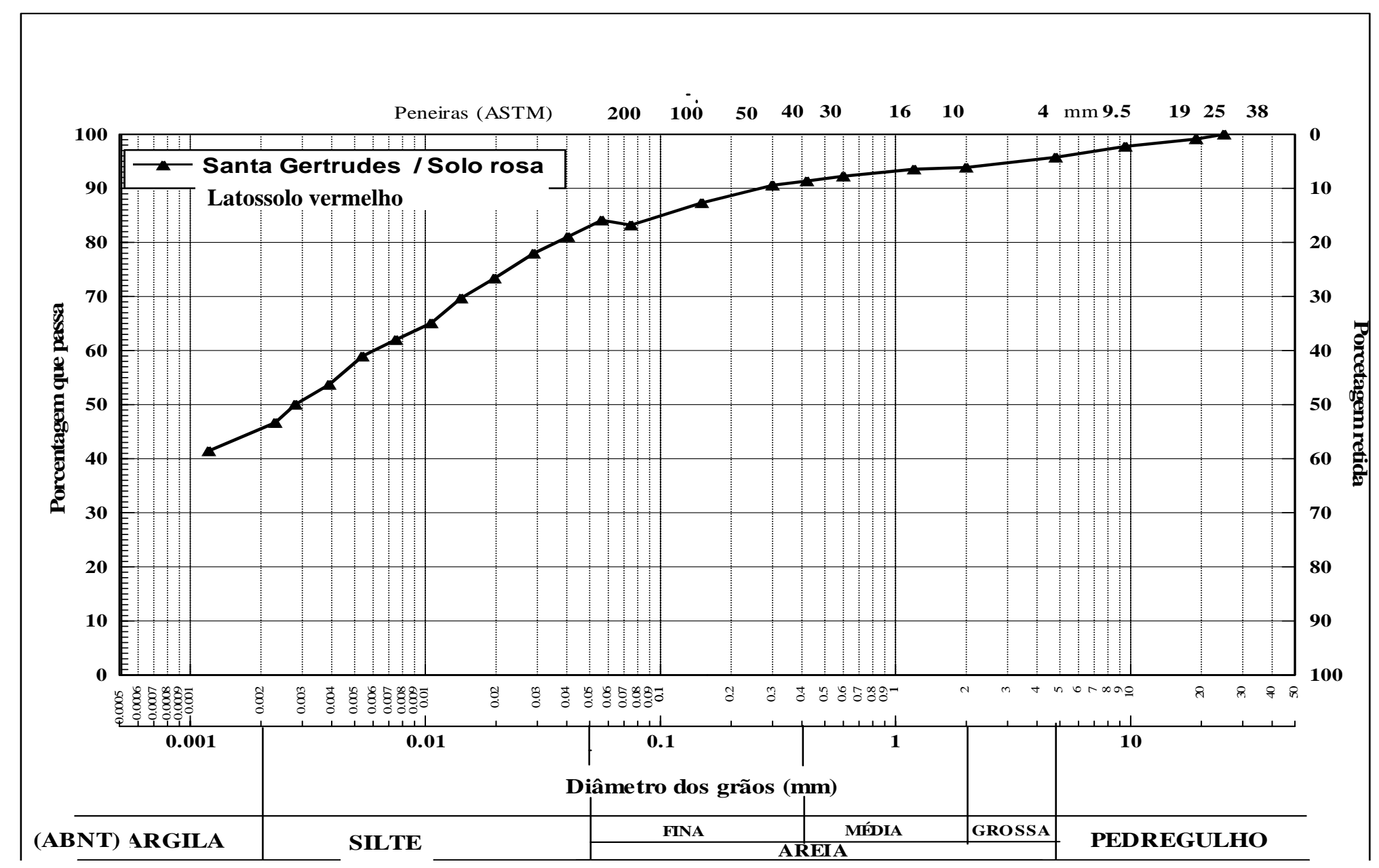

Figura 33 - Distribuição granulométrica do latossolo vermelho coletado na área de estudo 
Além dos ensaios geotécnicos, conduzidos na Escola Politécnica, foi executada análise granulométrica do latossolo vermelho no Laboratório de Solos e Nutrição de Plantas da Escola Superior de Agricultura Luiz de Queiroz (ESALQ), na qual se obteve o seguinte resultado: $6 \%$ de areia grossa (diâmetro dos grãos = 1 a $0,5 \mathrm{~mm}), 12 \%$ de areia fina $(0,25$ a $0,1 \mathrm{~mm}), 27 \%$ de silte $(0,05$ a 0,002 mm) e $55 \%$ de argila $(<0,002 \mathrm{~mm})$. O solo foi classificado como argiloso.

A presença de quartzo é muito freqüente nestes e noutros tipos de solos e freqüentemente predominante nas frações areia e pedregulho. Os grãos de quartzo, quando presentes na fração areia dos latossolos, estão envoltos por uma película de óxidos, que é a responsável pela tonalidade avermelhada, arroxeada ou amarelada do conjunto (NOGAMI, 1995).

Similarmente ao caso da fração areia, a constituição mineralógica da fração silte é quase sempre muito simples, sendo nítida a predominância do quartzo. É bastante freqüente a presença de torrões de argila; a laterita também pode ocorrer nesta fração, contudo é difícil sua distinção dos primeiros.

Os principais constituintes da fração argila, ou seja, da parte formada por grãos de diâmetro inferior a 0,002 mm, são os argilominerais, óxidos e hidróxidos de ferro e/ou alumínio e húmus ou ácidos húmicos.

Os argilominerais caracterizam-se por possuírem uma série de propriedades peculiares, das quais se destacam (BOHN; MCNEAL; O'CONNOR, 1985; MCLEAN; BLEDSOE, 1992; STUMM, 1992; NOGAMI, 1995):

a) Elevada superfície específica decorrente, sobretudo, de suas dimensões diminutas (da ordem de micrômetros a nanômetros) e de sua forma lamelar e/ou alongada;

b) Cargas elétricas predominantemente negativas, 0 que lhes confere capacidade de troca catiônica, quando em meio aquoso e, também, condiciona o $\mathrm{pH}$ do solo;

c) Adsorção de cátions devido à elevada área superficial específica e predominância de cargas elétricas negativas na superfície de suas partículas.

A carga de superfície do solo foi determinada no Laboratório de Solos e Nutrição de Plantas da ESALQ, segundo metodologia proposta por TAN (1993), para o qual a carga de superfície pode ser determinada através do diferencial do $\mathrm{pH}$ de uma solução de solo com água destilada e de solo com solução de cloreto de 
potássio. Neste caso, se o $\Delta \mathrm{pH}<0$, as cargas de superfície são predominantemente positivas e vice-versa. Quando $\Delta \mathrm{pH}=0$, tem-se o ponto de carga zero.

Obteve-se o seguinte resultado para a carga de superfície da amostra de latossolo vermelho:

$\Delta \mathrm{pH}=\mathrm{pH}\left(\mathrm{H}_{2} \mathrm{O}\right)-\mathrm{pH}\left(\mathrm{H}_{2} \mathrm{O}+\mathrm{KCl}\right)=(7,6 \pm 0)-(6,63 \pm 0,06)=0,97 \pm 0,06$

Portanto, o valor positivo do diferencial de $\mathrm{pH}$ indica que as cargas de superfície do solo são negativas, logo, possuem capacidade de adsorção de espécies catiônicas, que incluem os metais pesados.

A capacidade de troca catiônica também foi determinada no Laboratório de Solos e Nutrição de Plantas da ESALQ e resultou em 132,20 $\pm 7,12 \mathrm{mmol} / \mathrm{kg}$, ou seja, o latossolo vermelho possui capacidade de trocar seus cátions $\mathrm{Al}^{3+}, \mathrm{Ca}^{2+}, \mathrm{Mg}^{2+}$, $\mathrm{K}^{+}, \mathrm{Na}^{+}$e $\mathrm{H}^{+}+\mathrm{Al}^{3+}$ por outros, inclusive metais pesados. Este resultado está de acordo com o diferencial de $\mathrm{pH}$, mencionado no parágrafo anterior, e com o comportamento descrito por STUMM (1992) sobre a dependência das cargas elétricas superficiais com o $\mathrm{pH}$.

A presença de óxidos de Al, Fe, Mn, hidróxidos, carbonatos, fosfatos e argilominerais influenciam fortemente na concentração dos metais pesados na solução do solo, pois podem remover cátions da solução, através de reações de adsorção, precipitação e complexação. Outras importantes fontes de troca iônica de metais na solução do solo são as argilas, que possuem carga elétrica negativa e não dependente do pH (BOHN; MCNEAL; O'CONNOR, 1985; MCLEAN; BLEDSOE, 1992; STUMM, 1992).

As propriedades físicas, como o tamanho das partículas, cargas elétricas e capacidade de adsorção e, químicas, como raio iônico de seus constituintes minerais, força iônica da solução do solo, $\mathrm{pH}$ e potencial redox determinam o grau de contaminação do solo por metais pesados. Partículas finas são naturalmente mais reativas, pois possuem maior área superficial do que as partículas grosseiras, que tendem a expor a superfície da partícula a um maior grau de hidratação. Como resultado, a fração fina do solo, notadamente a argila, geralmente, concentra a maior parcela da contaminação de metais no solo (MCLEAN; BLEDSOE, 1992; STUMM, 1992; EVANGELOU, 1998). 


\subsection{Experimentos de biolixiviação}

Foram executados oito experimentos, que tiveram por objetivos: avaliar a eficiência do processo de biolixiviação com Acidithiobacillus sp na solubilização dos elementos $\mathrm{B}, \mathrm{Cd}, \mathrm{Pb}$ e $\mathrm{Zn}$, presentes no solo contaminado da área de estudo e, determinar as variáveis limitantes do processo.

A Tabela 23 mostra os teores dos elementos químicos, determinados pela técnica ICP-AES e pela análise elementar, para a amostra de latossolo roxo, que foi utilizada nos experimentos de biolixiviação $n^{\circ} 1, n^{\circ} 2$ e $n^{\circ} 3$.

Os resultados das determinações químicas da amostra de latossolo roxo revelaram que, segundo os critérios adotados pela agência ambiental paulista, ela não estava contaminada, pois os teores de $\mathrm{B}, \mathrm{Cd}, \mathrm{Pb}$ e $\mathrm{Zn}$ eram da mesma ordem de magnitude dos valores de referência admitidos pela CETESB (CETESB, 2005a) para solos naturais: $\mathrm{Pb}$ (17 mg/kg); Cd (<0,5 mg/kg), Zn (60 mg/kg).

Tabela 23 - Teores dos elementos químicos de interesse no solo contaminado.

\begin{tabular}{cc}
\hline Elemento & Teor $(\mathbf{m g} / \mathbf{k g})$ \\
\hline $\mathrm{B}$ & $55,82 \pm 1,19$ \\
$\mathrm{~Pb}$ & $23,2 \pm 0,29$ \\
$\mathrm{Cd}$ & $<0,1$ \\
$\mathrm{Zn}$ & $56,2 \pm 3,58$ \\
$\mathrm{P}$ & $384,75 \pm 1,63$ \\
$\mathrm{~S}$ & $6600 \pm 141,42$ \\
$\mathrm{C}$ & $8100 \pm 152$ \\
$\mathrm{H}$ & $9125 \pm 1096$ \\
$\mathrm{~N}$ & $800 \pm 230$ \\
\hline
\end{tabular}

A análise elementar indicou a presença de $8100 \pm 152 \mathrm{mg} / \mathrm{kg}$ de carbono no solo, sendo o teor de matéria orgânica estimada entre $0,7 \%$ a 1,3\%, condizente com os teores geralmente encontrados em solos tropicais da América do Sul (ALLOWAY, 1995).

Como os teores dos contaminantes no latossolo roxo foram baixos, executou-se uma nova coleta de solo, denominada $n^{\circ} 2$.

A Tabela 24 apresenta os teores dos elementos químicos, determinados pela técnica ICP-AES e pela análise elementar, para a amostra de latossolo vermelho, que foi utilizada em todos os demais experimentos de biolixiviação. 
A análise elementar indicou a presença de $4.890 \pm 766 \mathrm{mg} / \mathrm{kg}$ de carbono no solo, sendo o teor de matéria orgânica de 4,66 \pm 1,15 g/kg. SILVA (2001) analisou amostras de solo nesta área, que continham matéria orgânica na proporção de 0,5 $\% \pm 0,2 \%$, ou seja, $5,0 \pm 2,0 \mathrm{~g} / \mathrm{kg}$.

Os resultados obtidos na investigação de SILVA (2001) divergem significativamente dos obtidos por CETESB (2001b), em particular com relação aos teores máximos observados para $\mathrm{Zn}$ e $\mathrm{Pb}$ no solo da área da Região dos Lagos de Santa Gertrudes. SILVA (2001) relatou valores máximos de $34.706 \mathrm{mg} \mathrm{Pb/kg} \mathrm{e}$ $17.300 \mathrm{mg} \mathrm{Zn/kg}$, enquanto CETESB (2001b), 2.890 mg Pb/kg e 453 mg Zn/kg.

Tabela 24 - Teores dos elementos químicos de interesse na amostra de latossolo vermelho contaminado.

\begin{tabular}{cc}
\hline Elemento & Teor $(\mathbf{m g} / \mathbf{k g})$ \\
\hline $\mathrm{B}$ & $16,08 \pm 8,74$ \\
$\mathrm{~Pb}$ & $634,77 \pm 41,81$ \\
$\mathrm{Cd}$ & $<0,003$ \\
$\mathrm{Zn}$ & $182,76 \pm 13,30$ \\
$\mathrm{P}$ & $270,22 \pm 17,11$ \\
$\mathrm{~S}$ & $<0,05$ \\
$\mathrm{C}$ & $4890 \pm 766$ \\
$\mathrm{H}$ & $6600 \pm 1020$ \\
$\mathrm{~N}$ & $660 \pm 501$ \\
\hline
\end{tabular}

Os teores de $\mathrm{Pb}$ e $\mathrm{Zn}$, relatados por CETESB (2001b), são da mesma ordem de grandeza dos observados nesta pesquisa (Tabela 24), ou seja: $\mathrm{Pb}$ de $270 \mathrm{mg} / \mathrm{kg}$ a $702 \mathrm{mg} / \mathrm{kg}$ e $\mathrm{Zn}$ de $83 \mathrm{mg} / \mathrm{kg}$ a $213 \mathrm{mg} / \mathrm{kg}$.

A massa de íon metálico adsorvido pela superfície de um sólido cresce com o aumento do $\mathrm{pH}$, devido às substâncias húmicas, argilas ou misturas de argilas e ácido húmico. A massa de íons metálicos adsorvidos em meio ácido cresce com o $\mathrm{pH}$ até que um valor limite, requerido para a dissolução parcial do sólido e a formação de complexos humato-metálicos solúveis, seja excedido (EVANGELOU, 1998).

Os complexos organometálicos experimentam três tipos de interações, as quais determinam a solubilidade aparente dos metais em função do $\mathrm{pH}$ : a) prótons competem com cátions pelos sítios ativos; b) $\mathrm{OH}^{-}$compete com substâncias húmicas pelos íons metálicos; c) metais moles competem com metais duros pelos grupos funcionais (VERNET, 1991; EVANGELOU, 1998). 
O material húmico não forma somente complexo com íons metálicos, como também é capaz de reduzir a valência destes cátions. Isto é independente dos fatores ambientais do solo e microrganismos que são conhecidos por terem a mesma capacidade (VERNET, 1991).

As substâncias húmicas também formam complexos fortes com argila. Os mecanismos mais conhecidos de formação destes complexos são (BOHN; MCNEAL; O'CONNOR, 1985; VERNET, 1991; EVANGELOU, 1998):

$\checkmark$ Pelo ânion e ligante de troca para as extremidades da argila;

$\checkmark$ Pelo cátion ou pontes de água pelas superfícies basal da argila;

$\checkmark$ Pela ligação de hidrogênio ao siloxano ou a gipsita;

$\checkmark$ Por forças de van der Walls;

$\checkmark$ Por confinamento nos poros do cristal;

$\checkmark$ Por adsorção nos espaços intercamadas.

A contribuição relativa dos mecanismos de formação dos complexos argilohúmicos é diferente para cada argilomineral (EVANGELOU, 1998).

A matéria orgânica do solo pode ser a principal fonte da capacidade de troca catiônica do mesmo, contribuindo com mais de $200 \mathrm{meq} / 100 \mathrm{~g}$ em solos superficiais. Como o conteúdo de matéria orgânica decresce com o aumento da profundidade, o solo superficial é o mais importante em termos de sorção (BOHN; MCNEAL; O'CONNOR, 1985; MCLEAN; BLEDSOE, 1992; STUMM, 1992).

\subsubsection{Experimento $n^{\circ} 1$}

A Figura 34 mostra o monitoramento do $\mathrm{pH}$ para todos os reatores que receberam inóculo de $A$. ferrooxidans e a Figura 35, para dois reatores com mesma concentração de solo, onde apenas um deles recebeu o inóculo. 


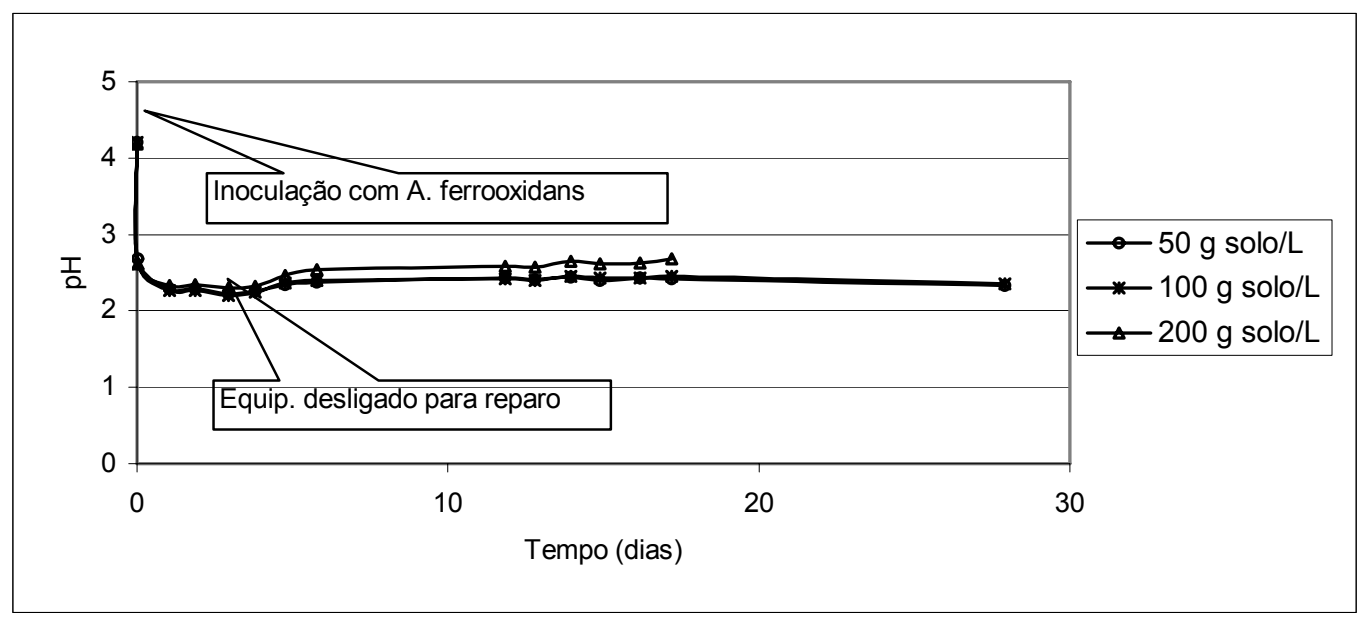

Figura 34 - Resultados do ensaio para avaliação do desempenho da biolixiviação, utilizando $A$. ferrooxidans, em diferentes concentrações de solo, realizado em temperatura ambiente.

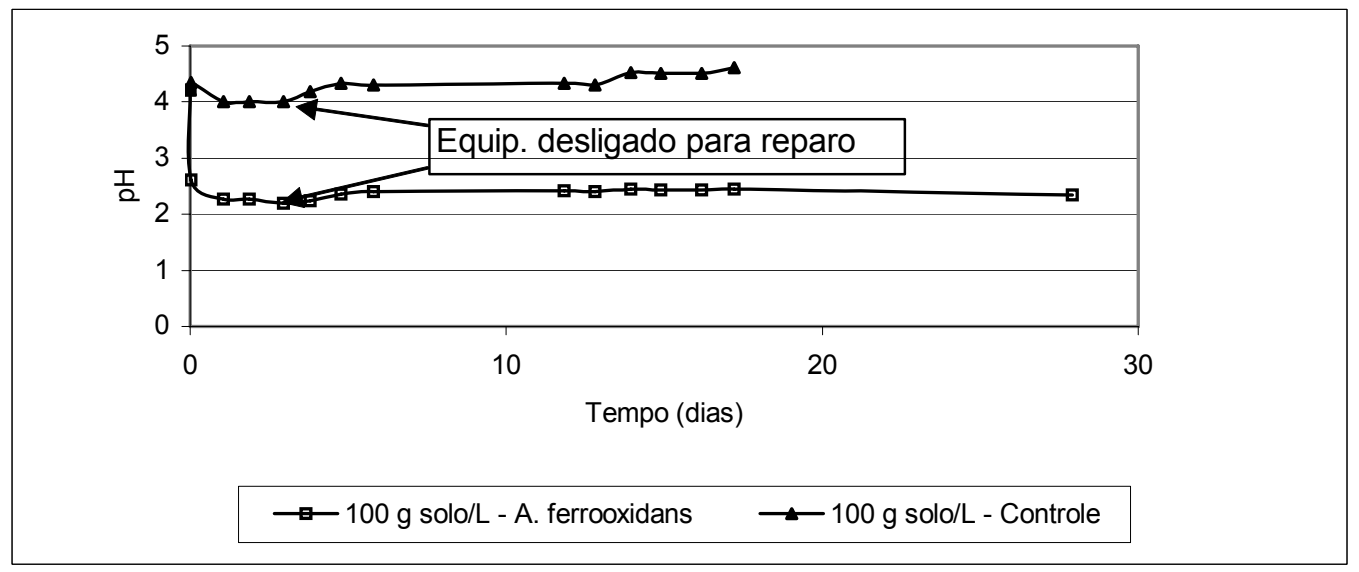

Figura 35 - Comportamento do $\mathrm{pH}$ em reatores de $100 \mathrm{~g}$ solo/L com e sem a introdução de suspensão bacteriana (controle).

Inicialmente, o $\mathrm{pH}$ do solo foi ajustado para 4,5, pois a literatura (CHARTIER; COUILLARD, 1997; BRANDL; BOSSHARD; WEGMANN, 2001; KREBS; BACHOFEN; BRANDL, 2001; ZAGURY; NARASIAH; TYAGI, 2001) recomendava este valor. Em seguida, foi adicionado o inóculo e verificou-se que o $\mathrm{pH}$ do solo sofreu uma redução, passando a 2,5.

A partir deste momento, se houvesse um crescimento do A. ferrooxidans, segundo a literatura (BRANDL; BOSSHARD; WEGMANN, 2001; KREBS; BACHOFEN; BRANDL, 2001; ZAGURY; NARASIAH; TYAGI, 2001; etc), verificar-seia uma redução do pH ao longo do tempo, o que não ocorreu (Figuras 34 e 35).

Diante dos resultados obtidos neste experimento, admitiram-se as seguintes hipóteses, a serem verificadas nos próximos ensaios: 
a) Não havia substrato disponível para suportar o crescimento bacteriano: $\mathrm{Fe}^{2+}$, sulfetos ou enxofre elementar. Se havia substrato, a produção de $\mathrm{H}_{2} \mathrm{SO}_{4}$ não tinha sido suficiente para causar um abaixamento no valor do $\mathrm{pH}$;

b) A quantidade de células adicionada foi insuficiente.

A abrupta redução do pH após a inoculação, provavelmente, deveu-se ao $\mathrm{H}_{2} \mathrm{SO}_{4}$ presente na suspensão bacteriana, pois esta foi utilizada sem qualquer tratamento para separar as células do ácido produzido durante o crescimento celular. Com relação à redução do $\mathrm{pH}$ ao longo do tempo, decidiu-se avaliar melhor seu comportamento.

\subsubsection{Experimento $n^{\circ} 2$}

No experimento $n^{\circ} 2$, foram testadas as hipóteses admitidas no $n^{\circ} 1$, quais sejam: adição múltipla de inóculo e do substrato enxofre $\left(S^{0}\right)$.

A adição do enxofre não resultou em alteração perceptível no valor do $\mathrm{pH}$ dos reatores que o receberam. Este fato poderia ter como causas: a quantidade reduzida de enxofre introduzida ou a curta duração do experimento. Mesmo que o enxofre tivesse sido integralmente convertido em $\mathrm{H}_{2} \mathrm{SO}_{4}$, este poderia não produzir um rebaixamento significativo nos valores do $\mathrm{pH}$ dos conteúdos dos reatores, uma vez que estes já estavam abaixo de 2,5.

As três adições de suspensão bacteriana, apesar de terem sido de mesmo volume e conterem a mesma densidade de células, resultaram em reduções decrescentes nos valores do $\mathrm{pH}$. Este comportamento corroborou as observações do experimento $\mathrm{n}^{\circ} 1$, quanto à redução imediata do $\mathrm{pH}$ devido ao $\mathrm{H}_{2} \mathrm{SO}_{4}$ presente na suspensão bacteriana e indicou que à medida que o $\mathrm{pH}$ se aproximava do valor 2,0 era necessário uma maior quantidade de ácido para a sua redução.

As Figuras 36 e 37 mostram o comportamento do $\mathrm{pH}$ ao longo do tempo para as diferentes concentrações de solo utilizadas neste experimento. 


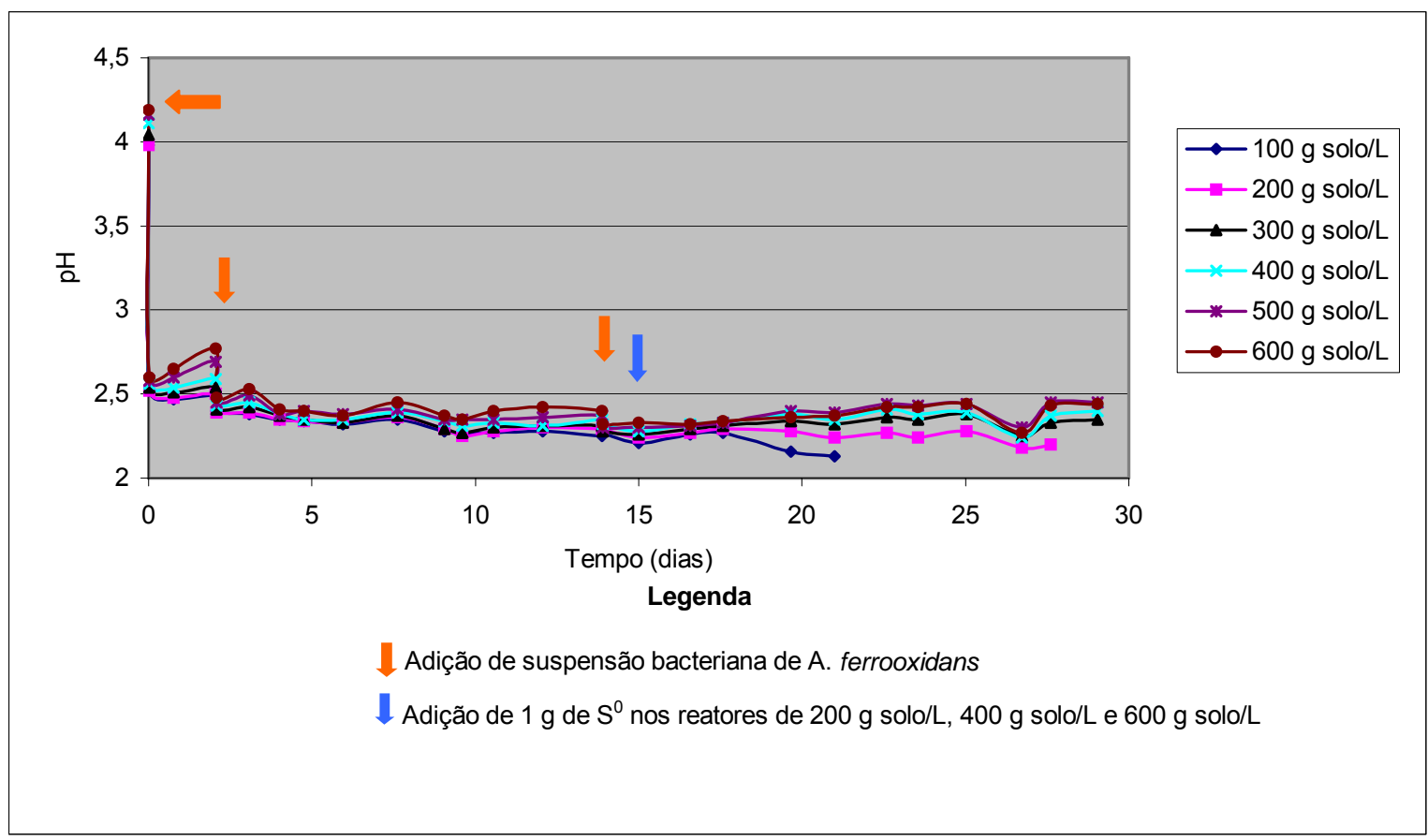

Figura 36 - Resultados do ensaio para avaliação do desempenho da biolixiviação, utilizando A. ferrooxidans em diferentes concentrações de solo.

A partir da observação do comportamento do $\mathrm{pH}$ nos experimentos $\mathrm{n}^{\circ} 1$ e $\mathrm{n}^{\circ}$ 2 e da constatação de que a adição sucessiva de inóculo resultava em reduções de $\mathrm{pH}$ decrescentes, decidiu-se determinar a curva de ajuste de $\mathrm{pH}$ da amostra de latossolo roxo. A Figura 38 mostra tal curva, que comprova a necessidade de uma grande quantidade de ácido para produzir uma pequena redução no valor do $\mathrm{pH}$ a partir de 2,0.

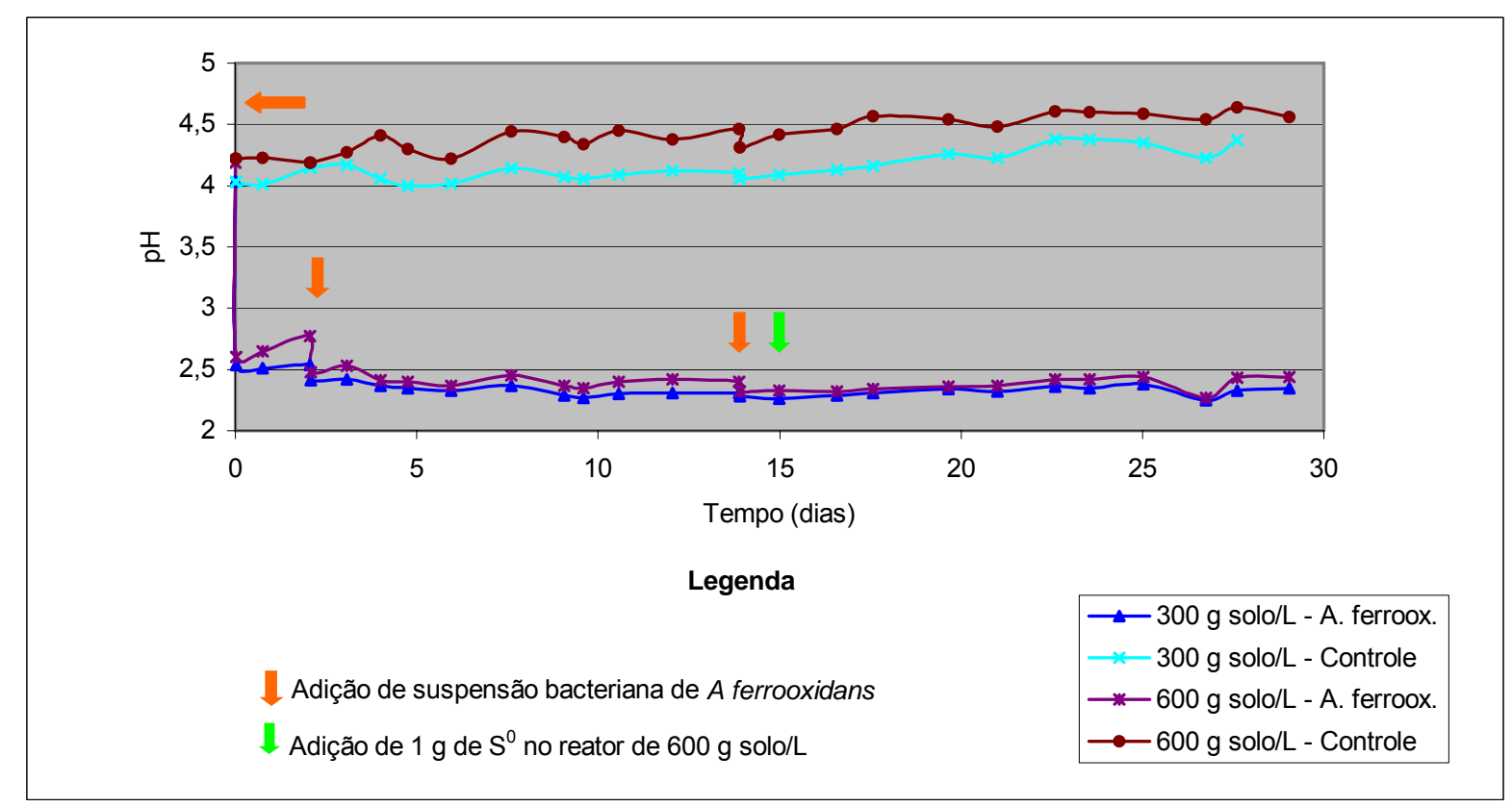

Figura 37 - Comportamento do $\mathrm{pH}$ ao longo do tempo nos reatores contendo $300 \mathrm{~g}$ solo/L e $600 \mathrm{~g}$ solo/L, com e sem a introdução de suspensão bacteriana. 


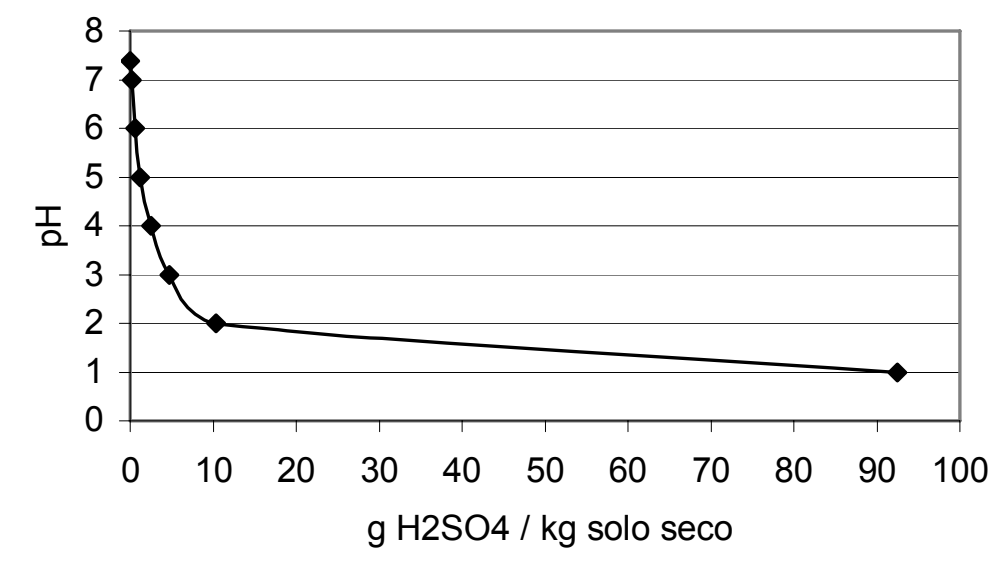

Figura 38 - Curva de ajuste de $\mathrm{pH}$ da amostra de latossolo roxo.

A Figura 38 comprova a hipótese considerada no experimento $n^{\circ} 1$, de que a produção de $\mathrm{H}_{2} \mathrm{SO}_{4}$ é insuficiente para abaixar o $\mathrm{pH}$ aquém de 2,5. O solo utilizado no presente estudo possui baixa capacidade de tamponamento para ácidos até $\mathrm{pH}=$ 3,0, o que não ocorre abaixo deste valor. Portanto, as bactérias deveriam produzir uma grande quantidade de $\mathrm{H}_{2} \mathrm{SO}_{4}$ para abaixar o $\mathrm{pH}$ da amostra de solo a valores inferiores a 2,5.

\subsubsection{Experimento $n^{\circ} 3$}

Há consenso que os principais parâmetros que governam e afetam a biolixiviação são o pH, o potencial redox, a temperatura, a densidade da polpa, a composição mineralógica do material a ser lixiviado, a afinidade da espécie de Acidithiobacillus $s p$ ao(s) metal(is) alvo(s), a atividade do próprio microrganismo, a capacidade de tamponamento do material contaminado, a presença de espécies indígenas de Acidithiobacillus sp no meio, a disponibilidade de compostos reduzidos de enxofre e de alguma fonte de carbono no meio (CHARTIER; COUILLARD, 1997; KREBS et alii, 1997; KREBS; BACHOFEN; BRANDL, 2001; BRANDL; BOSSHARD; WEGMANN, 2001; DOBLER et alii, 2001).

Assim, o experimento $n^{\circ} 3$ foi realizado com a adição de nutrientes, com e sem inóculo, com diferentes concentrações de solo, com as duas espécies de 
Acidithiobacillus sp e monitoramento do $\mathrm{pH}$ por 60 dias, este último em função da dúvida sobre a duração do ensaio, mencionada no item anterior.

As Figuras 39 e 40 mostram, respectivamente, a evolução do pH ao longo do tempo para as diferentes concentrações de solo e a comparação da evolução do $\mathrm{pH}$ nos reatores com mesma concentração de solo, onde apenas um deles recebeu a suspensão bacteriana. Ambas as figuras referem-se aos experimentos com $A$. ferrooxidans.

As Figuras 41 e 42 mostram, respectivamente, a evolução do $\mathrm{pH}$ ao longo do tempo para as diferentes concentrações de solo e a comparação da evolução do $\mathrm{pH}$ nos reatores com mesma concentração de solo, onde apenas um deles recebeu suspensão bacteriana. Ambas as figuras referem-se aos experimentos com $A$. thiooxidans.

$\mathrm{O} \mathrm{pH}$, tanto nos reatores do experimento com $A$. ferrooxidans quanto nos com A. thiooxidans, apresentou o mesmo comportamento observado no experimento $\mathrm{n}^{\circ} 2$, ou seja, a múltipla adição da suspensão bacteriana resultou em reduções cada vez menores no valor do $\mathrm{pH}$.

A influência da concentração de solo na suspensão, submetida ao processo de biolixiviação, independente da espécie de Acidithiobacillus sp utilizada, é evidenciada nas Figuras 39 e 41.

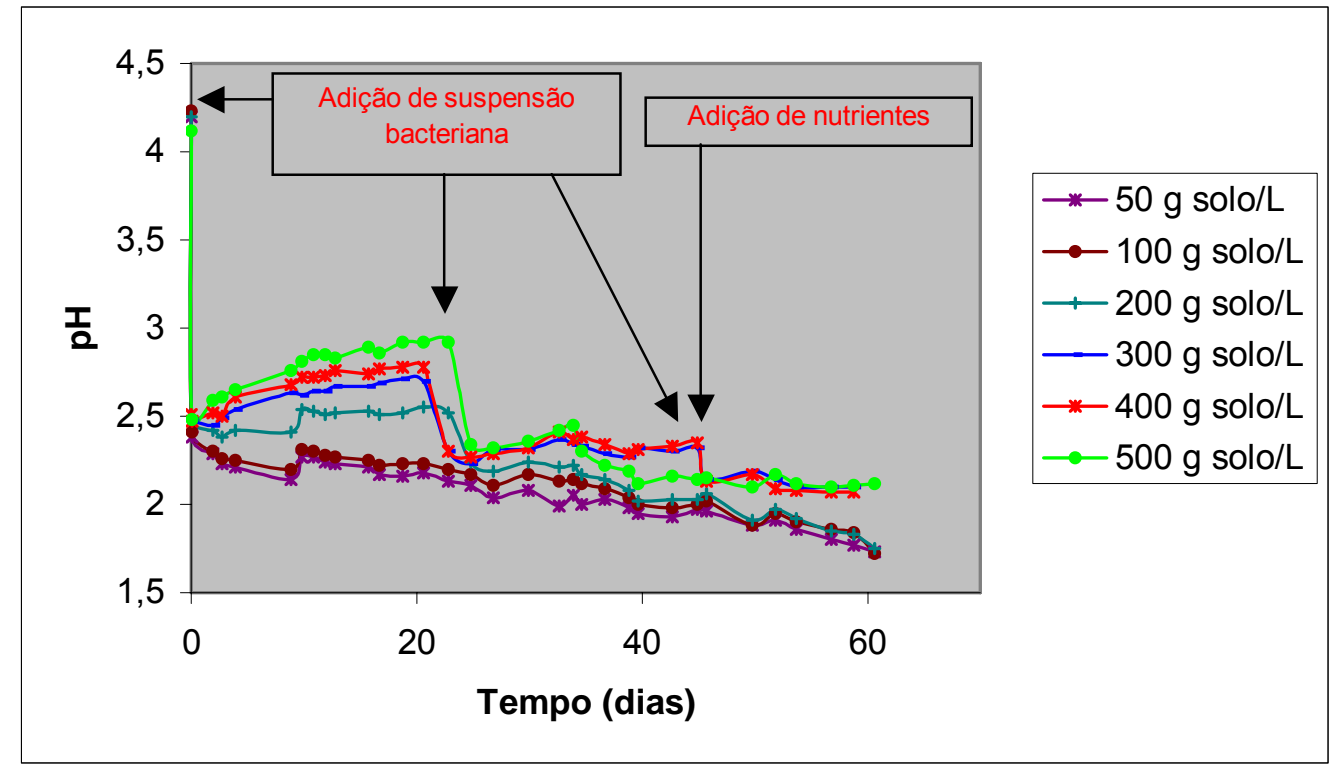

Figura 39 - Evolução do $\mathrm{pH}$ ao longo do tempo durante o processo de biolixiviação com $A$. ferrooxidans - experimento $n^{\circ} 3$. 


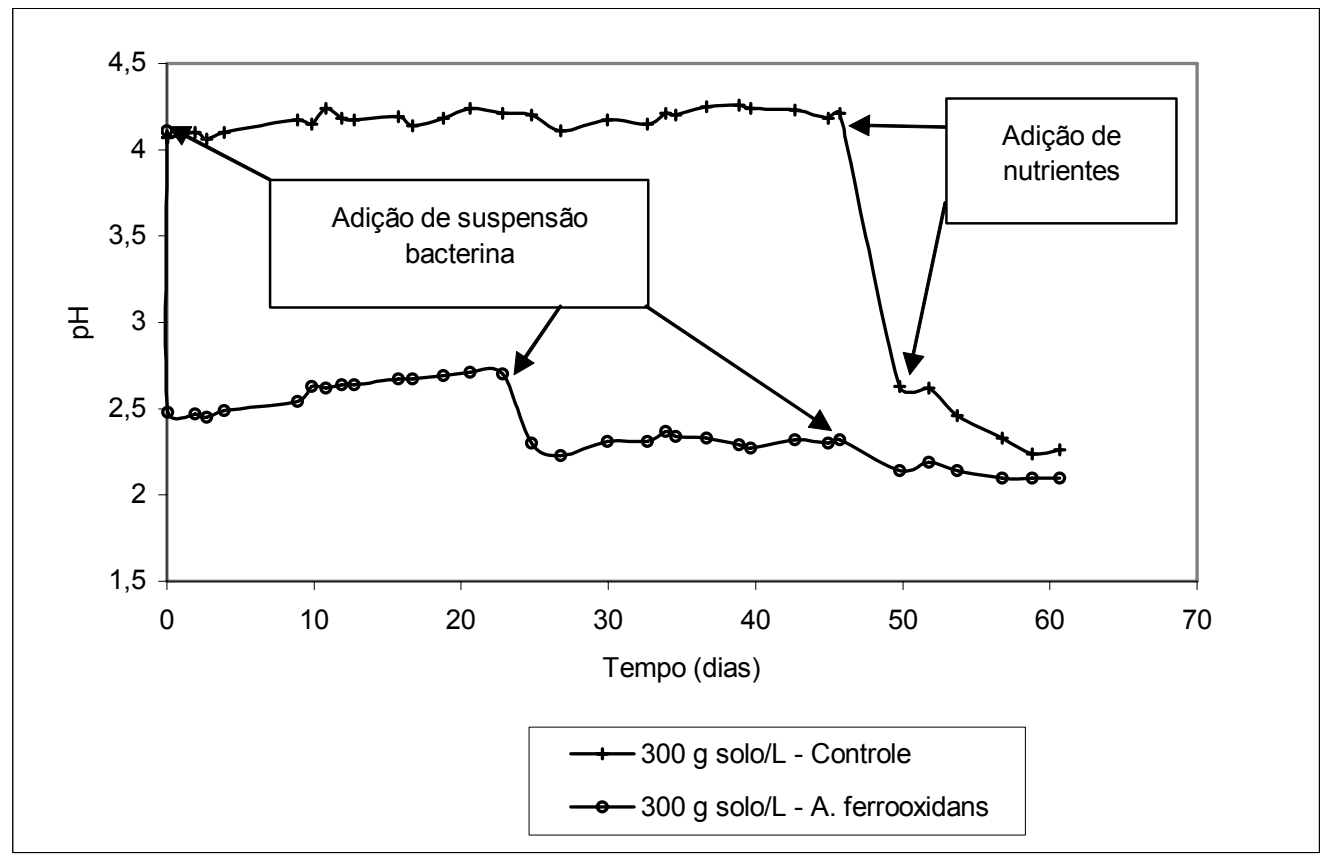

Figura 40 - Comportamento do $\mathrm{pH}$ dos reatores com $300 \mathrm{~g}$ solo/ $\mathrm{L}$ ao longo do tempo, com e sem a introdução de suspensão bacteriana de $A$. ferrooxidans.

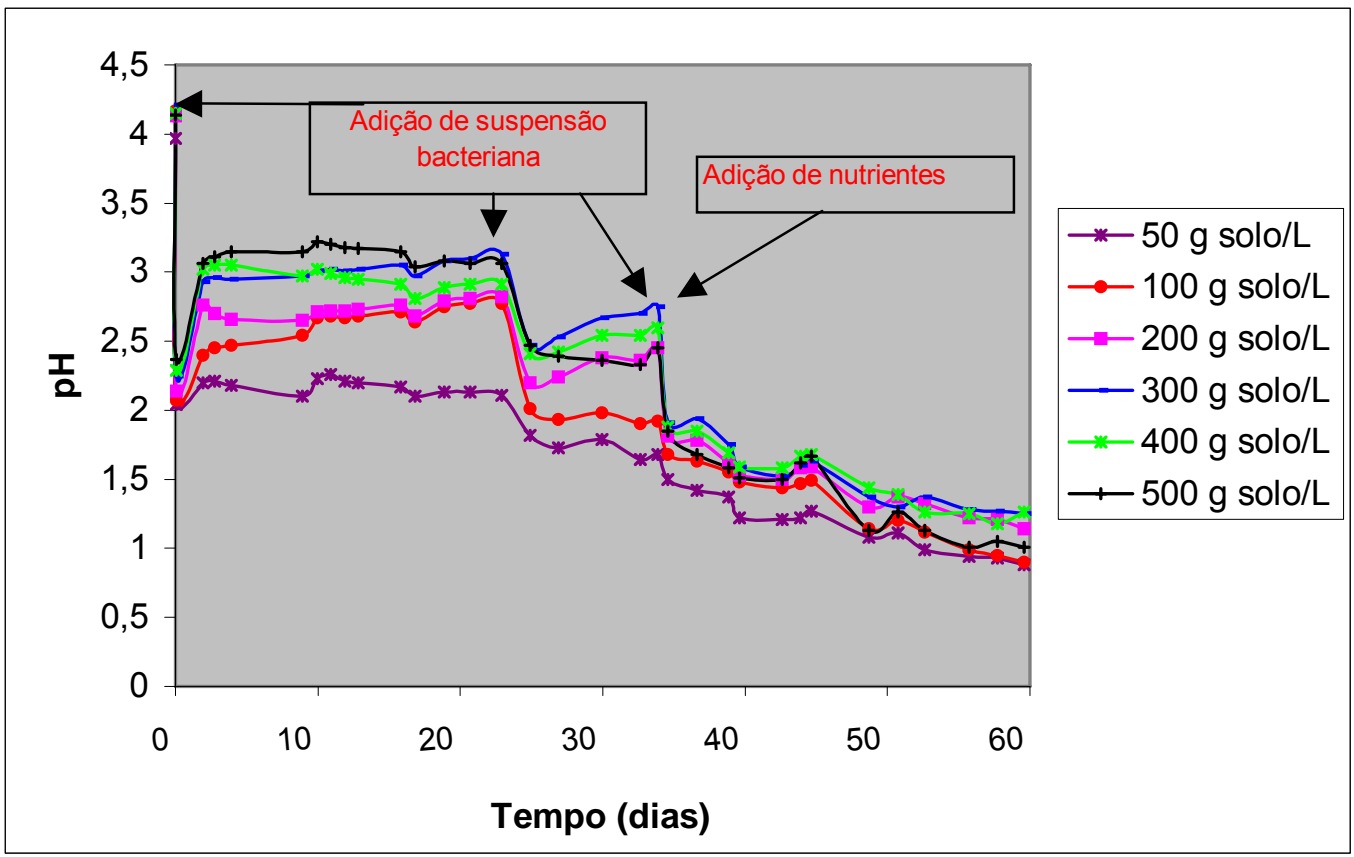

Figura 41 - Evolução do $\mathrm{pH}$ ao longo do tempo durante o processo de biolixiviação com $A$. thiooxidans - experimento $n^{\circ} 3$. 


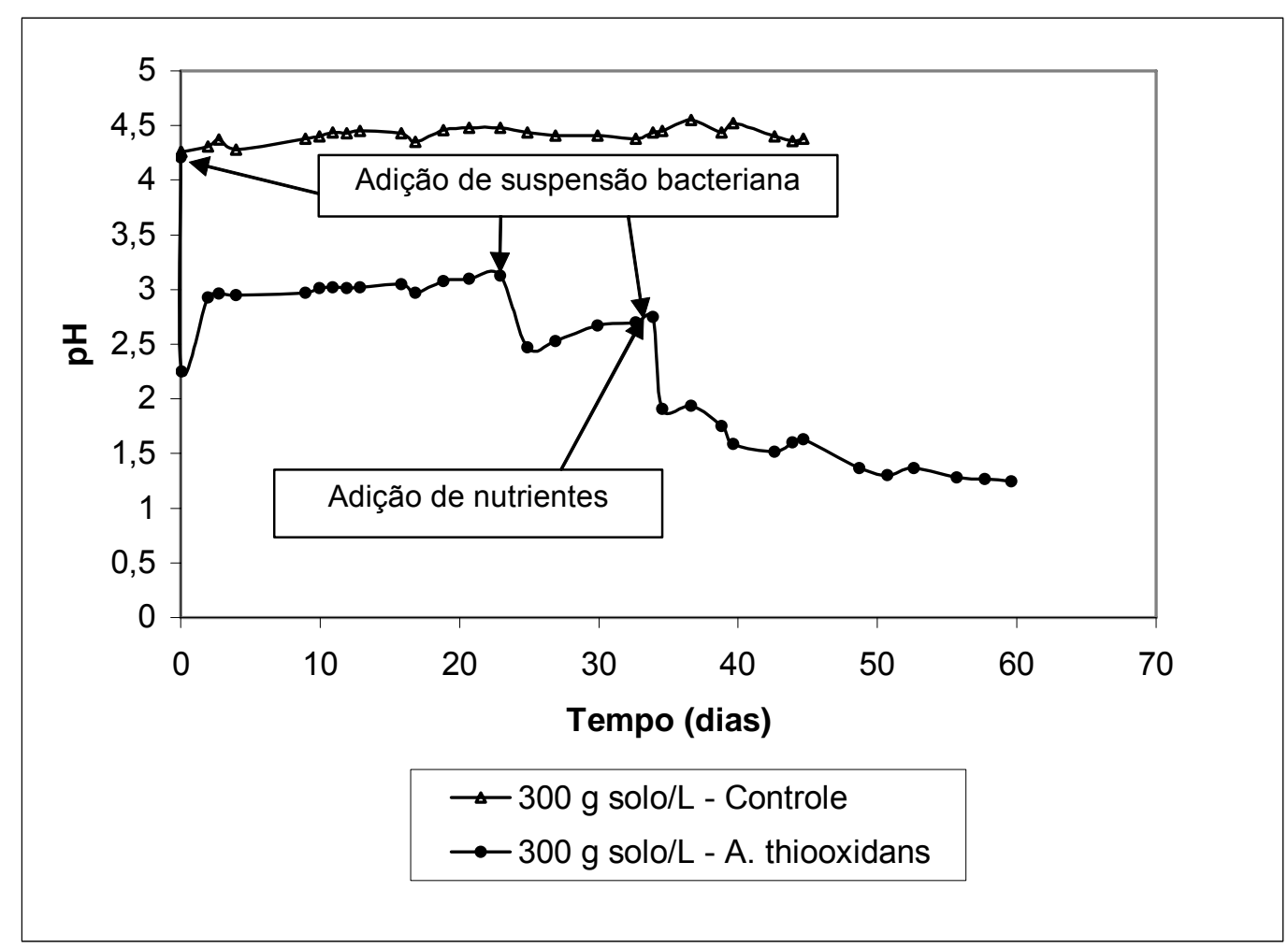

Figura 42 - Comportamento do $\mathrm{pH}$ dos reatores com $300 \mathrm{~g}$ solo/L ao longo do tempo, com e sem a introdução de suspensão bacteriana de $A$. thiooxidans.

$O$ efeito da adição dos nutrientes é evidenciado na Figura 39, onde se pode observar uma abrupta redução no valor do pH do reator controle após a introdução dos mesmos. Nesta mesma figura, observou-se um decréscimo muito menor no valor do $\mathrm{pH}$ do reator com $A$. ferrooxidans, sendo que tal decréscimo deve-se ao efeito combinado dos nutrientes e do ácido presente na suspensão bacteriana. $A$ razão deste menor decréscimo foi a dificuldade de reduzir o $\mathrm{pH}$ a valores abaixo de 2,0, característica intrínseca da amostra de solo utilizada no presente estudo.

As reações de hidrólise, o pH e as condições de óxido-redução são fatores que tendem a alterar, às vezes, sensivelmente, o equilíbrio das reações de dissolução/precipitação (CAMARGO; ALLEONI; CASAGRANDE, 2001). ĺons como fosfato, sulfato, sulfito e carbonato podem interferir nas relações de solubilidade dos elementos metálicos e formar precipitados pouco solúveis (STUMM, 1992; EVANGELOU, 1998).

A maior parte dos metais divalentes forma fosfato com fórmula geral $\mathrm{M}_{3}\left(\mathrm{PO}_{4}\right)_{2} \mathrm{nH}_{2} \mathrm{O}$, onde $\mathrm{M}$ é o metal e $\mathrm{n}$ o número de moléculas de água. Em meio ácido, pode ocorrer a Reação 10 (CAMARGO; ALLEONI; CASAGRANDE, 2001):

$\mathrm{M}_{3}(\mathrm{II})\left(\mathrm{PO}_{4}\right)_{2} \mathrm{nH}_{2} \mathrm{O}+4 \mathrm{H}^{+} \leftrightarrow 3 \mathrm{M}^{2+}+2 \mathrm{H}_{2} \mathrm{PO}_{4}^{-}+\mathrm{nH}_{2} \mathrm{O}$ 
Além disso, os nutrientes utilizados no experimento $n^{\circ} 3$ podem ter sofrido as seguintes reações de hidrólise:

a) Sulfato de magnésio:

$\mathrm{MgSO}_{4} \cdot 7 \mathrm{H}_{2} \mathrm{O}+\mathrm{H}_{2} \mathrm{O} \rightarrow \mathrm{Mg}^{2+}+\mathrm{SO}_{4}{ }^{2-}$

b) Sulfato ferroso heptahidratado

$\mathrm{FeSO}_{4} .7 \mathrm{H}_{2} \mathrm{O}+\mathrm{H}_{2} \mathrm{O} \rightarrow \mathrm{Fe}^{2+}+\mathrm{SO}_{4}{ }^{2-}+8 \mathrm{H}_{2} \mathrm{O}$

A oxidação do $\mathrm{Fe}^{2+}$ pode ocorrer naturalmente na presença do ar ou ser catalisada biologicamente (SIENKO, 1974; CHARTIER; COUILLARD, 1997).

$2 \mathrm{Fe}^{2+}+1 / 2 \mathrm{O}_{2}+2 \mathrm{H}^{+} \leftrightarrow \mathrm{Fe}^{3+}+\mathrm{H}_{2} \mathrm{O}$

Já o $\mathrm{Fe}^{3+}$ sofre as seguintes reações com a água:

$\mathrm{Fe}^{3+}+\mathrm{H}_{2} \mathrm{O} \leftrightarrow \mathrm{Fe}(\mathrm{OH})^{+}+\mathrm{H}^{+}, \log \mathrm{K}=-3,0$

$\mathrm{Fe}^{3+}+2 \mathrm{H}_{2} \mathrm{O} \leftrightarrow \mathrm{Fe}(\mathrm{OH})_{2}{ }^{+}+2 \mathrm{H}^{+}, \log \mathrm{K}=-6,4$

$2 \mathrm{Fe}^{3+}+2 \mathrm{H}_{2} \mathrm{O} \leftrightarrow \mathrm{Fe}_{2}(\mathrm{OH})_{2}{ }^{4+}+2 \mathrm{H}^{+}, \log \mathrm{K}=-3,1$

$\mathrm{Fe}^{3+}+3 \mathrm{H}_{2} \mathrm{O} \leftrightarrow \mathrm{Fe}(\mathrm{OH})_{3}+3 \mathrm{H}^{+}, \log \mathrm{K}=-13,5$

$\mathrm{Fe}^{3+}+4 \mathrm{H}_{2} \mathrm{O} \leftrightarrow \mathrm{Fe}(\mathrm{OH})_{3}{ }^{-}+4 \mathrm{H}^{+}, \log \mathrm{K}=-23,5$

$\mathrm{Fe}(\mathrm{OH})_{3 \mathrm{p}} \leftrightarrow \mathrm{Fe}^{3+}{ }_{(\mathrm{aq})}+3 \mathrm{OH}^{-}{ }_{(\mathrm{aq})}, \log \mathrm{K}=-37,5$

c) Sulfato de amônio

$\left(\mathrm{NH}_{4}\right)_{2} \mathrm{SO}_{4}+\mathrm{H}_{2} \mathrm{O} \rightarrow 2 \mathrm{NH}_{4}{ }^{+}+\mathrm{SO}_{4}{ }^{2-}$

$2 \mathrm{NH}_{4}^{+}+2 \mathrm{H}_{2} \mathrm{O} \leftrightarrow 2 \mathrm{NH}_{4}(\mathrm{OH})+2 \mathrm{H}^{+}$

d) Ácido sulfúrico

$\mathrm{H}_{2} \mathrm{SO}_{4}+\mathrm{H}_{2} \mathrm{O} \rightarrow \mathrm{HSO}_{4}{ }^{-}+\mathrm{H}_{2} \mathrm{O}+\mathrm{H}^{+}$

$\mathrm{O}$ efeito dos nutrientes sobre o $\mathrm{pH}$, embora evidente nos reatores do experimento com $A$. ferrooxidans, não pôde ser avaliado para os reatores do experimento com $A$. thiooxidans, pois estes não foram adicionados.

O prolongamento da duração do experimento $n^{\circ} 3$ (em relação aos $n^{0} 1$ e $n^{\circ}$ 2) possibilitou observar uma tendência de redução no valor do $\mathrm{pH}$, comportamento este que pode ser constatado na Figura 39. Esta tendência de decréscimo no valor do $\mathrm{pH}$ pode sugerir um aumento da atividade bacteriana, pois ele somente pode ser explicado pela geração de $\mathrm{H}_{2} \mathrm{SO}_{4}$ pela atividade do Acidithiobacillus sp.

Este foi o primeiro experimento, onde foram executadas análises químicas do solo tratado e do lixiviado. A análise dos resultados permite concluir que houve algum tipo de erro nas determinações do elemento $B$, pois seus teores foram maiores no solo tratado do que no natural. A lixiviação do B dos frascos de vidro, 
utilizados como reatores-testes, poderia explicar o maior teor deste elemento ao final do experimento. Entretanto, a pequena quantidade de solo utilizada não permitiu a repetição das determinações químicas. As Tabelas 25 e 26 mostram, respectivamente, os resultados das determinações químicas para o lixiviado e o solo tratado produzidos ao final do experimento $n^{\circ} 3 \mathrm{com} A$. ferrooxidans.

Tabela 25 - Concentrações dos elementos químicos de interesse no lixiviado produzido ao final do experimento $n^{\circ} 3 \operatorname{com} A$. ferrooxidans.

\begin{tabular}{cccccccc}
\hline \multirow{2}{*}{ Elemento } & \multicolumn{7}{c}{ Concentração do elemento no lixiviado (mg/L) } \\
& $\mathbf{5 0}$ & $\mathbf{1 0 0}$ & $\mathbf{2 0 0}$ & $\mathbf{3 0 0}$ & $\mathbf{3 0 0}$ * & $\mathbf{4 0 0}$ & $\mathbf{5 0 0}$ \\
\hline $\mathrm{B}$ & 22,39 & 8,3 & 12,59 & 0,359 & 0,657 & 0,419 & 0,219 \\
$\mathrm{~Pb}$ & $<0,0043$ & $<0,0043$ & $<0,0043$ & $<0,0043$ & $<0,0043$ & $<0,0043$ & $<0,0043$ \\
$\mathrm{Cd}$ & $<0,0014$ & $<0,0014$ & $<0,0014$ & 0,005 & 0,013 & 0,003 & 0,009 \\
$\mathrm{Zn}$ & 0,866 & 0,976 & 1,43 & 1,213 & 1,491 & 1,462 & 1,388 \\
\hline
\end{tabular}

Nota:

* = Reator controle - não recebeu inóculo de A. ferrooxidans.

Tabela 26 - Teores dos elementos químicos de interesse no solo tratado produzido ao final do experimento $\mathrm{n}^{\circ} 3 \mathrm{com} A$. ferrooxidans.

\begin{tabular}{|c|c|c|c|c|c|c|c|c|}
\hline \multirow[t]{2}{*}{ Elemento } & \multirow{2}{*}{$\begin{array}{c}\text { solo } \\
\text { natural }\end{array}$} & \multicolumn{7}{|c|}{$\begin{array}{l}\text { Teor do elemento (mg/kg) } \\
\text { Concentração de solo (g/L) }\end{array}$} \\
\hline & & 50 & 100 & 200 & 300 & $300 *$ & 400 & 500 \\
\hline$B$ & 55,82 & 187,6 & 94,3 & 108,15 & 20,3 & 54,9 & 15,65 & 14,9 \\
\hline $\mathrm{Pb}$ & 23,2 & 15,85 & 17,4 & 16,8 & 21,65 & 23,15 & 22,3 & 23,75 \\
\hline $\mathrm{P}$ & 384,75 & 669,65 & 554,4 & 550 & 424 & 384,75 & 408 & 372 \\
\hline $\mathrm{Cd}$ & $<0,1$ & $<0,1$ & $<0,1$ & $<0,1$ & $<0,1$ & $<0,1$ & $<0,1$ & $<0,1$ \\
\hline $\mathrm{Zn}$ & 56,2 & 47,3 & 41,1 & 41,3 & 41,4 & 53,9 & 41,45 & 55,2 \\
\hline$S$ & 6600 & 29700 & 16250 & 20450 & 7200 & 6600 & 7400 & 6850 \\
\hline C & 8100 & 16050 & 9800 & 9950 & 7550 & 7500 & 7300 & 7600 \\
\hline $\mathrm{H}$ & 9125 & 8850 & 8900 & 10050 & 8400 & 8700 & 9200 & 7850 \\
\hline $\mathrm{N}$ & 800 & 2900 & 1100 & 1200 & 1150 & 1000 & 900 & 950 \\
\hline
\end{tabular}

As Tabelas 27 e 28 apresentam, respectivamente, os resultados das determinações químicas para o lixiviado e o solo tratado produzidos ao final do experimento $\mathrm{n}^{\circ} 3 \mathrm{com} A$. thiooxidans.

Os teores observados para os elementos $\mathrm{Pb}$ e $\mathrm{Zn}$ no solo da região dos lagos situaram-se muito abaixo dos limites legais vigentes (CETESB, 2005a) para prevenção de contaminação do solo, ou seja, $72 \mathrm{mg} \mathrm{Pb/kg} \mathrm{e} 300 \mathrm{mg} \mathrm{Zn/kg}$. 
Oportuno citar que os valores de prevenção são inferiores aos fixados para intervenção, logo, a amostra de latossolo roxo utilizado neste experimento não é legalmente considerado contaminado, como já exposto anteriormente. Este foi o último experimento a utilizar o latossolo roxo, todos os executados posteriormente usaram o latossolo vermelho, que apresentava teores mais elevados dos elementos alvos.

A solubilização de cada elemento pode ser afetada pela concentração de solo na suspensão, pois quanto maior a quantidade de solo, maior poderá ser a concentração do elemento na fase líquida, a qual será limitada pelo produto de solubilidade das possíveis substâncias formadas por cada elemento nas mesmas condições físico-químicas.

Tabela 27 - Concentrações dos elementos químicos de interesse no lixiviado ao final do experimento $n^{\circ} 3 \mathrm{com} A$. thiooxidans.

\begin{tabular}{|c|c|c|c|c|c|c|c|}
\hline \multirow{3}{*}{ Elemento } & \multicolumn{7}{|c|}{ Concentração do elemento no lixiviado (mg/L) } \\
\hline & \multicolumn{7}{|c|}{ Concentração de solo (g/L) } \\
\hline & 50 & 100 & 200 & 300 & 300 * & 400 & 500 \\
\hline$B$ & 21,19 & 41,74 & 22,76 & 4,72 & 3,059 & 1,031 & 24,68 \\
\hline $\mathrm{Pb}$ & 0,292 & 0,667 & 0,695 & 1,006 & 0,42 & 1,093 & $<0,0043$ \\
\hline $\mathrm{Cd}$ & $<0,0014$ & $<0,0014$ & 0,003 & 0,005 & 0,01 & 0,006 & $<0,0014$ \\
\hline $\mathrm{Zn}$ & 1,303 & 2,336 & 1,58 & 2,008 & 1,689 & 2,405 & 1,3 \\
\hline
\end{tabular}

Conforme mostram as Tabelas 26 e 28, a eficiência na remoção do Zn dependeu da concentração de solo na suspensão e atingiu valores máximos de 1,49 $\mathrm{mg} / \mathrm{L}$ para o experimento com $A$. ferrooxidans (reator controle e teor de sólidos de $300 \mathrm{~g} / \mathrm{L})$.

A lixiviação biológica foi ligeiramente mais eficiente na remoção do $\mathrm{Zn}$ do que a lixiviação química. Entretanto, as reduzidas diferenças de eficiência de remoção obtidas pelos dois tipos de lixiviação não permitem afirmar conclusivamente qual dos processos foi mais eficiente.

Análogo ao obtido no experimento com $A$. ferrooxidans, a eficiência da biolixiviação com $A$. thiooxidans na remoção de metais foi dependente da concentração de solo na suspensão. Entretanto, o $A$. thiooxidans foi mais eficiente na remoção do $\mathrm{Zn}$ do que o $A$. ferrooxidans, pois se conseguiu a solubilização de 2,4 $\mathrm{mg} / \mathrm{L}$ no reator com $400 \mathrm{~g}$ solo/L. 
Tabela 28 - Teores dos elementos químicos de interesse no solo tratado ao final do experimento $n^{\circ} 3 \operatorname{com} A$. thiooxidans.

\begin{tabular}{ccccccccc}
\hline \multirow{2}{*}{ Elemento } & solo & \multicolumn{8}{c}{ Teor do elemento (mg/kg) } \\
& natural & \multicolumn{8}{c}{ Concentração de solo (g/L) } \\
& & $\mathbf{5 0 *}$ & $\mathbf{1 0 0}$ & $\mathbf{2 0 0}$ & $\mathbf{3 0 0}$ & $\mathbf{3 0 0} * *$ & $\mathbf{4 0 0}$ & $\mathbf{5 0 0}$ \\
\hline $\mathrm{B}$ & 55,82 & - & 210,65 & 157,65 & 62,7 & 56,75 & 28,75 & 10,55 \\
$\mathrm{~Pb}$ & 23,2 & - & 15,05 & 19,3 & 21,8 & 23,25 & 21,7 & 25 \\
$\mathrm{P}$ & 384,75 & - & 651,15 & 516,7 & 479,2 & 316,55 & 476,2 & 436,65 \\
$\mathrm{Cd}$ & $<0,1$ & - & $<0,1$ & $<0,1$ & $<0,1$ & $<0,1$ & $<0,1$ & $<0,1$ \\
$\mathrm{Zn}$ & 56,2 & - & 40,85 & 54,6 & 62,4 & 58,5 & 53,15 & 56,1 \\
$\mathrm{~S}$ & 6600 & - & 42150 & 21350 & 15750 & 6900 & 19250 & 35450 \\
$\mathrm{C}$ & 8100 & - & 16950 & 10350 & 8800 & 8200 & 9200 & 5800 \\
$\mathrm{H}$ & 9125 & - & 12550 & 11600 & 9900 & 8850 & 10500 & 11750 \\
$\mathrm{~N}$ & 800 & - & 1100 & 1750 & 800 & 600 & 1050 & 4850 \\
\hline
\end{tabular}

Nota:

* = A massa final de solo do reator não foi suficiente para a realização das determinações químicas.

${ }^{* *}=$ Reator controle - não recebeu inóculo de $A$. thiooxidans.

Os resultados fornecidos pelo experimento $n^{\circ} 3$ mostram que houve solubilização parcial dos metais. A análise das eficiências de remoção dos elementos $\mathrm{Pb}$ e $\mathrm{Zn}$, nos experimentos que utilizaram $A$. ferrooxidans e $A$. thiooxidans, não permitiu identificar uma faixa ótima de teor de sólidos nem qual das duas espécies seria a mais eficiente para estes elementos.

Fato que merece citação é a eficiência de remoção obtida nos reatores controle, pois mesmo sem a presença do Acidithiobacillus $s p$, observou-se significativa eficiência de remoção para todos os elementos, se comparada à obtida nos reatores de mesmo teor de sólidos que receberam inóculos.

De modo geral, apesar da ocorrência da solubilização dos elementos, as eficiências de remoção foram baixas, em particular a do $\mathrm{Pb}$, mesmo em meio estritamente ácido. Esta constatação suscitou questionamentos sobre os mecanismos envolvidos na solubilização dos elementos de interesse deste trabalho, especialmente o $\mathrm{Pb}$.

$\mathrm{O} \mathrm{Pb}$, sob a forma $\mathrm{Pb}^{2+}$, é a mais comum e é capaz de substituir os elementos $\mathrm{Ca}, \mathrm{Sr}, \mathrm{Ba}$ e $\mathrm{K}$ do solo. Sua velocidade de migração no solo é baixa, pois matéria orgânica e óxidos de ferro e alumínio possuem elevado potencial de adsorção, que resultam em sua retenção (MULLIGAN et alii, 2001). A pequena quantidade de matéria orgânica, presente no solo utilizado $(0,81 \%)$, não indica ser 
esta uma importante fonte para complexação do $\mathrm{Pb}$, já os óxidos de ferro e alumínio, ao contrário, estão presentes em expressiva quantidade (respectivamente 18,2 \% e 22,8 \%) e devem desempenhar um papel importante na retenção do $\mathrm{Pb}$ no solo.

Visto que os experimentos foram conduzidos em meio ácido, não é possível que o $\mathrm{Pb}$ tivesse precipitado sob a forma de hidróxido, carbonato, óxido ou fosfato, pois a precipitação de tais formas somente seria possível em condições alcalinas $(\mathrm{pH}>7)$. Além disso, a dissolução destes precipitados metálicos é dependente do $\mathrm{pH}$.

Caso o $\mathrm{Pb}$ estivesse presente no solo sob a forma de sulfeto, o mesmo seria utilizado como fonte de energia pelo $A$. ferrooxidans, e mesmo que nem todo o enxofre fosse utilizado durante o processo, este elemento seria liberado na solução, fenômeno este que não foi evidenciado em nenhum dos experimentos.

Outra possibilidade seria que o $\mathrm{Pb}$ estivesse adsorvido em óxidos hidratados de ferro e manganês, que sabidamente desempenham um papel importante na retenção de metais no solo. Todavia, esta possibilidade também pode ser descartada, pois a solubilidade de tais óxidos é dependente do $\mathrm{pH}$ e em um valor menor que 6,0, estes se dissolvem e liberam os íons metálicos neles adsorvidos para a solução (MCLEAN; BLEDSOE, 1992).

Em meio redutor, o $\mathrm{Pb}$ é pouco solúvel e bastante estável na forma de $\mathrm{PbS}$ (galena) e de $\mathrm{PbSO}_{4}$ (anglesita). Em meio oxidante; $\mathrm{pH} \geq 7$; o $\mathrm{Pb}$ ocorre como $\mathrm{PbCO}_{3}$ (cerusita) (FETTER, 1993).

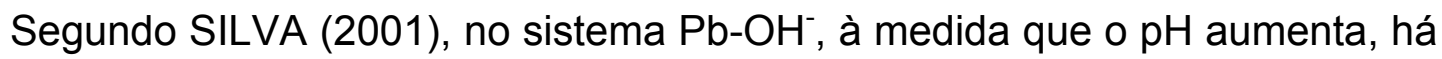
passagem, na solução, de $\mathrm{Pb}^{2+}$ para $[\mathrm{Pb}(\mathrm{OH})]^{+}$, sendo esta espécie predominante no intervalo de $\mathrm{pH}$ de 6 a 10. Em meio alcalino, há formação de $\mathrm{Pb}(\mathrm{OH})_{2},\left[\mathrm{~Pb}(\mathrm{OH})_{3}\right]^{-} \mathrm{e}$ $\left[\mathrm{Pb}(\mathrm{OH})_{4}\right]^{2-}$, este predominante em $\mathrm{pH}>11,5$. O íon $\mathrm{Cl}^{-}$pode ser um agente complexante importante, e competir com os compostos orgânicos. A especiação do sistema $\mathrm{Pb}^{-\mathrm{Cl}^{-}}$é função da concentração de $\mathrm{Cl}^{-}$, predominando $\mathrm{Pb}^{2+}$ em baixas concentrações. À medida que a concentração de $\mathrm{Cl}^{-}$aumenta, são formados $[\mathrm{PbCl}]^{-}$, $\mathrm{PbCl}_{2},\left[\mathrm{PbCl}_{3}\right]^{-}$e $\left[\mathrm{PbCl}_{4}\right]^{-}(\mathrm{ADRIANO}, 1986)$.

Em solos não originários de rochas carbonáceas, a solubilidade do $\mathrm{Pb}$ pode ser regulada por $\mathrm{Pb}(\mathrm{OH})_{2}, \mathrm{~Pb}_{3}\left(\mathrm{PO}_{4}\right)_{2}, \mathrm{~Pb}_{4} \mathrm{O}\left(\mathrm{PO}_{4}\right)_{2}$ ou $\mathrm{Pb}_{5}\left(\mathrm{PO}_{4}\right)_{3} \mathrm{OH}$, dependendo do $\mathrm{pH}$ (ADRIANO, 1986).

Segundo PORTER et alii (2004), em pH elevado, os complexos de carbonato acentuam a tendência do mineral ser anfótero e, certamente, um sistema 
com elevada concentração de íons cloreto ou fosfato pode resultar em um forte incremento na solubilidade do $\mathrm{Pb}$, conduzindo à precipitação de formas mais estáveis deste elemento.

$\mathrm{O} \mathrm{PbS}$ e $\mathrm{PbSO}_{4}$ podem coexistir em equilíbrio em valor constante de $(\mathrm{pH}+$ pe) $=5,055$. Virtualmente, todo o enxofre na solução destes dois minerais, na condição de equilíbrio, está sob a forma preferencial de sulfato e não de sulfeto. Se $(\mathrm{pH}+\mathrm{pe})>5,055$, então somente $\circ \mathrm{PbSO}_{4}$ será estável, enquanto $\circ \mathrm{PbS}$ permanecerá sem oxidação abaixo de 5,055 (PORTER et alii, 2004).

A Tabela 29 mostra o produto de solubilidade para alguns sais de $\mathrm{Pb}$ e, as Figuras 43 e 44, o diagrama de fases para o sistema $\mathrm{Pb}-\mathrm{S}-\mathrm{C}-\mathrm{O}-\mathrm{H}$ e as principais espécies de $\mathrm{Pb}$ em função do $\mathrm{pH}$, respectivamente.

Segundo a Figura 44, existem quinze espécies de chumbo, entretanto, apenas treze aparecem em quantidade suficiente para constar no gráfico. Destas, cinco são íns complexos de fosfato e cloreto, que em concentrações mais elevadas, pode aumentar a solubilidade substancialmente, mesmo quando estão presentes minerais de $\mathrm{Pb}$ muito insolúveis. Os dois complexos de carbonatos são importantes em $\mathrm{pH}$ elevado e forçam os minerais de $\mathrm{Pb}$ a terem um caráter anfótero (PORTER et alii, 2004).

Tabela 29 - Constantes do produto de solubilidade de sais de $\mathrm{Pb}$.

\begin{tabular}{lccccc}
\hline Composto & $\mathrm{PbCO}_{3}$ & $\mathrm{PbCl}_{2}$ & $\mathrm{~Pb}(\mathrm{OH})_{2}$ & $\mathrm{PbSO}_{4}$ & $\mathrm{PbS}$ \\
$\mathrm{K}_{\mathrm{sp}}$ & $3,3 \times 10^{-14}$ & $1,6 \times 10^{-5}$ & $2,5 \times 10^{-16}$ & $1,6 \times 10^{-8}$ & $7,0 \times 10^{-28}$ \\
\hline
\end{tabular}

Fonte: EVANGELOU (1998). 


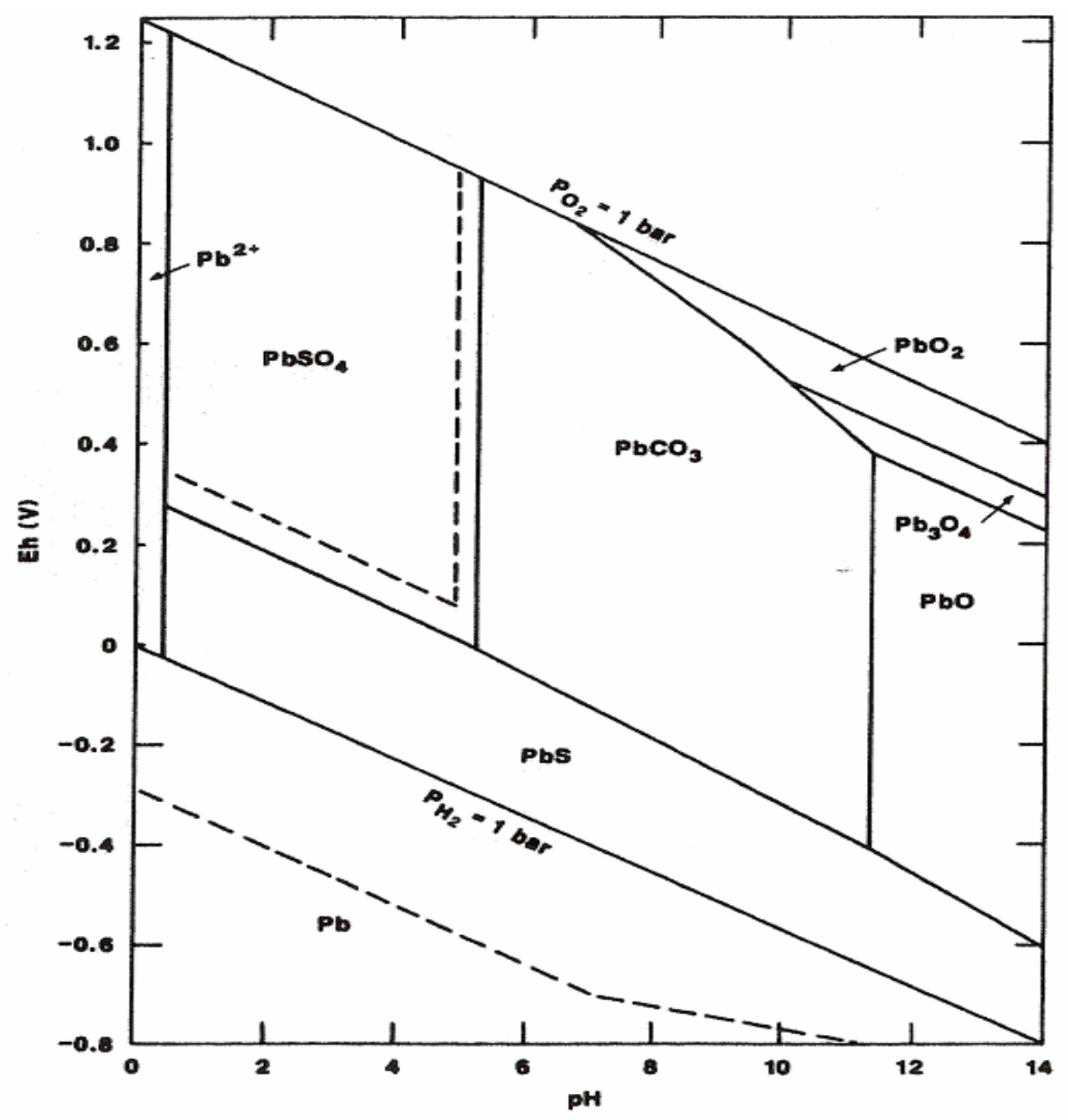

Figura 43 - Diagrama Eh/pH para o Sistema Pb-S-C-O-H $\left(25^{\circ} \mathrm{C}, 1\right.$ bar $)$ Fonte:BROOKINS (1988). 


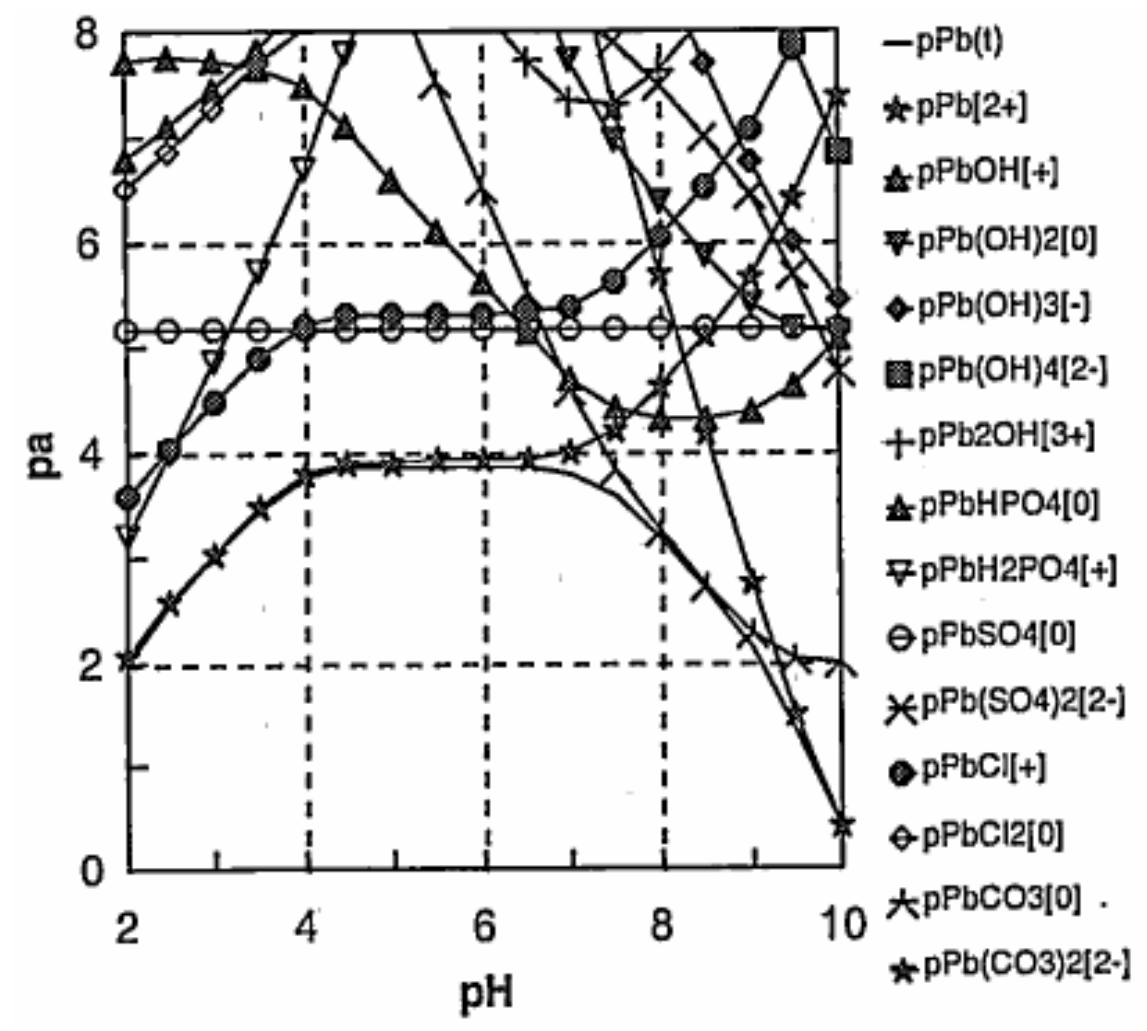

Figura 44 - Hidroxipiromorfita $\left(\mathrm{Pb}_{5}\left(\mathrm{PO}_{4}\right)_{3} \mathrm{OH}\right)$ com anglesita $\left(\mathrm{PbSO}_{4}\right)$ : atividades de importantes espécies de soluto de $\mathrm{Pb}$ versus $\mathrm{pH}$. Fonte: PORTER et alii (2004).

\subsubsection{Experimento $n^{\circ} 4$}

A Figura 45 mostra a curva de ajuste de $\mathrm{pH}$ da amostra de latossolo vermelho.

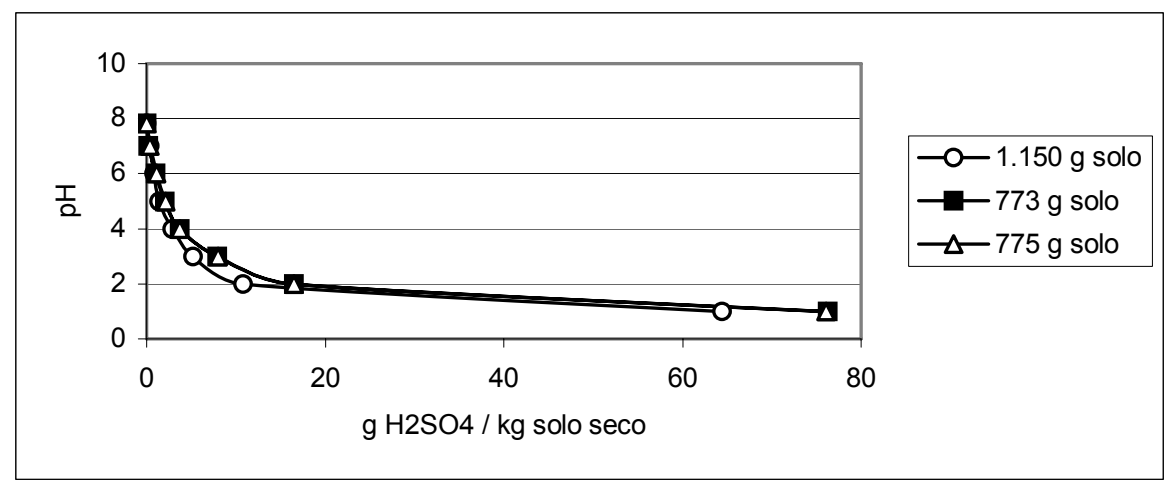

Figura 45 - Curva de ajuste de $\mathrm{pH}$ da amostra de latossolo vermelho. 
As quantidades de ácido necessárias para se atingir os valores de $\mathrm{pH}$ de 2 a 7 do solo, mostradas na Figura 45, são de mesma ordem de grandeza que os obtidos por OLIVEIRA (2006), que conduziu investigação paralela a esta e utilizou o mesmo latossolo vermelho; conforme mostra a Figura 46.

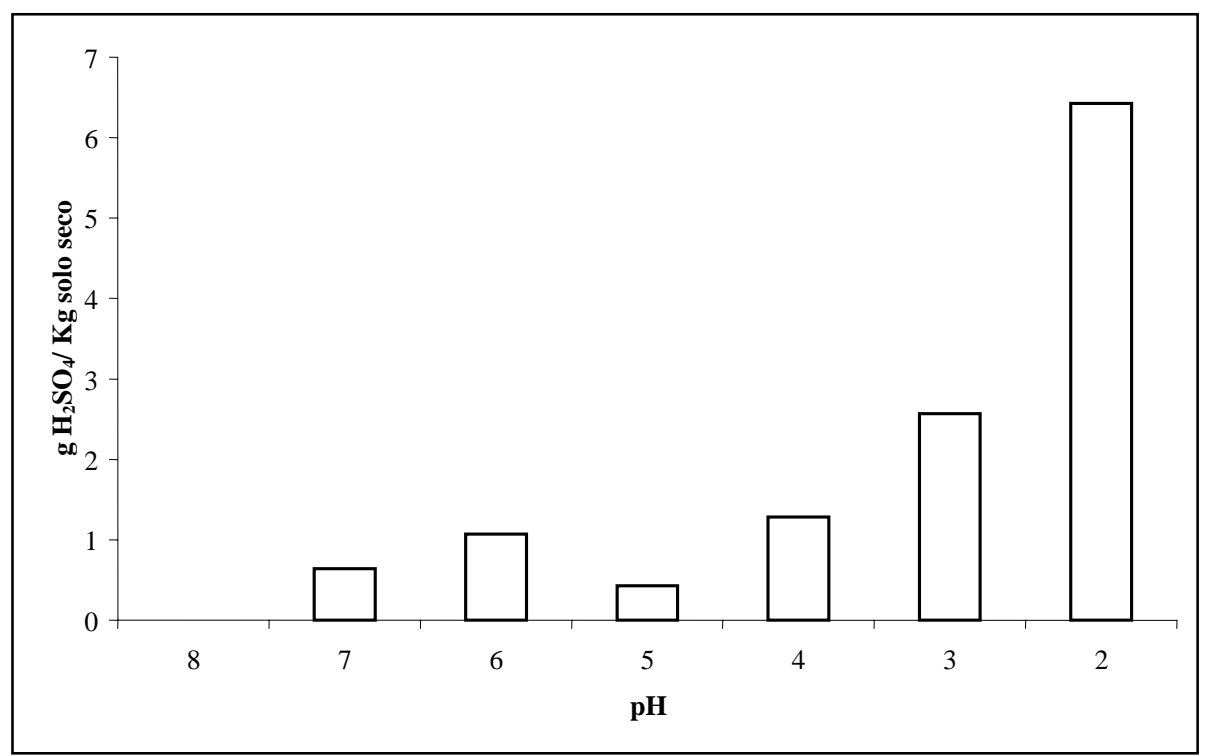

Figura 46 - Consumo de ácido sulfúrico concentrado por quilo de solo seco.

Fonte: OLIVEIRA (2006).

OLIVEIRA (2006) avaliou a eficácia da remoção dos metais $\mathrm{Pb}$ e $\mathrm{Zn}$ através da lavagem do solo com os agentes oxidantes: ácido sulfúrico concentrado, peróxido de hidrogênio a 30\% e solução de ácido clorídrico 0,1 M. Esta pesquisadora chegou as seguintes conclusões sobre sua investigação:

$\checkmark$ A lixiviação do $\mathrm{Pb}$ com ácido sulfúrico não se mostrou eficiente, pois foi produzido sulfato de chumbo, cuja solubilidade em água é baixa. Por esta razão, a massa de chumbo do solo tratado com o ácido aumentou com o decréscimo de $\mathrm{pH}$;

$\checkmark$ Obteve-se remoção de Zn, através da lavagem do solo com ácido sulfúrico, de até 50\%, sendo o teor remanescente igual a $117 \mathrm{mg} / \mathrm{Kg}$, valor abaixo do limite de prevenção determinado pelo órgão de controle ambiental do Estado de São Paulo, que indica que houve alteração das condições naturais do solo, porém a adoção de medidas corretivas não é necessária;

$\checkmark$ O consumo de ácido sulfúrico concentrado por quilo de solo tratado foi de 6,5 ;

$\checkmark$ A oxidação da suspensão com peróxido de hidrogênio foi ineficaz na remoção de $\mathrm{Pb}$ e $\mathrm{Zn}$, devido à transferência da massa dos metais da fase sólida para 
os sólidos em suspensão da fase líquida. A quantidade da solução de peróxido de hidrogênio a 30\% utilizada para tratamento do solo, conforme dosagens, esteve entre $151 \mathrm{gH}_{2} \mathrm{O}_{2} / \mathrm{Kg}$ solo seco (dosagem 4,53\%) e $1.666 \mathrm{~g}$ $\mathrm{H}_{2} \mathrm{O}_{2} / \mathrm{Kg}$ solo seco (dosagem $50 \%$ );

$\checkmark$ A lixiviação dos metais do solo produzida pela solução de ácido clorídrico 0,1 $\mathrm{M}$ reduziu os teores de $\mathrm{Pb}$ e $\mathrm{Zn}$ em 15 e 10\%, respectivamente, tendo sido consumido $196 \mathrm{~g}$ de $\mathrm{HCl}$ por quilo de solo tratado. Os teores remanescentes de chumbo e zinco, próximos de 806 mg Pb/Kg e 213 mg Zn/Kg, estão abaixo do limite estabelecido como valor de intervenção em áreas industriais, o que produziu a reclassificação da área de estudo como não contaminada.

A Figura 47 mostra o monitoramento do $\mathrm{pH}$ durante o experimento com $A$. ferrooxidans.

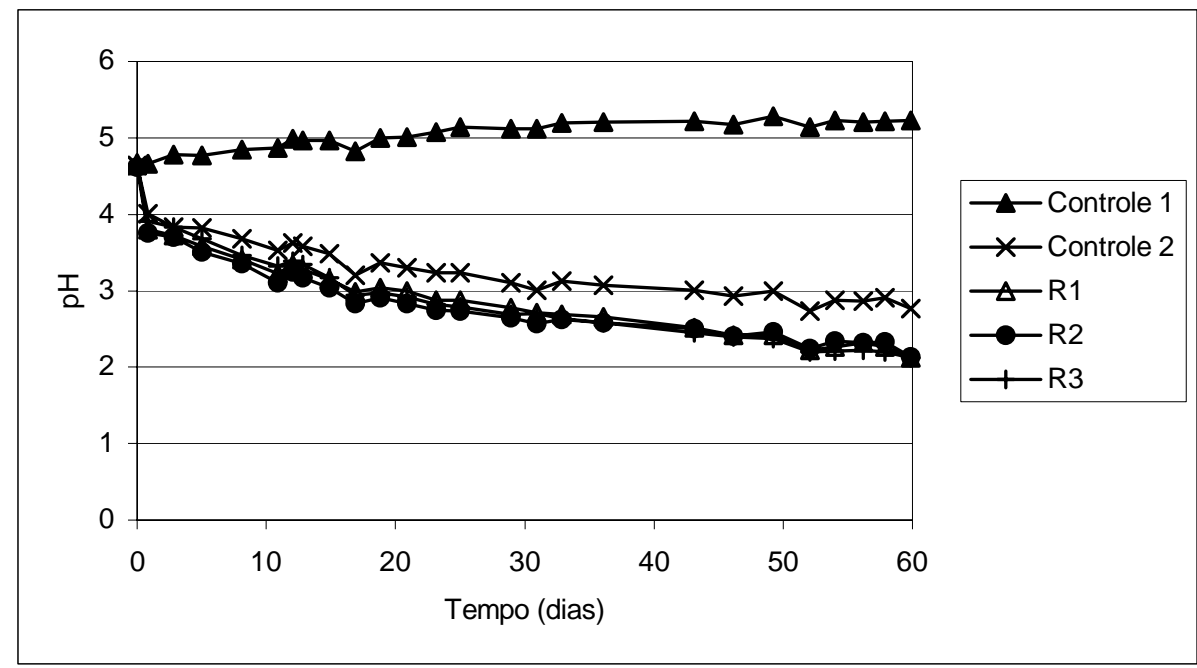

Reatores: Controle 1 - água de torneira + solo $+\mathrm{H}_{2} \mathrm{SO}_{4}$; Controle 2 - água de torneira + solo + substrato $+\mathrm{H}_{2} \mathrm{SO}_{4} ; \mathrm{R} 1, \mathrm{R} 2$ e R3 - água de torneira + solo + substrato $+\mathrm{H}_{2} \mathrm{SO}_{4}+$ suspensão bacteriana de $A$. ferrooxidans.

Figura 47 - Variação do pH durante o experimento de biolixiviação $n^{0} 4$ reatores com $A$. ferrooxidans.

A Figura 47 mostra comportamentos distintos do pH nos reatores controles 1 e 2. O reator controle 2, cujo único diferencial em relação ao 1 foi ter recebido os nutrientes, apresentou contínua redução no valor do $\mathrm{pH}$ ao longo do tempo, fato que indica o efeito dos nutrientes sobre o processo de biolixiviação ou mesmo sua utilização por microrganismos indígenas do solo.

Os reatores R1, R2 e R3, que receberam inóculo de A. ferrooxidans, exibiram um pequeno efeito aditivo sobre a redução do pH em relação aos valores deste parâmetro registrados no reator Controle 2. Todavia, este efeito aditivo pode 
estar relacionado à adição das células de $A$. ferrooxidans ou mesmo à solução ácida utilizada como veículo aquoso do inóculo (a suspensão bacteriana foi concentrada em $4 \mathrm{~mL}$ e adicionada aos reatores teste).

O efeito da adição de suspensão bacteriana sobre o $\mathrm{pH}$ foi relatado por CHARTIER; COUILLARD (1997), que observaram este mesmo fenômeno, acompanhado da elevação do potencial de óxido redução (POR), em seus experimentos e concluíram que ele deveu-se às condições ácidas da suspensão de A. ferrooxidans.

A Figura 48 mostra a evolução do pH ao longo do ensaio com $A$. thiooxidans nos reatores controles e testes.

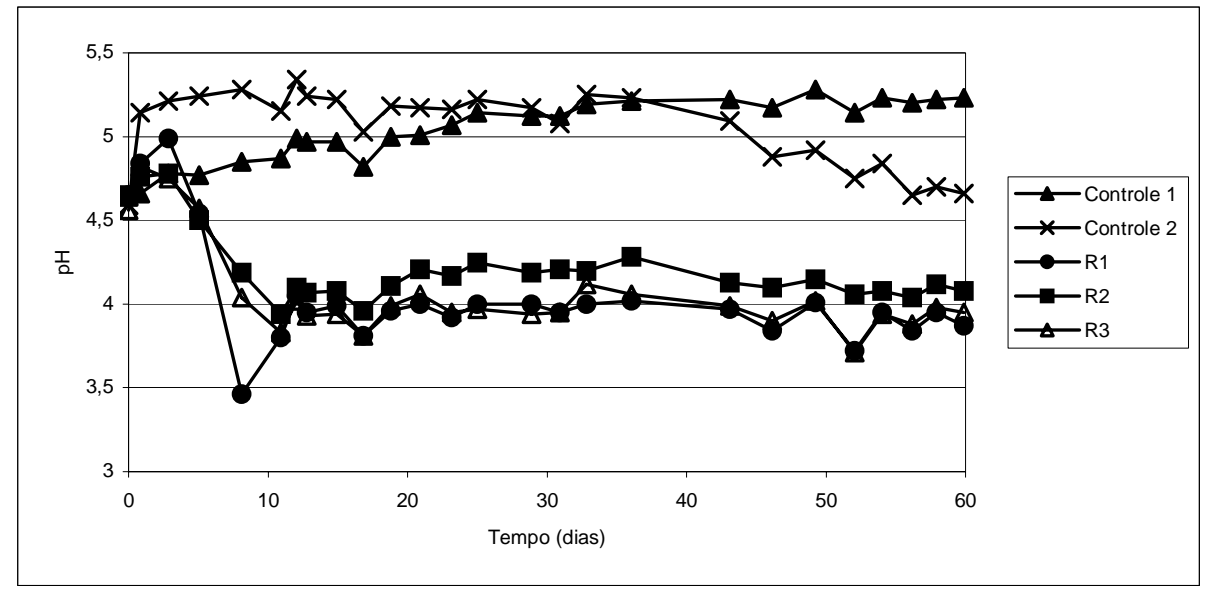

Reatores: Controle 1- água de torneira + solo $+\mathrm{H}_{2} \mathrm{SO}_{4}$; Controle 2- água de torneira + solo + substrato $+\mathrm{H}_{2} \mathrm{SO}_{4} ; \mathrm{R} 1, \mathrm{R} 2$ e R3 - água de torneira + solo + substrato $+\mathrm{H}_{2} \mathrm{SO}_{4}+$ suspensão bacteriana de $A$. thiooxidans.

Figura 48 - Variação do $\mathrm{pH}$ durante o experimento de biolixiviação $\mathrm{n}^{\circ} 4$ reatores $A$. thiooxidans.

A Figura 48 mostra que o comportamento do $\mathrm{pH}$ ao longo do tempo nos reatores controles foi muito similar. Entretanto, o reator Controle 2, cujo único diferencial em relação ao 1 foi ter recebido nutrientes, apresentou uma leve tendência de redução no valor do $\mathrm{pH}$ a partir de 45 dias, fato que não atesta o efeito daqueles sobre o processo de biolixiviação, nem descarta sua utilização por microrganismos indígenas do solo.

Os reatores R1, R2 e R3, que receberam inóculo de $A$. thiooxidans, exibiram um efeito aditivo constante sobre a redução do $\mathrm{pH}$, em relação aos valores deste parâmetro registrados nos reatores Controles 1 e 2. Todavia, este efeito aditivo estático descarta sua relação com a adição das células de $A$. thiooxidans, pois é evidente que se deveu à adição da solução ácida utilizada como veículo aquoso do 
inóculo (a suspensão bacteriana foi concentrada em $4 \mathrm{~mL}$ e adicionada aos reatores teste).

As Figuras 49 e 50 mostram, respectivamente, a evolução das populações de bactérias heterotróficas nos experimentos com $A$. ferrooxidans e com $A$. thiooxidans.

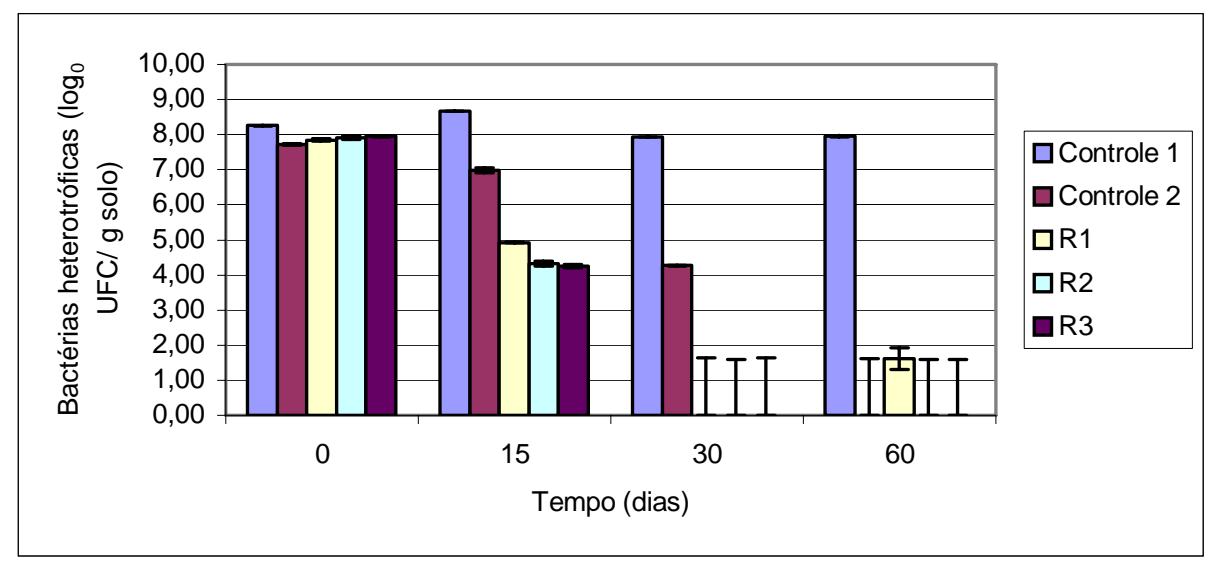

Figura 49 - Evolução da população de bactérias heterotróficas durante 0 experimento $n^{\circ} 4$ - reatores $A$. ferrooxidans.

A Figura 49 mostra que somente o reator Controle 1, que só recebeu o ácido, manteve uma população estável de bactérias heterotróficas. Todos os demais apresentaram uma tendência contínua de redução destas, que pode estar estritamente relacionada ao decréscimo do pH durante o experimento, pois este também é uma variável importante que afeta seu desenvolvimento (ALEF; NANNIPIERI, 1995; LORS; TIFFREAU; LABOUDIGUE, 2004).

A Figura 50 mostra que a densidade de bactérias heterotróficas se manteve estável apenas para o reator Controle 1 e apresentou tendência de redução para os demais reatores. Ao contrário do mostrado na Figura 49, não se observou um acentuado decréscimo na densidade de bactérias heterotróficas ao longo do tempo. Tal fato pode estar associado ao $\mathrm{pH}$, que se manteve em 4,0, enquanto que no experimento com A. ferrooxidans, este valor alcançou 2,0 após 60 dias.

A contagem de bactérias heterotróficas nestes experimentos mostrou que 0 solo contaminado utilizado, embora tenha sido esterilizado, oferecia diferentes condições para o crescimento celular, as quais se mostraram estreitamente relacionadas ao nível de acidificação do meio e ao tempo de exposição submetido ao ambiente agressivo. 


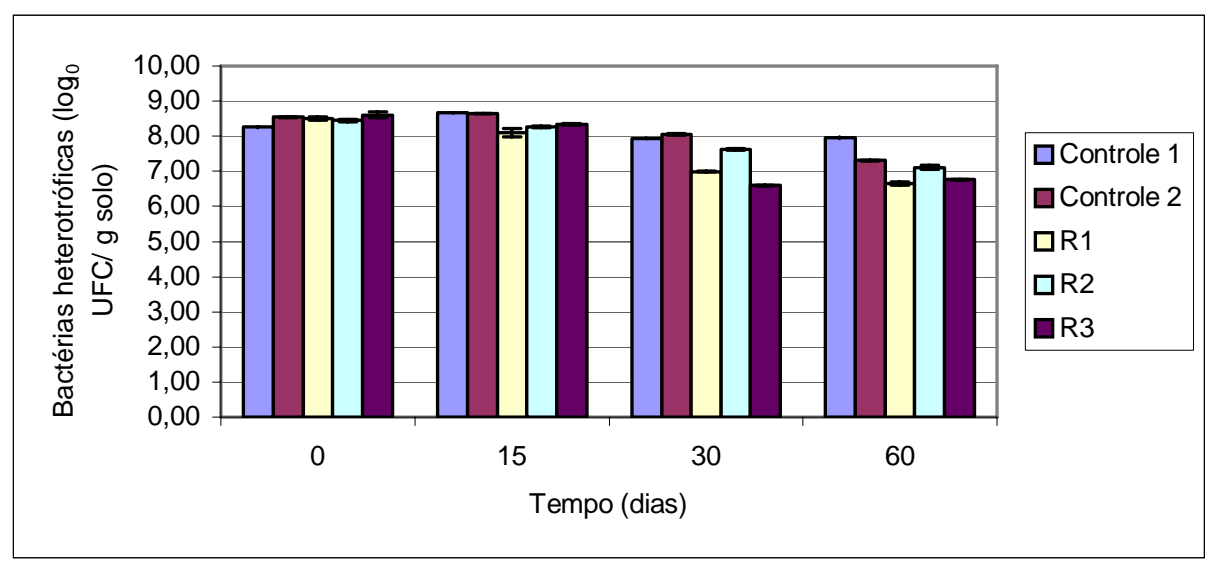

Figura 50 - Evolução da população de bactérias heterotróficas durante 0 experimento $n^{\circ} 4$ - reatores $A$. thiooxidans.

As Figuras 51 e 52 mostram, respectivamente, a evolução das populações de $A$. ferrooxidans e $A$. thiooxidans nos reatores do experimento 4 .

No ensaio com $A$. ferrooxidans, as populações nos reatores testes não apresentaram variação ao longo do tempo e permaneceram praticamente constantes. O contrário foi observado nos reatores testes inoculados com $A$. thiooxidans, onde a população apresentou tendência de redução.

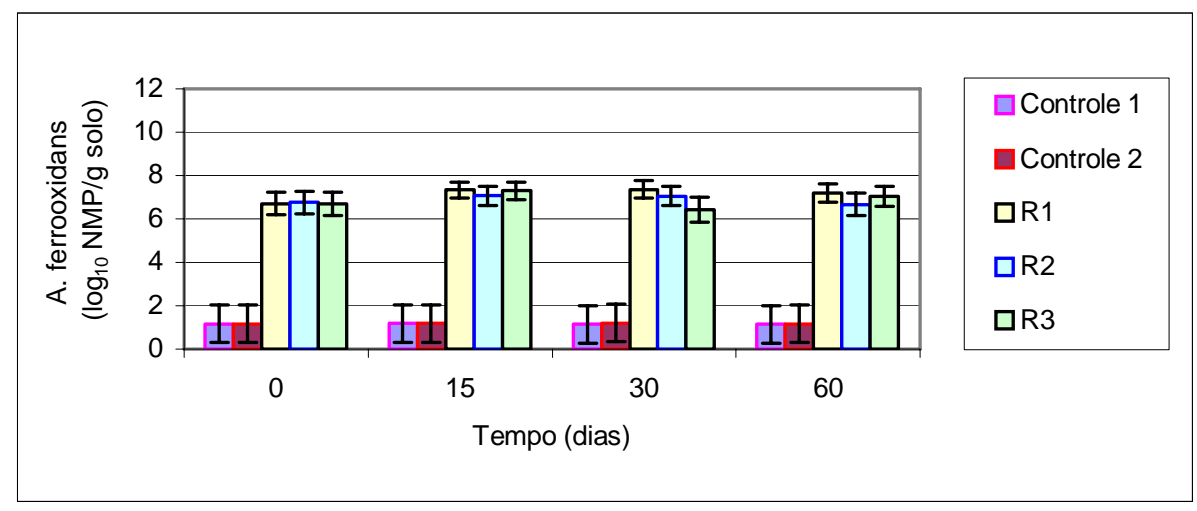

Figura 51 - Evolução da população de $A$. ferrooxidans durante 0 experimento $\mathrm{n}^{\circ} 4$ - reatores $A$. ferrooxidans.

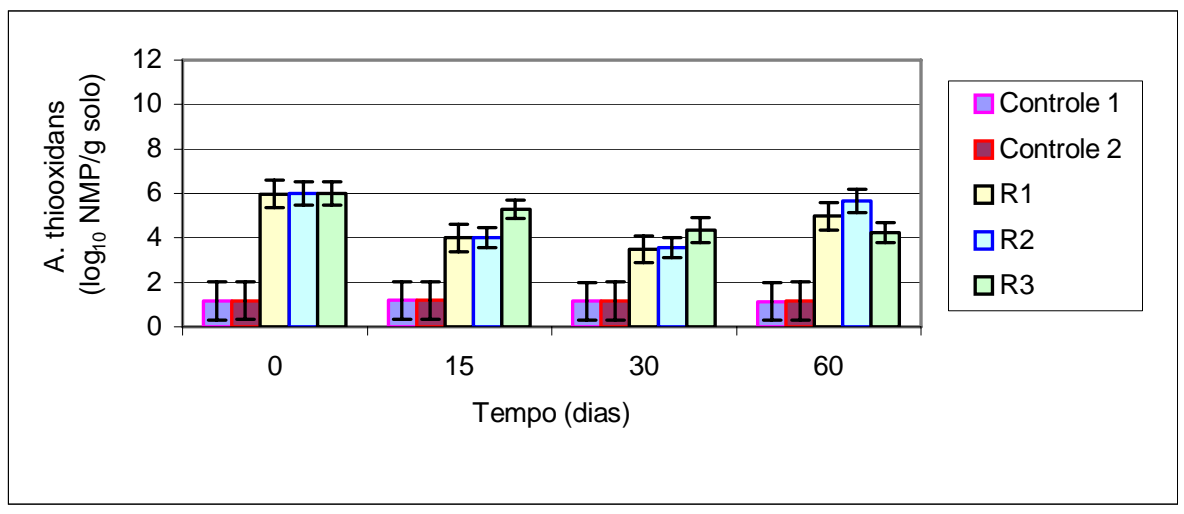

Figura 52 - Evolução da população de $A$. thiooxidans durante 0 experimento $n^{\circ} 4$ - reatores $A$. thiooxidans. 
Muitos fatores afetam o crescimento de microrganismos, todavia, admitindo que foram atendidas as condições necessárias para o desenvolvimento de ambas as espécies de Acidithiobacillus $s p$, notadamente: umidade, substrato e nutrientes disponíveis, temperatura e $\mathrm{pH}$, era esperado que as populações destas espécies apresentassem o mesmo comportamento, o que não foi verificado. Uma hipótese que pode explicar tal observação é o maior tempo requerido para se adaptar a um novo meio e menor taxa de crescimento do $A$. thiooxidans, quando comparado ao $A$. ferrooxidans (CHARTIER; COUILLARD, 1997; BRANDL; BOSSHARD; WEGMANN, 2001; KREBS; BACHOFEN; BRANDL, 2001; LORS; TIFFREAU; LABOUDIGUE, 2004).

Os experimentos $n^{\circ} 3$ e $n^{\circ} 4$ apresentam duas similaridades básicas: ambos receberam adição de suspensão bacteriana de $A$. thiooxidans e de nutrientes e tiveram duração de 60 dias. Portanto, era de se esperar que o pH de ambos os experimentos apresentasse o mesmo comportamento, particularmente o do reator do experimento $n^{\circ} 3$ que utilizou a mesma concentração de solo empregada no de $n^{\circ}$ 4. Mas, não foi isso que ocorreu. A segunda adição de suspensão bacteriana e a maior massa de nutrientes adicionada no experimento $n^{\circ} 3$ pode explicar a diferença de comportamento.

Em última análise, o experimento $n^{\circ} 4$ sugeriu que houve adaptação do $A$. ferrooxidans ao latossolo vermelho e às condições operacionais impostas no reator, indicando que há a possibilidade de reprodução durante o processo de biolixiviação.

\subsubsection{Experimento $n^{\circ} 5$}

As Figuras 53 e 54 mostram, respectivamente, o monitoramento do $\mathrm{pH}$ durante os experimentos com A. ferrooxidans e com A. thiooxidans. A Figura 53 mostra que o comportamento do $\mathrm{pH}$ nos reatores controles 1 e 2 foi distinto. Apenas o reator Controle 2, cujo único diferencial em relação ao 1 foi ter recebido nutrientes, apresentou redução contínua no valor do $\mathrm{pH}$. Este fato coincide com as observações (experimento com $A$. ferrooxidans) do experimento $\mathrm{n}^{\circ} 4$ e corrobora a hipótese sobre o efeito dos nutrientes sobre o processo de biolixiviação ou mesmo sua utilização por microrganismos indígenas do solo. 
Os reatores R1, R2 e R3, que receberam inóculo de $A$. ferrooxidans, não exibiram efeito aditivo significativo sobre a redução do $\mathrm{pH}$ em relação aos valores deste parâmetro registrados no reator Controle 2, até aproximadamente 30 dias. Após este período, há uma leve tendência ao decréscimo do pH, que pode estar associada à reprodução de $A$. ferrooxidans, hipótese sustentada pela densidade de organismos mostrada na Figura 57.

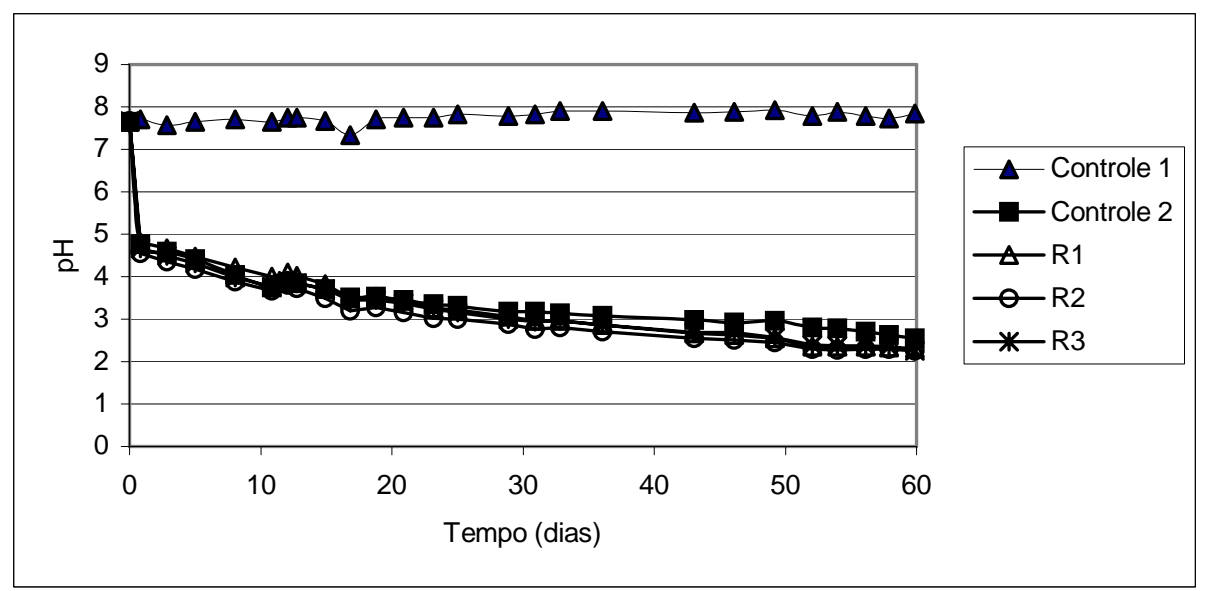

Reatores: Controle 1 - água de torneira + solo; Controle 2 - água de torneira + solo + substrato; R1, R2 e R3 - água de torneira + solo + substrato + suspensão bacteriana de A. ferrooxidans.

Figura 53 - Variação do pH durante o experimento de biolixiviação $\mathrm{n}^{\circ} 5$ reatores $A$. ferrooxidans.

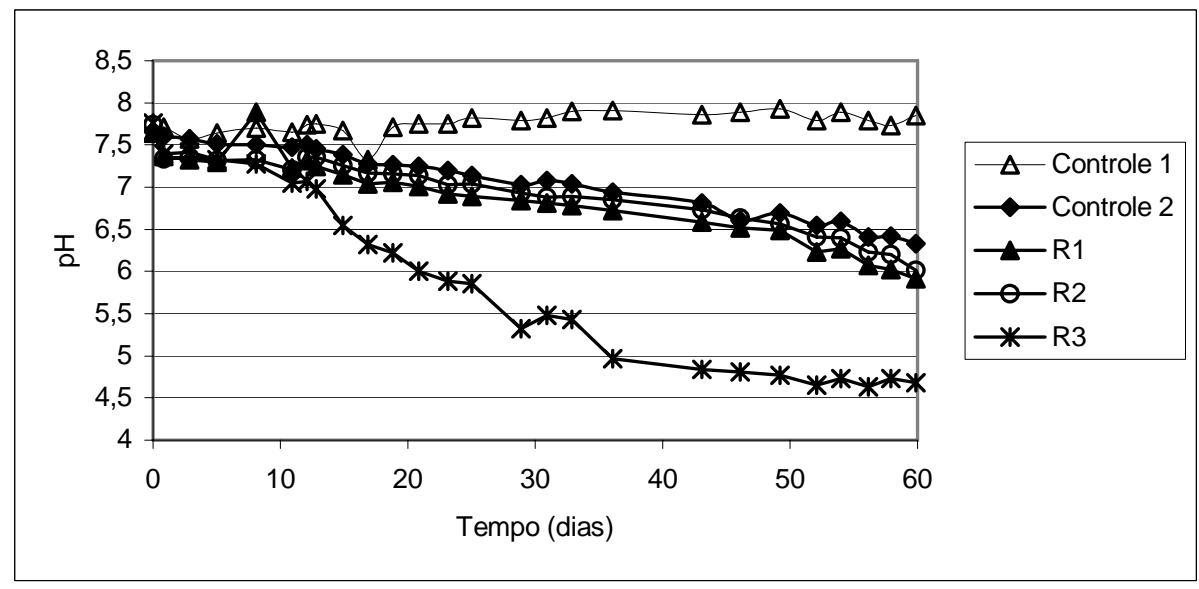

Reatores: Controle 1 - água de torneira + solo; Controle 2 - água de torneira + solo + substrato; R1, R2 e R3 água de torneira + solo + substrato + suspensão bacteriana de $A$. thiooxidans.

Figura 54 - Variação do pH durante o experimento de biolixiviação $n^{0} 5$ reatores $A$. thiooxidans.

A Figura 54 mostra que o comportamento do $\mathrm{pH}$ nos reatores controle apresentou significativa variação ao longo do tempo. Os reatores Controle 2 e R1 e R2 apresentaram comportamento similar em relação ao pH, embora apenas os dois últimos tenham recebido inóculo de $A$. thiooxidans. Entretanto, o reator R3, que 
também recebeu inóculo de $A$. thiooxidans apresentou comportamento distinto dos reatores R1 e R2, fato que pode estar associado a erros de medida ou experimentais, pois a Figura 58 mostra que a evolução da densidade de $A$. thiooxidans foi praticamente idêntica para os três reatores teste.

As Figuras 55 e 56 mostram, respectivamente, a evolução das populações de bactérias heterotróficas nos experimentos com $A$. ferrooxidans e com $A$. thiooxidans.

A Figura 55 indica que, a exemplo do observado no experimento $n^{\circ} 4$, houve uma tendência à redução drástica das bactérias heterotróficas. Esta redução parece estar ligada ao aumento da acidez do meio, decorrente da introdução do substrato $\mathrm{FeSO}_{4}$, pois apenas no reator Controle 1 (que não recebeu este nem os demais nutrientes), a população manteve-se relativamente estável.

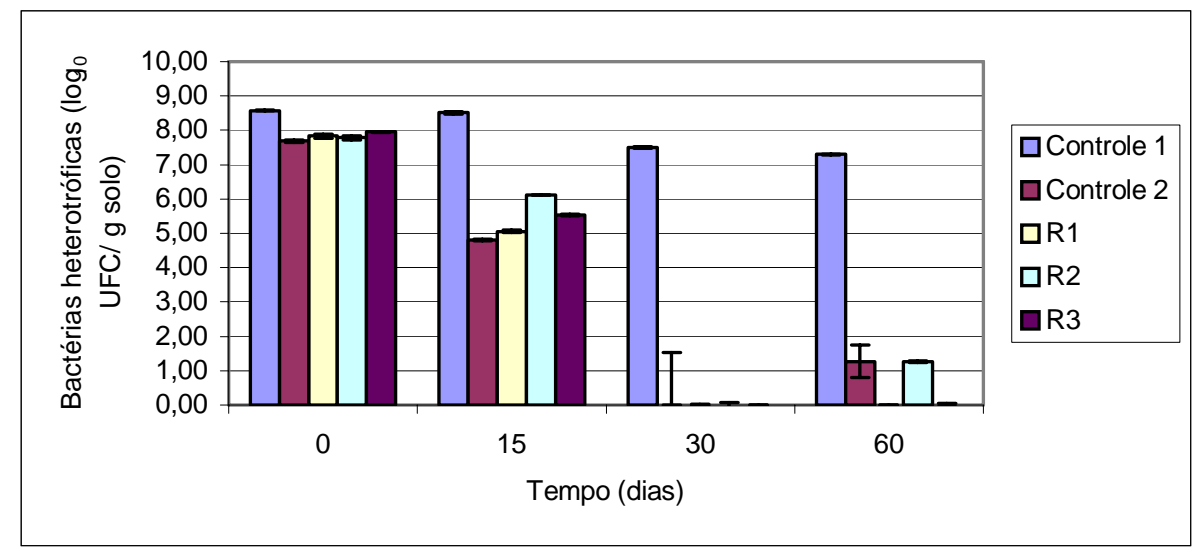

Figura 55 - Evolução da população de bactérias heterotróficas durante o experimento $n^{\circ} 5$ - reatores $A$. ferrooxidans.

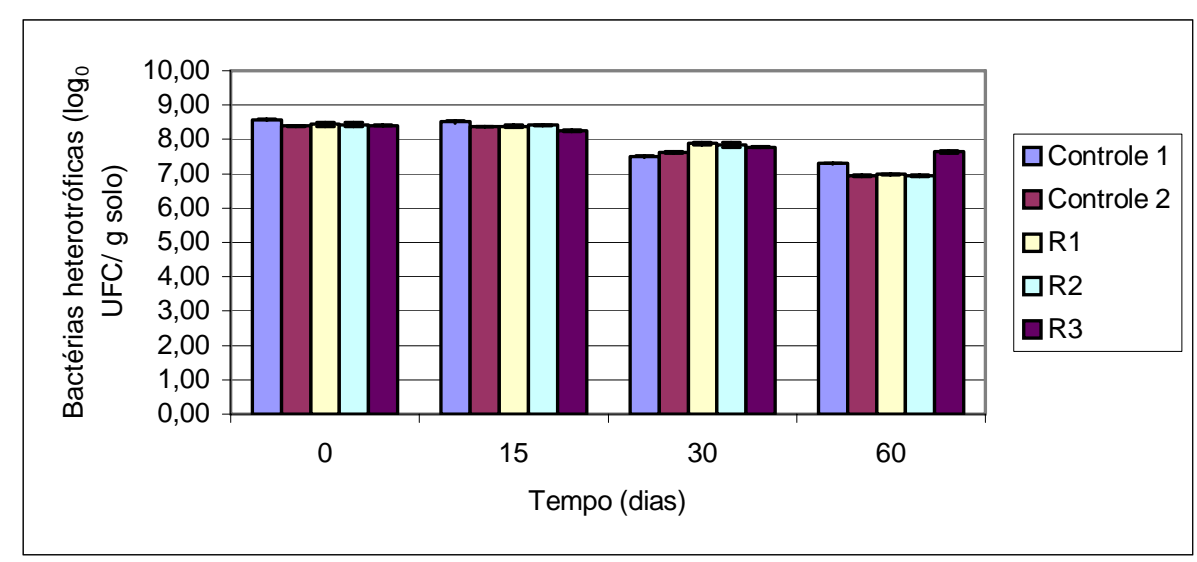

Figura 56 - Evolução da população de bactérias heterotróficas durante o experimento $n^{\circ} 5$ - reatores $A$. thiooxidans. 
A exemplo do observado no experimento $n^{\circ} 4$, a Figura 56 mostra que a população de bactérias heterotróficas se manteve estável no experimento com $A$. thiooxidans.

Considerando que os nutrientes utilizados nos experimentos com $A$. ferrooxidans e $A$. thiooxidans foram os mesmos, exceto o $\mathrm{FeSO}_{4}$ e o $\mathrm{S}^{0}$ e que os reatores nos quais foi introduzido o $S^{0}$ não apresentaram significativa variação da população de bactérias heterotróficas (Figuras 50 e 56), é razoável considerar que a adição do $\mathrm{FeSO}_{4}$ tenha exercido um forte efeito inibidor sobre tais microrganismos (Figuras 47 e 53). A inibição não ocorreria devido ao $\mathrm{FeSO}_{4}$ em si, mas à acidificação do meio provocada por sua hidrólise e conseqüente liberação de íons $\mathrm{H}^{+}$ na solução.

As Figuras 57 e 58 permitem visualizar, respectivamente, a evolução das populações de $A$. ferrooxidans e $A$. thiooxidans ao longo do experimento.

A Figura 57 mostra que a evolução da população de $A$. ferrooxidans apresentou uma pequena tendência de crescimento ao longo do tempo, ao contrário do que foi verificado com a população de A. thiooxidans (Figura 58). As Figuras 57 e 58 também mostram que não houve crescimento de $A$. ferrooxidans ou $A$. thiooxidans nos reatores controle, logo, é razoável admitir que o crescimento de ambas as espécies nos reatores teste deveu-se exclusivamente aos inóculos adicionados.

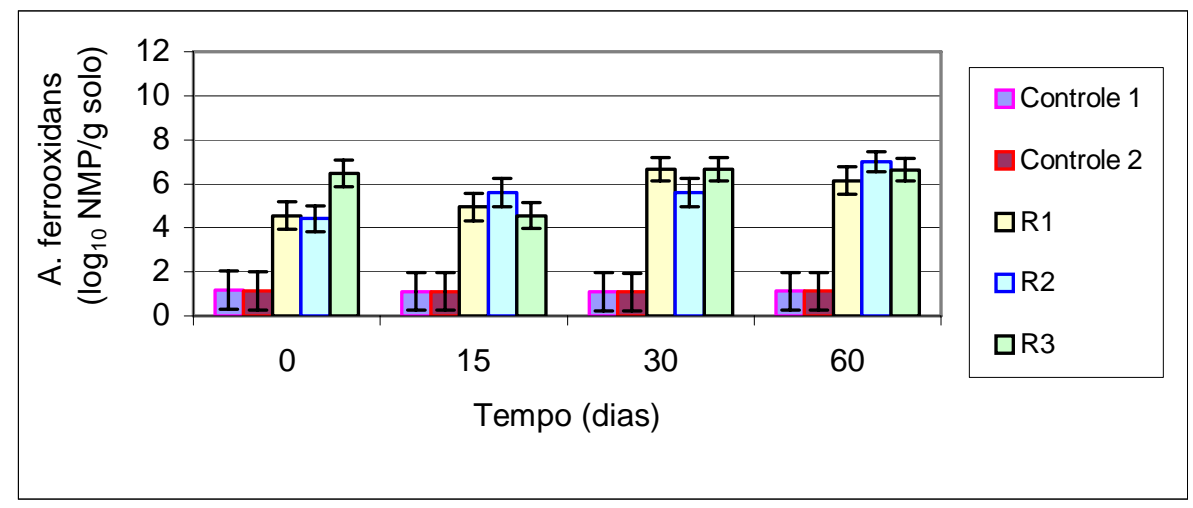

Figura 57 - Evolução da população de $A$. ferrooxidans durante o experimento $n^{\circ} 4$ - reatores $A$. ferrooxidans. 


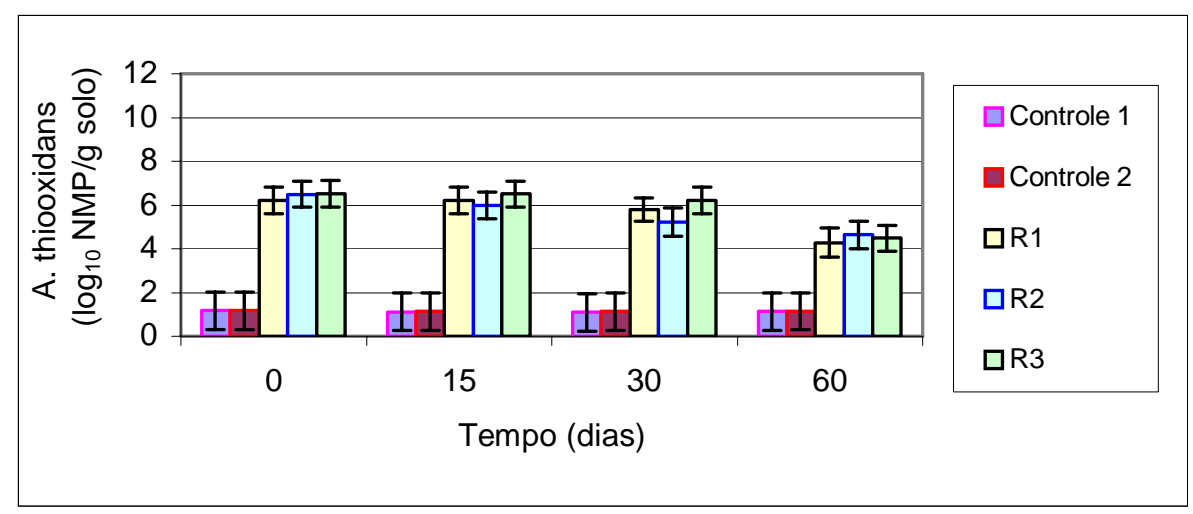

Figura 58 - Evolução da população de $A$. thiooxidans durante 0 experimento $n^{\circ} 4$ - reatores $A$. thiooxidans.

A adição de nutrientes e a baixa capacidade de tamponamento do solo utilizado nos experimentos $n^{\circ} 4$ e $n^{\circ} 5$ indicam que não há necessidade de correção prévia do $\mathrm{pH}$, fato comprovado no experimento $\mathrm{n}^{\circ} 5$. A utilização de suspensão bacteriana, independente da espécie de Acidithiobacillus sp aqui pesquisada, sem qualquer tratamento prévio de purificação, também foi capaz de promover um abaixamento no valor do $\mathrm{pH}$ dos reatores teste.

Portanto, para solos com características similares ao utilizado no presente estudo, não há necessidade de acidificação inicial da suspensão de solo, pois a acidez decorrente da hidrólise dos nutrientes e a contida na própria suspensão bacteriana podem promover a correção do $\mathrm{pH}$ para valores menores do que 6,0 (CHARTIER; COUILLARD, 1997; BRANDL; BOSSHARD; WEGMANN, 2001; KREBS; BACHOFEN; BRANDL, 2001; ZAGURY; NARASIAH; TYAGI, 2001; LORS; TIFFREAU; LABOUDIGUE, 2004).

A acidificação inicial da suspensão de solo para pH aproximado de 4,5, seguida pela introdução de suspensão bacteriana sem purificação, resultou em todos os experimentos até aqui executados, em redução do pH para valores de 2,0 a 3,0 . 


\subsubsection{Experimento $n^{\circ} 6$}

Considerando os resultados obtidos com $A$. thiooxidans e $A$. ferrooxidans nos ensaios anteriores, optou-se por utilizar apenas a última espécie neste e nos demais experimentos de biolixiviação.

A Figura 59 mostra a evolução do pH ao longo do tempo e a Tabela 30, os resultados das análises elementares realizadas com as amostras dos reatores no início e no final do experimento.

Todos os reatores, exceto o Controle, apresentaram comportamento idêntico quanto à variação do $\mathrm{pH}$ e possivelmente, apenas a adição dos nutrientes (fato comum a todos os demais reatores) foi responsável pelo abaixamento do pH para o valor de aproximadamente 2,0, a partir do qual, segundo a Figura 45, seria necessária uma grande quantidade de ácido para produzir uma redução mensurável no $\mathrm{pH}$.

A variável tempo foi limitada a 30 dias neste e nos próximos experimentos de biolixiviação aqui reportados.

A lavagem e concentração da suspensão bacteriana utilizada como inóculo foi uma medida tomada para evitar a queda abrupta do $\mathrm{pH}$ no início do processo de biolixiviação, mas não funcionou, pois a massa de $\mathrm{FeSO}_{4}$ utilizado promoveu a acidificação dos reatores; conforme demonstram as reações de hidrólise apresentadas no experimento $n^{\circ} 3$ e o relato de CHARTIER; COUILLARD (1997).

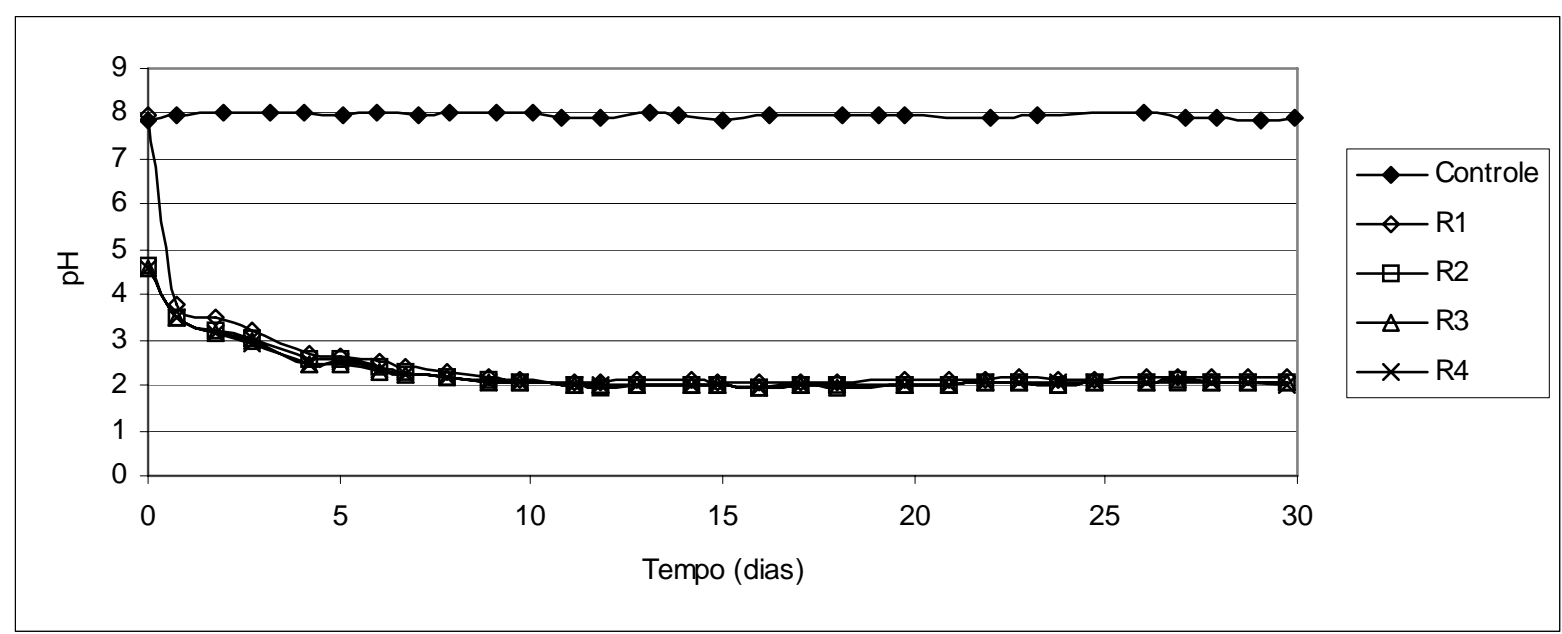

Reatores: Controle - água + solo; R1 - água + solo + substratos; R2 - água + solo + substratos + $\mathrm{H}_{2} \mathrm{SO}_{4}$; R3 e R4 - água + solo + substratos $+\mathrm{H}_{2} \mathrm{SO}_{4}+$ suspensão bacteriana.

Figura 59 - Variação do pH durante o experimento de biolixiviação $n^{\circ} 6$. 
Assim como nos experimentos reportados por estes pesquisadores, que avaliaram o efeito da adição de substratos e da suspensão bacteriana sobre o processo de biolixiviação, o uso de reator controle possibilitou uma comparação fidedigna entre os efeitos das diferentes variáveis sobre o solo natural e mostrou-se indispensável para aferir os resultados do processo de biolixiviação.

ZAGURY et alii (2001) não citam a utilização de um reator controle em seu experimento, empregando apenas substratos ou mesmo um outro agente extrator (particularmente $\circ \mathrm{H}_{2} \mathrm{SO}_{4}$ ) para comparação de resultados, ou seja, parte-se do princípio de que a biolixiviação ocorre e é o principal mecanismo de solubilização dos metais. Este pré-conceito pode não estar correto, pois os próprios autores reconheceram o efeito das condições iniciais do processo, ou seja, do $\mathrm{pH}$, que face à ausência de um reator controle contendo apenas substratos, não permite determinar o tempo necessário para que o sistema atinja o equilíbrio.

Outro ponto a ser considerado no relato de ZAGURY et alii (2001) é a composição granulométrica do solo utilizado, que continha apenas 0,4 \% de argila, indicando que os elementos $\mathrm{Cu}, \mathrm{Mn}$ e $\mathrm{Zn}$ poderiam estar adsorvidos em outras frações do solo, sendo, neste caso, a dessorção do contaminante mais fácil (MCLEAN; BLEDSOE, 1992). Condição oposta é observada no presente trabalho, onde $57 \%$ do solo é composto pela fração argila, portanto, de maior dificuldade de mobilização dos cátions nela adsorvidos.

Tabela 30 - Teores de carbono, hidrogênio e nitrogênio no início e no final do processo de biolixiviação $n^{\circ} 6$.

\begin{tabular}{ccccccc}
\hline Tempo (dias) & \multicolumn{2}{c}{$\mathbf{C}$} & \multicolumn{2}{c}{$\mathbf{H}$} & \multicolumn{3}{c}{$\mathbf{N}$} \\
Reator & $\mathbf{0}$ & $\mathbf{3 0}$ & $\mathbf{0}$ & $\mathbf{3 0}$ & $\mathbf{0}$ & $\mathbf{3 0}$ \\
Controle & & & \multicolumn{5}{c}{ Teores (g/kg) } & & \\
R1 & 4,2 & 4,2 & 6,9 & 7,9 & 0,1 & 0,7 \\
R2 & 3,6 & 5,9 & 4,9 & 0,3 & 2,2 \\
R3 & 6,8 & 3,5 & 7,2 & 7,8 & 0,9 & 0,4 \\
R4 & 4,4 & 4,5 & 8,8 & 5,2 & 1,0 & 1,4 \\
& & 4,2 & 6,2 & 9,2 & 0,3 & 0,8 \\
\hline
\end{tabular}

Antes de prosseguir, faz-se necessário esclarecer os motivos da não inclusão dos resultados obtidos para os elementos B e Cd na discussão. Esta omissão deve-se ao fato de o teor de $\mathrm{B}$, determinado através dos métodos 3050b e 
6010b (USEPA, 1996), apresentou enorme dispersão, variando de não detectável a $20 \mathrm{mg} / \mathrm{kg}$ para uma mesma amostra, não sendo, portanto, reprodutível.

Quanto ao Cd, em todos os experimentos, seu teor estava abaixo ou muito próximo do limite de detecção do método analítico utilizado, peculiaridade que reduz a confiabilidade dos resultados obtidos.

Os resultados das determinações dos elementos $\mathrm{B}, \mathrm{Cd}, \mathrm{P}, \mathrm{Pb}, \mathrm{S}$ e $\mathrm{Zn}$ no solo tratado e no lixiviado encontram-se no Apêndice A. A avaliação do processo de biolixiviação foi realizada com base na massa dos elementos de interesse nas fases sólida e líquida.

As Figuras 60 e 61 e, 62 e 63 mostram, respectivamente, as concentrações na fase líquida e o teor na fase sólida do $\mathrm{Pb}$ e do $\mathrm{Zn}$.

Para possibilitar a avaliação da influência de cada uma das substâncias adicionadas à suspensão de solo na solubilização dos elementos $\mathrm{Pb}$ e $\mathrm{Zn}$, foram calculadas as diferenças entre as remoções obtidas em cada um dos reatores. Assim, a solubilização no Controle deveu-se ao efeito da água; a diferença entre os resultados obtidos para o Controle e o R1 representa o efeito dos substratos; a diferença entre a solubilização alcançada em R2 e a obtida em R1 indica o efeito do $\mathrm{H}_{2} \mathrm{SO}_{4}$ e a diferença entre a solubilização alcançada em R3 e R4 em relação a R2 é devido ao efeito do $A$. ferrooxidans.

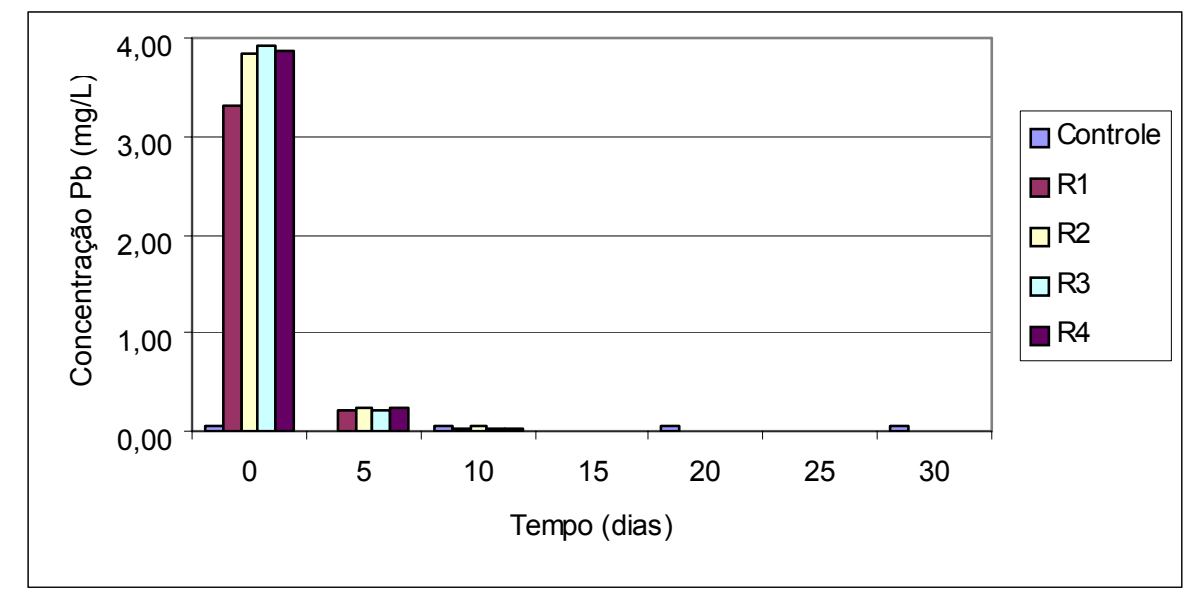

Figura 60 - Concentração do $\mathrm{Pb}$ na fase líquida durante o experimento de biolixiviação $n^{\circ} 6$. 


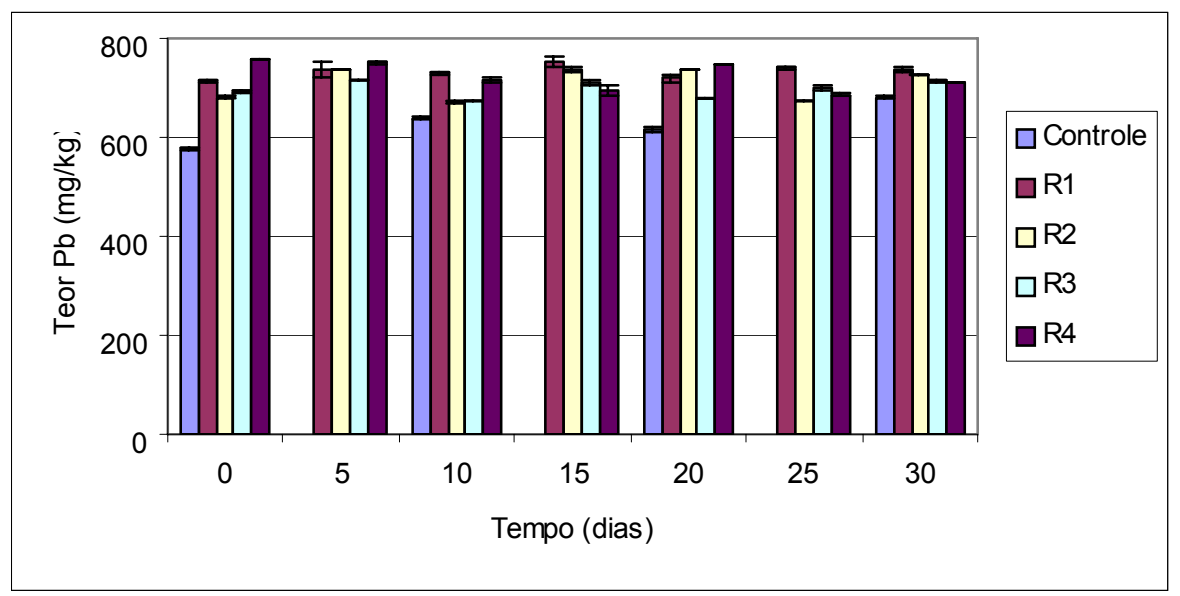

Figura 61 - Teor do $\mathrm{Pb}$ remanescente na fase sólida durante o experimento de biolixiviação $n^{\circ} 6$.

A presença de A.ferrooxidans indígena não pôde ter sua contribuição mensurada, logo, seu efeito sobre a solubilização dos elementos alvo desta pesquisa foi computada em conjunto com o dos substratos.

As Figuras 64 e 65 evidenciam o efeito inquestionável dos substratos e, provavelmente, do $A$. ferrooxidans indígena do solo, sobre a solubilização dos elementos $\mathrm{Pb}$ e $\mathrm{Zn}$. Os valores negativos do percentual de solubilização, constantes nestas figuras, referem-se estritamente às diferenças entre os percentuais de solubilização observados naqueles reatores em relação ao reator utilizado como referencial. No caso do $\mathrm{Pb}$, é provável que tenha ocorrido sua precipitação como $\mathrm{PbSO}_{4}$.

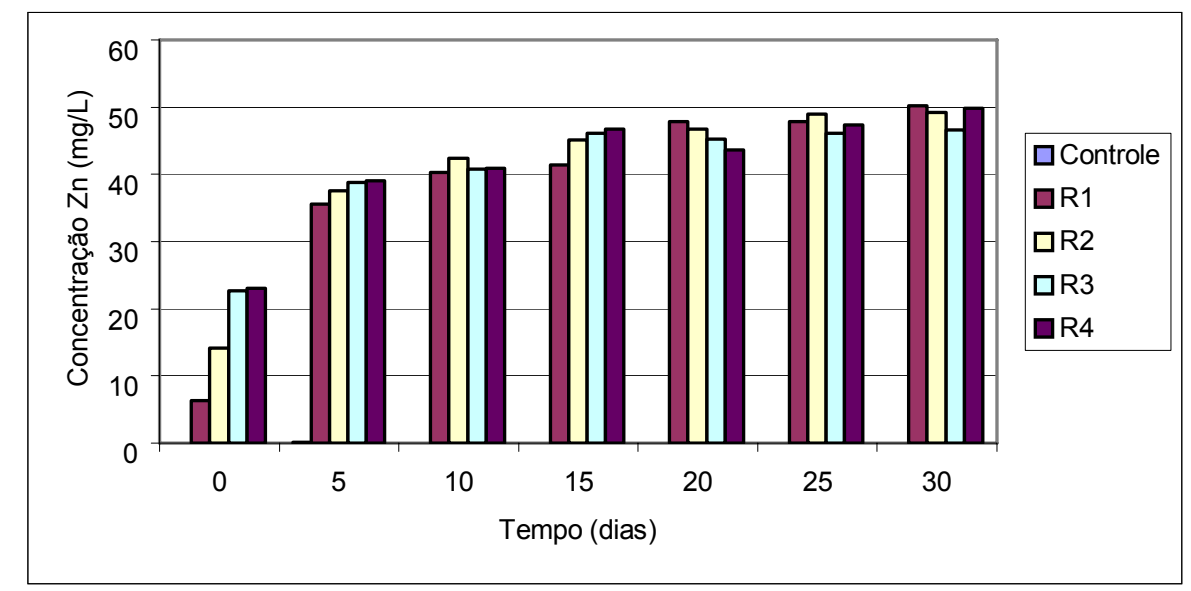

Figura 62 - Concentração do $\mathrm{Zn}$ na fase líquida durante o experimento de biolixiviação $n^{\circ} 6$. 


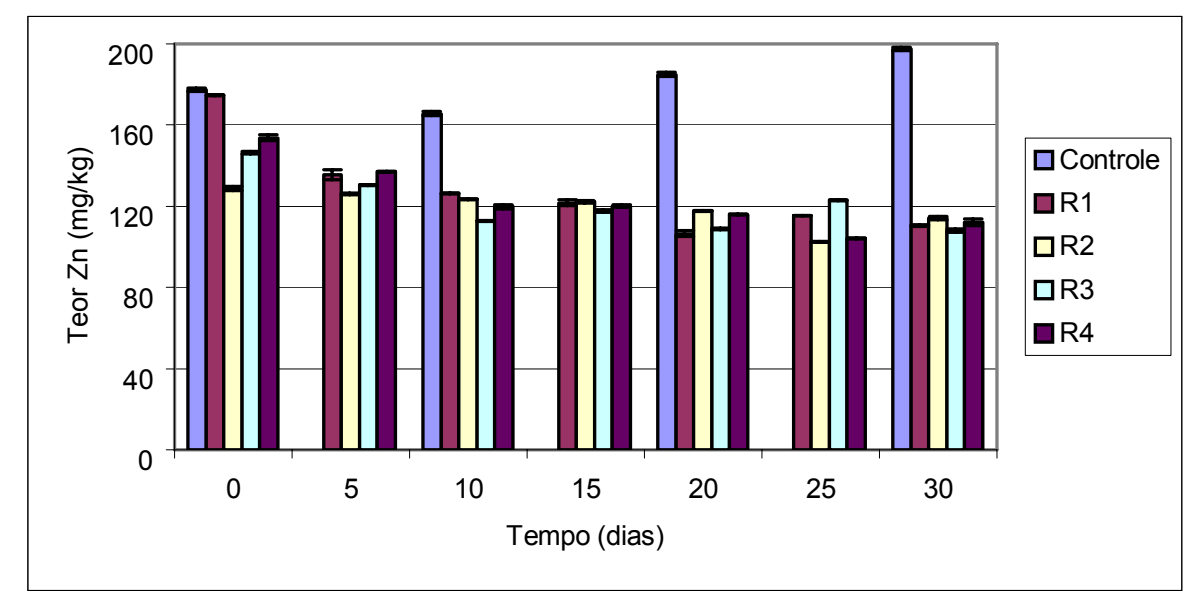

Figura 63 - Teor do $\mathrm{Zn}$ remanescente na fase sólida durante o experimento de biolixiviação $n^{\circ} 6$.

$\mathrm{O}$ elemento $\mathrm{Pb}$, principal contaminante no solo em estudo, apresentou solubilização desprezível. O mesmo comportamento foi observado e reportado por OLIVEIRA (2006), que não encontrou evidências de que a acidificação da suspensão deste mesmo latossolo vermelho mais água resultasse em transferência do $\mathrm{Pb}$ da fase sólida para a líquida, ao invés disso, relatou a tendência ao aumento do teor de $\mathrm{Pb}$ no solo em $\mathrm{pH}<6,0$. A hipótese considerada por OLIVEIRA (2006) para explicar tal fenômeno, foi a formação e a precipitação de $\mathrm{PbSO}_{4}$, tal hipótese é compartilhada na presente pesquisa e é amparada pela discussão do comportamento do $\mathrm{Pb}$ já apresentada no item 5.3.3.

Segundo a literatura (MCLEAN; BLEDSOE, 1992; STUMM, 1992; EVANGELOU, 1998), o pH afeta direta ou indiretamente diversos mecanismos de retenção dos metais no solo. A adsorção de espécies catiônicas aumenta com o pH do solo, embora tal aumento possa não ser significativo até um valor igual a 7,0. Segundo MCLEAN e BLEDSOE (1992), a dependência do pH das reações de adsorção de metais catiônicos é devida, ao menos em parte, à adsorção preferencial das espécies metálicas hidrolisadas em relação ao íon metálico livre, sendo que a proporção de espécies hidrolisadas do metal aumenta com o pH.

Os cátions em solução na água se comportam como ácidos de Lewis, ou seja, tendem a aceitar elétrons. Por outro lado, a água apresenta um comportamento de uma base de Lewis. Uma forte interação entre $\mathrm{H}_{2} \mathrm{O}$ e o metal permite à molécula de água se dissociar, então, o valor do pH é reduzido. O grau de dissociação de um cátion ( $\left(\mathrm{M}^{\mathrm{n}}\right)$ em meio aquoso é descrito pela Reação 23 (EVANGELOU, 1998):

$\mathrm{M}^{\mathrm{n}+}+\mathrm{H}_{2} \mathrm{O} \leftrightarrow \mathrm{MOH}^{(\mathrm{n}-1)}+\mathrm{H}^{+}$ 
Segundo BARROW et alli (1981), em solução aquosa, os íons metálicos hidratados sofrem reações que podem ser representadas por:

$$
\begin{aligned}
& \mathrm{Me}^{2+}+\mathrm{H}_{2} \mathrm{O} \leftrightarrow(\mathrm{k} 1) \mathrm{MeOH}^{+}+\mathrm{H}^{+} \\
& \mathrm{MeOH}^{+}+\mathrm{H}_{2} \mathrm{O} \leftrightarrow(\mathrm{k} 2) \mathrm{Me}(\mathrm{OH})_{2}+\mathrm{H}^{+} \\
& \mathrm{Me}^{2+}+\mathrm{Cl}^{-} \leftrightarrow\left(\mathrm{k}_{\mathrm{MeCl}}\right) \mathrm{MeCl}^{+}
\end{aligned}
$$

Em soluções concentradas e em pH elevado, pode ocorrer a formação de várias espécies poliméricas hidrolisadas, logo, outros produtos além dos mencionadas anteriormente são possíveis. Entretanto, em soluções diluídas e em $\mathrm{pH}$ moderado, as reações supracitadas são importantes.

Outro efeito da redução do $\mathrm{pH}$ é a competição de cátions pelos sítios de troca permanentes ocupados por $\mathrm{Al}^{3+}$ e $^{+}$(MCLEAN e BLEDSOE 1992).

A Figura 65 mostra que a solubilização do $\mathrm{Zn}$ decorreu, principalmente, do efeito dos substratos, mas que também houve efeito aditivo do $A$. ferrooxidans. Ao contrário do que foi observado com o chumbo, o efeito dos substratos sobre a solubilização do $\mathrm{Zn}$ foi crescente ao longo do tempo, o que demonstra a participação da biolixiviação no processo, embora não seja possível determinar se tal fenômeno esteve relacionado com a contribuição dos $A$. ferrooxidans indígenas ou de outra espécie presente no solo.

A Tabela 31 mostra as principais reações que ocorrem na superfície de solos, segundo STUMM (1992).

Tabela 31 - Principais reações que ocorrem nas superfícies de solos.

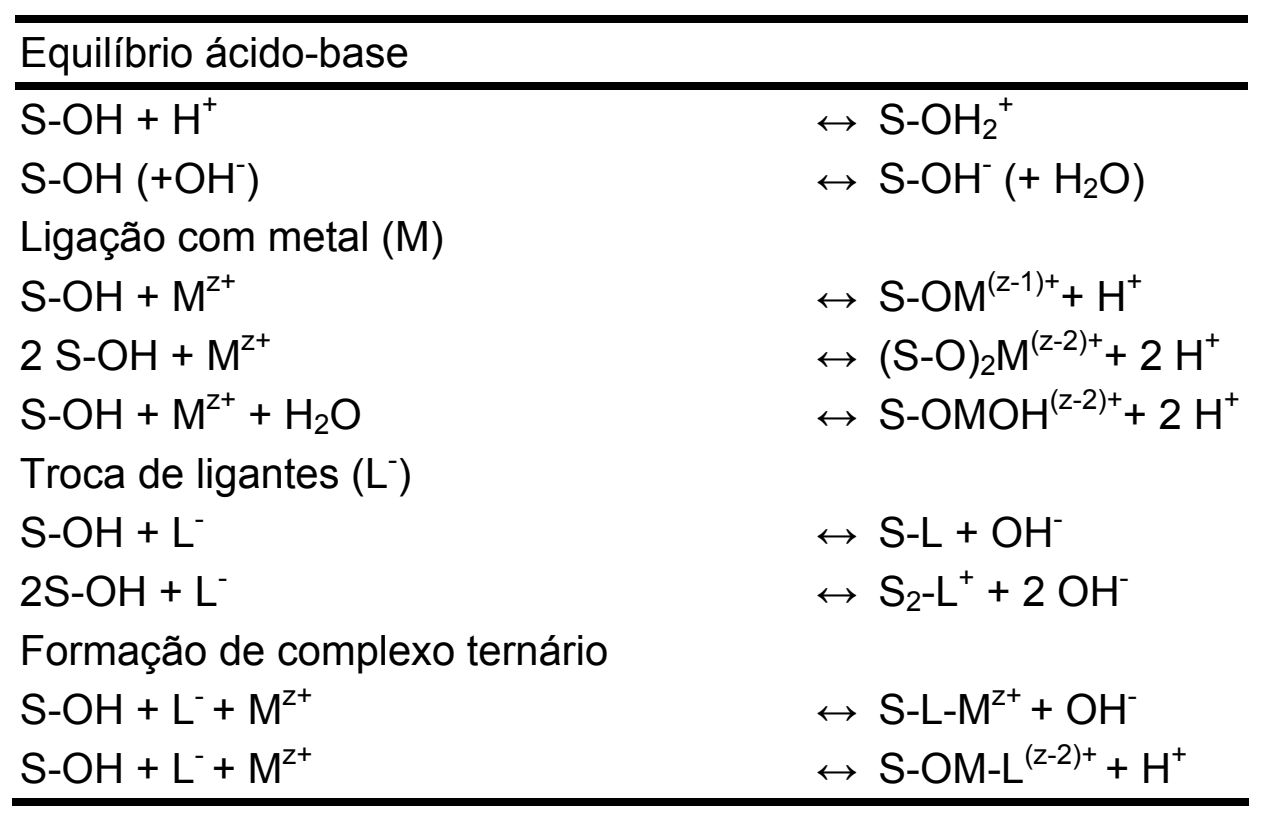

Fonte: STUMM (1992). 


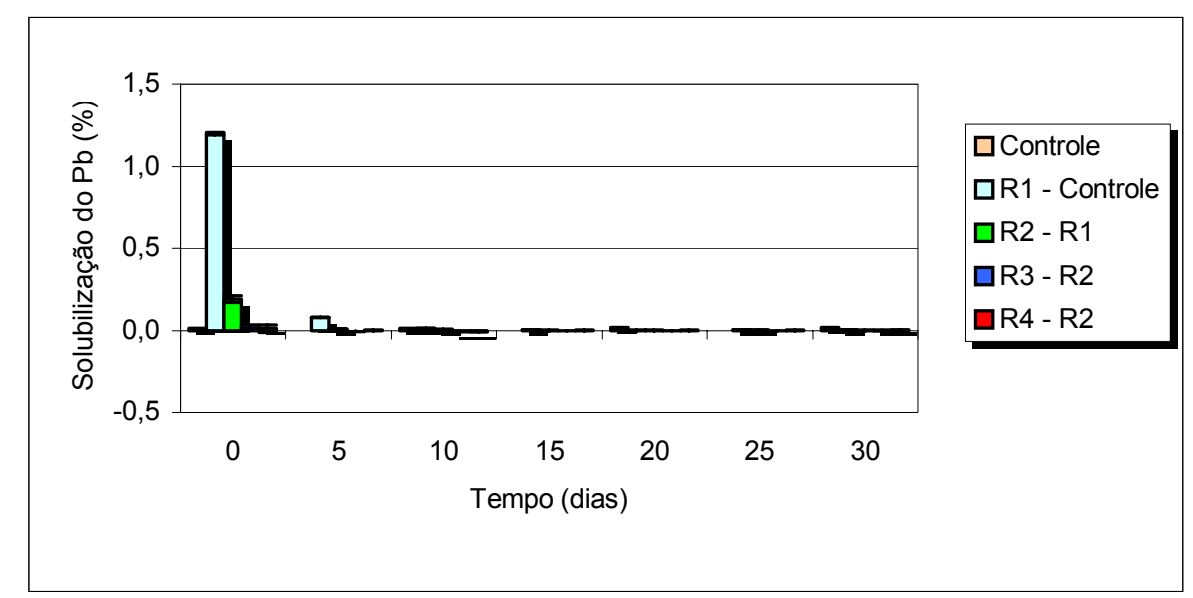

Figura 64 - Efeito dos substratos, do $\mathrm{H}_{2} \mathrm{SO}_{4}$ e do $A$. ferrooxidans na solubilização do elemento $\mathrm{Pb}$ durante o experimento $\mathrm{n}^{\circ} 6$.

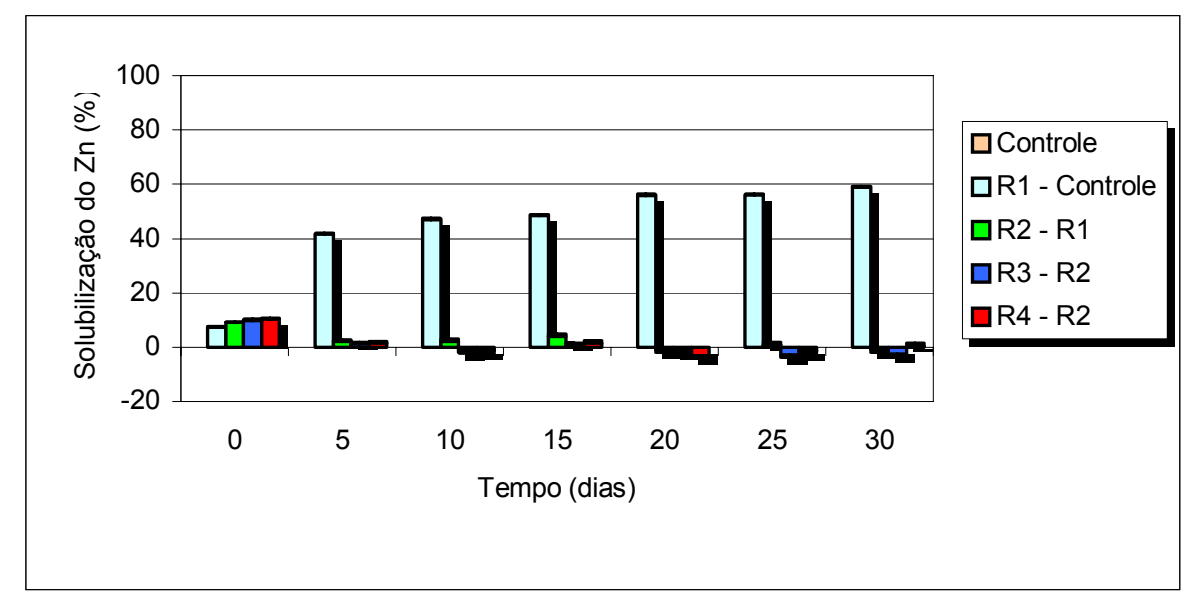

Figura 65 - Efeito dos substratos, do $\mathrm{H}_{2} \mathrm{SO}_{4}$ e do $A$. ferrooxidans na solubilização do elemento $Z n$ durante o experimento $n^{\circ} 6$.

Segundo ALLOWAY (2004), o Zn ocorre no solo sob as seguintes formas:

$>\quad$ ĺons livres $\left(\mathrm{Zn}^{2+}\right.$ e $\left.\mathrm{ZnOH}^{+}\right)$e complexos orgânicos na solução do solo;

> Adsorvido e trocável na superfície da fração de material coloidal do solo, que inclui: argila, compostos húmicos e óxidos hidratados de ferro e alumínio;

> Minerais secundários e compostos insolúveis na fase sólida do solo.

A distribuição do $\mathrm{Zn}$ nestas formas é controlada por constantes de equilíbrio das reações correspondentes nas quais o elemento está envolvido. Tais reações incluem: precipitação e dissolução; complexação e descomplexação; adsorção e dessorção.

A Figura 67 mostra o equilíbrio químico entre o $\mathrm{Zn}$ e os principais constituintes do solo, onde: A é um ânion, $L$ é um ligante orgânico e HA é ácido húmico. Os principais parâmetros que controlam as interações do Zn são (ALLOWAY, 2004): 
$\checkmark$ A concentração do $\mathrm{Zn}^{2+}$ e outros íons na solução do solo;

$\checkmark$ O tipo e a quantidade de sítios de adsorção associados com a fase sólida do solo;

$\checkmark$ A concentração de todos os ligantes capazes de formar complexos orgânicos com o Zn;

$\checkmark \mathrm{O} \mathrm{pH}$ e o potencial redox do solo.

Segundo KIEKENS (1995), o Zn no solo pode sofrer a seguinte reação:

solo- $\mathrm{Zn}+2 \mathrm{H}^{+} \Leftrightarrow \mathrm{Zn}^{2+}$

Com $\log \mathrm{k}^{0}=5,8$ que pode ser expresso como $\log \mathrm{Zn}^{2+}=5,8-2 \mathrm{pH}$ ou $\mathrm{pZn}=$ $2 \mathrm{pH}-5,8$.

Conforme a Reação 27, a atividade do $\mathrm{Zn}^{2+}$ no solo é diretamente proporcional ao quadrado da atividade do próton. Conseqüentemente, sua solubilidade aumenta com o decréscimo no valor do $\mathrm{pH}$.

As solubilidades de diversos minerais de $\mathrm{Zn}$ decrescem na seguinte ordem: $\mathrm{Zn}(\mathrm{OH})_{2}$ amorfo $>\alpha-\mathrm{Zn}(\mathrm{OH})_{2}>\beta-\mathrm{Zn}(\mathrm{OH})_{2}>\gamma-\mathrm{Zn}(\mathrm{OH})_{2}>\varepsilon-\mathrm{Zn}(\mathrm{OH})_{2}>\mathrm{ZnCO}_{3}>\mathrm{ZnO}>$ $\mathrm{Zn}\left(\mathrm{PO}_{4}\right)_{2} \cdot 4 \mathrm{H}_{2} \mathrm{O}>\mathrm{Zn}$ adsorvido no solo $>\mathrm{ZnFe}_{2} \mathrm{O}_{4}$. Todos os minerais de $\mathrm{Zn}(\mathrm{OH})_{2}$, $\mathrm{ZnO}$ e $\mathrm{ZnCO}_{3}$ são aproximadamente $10^{15}$ vezes mais solúveis do que o zinco adsorvido no solo (ALLOWAY, 2004).

$\mathrm{O}$ pH controla a especiação do $\mathrm{Zn}$ na solução do solo: em $\mathrm{pH}<7,7$, a espécie $\mathrm{Zn}^{2+}$ predomina; em $\mathrm{pH}>7,7 \circ \mathrm{Zn}(\mathrm{OH})^{+}$é a espécie predominante e, em $\mathrm{pH}>9,11$, é o $\mathrm{Zn}(\mathrm{OH})_{2}$ que predomina. $\mathrm{Em} \mathrm{pH}=5,0$, a atividade do $\mathrm{Zn}^{2+}$ é de $10^{-4} \mathrm{M}$ (6,5 mg/L), mas em $\mathrm{pH}=8$ é de apenas $10^{-10} \mathrm{M}(0,007 \mu \mathrm{g} / \mathrm{L})(\mathrm{ALLOWAY}, 2004)$. 


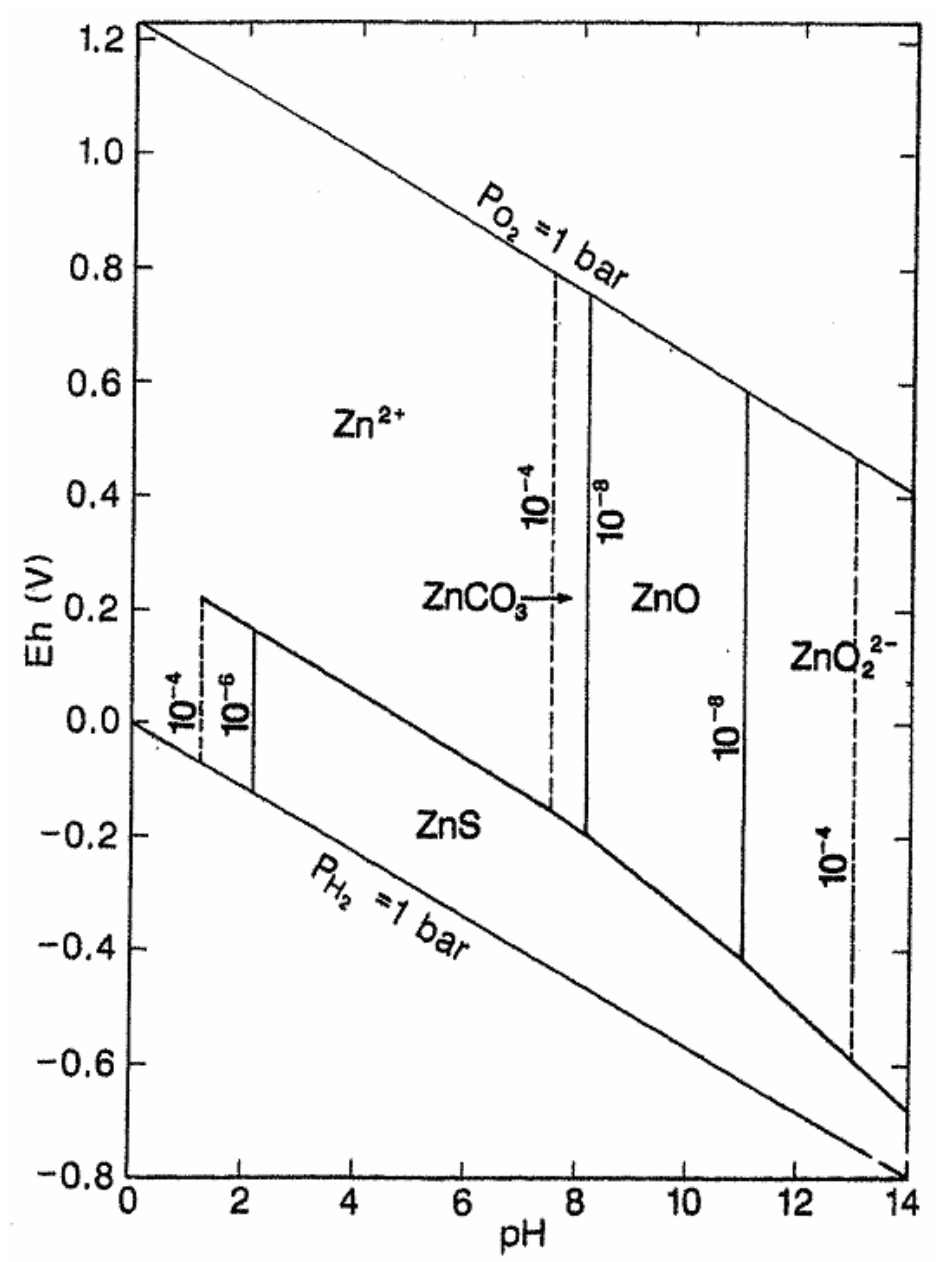

Figura 66 - Diagrama Eh/pH para o sistema Zn-O-H-S-C $\left(25^{\circ} \mathrm{C}, 1\right.$ bar $)$. Fonte: BROOKINS (1988).

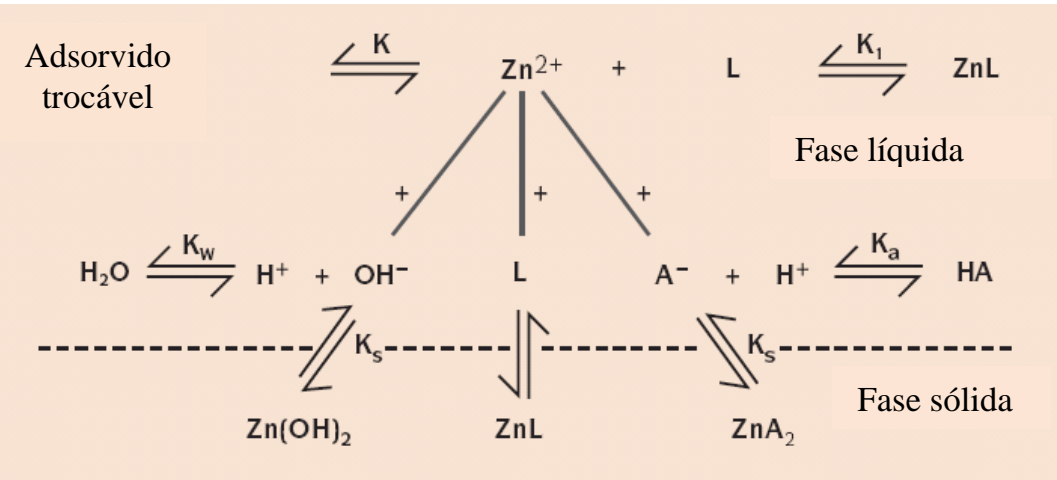

Figura 67 - Equilíbrio químico entre $\mathrm{Zn}$ e componentes do solo. Fonte: KIEKENS (1995) apud ALLOWAY (2004).

OLIVEIRA (2006) também investigou a solubilização de $\mathrm{Zn}$ neste mesmo latossolo mediante a adição de $\mathrm{H}_{2} \mathrm{SO}_{4}$ e concluiu que houve a formação de $\mathrm{ZnSO}_{4} \mathrm{e}$ a subseqüente liberação do íon $\mathrm{Zn}^{2+}$. Embora a pesquisadora não tenha executado a especiação do $\mathrm{Zn}$ no solo bruto, ela admitiu que este elemento em $\mathrm{pH}=8 \mathrm{e} \mathrm{em}$ ambiente oxidado pudesse estar presente sob as formas de hidróxidos $\left(\mathrm{Zn}(\mathrm{OH})_{2}\right)$, 
carbonatos $\left(\mathrm{ZnCO}_{3}\right)$ e óxidos $\left(\mathrm{ZnO}\right.$ e $\left.\mathrm{ZnO}_{2}\right)$, conforme mostra a Figura 65, que foram solubilizadas durante a acidificação do meio.

Finalmente, o comportamento observado na solubilização do Zn ocorreu conforme previsto na literatura (KIEKENS, 1995; ALLOWAY, 2004); foi compatível com os resultados obtidos por OLIVEIRA (2006) e idêntico ao reportado por CHARTIER; COUILLARD (1997); que também associou sua solubilização à adição do $\mathrm{FeSO}_{4}$ utilizado como substrato e à atividade do $A$. ferrooxidans.

Em síntese, a solubilização dos elementos $\mathrm{Pb}$ e $\mathrm{Zn}$ decorreu principalmente da redução do $\mathrm{pH}$ devido à adição dos substratos $\left(\mathrm{NH}_{4}\right)_{2} \mathrm{SO}_{4}, \mathrm{KCl}, \mathrm{K}_{2} \mathrm{HPO}_{4}$, $\mathrm{MgSO}_{4} .7 \mathrm{H}_{2} \mathrm{O}, \mathrm{Ca}\left(\mathrm{NO}_{3}\right)_{2}$ e $\mathrm{FeSO}_{4} .7 \mathrm{H}_{2} \mathrm{O}$. As bactérias $A$. ferrooxidans indígenas e as introduzidas proporcionaram aumento de solubilização no processo de biolixiviação, que pôde ser notado apenas na solubilização do Zn. As eficiências de solubilização obtidas foram distintas para cada um dos elementos avaliados, o que pode ser atribuído às propriedades e às formas químicas que cada um destes elementos se apresentava no solo estudado.

Os resultados das análises microbiológicas realizadas neste experimento encontram-se no Apêndice A. As Figuras 68 e 69 mostram, respectivamente, a evolução das populações de bactérias heterotróficas e de A. ferrooxidans ao longo do tempo.

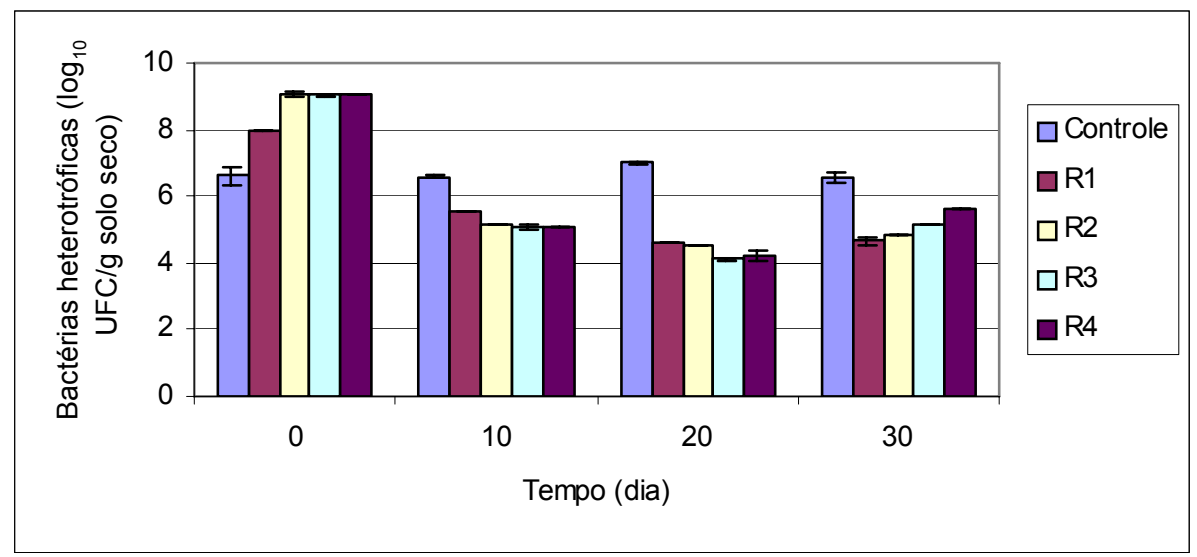

Figura 68 - Evolução da população de bactérias heterotróficas durante o experimento $n^{\circ} 6$.

Ao contrário do observado nos experimentos $n^{0} 4$ e $n^{0} 5$, onde o solo foi previamente esterilizado, não ocorreu um processo de redução drástica de bactérias heterotróficas e, embora tenha se verificado uma pequena redução de suas populações, ficou evidente que tais microrganismos se adaptaram às novas 
condições, o que pôde ser constatado pela tendência de crescimento ao longo do tempo.

Neste experimento, a contagem de células de $A$. ferrooxidans foi executada mediante contagem direta em microscópio, conforme metodologia descrita no item 4.6 e através da técnica de tubos múltiplos (CETESB, 1991).

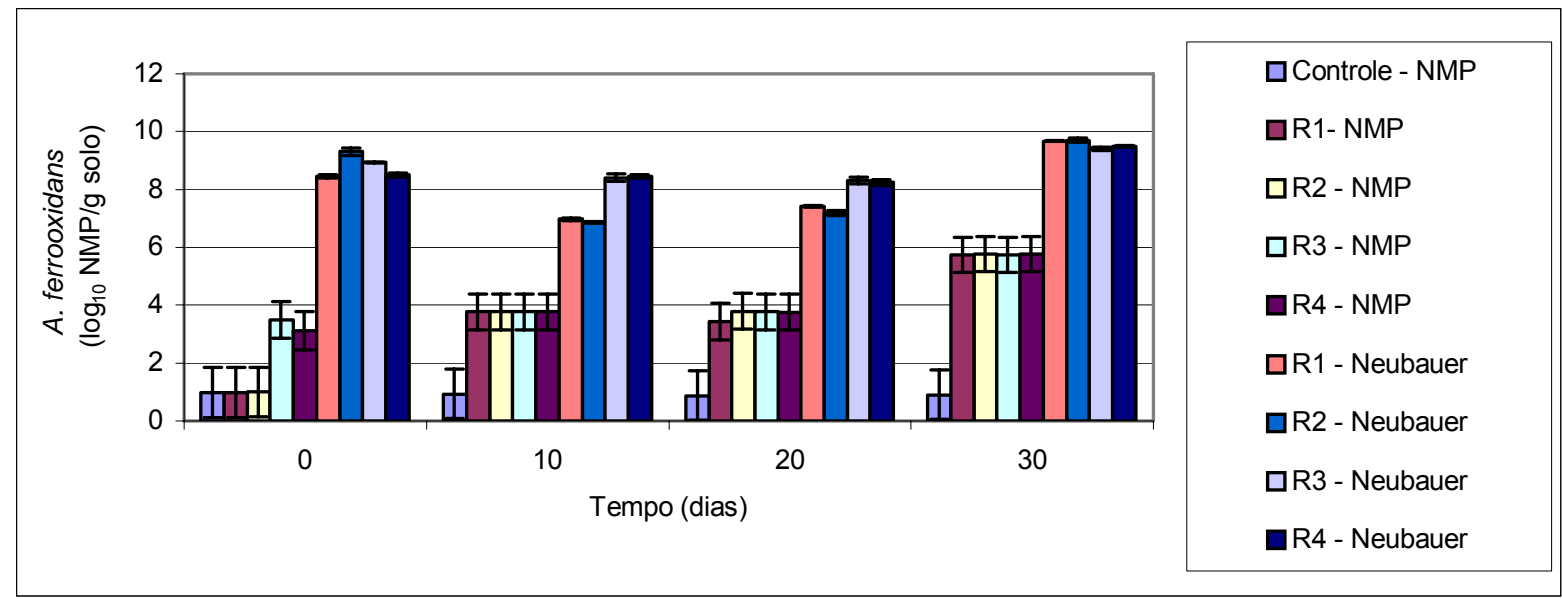

Nota:

NMP - quantificação de células obtida mediante emprego da técnica de tubos múltiplos. Neubauer - quantificação de células obtida mediante contagem direta em microscópio.

Figura 69 - Evolução da população de $A$. ferrooxidans durante o experimento $n^{\circ} 6$.

Estes ensaios permitiram uma conclusão fundamental: para o solo utilizado não havia necessidade de adição de inóculo. Pois, houve crescimento de $A$. ferrooxidans nos reatores R1 e R2, que não haviam recebido inóculo, fato não observado nos experimentos $n^{0} 4$ e $n^{0} 5$ (que utilizaram solo esterilizado em autoclave), ou seja, a microbiota natural do solo incluía bactérias $A$. ferrooxidans, que se multiplicaram após a introdução dos substratos e também atuaram no processo de biolixiviação.

A possibilidade de ter havido contaminação dos reatores controle (R1 e R2) é possível, mas remota, visto que foram tomadas medidas para minimizar tal risco, que incluíram:

> Utilização de tampas nos reatores: foi mantido apenas um orifício para a passagem do eixo do agitador;

> Lavagem múltipla do eletrodo e do sensor de temperatura do potenciômetro antes de cada medição: água destilada + solução de 2,5\% de hipoclorito de sódio + água destilada.

O conhecimento da população inicial de $A$. ferrooxidans, inoculada nos reatores teste, é fator chave para delimitar a quantidade de diluições necessárias 
para cada análise. A elevada duração da determinação do NMP (18 \pm 3 dias) e a quantidade de diluições utilizadas (3 a 8) são fatores que limitaram a aplicação desta técnica para períodos de tempo menores que 10 dias.

A Figura 70 mostra que houve pequena variação da população microbiana durante o experimento, o que já era esperado em função dos resultados obtidos nas contagens de bactérias heterotróficas de $A$. ferrooxidans. Os resultados fornecidos pelo DAPI serviram para validar os fornecidos pelos outras duas análises microbiológicas.

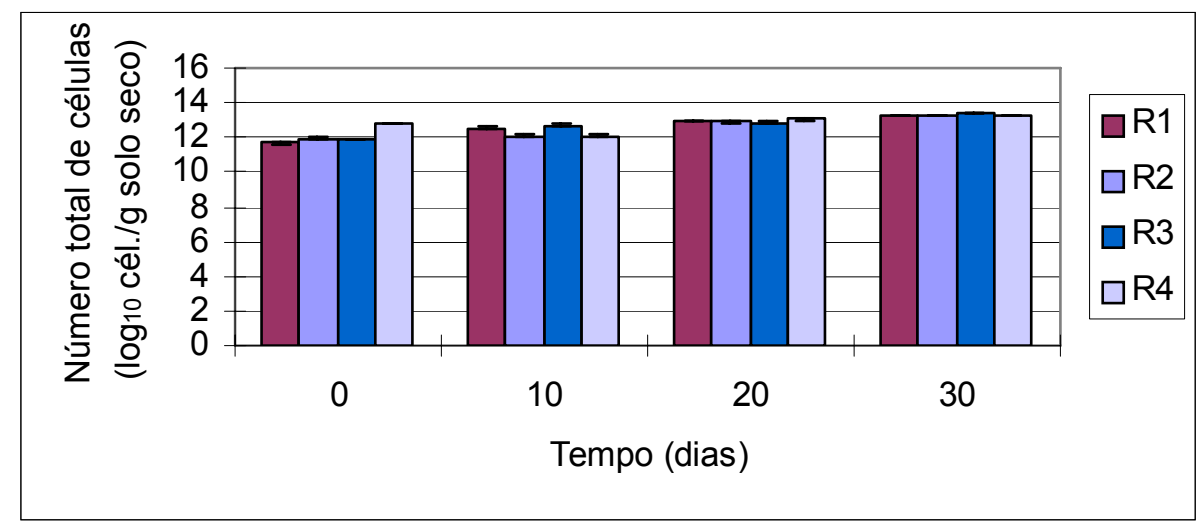

Figura 70 - Evolução do número total de células microbianas (medidas pelo DAPI) durante o experimento $n^{\circ} 6$.

\subsubsection{Experimento $n^{\circ} 7$}

A oxidação do íon $\mathrm{Fe}^{2+}$; resultante da reação de hidrólise do $\mathrm{FeSO}_{4}$; para $\mathrm{Fe}^{3+}$ pode ocorrer naturalmente na presença de $\mathrm{O}_{2}$ do ar ou ser biologicamente catalisada, conforme as reações já apresentadas no item 5.3.3..

Segundo CHARTIER; COUILLARD (1997), em pH < 3,5 e na ausência de bactéria, o íon $\mathrm{Fe}^{2+}$ é estável e a lixiviação devida ao íon $\mathrm{Fe}^{3+}$ é lenta. $\mathrm{O}$ A. ferrooxidans é capaz de oxidar o $\mathrm{Fe}^{2+}$ para $\mathrm{Fe}^{3+}$ em taxas de $5 \times 10^{5}$ a $1 \times 10^{6}$ vezes mais rápidas se comparadas às obtidas na ausência desta bactéria (CHARTIER; COUILLARD, 1997; HERBERT JR, 1999). Em pH igual a 7,0, o $\mathrm{Fe}^{2+}$ é quimicamente instável e é rapidamente oxidado para $\mathrm{Fe}^{3+}$, que precipita como hidróxido e produz um rebaixamento do $\mathrm{pH}$, conforme as Reações 12 a 19 do item 5.3.3. 
Logo, a adição de $\mathrm{FeSO}_{4}$ resulta na redução do pH devido a formação do $\mathrm{Fe}(\mathrm{OH})_{3}$ e na conseqüente liberação de íons $\mathrm{H}^{+}$, o equilíbrio de tal reação química é praticamente alcançado em $\mathrm{pH}=3,5$, abaixo do qual a oxidação do $\mathrm{Fe}^{2+}$ é lenta na ausência de algum fator que catalise tal reação.

A Tabela 32 mostra os íons produzidos pela adição do $\mathrm{FeSO}_{4},\left(\mathrm{NH}_{4}\right)_{2} \mathrm{SO}_{4} \mathrm{e}$ do $\mathrm{H}_{2} \mathrm{SO}_{4}$ nos reatores. Assim como reportado no item 5.3.6, as massas destes íons foram determinadas segundo as reações apresentadas no item 5.3.3. A comparação entre a concentração total de íons $\mathrm{H}^{+}$, resultante da adição conjunta destes reagentes, em relação àquela decorrente da adição do $\mathrm{H}_{2} \mathrm{SO}_{4}$ utilizado para ajuste de $\mathrm{pH}$ (Figura 45), evidencia que nem todo o íon $\mathrm{Fe}^{2+}$ foi oxidado para $\mathrm{Fe}^{3+}$.

Segundo os dados da curva de ajuste de pH do solo (Figura 45), referente à mesma concentração de solo do experimento $n^{\circ} 7$, haveria necessidade da adição

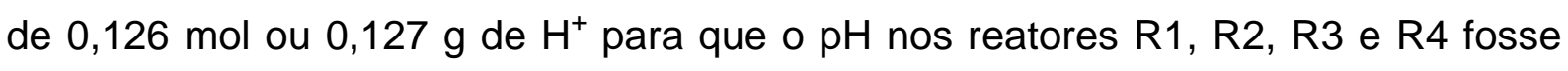
reduzido de 7,8 para aproximadamente 2,0. Entretanto, a massa máxima possível de $\mathrm{H}^{+}$; caso ocorresse a completa oxidação química do íon $\mathrm{Fe}^{2+}$; seria igual a 0,57 mol $\mathrm{H}^{+}(0,58 \mathrm{~g})$ nos reatores $\mathrm{R} 1, \mathrm{R} 2, \mathrm{R} 3$ e $\mathrm{R} 4$, o que permitiria que o $\mathrm{pH}$ fosse reduzido a valor próximo de 1,0, fato que não aconteceu.

CHARTIER; COUILLARD (1997) reportaram que, em seus experimentos, a oxidação química do $\mathrm{Fe}^{2+}$ para $\mathrm{Fe}^{3+}$ ocorreu nas primeiras vinte horas e que após este período e em $\mathrm{pH}<3,5$, somente a oxidação catalisada por algum microrganismo, admitida por estes autores como sendo linhagens indígenas de Thiobacilli $s p$, poderia explicar a oxidação do $\mathrm{Fe}^{2+}$ para $\mathrm{Fe}^{3+}$ e a conseqüente redução do $\mathrm{pH}$ para valores menores que 3,5.

Portanto, como mostra a Figura $71, \mathrm{o} \mathrm{pH}=3,5$ foi alcançado nas primeiras vinte e quatro horas do experimento; fato que condiz com as observações de CHARTIER; COUILLARD (1997); logo, é lícito admitir que sua redução deveu-se à liberação adicional de íons $\mathrm{H}^{+}$, iniciada pela oxidação do $\mathrm{Fe}^{2+}$ catalisada por atividade microbiológica.

$\mathrm{O} \mathrm{pH}$ apresentou comportamento idêntico ao do experimento $\mathrm{n}^{\circ} 6$, ou seja, os valores observados nos reatores que não receberam inóculo de $A$. ferrooxidans (R1 e R2) foram praticamente coincidentes com os que receberam o inóculo (R3 e $\mathrm{R} 4)$. 


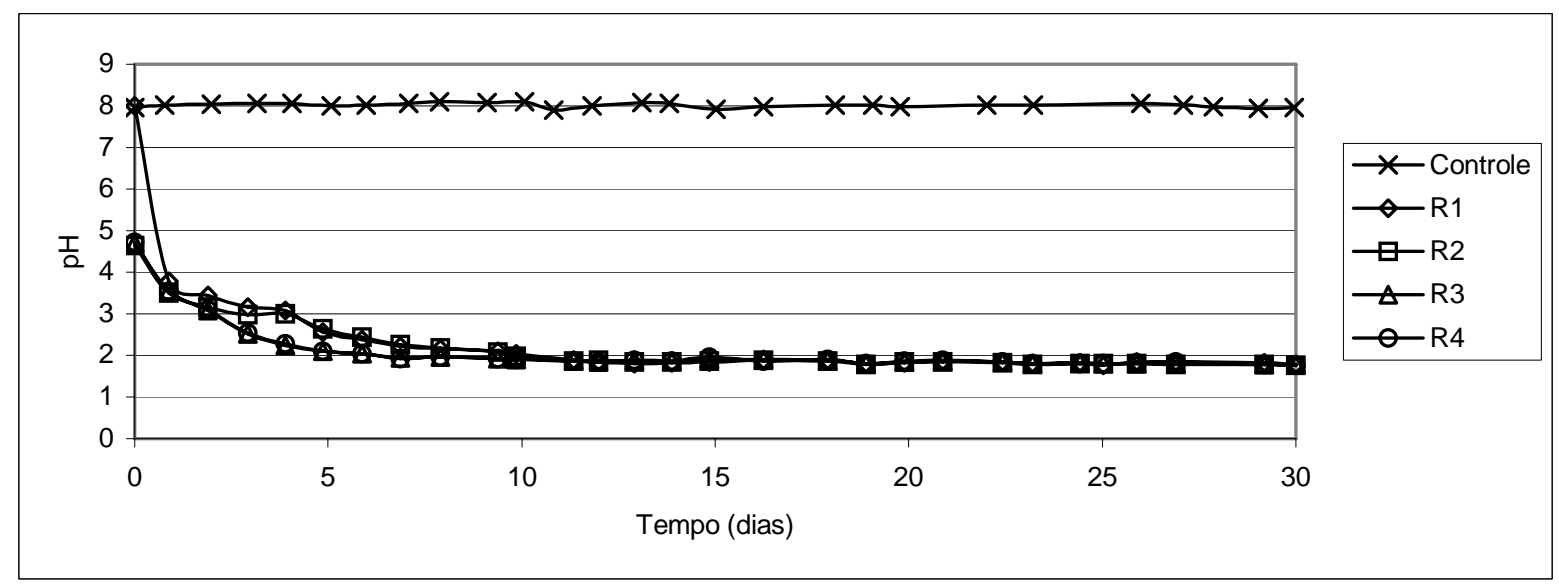

Reatores: Controle - água + solo; R1 - água + solo + substrato; R2 - água + solo + substrato + $\mathrm{H}_{2} \mathrm{SO}_{4}$; R3 e R4 - água + solo + substrato $+\mathrm{H}_{2} \mathrm{SO}_{4}$ + suspensão bacteriana.

Figura 71 - Variação do pH ao longo tempo no experimento $\mathrm{n}^{0} 7$.

Tabela 32 - Massa teórica máxima de íons liberados nos reatores, resultantes das reações de dissociação e solubilização dos reagentes $\mathrm{FeSO}_{4},\left(\mathrm{NH}_{4}\right)_{2} \mathrm{SO}_{4} \mathrm{e} \mathrm{H}_{2} \mathrm{SO}_{4}$.

\begin{tabular}{ccccccc}
\hline $\mathrm{SO}_{4}{ }^{2-}(\mathrm{g})$ & $\mathrm{HSO}_{4}{ }^{-}(\mathrm{g})$ & $\mathrm{Fe}(\mathrm{OH})_{3}(\mathrm{~g})$ & \multicolumn{4}{c}{$\mathrm{H}^{+}(\mathrm{g})$} \\
\hline $\mathrm{R} 1 \mathrm{a} \mathrm{R} 4$ & $\mathrm{R} 1 \mathrm{a} \mathrm{R} 4$ & $\mathrm{R} 1 \mathrm{a} \mathrm{R} 4$ & $\mathrm{R} 1$ & $\mathrm{R} 2$ & $\mathrm{R} 3$ & $\mathrm{R} 4$ \\
48,89 & 1,84 & 47,60 & 0,58 & 0,60 & 0,60 & 0,60 \\
\hline
\end{tabular}

Nota: Não foi adicionado nenhum dos reagentes no reator Controle.

A Tabela 33 mostra os resultados das análises elementares realizadas com as amostras dos reatores no início e no final do sétimo experimento de biolixiviação.

Os resultados das determinações dos elementos $\mathrm{B}, \mathrm{Cd}, \mathrm{P}, \mathrm{Pb}, \mathrm{S}$ e $\mathrm{Zn}$ do solo tratado e do lixiviado encontram-se no Apêndice A. As Figuras 72 e 73 e 74 e 75 mostram, respectivamente, as concentrações na fase líquida e os teores na fase sólida do $\mathrm{Pb}$ e do $\mathrm{Zn}$.

As Figuras 76 e 76 permitem a visualização, respectivamente, das frações dos elementos $\mathrm{Pb}$ e $\mathrm{Zn}$, que foram solubilizadas pela lixiviação química e biológica. Visto que persistiram os erros analíticos na determinação dos elementos B e Cd, optou-se por não apresentar a representação gráfica de seus resultados.

As Figuras 74, 75 e 77 evidenciam, assim como no experimento $n^{\circ} 6,0$ efeito do substrato na fase inicial, somado à atividade de microrganismos indígenas, provavelmente A. ferrooxidans. A solubilização do $\mathrm{Pb}$ foi desprezível.

Ao contrário do que foi observado para o $\mathrm{Pb}$, o efeito do substrato sobre a solubilização do $\mathrm{Zn}$ foi crescente ao longo do tempo, assim como registrado no experimento $\mathrm{n}^{\circ} 6$, fato que corrobora a tese da contribuição do $A$. ferrooxidans indígena do solo. 
Tabela 33 - Teores de carbono, hidrogênio e nitrogênio no início e no final do experimento $\mathrm{n}^{0} 7$.

\begin{tabular}{ccccccc}
\hline Tempo (dias) & \multicolumn{2}{c}{$\mathbf{C}$} & \multicolumn{2}{c}{$\mathbf{H}$} & \multicolumn{2}{c}{$\mathbf{N}$} \\
Reator & $\mathbf{0}$ & $\mathbf{3 0}$ & $\mathbf{0}$ & $\mathbf{3 0}$ & $\mathbf{0}$ & $\mathbf{3 0}$ \\
\hline Controle & 5,4 & 5,8 & 5,3 & 7,1 & 0,6 & 0,7 \\
R1 & 4,1 & 3,3 & 5,2 & 5,7 & 1,1 & 0,6 \\
R2 & 6,0 & 3,4 & 5,8 & 5,3 & 0,1 & 0,9 \\
R3 & 4,7 & 3,6 & 5,9 & 5,2 & 0,3 & 0,5 \\
R4 & 3,4 & 4,2 & 6,0 & 6,6 & 2,0 & 0,7 \\
\hline
\end{tabular}

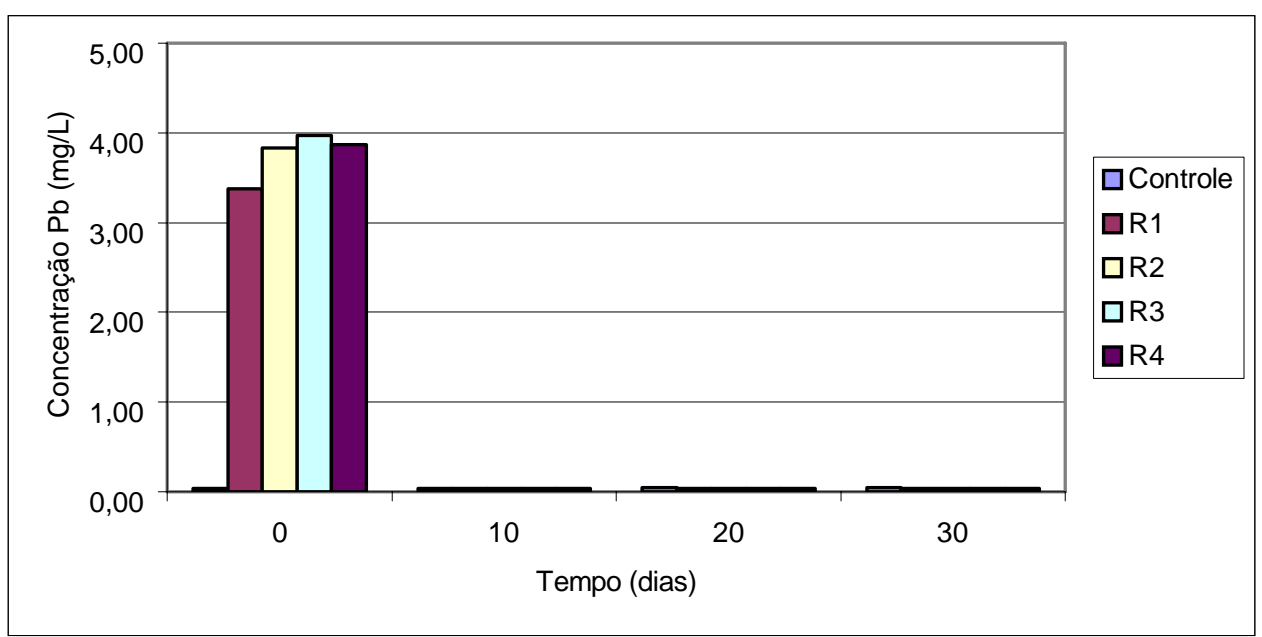

Reatores: Controle - água + solo; R1 - água + solo + substrato; R2 - água + solo + substrato $+\mathrm{H}_{2} \mathrm{SO}_{4} ; \mathrm{R} 3$ e R4 - água + solo + substrato $+\mathrm{H}_{2} \mathrm{SO}_{4}+$ suspensão bacteriana.

Figura 72 - Concentração do $\mathrm{Pb}$ na fase líquida durante o experimento de biolixiviação $n^{0} 7$.

Embora o arranjo experimental utilizado não permita mensurar com rigor o efeito dos microrganismos indígenas sobre conjunto dos experimentos executados, é possível afirmar, com base nos resultados obtidos, que coincidem com as observações de CHARTIER; COUILLARD (1997), que a solubilização do Zn devida ao efeito químico ocorre nas primeiras horas do experimento. Logo, a solubilização após quarenta e oito horas - no máximo - do início experimento é resultante da redução do pH para valor menor que 3,5, que por sua vez é decorrente da oxidação biológica do $\mathrm{Fe}^{2+}$ para $\mathrm{Fe}^{3+}$ e da conseqüente liberação de íons $\mathrm{H}^{+}$durante a formação e precipitação do $\mathrm{Fe}(\mathrm{OH})_{3}$. 


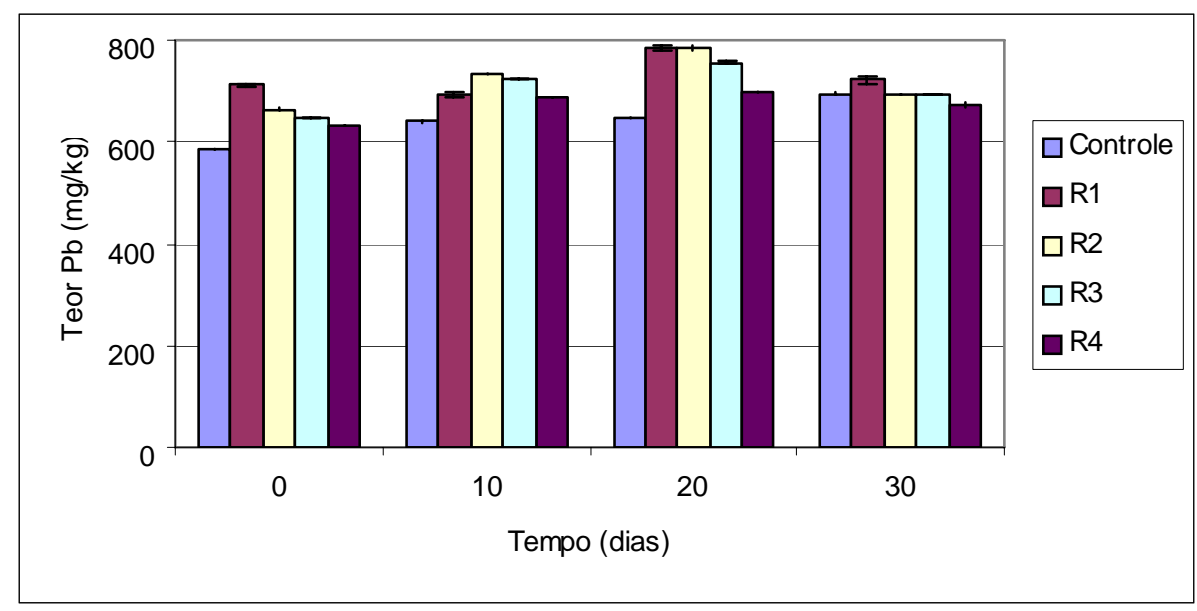

Reatores: Controle - água + solo; R1 - água + solo + substrato; R2 - água + solo + substrato $+\mathrm{H}_{2} \mathrm{SO}_{4} ; \mathrm{R} 3$ e R4 - água + solo + substrato $+\mathrm{H}_{2} \mathrm{SO}_{4}+$ suspensão bacteriana. Figura 73 - Teor do $\mathrm{Pb}$ remanescente na fase sólida durante 0 experimento de biolixiviação $n^{\circ} 7$.

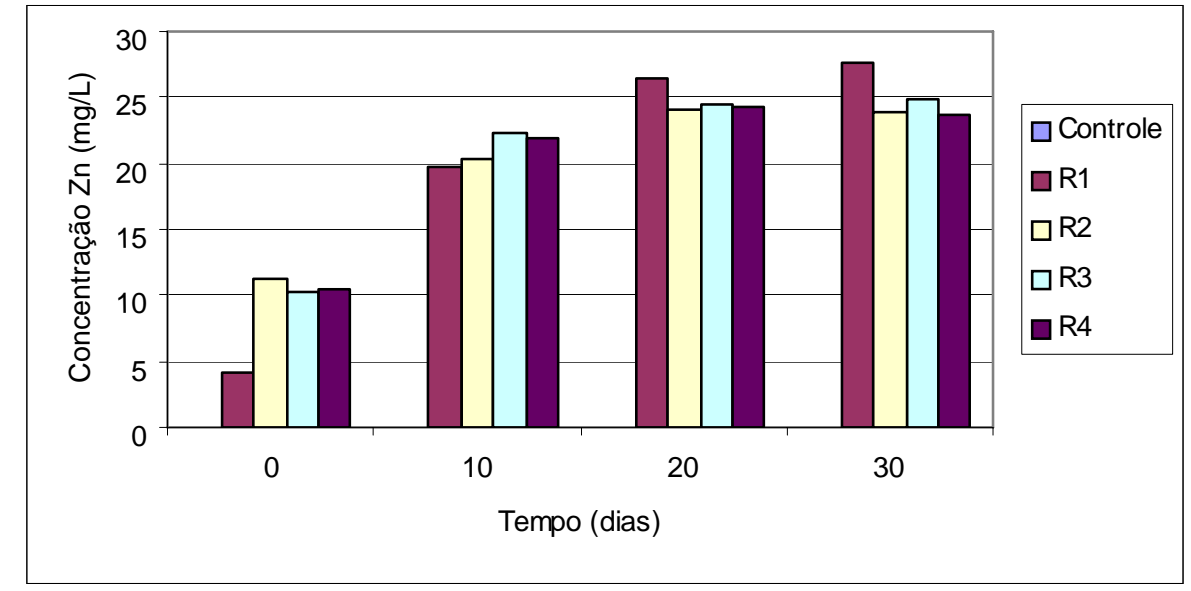

Reatores: Controle - água + solo; R1 - água + solo + substrato; R2 - água + solo + substrato $+\mathrm{H}_{2} \mathrm{SO}_{4} ; \mathrm{R} 3$ e R4 - água + solo + substrato $+\mathrm{H}_{2} \mathrm{SO}_{4}+$ suspensão bacteriana.

Figura 74 - Concentração do Zn na fase líquida durante o experimento de biolixiviação $\mathrm{n}^{0} 7$.

Portanto, é razoável considerar que a solubilização obtida nos experimentos ora reportados, após o décimo dia, deveu-se à atividade de $A$. ferrooxidans indígenas do solo, visto que os reatores que receberam o inóculo de $A$. ferrooxidans cultivados não propiciaram nenhum efeito aditivo.

Em síntese, assim como foi observado no experimento $n^{\circ} 6$, a solubilização dos elementos $\mathrm{Pb}$ e $\mathrm{Zn}$ decorreu essencialmente da adição do substrato $\left(\mathrm{NH}_{4}\right)_{2} \mathrm{SO}_{4}$, $\mathrm{KCl}, \mathrm{K}_{2} \mathrm{HPO}_{4}, \mathrm{MgSO}_{4} .7 \mathrm{H}_{2} \mathrm{O}, \mathrm{Ca}\left(\mathrm{NO}_{3}\right)_{2}$ e $\mathrm{FeSO}_{4} .7 \mathrm{H}_{2} \mathrm{O}$, especialmente deste último, e do efeito $\operatorname{dos} A$. ferrooxidans indígenas do solo. 


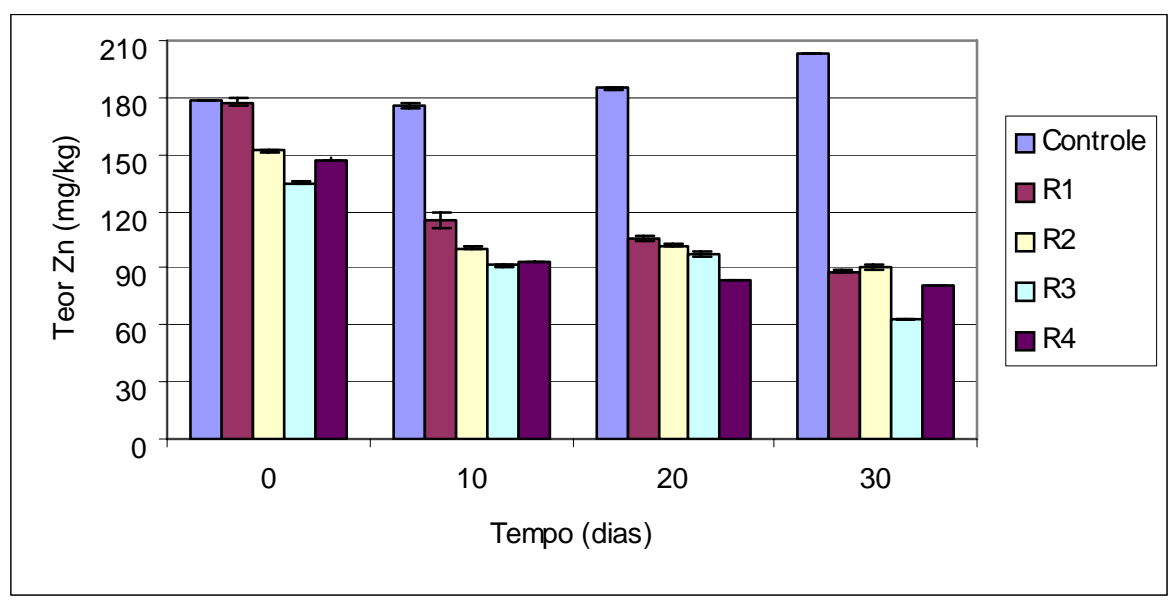

Reatores: Controle - água + solo; $\mathrm{R} 1$ - água + solo + substrato; R2 - água + solo + substrato $+\mathrm{H}_{2} \mathrm{SO}_{4} ; \mathrm{R} 3$ e R4 - água + solo + substrato $+\mathrm{H}_{2} \mathrm{SO}_{4}+$ suspensão bacteriana. Figura 75 - Teor do $\mathrm{Zn}$ remanescente na fase sólida durante 0 experimento de biolixiviação $n^{0} 7$.

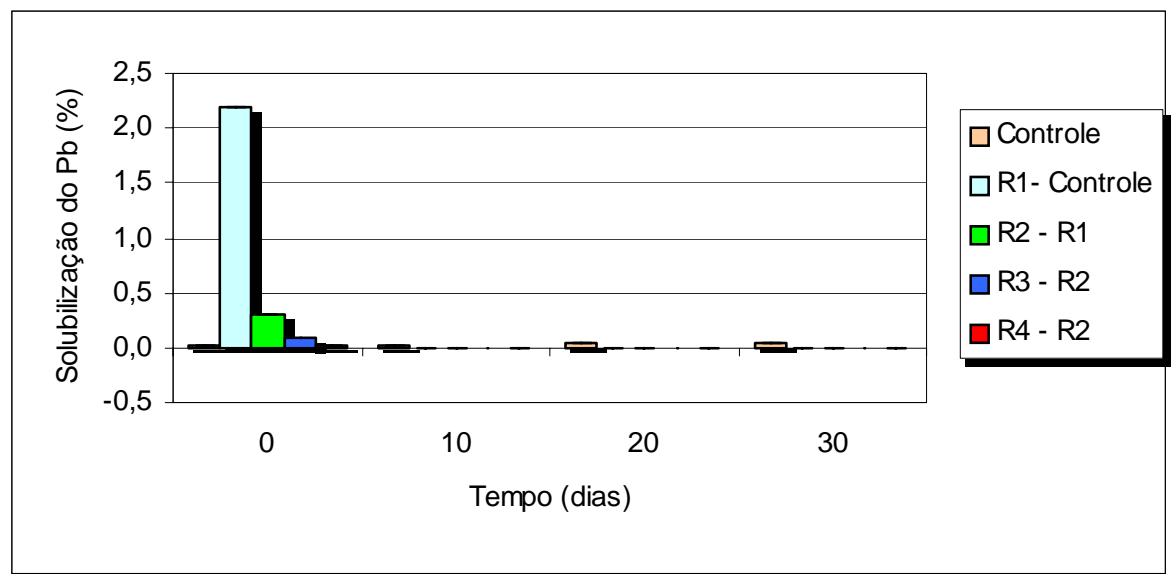

Reatores: Controle - água + solo; R1 - água + solo + substrato; R2 - água + solo + substrato $+\mathrm{H}_{2} \mathrm{SO}_{4} ; \mathrm{R} 3$ e R4 - água + solo + substrato $+\mathrm{H}_{2} \mathrm{SO}_{4}+$ suspensão bacteriana. Figura 76 - Efeito do substrato, do $\mathrm{H}_{2} \mathrm{SO}_{4}$ e do $A$. ferrooxidans na solubilização do elemento $\mathrm{Pb}$ durante o experimento $\mathrm{n}^{0} 7$.

Comparando os resultados obtidos neste experimento com o $\mathrm{n}^{\circ} 6$, verifica-se que a redução da concentração de solo na suspensão traduziu-se em acréscimo na solubilização do Zn. Quanto ao elemento Pb, sua solubilização com os agentes lixiviantes utilizados, não foi afetada pela variação da concentração de solo na suspensão e manteve-se desprezível.

Os resultados das análises microbiológicas do experimento $\mathrm{n}^{0} 7$ podem ser consultados no Apêndice A. As Figuras 78, 79 e 80 mostram, respectivamente, a evolução das populações de bactérias heterotróficas, $A$. ferrooxidans e do número total de células microbianas ao longo do tempo. 


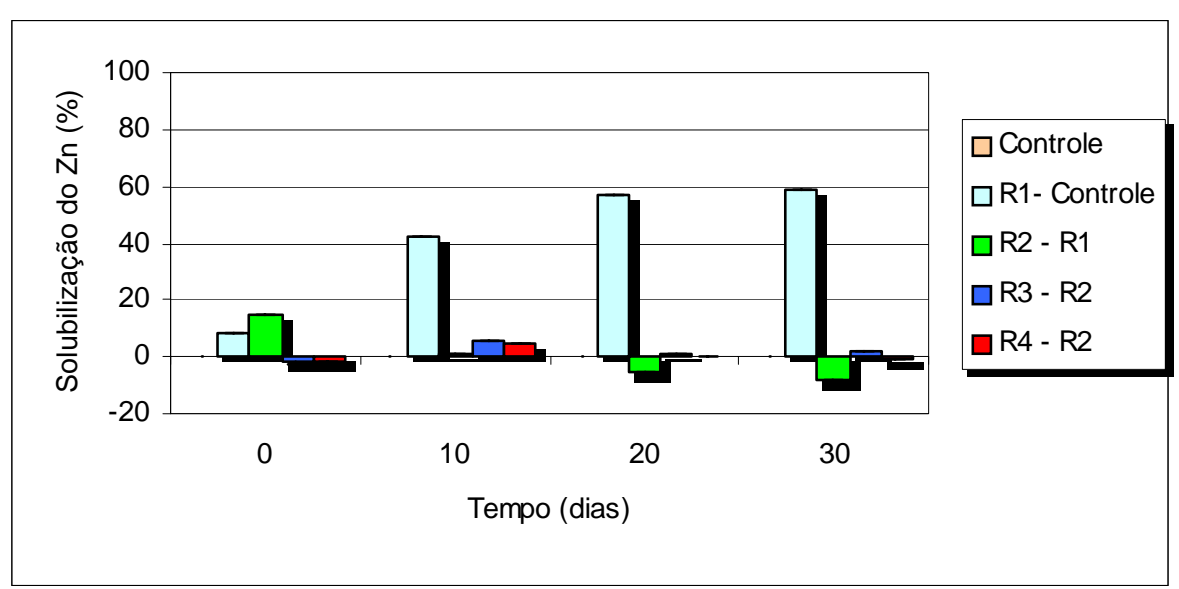

Reatores: Controle - água + solo; R1 - água + solo + substrato; R2 - água + solo + substrato $+\mathrm{H}_{2} \mathrm{SO}_{4} ; \mathrm{R} 3$ e R4 - água + solo + substrato $+\mathrm{H}_{2} \mathrm{SO}_{4}+$ suspensão bacteriana.

Figura 77 - Efeito do substrato, do $\mathrm{H}_{2} \mathrm{SO}_{4}$ e do $A$. ferrooxidans na solubilização do elemento $\mathrm{Zn}$ durante o experimento $\mathrm{n}^{\circ} 7$.

$O$ experimento de biolixiviação $n^{0} 7$ diferiu do $n^{\circ} 6$ apenas pela concentração de solo, que foi reduzida de $430 \mathrm{~g} / \mathrm{L}$ para $250 \mathrm{~g} / \mathrm{L}$ A variação das populações de bactérias heterotróficas e de $A$. ferrooxidans observadas neste experimento apresentaram tendências similares de redução e crescimento daquelas observadas no experimento $n^{\circ} 6$.

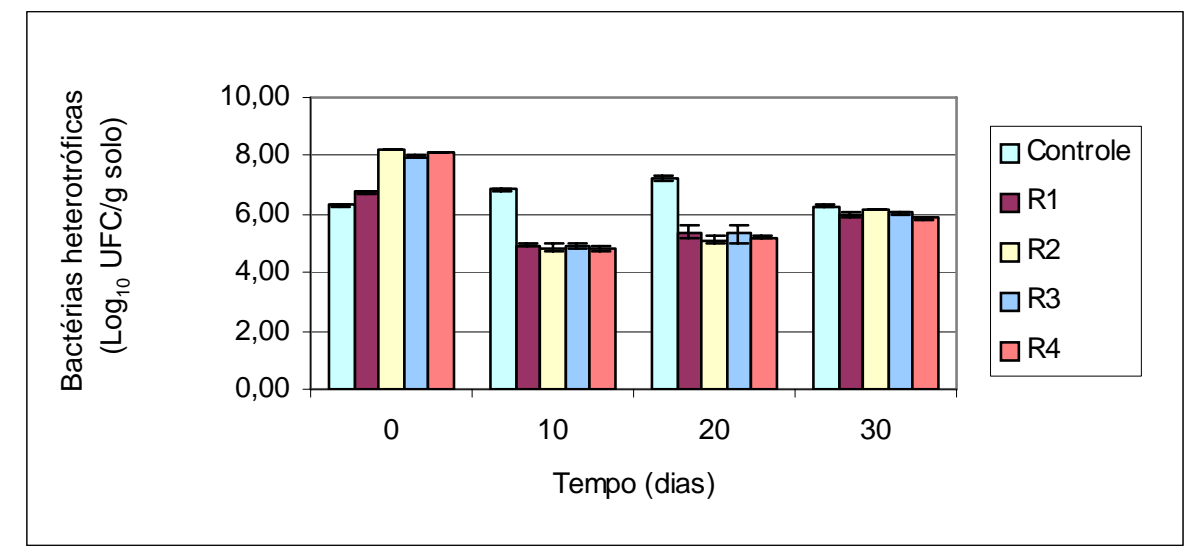

Figura 78 - Evolução da população de bactérias heterotróficas durante o experimento $n^{0} 7$. 


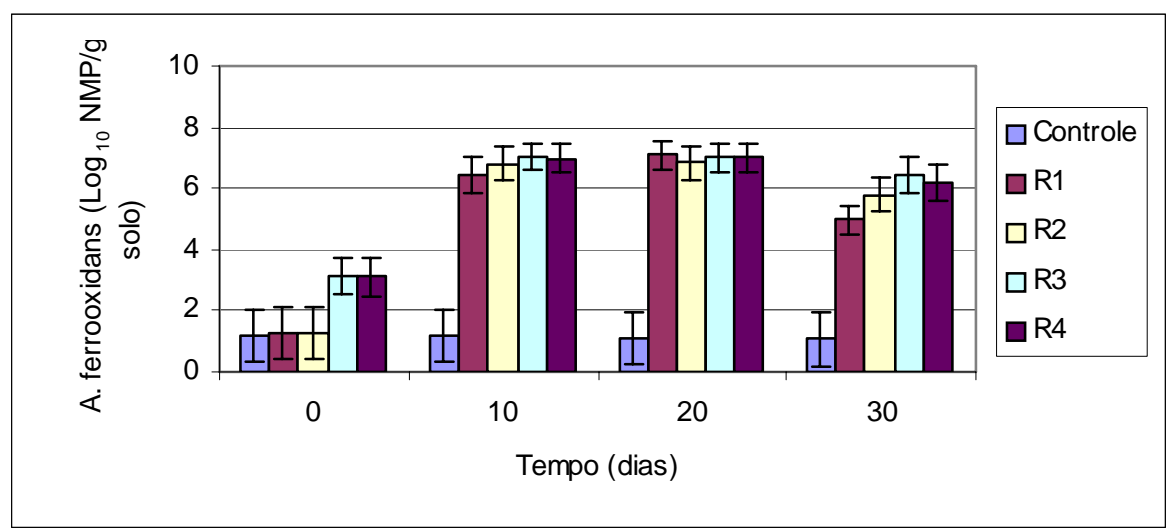

Figura 79 - Evolução da população de bactérias $A$. ferrooxidans durante o experimento $n^{0} 7$.

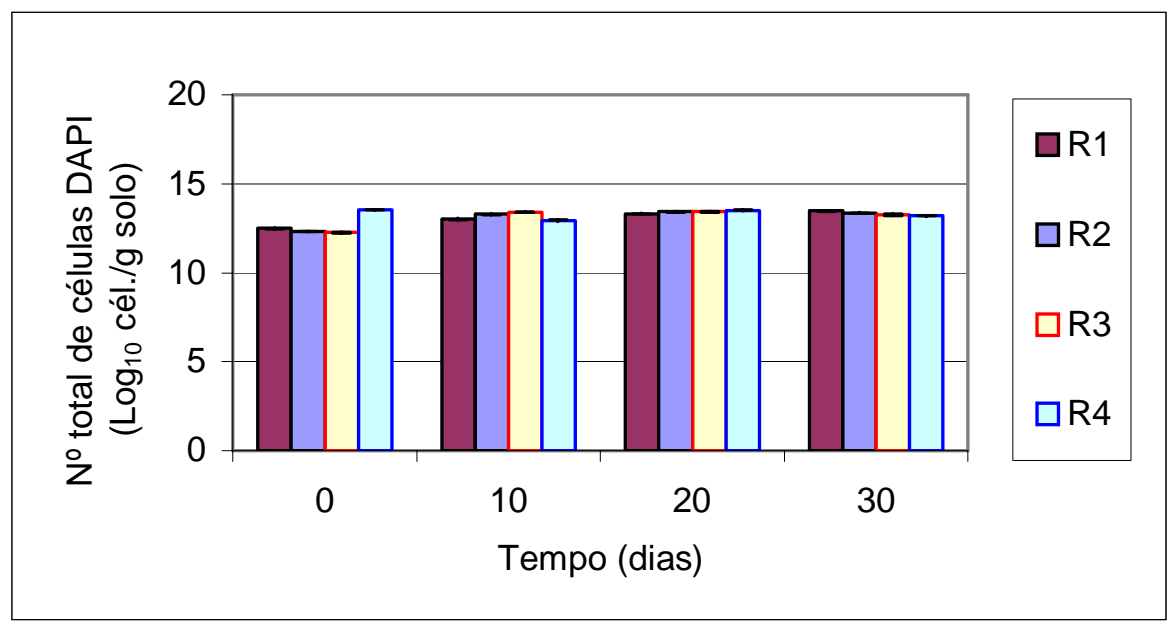

Figura 80 - Evolução do número total de microrganismos durante o experimento $n^{0} 7$.

\subsubsection{Experimento $n^{\circ} 8$}

Este experimento foi executado com a mesma concentração de solo utilizada no $n^{\circ} 7$, mas apresentou três diferenças: o inóculo foi concentrado em 40 $\mathrm{mL}$ (ao invés de $10 \mathrm{~mL}$ como nos experimentos $\mathrm{n}^{\circ} 6$ e $\mathrm{n}^{\circ} 7$ ), a composição do substrato foi modificada (não foram adicionados: $\mathrm{KCl} ; \mathrm{K}_{2} \mathrm{HPO}_{4} ; \mathrm{MgSO}_{4}$ e $\mathrm{Ca}\left(\mathrm{NO}_{3}\right)_{2}$ ), a massa de $\left(\mathrm{NH}_{4}\right)_{2} \mathrm{SO}_{4}$ foi aumentada de 8,4 $\mathrm{g}$ para 9,6 $\mathrm{g}$ e reduzida a de $\mathrm{FeSO}_{4} .7 \mathrm{H}_{2} \mathrm{O}$ de $123,8 \mathrm{~g}$ para $16 \mathrm{~g}$. 
Observou-se nos experimentos $n^{0} 6$ e $n^{0} 7$ que a adição dos reagentes utilizados como substrato provocou a queda do $\mathrm{pH}$ para valores de aproximadamente 2,0 em virtude da adição, particularmente do $\mathrm{FeSO}_{4}$, conforme já discutido nos itens 5.3.6 e 5.3.7.

As modificações quanto ao suprimento de substratos foram introduzidas para reduzir o efeito destes sobre o pH e, deste modo, possibilitar uma avaliação mais precisa e acurada do processo de biolixiviação, além de permitir a comparação dos resultados com aqueles obtidos por ZAGURY et alii (2001), que utilizaram $5 \mathrm{~g} / \mathrm{L}$ de $\mathrm{FeSO}_{4} .7 \mathrm{H}_{2} \mathrm{O}$ e $3 \mathrm{~g} / \mathrm{L}$ de $\left(\mathrm{NH}_{4}\right)_{2} \mathrm{SO}_{4}$. Já, o objetivo do aumento do volume do inóculo foi o de permitir um maior contato entre as bactérias e os contaminantes do solo.

A Figura 81 mostra que as alterações no suprimento de substrato surtiram os efeitos desejados, ou seja, o pH inicial manteve-se acima de 2,0, todavia, todos os reatores apresentaram comportamento similar em relação à este parâmetro e os reatores que receberam o inóculo de $A$. ferrooxidans (R3 e R4) não atingiram valores menores de $\mathrm{pH}$.

A Tabela 34 mostra os íons produzidos pela adição do $\mathrm{FeSO}_{4}$, do $\left(\mathrm{NH}_{4}\right)_{2} \mathrm{SO}_{4}$ e do $\mathrm{H}_{2} \mathrm{SO}_{4}$ nos reatores. Assim como reportado nos itens 5.3.6 e 5.3.7, as massas destes íons foram determinadas segundo as reações apresentadas no item 5.3.3. A comparação entre a concentração total de íons $\mathrm{H}^{+}$, resultante da adição conjunta destes reagentes, em relação ao decorrente da adição do $\mathrm{H}_{2} \mathrm{SO}_{4}$ utilizado para o ajuste de $\mathrm{pH}$ (Figura 45), evidencia, novamente, que nem todo o íon $\mathrm{Fe}^{2+}$ foi oxidado para $\mathrm{Fe}^{3+}$.

Tabela 34 - Massa teórica máxima de íons liberados nos reatores, resultantes das reações de dissociação e solubilização dos reagentes $\mathrm{FeSO}_{4},\left(\mathrm{NH}_{4}\right)_{2} \mathrm{SO}_{4} \mathrm{e} \mathrm{H}_{2} \mathrm{SO}_{4}$.

\begin{tabular}{ccccccc}
\hline $\mathrm{SO}_{4}{ }^{2-}(\mathrm{g})$ & $\mathrm{HSO}_{4}{ }^{-}(\mathrm{g})$ & $\mathrm{Fe}(\mathrm{OH})_{3}(\mathrm{~g})$ & \multicolumn{4}{c}{$\mathrm{H}^{+}(\mathrm{g})$} \\
\hline $\mathrm{R} 1$ a R4 & $\mathrm{R} 1 \mathrm{a} \mathrm{R} 4$ & $\mathrm{R} 1 \mathrm{R} 4$ & $\mathrm{R} 1$ & $\mathrm{R} 2$ & $\mathrm{R} 3$ & $\mathrm{R} 4$ \\
12,51 & 1,84 & 6,15 & 0,2 & 0,22 & 0,22 & 0,22 \\
\hline
\end{tabular}

Nota: Não foi adicionado nenhum dos reagentes no reator Controle.

A adição do inóculo não produziu efeito aditivo sobre a solubilização do $\mathrm{Pb}$. Embora tenha havido incremento de sua solubilização em relação ao experimento $\mathrm{n}^{\circ}$ 7, o valor absoluto da solubilização obtida foi irrisório (aproximadamente 2 \%). A solubilização do Zn foi menos afetada pela redução de substrato e nos reatores que 
receberam inóculo (R3 e R4) observou-se um efeito aditivo médio de 5,3 \% em relação ao reator $\mathrm{R} 2$, que não recebeu o inóculo.

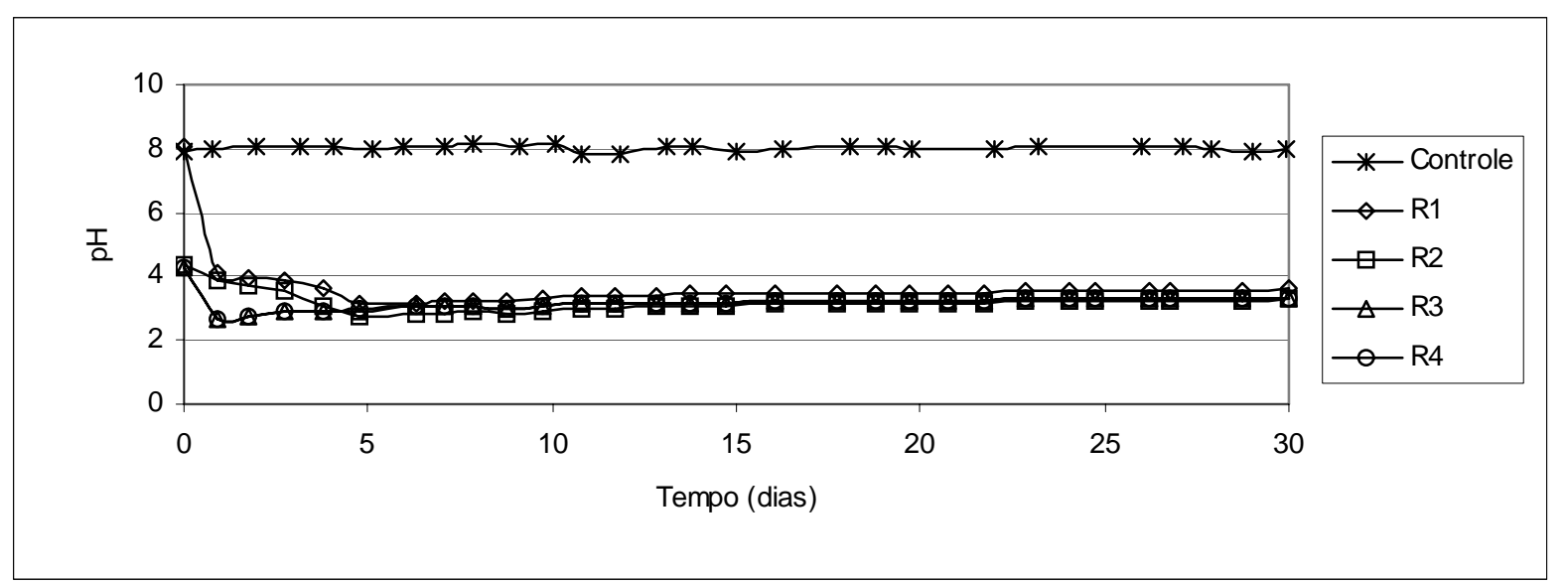

Reatores: Controle - água + solo; R1 - água + solo + substrato; R2 - água + solo + substrato + $\mathrm{H}_{2} \mathrm{SO}_{4} ; \mathrm{R} 3$ e $\quad \mathrm{R} 4$ - água + solo + substrato $+\mathrm{H}_{2} \mathrm{SO}_{4}$ + suspensão bacteriana.

Figura 81 - Variação do $\mathrm{pH}$ ao longo do tempo no experimento $\mathrm{n}^{\circ} 8$.

A Tabela 35 indica os resultados das análises elementares realizadas com as amostras dos reatores no início e no final deste experimento de biolixiviação. Os resultados das determinações dos elementos $\mathrm{B}, \mathrm{Cd}, \mathrm{P}, \mathrm{Pb}, \mathrm{S}$ e $\mathrm{Zn}$ do solo tratado e do lixiviado encontram-se no Apêndice A. As Figuras 82 e 83 e 84 e 85 mostram, respectivamente, as concentrações na fase líquida e o teor na fase sólida do $\mathrm{Pb}$ e do Zn.

Tabela 35 - Teores de carbono, hidrogênio e nitrogênio no início e no final do processo de biolixiviação $n^{\circ} 8$.

\begin{tabular}{|c|c|c|c|c|c|c|}
\hline \multirow{3}{*}{$\begin{array}{c}\text { Tempo (dias) } \\
\text { Reator }\end{array}$} & \multicolumn{2}{|c|}{ C } & \multicolumn{2}{|c|}{$\mathbf{H}$} & \multicolumn{2}{|c|}{$\mathbf{N}$} \\
\hline & 0 & 30 & 0 & 30 & 0 & 30 \\
\hline & \multicolumn{6}{|c|}{ Teores $(\mathrm{g} / \mathrm{kg})$} \\
\hline Controle & 4,2 & 5,0 & 6,6 & 6,3 & 0,9 & 0,5 \\
\hline R1 & 4,6 & 3,9 & 5,7 & 6,5 & 1,1 & 2,2 \\
\hline R2 & 4,4 & 4,2 & 4,8 & 7,0 & 0,1 & 2,1 \\
\hline R3 & 3,9 & 4,2 & 5,0 & 5,4 & 0,3 & 2,5 \\
\hline R4 & 4,1 & 4,2 & 5,2 & 5,2 & 2,0 & 1,0 \\
\hline
\end{tabular}

As Figuras 86 e 87 mostram, respectivamente, as frações dos elementos $\mathrm{Pb}$ e Zn, que foram solubilizadas pela lixiviação química e biológica. 


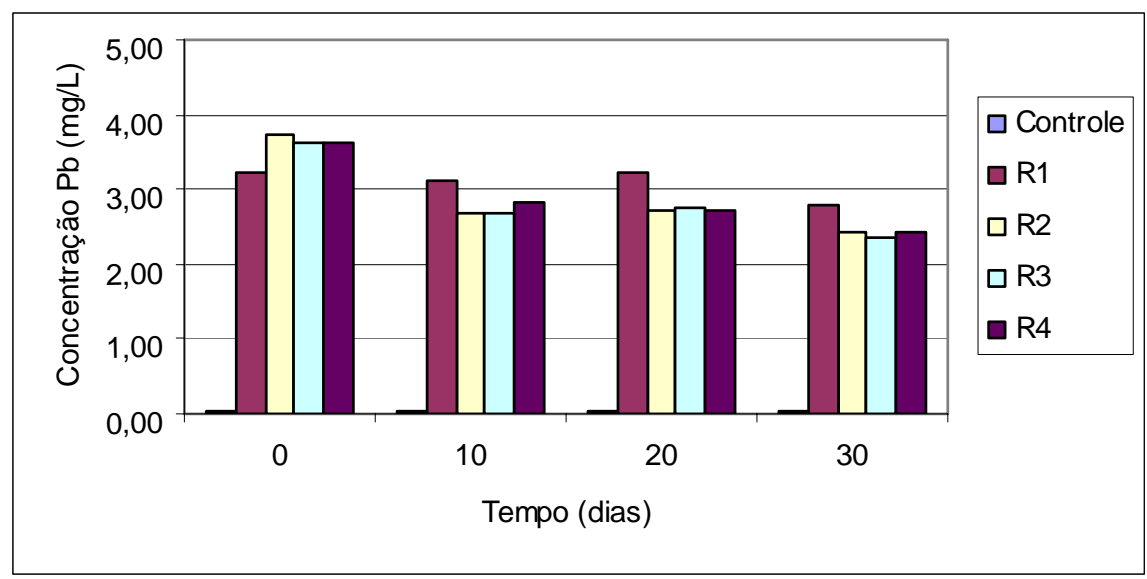

Figura 82 - Concentração do $\mathrm{Pb}$ na fase líquida durante o experimento de biolixiviação $n^{\circ} 8$.

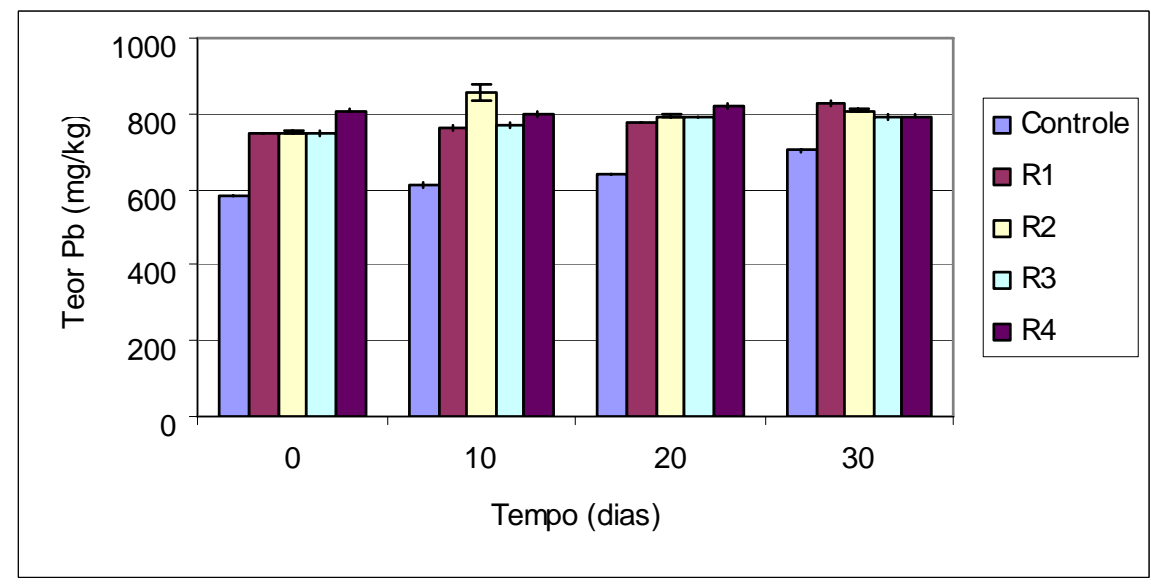

Figura 83 - Teor do $\mathrm{Pb}$ remanescente na fase sólida durante 0 experimento de biolixiviação $\mathrm{n}^{\circ} 8$.

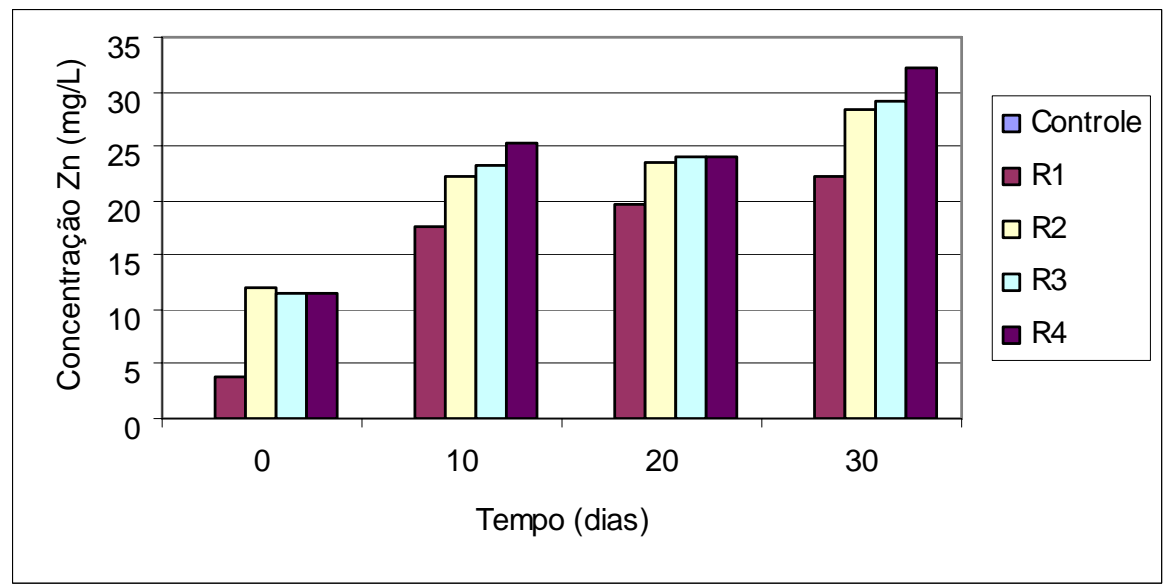

Figura 84 - Concentração do Zn na fase líquida durante o experimento de biolixiviação $n^{\circ} 8$. 


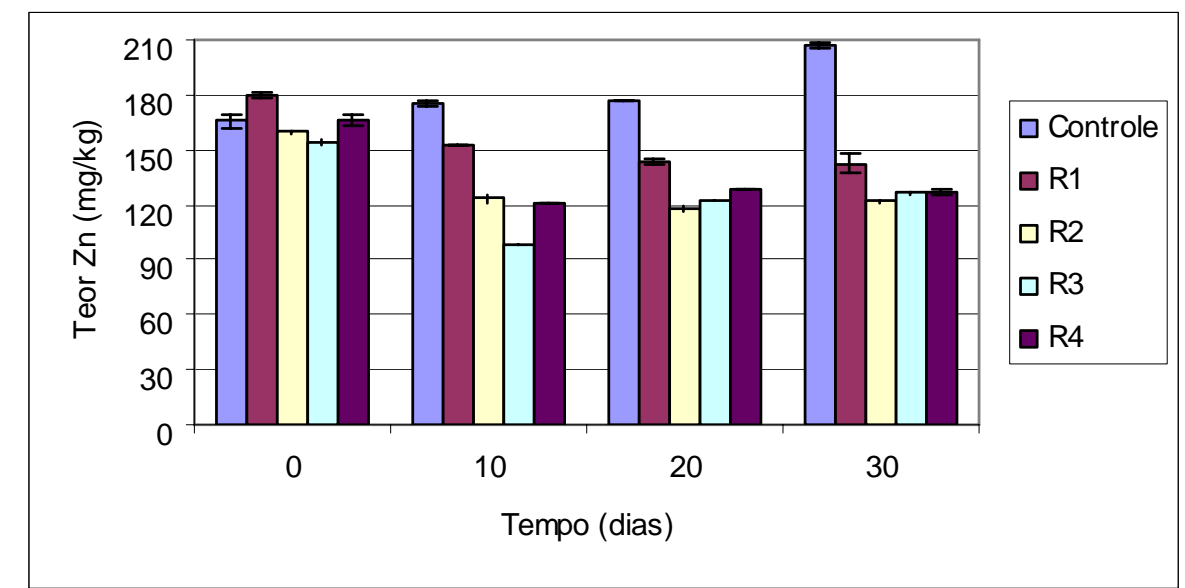

Figura 85 - Teor do $\mathrm{Zn}$ remanescente na fase sólida durante 0 experimento de biolixiviação $n^{\circ} 8$.

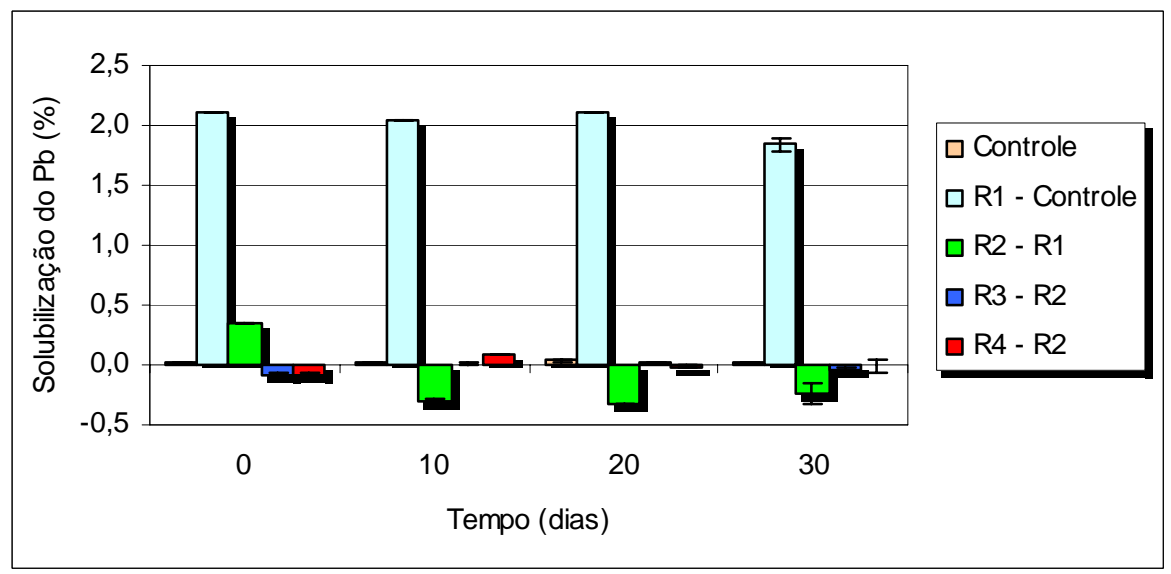

Figura 86 - Efeito do substrato, do $\mathrm{H}_{2} \mathrm{SO}_{4}$ e do $A$. ferrooxidans na solubilização do elemento $\mathrm{Pb}$ durante o experimento $\mathrm{n}^{\circ} 8$.

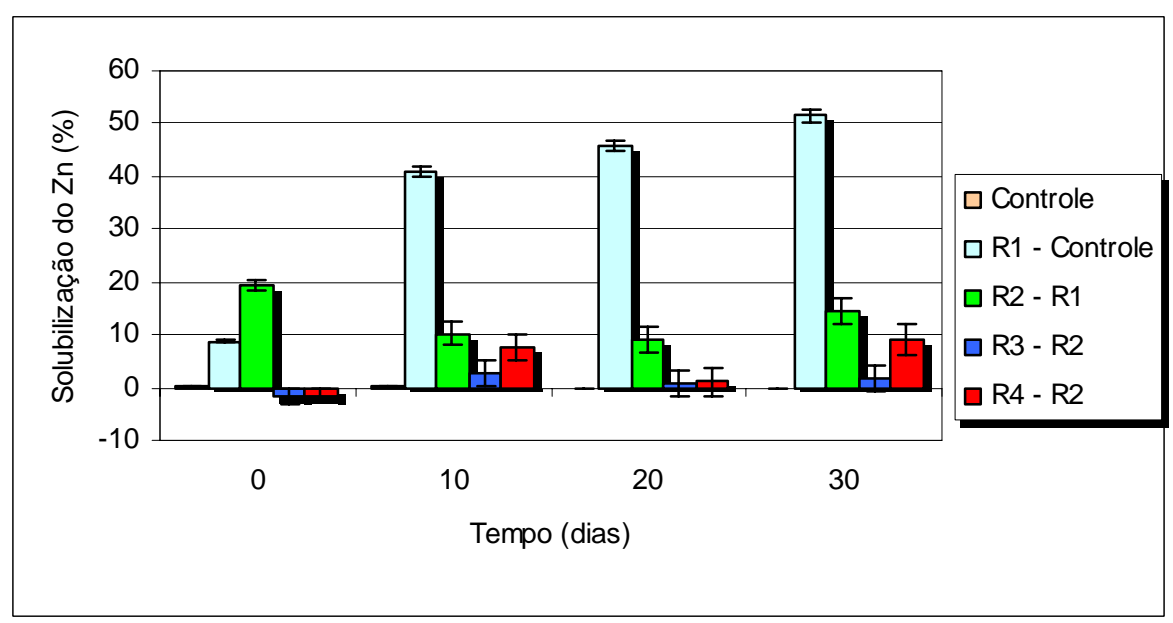

Figura 87 - Efeito do substrato, do $\mathrm{H}_{2} \mathrm{SO}_{4}$ e do $A$. ferrooxidans na solubilização do elemento $\mathrm{Zn}$ durante o experimento $\mathrm{n}^{\circ} 8$.

Os resultados das análises microbiológicas do experimento $\mathrm{n}^{0} 8$ estão apresentados no Apêndice A. As Figuras 88 e 89 mostram, respectivamente, a 
evolução das populações de bactérias heterotróficas e $A$. ferrooxidans ao longo do tempo.

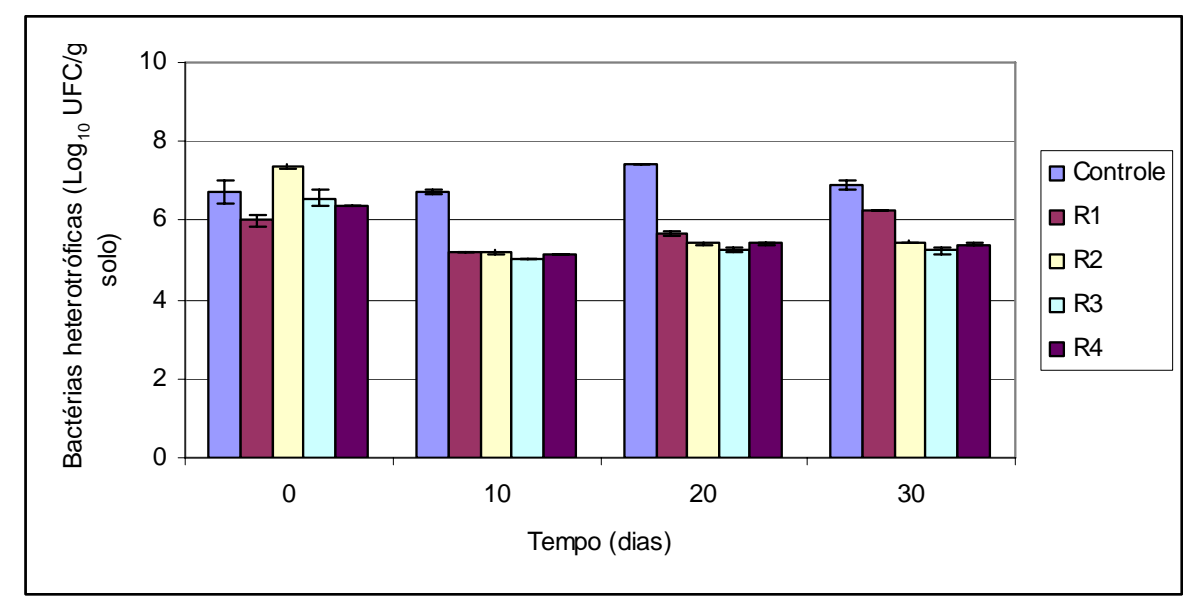

Figura 88 - Evolução da população de bactérias heterotróficas durante o experimento de biolixiviação $\mathrm{n}^{\circ} 8$.

Os resultados dos experimentos microbiológicos indicam o mesmo comportamento das populações bacterianas verificado nos experimentos de biolixiviação $n^{\circ} 6 \mathrm{e}^{\circ} 7$, exceto pela redução da quantidade de substrato, que reduziu o crescimento da população de $A$. ferrooxidans indígenas (R1 e R2).

Enquanto a população de $A$. ferrooxidans indígenas atingiu 7 logs no reator R1 do experimento $n^{0} 7$, que utilizou a mesma concentração de solo e menor quantidade de reagentes como substrato, neste experimento, não atingiu sequer 4 logs.

Importante ressaltar que, para o latossolo vermelho utilizado e as condições experimentais desta pesquisa, o A. ferrooxidans não se mostrou capaz de manter uma população estável sem a adição externa de substrato; conforme evidencia o comportamento do $\mathrm{pH}$ e o monitoramento da população do reator Controle, mostrado nas Figuras 81 e 89.

O tempo de exposição de 30 dias mostrou ser suficiente para determinar que o A. ferrooxidans não tem capacidade de obter do solo os nutrientes necessários para manter suas funções vitais, e evidenciou a impossibilidade de sua utilização (sem adição de substrato) em processos de biolixiviação neste, e possivelmente, noutros solos que exibam características similares.

Os resultados obtidos nos diferentes ensaios realizados permitiram retratar o comportamento das populações de $A$. ferrooxidans, que via de regra, apresentaram declínio após sua introdução nos reatores, seguida por uma fase de crescimento e, 
finalmente, a redução da população, sendo estas últimas mais ou menos intensas, dependendo da quantidade de reagentes adicionados como substrato em cada experimento.

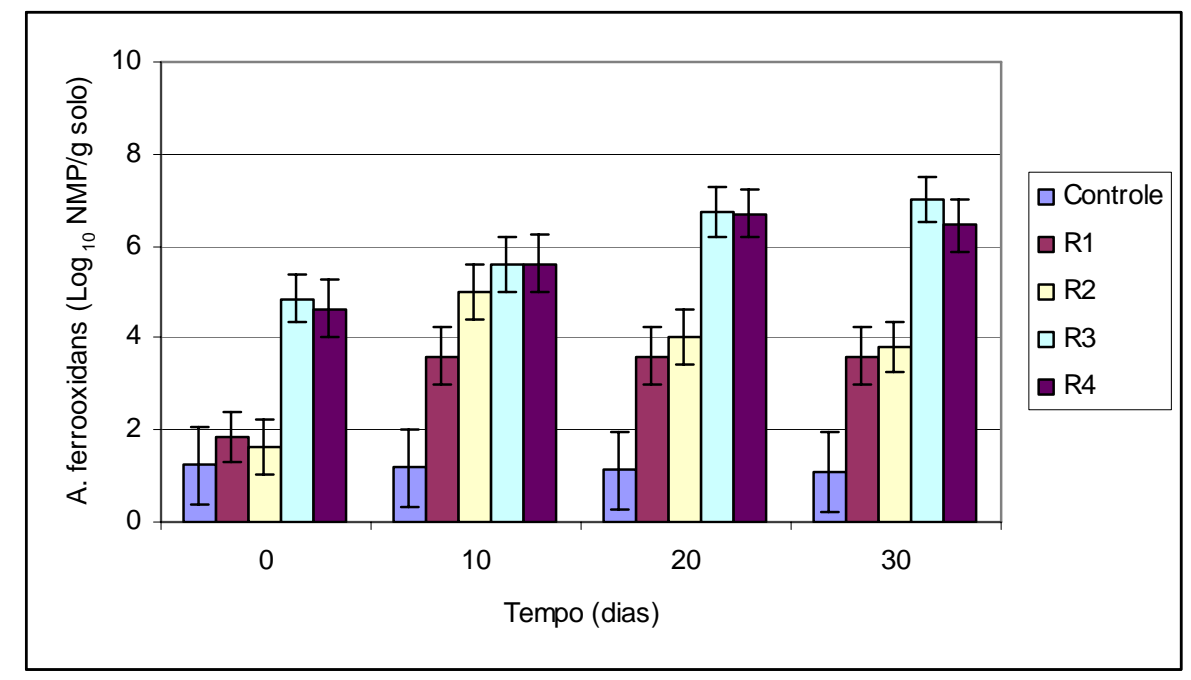

Figura 89 - Evolução da população de bactérias $A$. ferrooxidans durante o experimento de biolixiviação $n^{\circ} 8$.

O monitoramento das populações de bactérias heterotróficas, através da determinação de UFC, mostrou-se de fácil execução, embora tenha demandado a utilização de várias diluições em cada análise, pois eram grandes as incertezas quanto ao tamanho das populações durante os experimentos.

É importante ressaltar que a metodologia empregada para determinação da UFC é um indicativo grosseiro da população de bactérias heterotróficas, pois é raro conseguir quantificar $50 \%$ destes microrganismos através desta metodologia, sendo que, em média é contabilizada apenas $10 \%$ daquela população (ALEF; NANNIPIERI, 1995).

São diversas as causas que afetam a precisão do método de contagem de bactérias em placa, mas dentre as mais importantes estão o meio nutritivo utilizado (ágar), que pode não atender as necessidades nutricionais de todas as espécies de bactérias presentes na amostra em análise e a fração de células viáveis dentro da população que se pretende quantificar, pois apenas as células que apresentam condições vitais e fisiológicas adequadas crescem e multiplicam-se.

A despeito do elevado nível de incerteza, intrínseco ao método empregado, as populações de bactérias heterotróficas exibiram um comportamento similar em todos os experimentos nos quais foram monitoradas. Em suma, houve redução 
acentuada da população logo após o início dos experimentos, seguida por uma fase de estabilização e posterior crescimento. Ficou evidente que estas não foram extintas em nenhum dos experimentos, tendo-se adaptado às condições ambientais extremamente agressivas durante o processo de biolixiviação.

Portanto, é lícito afirmar que, para as condições experimentais aqui relatadas, a microbiota natural do solo é afetada pelo processo de biolixiviação, mas tem plenas condições de se adaptar e sobreviver. Todavia, este trabalho não avaliou, pois não era de seu escopo, as conseqüências do processo de biolixiviação sobre cada uma das espécies, denominadas neste trabalho genericamente por bactérias heterotróficas. 


\section{CONCLUSÕES}

Dos resultados obtidos concluiu-se que as máximas solubilizações dos elementos $\mathrm{Pb}$ e Zn ocorreram sob as seguintes condições:

a) $\mathrm{Pb}$ : temperatura de 30,2 $\pm 1,3\left({ }^{\circ} \mathrm{C}\right)$, agitação de $205 \pm 4$ (rpm), concentração de solo de $210 \mathrm{~g} / \mathrm{L}$, adição de nutrientes $\left(38,7 \mathrm{~g} \mathrm{FeSO}_{4} / \mathrm{L}, 2,6 \mathrm{~g}\right.$ de $\left(\mathrm{NH}_{4}\right)_{2} \mathrm{SO}_{4} / \mathrm{L}$, $87,5 \mathrm{mg} \mathrm{KCl} / \mathrm{L}, 0,44 \mathrm{~g} \mathrm{~K}_{2} \mathrm{HPO}_{4} ; 0,44 \mathrm{~g} \mathrm{mg} \mathrm{SO} / \mathrm{L}$ e 8,75 mg $\left.\mathrm{Ca}\left(\mathrm{NO}_{3}\right)_{2} / \mathrm{L}\right)$, adição de $10 \mathrm{~mL}$ de inóculo de $A$. ferrooxidans $\left(1,31 \times 10^{10} \pm 8,16 \times 10^{8}\right.$ células $/ \mathrm{mL}), \mathrm{pH}$ inicial $=4,7 \mathrm{e} \mathrm{pH}$ final $=4,7$ no instante inicial. A solubilização obtida nesta condição atingiu 17,7 mg Pb, que representou 2,61\% da quantidade total deste elemento no reator teste.

b) Zn: temperatura de $30 \pm 1,6$, ( $\left.{ }^{\circ} \mathrm{C}\right)$ agitação de $174 \pm 9$ (rpm), concentração de solo de $400 \mathrm{~g} / \mathrm{L}$, adição de nutrientes $\left(38,7 \mathrm{~g} \mathrm{FeSO}_{4} / \mathrm{L}, 2,6 \mathrm{~g}\right.$ de $\left(\mathrm{NH}_{4}\right)_{2} \mathrm{SO}_{4} / \mathrm{L}$, $87,5 \mathrm{mg} \mathrm{KCl} / \mathrm{L}, 0,44 \mathrm{~g} \mathrm{~K}_{2} \mathrm{HPO}_{4} ; 0,44 \mathrm{~g} \mathrm{MgSO}_{4} / \mathrm{L}$ e 8,75 mg Ca(NO$\left.)_{2} / \mathrm{L}\right)$, adição de $10 \mathrm{~mL}$ de inóculo de $A$. ferrooxidans $\left(7,96 \times 10^{8} \pm 2,24 \times 10^{8}\right.$ células $\left./ \mathrm{mL}\right)$, pH inicial $=4,61$ e pH final = 2,01 em 30 dias. A solubilização obtida nesta condição atingiu $131,77 \mathrm{mg} \mathrm{Zn}$, que representou $58,61 \%$ da quantidade total deste elemento no reator teste.

A biolixiviação funcionou apenas na solubilização do Zn, embora a lixiviação química tenha sido a principal responsável pela solubilização deste elemento. Para as condições investigadas não haveria necessidade de adicionar inóculo de $A$. ferrooxidans. A redução do teor de solo na suspensão melhorou a eficiência da solubilização dos metais.

As populações de $A$. ferrooxidans apresentaram declínio após sua introdução nos reatores, seguido por uma fase de crescimento e, novamente por uma fase de redução, sendo esta última mais ou menos intensa e dependente da quantidade de reagentes adicionados como substrato em cada um dos experimentos.

$\mathrm{O} \mathrm{pH}$ altera a microbiota natural do solo, cujo efeito foi revelado pelo monitoramento das populações de bactérias heterotróficas, que mostrou uma fase de redução acentuada destas populações; logo após o início dos experimentos; seguida por uma fase de estabilização e posterior crescimento. As bactérias 
heterotróficas não foram extintas em nenhum dos experimentos, pois se adaptaram às condições ambientais extremamente agressivas do meio durante o processo de biolixiviação.

Os resultados obtidos nesta pesquisa indicam que a biolixiviação não é uma tecnologia adequada para ser aplicada na remediação do solo da Região dos Lagos de Santa Gertrudes.

Entretanto, para situações onde o objetivo técnico do processo de remediação seja a imobilização do $\mathrm{Pb}$, a utilização de sulfatos solúveis, para a obtenção de sulfato de chumbo, é uma solução tecnicamente eficaz e eficiente, pois observou-se que o sulfato de chumbo é formado e precipita rapidamente. 


\section{REFERÊNCIAS}

ADRIANO, D.C. Trace elements in terrestrial environment. New York: SpringerVerlag, 1986. $533 \mathrm{p}$.

AGENCY FOR TOXIC SUBSTANCES AND DISEASE REGISTRY. Nickel: CAS\#: 7440-02-0. Atlanta: ATSDR,1997. Disponível em: <http://www.atsdr.cdc.gov/tfacts 15.html>. Acesso em: 20 jul. 2006.

Cadmium: CAS\#: 7440-43-9. Atlanta: ATSDR, 1999a. Disponível em: <http://www.atsdr.cdc.gov/tfacts5.html>. Acesso em: 20 jul. 2006.

. Lead: CAS\#: 7439-92-1. Atlanta: ATSDR, 1999b. Disponível em: <http://www.atsdr.cdc.gov/tfacts13.pdf>. Acesso em: 20 jul. 2006.

ALLCHIN, D. The poisoning of minamata. ShiPS Resource Center. 11 jan. 2002. Disponível em: <http://www1.umn.edu/ships/ethics/minamata.htm>. Acesso em: 20 ago. 2006.

ALEF, K.; NANNIPIERI, P. (Ed.). Methods in applied soil microbiology and biochemistry. San Diego: Academic Press, 1995. 512 p.

ALLOWAY, B. J. Heavy metals in soils. $2^{\text {nd }}$ ed. New York: Blackie Academic \& Professional, 1995. 368 p.

ALLOWAY, B. J. Zinc in soils and crop nutrition.brussels. International Zinc Association, Brussels, Belgium, p. 11-21, 2004.

AMERICAN WATER WORKS ASSOCIATION RESEARCH FUNDATION. Lyonnaise Des Eaux. Water Research Comission of South Africa. Water treatment membrane processes. New York: MacGraw-Hill, 1996. 1 v.

AMERICAN WATER WORKS ASSOCIATION. American Society of Civil Engineers. 3. ed. Water treatment plant design. New York: MacGraw-Hill, 1998. 806 p.

ASSOCIAÇÃO BRASILEIRA DE NORMAS TÉCNICAS. NBR 6508: grãos de solos que passam na peneira de $4,8 \mathrm{~mm}$ : determinação da massa específica. Rio de Janeiro, 1984a. 
. NBR7181: solo: análise granulométrica. Rio de Janeiro,1984b.

. NBR 6457: amostras de solo: preparação para ensaios de compactação e

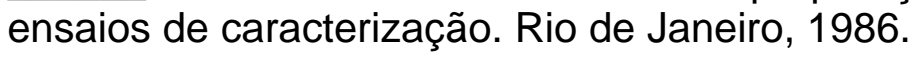

ASSOCIAÇÃO PAULISTA DAS CERÂMICAS DE REVESTIMENTO. Santa Gertrudes, SP. Disponível em: <www.aspacer.com.br>. Acesso em: 21. set. 2005.

ATLAS, R. M.; BARTHA, R. Microbial ecology: fundamentals and applications. 4. ed. Menlo Park, California: Addison Wesley Longman, 1997.

BAE, W.; CHEN, W.; MULCHANDANI, A.; MEHRA, R.. Enhanced bioaccumulation of heavy metals by bacterial cells displaying synthetic phytochelatins. Biotechnology and Bioengineering, Hoboken, v. 70, n. 5, p. 518-524, 2000.

BANCO NACIONAL DE DESENVOLVIMENTO. A indústria de cerâmica para revestimentos. Informe setorial, Rio de Janeiro, n. 17, set. 2001. Disponível em: <http://www.bndes.gov.br/conhecimento/setorial/is17_gs2.pdf>. Acesso em: 25 set. 2006.

BARBA, D.; BEOLCHINI, F.; VEGLIÒ, F. A simulation study on biosorption of heavy metals by confined biomass in UFrMF membrane reactors. Hydrometallurgy, Amsterdam, v. 59, p. 89-99, 2001.

BEYERSMANN, D. Effects of carcinogenic metals on gene expression. Toxicology Letters, Amsterdam, v. 127, p. 63-68, 2002.

BOHN, H. L.; MCNEAL, B. L.; O'CONNOR, G. A. Soil chemistry. $2^{\text {nd }}$ ed. New York: Wiley, 1985. $341 \mathrm{p}$.

BOON, M.; RAS, C.; HEIJNEN, J. J. The ferrous iron oxidation kinetics of Thiobacillus ferrooxidans in bath cultures. Applied Microbiology and Biotechnology, Berlim, v. 51, p. 813-819, 1999.

BOON, M.; MEEDER, T. A.; THÖNE, C.; RAS, C.; HEIJNEN, J. J. The ferrous iron oxidation kinetics of Thiobacillus ferrooxidans in continuous cultures. Applied Microbiology and Biotechnology, Berlim, v. 51, p. 820-826, 1999. 
BOSECKER, K. Bioleaching: metal solubization by microorganisms. FEMS Microbiology Reviews, Amsterdam, v. 20, p. 591-604, 1997.

BOSSHARD, P. P.; BACHOFEN, R.; BRANDL, H. Metal leaching from fly ash from municipal waste incineration by Aspergillus niger. Environmental science \& technology, Easton, v.30, p. 3066-3070, 1996.

BOYES, S.; ELLIOTT, M. Case study - heavy metals (mercury): minamata disease. In: CHEMGAPEDIA. Berlin: Fiz Chemie Berlin, 2006. Disponível em: <http://www.chemgapedia.de/vsengine/printvlu/vsc/en/ch/16/uc/vlus/mecury.vlu.ht>. Acesso em: 20 ago. 2006.

BRANDL, H. Microbial leaching of metals. In: REHM, H. J.; REED, G. (Ed.). Biotechnology: a multi-volume comprehensive treatise. $2^{\text {nd }}$ ed. New York: $\mathrm{VCH}$, 2001. v. 10, p.191-224.

BRANDL, H.; BOSSHARD, R.; WEGMANN, M. Computer-munching microbes: metal leaching from eletronic scrap by bacteria and fungi. Hydrometallurgy, Amsterdam, v.59, p.319-326, 2001.

BRASIL. Ministério da Saúde. Secretaria de Vigilância em Saúde. Vigisolo: identificação de populações sob risco de exposição e priorização de áreas com populações expostas a solo contaminado. Disponível em: <http://portal.saude.gov.br/portal/svs/visualizar_texto.cfm?idtxt=23900>. Acesso em: 30 jul. 2006.

BROOKINS, D.G. Eh-pH diagrams for geochemistry. Berlin: Springer-Verlag, 1988. $176 \mathrm{p}$.

BROMBACHER, C.; BACHOFEN, R.; BRANDL, H. Development of a laboratoryscale leaching plant for metal extraction from fly ash by Thiobacillus strains. Applied Microbiology and Biotechnology, Berlim, v. 64, p. 1237-1341, 1998.

. Microbial metal recovery from industrial waste. In: WORLD CONGRESS R'99, 4. 1999. Genebra, Suiça. Recovery, Recycling, Re-integration. Genebra, Suiça: Swiss Federal Laboratories for Materials Testing and Research (EMPA), 1999.

BUSANI, G.; PALMONARI, C.; TIMELLINI, G. Piastrelle ceramiche \& ambiente: emissioni gassose, acque, fanghi, rumore. Sassuolo, Pt: EdiCer, 1995. 
CAMARGO, O. C.; ALLEONI, L. R. F.; CASAGRANDE, J. C. Reações dos nutrientes e elementos tóxicos no solo. In: FERREIRA, M. E. et al. Micronutrientes e elementos tóxicos na agricultura. Jaboticabal: CNPq/FAPESP/POTAFOS, 2001. v. 1, p. 89-124.

CARIDADE, M. D.; TORKOMIAN, A. L. V. Estratégias de produção das empresas cerâmicas de Santa Gertrudes. Cerâmica Industrial, São Paulo, v.6, n.1, p. 32-39, jan.-fev. 2001.

CARVALHO, F. M.; SILVANY NETO, A. M.; LIMA, M. E. C.; TAVARES, T. M.; AZARO, M. G. A.; QUAGLIA, G. M. C.. Chumbo e cádmio no sangue e estado nutricional de crianças, Bahia, Brasil. Revista Saúde pública, São Paulo, 21: 44-50, 1987.

CARVALHO, F. M.; SILVANY NETO, A. M.; TAVARES, T. M.; COSTA, A. C. A.; CHAVES, C. R.; NASCIMENTO, L. D.; REIS, M. A.. Chumbo no sangue de crianças e passivo ambiental de uma fundição de chumbo no Brasil. Revista Panamericana de Salud Publica I Pan American Journal Public Health. 13(1), 2003.

CENTRO DE ESTUDO E PLANEJAMENTO AMBIENTAL. Atlas digital da bacia do Rio Corumbataí. Disponível em: <http://www.rc.unesp.br/igce/ceapla/atlas/ index.html>. Acesso em: 22 set. 2006.

CHARTIER, M.; COUILLARD, D. Biological processes: the effects of initial pH, percentage inoculum and nutrient enrichment on the solubilization of sediment bound metals. Water, air, \& soil pollution: an international journal of environmental pollution, Dordrecht, v.96, p. 249-267, 1997.

CICCU, R.; GHIANI, M.; SERCI, M.; FADDA, S.; PERETTI, R.; ZUCCA, A.. Heavy metal immobilization in the mining-contaminated soils using various industrial wastes. Mineral Engineering, Amsterdam, v. 16, p. 187-192, 2003.

COLORADO SCHOOL OF MINES. Thiobacillus ferroxidans. 2003. Disponível em: <http://www.mines.edu/fs_home/jhoran/ch126/thiobaci.htm>. Acesso em: 25 set. 2006.

COMPANHIA DE TECNOLOGIA DE SANEAMENTO AMBIENTAL. Norma técnica $\mathbf{n}^{\circ}$ L6.350: solos: determinação de biodegradação de resíduos: método respirométrico de Bartha - Método de ensaio. São Paulo: Cetesb, 1990. 15 p. 
. Norma técnica $\mathbf{n}^{\circ}$ L5.217: Thiobacillus: determinação do número mais provável pela técnica dos tubos múltiplos: método de ensaio. São Paulo: Cetesb, 1991. $13 \mathrm{p}$.

Norma técnica $\mathbf{n}^{\circ}$ L5.201: contagem de bactérias heterotróficas: (método de ensaio). São Paulo: Cetesb, 1996.

Parecer técnico $n^{\circ}$ 34/01/EQSS: diagnóstico da qualidade do solo e águas subterrâneas. São Paulo: Cetesb, 2001a. Relatório interno.

Projeto piloto de prevenção à poluição (P2) nas indústrias cerâmicas de região de Santa Gertrudes: informações sobre o desenvolvimento do projeto. São Paulo: Cetesb, 2001b. Relatório interno.

. Plano de intervenção da região dos lagos de Santa Gertrudes. São Paulo: CETESB, 2001c. Relatório interno.

Projeto de prevenção à poluição em indústria de piso e revestimento cerâmico. São Paulo: Cetesb, 2002a. Relatório interno.

Projeto Corumbataí cerâmicas: informação técnica. São Paulo: Cetesb, 2002b. Relatório interno.

. Valores orientadores para solos e águas subterrâneas no Estado de São Paulo. 2005a. Disponível em: <http://www.cetesb.sp.gov.br/Solo/relatorios/ tabela_valores_2005.pdf>. Acesso em: 14 jul. 2006.

Áreas contaminadas no Estado de São Paulo. 2005b. Disponível em:

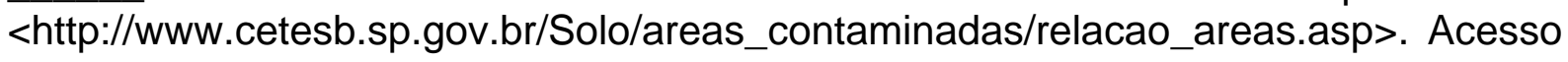
em: 14 jul. 2006.

COMPANHIA DE TECNOLOGIA DE SANEAMENTO AMBIENTAL (CETESB); DEUTSCHE GESELLSCHAFT FÜR TECHNISCHE ZUSAMMENARBEIT (GTZ). 2 ed.. Manual de Gerenciamento de áreas contaminadas. São Paulo: CETESB. 2001. 389 p.

DANA, J. D. Manual de mineralogia. Tradução Rui Ribeiro Franco. Rio de Janeiro: Ao Livro Técnico; São Paulo: EDUSP, 1969. v. 1. 
DERMATAS, D.; MENG, X. Utilization of fly ash for stabilization/solidification of heavy metal contaminated soils. Engineering Geology, Amsterdam, v. 70, p. 377-394, 2003.

DOBLER, R.; BURRI P., GRUIZ K.; BRANDL, H.; BACHOFEN, R.. Variability in microbial populations in soil highly polluted with heavy metals on the basis of substrate utilization pattern analysis. Journal of Soils and Sediments, Landsberg, v. 1, n. 3, p. 151-158, 2001.

DVORAK, D. H.; HEDIN, R. S.; EDENBORN, H. M.; MCINTIRE, P. E.. Treatment of metal-contaminated water using sulfate reduction: results from pilot-scale reactors. Biotechnology and Bioengineering, Hoboken, v. 40, p. 609-616, 1992.

ESPOSITO, A.; PAGNALELLI, F.; LODI, A.; SOLISIO, C.; VEGLIÒ, F.. Biosorption of heavy metals by Sphaerotilus natans: an equilibrium study at different $\mathrm{pH}$ and biomass concentrations. Hydrometallurgy, Amsterdam, v. 60, p. 129-141, 2001.

EUROPEAN ENVIRONMENT AGENCY. Technical report nº 13/1999: management of contaminated sites in western Europe. Copenhagen: EEA, 2000.

EVANGELOU, V. P. Environmental soil and water chemistry: principles and apllications. New York: Wiley, 1998. 564 p.

FAUST, S. D.; ALY, O. M. Chemistry of water treatment. $2^{\text {nd }}$ ed. Boca Raton: Lewis Publishers, 1999. 581 p.

FEDERAL REMEDIATION TECHNOLOGIES ROUNDTABLE. Abstracts of remediation case studies: EPA-542-R-00-006. 2000. v. 4. Disponível em: <http://www.epa.gov/tio/download/frtr/abstractsvol4.pdf>. Acesso em: 25 set. 2006.

Abstracts of remediation case studies: EPA-542-R-01-008. 2001. v. 5. Disponível em: <http://www.epa.gov/tio/download/frtr/abstractsvol5.pdf>. Acesso em: 25 set. 2006.

Abstracts of remediation case studies: EPA-542-R-02-006. 2002. v. 6. Disponível em: <http://www.epa.gov/tio/download/frtr/abstractsvol6.pdf>. Acesso em: 08 set. 2003. revestimentos cerâmicos (via úmida), com ênfase nos efluentes líquidos. 2000. 
166 f. Tese (Doutorado) - Instituto de Pesquisas Energética e Nucleares, Universidade de São Paulo, Sãao Paulo, 2000.

FRANÇA, R. G. Redução de metais pesados em lodo de esgoto por meio do processo de biolixiviação visando a produção agrícola. 2003. 134 f. Tese (Doutorado) - Faculdade de Engenharia Civil, Universidade Estadual de Campinas, Campinas, 2003.

FREEMAN, H. M.; HARRIS, E. F. (Ed.). Hazardous waste remediation: innovative treatment technologies. Lancaster: Technomic, 1995. 342 p.

FORD, D. L. (Ed.). Toxicity reduction: evaluation and control. Lancaster, Pensilvania: Technomic Publishing Company, 1992. v. 3.

GANDOLFI, N.; BJONBERG, A. J. S.; PARAGUASSU, A. B. Geologia para engenheiros civis. São Carlos: EESC-USP, 1999. 141 p.

GARCIA JR, O. Isolation and purification of Thiobacillus ferrooxidans and Thiobacillus thiooxidans from some coal and uranium mines of Brazil. Revista de microbiologia, São Paulo, v. 22, p. 1-6, 1991.

GENÇ, Ö.; ARPA, C.; BAYRAMOGLU, G.; ARICA, M. Y.; BEKTAS, S.. Selective recovery of mercury by Procion Brown $M X$ 5BR immobilized poly(hydroxyethylmethacrylate/chitosan) composite membranes. Hidrometallurgy, Amsterdam, v. 67, n.1, p. 53-62, 2002.

GEO-INF. Avaliação de área contaminada para fins de cubagem, em Santa Gertrudes, SP. São Paulo: GEO-INF, 2002. Relatório Técnico GEO-INF 025/2002.

GROUDEV, S. N.; GEORGIEV, P. S.; SPASOVA, I. I.; KOMNITSAS, K.. Bioremediation of a soil contaminated with radioactive elements. Hidrometallurgy, Amsterdam, v. 59, p. 311-318, 2001.

GROUDEV, S. N.; SPASOVA, I. I.; GEORGIEV, P. S. In situ bioremediation of soils contaminated with radioactive elements and toxic heavy metals. Hidrometallurgy, Amsterdam, v. 62, p. 301-308, 2001.

HAAS, C. N.; VAMOS, R. J. Hazardous and industrial waste treatment. Englewood Cliffs, N .J.: Prentice Hall, c1995. 363 p. 
HERBERT JR., R. B. MiMi - sulfide oxidation in mine waste deposits: a review with enphasis on dysoxic weathering. Stockholm: Department of Geology and Geochemistry, Stockholm University, 1999. 51 p. Disponível em: <http://www.mistra.org/download/18.c791f4103209a06ec80005685/1999_1.pdf>. Acesso em: 25 set. 2006.

HIRATA, A.Y. Caracterização do material dragado do Rio Tietê e avaliação de sua utilização na construção civil. 1997. 137 f. Dissertação (Mestrado) - Escola Politécnica, Universidade de São Paulo, São Paulo, 1997.

HONG, K. J.; TOKUNAGA, S.; TAJUUCHI, T. Evaluation of remediation process with biosurfactant for recovery of heavy metal from contaminated soils. Chemosphere, Amsterdam, v. 49, p. 379-387, 2002.

HUANG, J. P.; HUANG, C. P.; MOREHART, A. L. Removal of heavy metals by fungal. In: VERNET, J.-P. Heavy metals in the environment. Amsterdam: Elsevier, 1991. p. 329-349. (Trace metals in the environment; 1)

INTERNATIONAL PROGRAMME ON CHEMICAL SAFETY. Cadmium: environmental health criteria 134. Geneva: United Nations Environment Programme, International Labour Organization, World Health Organization, 1992.

KELLY, D. P.; WOOD, A. P. Reclassification of some species of Thiobacillus to the newly designated genera Acidithiobacillus gen. nov., Halothiobacillus gen. nov. and Thermithiobacillus gen. nov. International Journal of Systematic and Evolutionary Microbiology, Reading, UK, v. 50, p. 511-516, 2000.

KIEKENS, L. Zinc. In: ALLOWAY, B.J. (Ed) Heavy metals in soils. $2^{\text {nd }}$ ed. London: Blackie Academic and Professional, 1995. p. $284-305$.

KING. R. B.; LONG, G. M.; SHELDON, J. K. Practical environmental bioremediation: the field guide. $2^{\text {nd }}$ ed. Boca Raton: Lewis Publishers, 1998. $184 \mathrm{p}$.

KLICH, I.; BATCHELOR, B.; WILDING, L. P. PRESS, L. R.. Mineralogical alterations that affect the durability and metal containment of aged solidified and stabilized wastes. Cement and concrete research, Amsterdam, v. 29, p. 1433-1440, 1999.

KREBS, W.; BROMBACHER, C.; BOSSHARD, P.P.; BACHOFEN, R.; BRANDL H.. Microbial recovery of metals from solids. FEMS Microbioligal Reviews, Amsterdam, v. 20, p. 605-617, 1997. 
KREBS, W.; BACHOFEN, R.; BRANDL, H. Growth stimulation of sulfur oxidizing bacteria for optimization of metal leaching efficiency of fly ash from municipal solid waste incineration. Hydrometallurgy, Amsterdam, v. 59, p. 283-290, 2001.

KUYUCAK, N.; LYEN, D.; ST-GERMAIN, P.; WHEELAND, K. G.. In Site Bacterial treatment of acid mine drainage in open pits. In: $2^{\text {nd }}$ International Conference on the Abatement of Acid Drainage, Montreal, 1991.

LaGREGA, M. D.; BUCKINGHAM, P. L.; EVANS, J. C. Hazardous waste management. New York: McGraw-Hill, c1994. 1146 p.

LAL, R.; STEWART, B. A. (Ed.). Soil processes and water quality: advances in soil science. Boca Raton, FL: Lewis Publishers, c1994. 398 p.

LIN, C. F.; LO, S. S.; LIN, H. Y.; LEE, Y.. Stabilization of cadmium contaminated soils using sytethized zeolite. Journal of hazardous materials, Amsterdam, v. 60, p. 217226, 1998.

LIZAMA, H. M.; SUZUKI, I. Interaction of chalcopyrite and sphalerite with pyrite during leaching by $T$. ferrooxidans and $T$. thiooxidans. Canadian Journal of Microbiology, Toronto, v. 37, p. 304-311, 1991.

LLOYD, J. R. Bioremediation of metals; the application of micro-organisms that make and break minerals. Microbiology Today, Reading, UK, v. 29, p. 67-69, 2002.

LORS, C.; TIFFREAU, C.; LABOUDIGUE, A. Effects of bacterial activities on the release of heavy metals from contaminated dreged sediments. Chemosphere, Amsterdam, v. 56, p. 619-630, 2004.

MATTIGOD, S. V.; SPOSITO, G.; PAGE, A. L. Factors affecting the solubilities of trace metals in soils. In: BAKER, D. E. (Ed.). Chemistry in the soil environment. Madison: American Society of Agronomy, 1981. 259 p. (Special Publication; n. 40).

MAZONI, P.; CUIUMJIAN, R. M.. Poluição por chumbo em Santo Amaro da Purificação. Brasília: Instituto para o Desenvolvimento Ambiental. 08 de julho de 2002. Relatório.

MCLEAN, J. E.; BLEDSOE, B. E. Behavior of metals in soil. In: USEPA, office of solid waste an emergency response and office of research and development. 
Washington DC: Ground Water Issue, 1992. 540-S92-018. Disponível em: <http://www.epa.gov/swertio1/tsp/download/issue14.pdf>. Acesso em: 25 set. 2006.

MEUNIER, N.; BLAIS, J. F.; TYAGI, R. D. Selection of a natural sorbent to remove toxic metals from acidic leachate produced during soil decontamination. Hydrometallurgy, Amsterdam, v. 67, p. 19-30, 2002.

MONFORT, E.; ENRIQUE, J. E.; GAZULLA, M. F.; BALSCO, A.. Caracterización de residuos de la industria azulejera. Barcelona: Publica S.A.. Técnica cerámica: revista de los materiales, equipos y técnicas de fabricación de la cerámica industrial, v. 1994, n. 222, p 238-246, 1994.

MORAIS, M. R.; SICHIERI, E. P. Reciclagem de resíduos cerâmicos: porque, quando e como fazer.. In: CONGRESSO BRASILEIRO DE CERÂMICA, 46. São Carlos. 2002. Anais... São Paulo : Associação Brasileira de Cerâmica, 2002. ref. 1817.

MORAIS, M. R.; SICHIERI, E. P.; PAWLICKA, A. Identificação e classificação de amostras de resíduos sólidos das indústrias de revestimentos cerâmicos do pólo de Santa Gertrudes - SP. In: SIMPÓSIO EM CIÊNCIA E ENGENHARIA DE MATERIAIS, 3. São Carlos. 2000. Programa e resumos. São Carlos: USP, 2000. p. 51-52.

MORITA, D. M. Situação ambiental do Estado de São Paulo e necessidades de pesquisa. In: ENCONTRO SOBRE APLICAÇÕES AMBIENTAIS DE PROCESSOS OXIDATIVOS AVANÇADOS, 1. 2001. Águas de São Pedro. [Trabalhos apresentados]. Águas de São Pedro: Degussa/UNICAMP, 2001.

MULLIGAN, C. N.; YONG, R. N.; GIBBS, B. F. Remediation technologies for metalcontaminated soils and groundwater: an evaluation. Engineering Geology, Amsterdam, v. 60, p. 193-207, 2001.

NOGAMI, J. S.; VILLIBOR, D. F. Pavimentação de baixo custo com solos lateríticos. São Paulo: Villibor, 1995. 213 p.

OFFICE OF TECHNOLOGY ASSESSMENT. Technologies and management strategies for hazardous waste control. Washington, D.C.: Congress of the United States, 1983.

OLIVEIRA, L. P. Tratabilidade de solos tropicais contaminados por resíduos da indústria de revestimentos cerâmicos. 2006. 123 f. Dissertação (Mestrado) Escola Politécnica, Universidade de São Paulo, São Paulo, 2006. 
ORLOV, M. M.; MLADINIÉ, N. M.; KULIÉ, P. I. DOLINAC, D. Z.; DUBRAVCIÉ, M. N.; KURAJICA, L. B.. Health effects of the workers exposed to airborne lead. In: VERNET, J. P. Heavy metals in the environment. Amsterdam: Elsevier, 1991. p. 219-227.

PAGE, G. W. Contamined sites and environmental cleanup: international approaches to prevention, remediation and reuse. San Diego: Academic Press, 1997. 212 p.

PAREKH, B. S. Reverse osmosis technology: applications for high-purity-water production. New York: M. Dekker, 1988. 516 p.

PARKER, S. P. McGraw-Hill concise encyclopedia of science \& technology. New York: McGraw-Hill, 1992. 2241 p.

PATRIARCA, M.; MENDITTO, A.; ROSSI, B.; LYON, T. D. B.; FELL, G. S.. Environmental exposure to metals of newborns, infants and young children. Microchemical Journal, Amsterdam, v. 67, p. 351-361, 2000.

PORTER, K. G.; FEIG, Y. S. The use of DAPI for identifying and counting aquatic microflora. Limnology and Oceanography, Grafton,WIS, v. 25, n. 5, p. 943-948, 1980.

PORTER, S. K.; SCHECKEL, K. G.; IMPELLITTERI, C. A.; RYAN, J. A.. Toxic metals in the environment: thermodynamic considerations for possible immobilization strategies for $\mathrm{Pb}, \mathrm{Cd}, \mathrm{As}$, and Hg. Critical Reviews in Environmental Science and Technology, Boca Raton, n. 34, p. 495-604, 2004.

QUÍMICA QMCWEB: revista eletrônica da UFSC. Florianópolis: UFSC, v. 4, 2006. Disponível em: <http://www.qmc.ufsc.br/qmcweb/artigos/forças_intermoleculares. html>. Acesso em: 01 mar. 2006.

RIVETT; M. O.; PETTS, J.; BUTLER, B.; MARTIN, I... Remediation of contaminated soil and groundwater: experience in enland and wales. Journal of Enviromental Management, Amsterdam, v. 65, p. 251-268, 2002.

ROOTE, D. S. In situ flushing: technology overview report TO-97-02. Pittsburgh: Ground-water remediation technologies analysis center, 1997. 
ROULIER, M.; RYAN, J.; HOUTHOOFD, J.; PAHREN, H.; CUSTER, F.. In place treatment of contaminated soil at superfund sites: a review. In: ANNUAL RESEARCH SYMPOSIUM, 15., 1989, Cincinnati. Remedial action, treatment and disposal of hazardous waste: proceedings. Cincinnati: [s.n.], 1989.

RUSSEL, M.; COLGLAZIER, E.; ENGLISH, M. Hazardous waste remediation: the task ahead. Knowville: Waste Management Research and Education Institute, 1991.

SAND, W.; GEHRKE, T.; JOZSA, P. G.; SCHIPPERS, A.. (Bio)chemistry of bacterial leaching: direct vs indirect bioleaching. Hydrometallurgy, Amsterdam, v. 59, p. 159175, 2001.

SÃO PAULO (ESTADO). Secretaria de Estado do Meio Ambiente. Projeto Corumbataí Cerâmicas. Negociação de conflitos ambientais com a participação dos setores envolvidos: uma experiência com o pólo cerâmico de Santa Gertrudes e reigão. São Paulo: [s.n.], 2003. 21 p. Síntese das ações.

SCHNOOR, J. L.. Phytoremediation of soil and groundwater. Technology evaluation report TE-02-01. Pittsburgh: Ground-water remediation technologies analysis center, 2002.

SIENKO, M. J.; PLANE, R. A. Química. In: GIESBRECHT, E.; MENNUCCI, L.; GIESBRECHT, M. A. (Trad). Química. 4. ed. São Paulo: Nacional, 1974. 540 p.

SILVA, A. L. B. Caracterização ambiental e estudo do comportamento do chumbo, zinco e boro em área degradada por indústrias cerâmicas - região dos lagos de Santa Gertrudes, SP. 2001. 229 f. Dissertação (Mestrado) - Instituto de Geociências, Universidade de São Paulo, São Paulo, 2001.

SILVERMAN, M. P.; LUNDGREN, D. G. Studies on the chemoautotrophic iron bacterian Ferrobacillus ferrooxidans: an improved medium and a harvesting procedure for security high cell yields. Journal of Bacteriology, Baltimore,MD, $n$. 77, p. 642-647, 1959.

SOARES, S. R. Análise do ciclo de vida de produtos (revestimento, blocos e telhas) do setor cerâmico da construção civil. Florianólpolis: Universidade Federal de Santa Catarina, Centro Tecnológico, Engenharia Sanitária-Ambiental, 2002. p. 40-41. Relatório parcial II/IV: Indústria cerâmica e o meio ambiente.

SPOSITO, G. The future of an illusion: ion activities in soil solutions. Soil Science Society America Journal, Madison, v. 48, p. 451-531, 1984. 
SPOSITO, G. The chemistry of soils. New York: Oxford University Press, 1989. $277 \mathrm{p}$.

STEED, V. S.; SUIDAN, M. T.; GUPTA, M.; MIYAHARA, T.; ACHESON, C. M.; SAYLES, G. D.. Development of a sulfate-reducing biological process to remove heavy metals from acid mine drainage. Water Environment Research, Alexandria, VA, v. 72, n. 5, p. 530-535, 2000.

STOSS, F. W.; FABIAN, C. A. Love canal: reminder of why we celebrate earth day. Issues in Science and Technology Librarianship, Chicago, n. 26, 2000.

STUMM, W. Chemistry of the solid-water interface: processes at the mineralwater and particle-water interface in natural system. New York: Wiley, 1992. 428 p.

STURGES JR, S. G.; MCBETH JR, P.; PRATT, R. C. Performance of soil flushing and groundwater extraction at the United Chrome Superfund site. Journal of Hazardous Materials, Amsterdam, v. 29, p. 59-78, 1991.

TAN, K.H. Principles of soil chemistry. $2^{\text {nd }}$ ed. New York: Marcel Dekker, 1993. $361 \mathrm{p}$.

THE SOCIETY FOR APLLIED ANTHROPOLOGY. Case study one: love canal superfund site. Niagara Falls, New York. Draft. SFAA Project, Townsend, March, 2001.

THE TRADE \& ENVIRONMENTAL DATABASE. TED case studies: minamata disaster, v. 5, n. 1, 1996.

TRIBUTSCH, H. Direct versus indirect bioleaching. Hydrometallurgy, Amsterdam, v. 59, p. 177-185, 2001.

TUOVINEN, O. H.; KELLY, D. P. Studies on the growth of Thiobacillus ferrooxidans: use of membrane filters and ferrous iron agar to determine viable number and comparison $\mathrm{CO} 2$ fixation and iron oxidation as measures of growth. Archives of Microbiology, Heidelberg, n. 88, p. 285-298, 1973.

TÜRKDOGAN, M. K.; KILICEL, F.; KARA, K.; TUNCER, I.; UYGAN, I.. Heavy metals in soil, vegetable and fruits the endemic upper gastrointestinal cancer region of Turkey. Evironmental Toxicology and Pharmacology, Amsterdam, v. 13, p. 175179, 2002. 
UMBREIT, W. W.; ANDERSON, T. F. A study of Thiobacillus thiooxidans with the electron microscope. Journal of bacteriology, Baltimore,MD , v. 44, n. 3, p. 317320, sept. 1942.

UNITED STATES ARMY ENVIRONMENTAL CENTER. In situ electrokinetic remediation for metal contaminated soils. 2003a. Disponível em: <http://aec.army.mil/usaec/technology/cleanup04a.html>. Acesso em: 29 set. 2003.

Phytoremediation of lead-contaminated soil. 2003b. Disponível em: <http://aec.army.mil/usaec/technology/cleanup04a.html>. Acesso em: 29 set. 2003.

UNITED STATES ENVIRONMENTAL PROTECTION AGENCY. EPA superfund record decision: Lipari landfill, 1988. EPA/ROD/R02-88/074. Disponível em: <http://www.epa.gov/superfund/sites/rods/fulltext/r0288074.pdf>. Acesso em: 03 out. 2003.

Guide for conducting treatability studies under CERCLA: soil washing. Interim guidance, 1991. EPA/540/2-91/020A. Disponível em: <http://www.epa.gov/tio/download/remed/5402-91020a-s.pdf>. Acesso em: 25 set. 2006.

. Zinc and compounds. 1992. CASRN 7440-66-6. Disponível em: <http://www.epa.gov/IRIS/subst/0426.htm>. Acesso em: 25 set. 2006.

A literature review summary of metals extraction processes used to remove lead from soils. 1994. EPA/600/SR-94/006. Disponível em: <http://www.epa.gov/ORD/WebPubs/projsum/600sr94006.pdf>. Acesso em: 30 set. 2003.

Soil washing at the king of Prussia Technical Corporation Superfund Site: cost and performance report. 1995a. Disponível em: <http://www.epa.gov/IRIS/subst/0426.htm>. Acesso em: 25 set. 2006

$\begin{array}{lcccc}\text { Parsons } & \begin{array}{c}\text { Chemical/ETM Enterprises } \\ \text { report. }\end{array} & \begin{array}{c}\text { Superfund Site: cost and } \\ \text { performance }\end{array} & \text { Disponível } & \text { em: }\end{array}$ <http://www.epa.gov/tio/download/remed/parsons.pdf>. Acesso em: 01 set. 2006.

UNITED STATES ENVIRONMENTAL PROTECTION AGENCY. Method 3050b: acid digestion of sediments, sludges, and soils. 1996a. Disponível em: <http://www.epa.gov/epaoswer/hazwaste/test/pdfs/3050b.pdf>. Acesso em: 25 set. 2006. 
1996b.

Method 6010b: inductively coupled plasma-atomic emission spectrometry. <http://www.epa.gov/epaoswer/hazwaste/test/pdfs/6010b.pdf> >. Acesso em: 24 set. 2006.

Engineering forum issue paper: thermal desorption implementation issues. 1997a. EPA/540/F-95/031. Disponível em: <http://www.epa.gov/tio/download /remed/tdissue.pdf>. Acesso em: 25 set. 2006.

Recent developments for in situ treatment of metal contaminated soils. 1997b. EPA/68-W5-0055. Disponível em: <http://www.epa.gov/swertio1/download/ remed/metals2.pdf>. Acesso em: 08 set. 2006.

. Technology alternatives for the remediation of soils contaminated with As Cd $\mathrm{Cr} \mathbf{H g}$ and Pb. 1997c. EPA/540-S-97-500. Disponível em: <http://www.epa.gov/swertio1/download/remed/tdtchalt.pdf>. Acesso em: 08 set. 2006.

$\begin{array}{lll} & \\ \text { decision. } & 1997 d \text {. } & \text { AMD/R04-97/183. Disponível record- of }\end{array}$ <http://www.epa.gov/superfund/sites/rods/fulltext/a0497183.pdf.>. Acesso em: 02 set. 2006.

Presumptive remedy for metals-in soil sites. 1999. EPA/540-F-98-054. Disponível em: <http://www.epa.gov/superfund/resources/presump/finalpdf/metals pr.pdf>. Acesso em: 24 out. 2003.

Solidification/Stabilization use at superfund sites. 2000. EPA/542-R-00010. Disponível em: <http://www.epa.gov/swertio1/download/remed/ss_sfund.pdf>. Acesso em: 23 set. 2006.

Phytoremediation of contaminated soil and ground water at hazardous waste sites. 2001. EPA/540/S-01/500. Disponível em: <http://www.epa.gov/ada/download/issue/epa_540_s01_500.pdf.>. Acesso em: 16 out. 2003.

Lipari landfill. 2002a. Disponível em: <http://www.epa.gov/superfund/sites/nplfs/fs0200557.pdf>. Acesso em: 22 set. 2006. 
Arsenic treatment technologies for soil, waste, and water. 2002b. EPA/542-R-02-004. Disponível em <http://www.epa.gov/tio/download/remed/ 542r02004/arsenic_report.pdf>. Acesso em: 02 out. 2003.

. EPA's draft report on environment: technical document. Washington, D.C.: Office of research and development and the office of environmental information, 2003a. EPA/600-R-03-050. Disponível em: <http://www.epa.gov/ Envindicators/roe/pdf/EPA_Draft_ROE_TD.pdf>. Acesso em: 13 set. 2006.

Lead compounds. 2003b. Disponível em: <http://www.epa.gov/ttn/atw/

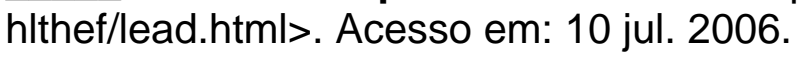

Letterkenny army depot: superfund site: results detailed information. 2003c. Disponível em: <http://cfpub.epa.gov/asr/detail.cfm?opnameid= 3039\&siteid=48817\&specificid=33> . Acesso em: 23 set. 2006.

Cape fear wood preserving: results detailed information. 2003d. Disponível em: <http://cfpub.epa.gov/asr/detail.cfm?opnameid=3215\&siteid=7942\&specificid $=33>$. Acesso em: 23 set. 2006.

UNITED STATES GENERAL ACCOUNTING AGENCY. Superfund cleanups nearing completion indicate future challenges. Washington, D.C.: Government Printing Office, 1993. GAO / RCED-93-188.

VALLS, M.; LORENZO, V. Exploiting the genetic and biochemical capacities of bacteria for the remediation of heavy metal pollution. FEMS Microbiology Reviews, Amsterdam,:v. 26, p. 327-338, 2002.

VEGLIÒ, F.; DI BIASI, A.; BEOLCHINI, F.; PAGNALELLI, F.. Heavy metal biosorption in binary system: simulation in single and two stage UF/MF membrane reactors. Hydrometallurgy, Amsterdam, v. 66, p. 107-115, 2002.

VERNET, J. P. (Ed.). Heavy metals in the environment. Amsterdam: Elsevier, 1991. $405 \mathrm{p}$.

WAISBERG, M.; JOSEPH, P.; HALE, B.; BEYERSMANN, D.. Molecular and cellular mechanisms of cadmium carcinogenesis. Toxicology, Amsterdam, v. 192, p. 95117, 2003. 
WANG, Y. M.; CHEN, T. C.; YEH, K. J. SHUE, M. F.. Stabilization of an elevated heavy metal contaminated site. Journal of hazardous materials, Amsterdam, v. B 88, p. 63-74, 2001.

WASAY, S. A.; BARRINGTON, S.; TOKUNAGA, S.. Eficiency of GAC for treatment of leachate from soil washing process. Water, air, and soil pollution, Netherlands, v. 116, p. 449-460, 1999.

WATER ENVIRONMENT FEDERATION. Manual of practice for water pollution control. Alexandria, VA: Water Environment Federation, 1994.

WATTS, R. J. Hazardous wastes: sources, pathways, receptors. New York: Wiley, 1997. $764 \mathrm{p}$.

WORLD HEALTH ORGANIZATION. Environmental health criteria: n. 221. Zinc. 2001. Disponível em: <http://www.who.int/pcs/ehc/summaries/ehc_221.html>. Acesso em: 10 jul. 2006.

ZAGURY, G. J.; NARASIAH, K. S.; TYAGI, R. D. Bioleaching of metal contaminated soil in semicontinuous reactor. Journal of Environmental Engineering, v. 127, n. 9, p. 812-817, sept. 2001.

ZIELINSKI, S.; BUCA, M.; FAMULSKI, M. Precipitation-stripping processes for heavy metals. Hydrometallurgy, Amsterdam, v. 48, p. 253-263, 1998.

\section{REFERENCIAS CONSULTADAS}

ASSOCIAÇÃO NACIONAL DOS PRODUTORES DE CERÂMICA PARA REVESTIMENTO. São Paulo. Disponível em: <www.anfacer.org.br>. Acesso em: 15 jun. 2003.

2001. Relatório interno.

Inventário das fontes prioritárias de poluição. São Paulo: CETESB,

FAGUNDES, A. Manual prático de introdução à cerâmica. Lisboa: Editorial Caminho S.A., 1997. 394 p. 


\section{APÊNDICE A - RESULTADOS DAS DETERMINAÇÕES FÍSICAS, QUÍMICAS E MICROBIOLÓGICAS}

\section{CARACTERIZAÇÃO FÍSICA DO SOLO}

\subsection{Determinação da massa específica}

\subsubsection{Latossolo roxo}

A Tabela 1 mostra os dados necessários para a determinação da massa específica dos grãos do latossolo roxo.

Tabela 1 - Massa específica dos grãos do latossolo roxo.

\begin{tabular}{lcc}
\hline \multicolumn{1}{c}{ Grandezas } & \multicolumn{2}{c}{ Picnômetros } \\
\hline Temperatura $\left({ }^{\circ} \mathrm{C}\right)$ & $\mathbf{M}$ & $\mathbf{F}$ \\
Solo úmido $(\mathrm{g})$ & 25,50 & 25,00 \\
$(\mathrm{~A})$ Solo seco $(\mathrm{g})$ & 64,16 & 64,64 \\
$(\mathrm{~B})$ Picnômetro + água $(\mathrm{g})$ & 57,59 & 58,02 \\
$(\mathrm{~A})+(\mathrm{B})(\mathrm{g})$ & $1.240,12$ & $1.207,54$ \\
$(\mathrm{C})$ Picnômetro + água + solo $(\mathrm{g})$ & $1.297,71$ & $1.265,56$ \\
$(\mathrm{~A})+(\mathrm{B})$ - (C) $(\mathrm{g})$ & $1.277,93$ & $1.245,79$ \\
Massa específica dos grãos $\left(\mathrm{g} / \mathrm{cm}^{3}\right)$ & 19,78 & 19,77 \\
Massa específica média dos grãos $\left(\mathrm{g} / \mathrm{cm}^{3}\right)$ & 2,91 & 2,93 \\
\hline
\end{tabular}

\subsubsection{Latossolo vermelho}

Tabela 2 mostra o resumo dos dados necessários à determinação da massa específica dos grãos. 
Tabela 2 - Massa específica dos grãos do latossolo vermelho.

\begin{tabular}{lcc}
\hline \multicolumn{1}{c}{ Grandezas } & \multicolumn{2}{c}{ Picnômetros } \\
& A & F \\
\hline Temperatura $\left({ }^{\circ} \mathrm{C}\right)$ & 22,0 & 22,0 \\
Solo úmido $(\mathrm{g})$ & 59,65 & 57,72 \\
$(\mathrm{~A})$ Solo seco $(\mathrm{g})$ & 52,32 & 50,63 \\
$(\mathrm{~B})$ Picnômetro + água $(\mathrm{g})$ & $1.214,75$ & $1.208,50$ \\
$(\mathrm{~A})+(\mathrm{B})(\mathrm{g})$ & $1.267,07$ & $1.259,13$ \\
$(\mathrm{C})$ Picnômetro + água + solo $(\mathrm{g})$ & $1.246,71$ & $1.239,42$ \\
$(\mathrm{~A})+(\mathrm{B})$ - (C) $(\mathrm{g})$ & 20,36 & 19,71 \\
Massa específica dos grãos $\left(\mathrm{g} / \mathrm{cm}^{3}\right)$ & 2,57 & 2,57 \\
Massa específica média dos $\mathrm{grãos}\left(\mathrm{g} / \mathrm{cm}^{3}\right)$ & \multicolumn{2}{c}{2,57} \\
\hline
\end{tabular}

\subsubsection{Análise granulométrica}

Este ensaio foi executado de acordo com a NBR 7181 (ABNT, 1984b) e constou das seguintes etapas:

Determinação de umidade;

Peneiramento grosso;

$>$ Peneiramento fino; e

Sedimentação.

A seguir, são apresentados os resultados de cada etapa do ensaio.

\subsubsection{Latossolo roxo}

a) Determinação de umidade

A Tabela 3 mostra o resumo dos dados necessários para a determinação da umidade do latossolo roxo. 
Tabela 3 - Determinação de umidade do latossolo roxo.

\begin{tabular}{lccc}
\hline \multirow{2}{*}{ Grandezas } & \multicolumn{3}{c}{ Cápsulas } \\
\hline Massa úmida + tara & $\mathbf{1 9 0}$ & $\mathbf{3 5}$ & $\mathbf{1 6 3}$ \\
(g) & 91,45 & 87,01 & 87,87 \\
Massa seca + tara (g) & 84,94 & 81,30 & 81,75 \\
Água (g) & 6,51 & 5,71 & 6,12 \\
Tara (g) & 27,88 & 31,13 & 28,16 \\
Massa seca (g) & 57,06 & 50,17 & 53,59 \\
Umidade (\%) & 11,41 & 11,38 & 11,42 \\
Umidade média (\%) & & 11,40 & \\
\hline
\end{tabular}

b) Peneiramento grosso
(A) - Amostra total úmida $(\mathrm{g})=5.697,00$
(B) Solo seco retido na peneira \# 10 (g) = 392,60
(C) Solo úmido passado na peneira \# 10 (A-B) $(\mathrm{g})=5.304,40$
(D) Solo seco passado na peneira \# $10(A-B) /(1+$ umidade $)(g)=4.761,79$
(E) Amostra total seca $(B+D)(g)=\quad 5.154,39$

A Tabela 4 mostra o resumo do peneiramento grosso.

Tabela 4 - Peneiramento grosso da amostra de latossolo roxo.

\begin{tabular}{ccccc}
\hline $\begin{array}{c}\text { Peneira } \\
\mathbf{n}^{\mathbf{0}}\end{array}$ & $\begin{array}{c}\text { Diâmetros } \phi \\
\mathbf{( m m})\end{array}$ & \multicolumn{3}{c}{ Massa da amostra seca } \\
& & Retido & Passado & \\
\hline 19 & 19 & 6,61 & $5.147,15$ & 99,87 \\
9 & 9,5 & 51,11 & $5.102,65$ & 99,01 \\
4 & 4,8 & 177,06 & $4.976,70$ & 96,56 \\
10 & 2 & 392,60 & $4.761,16$ & 92,38 \\
\hline
\end{tabular}

c) Peneiramento fino

Massa da amostra úmida $(\mathrm{g})=50,02$

Massa da amostra seca $(\mathrm{g})=44,90$

A Tabela 5 mostra o resumo do peneiramento fino da amostra de latossolo roxo. 
Tabela 5 - Peneiramento fino da amostra de latossolo roxo.

\begin{tabular}{|c|c|c|c|c|c|}
\hline \multirow{2}{*}{$\begin{array}{l}\text { Peneira } \\
n^{\circ}\end{array}$} & \multirow{2}{*}{$\begin{array}{l}\text { Diâmetros } \phi \\
(\mathbf{m m})\end{array}$} & \multicolumn{2}{|c|}{$\begin{array}{c}\text { Massa da amostra seca } \\
(\mathrm{g})\end{array}$} & \multirow{2}{*}{$\begin{array}{l}\%<\phi \\
\text { parcial }\end{array}$} & \multirow{2}{*}{$\%<\phi$} \\
\hline & & Retido & Passado & & \\
\hline 16 & 1,20 & 0,60 & 44,30 & 98,66 & 91,15 \\
\hline 30 & 0,60 & 1,32 & 43,58 & 97,06 & 89,67 \\
\hline 40 & 0,42 & 2,11 & 42,79 & 95,30 & 88,04 \\
\hline 50 & 0,30 & 3,01 & 41,89 & 93,30 & 86,19 \\
\hline 100 & 0,15 & 6,45 & 38,45 & 85,64 & 79,11 \\
\hline 200 & 0,075 & 10,52 & 34,38 & 76,57 & 70,74 \\
\hline
\end{tabular}

d) Sedimentação

A Tabela 6 mostra o resumo dos resultados do ensaio de sedimentação. 
Tabela 6 - Resultados do ensaio de sedimentação para o latossolo roxo.

\begin{tabular}{|c|c|c|c|c|c|c|c|c|c|}
\hline $\begin{array}{c}\text { Temperatura } \\
\left({ }^{\circ} \mathrm{C}\right)\end{array}$ & $\begin{array}{l}\text { Intervalo de } \\
\text { tempo }\end{array}$ & Hora & $\begin{array}{l}\text { Leitura } \\
\text { (cm) }\end{array}$ & $\begin{array}{l}\text { Altura de } \\
\text { queda } \\
\text { (cm) }\end{array}$ & $\begin{array}{c}\text { Correção } \\
(\Delta \mathrm{L}) \\
(\mathrm{cm})\end{array}$ & $\begin{array}{l}\text { Leitura corrigida } \\
\text { (Lc) (cm) }\end{array}$ & $\begin{array}{l}\gamma \text { da } \\
\text { água }\end{array}$ & $\begin{array}{c}\text { Diâmetro } \\
\text { dos grãos } \\
\phi \\
(\mathrm{mm}) \\
\end{array}$ & $\begin{array}{l}\mathbf{Q} \\
\%<\phi\end{array}$ \\
\hline 25,5 & $1 \mathrm{~min}$ & $10: 06$ & 23,00 & 11,70 & 4,20 & 18,80 & 0,9977 & 0,0406 & 58,73 \\
\hline 25,5 & $2 \mathrm{~min}$. & $10: 07$ & 22,20 & 11,86 & 4,20 & 18,00 & 0,9977 & 0,0289 & 56,23 \\
\hline 25,5 & $15 \mathrm{~min}$. & $10: 20$ & 20,50 & 11,25 & 4,20 & 16,30 & 0,9977 & 0,0103 & 50,92 \\
\hline 25,5 & $30 \mathrm{~min}$. & $10: 35$ & 20,00 & 11,40 & 4,20 & 15,80 & 0,9977 & 0,0073 & 49,36 \\
\hline 25,0 & 1 hora & $11: 05$ & 19,00 & 11,60 & 4,30 & 14,70 & 0,9977 & 0,0052 & 45,92 \\
\hline 25,0 & 2 horas & $12: 05$ & 18,50 & 11,75 & 4,30 & 14,20 & 0,9977 & 0,0037 & 44,36 \\
\hline 25,0 & 4 horas & $14: 05$ & 18,00 & 11,90 & 4,30 & 13,70 & 0,9977 & 0,0027 & 42,80 \\
\hline
\end{tabular}




\subsubsection{Latossolo vermelho}

A seguir, são apresentados os resultados de cada etapa do ensaio:

a) Determinação de umidade da amostra de latossolo vermelho

A Tabela 7 mostra os dados utilizados para a determinação de umidade.

Tabela 7 - Determinação da umidade do latossolo vermelho.

\begin{tabular}{lccc}
\hline \multicolumn{1}{c}{ Grandezas } & \multicolumn{3}{c}{ Cápsulas } \\
& $\mathbf{9 5}$ & $\mathbf{1 0 6}$ & $\mathbf{1 4 3}$ \\
\hline Massa úmida + tara & 75,19 & 75,35 & 80,87 \\
(g) & & & \\
Massa seca + tara (g) & 69,37 & 69,85 & 74,39 \\
Água (g) & 5,82 & 5,50 & 6,48 \\
Tara (g) & 27,77 & 30,68 & 28,16 \\
Massa seca (g) & 41,6 & 39,17 & 46,23 \\
Umidade (\%) & 13,99 & 14,04 & 14,02 \\
Umidade média (\%) & & 14,02 \\
\hline
\end{tabular}

b) Peneiramento grosso
(A) - Amostra total úmida $(\mathrm{g})=790,55$
(B) Solo seco retido \# $10(\mathrm{~g})=42,86$
(C) Solo úmido passado \# $10(\mathrm{~A}-\mathrm{B})(\mathrm{g})=747,69$
(D) Solo seco passado na peneira \# 10 (A-B) / (1+ umidade) $(\mathrm{g})=655,85$
(E) Amostra total seca $(B+D)(g)=698,71$

A Tabela 8 mostra o resumo do peneiramento grosso.

Tabela 8 - Peneiramento grosso da amostra de latossolo vermelho.

\begin{tabular}{|c|c|c|c|c|}
\hline \multirow{2}{*}{$\begin{array}{c}\text { Peneira } \\
n^{\circ}\end{array}$} & \multirow{2}{*}{$\begin{array}{c}\text { Diâmetros } \phi \\
(\mathrm{mm})\end{array}$} & \multicolumn{2}{|c|}{$\begin{array}{c}\text { Massa da amostra seca } \\
\text { (g) }\end{array}$} & \multirow[t]{2}{*}{$\%<\phi$} \\
\hline & & Retido & Passado & \\
\hline 19 & 19 & 6,14 & 692,57 & 99,12 \\
\hline 9 & 9,5 & 15,68 & 683,03 & 97,76 \\
\hline 4 & 4,8 & 29,79 & 668,92 & 95,74 \\
\hline 10 & 2 & 42,86 & 655,85 & 93,87 \\
\hline
\end{tabular}

c) Peneiramento fino

Massa da amostra úmida $(\mathrm{g})=56,99$

Massa da amostra seca $(\mathrm{g})=49,99$ 
A Tabela 9 mostra o resumo do peneiramento fino.

Tabela 9 - Peneiramento fino da amostra de latossolo vermelho.

\begin{tabular}{cccccc}
\hline $\begin{array}{c}\text { Peneira } \\
\mathbf{n}^{\circ}\end{array}$ & $\begin{array}{c}\text { Diâmetros } \phi \\
(\mathbf{m m})\end{array}$ & \multicolumn{2}{c}{$\begin{array}{c}\text { Massa da amostra } \\
\text { seca }(\mathbf{g})\end{array}$} & $\begin{array}{c}\%<\phi \\
\text { parcial }\end{array}$ & $\%<\phi$ \\
\hline 1,20 & 0,18 & 49,81 & 99,64 & 93,53 & 1,20 \\
0,60 & 0,86 & 49,13 & 98,28 & 92,25 & 0,60 \\
0,42 & 1,34 & 48,65 & 97,32 & 91,35 & 0,42 \\
0,30 & 1,76 & 48,23 & 96,48 & 90,56 & 0,30 \\
0,15 & 3,49 & 46,50 & 93,02 & 87,31 & 0,15 \\
0,07 & 5,68 & 44,31 & 88,64 & 83,20 & 0,07 \\
\hline
\end{tabular}

d) Sedimentação

A Tabela 10 mostra o resumo dos resultados do ensaio de sedimentação para a amostra de latossolo vermelho. 
Tabela 10 - Resultados do ensaio de sedimentação para o latossolo vermelho.

\begin{tabular}{|c|c|c|c|c|c|c|c|c|c|}
\hline $\begin{array}{c}\text { Temperatura } \\
\left({ }^{\circ} \mathrm{C}\right)\end{array}$ & $\begin{array}{l}\text { Intervalo } \\
\text { de tempo }\end{array}$ & Hora & $\begin{array}{l}\text { Leitura } \\
\text { (cm) }\end{array}$ & $\begin{array}{l}\text { Altura de queda } \\
(\mathrm{cm})\end{array}$ & $\begin{array}{c}\text { Correção } \\
(\Delta \mathrm{L}) \\
(\mathrm{cm})\end{array}$ & $\begin{array}{l}\text { Leitura corrigida } \\
\text { (Lc) }(\mathrm{cm})\end{array}$ & $\begin{array}{l}\gamma \text { da } \\
\text { água }\end{array}$ & $\begin{array}{l}\text { Diâmetr } \\
\text { o dos } \\
\text { grãos } \phi \\
\text { (mm) }\end{array}$ & $\stackrel{Q}{Q}<\phi$ \\
\hline 23,0 & $1 \mathrm{~min}$. & 09:36 & 31,00 & 9,50 & 4,60 & 26,40 & 0,9977 & 0,0404 & 81,04 \\
\hline 23,0 & $2 \mathrm{~min}$. & 09:37 & 30,00 & 9,70 & 4,60 & 25,40 & 0,9977 & 0,0289 & 77,97 \\
\hline 22,0 & $15 \mathrm{~min}$. & 09:50 & 26,00 & 9,70 & 4,80 & 21,20 & 0,9977 & 0,0106 & 65,08 \\
\hline 22,0 & $30 \mathrm{~min}$. & 10:05 & 25,00 & 9,90 & 4,80 & 20,20 & 0,9977 & 0,0075 & 62,01 \\
\hline 22,0 & 1 hora & 10:35 & 24,00 & 10,20 & 4,80 & 19,20 & 0,9977 & 0,0054 & 58,94 \\
\hline 21,0 & 2 horas & 11:35 & 22,50 & 10,60 & 5,00 & 17,50 & 0,9977 & 0,0039 & 53,72 \\
\hline 20,0 & 4 horas & $13: 35$ & 21,50 & 10,85 & 5,20 & 16,30 & 0,9977 & 0,0028 & 50,04 \\
\hline
\end{tabular}




\subsubsection{Determinação da densidade aparente, da umidade residual e da capacidade de campo do solo}

\subsubsection{Latossolo roxo}

A Tabela 11 mostra os resultados obtidos nas determinações da densidade aparente $\left(\rho_{a}\right)$, da umidade residual $\left(U_{R}\right)$ e da capacidade de campo $(C C)$.

Tabela 11 - Densidade aparente, umidade residual e capacidade de campo das amostras de solo da área de estudo.

\begin{tabular}{lccc}
\hline \multicolumn{1}{c}{ Grandezas } & \multicolumn{3}{c}{ Anéis } \\
& $\mathbf{4 9}$ & $\mathbf{5 0}$ & $\mathbf{1 4 1}$ \\
\hline $\mathrm{V}\left(\mathrm{cm}^{3}\right)$ & 240,36 & 240,36 & 237,15 \\
$\mathrm{~m} 1(\mathrm{~g})$ & 119,57 & 120,93 & 123,95 \\
$\mathrm{~m} 2(\mathrm{~g})$ & 116,27 & 117,83 & 120,74 \\
$\mathrm{~m} 3(\mathrm{~g})$ & 447,28 & 439,61 & 432,83 \\
$\mathrm{~m} 4(\mathrm{~g})$ & 412,00 & 405,63 & 400,11 \\
$\mathrm{~m} 5(\mathrm{~g})$ & 540,02 & 528,84 & 520,67 \\
$\rho_{a}\left(\mathrm{~g} / \mathrm{cm}^{3}\right)$ & 1,23 & 1,20 & 1,18 \\
$\rho_{a}$ média $\left(\mathrm{g} / \mathrm{cm}^{3}\right)$ & & 1,20 \\
$\mathrm{U}_{\mathrm{R}}\left(\mathrm{g} \mathrm{H}_{2} \mathrm{O} / 100 \mathrm{~g}\right.$ solo seco $)$ & 11,93 & 11,81 & 11,71 \\
$\mathrm{U}_{\mathrm{R} \text { média }}\left(\mathrm{g} \mathrm{H}_{2} \mathrm{O} / 100 \mathrm{~g}\right.$ solo seco $)$ & \multicolumn{3}{c}{11,82} \\
$\mathrm{CC}\left(\mathrm{g} \mathrm{H}_{2} \mathrm{O} / 100\right.$ g solo seco $)$ & 42,17 & 41,73 & 42,01 \\
$\mathrm{CC}_{\text {médio }}\left(\mathrm{g} \mathrm{H}_{2} \mathrm{O} / 100\right.$ g solo seco $)$ & \multicolumn{3}{c}{41,97} \\
\hline
\end{tabular}

Nota:

$\mathrm{V}=$ volume do anel $\left(\mathrm{cm}^{3}\right)$

$\mathrm{m} 1$ = massa úmida do conjunto anel + papel filtro $(\mathrm{g})$

$\mathrm{m} 2$ = massa seca $a 105^{\circ} \mathrm{C}$ do conjunto anel + papel filtro $(\mathrm{g})$

$\mathrm{m} 3=$ massa do conjunto anel + papel $\left(\operatorname{secos}\right.$ a $\left.105^{\circ} \mathrm{C}\right)+$ solo seco a temperatura ambiente $(\mathrm{g})$

$\mathrm{m} 4=$ massa seca $a 105^{\circ} \mathrm{C}$ do conjunto anel + papel filtro + solo $(\mathrm{g})$

m5 = massa saturada com $\mathrm{H}_{2} \mathrm{O}$ do conjunto anel + papel filtro + solo $(\mathrm{g})$

$\rho_{\mathrm{a}}=$ densidade aparente $\left(\mathrm{g} / \mathrm{cm}^{3}\right)$;

$\rho_{\text {a média }}=$ densidade aparente média $\left(\mathrm{g} / \mathrm{cm}^{3}\right)$

$\mathrm{U}_{\mathrm{R}}=$ umidade residual $\left(\mathrm{g} \mathrm{H}_{2} \mathrm{O} / 100 \mathrm{~g}\right.$ solo seco)

$\mathrm{U}_{\mathrm{R} \text { média }}=$ umidade residual média $\left(\mathrm{g} \mathrm{H}_{2} \mathrm{O} / 100 \mathrm{~g}\right.$ solo seco)

$\mathrm{CC}=$ capacidade de campo $\left(\mathrm{g} \mathrm{H}_{2} \mathrm{O} / 100 \mathrm{~g}\right.$ solo seco $) \mathrm{e}$

$\mathrm{CC}_{\text {média }}=$ capacidade de campo média $\left(\mathrm{g} \mathrm{H}_{2} \mathrm{O} / 100 \mathrm{~g}\right.$ solo seco).

Visto que a norma a Norma CETESB L6.350 (CETESB, 1990) não estabelece um limite máximo aceitável para o desvios observados entre as amostras 
ensaiadas, os resultados dos ensaios foram considerados válidos. Os desvios das 3 determinações foram $\leq 2,50$ \% em relação aos valores médios.

\subsubsection{Latossolo vermelho}

A Tabela 12 mostra os resultados obtidos nas determinações da densidade aparente $\left(\rho_{a}\right)$, da umidade residual $\left(U_{R}\right)$ e da capacidade de campo $(C C)$.

Tabela 12 - Densidade aparente, umidade residual e capacidade de campo do latossolo roxo.

\begin{tabular}{|c|c|c|c|}
\hline \multirow[t]{2}{*}{ Grandezas } & \multicolumn{3}{|c|}{ Anéis } \\
\hline & 1 & 2 & 3 \\
\hline $\mathrm{V}\left(\mathrm{cm}^{3}\right)$ & 240,36 & 237,15 & 240,36 \\
\hline m1 (g) & 120,33 & 118,25 & 124,08 \\
\hline $\mathrm{m} 2(\mathrm{~g})$ & 117,32 & 115,81 & 121,61 \\
\hline m3 (g) & 431,40 & 430,69 & 435,21 \\
\hline m4 (g) & 420,01 & 419,19 & 423,92 \\
\hline m5 (g) & 559,42 & 558,06 & 560,60 \\
\hline$\rho_{a}\left(\mathrm{~g} / \mathrm{cm}^{3}\right)$ & 1,26 & 1,28 & 1,26 \\
\hline$\rho_{\text {a média }}\left(\mathrm{g} / \mathrm{cm}^{3}\right)$ & & 1,27 & \\
\hline $\mathrm{U}_{\mathrm{R}}\left(\mathrm{g} \mathrm{H}_{2} \mathrm{O} / 100 \mathrm{~g}\right.$ solo seco $)$ & 3,76 & 3,79 & 3,73 \\
\hline $\mathrm{U}_{\mathrm{R} \text { média }}\left(\mathrm{g} \mathrm{H}_{2} \mathrm{O} / 100 \mathrm{~g}\right.$ solo seco $)$ & & 3,76 & \\
\hline $\mathrm{CC}\left(\mathrm{g} \mathrm{H}_{2} \mathrm{O} / 100 \mathrm{~g}\right.$ solo seco) & 45,06 & 44,97 & 44,39 \\
\hline $\mathrm{CC}_{\text {médio }}\left(\mathrm{g} \mathrm{H}_{2} \mathrm{O} / 100 \mathrm{~g}\right.$ solo seco) & & 44,81 & \\
\hline $\begin{array}{l}\text { Nota: } \\
\mathrm{V}=\text { volume do anel }\left(\mathrm{cm}^{3}\right) \\
\mathrm{m} 1=\text { massa úmida do conjunto anel }+\mathrm{pa} \\
\mathrm{m} 2=\text { massa seca a } 105^{\circ} \mathrm{C} \text { do conjunto a } \\
\mathrm{m} 3=\text { massa do conjunto anel }+ \text { papel } \\
\text { ambiente }(\mathrm{g}) \\
\mathrm{m} 4=\text { massa seca a } 150^{\circ} \mathrm{C} \text { do conjunto a } \\
\mathrm{m} 5=\text { massa saturada com } \mathrm{H}_{2} \mathrm{O} \text { do conju } \\
\rho_{\mathrm{a}}=\text { densidade aparente }\left(\mathrm{g} / \mathrm{cm}^{3}\right) \\
\rho_{\text {a média }}=\text { densidade aparente } \mathrm{média}(\mathrm{g} / \mathrm{c} \\
\mathrm{U}_{\mathrm{R}}=\text { umidade residual em }\left(\mathrm{g} \mathrm{H}_{2} \mathrm{O} / 100 \mathrm{~g}\right. \\
\mathrm{U}_{\mathrm{R} \text { média }}=\text { umidade residual média }\left(\mathrm{g} \mathrm{H}_{2} \mathrm{C}\right. \\
\mathrm{CC}=\text { capacidade de campo }\left(\mathrm{g} \mathrm{H}_{2} \mathrm{O} / 100\right. \\
\mathrm{CC} \text { média }=\text { capacidade de campo média }\left(\mathrm{g} \mathrm{H}_{2}\right.\end{array}$ & $\begin{array}{l}\text { pel filtro }(\mathrm{g}) \\
\text { nel + papel } \\
\text { (secos a } 1 \\
\text { nel + papel } \\
\text { ito anel + p } \\
\mathrm{m}^{3} \text { ) } \\
\text { solo seco ) } \\
\text { / } 100 \mathrm{~g} \mathrm{so} \\
\mathrm{g} \text { solo secc } \\
\text { / } 100 \text { g solc }\end{array}$ & $\begin{array}{l}\text { ) filtro }(\mathrm{g}) \\
\left.105^{\circ} \mathrm{C}\right)+\mathrm{s} \\
\text { filtro + sol } \\
\text { bapel filtro + } \\
\text { lo seco) } \\
\text { o) } \mathrm{e} \\
\text { lo seco). }\end{array}$ & $\begin{array}{l}\text { solo seco a temperatura } \\
\text { lo }(\mathrm{g}) \\
+ \text { solo }(\mathrm{g})\end{array}$ \\
\hline
\end{tabular}




\section{RESULTADOS DAS DETERMINAÇÕES QUÍMICAS E MICROBIOLÓGICAS}

\subsection{Resultados do experimento $n^{\circ} 6$}

As Tabelas 13, 14, 15 e 16 mostram, respectivamente, os resultados das determinações químicas para o lixiviado produzido ao longo do experimento de biolixiviação $\mathrm{n}^{\circ} 6 \operatorname{com} A$. ferrooxidans para os elementos $\mathrm{B}, \mathrm{Cd}, \mathrm{Pb}$ e $\mathrm{Zn}$.

Tabela 13 - Concentração do elemento B no lixiviado - experimento $n^{\circ} 6$.

\begin{tabular}{cccccccc}
\hline \multirow{2}{*}{ Reator } & \multicolumn{7}{c}{ Concentração B (mg/L) } \\
& $\mathbf{0}$ & $\mathbf{5}$ & $\mathbf{1 0}$ & $\mathbf{1 5}$ & $\mathbf{2 0}$ & $\mathbf{2 5}$ & $\mathbf{3 0}$ \\
\hline R1 & 1,73 & 2,62 & 2,35 & 2,12 & 2,62 & 2,83 & 2,54 \\
R2 & 2,05 & 1,89 & 1,78 & 1,76 & 1,66 & 1,75 & 1,69 \\
R3 & 1,80 & 1,59 & 1,50 & 1,35 & 2,28 & 1,46 & 1,52 \\
R4 & 2,30 & 1,99 & 1,71 & 2,04 & 1,65 & 1,75 & 1,66 \\
Controle & 0,62 & - & 0,85 & - & 1,43 & - & 1,02 \\
\hline
\end{tabular}

Tabela 14 - Concentração do elemento Cd no lixiviado - experimento $n^{\circ} 6$.

\begin{tabular}{cccccccc}
\hline & \multicolumn{7}{c}{ Concentração Cd (mg/L) } \\
Reator & \multicolumn{7}{c}{ Tempo (dias) } \\
& $\mathbf{0}$ & $\mathbf{5}$ & $\mathbf{1 0}$ & $\mathbf{1 5}$ & $\mathbf{2 0}$ & $\mathbf{2 5}$ & $\mathbf{3 0}$ \\
\hline R1 & 0,16 & 0,13 & 0,05 & 0,04 & 0,03 & 0,03 & 0,03 \\
R2 & 0,16 & 0,14 & 0,06 & 0,05 & 0,04 & 0,04 & 0,04 \\
R3 & 0,17 & 0,14 & 0,06 & 0,05 & 0,04 & 0,04 & 0,04 \\
R4 & 0,18 & 0,14 & 0,06 & 0,05 & 0,05 & 0,04 & 0,04 \\
Controle & $<0,005$ & - & $<0,005$ & - & $<0,003$ & - & $<0,003$ \\
\hline
\end{tabular}


Tabela 15 - Concentração do elemento $\mathrm{Pb}$ no lixiviado - experimento $\mathrm{n}^{\circ} 6$.

\begin{tabular}{cccccccc}
\hline Reator & \multicolumn{7}{c}{$\begin{array}{c}\text { Concentração Pb (mg/L) } \\
\text { Tempo (dias) }\end{array}$} \\
& $\mathbf{0}$ & $\mathbf{5}$ & $\mathbf{1 0}$ & $\mathbf{1 5}$ & $\mathbf{2 0}$ & $\mathbf{2 5}$ & $\mathbf{3 0}$ \\
\hline R1 & 3,31 & 0,21 & 0,03 & $<0,0028$ & $<0,0028$ & $<0,0028$ & $<0,0028$ \\
R2 & 3,84 & 0,23 & 0,04 & $<0,0028$ & $<0,0028$ & $<0,0028$ & $<0,0028$ \\
R3 & 3,93 & 0,22 & 0,03 & $<0,0028<0,0028$ & $<0,0028<0,0028$ \\
R4 & 3,87 & 0,23 & 0,02 & $<0,0028<0,0028$ & $<0,0028<0,0028$ \\
Controle & 0,04 & - & $<0,04$ & - & $<0,05$ & - & $<0,05$ \\
\hline
\end{tabular}

Tabela 16 - Concentração do elemento $Z n$ no lixiviado - experimento $n^{\circ} 6$.

\begin{tabular}{cccccccc}
\hline Reator & \multicolumn{7}{c}{ Concentração Zn (mg } \\
& $\mathbf{0}$ & $\mathbf{5}$ & $\mathbf{1 0}$ & $\mathbf{1 5}$ & $\mathbf{2 0}$ & $\mathbf{2 5}$ & $\mathbf{3 0}$ \\
\hline R1 & 6,33 & 35,60 & 40,24 & 41,39 & 47,84 & 47,87 & 50,26 \\
R2 & 14,11 & 37,62 & 42,35 & 45,15 & 46,68 & 48,99 & 49,16 \\
R3 & 22,70 & 38,86 & 40,78 & 46,08 & 45,24 & 46,15 & 46,66 \\
R4 & 23,04 & 39,11 & 40,96 & 46,76 & 43,64 & 47,35 & 49,89 \\
Controle & $<0,08$ & - & $<0,08$ & - & $<0,04$ & - & $<0,004$ \\
\hline
\end{tabular}

As Tabelas 17, 18, 19, 20, 21, 22, 23 e 24 mostram, respectivamente, os resultados das determinações químicas para o solo tratado ao longo do experimento de biolixiviação $n^{\circ} 6 \operatorname{com} A$. ferrooxidans para os elementos $\mathrm{Al}, \mathrm{B}, \mathrm{Cd}, \mathrm{Fe}, \mathrm{P}, \mathrm{Pb}, \mathrm{S}$ e $\mathrm{Zn}$.

Tabela 17 - Teor do elemento Al no solo tratado - experimento $n^{\circ} 6$.

\begin{tabular}{ccc}
\hline & \multicolumn{2}{c}{ Teor de AI (\%) } \\
Reator & \multicolumn{2}{c}{ Tempo (dias) } \\
& $\mathbf{0}$ & $\mathbf{3 0}$ \\
\hline R1 & $6,72 \pm 0,016,81 \pm 0,04$ \\
R2 & $7,17 \pm 0,067,37 \pm 0,04$ \\
R3 & $7,14 \pm 0,036,25 \pm 0,05$ \\
R4 & $5,57 \pm 0,037,29 \pm 0,02$ \\
Controle & $8,29 \pm 0,18$ & $9,68 \pm 0,01$ \\
\hline
\end{tabular}


Tabela 18 - Teor do elemento B no solo tratado - experimento $n^{\circ} 6$.

\begin{tabular}{cccccccc}
\hline \multirow{8}{*}{ Reator } & \multicolumn{7}{c}{ Teor de B (mg/kg) } \\
& $\mathbf{0}$ & $\mathbf{5}$ & $\mathbf{1 0}$ & $\mathbf{1 5}$ & $\mathbf{2 0}$ & $\mathbf{2 5}$ & $\mathbf{3 0}$ \\
\hline R1 & 23,62 & 20,90 & 20,08 & 22,34 & 17,37 & 20,43 & 22,74 \\
R2 & 11,91 & 14,35 & 19,17 & 14,28 & 21,01 & 16,55 & 20,22 \\
R3 & 14,06 & 16,64 & 15,66 & 15,06 & 13,78 & 15,14 & 14,08 \\
R4 & 12,60 & 14,41 & 12,69 & 15,03 & 16,66 & 16,61 & 13,78 \\
Controle & $<0,3$ & - & $<0,3$ & - & $<0,3$ & - & 0,3 \\
\hline
\end{tabular}

Tabela 19 -Teor do elemento Cd no solo tratado - experimento $n^{\circ} 6$.

\begin{tabular}{|c|c|c|c|c|c|c|c|}
\hline & \multicolumn{7}{|c|}{ Teor de Cd (mg/kg) } \\
\hline & \multicolumn{7}{|c|}{ Tempo (dias) } \\
\hline & 0 & 5 & 10 & 15 & 20 & 25 & 30 \\
\hline R1 & \multicolumn{4}{|c|}{$<0,002<0,002<0,002<0,002$} & \multicolumn{3}{|c|}{$<0,002<0,002<0,002$} \\
\hline $\mathrm{R} 2$ & \multicolumn{4}{|c|}{$<0,002<0,002<0,002<0,002$} & \multicolumn{3}{|c|}{$<0,002<0,002<0,002$} \\
\hline R3 & \multicolumn{4}{|c|}{$<0,002<0,002<0,002<0,002$} & \multicolumn{3}{|c|}{$<0,002<0,002<0,002$} \\
\hline $\mathrm{R} 4$ & \multicolumn{4}{|c|}{$<0,002<0,002<0,002<0,002$} & \multicolumn{3}{|c|}{$<0,002<0,002<0,002$} \\
\hline Controle & \multicolumn{4}{|c|}{$<0,003<0,003<0,003<0,003$} & \multicolumn{3}{|c|}{$<0,003<0,003<0,003$} \\
\hline
\end{tabular}

Tabela 20 -Teor do elemento Fe no solo tratado - experimento $n^{\circ} 6$.

\begin{tabular}{ccc}
\hline & \multicolumn{2}{c}{ Teor de Fe (\%) } \\
Reator & \multicolumn{2}{c}{ Tempo (dias) } \\
& $\mathbf{0}$ & $\mathbf{3 0}$ \\
\hline R1 & 4,94 & 6,19 \\
R2 & 4,94 & 6,41 \\
R3 & 4,99 & 6,01 \\
R4 & 5,03 & 6,16 \\
Controle & 4,49 & 4,76 \\
\hline
\end{tabular}

Tabela 21 - Teor do elemento P no solo tratado - experimento $n^{\circ} 6$.

\begin{tabular}{|c|c|c|c|c|c|c|c|}
\hline \multirow[t]{2}{*}{ Reator } & \multicolumn{7}{|c|}{$\begin{array}{c}\text { Teor de } \mathbf{P}(\mathrm{mg} / \mathrm{kg}) \\
\text { Tempo (dias) }\end{array}$} \\
\hline & 0 & 5 & 10 & 15 & 20 & 25 & 30 \\
\hline $\mathrm{R} 1$ & 379,57 & 379,91 & 365,09 & 368,23 & 353,65 & 362,51 & 358,55 \\
\hline $\mathrm{R} 2$ & 364,83 & 397,44 & 386,97 & 407,06 & 413,95 & 362,85 & 411,66 \\
\hline R3 & 399,35 & 418,29 & 361,44 & 20615 & 384,32 & 401,83 & 391,58 \\
\hline $\mathrm{R} 4$ & 442,02 & 425,89 & 391,40 & 398,00 & 411,00 & 397,54 & 393,09 \\
\hline Controle & 261,08 & - & - & - & - & - & 272,65 \\
\hline
\end{tabular}


Tabela 22 - Teor do elemento Pb no solo tratado - experimento $\mathrm{n}^{\circ} 6$.

\begin{tabular}{cccccccc}
\hline & \multicolumn{7}{c}{ Teor de Pb (mg/kg) } \\
Reator & \multicolumn{7}{c}{ Tempo (dias) } \\
& $\mathbf{0}$ & $\mathbf{5}$ & $\mathbf{1 0}$ & $\mathbf{1 5}$ & $\mathbf{2 0}$ & $\mathbf{2 5}$ & $\mathbf{3 0}$ \\
\hline R1 & 713,27 & 736,49 & 729,29 & 750,21 & 720,07 & 739,65 & 736,72 \\
R2 & 681,35 & 735,57 & 671,33 & 739,06 & 735,87 & 673,63 & 724,30 \\
R3 & 694,23 & 716,45 & 672,60 & 708,98 & 676,91 & 701,21 & 714,74 \\
R4 & 760,08 & 751,94 & 715,42 & 693,36 & 747,30 & 686,68 & 710,72 \\
Controle & 576,72 & - & 637,88 & - & 616,16 & - & 681,51 \\
\hline
\end{tabular}

Tabela 23 - Teor do elemento $S$ no solo tratado - experimento $n^{\circ} 6$.

\begin{tabular}{cccccccc}
\hline & \multicolumn{7}{c}{ Teor de S (\%) } \\
Reator & \multicolumn{7}{c}{ Tempo (dias) } \\
& $\mathbf{0}$ & $\mathbf{5}$ & $\mathbf{1 0}$ & $\mathbf{1 5}$ & $\mathbf{2 0}$ & $\mathbf{2 5}$ & $\mathbf{3 0}$ \\
\hline R1 & 0,31 & 0,53 & 0,82 & 0,85 & 0,85 & 0,92 & 0,83 \\
R2 & 0,31 & 0,54 & 0,64 & 0,75 & 0,77 & 0,89 & 0,79 \\
R3 & 0,29 & 0,55 & 0,71 & 0,77 & 0,75 & 0,83 & 0,78 \\
R4 & 0,32 & 0,58 & 0,75 & 0,73 & 0,78 & 0,76 & 0,74 \\
Controle & $<0,05$ & - & - & - & - & - & $<0,02$ \\
\hline
\end{tabular}

Tabela 24 - Teor do elemento $\mathrm{Zn}$ no solo tratado - experimento $\mathrm{n}^{\circ} 6$.

\begin{tabular}{cccccccc}
\hline Reator & \multicolumn{7}{c}{ Teor de Zn (mg/kg) } \\
& $\mathbf{0}$ & $\mathbf{5}$ & $\mathbf{1 0}$ & $\mathbf{1 5}$ & $\mathbf{2 0}$ & $\mathbf{2 5}$ & $\mathbf{3 0}$ \\
\hline R1 & 174,44 & 135,60 & 126,38 & 121,74 & 106,56 & 115,52 & 110,49 \\
R2 & 128,64 & 126,10 & 123,43 & 122,25 & 117,67 & 102,46 & 114,07 \\
R3 & 146,33 & 130,40 & 112,80 & 117,65 & 108,89 & 122,91 & 108,09 \\
R4 & 153,80 & 137,00 & 119,75 & 120,07 & 116,01 & 104,24 & 112,18 \\
Controle & 177,60 & - & 165,66 & - & 184,90 & - & 197,56 \\
\hline
\end{tabular}

As Tabelas 25, 26 e 27 mostram, respectivamente, os resultados obtidos nas análises de contagem de bactérias heterotróficas e $A$. ferrooxidans durante este experimento de biolixiviação $n^{\circ} 6$. A Tabela 26 mostra a contagem do número mais provável de A. ferrooxidans (CETESB, 1991) e, a Tabela 27 mostra a contagem executada em microscópio desta mesma bactéria. 
Tabela 25 - Evolução da população de bactérias heterotróficas - experimento nº 6 .

\begin{tabular}{cccccc}
\hline \multirow{2}{*}{ Reatores } & \multicolumn{4}{c}{ Log $_{10}$ UFClg solo } \\
& & $\mathbf{0}$ & $\mathbf{1 0}$ & $\mathbf{2 0}$ & $\mathbf{3 0}$ \\
\hline \multirow{2}{*}{1} & Tendência & 7,95 & 5,56 & 4,62 & 4,65 \\
& Incerteza & $*$ & 0,01 & 0,02 & 0,09 \\
\multirow{2}{*}{2} & Tendência & 9,07 & 5,15 & 4,53 & 4,85 \\
& Incerteza & 0,04 & $*$ & 0,02 & 0,02 \\
\multirow{2}{*}{3} & Tendência & 9,04 & 5,08 & 4,13 & 5,17 \\
& Incerteza & 0,02 & 0,05 & 0,04 & 0,03 \\
\multirow{2}{*}{4} & Tendência & 9,06 & 5,08 & 4,2 & 5,65 \\
& Incerteza & 0,02 & 0,03 & 0,14 & 0,01 \\
\multirow{2}{*}{ Controle } & Tendência & 6,62 & 6,6 & 7,0 & 5,54 \\
& Incerteza & 0,26 & 0,01 & 0,06 & 0,16 \\
\hline
\end{tabular}

Nota:

Incerteza = incerteza determinada para a duplicata de placas utilizadas na contagem.

* = incerteza não definida devido a contaminação em uma das placas utilizadas na contagem.

Tabela 26 - Evolução da população de bactérias $A$. ferrooxidans - experimento $n^{\circ} 6$ : número mais provável.

\begin{tabular}{cccccc}
\hline \multirow{2}{*}{ Reatores } & \multicolumn{4}{c}{ Log $_{\mathbf{1 0}}$ A. ferrooxidans/g solo } \\
& & $\mathbf{0}$ & $\mathbf{1 0}$ & $\mathbf{2 0}$ & $\mathbf{3 0}$ \\
\hline \multirow{2}{*}{1} & Tendência & $\mathbf{0 , 9 8}$ & 3,77 & 3,43 & 5,75 \\
& Incerteza & 0,86 & 0,62 & 0,63 & 0,61 \\
\multirow{2}{*}{2} & Tendência & 1,0 & 3,77 & 3,78 & 5,76 \\
& Incerteza & 0,86 & 0,62 & 0,62 & 0,61 \\
\multirow{2}{*}{3} & Tendência & 3,49 & 3,77 & 3,77 & 5,74 \\
& Incerteza & 0,63 & 0,62 & 0,62 & 0,61 \\
\multirow{2}{*}{4} & Tendência & 3,12 & 3,77 & 3,76 & 5,76 \\
& Incerteza & 0,67 & 0,62 & 0,62 & 0,61 \\
\multirow{2}{*}{ Controle } & Tendência & 0,98 & 0,94 & 0,88 & 0,91 \\
& Incerteza & 0,86 & 0,86 & 0,86 & 0,86 \\
\hline
\end{tabular}

Nota:

Incerteza = limite de confiança definido para uma probabilidade de $95 \%$.

Limite de detecção do método $=\leq 1 \log _{10} A$. ferrooxidans/g solo. 
Tabela 25 - Evolução da população de bactérias $A$. ferrooxidans - experimento $\mathrm{n}^{\circ}$ 6: contagem direta no microscópio.

\begin{tabular}{cccccc}
\hline \multirow{2}{*}{ Reatores } & \multicolumn{4}{c}{ Log $_{10}$ A. ferrooxidans/g solo } \\
& & \multicolumn{4}{c}{ Tempo (dias) } \\
& & $\mathbf{0}$ & $\mathbf{1 0}$ & $\mathbf{2 0}$ & $\mathbf{3 0}$ \\
\hline \multirow{2}{*}{1} & Tendência & 8,46 & 6,97 & 7,41 & 9,68 \\
& Incerteza & 0,06 & 0,03 & 0,02 & 0,02 \\
\multirow{2}{*}{2} & Tendência & 9,3 & 6,87 & 7,19 & 9,7 \\
& Incerteza & 0,13 & 0,03 & 0,09 & 0,08 \\
\multirow{2}{*}{3} & Tendência & 8,94 & 8,04 & 8,31 & 9,4 \\
& Incerteza & 0,01 & 0,13 & 0,12 & 0,05 \\
\multirow{2}{*}{4} & Tendência & 8,51 & 8,45 & 8,25 & 9,48 \\
& Incerteza & 0,07 & 0,05 & 0,1 & 0,03 \\
\multirow{2}{*}{ Controle } & Tendência & $*$ & $*$ & $*$ & $*$ \\
& Incerteza & $*$ & $*$ & $*$ & $*$ \\
\hline
\end{tabular}

Nota: * ${ }^{*}$ contagem não executada.

A Tabela 28 mostra a contagem do número total de microrganismos determinados através de microscopia utilizando o marcador de DNA 4-6 diamidino2-phenylindole (DAPI).

Tabela 28 - Evolução do número total de microrganismos - experimento $n^{\circ} 6$.

\begin{tabular}{cccccc}
\hline \multirow{2}{*}{ Reatores } & \multicolumn{5}{c}{$\begin{array}{c}\text { Log } \\
\text { Tempo (dias) }\end{array}$} \\
& & $\mathbf{0}$ & $\mathbf{1 0}$ & $\mathbf{2 0}$ & $\mathbf{3 0}$ \\
\hline \multirow{2}{*}{1} & Tendência & 11,68 & 12,56 & 12,92 & 13,26 \\
& Incerteza & 0,05 & 0,04 & 0,04 & 0,02 \\
\multirow{2}{*}{2} & Tendência & 11,94 & 12,09 & 12,9 & 13,31 \\
& Incerteza & 0,04 & 0,06 & 0,04 & 0,01 \\
\multirow{2}{*}{3} & Tendência & 11,87 & 12,68 & 12,87 & 13,38 \\
& Incerteza & 0,06 & 0,08 & 0,04 & 0,02 \\
\multirow{2}{*}{4} & Tendência & 12,83 & 12,1 & 13,04 & 13,25 \\
& Incerteza & 0,02 & 0,07 & 0,03 & 0,03 \\
\multirow{2}{*}{ Controle } & Tendência & $*$ & $*$ & $*$ & $*$ \\
& Incerteza & $*$ & $*$ & $*$ & $*$ \\
\hline
\end{tabular}

Nota: ${ }^{*}=$ contagem não executada. 


\subsection{Resultados do experimento $n^{\circ} 7$}

As Tabelas 29, 30, 31 e 32 mostram, respectivamente, os resultados das determinações químicas para o lixiviado produzido ao longo do experimento de biolixiviação com $A$. ferrooxidans para os elementos $\mathrm{B}, \mathrm{Cd}, \mathrm{Pb}$ e $\mathrm{Zn}$.

Tabela 29 - Concentração do elemento B no lixiviado - experimento $n^{\circ} 7$.

\begin{tabular}{ccccc}
\hline \multirow{2}{*}{ Reator } & \multicolumn{4}{c}{ Concentração B (mg/L) } \\
& $\mathbf{0}$ & $\mathbf{1 0}$ & $\mathbf{2 0}$ & $\mathbf{3 0}$ \\
\hline $\mathrm{R} 1$ & 0,99 & 1,57 & 1,68 & 1,62 \\
$\mathrm{R} 2$ & 1,67 & 1,63 & 1,55 & 1,55 \\
$\mathrm{R} 3$ & 1,55 & 1,60 & 1,54 & 1,40 \\
$\mathrm{R} 4$ & 1,59 & 1,56 & 1,51 & 1,44 \\
Controle & 0,42 & 0,57 & 1,09 & 0,59 \\
\hline
\end{tabular}

Tabela 30 - Concentração do elemento Cd no lixiviado - experimento $n^{0} 7$.

\begin{tabular}{ccccc}
\hline Reator & \multicolumn{4}{c}{ Concentração Cd (mg/L) } \\
& $\mathbf{0}$ & $\mathbf{1 0}$ & $\mathbf{2 0}$ & $\mathbf{3 0}$ \\
\hline R1 & 0,19 & 0,05 & 0,04 & 0,03 \\
R2 & 0,02 & 0,06 & 0,05 & 0,04 \\
R3 & 0,19 & 0,06 & 0,05 & 0,04 \\
R4 & 0,19 & 0,06 & 0,05 & 0,04 \\
Controle & $<0,005$ & $<0,005$ & $<0,003$ & $<0,003$ \\
\hline
\end{tabular}

Tabela 31 - Concentração do elemento $\mathrm{Pb}$ no lixiviado - experimento $\mathrm{n}^{\circ} 7$.

\begin{tabular}{ccccc}
\hline & \multicolumn{5}{c}{ Concentração Pb (mg/L) } \\
Reator & \multicolumn{4}{c}{ Tempo (dias) } \\
& $\mathbf{0}$ & $\mathbf{1 0}$ & $\mathbf{2 0}$ * & $\mathbf{3 0}$ \\
\hline R1 & 3,38 & $<0,04$ & $<0,04$ & $<0,04$ \\
R2 & 3,83 & $<0,04$ & $<0,04$ & $<0,04$ \\
R3 & 3,97 & $<0,04$ & $<0,04$ & $<0,04$ \\
R4 & 3,87 & $<0,04$ & $<0,04$ & $<0,04$ \\
Controle & $<0,04$ & $<0,04$ & $<0,05$ & $<0,05$ \\
\hline
\end{tabular}


Tabela 32 - Concentração do elemento Zn no lixiviado - experimento $n^{0} 7$.

\begin{tabular}{ccccc}
\hline \multirow{2}{*}{ Reator } & \multicolumn{4}{c}{ Concentração Zn (mg/L) } \\
& $\mathbf{0}$ & $\mathbf{1 0}$ & $\mathbf{2 0}$ & $\mathbf{3 0}$ \\
\hline R1 & 4,19 & 19,76 & 26,47 & 27,55 \\
R2 & 11,23 & 20,40 & 24,03 & 23,9 \\
R3 & 10,27 & 22,39 & 24,57 & 24,92 \\
R4 & 10,37 & 21,90 & 24,29 & 23,59 \\
Controle & $<0,08$ & $<0,08$ & $<0,004$ & $<0,004$ \\
\hline
\end{tabular}

As Tabelas 33, 34, 35, 36, 37 e 38 mostram, respectivamente, os resultados das determinações químicas para o solo tratado ao longo do experimento de biolixiviação $\mathrm{n}^{\circ} 7 \operatorname{com} A$. ferrooxidans para os elementos $\mathrm{B}, \mathrm{Cd}, \mathrm{P}, \mathrm{Pb}, \mathrm{S}$ e $\mathrm{Zn}$.

Tabela 33 - Teor do elemento B no solo tratado - experimento $n^{0} 7$.

\begin{tabular}{ccccc}
\hline \multirow{2}{*}{ Reator } & \multicolumn{4}{c}{ Teor de B (mg/kg) } \\
& $\mathbf{0}$ & $\mathbf{1 0}$ & $\mathbf{2 0}$ & $\mathbf{3 0}$ \\
\hline R1 & 19,47 & 13,015 & 15,39 & 10,99 \\
R2 & 15,13 & 15,91 & 14,39 & 15,86 \\
R3 & 10,15 & 14,55 & 7,29 & 15,94 \\
R4 & 13,55 & 12,19 & 10,09 & 17,47 \\
Controle & 0,1 & 24,03 & 11,45 & 0,3 \\
\hline
\end{tabular}

Tabela 34 -Teor do elemento Cd no solo tratado - experimento $n^{\circ} 7$.

\begin{tabular}{|c|c|c|c|c|}
\hline \multirow{3}{*}{ Reator } & \multicolumn{4}{|c|}{ Teor de Cd (mg/kg) } \\
\hline & \multicolumn{4}{|c|}{ Tempo (dias) } \\
\hline & 0 & 10 & 20 & 30 \\
\hline R1 & 1,18 & $<0,001$ & 1,75 & $<0,001$ \\
\hline R2 & 1,06 & $<0,001$ & 1,55 & $<0,001$ \\
\hline R3 & $<0,01$ & $<0,001$ & 1,55 & $<0,001$ \\
\hline R4 & 1,09 & $<0,001$ & $<0,001$ & $<0,001$ \\
\hline Controle & $<0,003$ & $<0,003$ & $<0,003$ & $<0,003$ \\
\hline
\end{tabular}


Tabela 35 - Teor do elemento P no solo tratado - experimento $\mathrm{n}^{0} 7$.

\begin{tabular}{ccc}
\hline \multirow{2}{*}{ Reator } & \multicolumn{2}{c}{ Teor de $\mathbf{P}$ (mg/kg) } \\
& Tempo (dias) \\
& $\mathbf{0}$ & $\mathbf{3 0}$ \\
\hline R1 & 502,85 & 433,59 \\
R2 & 518,28 & 413,14 \\
R3 & 496,03 & 396,25 \\
R4 & 516,48 & 407,9 \\
Controle & 252,53 & 279,65 \\
\hline
\end{tabular}

Tabela 36 - Teor do elemento $\mathrm{Pb}$ no solo tratado - experimento $\mathrm{n}^{\circ} 7$.

\begin{tabular}{ccccc}
\hline \multirow{2}{*}{ Reator } & \multicolumn{4}{c}{ Teor de Pb (mg/kg) } \\
& $\mathbf{0}$ & $\mathbf{1 0}$ & $\mathbf{2 0}$ & $\mathbf{3 0}$ \\
\hline R1 & 711,56 & 694,8 & 784,58 & 721,46 \\
R2 & 663,2 & 732,9 & 783,89 & 691,37 \\
R3 & 648,35 & 722,15 & 756,17 & 693,34 \\
R4 & 632,32 & 687,9 & 700,05 & 672,18 \\
Controle & 584,65 & 640,76 & 649,85 & 694,18 \\
\hline
\end{tabular}

Tabela 37 - Teor do elemento $S$ no solo tratado - experimento $n^{\circ} 7$.

\begin{tabular}{ccc}
\hline \multirow{2}{*}{ Reator } & \multicolumn{2}{c}{ Teor de S (\%) } \\
& \multicolumn{2}{c}{ Tempo (dias) } \\
& $\mathbf{0}$ & $\mathbf{3 0}$ \\
\hline R1 & 0,33 & 1,03 \\
R2 & 0,32 & 0,95 \\
R3 & 0,29 & 0,93 \\
R4 & 0,32 & 0,92 \\
Controle & 0,05 & 0,02 \\
\hline
\end{tabular}

Tabela 38 - Teor do elemento $\mathrm{Zn}$ no solo tratado - experimento $\mathrm{n}^{\circ} 7$.

\begin{tabular}{ccccc}
\hline \multirow{2}{*}{ Reator } & \multicolumn{5}{c}{ Teor de Zn (mg/kg) } \\
& $\mathbf{0}$ & $\mathbf{1 0}$ & $\mathbf{2 0}$ & $\mathbf{3 0}$ \\
\hline R1 & 177,66 & 115,55 & 106,18 & 88,25 \\
R2 & 151,87 & 100,55 & 102,22 & 90,59 \\
R3 & 135 & 91,8 & 97,59 & 63,32 \\
R4 & 147,255 & 93,22 & 83,85 & 80,97 \\
Controle & 178,17 & 175,99 & 184,69 & 203,26 \\
\hline
\end{tabular}


A Tabela 39 mostra os resultados obtidos nas análises de contagem de bactérias heterotróficas - experimento de biolixiviação $n^{\circ} 7$.

Tabela 39 - Evolução da população de bactérias heterotróficas - experimento $n^{\circ} 7$.

\begin{tabular}{cccccc}
\hline \multirow{2}{*}{ Reatores } & \multicolumn{5}{c}{ Log $_{10}$ UFC/g solo } \\
& & $\mathbf{0}$ & $\mathbf{1 0}$ & $\mathbf{2 0}$ & $\mathbf{3 0}$ \\
\hline \multirow{2}{*}{1} & Tendência & 6,74 & 4,95 & 5,37 & 5,96 \\
& Incerteza & 0,02 & 0,01 & 0,23 & 0,07 \\
\multirow{2}{*}{2} & Tendência & 8,18 & 4,87 & 5,12 & 6,17 \\
& Incerteza & $*$ & 0,10 & 0,11 & 0,04 \\
\multirow{2}{*}{3} & Tendência & 7,97 & 4,88 & 5,33 & 6,04 \\
& Incerteza & 0,03 & 0,1 & 0,3 & 0,07 \\
\multirow{2}{*}{4} & Tendência & 8,1 & 4,82 & 5,19 & 5,86 \\
& Incerteza & $*$ & 0,08 & 0,04 & 0,06 \\
\multirow{2}{*}{ Controle } & Tendência & 6,31 & 6,85 & 7,22 & 6,29 \\
& Incerteza & 0,05 & 0,06 & 0,09 & 0,05 \\
\hline
\end{tabular}

Nota:

Incerteza = incerteza padrão definida para a duplicata de placas utilizadas na contagem.

* = incerteza não definida devido a contaminação em uma das placas utilizadas na contagem.

A Tabela 40 mostra os resultados obtidos nas análises microbiológicas, para determinação do número mais provável de bactérias $A$. ferrooxidans, experimento $\mathrm{n}^{\circ} 7$.

Tabela 38 - Evolução da população de bactérias $A$. ferrooxidans - experimento $\mathrm{n}^{\circ} 7$.

\begin{tabular}{crcccc}
\hline \multirow{2}{*}{ Reatores } & \multicolumn{4}{c}{ Log $_{10}$ A. ferrooxidans/g solo } \\
& & $\mathbf{0}$ & $\mathbf{1 0}$ & $\mathbf{2 0}$ & $\mathbf{3 0}$ \\
\hline \multirow{2}{*}{1} & Tendência & 1,3 & 6,44 & 7,09 & 4,97 \\
& Incerteza & 0,86 & 0,58 & 0,44 & 0,46 \\
\multirow{2}{*}{2} & Tendência & 1,29 & 6,8 & 6,83 & 5,8 \\
& Incerteza & 0,86 & 0,54 & 0,54 & 0,52 \\
\multirow{2}{*}{3} & Tendência & 3,11 & 7,02 & 7 & 6,44 \\
& Incerteza & 0,61 & 0,43 & 0,49 & 0,57 \\
\multirow{2}{*}{4} & Tendência & 3,11 & 6,97 & 6,99 & 6,22 \\
& Incerteza & 0,61 & 0,49 & 0,49 & 0,59 \\
\multirow{2}{*}{ Controle } & Tendência & 1,21 & 1,16 & 1,08 & 1,08 \\
& Incerteza & 0,86 & 0,86 & 0,86 & 0,86 \\
\hline
\end{tabular}

Nota:

Incerteza $=$ limite de confiança definido para uma probabilidade de $95 \%$.

Limite de detecção do método $=\leq 1 \log _{10} A$. ferrooxidans/g solo 
A Tabela 41 mostra a contagem do número total de microrganismos determinados através de microscopia utilizando o marcador de DNA 4-6 diamidino2-phenylindole (DAPI).

Tabela 41 - Evolução do número total de microrganismos - experimento $n^{\circ} 7$.

\begin{tabular}{cccccc}
\hline \multirow{2}{*}{ Reatores } & \multicolumn{5}{c}{ Log $_{\mathbf{1 0}}$ A. ferrooxidans/g solo } \\
& & $\mathbf{0}$ & $\mathbf{1 0}$ & $\mathbf{2 0}$ & $\mathbf{3 0}$ \\
\hline \multirow{2}{*}{1} & Tendência & 12,5 & 13 & 13,32 & 13,47 \\
& Incerteza & 0,02 & 0,05 & 0,02 & 0,02 \\
\multirow{2}{*}{2} & Tendência & 12,32 & 13,3 & 13,43 & 13,26 \\
& Incerteza & 0,03 & 0,02 & 0,02 & 0,04 \\
\multirow{2}{*}{3} & Tendência & 12,26 & 13,4 & 13,43 & 13,26 \\
& Incerteza & 0,03 & 0,02 & 0,02 & 0,04 \\
\multirow{2}{*}{4} & Tendência & 13,54 & 12,94 & 13,51 & 13,21 \\
& Incerteza & 0,02 & 0,04 & 0,02 & 0,03 \\
\multirow{2}{*}{ Controle } & Tendência & $*$ & $*$ & $*$ & $*$ \\
& Incerteza & $*$ & $*$ & $*$ & $*$ \\
\hline
\end{tabular}

Nota: * = contagem não executada.

\subsection{Resultados do experimento $n^{\circ} 8$}

As Tabelas 42, 43, 44 e 45 mostram, respectivamente, os resultados das determinações químicas para o lixiviado produzido ao longo do experimento de biolixiviação $\mathrm{n}^{\circ} 8$ para os elementos $\mathrm{B}, \mathrm{Cd}, \mathrm{Pb}, \mathrm{S}$ e $\mathrm{Zn}$.

Tabela 42 - Concentração do elemento B no lixiviado - experimento $n^{\circ} 8$.

\begin{tabular}{ccccc}
\hline \multirow{2}{*}{ Reator } & \multicolumn{4}{c}{ Concentração B (mg/L) } \\
& $\mathbf{0}$ & $\mathbf{1 0}$ & $\mathbf{2 0}$ & $\mathbf{3 0}$ \\
\hline R1 & 1,55 & 3,21 & 3,49 & 3,15 \\
R2 & 2,41 & 2,84 & 3,22 & 2,99 \\
R3 & 2,24 & 3,02 & 3,28 & 3 \\
R4 & 2,23 & 3,37 & 3,09 & 3,25 \\
Controle & 0,48 & 0,52 & 0,95 & 0,44 \\
\hline
\end{tabular}


Tabela 43 - Concentração do elemento Cd no lixiviado - experimento $n^{\circ} 8$.

\begin{tabular}{ccccc}
\hline & \multicolumn{5}{c}{ Concentração Cd (mg/L) } \\
Reator & \multicolumn{4}{c}{ Tempo (dias) } \\
& $\mathbf{0}$ & $\mathbf{1 0}$ & $\mathbf{2 0}$ & $\mathbf{3 0}$ \\
\hline R1 & 0,001 & 0,024 & 0,025 & 0,023 \\
R2 & 0,025 & $0,0,25$ & $<0,001$ & 0,027 \\
R3 & 0,024 & 0,024 & 0,025 & 0,024 \\
R4 & 0,023 & 0,024 & 0,025 & 0,026 \\
Controle & $<0,005$ & $<0,005$ & $<0,003$ & $<0,003$ \\
\hline
\end{tabular}

Tabela 44 - Concentração do elemento $\mathrm{Pb}$ no lixiviado - experimento $\mathrm{n}^{\circ} 8$.

\begin{tabular}{ccccc}
\hline \multirow{4}{*}{ Reator } & \multicolumn{4}{c}{ Concentração Pb (mg/L) } \\
& $\mathbf{0}$ & $\mathbf{1 0}$ & $\mathbf{2 0}$ & $\mathbf{3 0}$ \\
\hline R1 & 3,22 & 3,13 & 3,22 & 2,81 \\
R2 & 3,74 & 2,68 & 2,72 & 2,45 \\
R3 & 3,62 & 2,70 & 2,76 & 2,36 \\
R4 & 3,62 & 2,81 & 2,70 & 2,44 \\
Controle & $<0,04$ & $<0,04$ & 0,19 & 0,04 \\
\hline
\end{tabular}

Tabela 45 - Concentração do elemento Zn no lixiviado - experimento nº 8.

\begin{tabular}{ccccc}
\hline & \multicolumn{4}{c}{ Concentração Zn (mg/L) } \\
Reator & \multicolumn{4}{c}{ Tempo (dias) } \\
& $\mathbf{0}$ & $\mathbf{1 0}$ & $\mathbf{2 0}$ & $\mathbf{3 0}$ \\
\hline R1 & 3,83 & 17,74 & 19,68 & 22,2 \\
R2 & 12,13 & 22,12 & 23,62 & 28,35 \\
R3 & 11,41 & 23,24 & 24,00 & 29,05 \\
R4 & 11,44 & 25,34 & 24,08 & 32,22 \\
Controle & 0,08 & 0,08 & $<0,04$ & $<0,04$ \\
\hline
\end{tabular}

As Tabelas 46, 47, 48, 49, 50, 51, 52 e 53 mostram, respectivamente, os resultados das determinações químicas para o solo tratado ao longo do experimento de biolixiviação $\mathrm{n}^{\circ} 8 \mathrm{com} A$. ferrooxidans para os elementos $\mathrm{Al}, \mathrm{B}, \mathrm{Cd}, \mathrm{Fe}, \mathrm{P}, \mathrm{Pb}, \mathrm{S}$ e $\mathrm{Zn}$. 
Tabela 46 - Teor do elemento Al no solo tratado - experimento $n^{\circ} 8$.

\begin{tabular}{ccc}
\hline & \multicolumn{2}{c}{ Teor de Al (\%) } \\
Reator & \multicolumn{2}{c}{ Tempo (dias) } \\
& $\mathbf{0}$ & $\mathbf{3 0}$ \\
\hline R1 & 8,4 & 8,44 \\
R2 & 7,81 & 9,72 \\
R3 & 8,35 & 8,59 \\
R4 & 7,42 & 8,38 \\
Controle & 8,53 & 8,39 \\
\hline
\end{tabular}

Tabela 47 - Teor do elemento B no solo tratado - experimento $\mathrm{n}^{\circ} 8$.

\begin{tabular}{ccccc}
\hline & \multicolumn{5}{c}{ Teor de B (mg/kg) } \\
Reator & \multicolumn{4}{c}{ Tempo (dias) } \\
& $\mathbf{0}$ & $\mathbf{1 0}$ & $\mathbf{2 0}$ & $\mathbf{3 0}$ \\
\hline R1 & 15,38 & 9,68 & 11,41 & 11,74 \\
R2 & 11,43 & 15,82 & 12,76 & 14,05 \\
R3 & 12,03 & 18,85 & 13,01 & 11,19 \\
R4 & 17,92 & 14,77 & 13,32 & 13,74 \\
Controle & 25,46 & 8,52 & 6,88 & 0,03 \\
\hline
\end{tabular}

Tabela 48 -Teor do elemento Cd no solo tratado - experimento $\mathrm{n}^{\circ} 8$.

\begin{tabular}{ccccc}
\hline & \multicolumn{5}{c}{ Teor de Cd (mg/kg) } \\
Reator & \multicolumn{5}{c}{ Tempo (dias) } \\
& $\mathbf{0}$ & $\mathbf{1 0}$ & $\mathbf{2 0}$ & $\mathbf{3 0}$ \\
\hline R1 & $<0,001$ & $<0,001$ & $<0,001$ & $<0,004$ \\
R2 & $<0,001$ & $<0,001$ & $<0,004$ & $<0,004$ \\
R3 & $<0,001$ & $<0,001$ & $<0,004$ & $<0,004$ \\
R4 & $<0,001$ & $<0,001$ & $<0,001$ & $<0,004$ \\
Controle & $<0,003$ & $<0,003$ & $<0,003$ & $<0,003$ \\
\hline
\end{tabular}

Tabela 49 - Teor do elemento Fe no solo tratado - experimento $n^{\circ} 8$.

\begin{tabular}{ccc}
\hline & \multicolumn{2}{c}{ Teor de Fe (\%) } \\
Reator & \multicolumn{2}{c}{ Tempo (dias) } \\
& $\mathbf{0}$ & $\mathbf{3 0}$ \\
\hline R1 & 4,92 & 5,21 \\
R2 & 4,61 & 5,03 \\
R3 & 4,95 & 5,35 \\
R4 & 5,04 & 5,27 \\
Controle & 4,74 & 4,67 \\
\hline
\end{tabular}


Tabela 50 - Teor do elemento $\mathrm{P}$ no solo tratado - experimento $\mathrm{n}^{\circ} 8$.

\begin{tabular}{ccccc}
\hline \multirow{2}{*}{ Reator } & \multicolumn{4}{c}{ Teor de P (mg/kg) } \\
& $\mathbf{0}$ & $\mathbf{1 0}$ & $\mathbf{2 0}$ & $\mathbf{3 0}$ \\
\hline R1 & 253,44 & 243,91 & 248,7 & 270,36 \\
R2 & 240,55 & 230,16 & 227,62 & 228,81 \\
R3 & 243,53 & 238,84 & 278,76 & 263,69 \\
R4 & 233,23 & 248,32 & 244,59 & 236,42 \\
Controle & 257,04 & $*$ & $*$ & 298,41 \\
\hline
\end{tabular}

Nota: * = determinação química não executada.

Tabela 51 - Teor do elemento $\mathrm{Pb}$ no solo tratado - experimento $\mathrm{n}^{\circ} 8$.

\begin{tabular}{ccccc}
\hline \multirow{2}{*}{ Reator } & \multicolumn{5}{c}{ Teor de Pb (mg/kg) } \\
& $\mathbf{0}$ & $\mathbf{1 0}$ & $\mathbf{2 0}$ & $\mathbf{3 0}$ \\
\hline R1 & 794,74 & 762,54 & 775,56 & 830,63 \\
R2 & 751,51 & 854,14 & 792,88 & 809,06 \\
R3 & 748,49 & 771,03 & 788,77 & 876,42 \\
R4 & 809,21 & 798,57 & 817,86 & 792,74 \\
Controle & 582,2 & 613,29 & 638,35 & 702,49 \\
\hline
\end{tabular}

Tabela 52 - Teor do elemento $S$ no solo tratado - experimento $n^{0} 8$.

\begin{tabular}{ccccc}
\hline \multirow{2}{*}{ Reator } & \multicolumn{4}{c}{ Teor de S (\%) } \\
& \multicolumn{4}{c}{ Tempo (dias) } \\
& $\mathbf{0}$ & $\mathbf{1 0}$ & $\mathbf{2 0}$ & $\mathbf{3 0}$ \\
\hline R1 & 0,07 & 0,12 & 0,12 & 0,14 \\
R2 & 0,09 & 0,14 & 0,14 & 0,15 \\
R3 & 0,09 & 0,14 & 0,14 & 0,16 \\
R4 & 0,09 & 0,14 & 0,15 & 0,16 \\
Controle & 0,005 & $*$ & $*$ & 0,01 \\
\hline
\end{tabular}

Nota: * = determinação química não executada.

Tabela 53 - Teor do elemento $\mathrm{Zn}$ no solo tratado - experimento $\mathrm{n}^{\circ} 8$.

\begin{tabular}{ccccc}
\hline \multirow{2}{*}{ Reator } & \multicolumn{4}{c}{ Teor de Zn (mg/kg) } \\
& $\mathbf{0}$ & $\mathbf{1 0}$ & $\mathbf{2 0}$ & $\mathbf{3 0}$ \\
\hline R1 & 179,79 & 152,81 & 143,41 & 142,75 \\
R2 & 159,53 & 123,77 & 117,7 & 122,02 \\
R3 & 154,55 & 98,66 & 122,49 & 133,6 \\
R4 & 165,93 & 120,82 & 128,73 & 126,26 \\
Controle & 165,96 & 175,21 & 176,87 & 207,31 \\
\hline
\end{tabular}


As Tabelas 54 e 55 mostram, respectivamente, os resultados obtidos nas análises de contagem de bactérias heterotróficas e de $A$. ferrooxidans - experimento de biolixiviação $n^{\circ} 8$.

Tabela 54 - Evolução da população de bactérias heterotróficas - experimento $\mathrm{n}^{\circ} 8$.

\begin{tabular}{cccccc}
\hline \multicolumn{2}{l}{ Reatores } & \multicolumn{4}{c}{$\begin{array}{c}\text { Log } \\
\text { Tempo (dias) }\end{array}$} \\
& & $\mathbf{0}$ & $\mathbf{1 0}$ & $\mathbf{2 0}$ & $\mathbf{3 0}$ \\
\hline \multirow{2}{*}{1} & Tendência & 6 & 5,21 & 5,69 & 6,26 \\
& Incerteza & 0,13 & 0,01 & 0,07 & 0,01 \\
\multirow{2}{*}{2} & Tendência & 7,37 & 5,2 & 5,41 & 5,47 \\
& Incerteza & 0,04 & 0,05 & 0,04 & 0,02 \\
\multirow{2}{*}{3} & Tendência & 6,57 & 5,04 & 5,26 & 5,24 \\
& Incerteza & 0,19 & 0,01 & 0,04 & 0,07 \\
4 & Tendência & 6,37 & 5,15 & 5,41 & 5,41 \\
& Incerteza & 0,01 & 0,01 & 0,01 & 0,03 \\
\multirow{2}{*}{ Controle } & Tendência & 6,73 & 6,75 & 7,41 & 6,89 \\
& Incerteza & 0,3 & 0,05 & 0,01 & 0,13 \\
\hline
\end{tabular}

Nota:Incerteza = incerteza padrão definida para a duplicata de placas utilizadas na contagem.

Tabela 55 - Evolução da população de bactérias $A$. ferrooxidans - experimento $\mathrm{n}^{\circ} 8$

\begin{tabular}{cccccc}
\hline \multirow{2}{*}{ Reatores } & \multicolumn{4}{c}{$\mathbf{L o g}_{\mathbf{1 0}}$ A. ferrooxidans/g solo } \\
& & $\mathbf{0}$ & $\mathbf{1 0}$ & $\mathbf{2 0}$ & $\mathbf{3 0}$ \\
\hline \multirow{2}{*}{1} & Tendência & 1,84 & 3,61 & 3,61 & 3,61 \\
& Incerteza & 0,52 & 0,62 & 0,62 & 0,62 \\
\multirow{2}{*}{2} & Tendência & 1,63 & 5,01 & 5,01 & 3,8 \\
& Incerteza & 0,62 & 0,61 & 0,61 & 0,52 \\
\multirow{2}{*}{3} & Tendência & 4,84 & 5,61 & 6,75 & 7 \\
& Incerteza & 0,52 & 0,62 & 0,54 & 0,49 \\
\multirow{2}{*}{4} & Tendência & 4,63 & 5,61 & 6,69 & 6,44 \\
& Incerteza & 0,62 & 0,62 & 0,51 & 0,58 \\
\multirow{2}{*}{ Controle } & Tendência & 1,23 & 1,18 & 1,12 & 1,1 \\
& Incerteza & 0,86 & 0,86 & 0,86 & 0,86 \\
\hline
\end{tabular}

Nota:

Incerteza = limite de confiança definido para uma probabilidade de $95 \%$.

Limite de detecção do método $=\leq 1 \log _{10} A$. ferrooxidans/g solo 